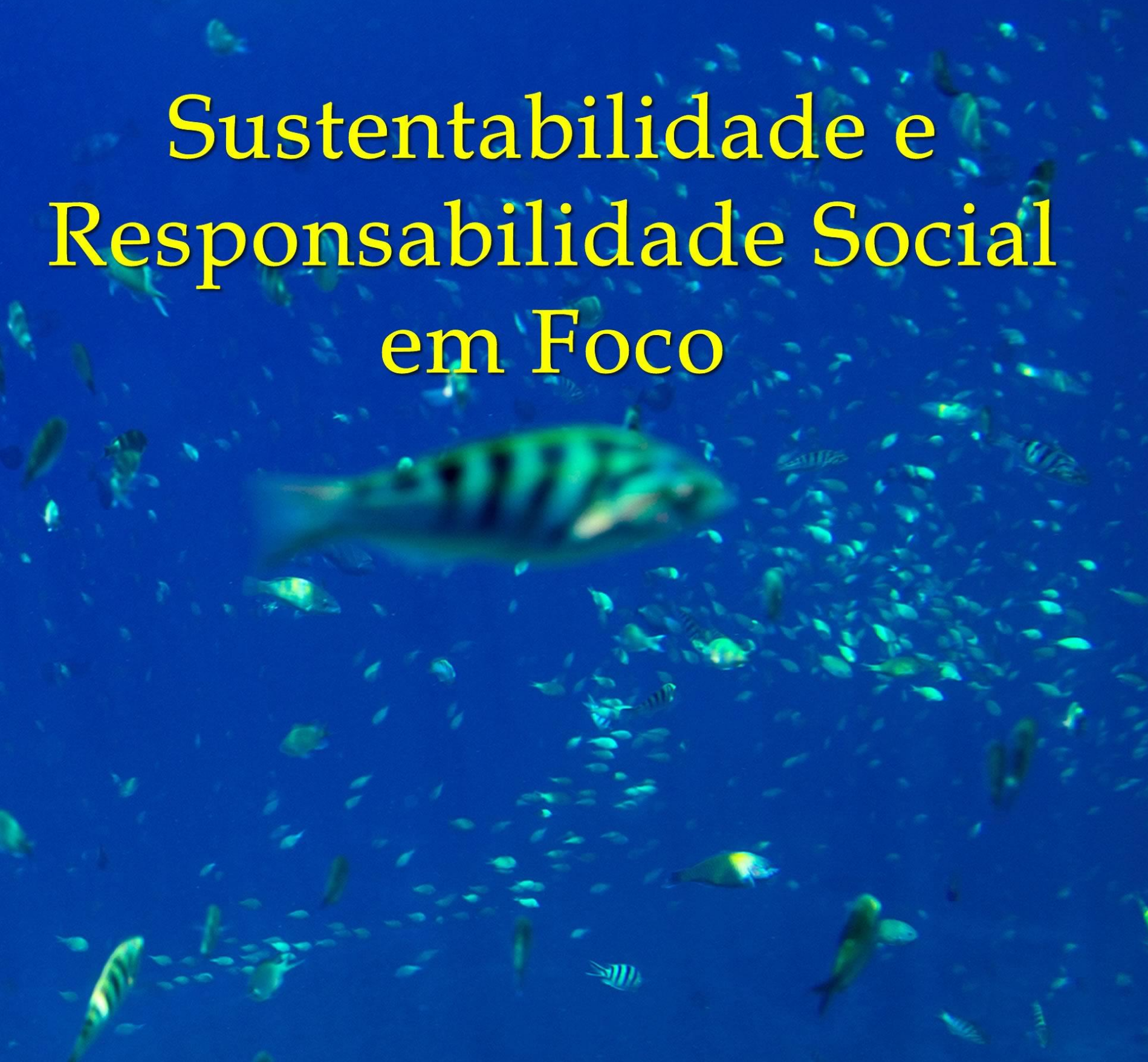

$$
\text { emFoco }
$$

11 
Editora Poisson

\section{Sustentabilidade e Responsabilidade Social em Foco Volume 7}

1a Edição

Belo Horizonte

Poisson

2018 
Editor Chefe: Dr. Darly Fernando Andrade

\section{Conselho Editorial}

Dr. Antônio Artur de Souza - Universidade Federal de Minas Gerais

Dra. Cacilda Nacur Lorentz - Universidade do Estado de Minas Gerais

Dr. José Eduardo Ferreira Lopes - Universidade Federal de Uberlândia

Dr. Otaviano Francisco Neves - Pontifícia Universidade Católica de Minas Gerais

Dr. Luiz Cláudio de Lima - Universidade FUMEC

Dr. Nelson Ferreira Filho - Faculdades Kennedy

Dados Internacionais de Catalogação na Publicação (CIP)

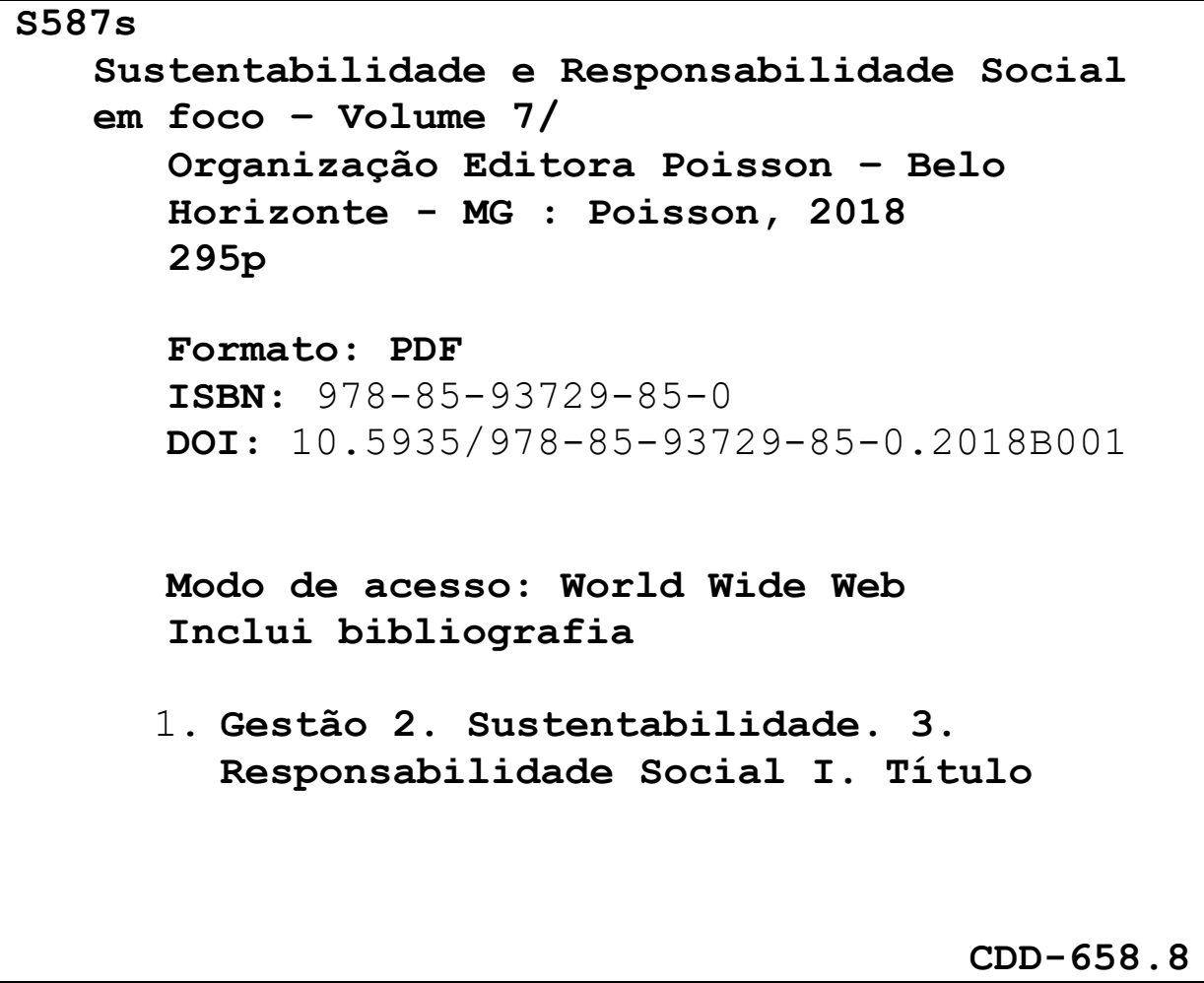

1. Gestão 2. Sustentabilidade. 3. Responsabilidade Social I. Título

CDD- 658.8

O conteúdo dos artigos e seus dados em sua forma, correção e confiabilidade são de responsabilidade exclusiva dos seus respectivos autores.

$\underline{\text { www.poisson.com.br }}$

contato@poisson.com.br 


\section{SUMÁRIO}

Capítulo 1: Contratações públicas sustentáveis: um longo caminho a ser percorrido

Carla Oliveira de Souza

Capítulo 2: Avaliação de modelos de negócio para produção de bioetanol de segunda geração em escala comercial.

Maria José de Oliveira Cavalcanti Guimarães, Estevão Freire, Antonio Calil Neto

Capítulo 3: Análise do perfil dos empreendimentos do entorno do Instituto Federal de Educação, ciência e tecnologia da Bahia na região do Barbalho, Salvador-BA

Laís Rocha Pires, Cláudio Palma de Mello, Alexandra Quadro Siqueira, Jowaner de Oliveira Araújo, Luana das Graças Queiróz Farias

Capítulo 4: Análise dos fatores motivadores de mortalidade das micro e pequenas empresas em Itaboraí/RJ a partir da implantação do COMPERJ (2006-2014)

Pando Angeloff Pandeff, Rafael de Abreu Pereira, Natalia Cristina Correa Castelo Branco, Sthefani Nogueira Saraiva

Capítulo 5: Análise da efetividade dos programas de inclusão social: o caso da zona especial de interesse social (ZEIS) no bairro esperança em Itaboraí/RJ

Pando Angeloff Pandeff, Luciana Teixeira da Silva Abreu, Natalia Cristina Correa Castelo Branco, Sthefani Nogueira Saraiva

Capítulo 6: Rede causa justa - fatores críticos de sucesso da rede de empreendimentos comunitários do médio e Baixo Rio Madeira

Andressa Samara Masiero Zamberlan, Mariluce Paes de Sousa

Capítulo 7: Desempenho organizacional e práticas sustentáveis em uma empresa de transportes de carga

Cesar Mauricio Kulak, Marcos de Castro, Marlete Beatriz Maçaneiro

Capítulo 8: Construção participativa de indicadores de sustentabilidade como suporte de tomada de decisão para a qualidade de vida nas comunidades em Luanda (Angola): estudo de caso na centralidade do Kilamba

Eduardo Lopes Marques, Lilhan Ferro de Souza Barbosa, Augusto Paulo Salelo José,

Capítulo 9: Reflexo das informações contábeis pelos produtores de leite da agricultura familiar no município de Guapó - GO Matheus Silva Bastos, Lorena Nogueira de Souza, Elizabeth Vieira Porto Pereira, Alexandre de Carvalho

Paranaiba, Jediel Teixeira Mendes 


\section{SUMÁRIO}

Capítulo 10: Impacto do teletrabalho na gestão socialmente responsável dos stakeholders

Simone Metello de Mattos Castro, Tatiana Metello Castro, Fernando Toledo Ferraz

Capítulo 11: INTELIAGRI - sistema inteligente para gestão do uso de recursos hídricos e insumos na agricultura Jose Airton Chaves Cavalcante Junior, Angel Ramon Sanchez Delgado, Maria Claudia Rodriguez, Jose Antonio Carlos Canedo de Medeiros

Capítulo 12: Aproveitamento de energia eólica em uma academia de ginástica na cidade de Cabo Frio.

Filipe Borges de Oliveira, Josaura de Oliveira Leite, Leonardo Rafael Brum

Capítulo 13: Avaliação da qualidade acústica pré-ocupação para o sistema de piso em ambiente construído de um apartamento residencial em Niterói-RJ

Wlander Belem Martins, Helton Luiz Santana Oliveira, Pedro Vieira de Souza Junior

Capítulo 14: A responsabilidade social empresarial e o marketing social nas organizações

Filipe de Castro Quelhas

Capítulo 15: Análise da função de despesa educação nos municípios de Rondônia com melhor índice firjan de desenvolvimento municipal...... Alexandre de Freitas Carneiro, Josias da Silva Nogueira, Sérgio Candido de Gouveia Neto, José Arilson de Souza

Capítulo 16: Aplicação do sistema contábil gerencial ambiental (SICOGEA): análise em uma instituição autárquica federal - Rio de Janeiro - RJ

Igor Laguna Vieira, Elmo Rodrigues da Silva

Capítulo 17: Avaliação das estações de monitoramento de qualidade da água da Baía de Guanabara com a utilização de técnicas estatísticas multivariadas

Raquel Emerick Pereira Mencarini, Maria José de Oliveira Cavalcanti Guimarães, Lidia Yokoyama

Capítulo 18: Avaliação de tecnologias de tratamento para fração orgânica de resíduos sólidos urbanos. Felipe Barbosa Cordeiro, Maria José de Oliveira Cavalcanti Guimarães, Juacyara Carbonelli Campos 


\section{SUMÁRIO}

Capítulo 19: Conflitos na prestação de serviços públicos em áreas de proteção permanente (APPs) - uma análise a partir do município de Itaboraí/RJ

Pando Angeloff Pandeff, Alexandre de Vasconcellos Faria, Louise Angeloff, Kely Betânia Abrão Borges

Capítulo 20: Cultura, mudança organizacional e qualidade de vida no trabalho: percepção dos professores de uma escola pública estadual de João Pessoa / PB

Amanda Raquel França Filgueiras D'Amorim, Ramon Schnayder de França

Filgueiras D’Amorim, Luciene Laranjeira Diniz, Tulio Gonzaga Brandão de Mendonça

Capítulo 21: Gestão de resíduos de serviço de saúde: uma abordagem técnica e teórica sobre incineração.

Débora Batista de Farias, Avenilson Gomes da Trindade, Luis Carlos Ufei

Hassegawa, Aloir Pedruzzi Junior, Jonimar da Silva Souza, Nubiana de Lima

Irmão Pedruzzi

Capítulo 22: Percepção de sustentabilidade do consumidor paulista de cosméticos.

Keli Cristiane Vido,Beatriz Goncalves Vicente,Marcela Amorim Fernandes, Luciano Gemignani Montessanti,Lia Mara Dib

Autores: 


\section{Gapítulo 1}

\section{CONTRATAÇÕES PÚBLICAS SUSTENTÁVEIS: UM LONGO CAMINHO A SER PERCORRIDO}

\section{Carla Oliveira de Souza}

Resumo: As contratações públicas sustentáveis representam uma mudança necessária e premente nos padrões de consumo da Administração Pública no Brasil. Este estudo consiste em propor alternativas que visem a consolidação destas contratações. Visando uma melhor compreensão do tema proposto, inicia-se com uma breve análise dos limites das licitações sustentáveis, reforçando-se a crença de que o maior responsável por este processo é o gestor público. Foram desenvolvidas pesquisas documentais e bibliográficas para levantamento de alternativas e métodos que podem ser utilizados por este gestor e destacar importantes iniciativas sustentáveis na esfera pública brasileira.

Palavras-chave: Sustentabilidade, Compras Públicas Sustentáveis, Iniciativas Sustentáveis 


\section{INTRODUÇÃO}

Nos últimos anos, a sociedade brasileira vem se deparando diariamente com o crescimento de problemas ambientais, alguns de grande proporção, tais como, o desmatamento da Amazônia. Pode-se perceber também que tem crescido a preocupação com o meio ambiente, sobretudo em virtude das mudanças climáticas - com alteração dos recursos hídricos -; a gestão de resíduos sólidos; a redução da biodiversidade, entre outras questões ambientais que ocupam o dia-a-dia do cidadão brasileiro.

$\mathrm{Na}$ Conferência das Nações Unidas sobre o Meio Ambiente e Desenvolvimento, CNUMAD, Rio 92, foi assinada a Agenda 21 Global, esta possui uma área pragmática que se refere ao desenvolvimento de políticas e estratégias nacionais para estimular mudanças nos padrões insustentáveis de consumo. No Brasil, estima-se que cerca de $15 \%$ do Produto Interno Bruto (PIB) anual em produtos e serviços, algo em torno de $R \$ 600$ bilhões, esteja relacionado às aquisições feitas pelo Poder Público (MPOG, 2012). Além do papel fundamental de preservar o meio ambiente, viu-se a necessidade do Poder Público de atuar com um papel indutor na economia, atividade presente nos itens 4.22 e 4.23 do referido documento, buscando assim influenciar o mercado e a sociedade através de seu poder de compra e da imposição de leis e decretos.

Dessa maneira, as contratações públicas sustentáveis (CPS), por meio do uso da lei 8.666/93, se constituem importante ferramenta para o Estado brasileiro estimular padrões sustentáveis de consumo. Uma pesquisa do MPOG (2009) apontou que a falta de capacidade técnica e a falta de informação são os principais obstáculos apresentados pelos gestores públicos para a incorporação de critérios ambientais em seus produtos ou serviços. Devido a esses fatores somados a complexidade da máquina estatal, muitas vezes, compras públicas são feitas sem considerar o critério da sustentabilidade. Deve-se evitar o repasse de recursos públicos para empresas que não respeitam as legislações ambientais, que desperdiçam matéria-prima e energia, que não são ecoeficientes e ignoram a acelerada destruição dos recursos naturais que, em escala global, ameaça à sobrevivência da espécie humana.
Daí surge a seguinte problemática: como desenvolver e consolidar a necessidade de inserção de critérios socioambientais nas licitações, aquisições e contratações públicas? O objetivo principal deste trabalho é propor alternativas a serem utilizadas para a efetivação das contratações públicas sustentáveis no Brasil. Como objetivos secundários têm-se: (1) analisar os limites das contratações públicas sustentáveis; (2) apresentar procedimentos administrativos a serem adotados pelo gestor público; (3) relatar iniciativas sustentáveis consideradas benchmarks no âmbito da esfera pública.

Como delimitação do estudo, optou-se por considerar prioritariamente os pilares econômico e ambiental que compõem, junto com o aspecto social, o conceito de sustentabilidade na discussão sobre licitações. Além disso, buscou-se primeiramente analisar o contexto jurídico em que está inserida esta problemática, para daí então propor caminhos que devem ser seguidos em prol da sustentabilidade nas contratações públicas.

Além desta introdução, o artigo está dividido em quatro seções: (1) referencial teórico (2) metodologia; (3) apresentação, análise e discussão das propostas e (4) considerações finais.

\section{REFERENCIAL TEÓRICO}

De acordo com Dias (2006), o conceito de desenvolvimento sustentável é amplo. Há aqueles que acreditam ser a busca do crescimento econômico por meio do uso de recursos naturais de maneira racional e da aplicação eficiente de tecnologias. Há também o conceito de que o desenvolvimento sustentável se dá, em primeira instância, com um projeto social e político destinado a eliminar a pobreza, focando as necessidades básicas e melhorando a qualidade de vida da população.

As organizações que buscam trabalhar tendo como base o desenvolvimento sustentável tem de ser: primeiramente, economicamente viáveis; em termos sociais, devem dar melhores condições de trabalho aos seus empregados; e, no viés ambiental, tem como obrigação serem ecoeficientes, fazendo uso de tecnologias limpas e adotando posturas de responsabilidade ambiental, conforme classificação de Dias (2006). 
Figura 1. Equilíbrio dinâmico da sustentabilidade

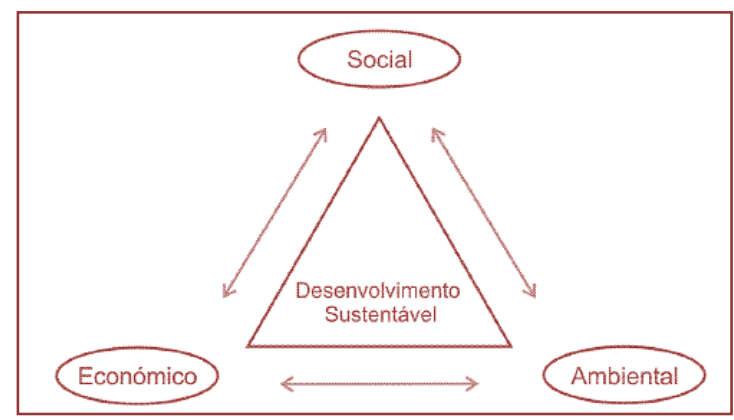

Fonte: DIAS, 2006

A Rio 92 teve como foco principal relacionar as metas ambientais $e$ as políticas de desenvolvimento. A Agenda 21 é composta por ações, recursos e responsabilidades definidos voltados para alcançar o desenvolvimento sustentável global. O documento mostra que o conceito de sustentabilidade é um princípio político e que só será possível a proteção do meio ambiente se os aspectos econômicos e sociais forem levados em consideração.

A Cúpula Mundial sobre Desenvolvimento Sustentável de Joanesburgo, em 2002, teve um viés para as contratações públicas sustentáveis, em que os governos foram incitados a buscarem alternativas para estimularem as compras e contratações públicas que priorizassem o desenvolvimento do meio ambiente (UN, 2002).

Conforme Meneguzzi (2011), as licitações sustentáveis são definidas pela sustentabilidade ambiental dos produtos e processos que a elas se relacionam. Santos (2011) afirma que a licitação sustentável é aquela que leva em consideração critérios de preferências socioambientais na escolha de bens, obras e serviços nas contratações do Poder Público, tendo como objetivo a preservação do meio ambiente.

A licitação sustentável também conhecida como ecoaquisição, licitação ecológica, verde ou ambiental, pode ser entendida como aquela:

influenciada por parâmetros de consumo menos agressivos ao meio ambiente. É a licitação que integra critérios ambientais de acordo com o estado da técnica, ou seja, com o melhor para o meio ambiente de acordo com a atual ciência num preço razoável. É um esforço governamental com base jurídica, propiciado não apenas por ela, mas principalmente pela consciência institucional do consumo sustentável (educação ambiental) para adquirir bens, serviços e obras com reduzido impacto ambiental em comparação com os outros que servem à mesma finalidade. Tal comparação poderá, por exemplo, considerar o material bruto, a produção, o fabrico, o empacotamento, a distribuição, o reuso, a operação, a manutenção ou a disposição/eliminação do produto ou serviço (BIM, 2011, p. 177, grifo nosso).

De acordo com Ferreira (2011), as licitações sustentáveis, também chamadas de licitações verdes, compõem a inserção de critérios ambientais e sociais nas aquisições e contratações do Poder Público, dando preferência a compra de produtos e serviços que atendam aos critérios de sustentabilidade, tais como reciclagem, vida útil mais longa, geração de menos resíduos, menor consumo de matéria-prima e energia. Para tal, considera-se o ciclo de fabricação do produto como um todo, ou seja, desde a extração da matéria-prima até o descarte.

O arcabouço legislativo brasileiro sobre a preservação ambiental por meio das licitações sustentáveis é bastante amplo e encontra-se pulverizado tanto na Constituição Federal, art. 170, inciso VI e caput do art. 225, quanto em diversas Leis e Decretos, tais como a Política Nacional sobre Mudança do Clima, Lei $n^{\circ}$ 12.187/2009, que trouxe em seu art. 6o, inciso XII, o estabelecimento de critérios de preferência, nas licitações e concorrências públicas, para as propostas que propiciem maior economia de energia, água e outros recursos naturais e redução da emissão de gases de efeito estufa e resíduos. No ano seguinte, $\mathrm{O}$ inciso XI do art. $7^{\circ}$ da Lei 
no 12.305/2010, apontou como um dos objetivos da Política Nacional de Resíduos Sólidos a prioridade, nas aquisições e contratações públicas, dos produtos reciclados e recicláveis, assim como os bens, serviços e obras que considerem critérios compatíveis com padrões de consumo social e ambientalmente sustentáveis.

A lei geral de licitações, lei no $8.666 / 93$, teve o caput $^{\dagger}$ do art. $3^{\circ}$ alterado por meio da Lei $n^{\circ}$ 12.349/2010, em que foi acrescentado outro objetivo, a saber, o da promoção do desenvolvimento nacional sustentável, além da garantia da observância do princípio constitucional da isonomia e da seleção da proposta mais vantajosa para a Administração. A Instrução Normativa $n^{\circ}$ 01/2010, da Secretaria de Logística e Tecnologia da Informação do Ministério do Planejamento, Orçamento e Gestão, em seus arts. 1ํ a $3^{\circ}$ traz importante obrigação para o gestor público, in verbis:

Art. 1ํ - Nos termos do art. 3을 da Lei $n^{\circ}$ 8.666, de 21 de junho de 1993, as especificações para a aquisição de bens, contratação de serviços e obras por parte dos órgãos e entidades da administração pública federal direta, autárquica e fundacional deverão conter critérios de sustentabilidade ambiental, considerando os processos de extração ou fabricação, utilização e descarte dos produtos e matérias primas. (grifo nosso)

Art. $2^{\circ}$ - Para o cumprimento do disposto nesta Instrução Normativa, o instrumento convocatório deverá formular as exigências de natureza ambiental de forma a não frustrar a competitividade.

Art. $3^{\circ}$ - Nas licitações que utilizem como critério de julgamento o tipo melhor técnica ou técnica e preço, deverão ser estabelecidos no edital critérios objetivos de sustentabilidade ambiental para a

\footnotetext{
1 Art. 3․ A licitação destina-se a garantir a observância do princípio constitucional da isonomia, a seleção da proposta mais vantajosa para a administração e a promoção do desenvolvimento nacional sustentável e será processada e julgada em estrita conformidade com os princípios básicos da legalidade, da impessoalidade, da moralidade, da igualdade, da publicidade, da probidade administrativa, da vinculação ao instrumento convocatório, do julgamento objetivo e dos que lhe são correlatos (grifo nosso).
}

avaliação e classificação das propostas. (grifo nosso)

A edição da supramencionada Instrução Normativa trouxe avanços consideráveis, pois de acordo com as Informações Gerenciais de Contratações Públicas Sustentáveis de 2010 a 2012, as compras sustentáveis saíram de $\mathrm{R} \$ 12,7$ milhões para uma participação de $\mathrm{R} \$$ 39,9 milhões nas aquisições dos órgãos do Sistema de Serviços Gerais (SISG), o que representa um crescimento de $214 \%$ ao longo destes 3 anos (MPOG, 2013).

\section{METODOLOGIA}

O presente artigo tem um caráter exploratório, trazendo a discussão sobre a adoção das contratações públicas sustentáveis como medida a ser adotada pelo poder público, observando, ao mesmo tempo, os limites da licitação sustentável e o papel do gestor público na adoção de iniciativas sustentáveis em suas contratações.

No que tange aos procedimentos técnicos, trata-se de uma pesquisa bibliográfica e documental. Este trabalho foi desenvolvido por meio de pesquisas em fontes bibliográficas, por meio de análises na literatura e artigos já publicados. Com relação à pesquisa documental, foram destacados alguns manuais, relatórios e orientações de organizações-modelo.

Finalmente, quanto ao método e a forma de abordar do problema, esta pesquisa tem caráter qualitativo, caracterizando-se, em princípio, pela não-utilização de instrumental estatístico na análise de dados. Essa análise tem por base conhecimentos teóricosempíricos que permitem atribuir-Ihe cientificidade (RICHARDSON et al., 2007).

\section{DISCUSSÃO DAS PROPOSTAS}

\subsection{OS LIMITES DAS CONTRATAÇÕES SUSTENTÁVEIS}

O arcabouço normativo brasileiro é bastante amplo e possui diversos dispositivos para impor ao Poder Público a responsabilidade ambiental que lhe é inerente, no que concerne as licitações. Há que se salientar, entretanto, que muito ainda é discutido sobre os limites destas contratações, cita-se como exemplo, o questionamento da amplitude dos critérios utilizados, se são aplicáveis aos produtos 
adquiridos ou também ao fabricante/fornecedor, entre outros. Bim (2011) afirma que a implementação da licitação sustentável possui ainda algumas resistências, em parte pelos supostos obstáculos jurídicos que the são opostos e também pela amplitude que a inserção de critérios ambientais nas compras governamentais pode alcançar.

Diante da inclusão da promoção do desenvolvimento nacional sustentável como um dos objetivos da licitação, deve-se enxergá-la com um olhar mais sustentável e não somente financeiro, pois a proposta mais vantajosa para a administração não é pura e simplesmente a de menor valor, mas a que atenda também a critérios de sustentabilidade ambiental. Quando o gestor público busca escolher a proposta mais vantajosa para a administração está, em última instância, optando também pela melhor escolha para a sociedade, pois os contratos administrativos têm o objetivo de atender a determinada demanda da coletividade. Entre uma das preocupações da sociedade brasileira está a da manutenção e preservação ambiental, obrigação esta imposta no art. 170, inciso VI e caput do art. 225 da Carta Magna.

O estabelecimento de critérios sustentáveis para participação nas licitações não tem por objetivo restringir ou frustrar a concorrência, mas sim assegurar que as empresas competirão em igualdade de condições, de acordo com parâmetros mínimos previamente estipulados no edital de licitação. Evita-se, por exemplo, que um licitante ofereça preços mais baixos que os demais em razão do mau uso do meio ambiente. Isto sim seria antiisonômico e um ataque contra a livre concorrência, pois colocaria em desvantagem a empresa que cumpre com suas obrigações ambientais, preservando o meio ambiente. Bim (2011) afirma que o uso de critério ambiental nas licitações não é apenas razoável, mas obrigatório, sendo também pertinente e relevante, não significando todavia o fim da competitividade.

Torna-se claro que é possível e recomendável a inserção de critérios de sustentabilidade na especificação do objeto da licitação, entretanto o uso de fatores sustentáveis na fase de habilitação não é permitido. Justen Filho (2009) define esta fase como o momento em que a Administração comprova a aptidão da empresa para a futura contratação. Desta maneira, não compete ao órgão licitante fazer qualquer exigência que não esteja relacionada com o que reza o contrato. A lei no 8.666/93 prevê, em seu art. 27을 exclusivamente, cinco documentações relativas a habilitação nas licitações: habilitação jurídica, qualificação técnica, qualificação econômico-financeira, regularidade fiscal e trabalhista, e cumprimento do disposto no inciso XXXIII do art. 7ํㅡㄹ da Constituição Federal.

Há que se dizer que a inclusão de certificações ambientais, tais como licenças, alvarás etc podem ser exigidas quando da habilitação jurídica, porém a atividade da licitação deverá exigir tal documentação que consistirá em, como preceitua o inciso $\mathrm{V}$, do artigo 28, da supramencionada lei: "ato de registro ou autorização para funcionamento expedido pelo órgão competente, quando a atividade assim o exigir", se trata do caso, por exemplo, de exigir documentação que certifique a procedência da madeira. Todavia, tratando-se de qualificação técnica, a possibilidade é remota, mais do que isso, trata-se de inconstitucional (ainda que algumas leis estaduais e municipais já o tenham feito), já anteriormente declaradas desta maneira pelo Supremo Tribunal Federal, como, por exemplo, na ADI no 3.670, em que se tratou um caso do direito do trabalho.

Desta forma, é vedado aos gestores limitar a concorrência por meio da estipulação de novos requisitos de habilitação, exemplo clássico desta discussão é a exigência de certificações ISO, ou seja, a certificação de uma empresa pela norma da qualidade ISO não deve ser solicitada pelo Poder Público na fase de habilitação da licitação. Contudo, como dito anteriormente, se determinada certificação tiver relação com o processo de fabricação do produto e não com o produtor em si (ou revendedor), este pedido de certificação relativa ao bem pode ser exigido quando da apresentação da proposta. Conforme afirma Justen Filho (2009), uma empresa pode preencher todos os requisitos para obter determinada certificação, mas nunca haver formalizado esse trâmite. O essencial não é a certificação em si, mas o preenchimento dos requisitos necessários para se atender ao interesse público.

\subsection{PROCEDIMENTOS ADMINISTRATIVOS A SEREM ADOTADOS PELO GESTOR PÚBLICO}

O Guia de Compras Públicas Sustentáveis desenvolvido pelo ICLEI — Governos Locais pela Sustentabilidade, Secretariado para 
América Latina e Caribe (LACS) e Centro de Estudos em Sustentabilidade da Escola de Administração de Empresas de São Paulo da Fundação Getúlio Vargas (GVces) apresenta o processo de marcos Procura + que baseiase no modelo "planeja, faça, controle e aja" que é a base de muitos sistemas de gestão e campanhas do Iclei. O ponto crucial é estabelecer uma quantidade de produtos sustentáveis comprados para servir de indicador fundamental.

O processo de marcos tem início com um inventário de base das práticas atuais de contratação do órgão público, por meio de busca das informações acerca da quantidade e especificação dos produtos comprados, as quantidades gastas e a análise da aplicação de critérios ambientais, se for o caso. O próximo passo é delinear objetivos que mostrem a percentagem dos produtos sustentáveis e o período dentro do qual devem ser cumpridos. O terceiro e quarto passos consistem em estabelecer um plano de ação e implementá-lo. Finalmente, o quinto passo avalia novamente os dados coletados no inventário e os analisa com o uso da ferramenta procurement scorecard.

Terra et al. (2011) sugere três passos práticos para a implementação concreta da licitação sustentável: a inserção de critérios socioambientais na especificação técnica do objeto (fase interna), nos requisitos de habilitação e nas obrigações da empresa contratada.

A fase interna é o momento mais importante do procedimento licitatório, nesta ocorre a escolha do objeto e a preparação do edital que acompanharão as demais fases. Justen Filho (2011) afirma que para a licitação sustentável ocorrer faz-se necessário que a Administração adote um nível de detalhamento compatível com as suas necessidades, inserindo os critérios ambientais pertinentes e desclassificando as propostas que estejam em desacordo, atentando, entretanto, para que estas especificações não restrinjam a competitividade ou favoreça algum fornecedor.

A inserção de critérios ambientais nos requisitos de habilitação pode ocorrer na habilitação jurídica e na qualificação técnica. A primeira está de acordo com o inciso $\mathrm{V}$, art. 28, da Lei 8.666/93, quando a atividade assim o exigir, é permitido a administração solicitar documentação de autorização para funcionamento. Pode-se citar o caso de atividade envolvendo produção industrial, importação, comercialização ou utilização de produtos preservativos da madeira, em que se é solicitado ato de registro ou cadastramento expedido pelo IBAMA. A segunda está de acordo com o inciso II, art. 30, da Lei 8.666/93, pode ser requisito a apresentação de atestados de qualificação técnica comprovando a aptidão para desempenho de atividade pertinente e compatível em características, quantidades e prazos com o objeto da licitação, e indicação das instalações e do aparelhamento e do pessoal técnico adequados e disponíveis para a realização do objeto da licitação, bem como da qualificação de cada um dos membros da equipe técnica que se responsabilizará pelos trabalhos. Neste caso em especial, tem-se, por exemplo, a contratação de serviços com grave risco de poluição ambiental, tais como produtos tóxicos.

O uso de critérios socioambientais nas obrigações da contratada é o instrumento conferido ao gestor para fiscalizar a execução contratual, de acordo com o especificado no edital de licitação. Diversos órgãos públicos vem aderindo a este procedimento e inserindo critérios socioambientais nas obrigações da empresa contratada, pode-se citar como exemplos: a questão do descarte dos resíduos sólidos, quando da contratação de uma empresa para construção de determinada edificação, em que se deve atentar para o correto descarte dos entulhos; e a aquisição de equipamentos de Tecnologia da Informação com a obrigação da contratada de providenciar o correto descarte dos itens que vierem a se tornar obsoletos.

\subsection{INICIATIVAS SUSTENTÁVEIS CONSIDERADAS BENCHMARKS NA ESFERA PÚBLICA}

A Agenda Ambiental na Administração Pública (A3P) é uma iniciativa do Ministério do Meio Ambiente (MMA) que tem por objetivo principal promover e incentivar as organizações públicas a adotarem ações de responsabilidade socioambiental em suas atividades. Para o alcance de seus objetivos, a A3P está estruturada nos seguintes eixos temáticos: uso racional de recursos, gestão adequada de resíduos, qualidade de vida no trabalho, sensibilização e capacitação de servidores e o uso das licitações sustentáveis 
(MMA, 2015). O gráfico abaixo apresenta o histórico da adesão à rede A3P por esfera de governo, que tem sido um importante canal de comunicação para troca de experiências.

Gráfico 1. Adesão à rede A3P

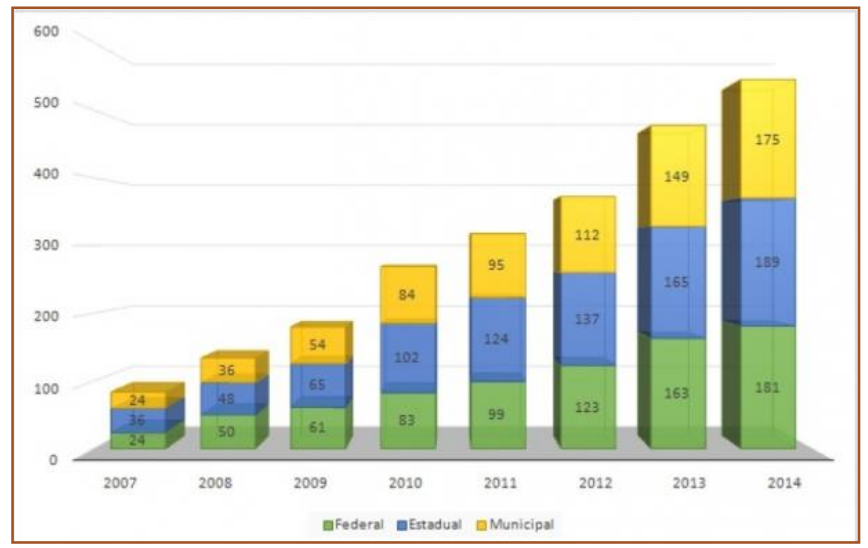

*Os dados são cumulativos Fonte: A3P/SAIC/MMA

O Ministério do Meio Ambiente se destaca entre outros órgãos federais pelas mudanças efetivas que alcançou, equipamentos foram trocados - como o uso de lâmpadas fluorescentes e sistema de ar-condicionado mais eficiente - e hábitos foram mudados. $O$ relatório de monitoramento do $\mathrm{A} 3 \mathrm{P}$ do MMA 2013/12 apresenta diversos bons exemplos de eficiência interna, como a aquisição de torneiras com válvulas redutora de pressão e temporizadores, o que gerou diminuição no consumo de água; e a compra de veículos flex, estimulando o uso do álcool como combustível (MMA, 2013).

Pode-se dizer que atualmente, no Brasil, o Programa A3P é a principal referência em gestão pública socioambiental, no entanto, este não possui natureza impositiva, servindo apenas para induzir a administração pública às boas práticas de gestão sustentável. $\mathrm{O}$ Programa A3P trata-se de um convênio com o Ministério do Meio Ambiente a que cada órgão público decide ou não aderir. Este não é uma determinação do alto escalão do Poder Público e nem um decreto presidencial em que serão cobrados relatórios com o alcance de metas, mas tão somente um programa baseado na voluntariedade.

O uso da Compra Compartilhada Sustentável tem se demonstrado importante ferramenta para a introdução de políticas e critérios sustentáveis nas contratações. A licitação compartilhada facilita as compras públicas uma vez que garante preços mais competitivos e condições mais favoráveis de compras, reduzindo de forma expressiva os custos finais das contratações, contribuindo para evitar os desperdícios. Pode-se destacar, a título de exemplo, a análise feita por Silva e Barki (2012) da compra compartilhada ocorrida entre o Jardim Botânico e mais oito órgãos no ano de 2010. Com a adesão destes últimos, foi realizada a compra compartilhada sustentável, uma vez que aumentou significativamente o número de unidades de cada produto, tendo sido adquirido 48 itens de material de expediente sustentáveis. Observou-se ainda que o ganho de escala trouxe uma economia de $R \$ 723.263,78$, o que correspondia a $49,89 \%$ do valor estimado no termo de referência.

Com o intuito de apresentar algumas iniciativas sustentáveis em alguns estados e municípios do Brasil, em especial as regiões sul e sudeste, foi elaborada a tabela a seguir. É importante salientar que todas estas medidas não ferem o ordenamento jurídico ambiental, antes a garantia do atendimento à legislação ambiental é premissa básica para cada uma destas normas e procedimentos. 
Tabela 1. Iniciativas sustentáveis nos municípios e estados do Brasil

\begin{tabular}{l} 
Iniciativas Municipais \\
Prefeitura de São Paulo \\
- Decreto no 42.318/2002, que cria o PMQA - Programa Municipal de Qualidade Ambiental. \\
- Diversas portarias que tiveram como objetivo: criar conselho para revisão de critérios para aquisição de \\
mobiliário; incentivar a compra de madeira certificada; proibir a compra de mogno; estimular a substituição do \\
uso de asbestos na construção, além de criar a comissão gestora da A3P na Secretaria do Verde e do Meio \\
Ambiente. \\
\hline Prefeitura do Rio de Janeiro \\
- Decreto no 21.806/2002, que dispõe sobre o caderno de Encargos para eficiência energética em prédios \\
públicos. \\
- Decreto no 35.745/2012, que cria os selos de qualificação Qualiverde para incentivo dos "prédios verdes" - \\
que adotam métodos construtivos menos agressivos ao meio ambiente e tecnologias de economia e \\
eficiência no uso de água e energia. \\
\hline Municípios dos Estados do Paraná, Santa Catarina e Rio Grande do Sul \\
A produção agrícola orgânica é subsidiada pelos municípios para merenda das escolas públicas. Cerca de \\
230 famílias produzem alimentos para mais de 8 mil estudantes de 4 diferentes cidades. \\
Criação de parcerias entre prefeituras e pequenos produtores familiares para uso de alimento mais saudável \\
nestas escolas.
\end{tabular}

\section{Governo do Estado do Rio de Janeiro}

- Decreto ํㅜ 3.908/2002, que proíbe o uso de alimentos geneticamente modificados nas merendas escolares. - Lei no 5.248/2011, que institui a Política Municipal sobre Mudança do Clima e Desenvolvimento Sustentável da cidade do Rio de Janeiro.

- Lei no 6.439/2013, que determina que veículos leves comerciais, ou pesados devem atender as exigências do Programa de Controle da Poluição do Ar por Veículos Automotores - PROCONVE

\section{Governo do Estado de Minas Gerais}

- Decreto no 44.817/2008, que institui o Projeto Compras Públicas com a finalidade de coordenar a formulação, a execução e a avaliação de políticas públicas, visando ao desenvolvimento econômico, social e institucional do Estado, além de propor e executar políticas públicas nas áreas de recursos humanos, orçamento, recursos logísticos e tecnológicos, modernização administrativa, bem como exercer a coordenação geral das ações do governo.

\section{Governo do Estado de São Paulo}

- Decreto no 41.629/97, que proíbe a aquisição, por entidades do governo, de produtos ou equipamentos com substâncias degradadoras da camada de ozônio controladas pelo Protocolo de Montreal.

- Decreto no 42.836/98, que impõe para a frota do grupo especial da administração direta e indireta a aquisição de veículos movidos a álcool, em caráter excepcional, devidamente justificada, e a aquisição de veículos na versão bicombustível, ou movidos a gasolina, quando não houver modelos na mesma classificação movidos a álcool.

- Lei no 10.761/2001, que dispõe sobre a proibição da utilização de alimentos transgênicos na composição da merenda fornecida aos alunos dos estabelecimentos de ensino oficiais do estado.

- Lei no 10.888/2001, que dispõe sobre o descarte final de produtos potencialmente perigosos do resíduo urbano que contenham metais pesados.

- Decreto n 45.643/2001, que obriga a aquisição, pela administração pública direta, autárquica e fundacional, de lâmpadas de alto rendimento, com o menor teor de mercúrio, entre as disponíveis no mercado (com base em laudos técnicos) e de cabos e fios de alta eficiência elétrica e baixo teor de chumbo e policloreto de vinila (PVC); e recomenda a adoção de providências para observância pela administração indireta.

- Decreto no 45.765/2001, que institui o Programa Estadual de Redução e Racionalização do Uso de Energia e dá providências correlatas.

- Decreto no 48.138/2003, que institui medidas de redução de consumo e racionalização de água.

- Decretos no 49.673/2005 e 49.674/2005, que tornam obrigatório no Estado de São Paulo o uso de madeira legalizada no Estado.

- Lei no 11.878/2005, que institui o "Selo Verde Oficial do Estado de São Paulo".

- Lei no 12.684/2007, que proíbe o uso, no Estado de São Paulo, de produtos, materiais ou artefatos que contenham quaisquer tipos de amianto ou asbesto ou outros minerais que, acidentalmente, tenham fibras de amianto na sua composição.

- Decreto n 53.336/2008 que institui o chamado Programa Estadual de Contratações Públicas Sustentáveis.

\section{Governo do Estado do Paraná}

- Lei no 15.608/2007, que traz a redação em seu art. 5o de que a realização de contratos e convênios está juridicamente condicionada aos princípios universais da isonomia e sustentabilidade ambiental.

- Lei no 16.751/2010, que institui no âmbito do sistema estadual de ensino fundamental e médio, a merenda escolar orgânica. 
No âmbito municipal, foi verificado claramente um baixo número de iniciativas encontradas nos municípios da região Sul, o que vem demonstrar que tal movimento ainda é embrionário.

$\mathrm{Na}$ esfera estadual, observou-se um destaque do estado de São Paulo frente aos demais, devido ao número elevado de leis e regulamentações.

\section{CONSIDERAÇÕES FINAIS}

Ao longo desta pesquisa, pode-se perceber que diversas medidas acerca das CPS foram tomadas nos últimos anos, porém ainda subsistem diversos questionamentos devido à grande complexidade destas contratações, sobretudo no que diz respeito a juridicidade e os limites da licitação sustentável.

Outro ponto que merece destaque é o entendimento limitado do que seja Licitação Sustentável, pois é comumente associada somente a quesitos ambientais, deixando de lado a dimensão social, pilar igualmente importante. Tal desvio pode ser decorrente da importação deste conceito de países de primeiro mundo, que, em sua maioria, já superaram diversos problemas sociais como a escravidão ou o trabalho infantil.

Diante do exposto neste trabalho, observouse que as leis $\mathrm{n}^{-}$12.187/2009 e $\mathrm{n}^{\circ}$ 12.305/2010, bem como a Lei $n^{\circ}$ 12.349/2010, que deu nova redação ao art. 3ำ da Lei ํo 8.666/93, tornaram o arcabouço legislativo suficiente para a consolidação da prática das CPS, confirmando assim, fundamentos jurídicos anteriores, tais como os previstos na CRFB/88.

É inegável que o poder de implantar as licitações sustentáveis está nas mãos do gestor público, que observando os limites de tais contratações, poderá estimular o setor produtivo a fazer mudanças em suas matrizes, tornando disponível à sociedade produtos e serviços socioambientalmente adequados.

Assim, neste estudo foram apresentados procedimentos a serem adotados pelo gestor público e relatadas importantes iniciativas na esfera pública, destacando-se sobretudo a importância do uso adequado da especificação técnica do objeto para a inserção dos critérios ambientais pertinentes e o uso adequado da compra compartilhada sustentável. Destaca-se que a adesão ao Programa A3P tem crescido e se tornado referência quanto à sustentabilidade no setor público, no entanto, por não ser obrigatória a sua adesão e o monitoramento do cumprimento das ações da A3P pelas instituições parceiras, seu efetivo sucesso pode ficar aquém do esperado.

Como limitação, cita-se o levantamento exclusivamente de leis e decretos em alguns estados e municípios da região sul e sudeste, sem considerar a análise da inserção de critérios sustentáveis nos editais de licitação. Outra barreira encontrada é a ausência de comprovação na literatura de que todos os órgãos que aderiram à $\mathrm{A} 3 \mathrm{P}$ transformaram a intenção em prática.

Por fim, este trabalho constatou também que os estados e municípios tem contribuído de maneira incipiente para a implantação das CPS, com destaque apenas para o estado de São Paulo. Para novos estudos, propõe-se investigar as razões da baixa adesão a esta política pública. Futuras pesquisas poderiam verificar ainda a relação entre a organização e o gestor público na escolha por contratações sustentáveis. 


\section{REFERÊNCIAS}

[1] Bim, E. F. Considerações sobre a juridicidade e os limites da licitação sustentável. In: SANTOS, Murillo Giordan; Barki, Teresa Villac Pinheiro (Coord.). Licitações e Contratações Públicas Sustentáveis. Belo Horizonte: Fórum, 2011. p. 175-217.

[2] Biderman, R., L. Betiol, L. Macedo, M. Monzoni, R. Mazon (orgs) ICLEl (2008). Guia de compras públicas sustentáveis. Uso do poder de compra do governo para a promoção de desenvolvimento sustentável. $2^{2}$ Edição, Editora FGV, Rio de Janeiro.

[3] Brasil. Constituição da República Federativa do Brasil de 1988. Disponível em: <http://www.planalto.gov.br/ccivil_03/Constituicao/ Constituicao.htm> Acesso em: 15 jan. 2015.

[4] Brasil. Lei $n$ - 8.666, de 21 de junho de 1993. Dispõe sobre normas gerais de licitações e contratos administrativos no âmbito dos Poderes da União, dos estados, do Distrito Federal e dos municípios. Disponível

em: $<$ http://www.planalto.gov.br/ccivil_03/leis/18666cons .htm> Acesso em: 15 jan. 2015.

[5] Brasil. Lei no 12.187, de 29 de dezembro de 2009. Institui a Política Nacional sobre Mudança do Clima - PNMC e dá outras providências. Disponível

<http://www.planalto.gov.br/ccivil_03/_ato20072010/2009/lei/l12187.htm> Acesso em: 15 jan. 2015.

[6] Brasil. Lei no 12.305, de 2 de agosto de 2010. Institui a Política Nacional de Resíduos Sólidos; altera a Lei no 9.605, de 12 de fevereiro de 1998; e dá outras providências. Disponível em: <http://www.planalto.gov.br/ccivil_03/_ato20072010/2010/lei/l12305.htm> Acesso em: 15 jan. 2015.

[7] Brasil. Lei no 12.349 , de 15 de dezembro de 2010. Altera a Lei $n^{\circ}$ 8.666, de 21 de junho de 1993, 8.958, de 20 de dezembro de 1994, e 10.974, de 2 de dezembro de 2004; e revoga o $\S 1^{\circ}$ do art. $2^{\circ}$ da Lei $n^{\circ} 11.273$, de 6 de fevereiro de 2006. Disponível em: <http://www.planalto.gov.br/ccivil_03/_Ato20072010/2010/Lei/L12349.htm> Acesso em: 15 jan. 2015.

[8] Brasil. Ministério do Meio Ambiente. Agenda Ambiental na Administração Pública A3P. Disponível em: <http://www.mma.gov.br/responsabilidadesocioambiental/a3p/adesão-à-a3p> Acesso em: 28 fev. 2015.

[9] Brasil. Ministério do Meio Ambiente. Adesão à Rede A3P. Disponível em: <http://www.mma.gov.br/mma-em-numeros/a3p> Acesso em: 28 mar. 2015.

[10] BRASIL. Ministério do Meio Ambiente. Relatório de Monitoramento da A3P 2013/12.
Disponível em: <http://www.mma.gov.br/images/arquivo/80063/Apr esentacao\%20de\%20Monitoramento\%20MMA\%20\%202012-2013.pdf> Acesso em: 28 mar. 2015.

[11] Brasil. Ministério do Planejamento, Orçamento e Gestão. Contratações Públicas Sustentáveis. Brasília, 2009. Disponível em: < http://a3p.jbrj.gov.br/pdf/Compras_publicas.pdf> Acesso em: 03 jan. 2015

[12] Brasil. Ministério do Planejamento, Orçamento e Gestão. Compras Sustentáveis na Administração Pública ganham em eficiência econômica. Brasília, 2012. Disponível em: $<$ http://cpsustentaveis. planejamento.gov.br/noticias /compras-sustentaveis-na-administracao-publicaganham-em-eficiencia-economica> Acesso em: 15 jan. 2015.

[13] Brasil. Ministério do Planejamento, Orçamento e Gestão. Informações Gerenciais de Contratações Públicas Sustentáveis. Brasília, 2013. Disponível em: $<$ http://comprasgovernamentais.com.br/wpcontent/uploads/2014/01/01_A_06_INFORMATIVO_ COMPRASNET_Compras_Sustentaveis_2013.pdf> Acesso em: 25 jan. 2015.

[14] Brasil. Supremo Tribunal Federal. ADI n. 3670 DF. Ação Direta de Inconstitucionalidade. Relator: Min. Sepúlveda Pertence. Brasília, 02 de abril de 2007. Disponível em: <http://stf.jusbrasil.com.br/jurisprudencia/14729135 /acao-direta-de-inconstitucionalidade-adi-3670-df> Acesso em: 01 abr. 2015.

[15] Brasil. Instrução Normativa no 01, de 19 de janeiro de 2010. Dispõe sobre os critérios de sustentabilidade ambiental na aquisição de bens, contratação de serviços ou obras pela Administração Pública Federal direta, autárquica e fundacional e dá outras providências. Disponível em:

http://www.comprasnet.gov.br/legislacao/legislacao Detalhe.asp?ctdCod=295> Acesso em: 23 jan. 2015.

[16] Dias, R. Gestão Ambiental: responsabilidade social e sustentabilidade. São Paulo: Atlas, 2006.

[17] Ferreira, M. A. S. O. As licitações públicas $\mathrm{e}$ as novas leis de mudança climática e de resíduos sólidos. In: Santos, Murillo Giordan; BARKI, Teresa Villac Pinheiro (Coord.). Licitações e Contratações Públicas Sustentáveis. Belo Horizonte: Fórum, 2011. p. 117-135

[18] Justen, F. M. Comentários à lei de licitações e contratos administrativos. São Paulo: Dialética, 2009

[19] Curso de direito administrativo. 7. ed. rev. e atual. Belo Horizonte: Fórum, 2011

[20] Meneguzzi, R. M. Conceito de Licitação Sustentável. In: SANTOS, Murillo Giordan; BARKI, 
Teresa Villac Pinheiro (Coord.). Licitações e Contratações Públicas Sustentáveis. Belo Horizonte: Fórum, 2011. p. 19-38

[21] Richardson et al. Pesquisa social: métodos e técnicas. 3. ed. ver. ampl. São Paulo: Atlas, 2007.

[22] Santos, M. G. Poder normativo nas licitações sustentáveis. In: SANTOS, Murillo Giordan; BARKI, Teresa Villac Pinheiro (Coord.). Licitações e Contratações Públicas Sustentáveis. Belo Horizonte: Fórum, 2011. p. 153-173

[23] Silva, R. C.; Barki T. V. P. Compras Públicas Compartilhadas: a prática das licitações sustentáveis. Revista do Serviço Público, Brasília, vol. 63, no 2, abr/jun 2012. Disponível em: < <http://seer.enap.gov.br/index.php/RSP/issue/view/ 19/showToc> Acesso em: 02 abr. 2015.
[24] Terra, L. M. J.; Csipai, L. P.; Uchida, M. T. Formas práticas de implementação das licitações sustentáveis: três passos para a inserção de critérios socioambientais nas contratações públicas. In: SANTOS, Murillo Giordan; BARKI, Teresa Villac Pinheiro (Coord.). Licitações e Contratações Públicas Sustentáveis. Belo Horizonte: Fórum, 2011. p. 219-245

[25] United Nations Department OF Economic And Social Affairs: Division For Sustainable Development. Agenda 21. Rio de Janeiro. 1992. Disponível em: https://sustainabledevelopment.un.org/content/doc uments/Agenda21.pdf> Acesso em: 12 jan. 2015.

[26] United Nations. Report of the World Summit on Sustainable Development Johannesburg, South Africa, 26 August-4 September, 2002. 


\section{Bapítulo 2}

\section{AVALIACÃO DE MODELOS DE NEGÓCIO PARA PRODUÇÃO DE BIOETANOL DE SEGUNDA GERAÇÃO EM ESCALA COMERCIAL}

\section{Maria José de Oliveira Cavalcanti Guimarães \\ Estevão Freire \\ Antonio Calil Neto}

Resumo: Em um mundo em que as economias possuem expressiva dependência do petróleo - principal insumo da matriz energética global - as matérias-primas renováveis, baseadas em tecnologias mais limpas, ganham importância na pesquisa de um novo paradigma para a indústria de biocombustíveis, com vistas à competitividade. Para atingir a produção em escala comercial de bioetanol de segunda geração, através do aproveitamento da palha e do bagaço da cana-deaçúcar, duas empresas brasileiras, GranBio e Raízen, se utilizam de modelos de negócio com vistas a viabilizar a aplicação de estratégias tecnológicas, nas diversas fases de produção, de forma a alcançarem suas respectivas metas de produtividade. Neste trabalho, serão analisados indicadores de parâmetros relativos aos modelos de negócio destas empresas para a produção de bioetanol de segunda geração, a saber: capacidade de absorver inovações, proposta de valor e potencial para incrementar o domínio tecnológico da empresa. Através de análise comparativa destes indicadores, será verificado o grau de excelência do modelo de negócio de cada empresa, considerando as tecnologias por elas utilizadas.

Palavras-chave: Modelo de Negócio; Tecnologia; Bioetanol de Segunda Geração; Escala Comercial; Estratégia. 


\section{INTRODUÇÃO}

As economias do mundo possuem expressiva dependência do petróleo, o principal insumo da matriz energética global, o qual, entretanto, tem causado graves danos ao meio ambiente. Essa ameaça não se limita, entretanto, a questões ambientais, afetando também o plano econômico. Levando-se em conta que o petróleo não é renovável, cada barril processado consiste em um barril a menos nas reservas mundiais.

Neste contexto, as matérias-primas renováveis, baseadas em tecnologias mais limpas, ganham importância na pesquisa de um novo paradigma para a indústria de biocombustíveis, com vistas à competitividade.

Com o intuito de agregar valor aos resíduos gerados nos processos de produção de biocombustíveis de primeira geração, desenvolveu-se a indústria de produção de biocombustíveis de segunda geração, a partir da utilização desses resíduos como matériaprima no processo de produção, com destaque, no Brasil, para a produção de bioetanol de segunda geração.

Ocorre que, para se alcançar a escala comercial, neste e outros segmentos industriais, dois conceitos se ressaltam: tecnologia e modelo de negócio. Segundo Chesbrough (2010), a tecnologia por si só não tem um valor individual objetivo. O valor econômico da tecnologia permanece latente até que seja comercializada de algum modo via um modelo de negócio.

Desta forma, estudar e compreender o modelo de negócio das empresas voltadas para produção em escala comercial do bioetanol de segunda geração contribui para que possam ser desenvolvidas ações de natureza governamental para o fortalecimento do segmento, bem como ações de natureza interna e gerencial, no âmbito das próprias empresas.

\section{OBJETIVO E METODOLOGIA}

Este trabalho possui como objetivo avaliar estratégias com base na comparação de indicadores dos modelos de negócio utilizados por duas empresas nacionais produtoras de bioetanol de segunda geração em escala comercial.

A metodologia utilizada consiste na análise comparativa de indicadores do modelo de negócio de cada empresa produtora de bioetanol de segunda geração em escala comercial, atribuindo-se valores para cada indicador analisado, de acordo com a escala Likert (1979).

\section{MODELO DE NEGÓCIO: VIABILIZANDO A COMERCIALIZAÇÃO DA TECNOLOGIA}

Christensen et al (2009) apresentaram o conceito de modelo de negócio como sendo um sistema interdependente composto por quatro elementos: proposta de valor, recursos, processos e fórmula de lucro. A proposta de valor consiste no produto ou no serviço que pode ajudar os clientes-alvo a realizarem de forma mais eficaz, conveniente e acessível um trabalho que pretendem fazer. Em seguida, os gestores, normalmente, precisam utilizar um conjunto de recursos incluindo pessoas, produtos, equipamentos, instalações, e assim por diante - em determinados processos, os quais são necessários à entrega da proposta de valor aos clientesalvo, de modo a materializar o que se estabeleceu na fórmula de lucro, a saber, o preço exigido, as margens brutas e líquidas de lucros, e os volumes necessários para cobrir vantajosamente os custos dos recursos e processos necessários à entrega da proposta de valor.

Segundo Chesbrough (2010), uma dada tecnologia deverá render pouco valor para a empresa, a menos que um modelo de negócio possa ser encontrado. Também entende que, se outras pessoas, fora da empresa, descobrirem um adequado modelo de negócio, poderão perceber muito mais valor do que a empresa que originalmente descobriu a tecnologia.

Vale frisar que, enquanto Chesbrough (2010) entende que tecnologia só tem valor quando comercializada por meio de um modelo de negócio; Christensen et al (2009) entendem que, para que haja ruptura, não basta possuir tecnologia disruptiva, mas que a mesma seja levada ao mercado por meio de um modelo de negócio.

A crescente importância conferida ao modelo de negócio, visto como mecanismo organizacional para proporcionar tecnologia ao mercado, requer um processo de seleção capaz de identificar qual nova tecnologia mais se adapta à organização, cabendo ao modelo de negócio a função de transformar a tecnologia selecionada em valores 
econômicos para a organização (CHESBROUGH e ROSENBLOOM, 2002), uma vez que descreve a forma de gerar, capturar e entregar valor para a organização (OSTERWALDER e PIGNEUR, 2011).

\section{EMPRESAS BRASILEIRAS PRODUTORAS DE BIOETANOL DE SEGUNDA GERAÇÃO}

Até o fim de 2014, entraram em operação, no Brasil, as duas primeiras fábricas brasileiras de bioetanol de segunda geração, que utilizam a celulose como matéria-prima, oriunda do bagaço e da palha de cana-deaçúcar: uma da GranBio e a outra da Raízen.

A Granbio é uma empresa de biotecnologia, que busca gerar soluções para transformar biomassa em produtos renováveis: biocombustíveis e bioquímicos. A companhia atua em toda a cadeia produtiva do bioetanol de segunda geração - da matéria prima à distribuição do produto final, integrando tecnologias (GRANBIO, 2016a).
A Raízen, por seu turno, é uma empresa de energia, tendo sido criada a partir da união de parte dos negócios da Shell e da Cosan, se encontrando atualmente entre as maiores distribuidoras de combustíveis do Brasil, bem como entre as maiores empresas produtoras de bioetanol de primeira geração do país (RAÍZEN, 2016a).

A primeira fábrica a entrar em operação foi a Bioflex 1, em setembro de 2014, uma unidade da GranBio em S. Miguel dos Campos, em Alagoas, com capacidade inicial de produção de 82 milhões de litros anuais, orçada em R\$ 350 milhões (GRANBIO, 2016b; BATISTA, 2013). A segunda fábrica a entrar operação em escala em comercial no Brasil, em novembro de 2014, pertence à Raízen. Tendo consumido investimentos da ordem de $R \$ 237$ milhões, a unidade foi erguida em Piracicaba, no interior paulista, ao lado da Usina Costa Pinto, que pertence ao grupo, possuindo capacidade para produzir 40 milhões de litros por ano (RAíZEN, 2016b). Os principais atributos de ambas as empresas se encontram descritos na tabela 1:

Tabela 1 - Atributos das empresas voltadas para a produção em escala comercial

\begin{tabular}{|l|l|l|}
\hline \multicolumn{1}{|c|}{ Atributo da empresa } & \multicolumn{2}{c|}{ Granbio } \\
\hline Área & Biotecnologia & Energia \\
\hline Escala comercial & $\begin{array}{l}\text { Em operação desde setembro de } \\
2014\end{array}$ & $\begin{array}{l}\text { Em operação desde novembro de } \\
2014\end{array}$ \\
\hline $\begin{array}{c}\text { Orçamento da fábrica } \\
\text { Capacidade de } \\
\text { Produção }\end{array}$ & $\mathrm{R} \$ 350$ milhões & $\mathrm{R} \$ 237$ milhões \\
\hline
\end{tabular}

Fonte: Adaptado de GRANBIO, 2016b; RAÍZEN, 2016b; BATISTA, 2013

\section{PARÂMETROS E INDICADORES DO MODELO DE NEGÓCIO}

De acordo com Rechziegel e Rodrigues (2013), um Modelo de Negócio apto à seleção de novas tecnologias, em um contexto de inovação aberta, tal como o que caracteriza as estratégias de inovação na arena em foco, haja vista a necessidade de estabelecimento de parcerias entre os principais players, pode ser analisado a partir de três parâmetros desenho organizacional, fatores de negócio e indução competitiva - os quais se encontram divididos em indicadores. De cada um dos citados parâmetros, será selecionado um indicador para ser avaliado, conforme a tabela 2: 
Tabela 2 - Parâmetros e Indicadores Selecionados para Análise do Modelo de Negócio

\begin{tabular}{|c|c|c|c|}
\hline PARAMETRO & $\begin{array}{c}\text { DESENHO } \\
\text { ORGANIZACIONAL }\end{array}$ & $\begin{array}{c}\text { FATORESDE } \\
\text { NEGOCIOS }\end{array}$ & $\begin{array}{c}\text { INDUCAO } \\
\text { COMPETITIVA }\end{array}$ \\
\hline INDICADOR & $\mathrm{x}$ & & \\
\hline Papacida de de Absorver Inovações & & $\mathrm{x}$ & \\
\hline Potencial de Valor & & & $\mathrm{x}$ \\
\hline
\end{tabular}

Fonte: Adaptado de RECHZIEGEL e RODRIGUES, 2013

\subsection{DESENHO ORGANIZACIONAL}

O parâmetro Desenho Organizacional está detalhado nos indicadores da Figura 1.

No âmbito do parâmetro desenho organizacional, quanto ao indicador capacidade de absorver inovações, vale mencionar que, segundo Passos (1999), com a flexibilização da produção, desenvolveramse empresas com enorme capacidade de absorver inovações, tanto as resultantes do esforço interno em pesquisa e desenvolvimento, como as adquiridas de terceiros. A capacidade de absorver inovações ganhou novos contornos nas estratégias empresariais com a difusão por Chesbrough (2003) do conceito de inovação aberta, segundo o qual as empresas exploram novos conhecimentos para além dos limites internos de sua organização e onde a cooperação com empresas e profissionais externos passa a ter um papel preponderante, aliando conhecimentos internos e externos dentro de arquiteturas e sistemas, cujos requisitos são definidos por um modelo de negócio.

Figura 1: Indicadores do Parâmetro Desenho Organizacional

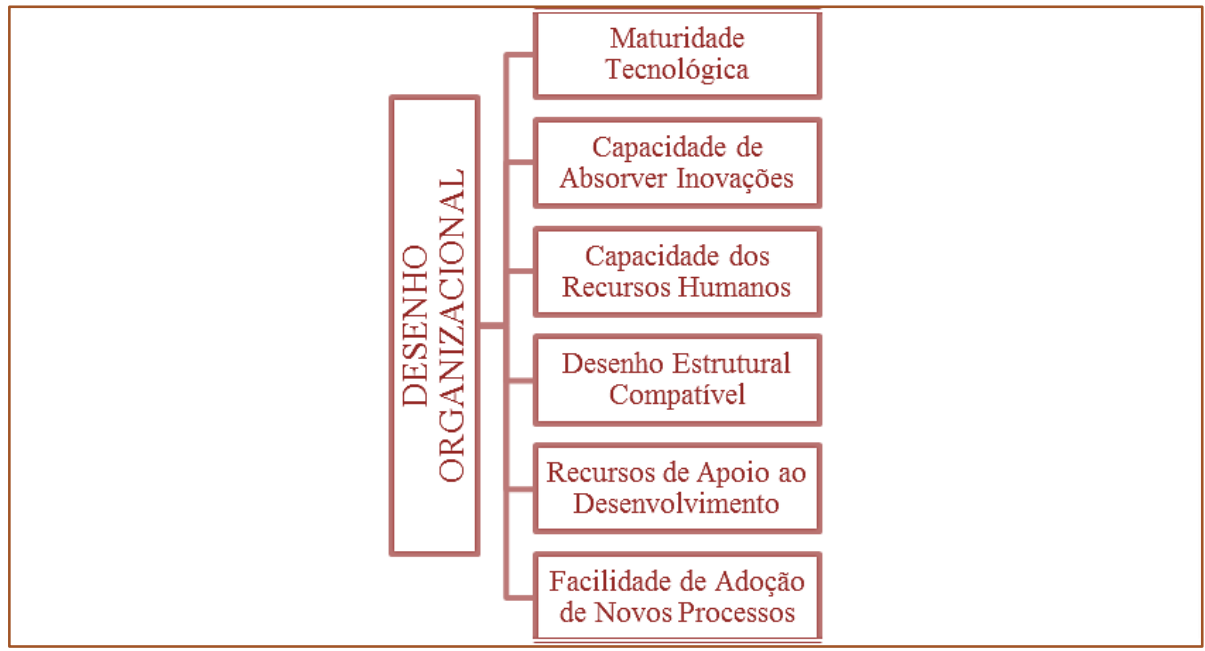

Fonte: Adaptado de RECHZIEGEL e RODRIGUES, 2013

Também no contexto do desenho organizacional, vale destacar o indicador desenho estrutural compativel, que, segundo Carley et al (2008), consiste, para a organização, no adequado relacionamento entre seu pessoal, conhecimento, recursos e atividades. Como explicado por Hoffman \& Kaplinsky (apud AMATO NETO, 1995), um dos principais mecanismos organizacionais para a melhoria da competitividade é a adequação da estrutura ao foco de atenção da empresa, ou seja, aos objetivos que se quer atingir, buscando a obtenção de vantagens decorrentes da diferenciação estrutural. 
Também no contexto do desenvo/vimento organizacional, deve ser destacada a facilidade de adoção de novos processos, a qual pode ser alcançada através da implantação de uma arquitetura corporativa de modo a garantir, por exemplo, o alinhamento da área de tecnologia da informação com a área de negócios, constituindo uma forma abrangente de buscar soluções para questões gerenciais da organização, bem como facilitar a organização nos momentos de mudança ou na incorporação de novas formas de gestão ou ainda na adaptação às novas tecnologias, de modo a assim manter o seu potencial competitivo (LIMBERGER et al, 2010) .

\subsection{FATORES DE NEGÓCIO}

O parâmetro Fatores de Negócio está detalhado nos indicadores mostrados na Figura 2:

Figura 2: Indicadores do Parâmetro Fatores de Negócio

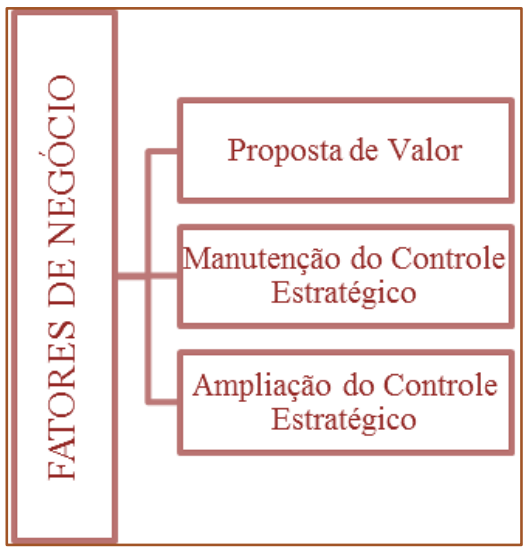

Fonte: Adaptado de RECHZIEGEL e RODRIGUES, 2013

Quanto ao parâmetro fatores de negócio, seu principal indicador consiste na proposta de valor. Teece (2010) identifica modelo de negócio como um conjunto de dados e outras evidências que apresentam a proposta de valor aos clientes, a estrutura viável de receitas e os custos para entregar esse valor. Para Magretta (2002), a proposta de valor de um empreendimento se constitui na junção das diversas partes do negócio, de forma a criar um valor apropriado. Em suma, é o produto e/ou serviço a ser vendido. Conforme afirmam Churchill e Peter (2000) há diversos fatores que podem influenciar o processo de compra do consumidor, dentre eles, pode-se frisar o aspecto novidade do produto, complexidade, qualidade percebida, além da aparência do produto.

\subsection{INDUÇÃO COMPETITIVA}

Na Figura 3, é mostrado o parâmetro Indução Competitiva e os respectivos indicadores: 
Figura 3: Indicadores do Parâmetro Indução Competitiva

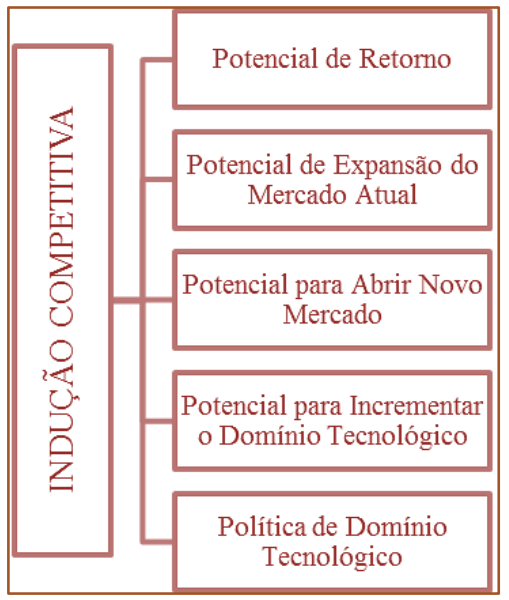

Fonte: Adaptado de RECHZIEGEL e RODRIGUES, 2013

No parâmetro indução competitiva, se destacam os indicadores potencial para incrementar o domínio tecnológico da empresa e política de domínio tecnológico. Vale citar um modelo desenvolvido por Chesbrough (2006) que ilustra a mudança de paradigma da inovação aberta, com repercussão nas estratégias da empresa, em especial quanto à sua política de domínio tecnológico, baseado no modelo do funil de desenvolvimento de produtos proposto por Clark e Wheelwright (1993), no qual são selecionadas apenas ideias com real potencial de retorno financeiro, dentro do modelo de negócio pré-determinado da empresa. Este modelo serviu perfeitamente para a inovação fechada. Entretanto, por apresentar uma série de inconsistências, foi necessária sua retificação, com base no conceito de inovação aberta, de forma a possibilitar que ideias internas as quais, no modelo fechado, seriam filtradas e eliminadas, pudessem buscar lugar em outros modelos de negócio, com a participação da empresa que gerou a ideia, por meio de licenciamento ou royalties

(CHESBROUGH, 2006). Assim, por esse funil "poroso", torna-se possível o fluxo de ideias externas para que sejam absorvidas e incorporadas no modelo de negócio da empresa. Deste modo, modelos de negócio abertos tornam possível que uma empresa seja mais eficiente na criação e na captura de valor, repercutindo favoravelmente no potencial para incrementar o seu domínio tecnológico (CHESBROUGH, 2007).

\section{ANÁLISE E RESULTADOS}

No exame comparativo dos Modelos de Negócios utilizados pelas empresas GranBio e Raízen para a produção de bioetanol de segunda geração, será selecionado para análise um indicador de cada um dos parâmetros acima relacionados.

O método de valoração utilizado será o da Escala Likert, cujo sistema, simples, permite um considerável número de proposições, relacionadas com o objeto a ser estudado. Assim, as proposições são, normalmente, apresentadas de 1 a 5 , onde 1 significa "forte discordância", 2

"discordância", 3 "neutro", 4 "concordância" e 5 "forte concordância" (LIKERT, 1979). Desta maneira, a medição poderá retratar com maior fidedignidade a realidade dos indicadores avaliados, de modo que, quanto maior o grau recebido por uma empresa em relação a um dado indicador, maior é a concordância de que a mesma está atendendo ao citado indicador.

\subsection{DESENHO ORGANIZACIONAL: CAPACIDADE DE ABSORVER INOVAÇÕES}

No que se refere ao parâmetro desenho organizacional, será abordado o indicador capacidade de absorver inovações.

A GranBio tem revelado possuir importante capacidade de absorver inovações, haja vista os resultados obtidos com as parcerias tecnológicas que tem firmado, fazendo uso de tecnologias de ponta desenvolvidas por outras empresas para atender às diversas etapas de produção do bioetanol celulósico. 
Em abril de 2013, a empresa começou o seu processo de internacionalização, adquirindo 25\% da American Process Incorporated (API), nos Estados Unidos, passando a ter acesso a uma plataforma proprietária de pré-tratamento de biomassa que torna possível, com custos reduzidos, o desenvolvimento de açúcar de celulose como matéria-prima para a produção de grande variedade de renováveis (MAXPRESS, 2016). Para que a celulose e a hemicelulose sejam acessadas, o prétratamento da biomassa é realizado com tecnologia desenvolvida pela empresa Beta Renewables. Na etapa seguinte, a hidrólise enzimática é promovida pela ação de enzimas da empresa Novozymes, que quebram a celulose e a hemicelulose em moléculas de açúcares simples, como glicose e xilose. Já na etapa da fermentação, os açúcares são transformados em etanol por leveduras desenvolvidas pela empresa DSM (ZAPAROLLI, 2015).

A Raízen, por seu turno, possui o licenciamento da tecnologia de bioetanol celulósico desenvolvida pela empresa canadense logen Energy, uma join venture em que Raízen e logen Corporation são acionistas com partes iguais. Os resíduos da primeira geração passam por um prétratamento, em que as fibras são desestruturadas e depois transformadas em açúcares solúveis por meio de hidrólise enzimática, sendo utilizada tecnologia de enzimas específicas para a produção de bioetanol de segunda geração, a partir de parceria firmada com a empresa Novozymes, com vistas ao fornecimento e aprimoramento de tecnologia enzimática (SIFAEG, 2016).

Assim, quanto ao indicador capacidade de absorver inovações, verifica-se que ambas as empresas se utilizam de parcerias tecnológicas com vistas a absorver inovações. No entanto, observa-se que a GranBio busca estabelecer parcerias - a fim de otimizar cada uma de todas as principais etapas do processo produtivo de bioetanol celulósico - com empresas cujas inovações se destacam em cada etapa do processo, revelando, assim, dispor a GranBio de significativa capacidade de absorção das diversas inovações geradas pelas diferentes empresas parceiras; ao passo que a Raízen, ao licenciar, praticamente, toda a tecnologia da logen Energy, parece não necessitar da utilização de diferentes estratégias com vistas à absorção das inovações, já que lida, prioritariamente, com sua parceira canadense. Assim, enquanto a GranBio estabelece parcerias com diversas empresas, focando na melhoria da eficiência de cada etapa com vistas a otimizar a eficácia do processo como um todo; a Raízen se concentra em priorizar tecnologias - que tratem de quase todas as etapas desenvolvidas, prioritariamente, por poucas empresas. Desta forma, em que pese ambas as empresas atenderem satisfatoriamente $\mathrm{O}$ indicador em foco, já que revelam capacidade de absorver inovações geradas pelas empresas parceiras, atribui-se, uma pontuação levemente superior para a GranBio, por estar sendo capaz de, ao estabelecer parcerias bem sucedidas com diversas empresas de ponta, absorver inovações especificamente por elas geradas para cada etapa do processo de produção do bioetanol de segunda geração.

\subsection{FATORES DO NEGOCCIO: PROPOSTA DE VALOR}

No que tange ao parâmetro fatores do negócio, será abordado o indicador proposta de valor, o qual está intimamente ligado ao bem produzido em escala comercial, a saber, o bioetanol de segunda geração. Considerando que ambas as empresas buscam agregar valor à sua proposta com vistas à obtenção de preços e custos competitivos para fins de comercialização de bioetanol de segunda geração em escala comercial, nesta análise será abordado o valor sustentabilidade.

O bioetanol de segunda geração da GranBio, por ser criado a partir de um subproduto limpo e renovável, é considerado ecologicamente correto. Segundo a assessoria de imprensa da empresa, trata-se do combustível mais limpo do mundo em intensidade de carbono (7,49g CO2/MJ) índice comprovado pelo ARB (Air Resources Board), da Califórnia, nos Estados Unidos. O cálculo considera as emissões de gás carbônico (responsável pelo efeito estufa) desde a colheita até $\mathrm{o}$ transporte e a distribuição (IAC, 2015).

Por outro lado, a Better Sugarcane Initiative (Bonsucro) é uma certificação global, lançada em julho de 2011, que avalia a sustentabilidade dos produtos fabricados a partir da cana-de-açúcar. A Unidade de produção de bioetanol de segunda geração da Raízen foi certificada com o selo da Bonsucro no início da safra 2014/2015. 
Quanto aos processos certificados, a Raízen foi pioneira na adoção da certificação internacional Bonsucro, criada para a cadeia produtiva da cana-de-açúcar (RAízEN, 2015).

Assim, considerando que o aspecto sustentabilidade dos produtos tem recebido cada vez maior relevância dos órgãos de certificação, verifica-se que as propostas de valor de ambas as empresas, no tocante ao valor sustentabilidade, atendem satisfatoriamente o indicador em análise, uma vez que, se de um lado, o produto entregue pela GranBio revela expressivo valor agregado em face de seu reconhecimento pela ARB; por outro lado, o produto da Raízen, em razão de sua certificação pela Bonsucro, revela também considerável agregação de valor, avaliando-se, portanto, ambas as empresas com a mesma pontuação no que tange a este indicador.

\subsection{INDUÇÃO COMPETITIVA: POTENCIAL PARA INCREMENTAR O DOMÍNIO TECNOLÓGICO DA EMPRESA}

No que concerne ao parâmetro indução competitiva, será abordado 0 indicador potencial para incrementar o domínio tecnológico da empresa.

Através do seu Centro de Pesquisas em Biologia Sintética (Campinas), a GranBio tem focado de forma multidisciplinar, em todas as etapas da cadeia produtiva: desde o campo, através do mapeamento genético da cana-deaçúcar e de estudos de sua composição química, até a indústria, com o desenvolvimento de processos para conversão do açúcar celulósico em produtos renováveis. Além do desenvolvimento de tecnologias próprias, o núcleo atua no codesenvolvimento de tecnologias de parceiros, buscando identificar e testar as melhores tecnologias do processo industrial de produção de bioquímicos e biocombustíveis disponíveis no mundo (LATINOAMERICA, 2016). Outro aspecto que aponta favoravelmente para o potencial de incremento do seu domínio tecnológico se refere ao desenvolvimento da chamada canaenergia, variedade de cana-de-açúcar, com maior potencial produtivo e teor de fibra, adequada para fabricação de bioquímicos e biocombustíveis de segunda geração. Assim, a cana-energia tem se mostrado altamente competitiva como matéria-prima em decorrência de alguns fatores, dentre os quais se destacam: (i) alta capacidade de conversão do carbono atmosférico em carbono orgânico na formação de biomassa; (ii) alta densidade de energia, ou seja, energética e economicamente é uma matériaprima mais eficiente do que aquela de plantas alimentícias; e (iii) plantas adaptadas às condições de estresse e resistentes aos microrganismos maléficos (MATSUOKA et al, 2012). Estes aspectos apontam favoravelmente para a expansão do domínio tecnológico empresa.

Na Raízen, por sua vez, os coprodutos da produção de bioetanol de primeira geração e de açúcar, em parte, são direcionados à cogeração de energia, e, em parte, são utilizados no processo de produção de bioetanol de segunda geração (SIAFEG, 2016). Desta forma, a Raízen tem focado seu negócio também na cogeração de energia, diferentemente da GranBio, cujo modelo de negócio se concentra, prioritariamente, na própria produção de bioetanol de segunda geração. Assim, o potencial para expansão do domínio tecnológico da Raízen, no que concerne à produção de bioetanol celulósico, indicar alguma limitação, uma vez que seu negócio se direciona de forma expressiva para a fabricação de outros produtos, ficando, assim, mais dependente do modelo de aliança com sua parceira, a canadense logen Energy, para o incremento do domínio tecnológico relativo ao processo produtivo do bioetanol de segunda geração.

Em face do exposto, no que tange a este indicador, se avalia a GranBio com um grau levemente superior, mormente por adotar estratégias em pesquisa e desenvolvimento que busquem a expansão de seu domínio tecnológico, com foco específico no processo de produção de bioetanol de segunda geração, não dispersando, de forma significativa, seu esforço tecnológico com a fabricação de outros produtos.

\subsection{CONSOLIDAÇÃO DOS RESULTADOS}

Como resultado da análise dos indicadores relacionados aos modelos de negócio das duas empresas brasileiras produtoras de bioetanol de segunda geração em escala comercial, foram atribuídos os valores dispostos na tabela 3, conforme valoração definida pela Escala Likert. Vale frisar que a avaliação se refere especificamente aos indicadores dos modelos de negócio relacionados à produção de bioetanol de segunda geração, não tendo sido avaliadas 
outras indústrias em que atuem as empresas em pauta. Assim sendo, a empresa GranBio foi avaliada com "forte concordância" em relação aos três indicadores analisados, demostrando que os atende com excelência. A empresa Raízen também foi avaliada com "forte concordância" em relação ao indicador proposta de valor, revelando também que o atende de modo excelente. Quanto aos indicadores capacidade de absorver inovações e potencial para incrementar o domínio tecnológico da empresa, a empresa Raízen foi avaliada com "concordância", tendo em vista que os atende de forma satisfatória, conforme tabela 3.

Tabela 3 - Avaliação Comparativa dos Indicadores dos Modelos de Negócio pela Escala

Likert

\begin{tabular}{|l|c|c|c|}
\multicolumn{1}{c}{ Indicador } & \multicolumn{2}{c|}{ Resa } \\
\cline { 2 - 4 } \cline { 3 - 4 } & Granbion & 4 \\
\hline Capacidade de Absorver Inovações & 5 & & 5 \\
\hline Proposta de Valor & 5 & & 4 \\
\hline $\begin{array}{l}\text { Potencial para Incrementar o Domínio } \\
\text { Tecnológico }\end{array}$ & 5 & & 4 \\
\hline
\end{tabular}

Fonte: Elaboração Própria

\section{CONSIDERAÇÕES FINAIS}

$\mathrm{Na}$ arena competitiva da produção de bioetanol de segunda geração, uma das estratégias adotadas pelos principais players tem sido desenvolver sua própria tecnologia. Outra estratégia consiste em fazer uso de uma tecnologia desenvolvida por outra empresa e montar seu próprio negócio em cima de elementos já existentes.

As principais empresas podem também não desenvolver nenhuma tecnologia própria relevante, mas se dedicar a realizar um mapeamento da arena competitiva para, em seguida, localizar os parâmetros tecnológicos que Ihes faltem para implementação de sua estratégia.

A estratégia competitiva será bem sucedida quando os resultados apontarem que o modelo de negócio utilizado tem potencial para gerar valor para as tecnologias predominantes, atendendo, por conseguinte, os interesses dos stakeholders.

\section{REFERÊNCIAS}

[1] Amato Neto, J.: Reestruturação industrial, terceirização e redes de subcontratação.

[2] Revista de Administração de Empresas, vol.35, n.2, p.32-42, mar/abr, 1995.

[3] Batista, F. Etanol de Segunda Geração ganha escala comercial: Brasil terá 3 Usinas de Etanol Celulósico até 2015. Valor Econômico. São Paulo, 2013.

[4] Carley, K.M.; Columbus, D; DERENO M.; Reminga J.; Moon II-C. Ora User's

[5] Guide 2008. Carnegie Mellon University, 2008.

[6] Chesbrough, H. Open Innovation: The New Imperative for Creating and Profiting from
Embora atuando em setores diversos, duas empresas brasileiras - a GranBio, empresa de biotecnologia, e a Raízen, empresa de energia - operam a produção de biotenol de segunda geração em escala comercial, revelando atender satisfatoriamente indicadores específicos de três parâmetros característicos de modelos de negócio: desenho organizacional, fatores de negócio e indução competitiva, conforme os resultados obtidos na análise e avaliação efetuadas, tendo a GranBio demonstrado atender os referidos indicadores com excelência.

Pode-se imaginar, inclusive, que, considerando que, entre os objetivos dos principais players, se encontra a maximização de resultados, sua atuação vise ir além da produção de bioetanol celulósico, como, por exemplo, no retorno auferido por produtos de maior valor agregado.

Technology. Harvard Business School Press, Boston, MA., 2003.

[7] Chesbrough, $\mathrm{H}$. Open Business Models: How to Thrive in the New Innovation Landscape. Harvard Business School Press, 2006.

[8] Chesbrough, $H$. As novas regras de P\&D, apud: HARVARD BUSINESS SCHOOL

[9] Implementando a Inovação, Elsevier Editora, Rio de Janeiro, pp.57-62, 2007.

[10] Chesbrough, $H$. Business Model Innovation: Opportunities and Barriers. Long Range Planning, Vol. 43, 2010.

[11] Chesbrough, H.; Rosenbloom, R. S. The role of the business model in capturing value from 
innovation: Evidence from Xerox Corporation's technology spinoff companies. Industrial and Corporate Change, v.11, n.3, p.529-555, 2002.

[12] Christensen, C.M.; Grossman, J.H.; Hwang, J. The Innovator's Prescription: A Disruptive Solution for Health Care. McGraw-Hill, 2009.

[13] Churchill, Jr., G. A.; Peter, J. P. Marketing: criando valor para o cliente. 2. ed. São Paulo: Saraiva, 2000.

[14] clark, K.B.; Wheelwright, S.C. Managing new product and process development - Text and cases, Harvard Business School, The Free Press, 1993.

[15] Granbio. Disponível em: <http://www.granbio.com.br/conteudos/quemsomos/>. Acesso em: 10 mai 2016a.

[16] Granbio. Disponível em: $<$ http://www.granbio.com.br/conteudos/biocombust iveis/>.

[17] Acesso em: 10 mai. 2016b.

[18] IAC - Informativo Agropecuário Camrey Ano II. 7aㅡ Edição. S. José do Rio

[19] Preto, 2015.

[20] Latinoamerica Renovable. Brasil: Primera Planta de Etanol 2G de Todo el Hemisferio Sur. Disponível em:

http://latinoamericarenovable.com/2015/02/04/brasi Iprimera-planta-de-etanol-2g-de-todo-el-hemisferiosur/ >. Acesso em: 28 mar 2016.

[21] LIKERT, H. Novos padrões de administração. 2ed. São Paulo: Pioneira, 1979.

[22] Limberger, S. J.; VIANNA, W. B.; SELIG, P. M. Alinhamento estratégico da Tecnologia da Informação (TI) com áreas estratégicas: Uma análise de Abordagens para integração.

[23] Ingepro - Inovação, Gestão e Produção, vol. 02, no. 06, 2010.

[24] Magretta, J. Why business models matter. Harvard business review, v. 80, n. 5, p. 86-93, 2002.

[25] Matsuoka, S.; Bressiani, J. A.; Maccheroni, W.; Fouto, I. Bioenergia da Cana. In: SANTOS, F.; Borém, A.; caldas, C. (Ed.). Cana-de-açúcar: Bioenergia, Açúcar e Álcool. 2 ed. Viçosa: UFV, 2012.
[26] Maxpress. GranBio compra 25\% da empresa norte-americana de tecnologia limpa American Process Inc. (API). Disponível em: <http://www.maxpressnet.com. br/Conteudo/1,5778 91,GranBio_compra_25 da_empresa_nort eamericana_de_tecnologia_limpa_American_Proces S_Inc_API_,577891,4.htm > Acesso em:

[27] 28 março 2016.

[28] Osterwalder, A.; Pigneur, Y. Business Model Generation - Inovação em Modelos de Negócios. Rio de Janeiro: Alta Books, 2011.

[29] Passos, C. A. K. Novos Modelos de Gestão e as Informações. Albagli, Sarita, Lastres, Helena M.M.(org).In: Informação e Globalização na Era do Conhecimento. 1a.ed., Rio de Janeiro: Editora Campus, 1999.

[30] Raízen. Relatório de Sustentabilidade 2014/2015. São Paulo, 2015.

[31] Raízen. Disponível em: $<$ http://www.raizen.com/sobre-raizen/perfil-daempresa-0>. Acesso em: 12 abr 2016a.

[32] Raízen. Disponível em: $<$ http://www.raizen.com.br/energia-do-futurotecnologia-emenergia-renovavel/etanol-desegunda-geracao>. Acesso em: 10 mai 2016b.

[33] Rechziegel, W.; Rodrigues, L.C. Seleção de Novas Tecnologias no Contexto da Gestão da Inovação Aberta: Uma Proposta de Modelo. II Simpósio Internacional de Gestão de Projetos. Simpósio Internacional de Inovação e Sustentabilidade. São Paulo, 2013.

[34] Sifaeg - Sindicato da Indústria de Fabricação de Etanol do Estado de Goiás. Raízen inicia operação de sua primeira unidade de etanol de segunda geração. Disponível em:

[35] <http://www.sifaeg.com.br/informesifaeg/page/11/>. Acesso em: 25 mar 2016.

[36] Teece, D.J. Business Models, Business Strategy and Innovation. Long Range Planning, Vol.43 (Amsterdam: Elsevier Science), 2010.

[37] Zaparolli, D. Biocombustíveis: etanol celulósico enfrenta crise setorial e petróleo mais barato. Química e Derivados. Editora QD. São Paulo, 2015. 


\section{Capítulo 8}

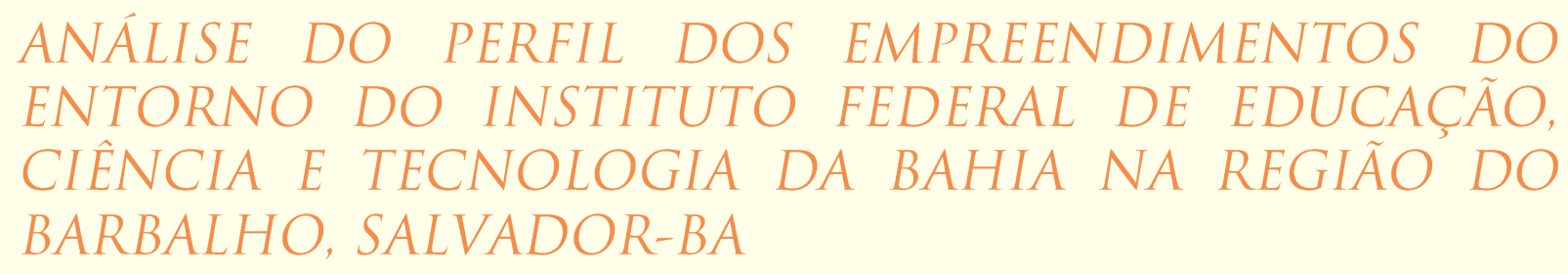

Laís Rocha Pires

Cláudio Palma de Mello

Alexandra Quadro Siqueira

Jowaner de Oliveira Araújo

Luana das Graças Queiróz Farias

Resumo: O entorno do Instituto Federal de Educação, Ciência e Tecnologia da Bahia, tem como uma das principais características a presença de variados empreendimentos comerciais e organizações sem fins lucrativos. Diante dessa observação o IFBA identificou a possibilidade de estabelecer uma aproximação com essas empresas para obtenção de um diagnóstico para futura intervenção. O objetivo geral da pesquisa consiste em traçar um diagnóstico sobre os empreendimentos localizados no entorno do IFBA câmpus Salvador identificando suas principais características e necessidades emergentes a fim de desenvolver futuras intervenções de melhorias. No que se refere à metodologia, a pesquisa em questão classifica-se quanto à natureza, de forma qualitativa e quantitativa; quantos aos objetivos, de caráter exploratório e descritivo. Inicialmente foi feita uma pesquisa bibliográfica, paralelamente a visitas à empresa a fim de se conhecer os métodos de trabalho e analisar as ações sustentáveis desenvolvidas pela mesma durante o processo, além da aplicação de questionário aos colaboradores.

Palavras-chave: Desenvolvimento Econômico, Cultura Glocal, Empreendedorismo 


\section{INTRODUÇÃO}

O Instituto Federal de Educação, Ciência e Tecnologia da Bahia é uma instituição pública que oferece educação gratuita de ensino superior, nível básico e profissional, além de realizar pesquisas e atividades de extensão. Possui 23 câmpus espalhados em toda a região do estado da Bahia, sendo um deles o câmpus Salvador, localizado no bairro do Barbalho.

O estudo em questão surgiu a partir do seguinte questionamento: "Quais as principais características e necessidades emergentes dos empreendimentos localizados no entorno do IFBA, câmpus Salvador ?". Foi fomentada por um grupo de professores e graduandas do curso de Administração, bolsistas do ESTADES (Escritório Técnico de Acolhimento a Demandas e Projetos Sociais). Verificou-se que, as necessidades prioritárias destes sejam relacionadas às qualificações dos responsáveis pelos principais processos gerenciais e sua base empreendedora.

Para atingir tal intento, temos como objetivo geral: traçar um diagnóstico sobre os empreendimentos localizados no entorno do IFBA câmpus Salvador, identificando suas principais características e necessidades emergentes a fim de desenvolver futuras intervenções de melhorias. E, como objetivos específicos: conceituar crescimento econômico e desenvolvimento econômico; distinguir os significados de cultura local, cultura global e cultura glocal; compreender, historicamente, o surgimento e a importância do empreendedorismo para a economia local; realizar um levantamento de dados sobre os empreendimentos situados no entorno da instituição, através da aplicação de questionários; analisar o contexto socioeconômico do bairro do Barbalho e identificar os principais fatores que caracterizam a região; obter um diagnóstico dos empreendimentos locais de maneira a identificar os principais pontos de futura intervenção.

Os empreendimentos situados no entorno do Instituto são caracterizados por apresentar uma grande variedade de segmentos. Foram identificadas empresas que se enquadram como comércio varejista, outras que prestam serviços variados e organizações sem fins lucrativos. Sendo assim, primeiramente, buscamos promover uma maior interação e proximidade entre a instituição e esses empreendedores através de uma pesquisa de campo. Esta pesquisa consistiu na obtenção de informações, mediante aplicação de um questionário elaborado de forma a identificar os fatores de funcionamento operacional e de gestão desses empreendimentos.

Na primeira parte deste artigo, foi feita uma distinção entre crescimento econômico e desenvolvimento econômico, cultura local, global e glocal, relacionando tais conceitos com a economia local. Através desse estudo, buscou-se também compreender alguns aspectos históricos do Barbalho situado em Salvador-BA, e a importância do empreendedorismo para a economia local. $\mathrm{Na}$ segunda parte, foi apresentada a metodologia do trabalho empírico e o diagnóstico proposto. Por fim, as considerações finais encerram temporariamente tal pesquisa, trazendo contribuições relevantes através do levantamento de dados dos empreendimentos de entorno do IFBA para possíveis atuações quanto à solução dos problemas encontrados na pesquisa.

\section{ESTUDO DO CONTEXTO SOCIOECONÔMICO E CULTURAL}

É pertinente destacar alguns termos para facilitar a contextualização das informações levantadas durante a coleta dos dados. A primeira definição relevante é a diferenciação entre 0 crescimento econômico e o desenvolvimento econômico de uma região. Este primeiro corresponde ao crescimento contínuo da renda per capta ao longo do tempo, enquanto o desenvolvimento econômico inclui as alterações da composição do produto e a alocação dos recursos pelos diferentes setores da economia (VASCONCELLOS, 2006, p.403).

Sendo assim, o desenvolvimento econômico abrange o crescimento econômico e a forma como os recursos decorrentes são distribuídos para a promoção qualidade de vida de uma determinada localidade. O alcance do desenvolvimento econômico de uma determinada região pode ser global, glocal e local. Em âmbito global, pode-se retratar o impacto da globalização das economias e a interdependência que se estabeleceu e ainda se estabelece entre os diversos países.

A globalização que promove a interação entre as nações, permitindo aproximação desses países no aspecto econômico, social, político 
assim como também, a comunicação se torna um processo mais rápido independentemente da distância geográfica.

No que se refere ao desenvolvimento local de uma determinada região, verifica-se que está diretamente associado com 0 seu desenvolvimento econômico. São também considerados fatores como as condições em que as pessoas vivem e as perspectivas que possuem em longo prazo. Esse desenvolvimento implica em melhorias no contexto socioeconômico em que esses indivíduos estão inseridos. Segundo pesquisas do sociólogo Juarez de Paula (2008, p.06), o desenvolvimento exige o crescimento das habilidades, conhecimentos e competências das pessoas", o mesmo ainda ressalta que "Investir em capital humano significa investir, sobretudo em educação, condições de saúde, alimentação, habitação, saneamento, transporte, segurança etc."

O sociólogo evidencia que o fator humano é indispensável para a obtenção de resultados, pois buscam idealizar, dinamizar e promover mudanças nesse cenário socioeconômico. Também discute a possibilidade da gestão compartilhada como uma estratégia de desenvolvimento, dessa maneira, a comunidade em questão seria beneficiada com todo o conhecimento de que necessitam para que possam identificar suas oportunidades e dificuldades.

Ainda segundo o autor, a cultura pode ser entendida como algo inerente aos hábitos, costumes e crenças de determinado povo, assim como também, abrange aspectos religiosos artísticos e a ciência. Nesse sentido, a cultura corresponde a uma série de fatores que representam ou caracterizam determinada região, o que influencia o comportamento dos moradores locais e o modo que eles se comportam dentro daquele contexto. Daí temos a descrição do conceito de cultura local.

A primeira definição de cultura que foi formulada do ponto de vista antropológico pertence a Edward Tylor, no primeiro parágrafo do livro Primitive Culture (1871). Tylor procurou demonstrar que cultura pode ser objeto de um estudo objetivo e de uma análise capaz de proporcionar a formulação de leis sobre o processo cultural e evolução. (LARAIA, 2015).

No que se refere à cultura glocal, segundo Turek (2008) Glocal é um conceito up-to- date da antropologia cultural, que denomina a mistura de culturas globais modernas e locais tradicionais. Basicamente, um intercâmbio entre as culturas em todas as suas modalidades. Sendo assim, a cultura glocal corresponde à agregação de culturas globais dentro de uma cultura já existente e, consequentemente, resultando em uma interação global. Nota-se daí que, as culturas não vivem isoladas, portanto, tanto cada cultural local influencia a global, do mesmo modo, a global incide na local. Por isso, vale considerarmos que estes aspectos não podem e nem devem estar desassociados da cultura organizacional dos empreendimentos de qualquer mercado, área de atuação, porte, dentre outros.

\section{A IMPORTÂNCIA DO EMPREENDEDORISMO PARA O DESENVOLVIMENTO UNIVERSIDADE X EMPRESAS \\ LOCAL:}

Considerando aspectos históricos, a origem do empreendedorismo possui diferentes contextos. Dornelas (2015) apresenta alguns exemplos para a definição do termo: Primeiramente, retrata o momento em que Marco Polo buscou estabelecer uma rota comercial para o oriente, no momento seguinte considera o período da Idade Média, em que o empreendedor seria aquele que realizava o gerenciamento de grandes projetos de produção. Posteriormente, no século XVII o empreendedor seria aquele que possuía contratos com o governo para desenvolver alguma atividade ou fornecimento de algum produto.

Segundo Dornelas (2015), o empreendedorismo no Brasil começou a tomar forma na década de 1990, com a criação de entidades como SEBRAE e a Sociedade Brasileira para Exportação de Software (Softex). O SEBRAE oferece todo o auxílio necessário para aqueles que querem iniciar seus empreendimentos e ajudam também na solução dos problemas que esses empreendedores possam encontrar no dia-adia através de cursos e consultorias.

No cenário atual, de acordo com pesquisas realizadas pelo Instituto Brasileiro de Qualidade e Produtividade, o país está dentre os que mais empreendem no mundo. Segundo informações disponibilizadas pelo IBQP (2014), a taxa empreendedora passou de $23 \%$ para $34,5 \%$ nos últimos dez anos. A porcentagem representa a parcela da 
população (na faixa entre 18 e 64 anos) envolvida com um negócio próprio.

De acordo com Dornellas (2015) o surgimento desses empreendimentos gera um impacto bastante positivo na medida em que promove a criação de novos empregos. Essas iniciativas podem ser atribuídas a uma série de fatores a exemplo das dificuldades de alguns conseguirem um trabalho formal que contribui para que busquem diferentes formas de obtenção de renda. Outros acreditam que esse estímulo decorre de mudanças na legislação para os pequenos empreendimentos em 2006. De fato, a Lei Geral da Micro e Pequena Empresa, apresenta uma série de vantagens como, por exemplo, a redução de alguns impostos, facilidade da obtenção de créditos e do alvará de funcionamento entre outros.

Para a conceituação do termo empreendedor, houve muitas discussões e divergências acerca da diferenciação com o termo administrador, sobre quais seriam as semelhanças e diferenças. Segundo Dornelas (2015) o empreendedor tem algumas características e atitudes que 0 diferenciam do administrador tradicional. O empreendedor busca constantemente por inovações, possui um comportamento de proatividade, busca participar ativamente do contexto em que está inserido, está sempre motivado com novas ideias, identifica oportunidade e riscos calculados. O empreendedor precisa estar sempre atualizado e sintonizado com o ambiente para que sua ideia tenha alguma aplicabilidade, atendendo às demandas identificadas ou aproveitando alguma variável ambiental que possa surgir no momento, enfim, que tem atitude necessária para empreender.

Quanto às parecerias entre as Universidades e as empresas, observa-se que, segundo Dornellas (2005), de um modo geral, as empresas não buscam as universidades ou institutos de pesquisas para a obtenção de auxílio em suas atividades. Isso pode ocorrer pela falta de informações, pois muitos não sabem que podem contar com esse tipo de apoio. Dornelas (2015) traz como exemplo o Disque Tecnologia que, além de solucionar os problemas das empresas, é uma forma de baixo custo e acessível a qualquer pequena empresa com problemas tecnológicos.

Visando atender as necessidades identificadas após o diagnóstico, que será detalhado mais adiante, o ESTADES
(Escritório Técnico de Acolhimento a Demandas e Projetos Sociais) surgiu com a proposta de estabelecer um contato com o entorno e com isso acolher os empreendimentos comerciais e sociais de forma a intervir na realidade local, mobilizando e assessorando os grupos locais identificados. Dentro da proposta do ESTADES foi idealizado, o PAEE (Projeto de Apoio aos Empreendimentos do Entorno) do IFBA (Instituto Federal de Educação, Ciência e Tecnologia da Bahia), cuja finalidade estabelecer um vínculo entre IFBA e a comunidade, a princípio com foco no entorno. Será efetuado um diagnóstico do contexto local de maneira a obter informações detalhadas sobre a gestão desses empreendimentos, identificando aqueles que necessitam de intervenção em suas atividades seja de produção, comércio ou organizações sociais sem fins lucrativos, auxiliando-os na busca por melhorias e correções dos problemas encontrados.

\section{ENFOQUE METODOLÓGICO DA PESQUISA}

O bairro do Barbalho, espaço delimitado para a pesquisa, está situado no Centro Histórico de Salvador, primeira capital do Brasil. A região mantém a mesma este estrutura do período da colonização. O Elevador Lacerda, um dos principais pontos turísticos da cidade, estabelece uma conexão entre a cidade alta e baixa e do Pelourinho até o Barbalho. Esses locais são conhecidos em todo mundo, pela arquitetura dos casarões antigos, museus e igrejas além das ladeiras que ligam essas localidades.

Por estar localizado na cidade alta, o primeiro local representativo do bairro é o Forte, como é conhecido, segundo Castro (2007), o local foi um dos principais baluartes na expulsão dos holandeses da Bahia no século XVII. Caracteriza-se por ser uma das mais antigas construções onde aconteceram grandes conflitos na busca pela independência do país desde o ano de 1638.

O bairro apresenta como principais vias de acesso a Ladeira da Água Brusca e também pela Ladeira do Arco e do Funil. A região possui os mais variados empreendimentos comerciais, voltados para a comercialização de produtos e algumas empresas que também prestam serviços. São lojas de roupas, supermercados, farmácias, assim 
como também, distribuidora de água, gráficas, dentre outros.

No que se refere à metodologia, o estudo em questão classifica-se quanto à natureza, de forma qualitativa e quantitativa; quanto aos objetivos, de caráter exploratório e descritivo. O presente estudo foi desenvolvido inicialmente através de uma pesquisa bibliográfica, para compor o referencial teórico, paralelamente a visitas que foram feitas aos estabelecimentos juntamente com os integrantes do ESTADES, a fim de se conhecer a realidade local.

As informações que compõem este artigo foram obtidas através de visitas exploratórias nos empreendimentos estabelecidos no entorno da instituição com aplicação de questionários com os gestores de cada empresa. A pesquisa caracterizou-se pela obtenção de dados primários na medida em que foram coletados diretamente no local de estudo, e dados secundários, pois, foram necessárias informações previamente obtidas em outras fontes atualizadas para composição do aporte teórico e elaboração do questionário.

Os dados obtidos se baseiam em pesquisas, predominantemente, quantitativas em que foram identificados determinados padrões representados em valores percentuais em ilustrações gráficas. O questionário foi elaborado após adaptações do caderno de questões do SEBRAE (Serviço Brasileiro de Apoio às Micro e Pequenas Empresas), de maneira a alcançar a maior objetividade, aproveitamento e facilidade na posterior tabulação e interpretação dos resultados.

Inicialmente, foram aplicados modelos com perguntas subjetivas, porém, verificou-se que a interpretação dos dados não seria tão simples quanto um modelo com questões objetivas. Além disso, o modelo inicial não possuía as questões necessárias para a obtenção de um maior detalhamento sobre as empresas pesquisadas. A partir do modelo inicial, foram sugeridas algumas melhorias tais como, reformulação de perguntas, alterações no formato e organização das perguntas em blocos específicos. Esses blocos visavam agrupar as perguntas sobre aspectos operacionais, relacionadas às finanças e voltadas para o mercado e calculados os percentuais das respostas para posterior intepretação dos resultados.

O grupo Questões Caracterização do Empreendimento objetiva a obtenção de informações relacionadas ao número de funcionários, tamanho do empreendimento, tipo de organização, horário de funcionamento, tempo de existência e a descrição dos produtos e serviços ofertados. O grupo Perfil do gestor visa obter informações sobre o perfil do gestor, a formação profissional do gestor, a renda, o tempo de experiência na área $e$ as necessidades de treinamento e consultoria. $\mathrm{O}$ grupo referente às Questões de Operacionais tem como finalidade de identificar características relacionadas ao funcionamento do empreendimento a Antecipação a problemas operacionais, tais como produção, atendimento, administração, eficiência e prazo de entrega. O grupo Questões de Finanças identifica aspectos relacionados ao fluxo de caixa, receita total, cálculo de indicadores de desempenho (lucro mensal, margem de contribuição, lucratividade e rentabilidade) e cálculo periódico do lucro. O grupo de Questões de Mercado refere-se a informações de atualização de cadastro de clientes e atendimento das exigências dos clientes, os meios de divulgação utilizados, atualização de cadastro de fornecedores, a visibilidade do empreendimento da comunidade e os principais problemas e desafios. Todos esses ajustes finais possibilitaram uma pesquisa rápida, organizada e de fácil entendimento.

A pesquisa ocorreu no período entre a segunda semana de outubro e a primeira semana de novembro do ano de 2015, perfazendo o total de 43 empreendimentos, desse quantitativo, apenas, 38 se disponibilizaram a responder o questionário. No que se refere à tabulação dos dados, foi utilizado uma planilha eletrônica como ferramenta para análise, onde os dados foram analisados de forma quantitativa e qualitativa, a fim de se obter uma melhor compreensão sobre as atividades desempenhadas pelo projeto e bem como a sua integração a referida empresa e seus resultados.5.

\section{DISCUSSÃO E ANÁLISE DOS RESULTADOS}

Esta seção discute os resultados obtidos durante o levantamento de dados para o estudo de caso e é composta pelas seguintes seções: $5.1 \quad$ Caracterização do Empreendimento, 5.2 Perfil do Gestor, 5.3 Questões Operacionais, 5.4 Questões de Finanças e 5.5 Questões de Mercado. 


\section{1 CARACTERIZAÇÃO \\ EMPREENDIMENTO}

DO

O primeiro grupo de perguntas consistia na caracterização dos empreendimentos, como

Figura 1: Número de funcionários

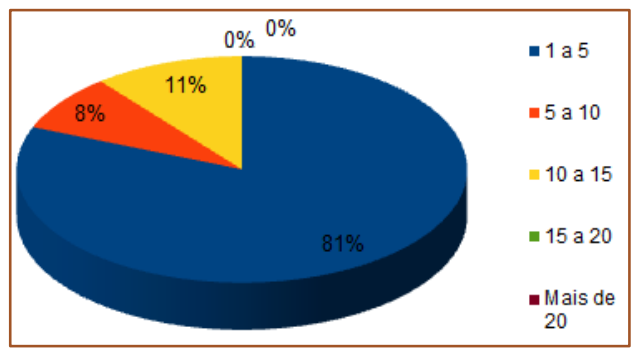

Fonte: Elaborado pelo autor

Conforme ilustrado na figura 1 , foi constatado que $81 \%$ dos empreendimentos possuem de 1 a 5 funcionários apenas, tal quantitativo provavelmente está relacionado ao fato de grande parcela se caracterizar como microempreendimentos, o que corresponde a $62 \%$ do total, de acordo com a figura 2. Os restantes dos empreendimentos apresentam por exemplo, os dados de identificação e caracterização da empresa, produtos e serviços ofertados. Os gestores foram questionados sobre o número de funcionários que possuíam no estabelecimento. Segue a representação gráfica das respostas obtidas:

Figura 2: Tamanho do empreendimento

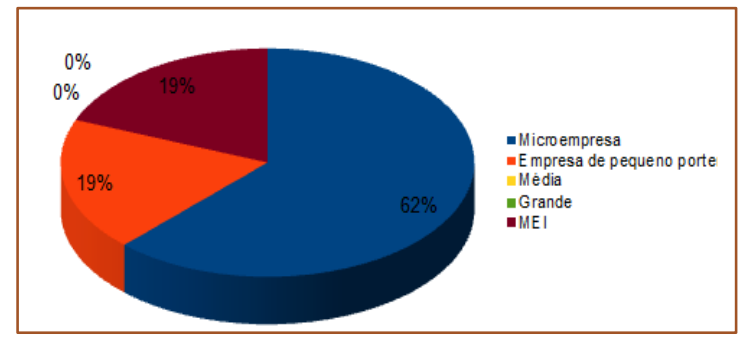

Fonte: Elaborado pelo autor

apenas de 10 a $15(11 \%)$ e 5 a 10 (8\%) funcionários. Constata-se ainda que, nenhuma empresa possui um quantitativo acima de 15 funcionários.

$\mathrm{Na}$ análise seguinte foram questionados sobre o tipo de organização, ou seja, como a empresa se classificava. Segue abaixo o gráfico que representa os dados obtidos:

Figura 3 - Tipo de organização

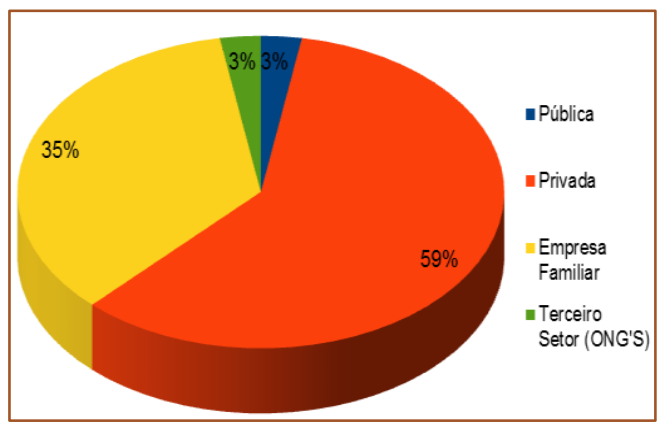

Fonte: Elaborado pelo autor

Como representado na figura 3 , verificou-se que, as maiores parcelas são compostas por empreendimentos privados, correspondente a 59\% do total e Empresas Familiares, 35\%. O restante $(6 \%)$ representa o quantitativo de empreendimentos públicos e do terceiro setor ( $3 \%$ cada).

Posteriormente, foram questionados sobre o tempo de existência da empresa, segue representação na Figura 4: 
Figura 4: Tempo de existência

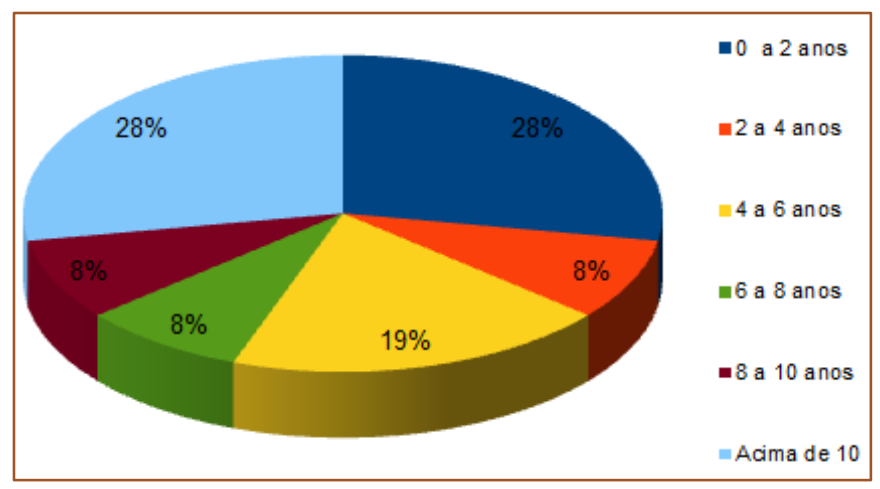

Fonte: Elaborado pelo autor

Identificou-se que, 28\% correspondem a empreendimentos que se enquadram no intervalo de 0 a 2 anos, assim como, também, o mesmo percentual representa aqueles que estão no mercado acima de 10 anos. O terceiro maior quantitativo é composto por empreendimentos que estão no mercado no período de 4 a 6 anos. Os que estão no intervalo de 2 a 4 anos, 6 a 8 anos e 8 a 10 anos, representam $8 \%$ do total pesquisado.

Os gestores foram questionados também sobre os tipos de produtos e serviços ofertados pela empresa, segue ilustração:

Figura 5 - Descrição dos Produtos e Serviços Ofertados

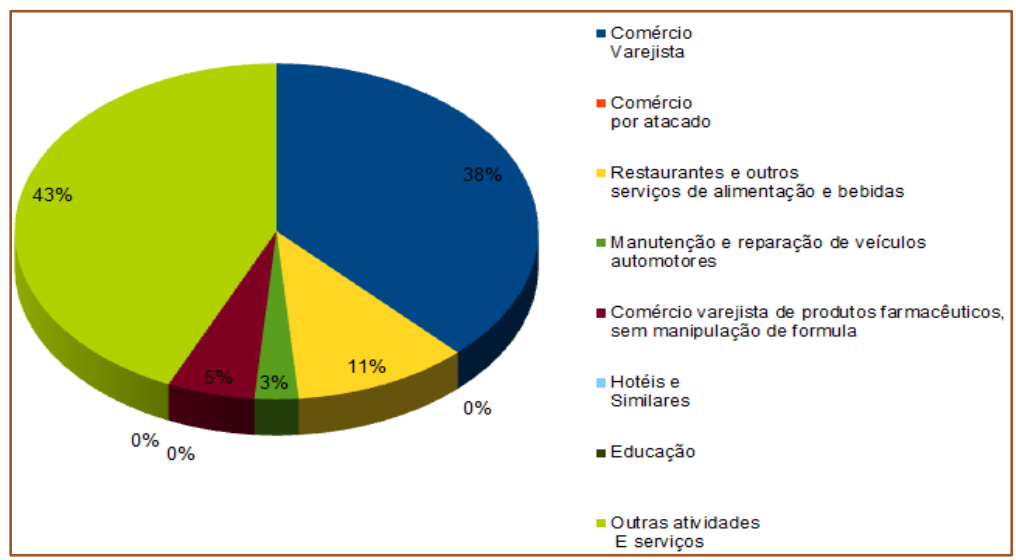

Fonte: Elaborado pelo autor

Na região pesquisada, ao se considerar o tipo de produto e/ou serviço ofertado, verificou-se que as atividades são bastante variadas, sendo que esse quantitativo representa $43 \%$ do total. São atividades diversas como: confecção de cópias de chaves, petshops, gráficas, vendas de produtos artesanais, entre outros. A segunda maior parcela (38\%) é representada por empreendimentos enquadrados como comércio varejista, seguindo por restaurantes e outros serviços de alimentação que corresponde a $11 \%$ do total. De todas as empresas pesquisadas $89 \%$ possui registro.

\subsection{PERFIL DO GESTOR}

Quando perguntados sobre a sua formação profissional os resultados obtidos foram os seguintes: 
Figura 6 - Formação Profissional do Gestor

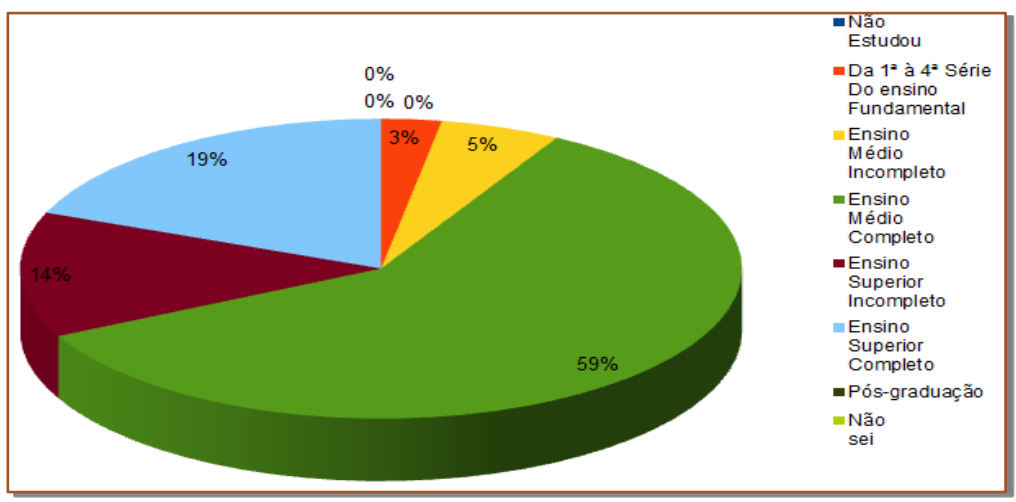

Fonte: Elaborado pelo autor

Verificou-se que 59\% dos gestores possuem como formação acadêmica apenas o ensino médio completo e 19\% apresenta ensino superior. O restante possui ensino médio incompleto, que corresponde a $14 \%$, e outros possuem somente o ensino médio incompleto e conclusão da $1^{a}$ a $4^{\text {a }}$ série, $5 \%$ e $3 \%$ respectivamente. É importante ressaltar a importância de oferecer uma boa capacitação profissional a esses empreendedores, visto que muitos demandam conhecimentos específicos em determinadas áreas, principalmente, por serem empreendimentos gerenciados por poucos que não apresentam conhecimentos administrativos, financeirocontábeis e econômicos.

Os gestores também foram questionados sobre a sua Renda. Segue o gráfico com representação:

Figura 7 - Renda do Gestor

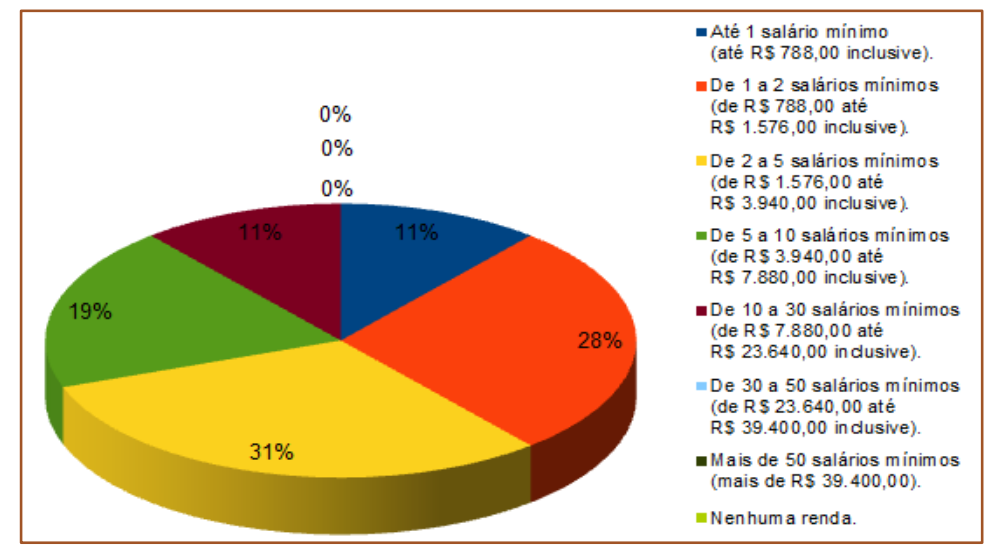

Fonte: Elaborado pelo autor

A grande parcela (31\%) da renda desses gestores está no intervalo de dois a cinco salários mínimos, essa renda razoável pode estar relacionado ao fato de a grande maioria desses estabelecimentos possuírem, apenas, pouco tempo no mercado. Ainda sobre o levantamento das características operacionais da empresa, os empresários foram questionados sobre o tempo de experiência que possuíam na área. Segue a representação: 
Figura 8 - Tempo de experiência na área

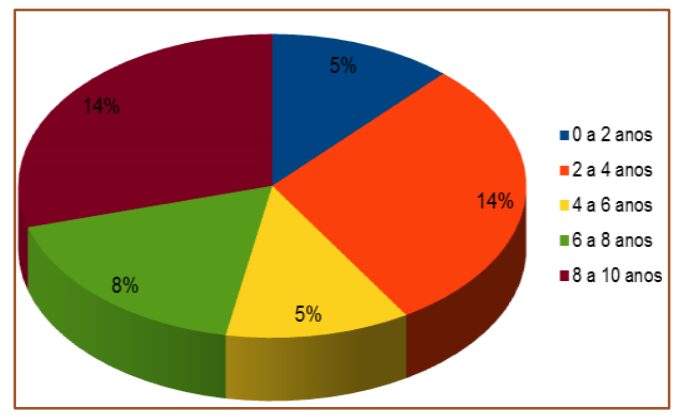

Fonte: Elaborado pelo autor

Constatou-se que, a maioria dos entrevistados apresenta de 2 a 4 anos e 8 a 10 anos atuando nessa área, ambos correspondem a $14 \%$. Foram levantadas questões de Funcionamento Operacional, e os gestores foram questionados sobre o recebimento de

Figura 9 - Áreas com necessidades de treinamentos e consultorias

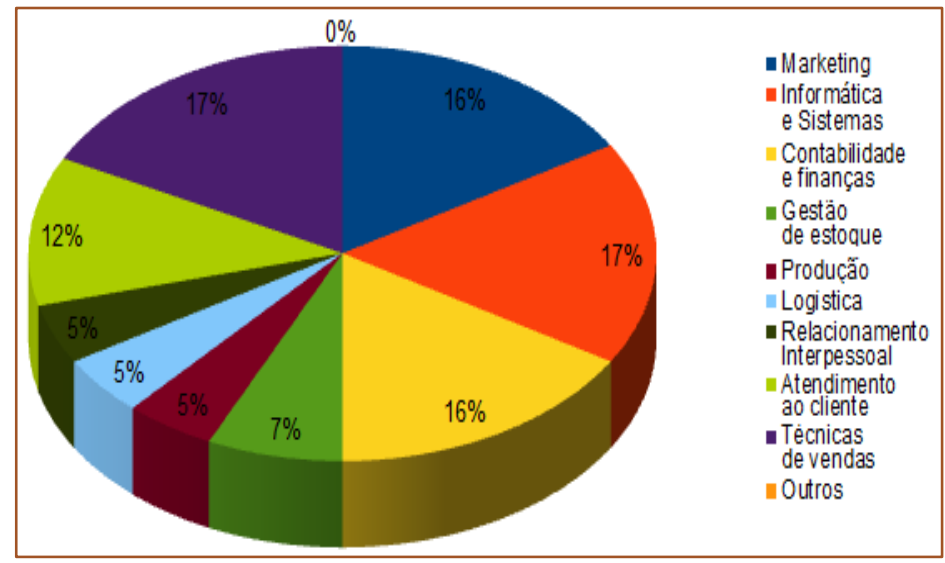

Fonte: Elaborado pelo autor

As principais demandas identificadas para futuras intervenções através de treinamentos e minicursos foram: Técnica de vendas e Informática representando o mesmo percentual (17\%), posteriormente, o Marketing que correspondeu a $16 \%$ e Atendimento ao cliente, $12 \%$.

São cargos que demandam conhecimentos em gestão empresarial e, como exposto, foram delimitadas em áreas específicas como, por exemplo, marketing, finanças, vendas entre outras. Essas constatações foram obtidas após levantamento e o diagnóstico das dificuldades identificadas pelos gestores. algum tipo de apoio institucional nas atividades da empresa. Muitos informaram que não receberam auxílio institucional de nenhuma empresa em suas atividades, representando $73 \%$ total, enquanto 27 informaram que receberam algum tipo de auxílio. 
Figura 10 - Antecipação a problemas operacionais (produção, atendimento, administração, eficiência e prazo de entrega)

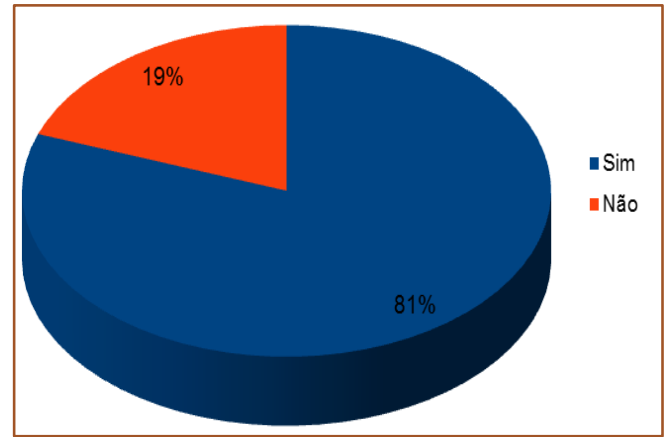

Fonte: Elaborado pelo autor

Aproximadamente $81 \%$ dos gestores entrevistados informaram que se antecipam a possíveis problemas operacionais. Destacase a importância de se implementar uma gestão com ações preventivas diante das possíveis falhas operacionais, considerando os fatores citados evitando assim possíveis prejuízos.

Os gestores também foram questionados sobre a definição de funções dos colaboradores e se existe o compartilhamento dessas informações. Como a maioria dos empreendimentos são classificados como microempreendimentos o número de funcionários tende a ser menor. Uma parcela considerável de $45 \%$ informou que apresentam poucos funcionários, não necessitando dessas definições.

Sobre as áreas que acreditam necessitar de treinamentos e consultorias e, dentre as alternativas informadas, seguem os resultados obtidos:

\subsection{QUESTÕES DE FINANÇAS}

No momento seguinte foram aplicadas Questões de Finanças sobre os aspectos financeiros, os gestores foram questionados se efetuam atualização no fluxo de caixa. Segue representação gráfica:

Figura 11 - Atualizam o fluxo de caixa

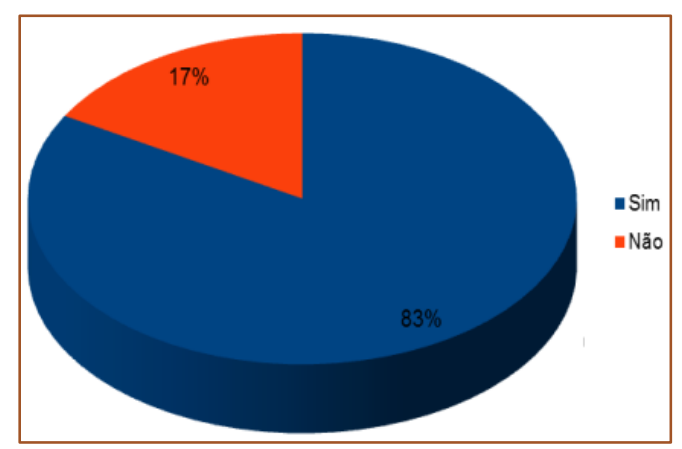

Fonte: Elaborado pelo autor

A grande maioria, que representa $83 \%$ do total pesquisado, informou que realiza a atualização do fluxo de caixa periodicamente o restante 17\% informou que não o faz.

Ainda, com relação às finanças da empresa, os gestores foram questionados se efetuam o
Cálculo da Receita Total, Cálculo do Indicador de Desempenho (lucro mensal, a margem de contribuição, a lucratividade e a rentabilidade) e o Cálculo Periódico do Lucro. Seguem as representações gráficas

a seguir: 
Figura 12 - Cáculo da ReceitaTotalFigura

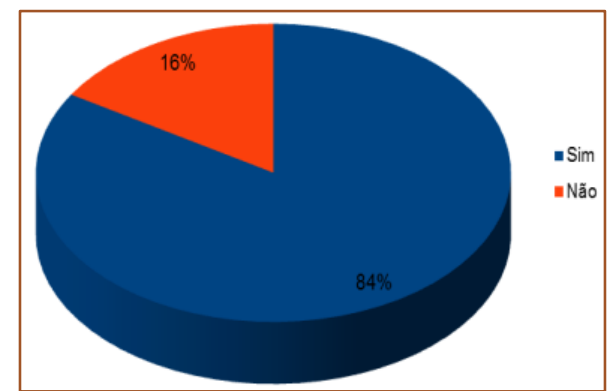

Fonte: Elaborado pelo autor
Figura 13 - Cálculo do indicador de desempenho abaixo:

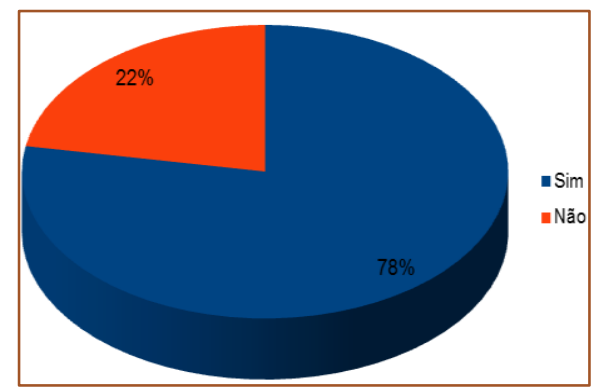

Fonte: Elaborado pelo autor

Figura 14 - Cálculo periódico do lucro

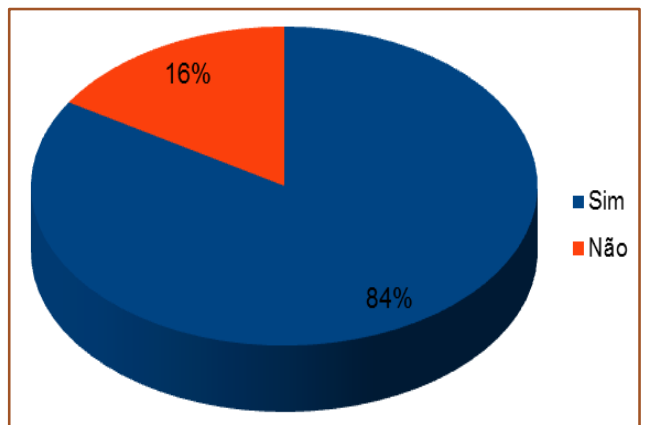

Fonte: elaborado pelo autor

Referente ao Cálculo da Receita Total 84\% informou que efetua o cálculo assim como o mesmo quantitativo informou que realiza o Cálculo Periódico do lucro. 78\% responderam que também realizam o cálculo do indicador de desempenho.

Foi identificado que alguns não apresentavam conhecimentos muito específicos sobre os aspectos financeiros da empresa, pois demostraram um pouco de incerteza durante a entrevista.

\subsection{QUESTÕES DE MERCADO}

No quesito referente a Questões de mercado, foram questionados sobre a existência e atualização de um cadastro de clientes. Segue representação gráfica:

Figura 15 - Atualizam um cadastro de clientes

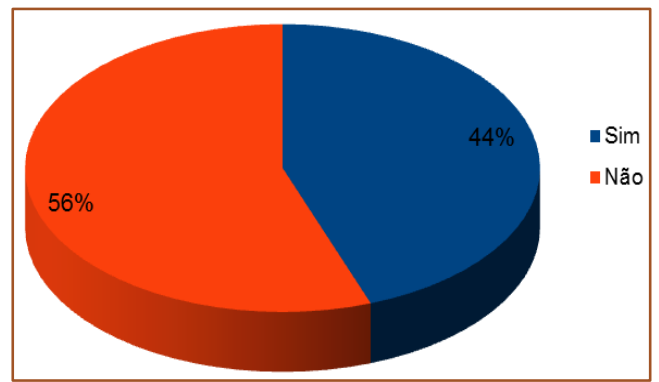

Fonte: Elaborado pelo autor 
Conforme ilustrado na figura 56\% informou que não é efetuada nenhuma atualização como ilustrado, em contrapartida 44\% informou que sim. Nesse aspecto o quantitativo de empreendimentos que não atualizam um cadastro de clientes é muito representativo, sendo que o contato com o cliente e sua manutenção é de fundamental importância para fidelizá-los e até ampliar o seu quantitativo.

No momento seguinte foram questionados se atendem as exigências desses clientes e se buscam obter informações sobre a satisfação deles, $89 \%$ informou que Sim.

Figura 16 - Atende as exigências dos clientes e preocupa-se em obter informações a respeito da satisfação deles

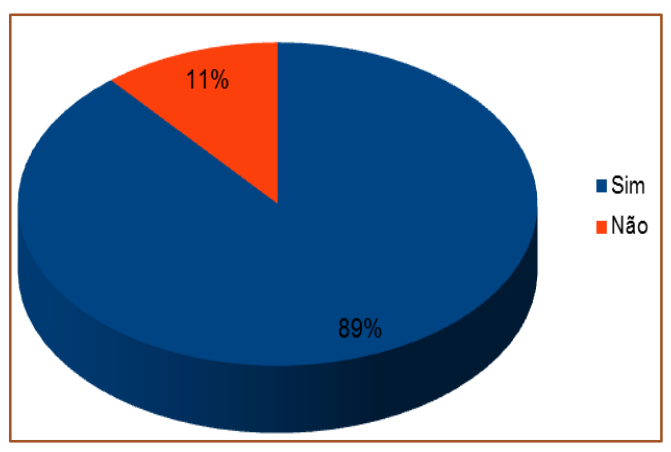

Fonte: Elaborado pelo autor

Considerando a divulgação do empreendimento, os gestores foram questionados sobre tal prática e os meios que normalmente utilizam com esse fim. Seguem resultados obtidos em representação gráfica:
Figura 17 - Meios de divulgação mais utilizados

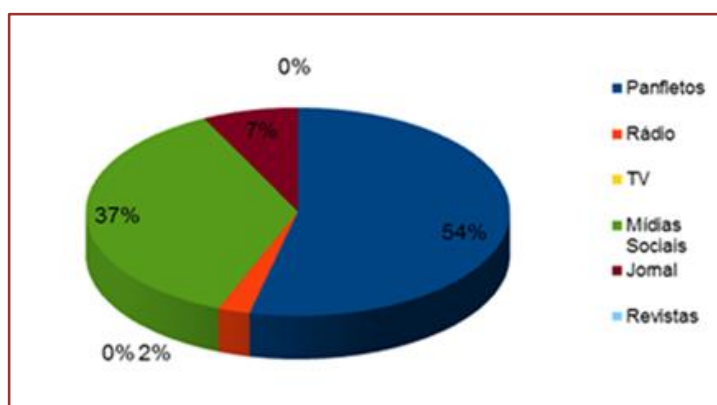

Fonte: Elaborado pelo autor
Figura 18 - Divulgam o negócio?

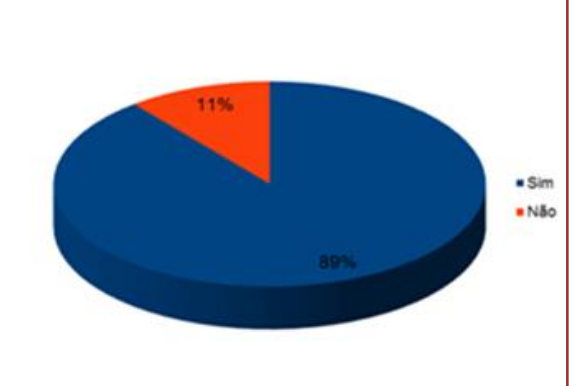

Fonte: Elaborado pelo autor
Foi constatado que a grande maioria que representa $89 \%$ do total, busca a divulgação do negócio, sendo que os principais meios utilizados são a distribuição de panfletos (54\%), as mídias sociais (37\%), uma minoria utiliza jornais $(7 \%)$ e rádios $(2 \%)$. Sobre a atualização do cadastro de fornecedores, segue ilustrado no gráfico abaixo: 


\section{0}

Figura 19 - Atualiza cadastro de fornecedores (preço, condição de pagamento)

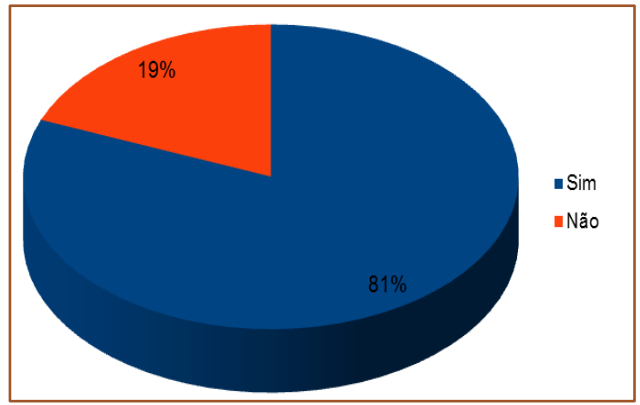

Fonte: Elaborado pelo autor

Os gestores foram questionados se possuíam algum controle (planilhas, tabelas) dos preços e das condições de pagamento. 81\% dos entrevistados informou que possuíam. Os responsáveis pela organização também foram

\begin{abstract}
questionados se acreditavam que seu empreendimento é conhecido na comunidade, a grande maioria (83\%) informou que acreditavam que sim, segue ilustração:
\end{abstract}

\section{Figura 20 - Visibilidade do empreendimento na comunidade}

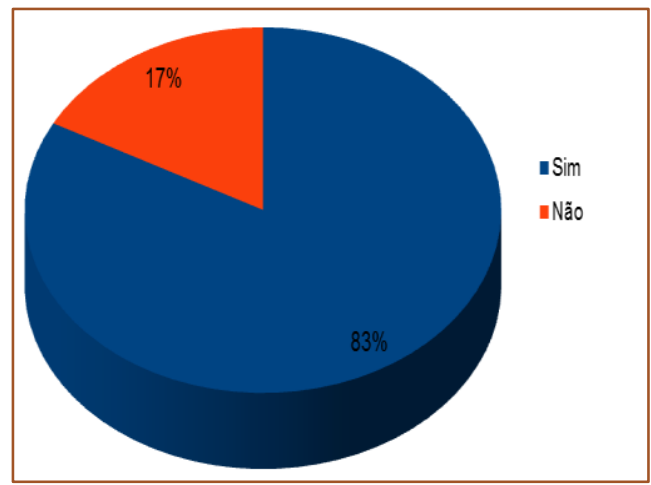

Fonte: Elaborado pelo autor

Quando questionados sobre os principais problemas e desafios encontrados por esses empreendimentos segue a representação gráfica.

Figura 21 - Principais problemas e desafios

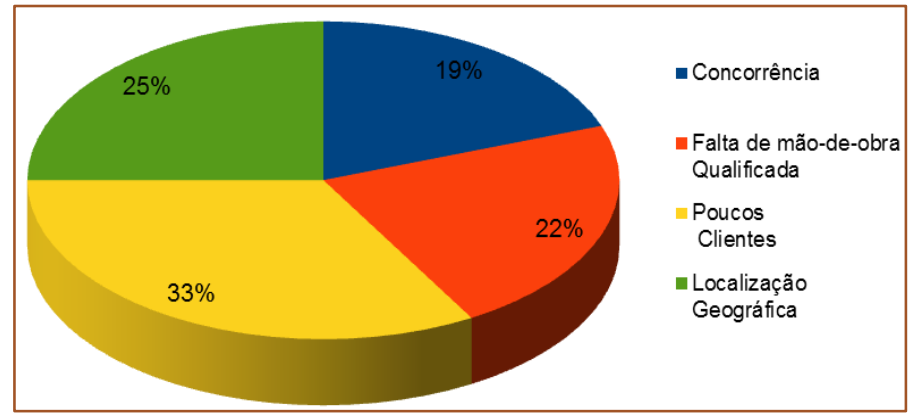

Fonte: Elaborado pelo autor 
Os gestores informaram que o maior problema é o quantitativo de clientes, considerado insuficiente, que representou $33 \%$ do total. O segundo maior problema exposto foi a localização geográfica, que resultou em $25 \%$ das opiniões e, em seguida, $22 \%$ informaram que a falta de mão de obra também é considerada bastante escassa. Logo, 19\% afirmou que a concorrência seria um problema relevante para a empresa.

No que se refere aos principais problemas identificados e os respectivos percentuais quantificados podem ser sugeridas alternativas considerando os meios de divulgação utilizados de maneira a alcançar um maior público, gerando maior visibilidade para o empreendimento.

\section{CONSIDERAÇÕES FINAIS}

A pesquisa surgiu da possibilidade de se identificar as características e necessidades dos empreendimentos comerciais e sem fins lucrativos situados no entorno do instituto resultando em um diagnóstico para futuras intervenções.

Iniciou-se com a contextualização geral e embasamento teórico e posterior aplicação de questionário com vistas exploratórias nos empreendimentos. A princípio o perfil dos gestores foi analisado (nível de escolaridade, idade, experiência e renda), posteriormente foram questionados com perguntas de cunho operacional, questões sobre as finanças, sobre o mercado no qual a empresa está inserido.

A estimativa inicial foi de alcançar no mínimo

\section{REFERÊNCIAS}

[1] Araújo, Bráulio S. Lei Geral das Micro e Pequenas Empresas - Quais os principais desafios? Disponível em: <http://www.ibahia.com/> Acesso em 15 de Dezembro de 2015.

[2] Castro, Zezão. Um bairro que é pura história.Disponível em: <http://atarde.uol.com.br/> Acesso em 28 de Dezembro de 2015.

[3] Conheça Salvador da Bahia Disponível em: <http://www.salvadorbahia.org/> Acesso em 28 de Dezembro de 2015.

[4] Cultura - Disponível em: $<$ http://brasilescola.uol.com.br/cultura/> Acesso em 25 de Janeiro de 2016;

[5] Dornelas, José Carlos Assis. Empreendedorismo: Transformando ideias em negócios. Rio de Janeiro: Empreende/LTC, 2015. [6] Ibpt (Instituto Brasileiro de Planejamento e Tributação)Disponível em:
43 empreendimentos, porém apenas 38 se disponibilizaram a responder. Com esses dados foi realizada a tabulação de todas as informações, com a utilização de planilhas eletrônicas, que resultou na elaboração de gráficos ilustrativos com os resultados obtidos.

Através da consolidação dos dados foi possível obter uma visão geral das principais demandas por treinamentos e/ou consultorias e suas respectivas áreas. Grande percentual das empresas enquadra-se como microempreendimentos com poucos funcionários cujo tempo de existência é variável. São empresas caracterizadas como comércio varejista e prestadores de serviços. Não existe um acompanhamento das ações dos concorrentes diretos e indiretos e um pouco de descaso quanto a elaboração de pesquisas de satisfação dos clientes. Carecem de sistemas de informação para registro e controle dos dados e informações, além disso, possuem conhecimentos insuficientes sobre operações financeiras relacionadas à gestão do empreendimento.

Enfim, com base no estudo foram obtidas as principais deficiências gerenciais dos empreendimentos e identificados os pontos de intervenções futuras a serem propostas pela instituição por intermédio do projeto ESTADES (Escritório Técnico de Acolhimento a Demandas e Projetos Sociais) e da Empresa Júnior de Administração. Com essas demandas identificadas serão propostos cursos e treinamentos de capacitação específicos considerando as áreas apontadas.

http://www.ibpt.com.br/> Acesso em 16 de Dezembro.

[7] Ibqp - Instituto Brasileiro de Qualidade e Produtividade Disponível em: < http://www.ibqp.org.br> Acesso em 15 de Dezembro.

[8] Laraia, Roque de Barros. Cultura: Um conceito Antropológico. 27 ed. Rio de Janeiro: Zahar, 2015.

[9] Lacerda, Daniel Pacheco et al. Negócio a negócio - Caderno de ferramentas do SEBRAE. Brasília: i-comunicação, 2012.

[10] Paula, Juarez de. Desenvolvimento Local: Como fazer? Brasília: SEBRAE, 2008.

[11] Portal Brasil. Disponível em: $<$ http://www.brasil.gov.br/> Acesso em 15 de Dezembro de 2015.

[12] Secretaria da Cultura - Bahia Criativa promove atividades de formação e consultorias gratuitas em agosto. Disponível em: 
$<$ http://www2.cultura.ba.gov.br/> Acesso em 18 de Março de 2016

[13] Rocha, J.M. O local e o Global: Conceitos e Tendências do Ciberjornalismo Regional de Dourados Disponível em: <http://www.unigran.br/mercado/paginas/arquivos/ edicoes/8/12. pdf> Aceso em 17 de março.
[14] Salvador - Cultura todo dia. Disponível em: <http://www.culturatododia.salvador.ba.gov.br/> Acesso em 24 de Novembro.

[15] Turek, Cris. Glocal, sabe o que significa?. Disponível em:http://www. viladoartesao.com.br/. Acesso em 25 de Janeiro de 2016.

[16] Vasconcellos, Marco Antônio Sandoval. Economia Micro e Macro. 4.ed. São Paulo: Atlas, 2006. p.403. 


\section{Papítulo 4}

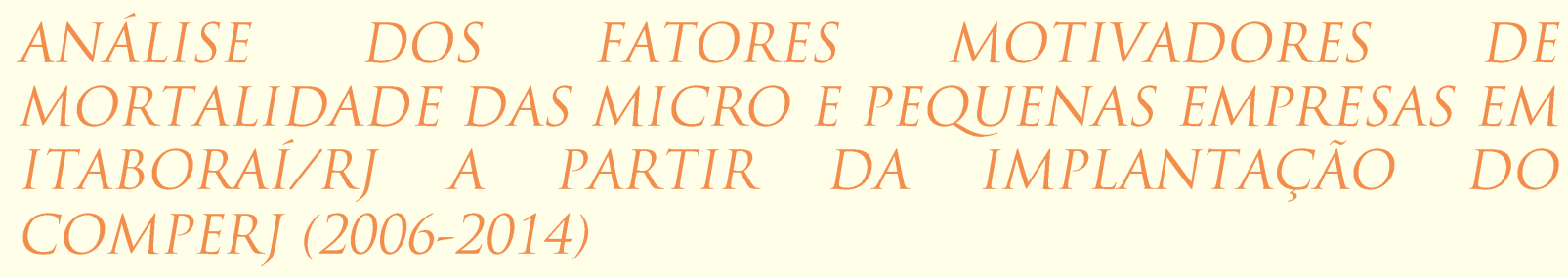

Pando Angeloff Pandeff

Rafael de Abreu Pereira

Natalia Cristina Correa Castelo Branco

Sthefani Nogueira Saraiva

Resumo:O estudo buscou analisar e ampliar a compreensão dos principais fatores motivadores da mortalidade de micro e pequenas empresas no Município de Itaboraí/RJ a partir das influências geradas sobre a economia local com o anúncio e posterior processo de implantação do COMPERJ - Complexo Petroquímico do Estado do Rio de Janeiro. A mortalidade de empresas está associada à falta (ausência) de uso de ferramentas de Planejamento Estratégico e considerando que planejar de modo estratégico se faz cada dia mais necessário para garantir competitividade, a análise das pressões provocadas pela instalação de empreendimentos de grande porte sobre as economias municipais pode possibilitar aos pequenos e médios empreendedores readequar suas estratégias de negócios e reposicionarem produtos e serviços. Tomando como base 0 Município de Itaboraí/RJ, o que se verificou apos realizada pesquisa de campo com empresários locais foi uma elevação das taxas de mortalidade em decorrência da crise provocada pela paralisação das obras. Os resultados indicaram que o COMPERJ desencadeou diversos processos que levaram à economia local a se desestruturar quando projeções equivocadas foram feitas e os empreendedores, sem conhecimento adequado, apostaram na incerteza e começaram a perder competitividade. O estudo é fruto de trabalho monográfico do curso de Administração da Faculdade Itaboraí em continuidade a outros correlatos no Município de Itaboraí/RJ.

Palavras chave: COMPERJ. Itaboraí/RJ. Micro e Pequenas Empresas. Mortalidade. 


\section{INTRODUÇÃO}

O Município de Itaboraí vem sofrendo profundas alterações estruturais e econômicas desde o anúncio em abril de 2006 da implantação do Complexo Petroquímico do Estado do Rio de Janeiro COMPERJ e com obras iniciadas a partir de 2008 com instalação do canteiro e a terraplanagem da área.

O processo de implantação do empreendimento afetou o Município nos mais diversos segmentos, variável de acordo com cada segmento econômico, possibilitando o surgimento de novos negócios e aquecimento da economia como um todo. Com a crise estabelecida a partir do ano de 2013 iniciada com a paralisação das obras, a economia local foi severamente impactada e os desdobramentos percebidos se associam diretamente a elevação da taxa de mortalidade de micro e pequenas empresas.

Inicialmente, a implantação do Complexo viabilizou $O$ surgimento de inúmeras oportunidades de negócios, estimulando assim ações empreendedoras e o surgimento de novas, micro e pequenas empresas no mercado local para atender às demandas por bens e serviços decorrentes do aquecimento da economia e do elevado contingente de trabalhadores que fixaram residência no município, vinculados ao processo de construção do Complexo.

O aquecimento inicial da economia em 2008 com o início das obras do complexo dá lugar hoje a profunda crise econômica e social, levando o mercado local a se reestruturar, e diversas empresas criadas no período de aquecimento a encerrarem suas atividades e outras ainda em processo de encerramento.

Verifica-se assim que, em pequenas economias influenciadas diretamente por empreendimentos industriais de grande porte, para que as pequenas e médias organizações continuem ativas e operacionais e possam ainda expandir seus negócios, torna-se necessário que os empreendedores e Poder Executivo Municipal busquem estabelecer um pacto de desenvolvimento com base na disseminação de informações e ampliação da capacitação dos pequenos e médios empreendedores para que iniciem processos de reestruturação de seus negócios com base na técnica, identificando novas demandas e implantando novas metodologias e estratégias de negócios para atender às novas realidades do mercado.
Garantir vantagem competitiva em um mercado dinâmico e instável, onde o principal fator de interferência é provocado pelo processo de implantação de um grande empreendimento, torna-se cada vez mais necessário ao pequeno e médio empresário a utilização de ferramentas do planejamento estratégico para fortalecer suas potencialidades e em contrapartida, minimizar suas fraquezas, a partir de uma mudança cultural de fazer e manter o negócio.

Com base nesse contexto, o estudo buscou analisar, dentro do corte cronológico proposto, como o cenário econômico foi sendo transformado, tendo em vista o período de tempo considerado (2006 a 2014) levando em contas as influências provocadas pelo processo de implantação do empreendimento, e como essas transformações promoveram a elevação da taxa de mortalidade das pequenas e médias empresas.

Ampliar o entendimento sobre os fatores motivadores da elevação da taxa de mortalidade de empresas em uma economia influenciada pela implantação de empreendimentos de grande porte torna-se essencial como instrumento auxiliar a formulação de políticas públicas de fomento econômico e de desenvolvimento local.

O estudo buscou ainda identificar e analisar os principais fatores motivadores da mortalidade de micro e pequenas empresas no Município de Itaboraí/RJ com base em pesquisa de campo realizada junto ao empresariado local com base em entrevistas para coletar informações que permitiram identificar as potenciais causas para a elevação da taxa de mortalidade dessas organizações, que em geral, tiveram boa alavancagem no período de implantação do COMPERJ e impactados com a crise instalada a partir de 2013.

Identifica-se ainda um fio condutor em comum junto aos pequenos e médios empreendedores, que justificaria a mortalidade como fenômeno que advém da falta ou ausência do uso de ferramentas de Planejamento Estratégico no dia a dia das pequenas organizações.

Assim, o estudo se justifica pela necessidade de ampliar o entendimento sobre os impactos econômicos e sociais provocados sobre economias municipais a partir da decisão de implantação de empreendimentos de grande 
porte e que alteram significativamente a dinâmica dessas economias.

\section{OBJETIVOS}

\subsection{OBJETIVO GERAL}

Analisar os fatores que levam à mortalidade das micro e pequenas empresas, a partir das influências sobre a economia local da implantação de grandes empreendimentos industriais tomando como base o COMPERJ em Itaboraí/RJ.

\subsection{OBJETIVOS ESPECÍFICOS}

- Promover revisão das bases teórico conceituais correlatos ao estudo proposto;

- Identificação do atual perfil do mercado local envolvendo as pequenas e médias empresas e a taxa de mortalidade no período proposto;

- Desenvolvimento de pesquisa quantitativa junto às pequenas empresas buscando identificar o conhecimento e uso das ferramentas de gestão estratégica pelas mesmas;

- Comparação dos resultados da pesquisa com a taxa de mortalidade para verificar a correlação existente.

- Proposição de alternativas que viabilizem a adoção das técnicas de planejamento e gestão pelos empreendedores.

\section{METODOLOGIA}

O presente artigo foi baseado em trabalho monográfico desenvolvido no curso de Administração da Faculdade Itaboraí e elaborado com base nos resultados finais obtidos.

A escolha do tema deve-se à continuidade de estudos já realizados na região pelos orientadores, com foco no desenvolvimento local, adequando-se ao seu desenvolvimento e buscando analisar a economia local, as políticas de desenvolvimento e os impactos econômicos e sociais provocados a partir da decisão de implantação de grandes empreendimentos sobre s pequenas e médias empresas instaladas no município de Itaboraí/RJ.
O estudo se desenvolve inicialmente com a realização de uma pesquisa bibliográfica de forma a estabelecer os principais conceitos sobre a temática proposta a partir de livros, artigos e conteúdos publicados de autores que versam sobre a temática em questão de forma a fundamentar $\mathrm{o}$ entendimento necessário sobre determinados conteúdos relevantes ao estudo e às análises propostas, além de acesso às bases de dados oficiais disponíveis para maior fundamentação.

De forma complementar foi realizada uma pesquisa exploratória junto ao empresariado local buscando identificar suas experiências práticas a partir das questões levantadas e como estes percebiam as influências do COMPERJ sobre seus negócios.

A pesquisa foi realizada junto à micro e pequenas empresas no centro do primeiro distrito do Município de Itaboraí/RJ, com base em um roteiro de perguntas pré-estabelecidas de forma a se seguir padrão de abordagem especifico, se concentrando no eixo da principal via que corta o distrito, a Avenida Vinte e Dois de Maio, levando em conta as influências da economia local sobre as empresas de pequeno porte em atividade, seu perfil e sua capacidade efetiva para garantir sobrevivência frente a um mercado cada vez mais competitivo e instabilidade na economia local.

Os resultados obtidos foram analisados e permitiram o desenvolvimento de proposições sobre como o processo de mortalidade das MPEs locais se configura e sustenta as conclusões do estudo, possibilitando ainda a proposição de sugestões de metodologias e estratégias a serem adotadas pelas empresas para garantirem maior capacidade competitiva e sobreviverem em um mercado cada vez mais instável e dinâmico.

\section{DESENVOLVIMENTO}

\subsection{MICRO E PEQUENAS EMPRESAS (MPES)}

Com base em diversos estudos, verifica-se uma tendência crescente no surgimento de novos negócios e nos segmentos mais diversificados de mercado, decorrente de diversos fatores econômicos e sociais.

Esses negócios, considerando suas características, como porte e faturamentos anuais diversificados, são denominados então como micro e pequenas empresas, e a partir 
desta ótica são classificados e definidos parâmetros e limitadores legais.

Segundo a Lei Geral da Micro e Pequena Empresa (SEBRAE, 2007, p. 07):

A Microempresa (ME) define a pessoa jurídica que aufere, em cada anocalendário, receita bruta igual ou inferior a $\mathrm{R} \$ 240$ mil e as Empresas de Pequeno Porte (EPP) com pessoa jurídica que aufere, em cada ano-calendário, receita bruta superior a $R \$ 240$ mil e igual ou inferior a $\mathrm{R} \$ 2,4$ milhões.

Pode-se atribuir como comparativo e também com intuito de reiterar a definição das micro e pequenas empresas, o que preceituam Santos, Krein e Calixtre. (IPEA, 2012, p. 17):
Outra definição adotada pelo Serviço Brasileiro de Apoio às Micro e Pequenas Empresas (SEBRAE), limita a microempresas a aquelas que empregam até 9 pessoas, no caso de comércio e serviços, ou até 19 pessoas, no caso dos setores industrial ou de construção. Já as pequenas são definidas como as que empregam de 10 a 49 pessoas, no caso de comércio e serviços, e de 20 a 99 pessoas, no caso de indústria e empresas de construção

Assim, a definição legal para as micro e pequenas empresas (MPEs), também pode ser representada no quadro 1, constante do Anuário do Trabalho na Micro e Pequena empresa do SEBRAE (2010-2011).

Quadro 1: Classificação das empresas segundo o porte

\begin{tabular}{|c|c|c|}
\hline \multirow{2}{*}{ Porte } & \multicolumn{2}{|c|}{ Setores } \\
\hline & Indústria & Comércio e Serviços \\
\hline Microempresa & Até 19 pessoas ocupadas & Até 9 pessoas ocupadas \\
\hline Pequena Empresa & De 20 a 99 pessoas ocupadas & De 10 a 49 pessoas ocupadas \\
\hline Média Empresa & De 100 a 499 pessoas ocupadas & De 50 a 99 pessoas ocupadas \\
\hline Grande Empresa & 500 ou mais pessoas ocupadas & 100 ou mais pessoas ocupadas \\
\hline
\end{tabular}

Fonte: http://www. sebrae.com.br/Sebrae/Portal\%20Sebrae/Anexos/Anuario\%20do\%20Trabalho\%20a\%20 Micro\%20e\%20Pequena\%20Empresa_2010_2011.pdf

Estas organizações estão diretamente inseridas em um mercado cada vez maior e exigente. Dados do SEBRAE (2011) indicam que em 2000 haviam 4,2 milhões de micro e pequenas empresas. Dez anos depois esse número em 2010 alcança um total de 6,1 milhões de MPEs em atividade, contribuindo significativamente para o desenvolvimento do país, ressaltando ainda o estudo que, mesmo com todas as dificuldades, a taxa de sobrevivência destas organizações vem aumentando a cada ano.

Porém, sem infraestrutura e sem pessoal qualificado, as MPEs não conseguem se adequar de modo rápido às mudanças recorrentes do mercado, devido a obtenção e ao processamento de informações estratégicas normalmente serem realizadas de modo lento acarretando em resultados ruins (prejuízos significativos) e, em muitos casos, a partir desses resultados se inicia o processo de falência.
Amato Neto (2000) descreve que as micro e pequenas empresas atuam geralmente em setores mais tradicionais da economia, como o comércio varejista e serviços. No setor manufatureiro, estas apresentam participação menor face a seu perfil e as características dessas organizações.

A forma como os produtos ou serviços são vendidos ou locais em que são vendidos pouco importa. Porém, aquelas que não incutem as bases estratégicas mínimas em sua cultura e em seus processos de desenvolvimento de atividades, verifica-se tendência a prejuízos e enfrentamento de dificuldades que culminam em mortalidade, em muitos casos, precoce e em um período inferior a dois anos após sua fundação.

\subsection{MORTALIDADE EMPRESARIAL}

O contexto que envolve a mortalidade de empresas não é algo que seja recente, sendo essa realidade presente ao longo da história, 
porém passou a ter maior atenção de pesquisadores a partir dos anos 1930.

Mais recentemente, a partir dos anos 1970, inicia-se a aplicação de ferramentas da administração moderna que buscavam antever a falência das organizações hoje classificadas como micro e pequenas empresas. O estudo de análises financeiras e sofisticadas técnicas estatísticas já indicavam que a má gestão financeira era um fator contribuinte significativo para a mortalidade tão precoce destas organizações.

Os estudos indicaram que era possível prever a falência de uma pequena empresa com até 5 (cinco) anos de antecedência, mantendo-se uma margem de erro potencial e que a má gestão financeira considerada como um dos principais fatores contribuintes para a mortalidade precoce.

Adota-se para o presente estudo a definição de falência formal, principalmente pela disponibilidade de informações junto aos órgãos oficiais e especialmente as juntas comerciais, uma vez que dependendo do conceito que se tome por base, o resultado de uma pesquisa sobre mortalidade ou falência de empresas pode variar muito e gerar resultados pouco confiáveis, e que, quanto mais amplo o conceito, maior será a taxa de mortalidade encontrada, sendo uma constante considerada para a mortalidade, a falta de competência gerencial e a falta de experiência no ramo de negócio (ZACCARELLI, 1994)

Verifica-se ainda que as razões pelas quais as pequenas empresas fechavam seriam: a falta de experiência do empreendedor; a falta de estratégia de marketing; avaliação demasiadamente otimista do tamanho do mercado; subestimação do tempo de alavancagem do negócio; a falta de capital de giro; o custo de criação da empresa muito alto; a capacidade produtiva menor do que a demanda; a escolha errada do ponto considerando maior volume de pessoas do que o real e a seleção e gestão de pessoas sem competência para o negócio.

Nesse contexto, cabe destacar que outros estudos sobre sobrevivência e crescimento das pequenas empresas indicam que em um período de 10 anos, as empresas que tendem a sobreviver são aquelas que têm um tamanho maior, investem mais em inovação e, portanto, crescem mais rápido.

Santos e Pereira (1995) consolida os motivos que efetivamente tem levado muitos empreendimentos novos ao fracasso, como se verifica no quadro 2 :

Quadro 2: Fatores motivadores que levam a organização ao fracasso

\begin{tabular}{|l|l|}
\hline \multicolumn{3}{|c|}{ A partir dos aspectos técnicos do empreendedor } \\
\hline Inexperiência empresarial anterior; & Ausência de competência enquanto gestor. \\
\hline Falta de conhecimento do mercado; Na Área Mercadológica \\
\hline \multicolumn{2}{|c|}{ Na Área Técnico-Operacional } \\
\hline Falta de qualidade nos produtos e serviços; & $\begin{array}{l}\text { Deficiência no relacionamento com os } \\
\text { fornecedores; }\end{array}$ \\
\hline Localização inadequada do imóvel ou do ponto; & Tecnologia de produção ultrapassada. \\
\hline $\begin{array}{l}\text { Imobilização em excesso do capital em ativos } \\
\text { fixos; }\end{array}$ & Política de créditos inadequada aos clientes; \\
\hline Inexistência de controles de custos e de gestão financeira. \\
\hline \multicolumn{2}{|c|}{ Na Área Jurídica / Organizacional } \\
\hline Estrutura organizacional inadequada; & Falta de Inovações Gerenciais. \\
\hline Falta de Planejamento e Informações Gerenciais; \\
\hline
\end{tabular}
Fonte: Adaptado de Santos e Pereira (1995, p. 257)

O autor destaca ainda que outros fatores contribuintes para o fracasso dos negócios como o baixo nível de escolaridade e renda do empreendedor, que por falta de crédito junto às instituições financeiras utiliza capital próprio ou da família, o que limita o crescimento da empresa e a torna vulnerável às oscilações e a sazonalidade do mercado, além da legislação que por vezes restringe a atuação das MPEs pela sua complexidade. 


\subsection{AS MICRO E PEQUENAS EMPRESAS EM ITABORAÍ/RJ E O COMPERJ}

\subsubsection{CARACTERIZAÇÃO DO MUNICÍPIO DE ITABORAÍ}

O município de Itaboraí/RJ está inserido na região metropolitana do Estado (figura 1), com população estimada para o ano de 2015 em 229.007 habitantes (IBGE Cidades, 2015), distribuída no território de 430,5 Km2 nos oito distritos que integram a estrutura administrativa municipal.
Sua localização estratégica e cortado por cinco rodovias, sendo duas federais como a BR 101, a partir do município de São Gonçalo e a BR-493 a partir do Município de Magé, além de três rodovias estaduais: a RJ-104, a RJ 116 e a RJ-114 (ligação Itaboraí-Maricá) proporcionam fácil acesso e saída do município, viabilizando escoamento de cargas e trânsito de pessoas, características consideradas para a decisão locacional do COMPERJ (DER-RJ, 2015).

Figura 1: Mapa Rodoviário de Itaboraí com principais rodovias e acessos

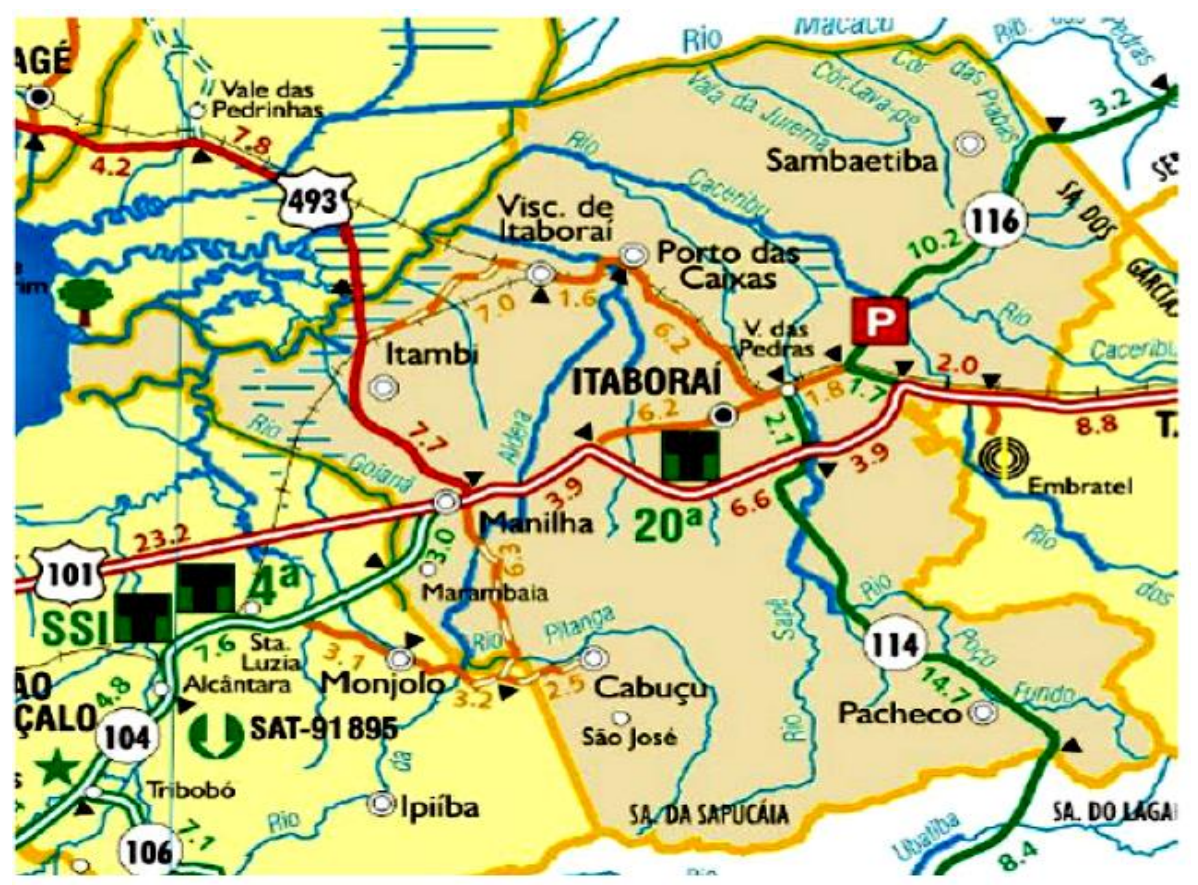

Fonte: http://www.der.rj.gov.br/mapas_n/mapas.htm (2015)

A economia municipal é estruturada em atividades de manufatura de cerâmica (decorativa e utilitária), fruticultura, apicultura, pecuária extensiva, comércio e serviço, envolvendo essencialmente pequenas e médias empresas (tabela 1), cabendo

Tabela 1: Adaptado de Produto Interno Bruto (Valor Adicionado ano 2013)

\begin{tabular}{|c|c|c|c|}
\hline Variável & Itaboraí & Rio de janeiro & Brasil \\
\hline Agropecuária & 7.610 & 1.072 .848 & 105.163 .000 \\
\hline Indústria & 1.544 .336 & 62.966 .386 & 539.315 .998 \\
\hline Serviços & 1.545 .306 & 144.387 .422 & 1.197 .774 .001 \\
\hline
\end{tabular}

Fonte: IBGE Cidades (2015)

\footnotetext{
Na compilação dos dados da tabela 1 , o
município de Itaboraí participa com
aproximadamente de $0,71 \%$ do PIB no
segmento agropecuário do Estado do Rio de
Janeiro, assim como $2,45 \%$ da indústria e o

Na compilação dos dados da tabela 1 , o
município de Itaboraí participa com
aproximadamente de $0,71 \%$ do PIB no
segmento agropecuário do Estado do Rio de
Janeiro, assim como $2,45 \%$ da indústria e o

Na compilação dos dados da tabela 1 , o
município de Itaboraí participa com
aproximadamente de $0,71 \%$ do PIB no
segmento agropecuário do Estado do Rio de
Janeiro, assim como $2,45 \%$ da indústria e o

Na compilação dos dados da tabela 1 , o
município de Itaboraí participa com
aproximadamente de $0,71 \%$ do PIB no
segmento agropecuário do Estado do Rio de
Janeiro, assim como $2,45 \%$ da indústria e o

Na compilação dos dados da tabela 1 , o
município de Itaboraí participa com
aproximadamente de $0,71 \%$ do PIB no
segmento agropecuário do Estado do Rio de
Janeiro, assim como $2,45 \%$ da indústria e o
}

destacar que a implantação do COMPERJ e sua entrada em operação pressiona a economia local e promove o redesenho dessas atividades e da vocação econômica municipal.

segmento de serviços contribuindo com cerca de $1,07 \%$ do PIB.

O que se verifica na análise ratifica as inferências sobre a base da economia municipal e sua baixa importância econômica 
em relação à economia do estado, constatando-se expressivo volume do segmento de serviços e da indústria ceramista que representam quase $50 \%$ de participação de cada segmento na economia (gráfico 1).

Gráfico 1: Produto Interno Bruto (Valor Adicionado ano 2013)

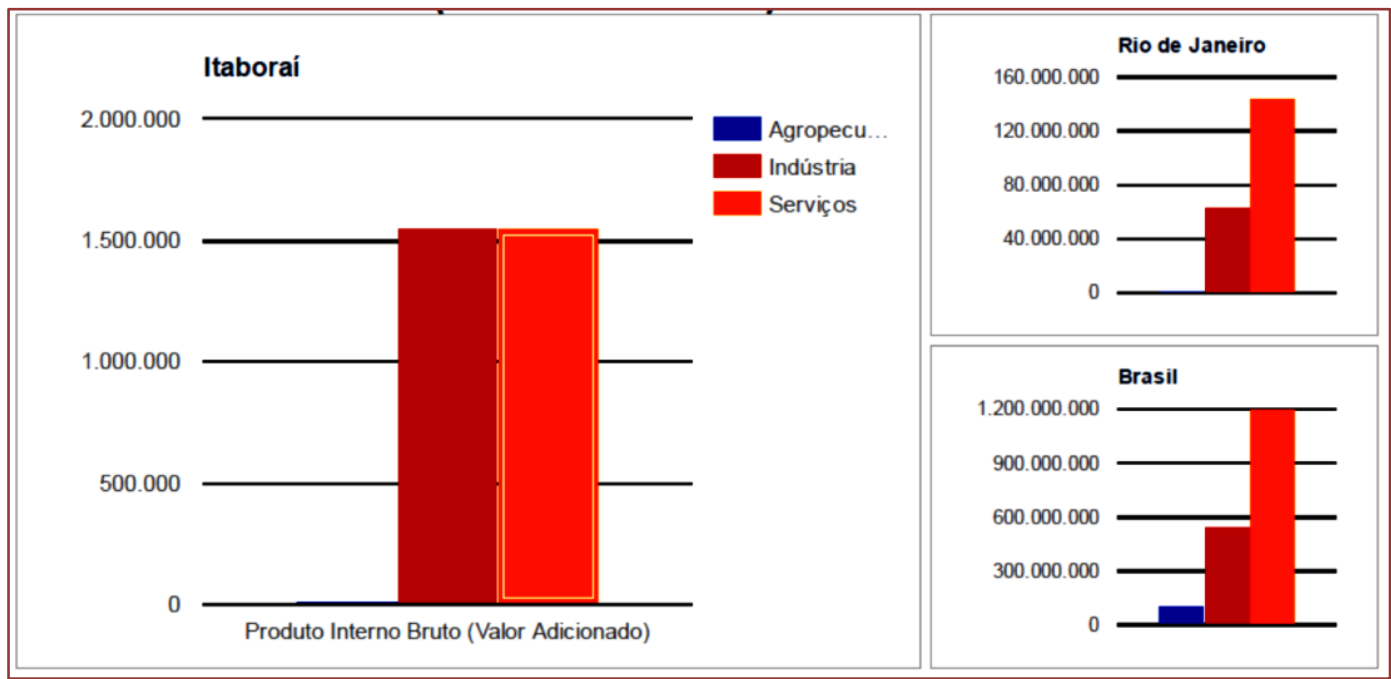

Fonte: IBGE Cidades (2015)

Esse quadro começou a ser alterado com as expectativas criadas em torno do processo de implantação do COMPERJ desde seu anúncio e em particular após início das obras no ano de 2010.

\subsubsection{O COMPERJ - DADOS GERAIS E EXPECTATIVAS}

Em estudo inicial realizado pela Fundação Getúlio Vargas - FGV (2006), a implantação do COMPERJ se apresentava como a oportunidade de crescimento econômico necessária para que o estado pudesse se recuperar depois de décadas de estagnação, sendo o maior projeto de investimento individual da história da Petrobras e em fase de implantação no município de Itaboraí, com área total de $45 \mathrm{~km}^{2}$, equivalente a quase $11 \%$ do território municipal (Figura 2).

A escolha foi a que proporcionou o melhor aproveitamento da logística existente, mais competitividade para a cadeia produtiva e indicação de maior possibilidade de inclusão social, já que sua instalação irá distribuir benefícios para um número maior de municípios do estado e sendo prevista a criação de mais de 200 mil empregos diretos, indiretos e por efeito-renda, nos planos: local, regional e nacional.
O COMPERJ irá processar petróleo pesado do campo de Marlim (150 mil barris por dia), proveniente da Bacia de Campos e sua transformação em matéria-prima para a indústria petroquímica nacional, representando para o país uma economia prevista superior a $R \$ 4$ bilhões por ano em decorrência da redução na importação de fontes de matéria-prima petroquímica e na exportação do petróleo pesado.

Além das empresas que estariam diretamente envolvidas na construção, o estudo da FGV (2006) indicou que em torno de outras 720 empresas poderiam se instalar na região até fins de 2015, na indústria de transformação, para produzir plásticos e afins a partir dos produtos do COMPERJ, cenário que não se consolidou em decorrência da crise iniciada em 2013 que acabou por paralisar as obras.

A decisão locacional por Itaboraí levou em consideração a disponibilidade e as facilidades da região após análise de outras locações, viabilizando ainda o Arco Metropolitano - Importante via rodoviária que fará a ligação entre Itaboraí ao Porto de Itaguaí e onde poderão se instalar indústrias que serão consumidoras de matérias-primas produzidas pelas indústrias de base situadas nas extremidades do Arco: aço em Itaguaí e plásticos em Itaboraí. 
Figura 2: Imagem da área de instalação do COMPERJ e detalhe (14/12/2105)

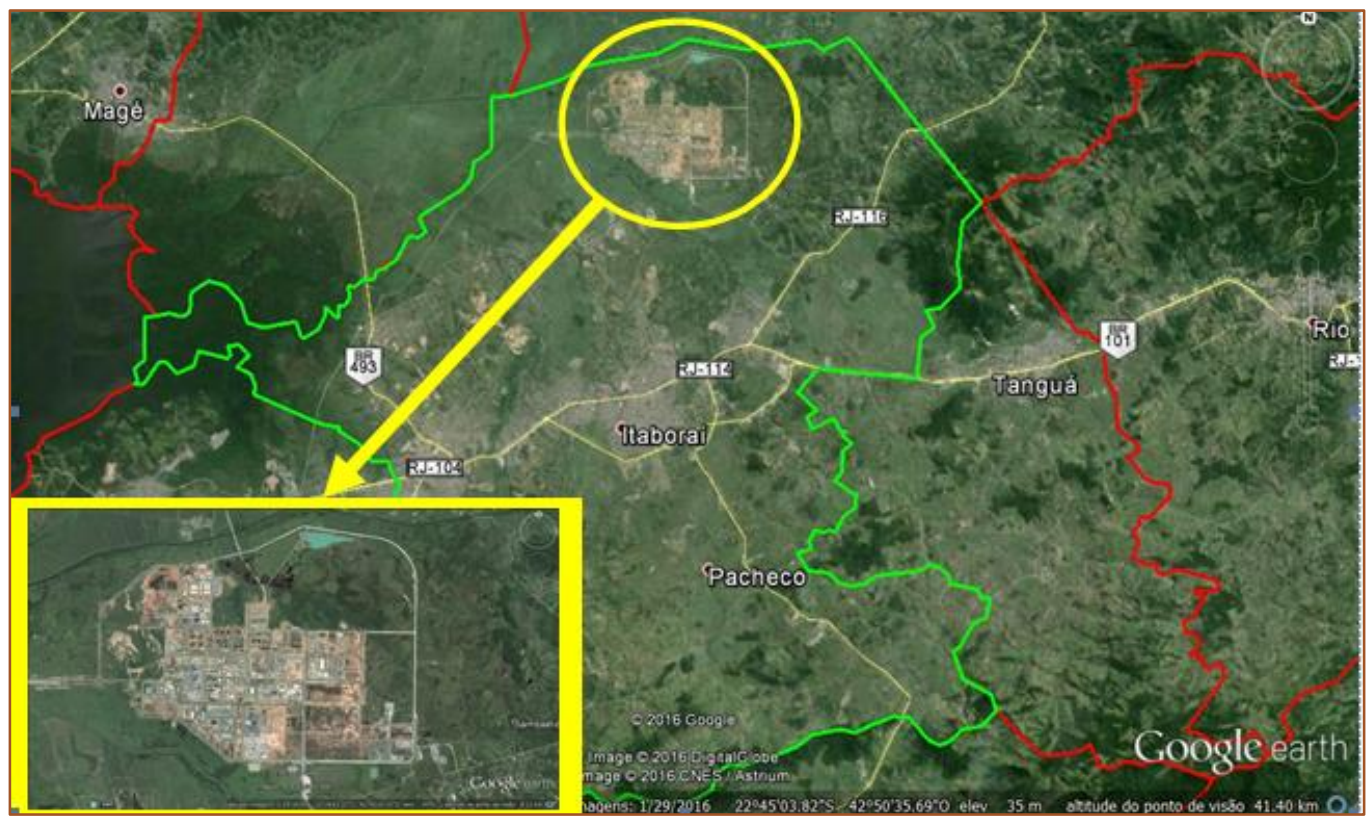

Fonte: Google Earth (2016)

Hoje o projeto do COMPERJ está sendo revisado pela terceira vez e a previsão mais conservadora indica para 2021 a sua conclusão. Os custos iniciais de $\cup \$ 8,4$ bilhões já estariam em U\$ 47,7 bilhões, segundo relatório divulgado pelo TCU (2014).

Para estimar os impactos em relação ao número de empregos para cada ano em cada área, a FGV considerou as taxas de desemprego à época, sem admitir que os empregos na área do COMPERJ viessem a ser ocupados por pessoas de fora (o que ocorreu em larga escala e o Município hoje sofre as consequências desse aumento não considerado na população flutuante), concluindo que somente mantendo as taxas de desemprego de $6 \%$, ou mais, haveria pressão demográfica associada à construção e operação na sua região de influência e onde o maior desafio do COMPERJ seria a redução do número de empregos, que ocorreria já a partir de 2012 (após a previsão inicial de conclusão das obras, e início da operação do complexo).

Hoje essa pressão persiste face aos inúmeros atrasos no cronograma das obras e desaceleração do ritmo de construção, fazendo com que um grande número de trabalhadores desmobilizados permaneça no município e seu entorno, sem emprego agravando o quadro de problemas sociais e essa influência já se observa em função do aumento significativo da população flutuante que demanda moradia e serviços públicos diversos, ressaltando os problemas locais existentes e impactando diretamente a economia local e em particular as pequenas e médias empresas.

Até dezembro de 2013, o número médio de trabalhadores alocados nas diversas empresas e consórcios contratados para a realização das obras foi estimado em cerca de 35.000 (trinta e cinco mil) segundo dados fornecidos pela Prefeitura de Itaboraí (2015), o que correspondia a cerca de $15,40 \%$ da população total do município, estimada pelo IBGE Cidades (2014) em 227.168 habitantes.

\subsubsection{A PESQUISA RELACIONANDO AS MPES E OS IMPACTOS PRODUZIDOS PELO COMPERJ}

A pesquisa foi realizada com os empreendedores no período de 19 a 22 e outubro de 2015, tendo como o foco as empresas instaladas no eixo da Avenida 22 de maio entre os bairros de Venda das Pedras a Outeiro das Pedras, principal avenida do município de Itaboraí/RJ, na região central e que concentra grande número de MPEs, segundo informações da Prefeitura Municipal de Itaboraí - Secretaria de Fazenda indicando ainda que no período atribuído, de 2006 a 2014, foram criadas 2.753 micro e pequenas empresas e no mesmo período foram encerradas 632 no município. 
O questionário aplicado foi estruturado em 12 perguntas fechadas, sendo visitadas cerca de 100 MPEs que compõe a amostra e dos 100 questionários distribuídos, 80 retornaram preenchidos, equivalente a $80 \%$ de retorno em relação ao total.

A pesquisa buscou ampliar o entendimento sobre o comportamento das micro e pequenas empresas, suas peculiaridades e características comuns dentro do ambiente de negócios que estão inseridas e considerou ainda as perspectivas futuras, dado o atual cenário econômico local e regional, além das influências produzidas pelo COMPERJ sobre os negócios sob a ótica dos pequenos empresários.

Com base nos resultados obtidos após tabulação dos dados da pesquisa, estes passam a ser destacados a seguir buscando estabelecer o perfil dos empreendimentos e associação com o COMPERJ e impactos percebidos pelos pequenos empresários.

Inicialmente o estudo buscou identificar os segmentos de atuação dos empreendimentos, sendo os resultados apurados (tabela 2) indicando para a seguinte distribuição:

Tabela 2: Ramo de Atuação das Micro e pequenas empresas

\begin{tabular}{|l|c|c|}
\hline \multicolumn{1}{|c|}{ Segmento De Atuação } & № & $\%$ \\
\hline Comércio & 67 & $83,8 \%$ \\
\hline Indústria & 2 & $2,4 \%$ \\
\hline Serviço & 11 & $13,8 \%$ \\
\hline TOTAL & 80 & $100,0 \%$ \\
\hline
\end{tabular}

Fonte: Elaborado pelos autores

Verifica-se que a grande maioria dos empreendimentos atuam no segmento de comércio varejista, uma característica da economia local, com cerca de $83,8 \%$ seguido pelo segmento de serviços com cerca de $13,8 \%$ dos empreendimentos, em geral relacionados a: oficinas mecânicas, auto centers, provedores de internet e serviços de manutenção em geral.
$\mathrm{Na}$ etapa seguinte se buscou identificar o nível de renda mensal gerada pelo negócio como forma a caracterizar o perfil de renda dos empreendedores.

Os resultados indicaram para os seguintes resultados (tabela 3):

Tabela 3: Renda Mensal dos entrevistados

\begin{tabular}{|l|c|c|}
\multicolumn{1}{|c|}{ Renda Mensal (Base $\mathrm{Sm}$ ) } & № Respostas & $\%$ \\
\hline Até $\mathrm{R} \$ 724,00$ & 0 & $0,0 \%$ \\
\hline De $\mathrm{R} \$ 724,01$ a $\mathrm{R} \$ 2.172,00$ & 22 & $27,5 \%$ \\
\hline De $\mathrm{R} \$ 2.172,01$ a $\mathrm{R} \$ 3.620,00$ & 22 & $27,5 \%$ \\
\hline De $\mathrm{R} \$ 3.620,01$ a $\mathrm{R} \$ 5.068,00$ & 21 & $26,3 \%$ \\
\hline De $\mathrm{R} \$ 5.068,01$ a $\mathrm{R} \$ 7.240,00$ & 7 & $8,7 \%$ \\
\hline Mais de $\mathrm{R} \$ 7.240,01$ & 8 & $10,0 \%$ \\
\hline TOTAL & 80 & $100,0 \%$ \\
\hline
\end{tabular}

Fonte: Elaborado pelos autores

Verifica-se que a grande maioria dos negócios $(53,8 \%)$ geram renda mensal total para os empreendedores entre $R \$ 2.172,01$ a $\mathrm{R} \$ 5.068,00$, valores que se alinham com as características de micro e pequenas empresas e indicativo de que os negócios geram renda básica voltada à subsistência familiar.
A renda mensal auferida no negócio foi associada às faixas de faturamento para as MPEs buscando validar a coerência das informações e após tabulação dos dados da pesquisa, os resultados foram consolidados e apresentados na tabela 4. 
Tabela 4 Faturamento Anual das Micro e pequenas empresas

\begin{tabular}{|l|c|c|}
\hline \multicolumn{1}{|c|}{ Faturamento Anual } & № & $\%$ \\
\hline De $\mathrm{R} \$ 1,00$ a $\mathrm{R} \$ 60.000,00$ & 18 & $22,5 \%$ \\
\hline De $\mathrm{R} \$ 60.000,01$ a $\mathrm{R} \$ 120.000,00$ & 18 & $22,5 \%$ \\
\hline De $\mathrm{R} \$ 120.000,01$ a $\mathrm{R} \$ 160.000,00$ & 14 & $17,5 \%$ \\
\hline De $\mathrm{R} \$ 160.00,01$ a $\mathrm{R} \$ 240.000,00$ & 23 & $28,8 \%$ \\
\hline Acima de $\mathrm{R} \$ 240.000,00$ & 7 & $8,7 \%$ \\
\hline TOTAL & 80 & $100,0 \%$ \\
\hline
\end{tabular}

Fonte: Elaborado pelos autores

Verifica-se que $62,5 \%$ das MPEs se enquadram na faixa de faturamento de até $\mathrm{R} \$$ 160.000,00 (equivalente a uma média mensal de até $R \$ 13.334,00)$. Por outro lado, $28,8 \%$ das MPEs informaram faturamento entre $R \$ 160.000,01$ a $R \$ 240.000,00$ (equivalente a uma média mensal de até $\mathrm{R} \$ 20.000,00)$ e apenas $8,7 \%$ informaram faturamento na maior faixa.

Comparando-se esses resultados com a renda mensal informada, verifica-se alinhamento e coerência nos resultados comparados e ainda, que a grande maioria das MPEs, por terem faturamento limitado às faixas menores, não conseguem ter capacidade financeira efetiva para investimentos face a essa limitação que podese inferir, causada pela crise desencadeada a partir da paralisação das obras do COMPERJ e agravada pela crise nacional.

Outro aspecto relevante refere-se ao tempo de existência das empresas, onde se buscou identificar se estas foram criadas a partir de oportunidades produzidas inicialmente pelo processo de instalação do empreendimento ou se já estariam em operação antes do início desse processo que alterou a dinâmica da economia municipal.

A tabulação dos dados apontou para os seguintes resultados (tabela 5):

Tabela 5: Tempo de existência das MPEs no mercado

\begin{tabular}{|l|c|c|}
\hline \multicolumn{1}{|c|}{ Tempo De Atuação No Mercado } & № & $\%$ \\
\hline De 0 a 1 ano & 9 & $11,3 \%$ \\
\hline De 1 a 2 anos & 22 & $27,5 \%$ \\
\hline De 3 a 5 anos & 5 & $6,2 \%$ \\
\hline Mais de 5 anos & 44 & $55,0 \%$ \\
\hline TOTAL & 80 & $100,0 \%$ \\
\hline
\end{tabular}

Fonte: Elaborado pelos autores

A análise dos resultados indica que 45,0\% das MPEs foram criadas no período de até 5 (cinco) anos, o que leva a inferir que os negócios podem estar relacionados às oportunidades geradas pelo aumento da demanda decorrente da instalação do COMPERJ, ao passo que 55,0\% dos negócios já estavam criados e operando, antes do processo de implantação do complexo se iniciar.

Outro aspecto de destaque refere-se ao fato de que $38,8 \%$ dos negócios foram criados no período de até 2 (dois) anos, o que indica que as alterações no mercado propiciaram dois movimentos associados à mortalidade de empresas - o primeiro com o surgimento de negócios em substituição a outros que pereceram - o segundo é terem sido criados em meio à severa crise econômica que se iniciou em fins do ano de 2013 e vem se agravando até os dias atuais, podendo levar a mortalidade dessas empresas, realimentando o ciclo.

A pesquisa buscou ainda demonstrar, a partir do perfil de pequenos negócios, o nível de empregabilidade gerada a partir do número de colaboradores que empregam e o impacto social gerado pela desmobilização desses trabalhadores em caso de encerramento das atividades.

Os resultados apurados após tabulação dos dados são apresentados na tabela 6. 
Tabela 6: Quantitativos de colaboradores empregados nas MPEs

\begin{tabular}{|l|c|c|}
\hline \multicolumn{1}{|c|}{ Colaboradores Das Micro E Pequenas Empresas } & № & $\%$ \\
\hline De 1 a 5 colaboradores & 39 & $48,8 \%$ \\
\hline De 6 a 10 colaboradores & 22 & $27,5 \%$ \\
\hline De 11 a 15 colaboradores & 10 & $12,5 \%$ \\
\hline De 16 a 20 colaboradores & 4 & $5,0 \%$ \\
\hline Acima de 21 colaboradores & 5 & $6,2 \%$ \\
\hline TOTAL & 80 & $100,0 \%$ \\
\hline
\end{tabular}

Fonte: Elaborado pelos autores

Verifica-se que na faixa de 1 a 10 colaboradores contratados estão cerca de $76,3 \%$ das empresas. $12,5 \%$ empregam entre 11 e 15 colaboradores e apenas $11,2 \%$ empregam acima de 16 colaboradores.

Esses resultados ratificam que as MPEs são efetivamente as grandes geradoras de emprego e renda, principalmente em economias de pequenos municípios como Itaboraí e entorno, e que estão sendo diretamente afetados pela paralisação das obras do COMPERJ e podendo-se inferir que o encerramento dessas atividades produzirá efeitos negativos de elevada significância

Tabela 7: Influências potenciais do COMPERJ sobre os negócios na fase de implantação

\begin{tabular}{|l|c|c|}
\hline \multicolumn{1}{|c|}{ Instalação Do Comperj } & № & $\%$ \\
\hline Bom para os negócios & 68 & $85,0 \%$ \\
\hline Ruim para os negócios & 7 & $8,8 \%$ \\
\hline Não fez diferença & 5 & $6,2 \%$ \\
\hline TOTAL & 80 & $100,0 \%$ \\
\hline
\end{tabular}

Fonte: Elaborado pelos autores
O resultado indica para um elevado grau de expectativa em relação às oportunidades que poderiam ser geradas com o aumento da demanda por bens e serviços a partir do processo de implantação do COMPERJ, com $85,0 \%$ das respostas indicando que esse processo seria bom para os negócios.

Analisando os demais $15,0 \%$ dos resultados, pode-se inferir que as respostas estão relacionadas ao tipo de negócio e segmento de atuação, levando-se em conta que as alterações produzidas na economia local, a partir da implantação de um empreendimento de porte do COMPERJ leva ao incremento de novos negócios por um lado e para alguns segmentos esse processo não provoca impactos significativos em decorrência de se considerar população flutuante e a sazolanidade das demandas. social e econômica, agravando ainda mais a crise em curso, levando-se em conta que para cada posto de trabalho existem mais três pessoas em média que integram o grupo familiar estimado em 4 (quatro) componentes, segundo dados do IBGE Cidades (2015)

Outro aspecto considerado para associação dos impactos produzidos pelo COMPERJ levou em conta a percepção inicial dos empreendedores sobre as influências que poderiam ser geradas para os negócios, sendo os resultados consolidados, apresentados na tabela 7 .

\section{RESULTADOS E DISCUSSÕES}

Para fins de consolidação de resultados do estudo, o que se verifica é que existe uma relação direta entre os processos de implantação de grandes empreendimentos como o COMPERJ e as economias municipais na área de influência destes.

Sendo assim, essas influências podem ser positivas ou negativas, e dependem fundamentalmente do cumprimento do cronograma de obras, bem como do fluxo dos investimentos.

Dessa forma e buscando estabelecer como as influências econômicas e sociais podem se configurar, as tabelas 8 e 9 traduzem as percepções dos pequenos empresários locais que foram diretamente impactados e como estes entendem os efeitos inicialmente positivos e que com a paralisação das obras se transformaram em ameaças potenciais 
para seus negócios, sendo possível extrapolar essas percepções para a economia municipal como um todo em decorrência da tendência que se verifica.

Os empresários, ao serem solicitados a externar seus entendimentos sobre as influências que o processo de implantação do COMPERJ produziu sobre seus negócios, levaram em conta os impactos inicialmente percebidos, sendo os resultados consolidados na tabela 8.

Tabela 8: Influência do COMPERJ sobre as MPEs no Município

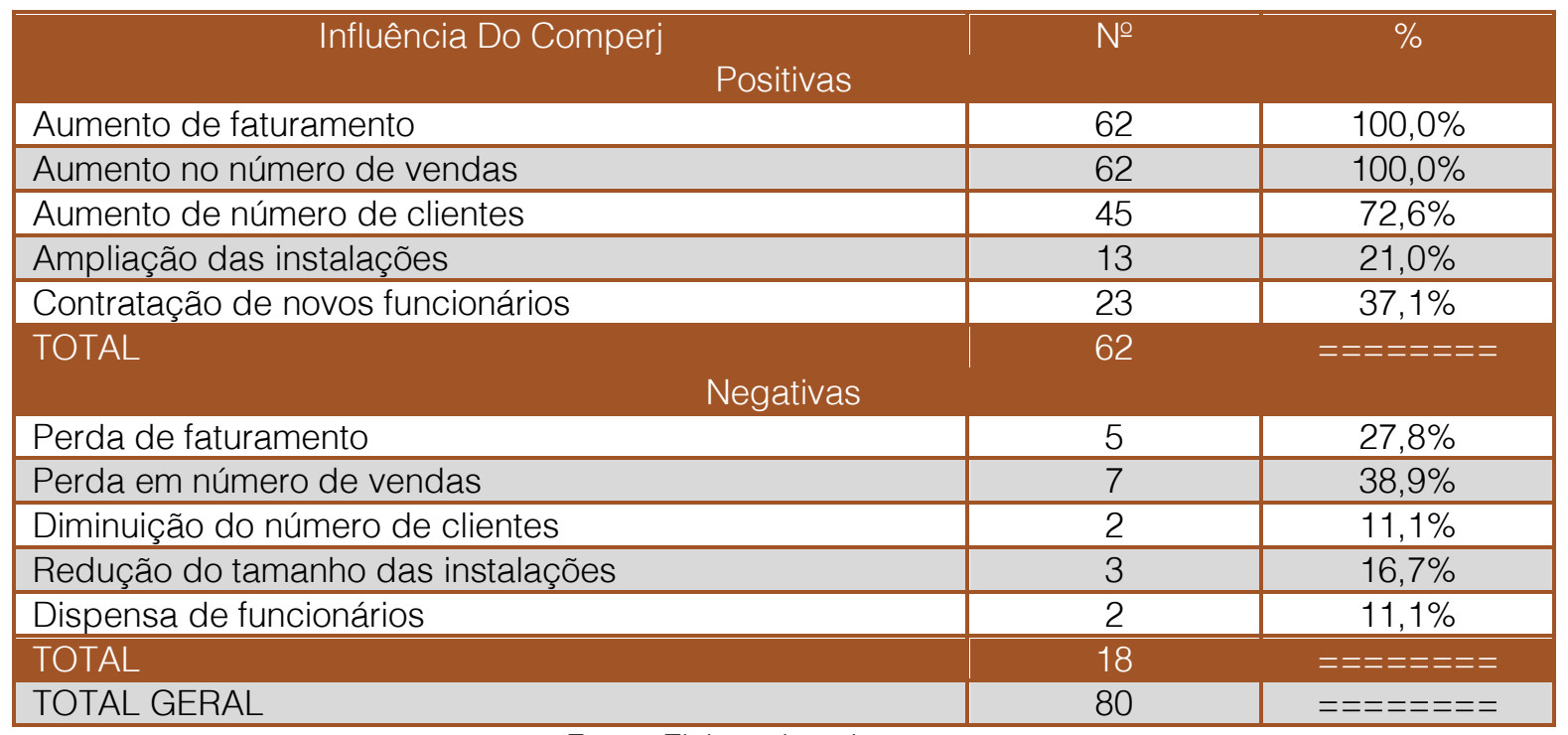

Fonte: Elaborado pelos autores

As respostas foram agrupadas em relação à amostra total de 80 questionários, indicando que a grande maioria, 62 (77,5\%) responderam que os efeitos percebidos inicialmente foram positivos para seus negócios e 18 (22,5\%) responderam que os impactos iniciais percebidos foram negativos.

Aqui se verifica mais uma vez que, dependendo do tipo de negócio e segmento de atuação, as influências estão relacionadas a oportunidades para alguns e ameaças para outros em decorrência de se considerar para fins de demanda, o perfil da população flutuante que ingressou no município para atuar nas obras e a sazonalidade das demandas associadas ainda a questões culturais e necessidades específicas.

Percebe-se que os impactos positivos iniciais ratificam essa tendência da demanda que foi identificada e estão associados ao aumento de faturamento, aumento no número de clientes e aumento no número de itens comercializados, levando a investimentos em ampliação de instalações e incremento na contratação de trabalhadores.
Por outro lado, os impactos negativos apontados indicam para o movimento contrário ao incremento relatado, sendo verificado que os empreendedores desse grupo mantiveram suas operações sem considerar as mudanças que estava ocorrendo na economia local, verificando-se a falta de inovação e capacidade de planejamento foram os principais contribuintes para a produção de resultados negativos dos negócios.

$\mathrm{Na}$ sequência do processo de pesquisa, os empreendedores foram solicitados a externar seus entendimentos e expectativas em relação ao futuro de seus negócios, levando em conta agora o processo de paralisação das obras do COMPERJ, a desmobilização da mão de obra que estava alocada no processo de construção do Complexo e a crise econômica local iniciada no ano de 2013, agravada até o ano de 2015.

Os resultados foram consolidados na tabela 9. 
Tabela 9: Expectativas de futuro na percepção dos empreendedores

\begin{tabular}{|l|c|c|}
\multicolumn{2}{c|}{$\begin{array}{c}\text { Expectativas Quanto Ao Futuro Da Empresa } \\
\text { Pretende Se Manter No Segmento }\end{array}$} \\
\begin{tabular}{|l|c|c|}
\hline Dentro do município & 52 & $78,8 \%$ \\
\hline Fora do município & 3 & $4,5 \%$ \\
\hline Pretensão de expansão & 11 & $16,7 \%$ \\
\hline TOTAL Motivos Para Saída Do Segmento De Atuação Atual & 66 & $100,0 \%$ \\
\hline \multicolumn{1}{|c|}{} & 8 & $57 \%$ \\
\hline Declínio do COMPERJ & 6 & $43 \%$ \\
\hline Perda da fatia de mercado & 0 & $0 \%$ \\
\hline Redução de espaço Físico & 14 & $100,0 \%$ \\
\hline TOTAL & 80 & $100,0 \%$ \\
\hline TOTAL GERAL
\end{tabular}
\end{tabular}

Fonte: Elaborado pelos autores

As respostas quanto à expectativa de futuro foram agrupadas em relação à amostra total de 80 questionários, indicando que a grande maioria, $66(82,5 \%)$ responderam que apesar da crise e das dificuldades pretendem manter seus negócios e segmento de atuação, destacando-se que 78,8\% consideram que vão conseguir se manter no mercado local e outros $16,7 \%$ ainda pretendem expandir para garantir a necessária vantagem competitiva para se manterem no mercado.

Mesmo com a pretensão de manter seus negócios e no mesmo segmento, 4,5\% informaram que pretendem investir em outros municípios que apresentariam melhores oportunidades de mercado.

Em contrapartida, em decorrência da crise 14 $(17,5 \%)$ responderam encerrarão suas atividades destacando principalmente a perda de participação no mercado em decorrência da crise decorrente da paralisação das obras do COMPERJ.

Nesse contexto, os negócios mais afetados são os que estão associados às demandas sazonais como restaurantes, pousadas, lavanderias, entre outros.

\section{CONCLUSÕES E RECOMENDAÇÕES}

O estudo proposto buscou analisar os fatores motivadores da mortalidade de micro e pequenas empresas (MPEs) ou a manutenção de suas atividades em decorrência das influências provocadas sobre as economias locais quando da instalação de grandes empreendimentos com recorte para o Complexo Petroquímico do Estado do Rio de Janeiro (COMPERJ) no Município de Itaboraí/RJ para o período de 2006 a 2014, compreendendo o processo de anúncio, instalação, inicio de obras e posterior paralisação.

Buscou ainda entendimento sobre o ambiente de negócios das MPEs, expectativas geradas com o processo de implantação do empreendimento, bem como estudos iniciais indicativos de cenários que seriam configurados com a instalação do Complexo.

O estudo contextualiza inicialmente conceitos fundamentais sobre as MPEs e mortalidade empresarial, destacando os principais fatores contribuintes que levam ao encerramento de atividades, por vezes, precoce.

O objetivo geral foi alcançado com a identificação e análise dos impactos positivos e negativos produzidos pelo COMPERJ sobre a economia local e os pequenos empreendedores através do desenvolvimento de pesquisa amostral junto à as MPEs.

Com a consolidação dos resultados da pesquisa de campo foi possível estabelecer o perfil das empresas e captar o entendimento dos empreendedores sobre como estes perceberam as influências do COMPERJ sobre seus negócios.

Apesar da elevada taxa de mortalidade no que diz respeito às MPEs, o estudo indicou que, mesmo diante das dificuldades enfrentadas e do desconhecimento das ferramentas de planejamento estratégico e sua efetiva utilização, a grande maioria dos empreendedores pretende continuar no mercado e fazer investimentos buscando adequação de seus negócios às demandas do mercado.

Foi evidenciado ainda a deficiência de controles efetivos da estrutura do executivo municipal que devem acompanhar com maior nível de detalhamento as movimentações 
envolvendo a criação e encerramento de empresas associadas ao processo de implantação de grandes empreendimentos.

Considerando as pressões que são provocadas sobre a economia local quando da decisão de instalação desses empreendimentos, recomenda-se 0 desenvolvimento de políticas públicas voltadas ao fomento da capacitação dos pequenos empreendedores e ritos mais simplificados para legalização e licenciamento das novas empresas.

Destaque se faz ao potencial para geração de emprego e renda dessas organizações, que

\section{REFERÊNCIAS}

[1] Amato Neto, J. Redes de cooperação produtiva e clusters regionais oportunidades para as pequenas e médias empresas. São Paulo: Atlas, 2000

[2] Complexo Petroquímico do Rio de Janeiro (Comperj): Informações Gerais sobre o Empreendimento. Disponível em: $<$ http://www.petrobras.com.br/pt/nossasatividades/principais-

operacoes/refinarias/complexo-petroquimico-dorio-de-janeiro.htm>. Acesso em: 18 nov. 2015

[3] Der - Departamento de Estradas e Rodagens do Estado do Estado do Rio de Janeiro (DER-RJ): Mapa rodoviário e informações sobre o município de Itaboraí. Disponível em: em: <http://www.der.rj.gov.br/mapas_n/map.htm\#>. Acesso em: 10 out. 2015

[4] Ibge Cidades - Instituto Brasileiro de Geografia e Estatística (IBGE): Localização Geográfica do Município de Itaboraí/RJ - Divisão por gênero e faixa etária, Distrito - 2013. Disponível em: <www.cidades.ibge.gov.br>. Acesso em: 10 out. 2015

[5] Prefeitura Municipal de Itaboraí Secretaria Municipal de Planejamento e coordenação: Caderno Itadados, versão 1, 2006 e versão 2, 2007. Disponível em: $<$ http://legislaitaborai.com.br/leis/cadernos_itadado s.pdf>. Acesso em: 10 out. 2015

[6] Prefeitura Municipal e Itaboraí - Secretaria Municipal de FazendaDisponível em: Sistema Supernova T.G. Sistemas. Acesso em: 29 out. 2015 [7] Santos, Anselmo Luís dos; krein, José Dari; Calistre, André Bojikian. Micro e Pequenas Empresas Mercado de Trabalho e Implicação para respondem por grande parte dos empregos gerados, tanto no plano local quanto regional, e, portanto torna-se significativo o investimento em capital humano e sua qualificação.

Considerando o presente estudo ser fruto de monografia apresentada no curso de Administração de Empresas da Faculdade Itaboraí, não se pretende aqui encerrar as discussões sobre o tema, sendo este, base para discussões e estudos futuros a serem desenvolvidos pelo autor e seus orientadores.

o Desenvolvimento. Rio de Janeiro: IPEA, 2012. Disponível em: $<$ http://www.ipea.gov.br/agencia/images/stories/PD Fs/livros/livros/livro_micro_pequenasempresas.pdf >. Acesso em: 26 nov. 2015

[8] Sebrae - Serviço Brasileiro de Apoio ÀS Micro e Pequenas Empresas: Lei Geral da Micro e Pequena Empresa. Brasília, 2007. Disponível em: <http://www.leigeral.com.br/portal/lumis/portal/file/fil eDownload.jsp?fileld=FF8080812993A8DE0129CD CCC81B7959>. Acesso em: 10 out. 2015

[9] Sebrae - Serviço Brasileiro de Apoio às Micro e pequenas Empresas: Anuário do Trabalho na Micro e Pequena Empresa 2013 - 6a․ edição. DIEESE, São Paulo, 2013. Disponível em: <http://www.sebrae.com.br/Sebrae/Portal\%20Sebra e/Anexos/Anuario\%20do\%20Trabalho\%20Na\%20M icro\%20e\%20Pequena\%20Empresa_2013.pdf>.

Acesso em: 10 out. 2015

[10] Tce-RJ. Tribunal de Contas do Estado do Rio de Janeiro. Secretaria Geral de Planejamento. Coordenadoria de Comunicação Social, Imprensa e Editoração: Estudo Socioeconômico 2014: Itaboraí. Disponível em: $<$ http://www.tce.rj.gov.br/web/guest/estudossocioeconomicos1>. Acesso em: 13 out. 2015.

[11] Santos, Silvio Aparecido e PEREIRA, Heitor José. Criando seu próprio negócio: como desenvolver o potencial. Brasília: Ed. SEBRAE, 1995.

[12] Zaccarelli, Sérgio Baptista; Fischmann, Adalberto A. Estratégias genéricas: classificação e usos. Revista de Administração de Empresas, São Paulo (SP): Escola de Administração de Empresas de São Paulo - Fundação Getúlio Vargas, v. 34, n. 4, p. 13-22, jul./ago. 1994 


\section{Bapítulo 5}

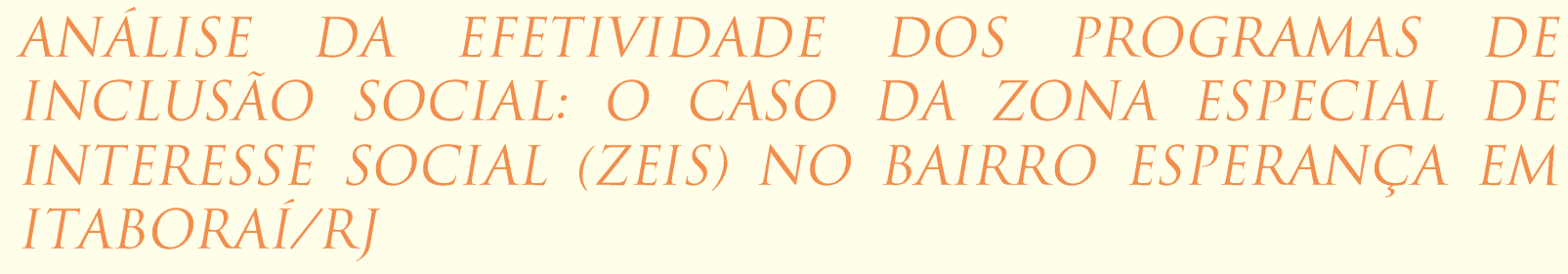

Pando Angeloff Pandeff

Luciana Teixeira da Silva Abreu

Natalia Cristina Correa Castelo Branco

Sthefani Nogueira Saraiva

Resumo:O estudo buscou analisar as políticas públicas de inclusão social a partir da implantação do PAC Vila Esperança em Itaboraí/RJ. A partir da visão dos autores utilizados, os Programas Sociais são relevantes na vida da sociedade de um modo geral, principalmente para às populações que residem em locais de grande vulnerabilidade, risco social e com altos índices de criminalidade e violência. Nesse contexto se promove uma análise desses programas, sua funcionalidade e eficácia, com ênfase nas políticas públicas de inserção social, que visam o bem estar da sociedade, seu desenvolvimento e minimização de processos de exclusão social. O estudo promove uma revisão teórica e conceitual dos principais eixos norteadores. Para fins comparativos o objeto de estudo definido foi o Bairro Esperança localizado no 1‥ Distrito do Município de Itaboraí/RJ, que hoje recebe diversas intervenções do poder público através de programas de inclusão social e voltados ao desenvolvimento local. Foi desenvolvida a caracterização da área objeto do estudo e se analisou as políticas e programas de inclusão social em curso, comparando as mesmas em ralação às demandas locais, mediante as necessidades dos moradores, verificando sua funcionalidade, eficácia e os impactos produzidos sobre a vida dos moradores e como estes percebem essas intervenções. Os resultados de pesquisa realizada junto à comunidade permitiram melhor compreensão se duas necessidades e compara os resultados com as propostas gerais dos programas, em particular o Minha Casa Minha Vida. O estudo é fruto de trabalho monográfico do curso de Administração da Faculdade Itaboraí em continuidade a outros correlatos no Município de Itaboraí/RJ.

Palavras chave: Esperança. Inclusão. Itaboraí/RJ. Políticas Públicas. Vulnerabilidade. 


\section{INTRODUÇÃO}

A avaliação de políticas públicas, nos dias de hoje, já é reconhecidamente um instrumento de intervenção social de modo a contribuir diretamente para o sucesso das iniciativas, levando em conta seus objetivos, definição de necessidades e sua implementação, avaliação e controle, sendo estes, fatores de grande relevância para o sucesso das iniciativas desenvolvidas nessa área.

Consiste basicamente em uma pesquisa avaliativa baseada em métodos científicos tendo como objeto de estudo os programas sociais implementados em uma determinada localidade, sejam pela esfera governamental ou por outras organizações. São entendidas como intervenções sistemáticas e planejadas com o objetivo de contribuir positivamente para o desenvolvimento local contribuindo para a melhoria da qualidade de vida e a inclusão social.

Sendo assim, as análises destas políticas indicam a verificação de sua eficácia e os impactos causados no processo de transformação da realidade social em que vivem.

Os programas sociais, embutidos nas políticas públicas desenvolvidas, representam um conjunto de ações que são desenvolvidas com o objetivo de minimizar as desigualdades de um determinado nicho da população, de certa forma excluída e/ou marginalizada da sociedade, buscando garantir o acesso aos bens e serviços públicos devidos.

A proposta do estudo está pautada no entendimento da necessidade do desenvolvimento de projetos e ações sociais voltados à inclusão social que visam garantir direitos sociais básicos, como o direito a habitação digna, acesso aos serviços públicos e a participação política e social, conforme explicito na Constituição Federal de 1988 (CF-88).

Segundo Fleury (2005, p. 321), a política social, iniciou-se no século XX e perdurou por muito tempo, conhecida como um tipo de proteção para a sociedade, só foi alterado com a chegada da constituição de 1988, e até hoje norteia os governos quanto as normas a serem seguidas para proteger a população. É entendida como instrumento da política pública e como ação do governo com objetivos específicos.

Com a Constituição de 1988, há uma profunda transformação no padrão de proteção social brasileiro que atende as reivindicações da sociedade por políticas sociais com maior inserção social e redução de desigualdades. Este novo modelo de seguridade social prevê a universalidade da cobertura, o reconhecimento dos direitos sociais, a (re) afirmação do dever do Estado na regulamentação das ações e serviços públicos, portanto, os benefícios passam a ser concedidos a partir das necessidades integrando as estruturas governamentais, onde se buscou a universalização da cidadania e a garantia dos direitos sociais.

De acordo com o artigo $5^{\circ}$ da CF-88, a igualdade de todos os cidadãos brasileiros perante a lei e a inviolabilidade do direito à vida, à liberdade, à igualdade, à segurança e à propriedade. No artigo $6^{\circ}$, lê-se que são direitos sociais a educação, a saúde, o trabalho, a moradia, o lazer, a segurança, a previdência social, a proteção à maternidade e à infância, a assistência aos desamparados, na forma desta Constituição.

Desta forma, entende-se que esses direitos são direitos constituídos, e que o governo garante à população a inserção, através de Programas Sociais, visando oferecer uma vida digna a população. Souza (2006, p. 46), considera a questão social envolvida em uma relação direta com as políticas públicas para o desenvolvimento local e sua influência na vida dos cidadãos, sendo ainda verificados os benefícios produzidos pelos programas e quantas pessoas são ou deveriam ser beneficiadas.

Entende-se a relevância de implantação de políticas sociais, para que a população em risco social, possa ser igualada as demais parcelas de população, contudo sabe-se que é responsabilidade dos gestores públicos o planejamento, implantação, monitoramento e controle destas políticas sociais através de projetos e programas de inclusão.

\section{OBJETIVOS}

\subsection{OBJETIVO GERAL}

Analisar a efetividade dos programas de inclusão social propostos pelo Governo Federal desenvolvidos no Bairro Esperança em Itaboraí/RJ, a partir das ações da Prefeitura Municipal e suas diversas secretarias como contribuinte para o desenvolvimento local e inclusão social. 


\subsection{OBJETIVOS ESPECÍFICOS}

- Realizar um diagnóstico através de informações oficiais e "in loco" dos programas sociais desenvolvidos na localidade selecionada para estudo de caso;

- Mapear, quantificar e detalhar os programas sociais existentes a fim de identificar suas características para uma melhor descrição dos mesmos;

- Identificar as características destes programas, comparando com as metas e objetivos;

- Verificar o funcionamento, a efetividade e eficácia para o processo de fomento das atividades empreendedoras e para desenvolvimento local com inclusão social.

\section{METODOLOGIA}

O presente artigo foi baseado em trabalho monográfico desenvolvido no curso de Administração da Faculdade Itaboraí, com base nos resultados finais obtidos.

A escolha do tema deve-se à continuidade de estudos já realizados na região pelos orientadores, com foco no desenvolvimento local, programas de inclusão e as zonas especiais de interesse social, a partir de programas governamentais.

Analisa sua efetividade a partir da realidade percebida, tomando como base a problemática envolvida e as dificuldades na busca de alternativas que promovam 0 desenvolvimento local e a inclusão social, através da implantação efetiva das propostas.

A base teórica conceitual foi extraída da literatura específica, bases legais, estudos já desenvolvidos e observações de campo para a produção do conteúdo necessário às análises.

O método de pesquisa adotado foi o bibliográfico, associado a um estudo de caso de Bairro Esperança localizado no município de Itaboraí/RJ, utilizando ainda informações coletadas das bases oficiais como: $O$ Instituto Brasileiro de Geografia e Estatística (IBGE), Ministério das Cidades (MC), Tribunal de Contas do Estado do Rio de Janeiro (TCE-RJ), Plano Diretor Municipal e dados sobre o Zoneamento.
A partir de dados coletados, ênfase foi dada às questões que envolvem o desenvolvimento local a partir da implantação dos programas sociais governamentais, abordando a eficácia dessas iniciativas no âmbito da localidade especificada e como o desenvolvimento dos mesmos possibilitou o incremento da inclusão social.

Para uma melhor compreensão da realidade temática foi desenvolvida uma pesquisa junto á população local buscando identificar o perfil socioeconômico da população e sua percepção e entendimento acerca dos programas sociais em curso nesta localidade. Dessa análise foi possível identificar quais programas estão sendo desenvolvidos, quais são percebidos pela população, os resultados efetivos percebidos, os problemas decorrentes das distorções encontradas e o papel dos agentes envolvidos nessas intervenções.

A resultante do confronto entre as bases teóricas e legais, associada ao estudo de caso possibilitou identificar a efetividades dos programas sociais e permitiu fundamentar as conclusões sobre as políticas de inclusão social na ZEIS Esperança e o papel dos agentes envolvidos nessas intervenções.

\section{DESENVOLVIMENTO}

\subsection{PROGRAMAS FEDERAIS DE INCLUSÃO - PANORAMA GERAL}

A autonomia do Estado e de seus gestores gera possibilidades de implementação de políticas públicas, criando condições de desenvolvimento para diversos locais, contudo para um amadurecimento dessa autonomia e o desenvolvimento das criações e implementações, depende de diversos fatores que variam de local para local, podendo ser externos ou internos.

Logo, entende-se que o gerador das políticas públicas é o Governo constituído, e a ele cabe, dentre outras coisas, a inserção dos projetos voltados para a sociedade, com o objetivo de promover maior igualdade diminuindo a desigualdade para exclusão social, proporcionando uma vida digna e cumprindo as leis de proteção direcionada aos mesmos.

Entende-se então, que as políticas públicas em sua essência estão ligadas ao Estado, é este quem determina como os recursos são usados para o benefício de seus cidadãos. 
Souza (2006, p. 53), descreve que é o Estado quem define como o dinheiro arrecadado deve ser acumulado e como este deve ser investido e fazer a prestação de contas do dinheiro gasto em favor da sociedade.

Logo, as ações do Estado afetam de forma relevante a vida cotidiana da população, visando sempre a forma coletiva, contudo um indivíduo agindo isoladamente nada pode fazer para alterar as decisões do estado (FLEURY, 2005, p. 447).

Os programas sociais do Brasil representam um conjunto de políticas públicas, que têm como objetivo distribuir de forma adequada, benefícios sociais à população em condições de vulnerabilidade.

Para que pessoas com tais necessidades recebam o benefício adequado, é necessário um cadastro, através do qual os indivíduos devem se adequar às normas do programa que desejam se incluir. Este processo é chamado de Cadastro Único (CadÚnico).

O cadastro único é utilizado apenas para programas do Governo Federal, funciona como um sistema que identifica e caracteriza as famílias de baixa renda, as quais possuem renda mensal de até meio salário mínimo por pessoa ou renda mensal total de até três salários mínimos. Este sistema permite conhecer a realidade socioeconômica dessas famílias, trazendo informações de todo o núcleo familiar, das características do domicílio, das formas de acesso a serviços públicos essenciais e, também, dados de cada um dos componentes da família. Atualmente o cadastro único conta com 21 milhões de famílias inscritas.

O quadro 1 apresenta alguns desses programas desenvolvidos na área de estudo.

Quadro 1: Programas Federais de Inclusão Social

\begin{tabular}{|c|c|}
\hline & \\
\hline Bolsa Família & $\begin{array}{l}\text { Programa desenvolvido em 2004, para apoiar famílias em situação de } \\
\text { pobreza. }\end{array}$ \\
\hline $\begin{array}{l}\text { Benefício de Prestação } \\
\text { Continuada (BPC) }\end{array}$ & Inclusão do idoso ou pessoa com deficiência à previdência social. \\
\hline $\begin{array}{l}\text { Programa de Erradicação } \\
\text { do Trabalho Infantil (PETI) }\end{array}$ & $\begin{array}{l}\text { Programa de transferência direta de renda para famílias de crianças e } \\
\text { adolescentes envolvidos no trabalho infantil. }\end{array}$ \\
\hline $\begin{array}{llr}\text { Programa } & \text { Nacional de } \\
\text { Inclusão de Jovens } \\
\text { (PROJOVEM) }\end{array}$ & $\begin{array}{l}\text { Objetivando estimular o desenvolvimento social e pessoal, incentivar a } \\
\text { permanência e/ou retorno a escola, enfrentar as situações de risco } \\
\text { social às quais os jovens estão expostos diariamente. }\end{array}$ \\
\hline $\begin{array}{l}\text { Programa Nacional de } \\
\text { Acesso ao ensino técnico } \\
\text { e Emprego (PRONATEC) }\end{array}$ & $\begin{array}{l}\text { Programa criado em 2011, objetivando a expansão, interiorização e } \\
\text { democratização da oferta de cursos de educação profissional e } \\
\text { tecnológica (EPT) para a população brasileira. }\end{array}$ \\
\hline Rede Cegonha & $\begin{array}{l}\text { Tem por objetivo apoiar as gestantes usuárias do Sistema Único de } \\
\text { Saúde (SUS). }\end{array}$ \\
\hline Brasil Carinhoso & Visa atender as famílias que tenham crianças de 0 a 6 anos \\
\hline $\begin{array}{l}\text { Educação de Jovens e } \\
\text { Adultos (EJA) }\end{array}$ & $\begin{array}{l}\text { Programa desenvolvido para inserir jovens e adultos novamente à sala } \\
\text { de aula. }\end{array}$ \\
\hline $\begin{array}{l}\text { CEAM } \\
\text { (Centro Especializado de } \\
\text { Atendimento à Mulher) }\end{array}$ & $\begin{array}{l}\text { Atendimento especializado para as mulheres em situação de } \\
\text { vulnerabilidade }\end{array}$ \\
\hline $\begin{array}{l}\text { Mais médicos para } 0 \\
\text { Brasil }\end{array}$ & Programa amplia a quantidade de profissionais nos municípios. \\
\hline Minha Casa, Minha Vida. & Auxilia as famílias a concretizarem o sonho da casa própria. \\
\hline Luz para Todos & Acesso a fonte permanente de eletricidade. \\
\hline
\end{tabular}
Fonte: Portal Brasil (2014)

Segundo Silva (2014, p. 42), os programas do Governo Federal atuam como vetor para o desenvolvimento social no país, facilitando a integração social e o acesso aos serviços públicos. Também atuam como um censo que identifica qual área social necessita de mais atenção, onde através de um programa outros podem ser desenvolvidos.

Em 1993, o Congresso Nacional aprovou a Lei Orgânica da Assistência Social (LOAS), que regulamentou os Artigos 203 e 204 da Constituição Federal, "reconhecendo a 
Assistência Social como política pública, direito do cidadão e dever do Estado, além de garantir a universalização dos direitos sociais", visando a proteção da sociedade e auxiliando a inclusão destes (SILVA, 2006, p. 26).

\subsection{POPULAÇÃO EM RISCO SOCIAL}

Vulnerabilidade e risco social são sinônimos de pobreza, porém, uma é consequência da outra, uma vez que a vulnerabilidade é que coloca as pessoas em um risco social. A pobreza dessas pessoas é medida através da linha de pobreza, que é definida através dos hábitos de consumo das pessoas e o valor de referência utilizado é equivalente a meio salário mínimo.

Segundo Carvalho (2002, p. 68) a exclusão é um fenômeno presente na sociedade brasileira desde a formação das primeiras cidades, a existência de pessoas em risco social, traz no próprio conceito o estigma da exclusão a que são submetidas. Desde a criação das primeiras cidades, verificam-se grupos de pessoas em risco social devido aos processos de exclusão a que são submetidas;

Sawaia (2001, p. 45), afirma que não é apenas um fenômeno que atinge os países pobres, ao contrário, ele sinaliza o destino excludente de parcelas majoritárias da população mundial, e dessa forma entende-se que esta, assim como as demais parcelas da população, deve ser protegida e direcionada a programas com a finalidade de acabar e/ou minimizar a exclusão, com a intenção de diminuir ao máximo os impactos sociais causados pela vulnerabilidade, devendo ser amparados por programas de inclusão e por políticas públicas que visam à melhoria de vida destes.

Segundo o Jornal o Globo (24/07/2014, por Beck e Valente), o Brasil tem 6,083 milhões de pessoas que vivem em situação de pobreza, segundo o Relatório de Desenvolvimento Humano (RDH), 2014. Esse número, que equivale a $3,1 \%$ da população do país abrange indivíduos que, além de não terem renda, vivem sem acesso à educação, saúde ou condições de vida consideradas dignas (com água, luz e saneamento básico, por exemplo). Para as Nações Unidas, a pobreza deve ser medida não apenas de acordo com a renda, mas com as privações que os indivíduos enfrentam para ter qualidade de vida.
O relatório traz desde 2010 o chamado Índice de Pobreza Multidimensional (IPM). Através deste, é classificado como pobre qualquer indivíduo privado de pelo menos três de um total de 10 indicadores considerados importantes para se ter qualidade de vida: São eles: nutrição, baixa mortalidade infantil, anos de escolaridade, crianças matriculadas em escolas, energia para cozinhar, saneamento, água, eletricidade, moradia digna e renda. E quanto maior o número de indicadores, mais grave é a situação.

Por esses critérios, 1,5 bilhão de pessoas em 99 países vivem em situação de pobreza hoje. O número é ainda maior do que o grupo de 1,2 bilhão de pessoas que vivem com US\$ 1,25 ou menos por dia, que é a linha internacional de pobreza. De acordo com o relatório, Níger é o país com maior proporção de pessoas em pobreza multidimensional, com $89 \%$ da população nessas condições.

No caso brasileiro, que conta com uma população de aproximadamente 190.732.694 pessoas, quando se considera a proporção de pessoas em situação de pobreza grave (com privação em pelo menos 5 dos 10 indicadores), 0,5\% da população, ou quase 1 milhão de indivíduos são afetados. No entanto, mais de 14 milhões de pessoas $(7,4 \%$ do total) se encontram numa situação vulnerável, ou seja, sofrem até três privações.

\subsection{CONTEXTUALIZAÇÕES SOBRE POLÍTICAS PÚBLICAS}

Tanto a Política Pública Geral quanto a Política Social são campos multidisciplinares, ou seja, vários campos que buscam um objetivo final, em que o principal foco é explicar a natureza da política pública e seus processos.

A teoria geral da política pública busca condensar teorias construídas no campo da sociologia, da ciência política e da economia. É através da economia e nas sociedades que as políticas públicas são disseminadas, daí o porquê de qualquer teoria da política pública precisar também explicar as inter-relações entre Estado, política, economia e sociedade.

Assim, percebe-se que o termo "Políticas Públicas" está relacionado à soma das atividades dos governos, que agem diretamente ou através de delegação, e que influenciam a vida dos cidadãos e está diretamente ligada ao Governo, e resumidamente pode ser o que o Governo decide ou não fazer. 
Dessa forma, as políticas públicas em sua essência estão ligadas fortemente ao Estado, é este quem determina como os recursos são usados para o beneficio de seus cidadãos. É - Estado quem define como o dinheiro, arrecadado sob a forma de impostos, deve ser acumulado e como este deve ser investido e fazer a prestação de contas do dinheiro gasto em favor da sociedade (SOUZA, 2006).

No que se refere a inclusão social, em suas diferentes faces, esta é praticada por meio de políticas públicas, que além de oficializar, devem também viabilizar a inserção dos indivíduos aos meios sociais, a exclusão social se dá através da falta de meios econômicos, do isolamento social e de acesso limitado aos direitos sociais e civis.

Dessa forma, os fatores que podem contribuir para a exclusão social são: problemas laborais, padrões de educação e de vida, a saúde, a nacionalidade, a desigualdade econômica, entre outros tantos.

A exclusão social tem base multidimensional e pode ser expressa em diversos níveis, como: ambiental, cultural, econômico, político e social. Na maioria das vezes ela compreende vários níveis, ou até mesmo todos.

Assim, e de forma mais abrangente, o objetivo das políticas públicas de Inclusão Social é o de fazer com que, através das oportunidades geradas, pessoas mais necessitadas tenham a chance de participar da distribuição de renda do País, inserindo-os em programas em que todos sejam beneficiados e não apenas parte da sociedade. (SASSAKI, 2006)

Segundo Souza (2006, p. 33), as políticas públicas na sua essência estão ligadas fortemente ao Estado, este que determina como os recursos são usados para o benefício dos cidadãos. Ela faz uma síntese dos principais estudiosos desse tema, descrevendo quais instituições são responsáveis por sua execução, como os recursos devem ser guardados ou gastos, contudo todos esses processos devem ser transparentes e deve haver prestação de contas junto a sociedade.

Assim, os instrumentos de desenvolvimento das políticas sociais municipais são articulados pelos gestores públicos através
Secretaria Municipal de Desenvolvimento Social (SMDS) que tem a finalidade de propagar o desenvolvimento do município, utilizando ferramentas e buscando recursos para alavancar o desenvolvimento local.

\subsection{AS POLÍTICAS DE INCLUSÃO NA ÁREA DE ESTUDO}

Com base na proposta do estudo em analisar os programas sociais de inclusão social no âmbito do Governo Federal no Bairro esperança localizado no município de Itaboraí/RJ como vetor de desenvolvimento local e de inclusão social e sua implantação através de desenvolvidos pela prefeitura e suas secretarias, questões importantes foram levantadas e algumas lacunas ainda necessitam ser preenchidas.

Inicialmente foi analisada a estrutura políticoadministrativa do Município e do Bairro Esperança, objeto de estudo, localizado no Estado do Rio de Janeiro, na região metropolitana e tem uma população estimada de 227.168 para o ano de 2014, com base no censo de 2010 (IBGE, 2014), com 95\% de taxa de urbanização e cobrindo uma área de $430,37 \mathrm{~km}^{2}$.

A divisão político-administrativa compreende 08 (oito) distritos, sendo objeto do presente estudo o $1^{\circ}$ Distrito e o Bairro Esperança, que juntamente com ele, estão mais 29 bairros.

Segundo o IBGE (2010), o crescimento populacional se mantém dentro da taxa média estadual desde a década de 90 do século passado, contudo o processo de desenvolvimento acentuou fluxos migratórios, sendo o município localizado de forma estratégica, cortado por diversas rodovias e próximo à capital do estado, facilitando o deslocamento de residentes e acesso de pessoas que residiam em outras regiões.

A tabela 1 a seguir ilustra a evolução da população do município com destaque para o ano de 2014 (população projetada) sendo esse crescimento atribuído à instalação do Complexo Petroquímico do Estado do Rio de Janeiro (COMPERJ), anunciado em 2006 e início das obras em 2008. 
Tabela 1: Evolução Populacional

\begin{tabular}{|l|c|}
\hline \multicolumn{2}{|c|}{ ANO ITABORAÍ } \\
\hline 1991 & 162.742 \\
\hline 1996 & 183.561 \\
\hline 2000 & 187.479 \\
\hline 2007 & 215.792 \\
\hline 2010 & 218.008 \\
\hline 2014 (Projeção) & 227.168 \\
\hline
\end{tabular}

A implantação do COMPERJ propiciou o aumento do fluxo migratório no município, em decorrência das ofertas de emprego e da população flutuante, o que aumenta a pressão sobre a infraestrutura de serviços públicos e com consequente agravamento dos problemas sociais.

Quanto ao objeto de estudo, o bairro denominado Esperança está localizado no 1‥ Distrito do município e bem próximo ao centro da cidade, estando inserido em área classificada como zona urbana de acordo com o Zoneamento Municipal, contudo ainda não dispõe de infraestrutura adequada de serviços públicos que possibilitem o desenvolvimento pleno do bairro e melhoria da qualidade de vida de seus moradores.

O bairro Esperança possui cerca de 13.742 moradores, de acordo com o IBGE (2015). Inicialmente havia três subdivisões, e eram conhecidas pela população por estes nomes: Reta Velha, Reta Nova e BNH, embora as autoridades e pessoas externas à comunidade desconhecessem estes nomes. Há aproximadamente 4 anos a Prefeitura Municipal de Itaboraí unificou os três subbairros com o nome de Esperança.

Considerando como um bairro com elevado adensamento, de acordo com dados do Diagnóstico de Segurança de Itaboraí, realizado pela organização não governamental: Viva Rio Socioambiental (2014) e apresentado aos Secretários Municipais, o bairro Esperança possui índices de violência e criminalidade elevados, sendo conhecido principalmente pelo histórico de área violenta e onde o tráfico de drogas é uma constante.

Quando se compara o Bairro Esperança (Reta) aos demais bairros do município, verifica-se que o adensamento populacional é bastante significativo e apresenta, como em outros bairros com as mesmas características, sinais da desigualdade e pobreza.
Em Itaboraí, com a Lei Orgânica do Municipal, o Código de Obras e o Plano Diretor - Lei de Zoneamento (Lei Complementar no: 54/2006), se instituem diretrizes básicas para atender a questão da habitação do Município.

Alinhada com a legislação Federal e a Carta Magna, observa-se destaque no texto da Constituição Federal de 1988, em seu art. 182 que define que:

A política de desenvolvimento urbano, executada pelo Poder Público municipal, conforme diretrizes gerais fixadas em lei, tem por objetivo ordenar o pleno desenvolvimento das funções sociais da cidade e garantir 0 bem-estar de seus Habitantes.

Considerando o texto, o Zoneamento se torna ferramenta auxiliar na busca por igualdade e integração dos processos de desenvolvimento municipal e a população de forma geral.

\subsubsection{AS ZEIS}

Segundo o Plano Diretor Municipal (PDM), as Zonas de Interesse Social (ZEIS), são áreas demarcadas no território municipal, destinadas a assentamentos habitacionais de população de baixa renda. Podem ser espaços já ocupados por assentamentos precários ou demarcados sobre terrenos vazios. Na primeira situação, o objetivo é flexibilizar normas e padrões urbanísticos para, por meio de um planejamento de urbanização regulariza este assentamento. No caso das áreas vazias, a ideia é aumentar a oferta de terrenos para habitação digna e reduzir os custos.

As ZEIS têm por finalidade integrar as áreas tradicionalmente "marginalizadas" e melhorar a qualidade de vida da população, delimitando os parâmetros para construções e controlando o crescimento desordenado, evitando desta forma os processos de favelização.

São objetivos das ZEIS: Incorporar a cidade clandestina à cidade legal; Reconhecer a 
diversidade local no processo de desenvolvimento; Urbano (x padronização dos critérios e intervenções); Estender o direito à cidade e à cidadania; Associar de desenvolvimento urbano à gestão participativa; Estimular a produção de
Habitação de Interesse Social; Estimular a regularização fundiária e Estimular ampliação da oferta de serviços e equipamentos urbanos.

De acordo com o PDM, as ZEIS são classificadas da seguinte forma:

Quadro 2: Classificação das ZEIS no município

\begin{tabular}{|l|l|}
\hline ZEIS & DEFINIÇÕES \\
\hline ZEIS 1 & $\begin{array}{l}\text { Favelas, loteamentos irregulares e conjuntos habitacionais de interesse social, nos quais, podem ser } \\
\text { feitas intervenções de recuperação urbanística, regularização fundiária, produção e manutenção de } \\
\text { habitações de interesse social. }\end{array}$ \\
\hline ZEIS & $\begin{array}{l}\text { Terrenos baldios ou subutilizados, nos quais deve ser proposta a produção de moradias de interesse } \\
\text { social, equipamentos sociais, culturais, etc. }\end{array}$ \\
\hline ZEIS 3 & $\begin{array}{l}\text { Terrenos ou imóveis subutilizados em áreas com infraestrutura urbana, serviços e oferta de emprego } \\
\text { (geralmente na região central), nos quais se propõe a produção e reforma de moradias para a } \\
\text { habitação de interesse social, assim como de mecanismos de alavancagem de atividades de } \\
\text { geração de emprego e renda. }\end{array}$ \\
\hline ZEIS 4 & $\begin{array}{l}\text { Glebas ou terrenos em áreas de proteção aos mananciais dotados de infraestrutura urbana, nos } \\
\text { quais se permite a produção de habitações de interesse social, exclusivamente destinadas à } \\
\text { população transferida de áreas de risco e das margens das represas. }\end{array}$ \\
\hline
\end{tabular}
Fonte: PDM (2006)

Cabe destacar que para cada classificação de uma ZEIS, algumas características são associadas de forma a permitir melhor enquadramento dessas áreas e alinhar políticas públicas específicas para cada uma delas. No caso da ZEIS no bairro Esperança, a mesma está classificada como ZEIS 1, considerando as características de uso e ocupação da área.

Para a caracterização da ZEIS Esperança (Reta Nova), foi utilizada a base de dados do zoneamento municipal associado a plataforma de dados se sensoriamento remoto do Google Earth se forma a permitir melhor entendimento do leitor sobre a área.

A ZEIS-1 Esperança em sua demarcação possui perímetro de 6.176 metros e área total de $1,33 \mathrm{Km}^{2}$ e pela figura 6 a seguir pode-se perceber que é uma área relativamente pequena e com alta densidade demográfica.
A área demarcada a oeste é a área de intervenção onde está sendo implantado o empreendimento do programa Minha Casa Minha Vida, com perímetro de aproximadamente 3.169 metros e área total de $0,49 \mathrm{Km}^{2}$.

De acordo com a Lei de Zoneamento, $70 \%$ do Bairro Esperança está inserida na ZEIS, e sendo assim, os serviços públicos devem ser ofertados para acesso comum à população e com tarifas diferenciadas face as características socioeconômicas da população para se beneficiarem efetivamente dos serviços essenciais.

Nesse contexto, as ZEIS são instrumentos da regularização fundiária e a concessão especial para fins de moradia está previsto na Lei Federal o 10.257, de 10 de julho de 2001 (Estatuto das Cidades).

Figura 1: Imagem em detalhe do Bairro Esperança e da área de expansão (MCMV)

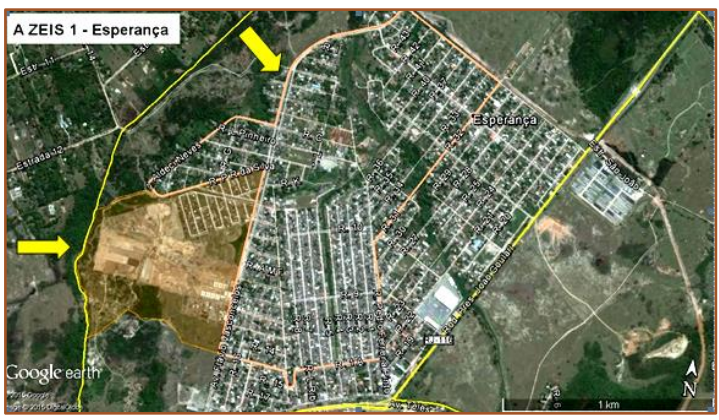

Fonte: Google Earth (2015) 
Alinhado à legislação e ao papel de intervenção pública, verificou-se a implantação de empreendimento do programa Minha Casa Minha Vida que está sendo implantado em uma ZURB ao lado da ZEIS para atender a uma demanda social por moradias de famílias hoje instaladas em áreas de risco - Já estando em fase de implantação um conjunto habitacional do programa que irá beneficiar cerca de 3.000 famílias e aproximadamente 12.000 pessoas - São 3.000 unidades habitacionais em construção de acordo com o projeto, mais as unidades complementares de apoio como creche, posto de saúde, uma UPP, entre outras.

As ZEIS foram implementadas com função de políticas sociais necessárias, buscando: minimizar as desigualdades sociais, transformando as cidades em espaços mais humanizados, ampliando o acesso da população à moradia, contribuindo para o desenvolvimento local.

\subsubsection{PROGRAMAS SOCIAIS NO BAIRRO ESPERANÇA}

O Bairro Esperança, por ser considerada uma área de subnormalidade, hoje é atendido por alguns dos diversos programas sociais do governo federal que objetivam a melhor qualidade de vida da população, levando serviços diversos a comunidade e seus moradores.

Hoje existem alguns programas de inclusão sendo desenvolvido na comunidade, sendo detalhados no quadro 3 :

\section{Quadro 3: Programas Sociais}

\begin{tabular}{|c|c|}
\hline & \\
\hline $\begin{array}{l}\text { CRAS } \\
\text { (Centro de Referência } \\
\text { e Atendimento Social) }\end{array}$ & $\begin{array}{l}\text { É a principal porta de entrada do Sistema Único de Assistência Social } \\
\text { (SUAS), é a unidade que possibilita o acesso das famílias à rede de } \\
\text { proteção social básica, ofertando serviços e ações da proteção social } \\
\text { básica e realizar o cadastro único (cadÚnico) das famílias em situação de } \\
\text { miséria e realizar o trabalho social daqueles que são atendidos pelo } \\
\text { programa de Atendimento Integral as Famílias (PAIF), oferecendo cursos } \\
\text { e oficinas. }\end{array}$ \\
\hline $\begin{array}{l}\text { NAPEM } \\
\text { (Núcleo } \\
\text { Atendimento } \\
\text { Pedagógico) } \\
\end{array}$ & $\begin{array}{l}\text { Atendimentos de crianças e adolescentes na rede municipal de } \\
\text { educação, em psicólogos, fonoaudiólogos e ass. Social, auxiliando na } \\
\text { inclusão da criança, seja na escola ou na sociedade. }\end{array}$ \\
\hline $\begin{array}{ll}\text { PETI } & \\
\text { (Programa } & \text { de } \\
\text { Erradicação } & \text { do } \\
\text { Trabalho Infantil) } & \end{array}$ & $\begin{array}{l}\text { É um programa do governo federal de transferência direta de renda para } \\
\text { famílias de crianças e adolescentes envolvidos no trabalho infantil. }\end{array}$ \\
\hline $\begin{array}{l}\text { EJA } \\
\text { (Educação de jovens e } \\
\text { Adultos) }\end{array}$ & $\begin{array}{l}\text { Programa desenvolvido para inserir jovens e adultos novamente à sala de } \\
\text { aula. }\end{array}$ \\
\hline Bolsa Família & $\begin{array}{l}\text { Programa que visa à erradicação da miséria extrema, contribuindo para a } \\
\text { saúde da família e dando-lhes qualidade de vida. }\end{array}$ \\
\hline PROJOVEM & $\begin{array}{l}\text { Inserção de jovens do ensino fundamental, ás salas de aula com curso } \\
\text { de qualificação em um período já estipulado de } 18 \text { meses. }\end{array}$ \\
\hline Auxílio Funeral & $\begin{array}{l}\text { Auxilio funeral às famílias em situação de vulnerabilidade e risco social } \\
\text { com o pagamento das despesas de uma funerária, de velório e de } \\
\text { sepultamento. }\end{array}$ \\
\hline $\begin{array}{l}\text { Minha Casa Minha } \\
\text { Vida }\end{array}$ & $\begin{array}{l}\text { Auxilio funeral às famílias em situação de vulnerabilidade e risco social } \\
\text { com o pagamento das despesas de uma funerária, de velório e de } \\
\text { sepultamento }\end{array}$ \\
\hline
\end{tabular}

Fonte: Portal Brasil (2015)

Considerando ser objetivo do estudo, analisar os programas sociais, os programas listados no quadro 3 foram objeto de avaliação com a pesquisa de campo junto à comunidade onde os moradores foram interpelados sobre a efetividade desses programas. 
Buscando melhor entendimento sobre a efetividade dos programas sociais em desenvolvimento no bairro e de forma a sustentar às discussões do estudo, foi desenvolvida pesquisa com a população local e cujos resultados permitiram inferir tendências e propor alternativas de melhoria para os mesmos, sendo esse processo detalhado a seguir.

\subsection{PESQUISA JUNTO À COMUNIDADE}

A pesquisa buscou identificar questões específicas em relação aos programas sociais em desenvolvimento no bairro e sua efetividade. Por questões de custo e de tempo, dificilmente se realiza um censo com toda população, desta forma a grande maioria das pesquisas elabora uma amostra da população que pretende ser analisada, a amostra é amplamente concebida pela literatura como um fragmento de uma determinada população, através do qual se procura estimar as características e propriedades de determinada população.

A pesquisa foi desenvolvida a partir de questionário composto por 20 perguntas fechadas, cada uma com cinco opções de respostas.

Foi realizada entre dos dias 18 e 19 de junho de 2015, com 450 questionários respondidos. Para fins de amostragem, os pesquisados foram escolhidos de forma aleatória em vários pontos do bairro e em horários diversificados, buscando dessa forma variar ao máximo possível a amostra. O resultado possibilitou fornecer estimativas com nível de confiança de $95 \%$ e margem de erro de 4,5 pontos percentuais para mais ou para menos.

Após a aplicação dos questionários os dados foram tabulados e os resultados consolidados, o que permitiu estabelecer tendências e contribuir com respostas aos questionamentos fundamentais do estudo.

\subsubsection{APRESENTAÇÃO DOS RESULTADOS}

Nessa etapa do estudo são apresentados os questionamentos da pesquisa e apresentados os resultados obtidos, que permitiram subsidiar a análise de resultados $e$ as conclusões do estudo.

Primeiramente buscou-se traçar o perfil da população entrevistado através das variáveis: sexo, faixa etária, composição familiar, perfil familiar, composição econômica.

Sendo assim, pode-se perceber que dentre os entrevistados houve uma predominância no número de mulheres, totalizando $55,0 \%$ da amostra. No que diz respeito a faixa etária, a maior parte dos entrevistados possuem entre 29 e 39 anos de idade (35,0\%). Percebe-se equivalência entre as faixas de 18 a 28 e 51 a 61 anos ficaram ambas com $20 \%$, totalizando $40 \%$ da população pesquisada. O que se verifica é que $55 \%$ da população encontra-se na faixa de 18 a 39 anos, indicando para uma população relativamente jovem e já com a responsabilidade de manter família, o que demanda emprego e renda.

Em relação a quantidade de moradores na residência, a resposta predominante foi de 1 a 4 com $55 \%$ e de 5 a 8 com $45 \%$ das respostas. A opção, acima de 9, não obteve percentual. Entende-se então, que a média de moradores está entre 1 a 4 pessoas, coincidindo com a média fornecida pelo IBGE (2015).

Com relação a situação econômica do chefe da família dos entrevistados, a opção desempregado ficou com 40\%, a opção empregado formal ficou em segundo lugar com $25 \%$, empregado informal teve $20 \%$, e a opção outros ficou com 15\%, e a opção nunca trabalhou não obteve pontuação. Visto que $40 \%$ dos entrevistados afirmaram, que ele ou o chefe da família na qual ele está inserido encontra-se desempregado e sem renda.

Na questão da renda média da família, foram perguntados quanto a remuneração familiar, e os entrevistados apontaram os seguintes dados. A opção de 1 a 2 salários teve $45 \%$, com menos de um salário mínimo teve 40\%, e a opção de 3 a 4 salário teve 15\%. As alternativas 5 a 6 e acima de 7 salários não obtiveram percentual. Nota-se que 95\% das famílias têm sua renda média de até dois salários mínimos, considerando que $40 \%$ dos considerados os chefes das famílias estão desempregados e que as famílias são formadas pelo perfil tradicional, podemos concluir que mais um dado estatístico se caracteriza de forma fiel. As mulheres estão cada vez mais no mercado de trabalho e assumindo a chefia das famílias, mesmo que não reconhecidas como tal.

Buscou-se também identificar a composição familiar do domicílio, no que se refere aos adultos a alternativa referente à de 1 a 3 adultos teve $75 \%$ das respostas, pensando 
em uma composição familiar tradicional, podemos considerar que um dos filhos se tornou adulto, desta forma pode também está compondo e auxiliando na renda média desta família.

Com relação ao quantitativo de adolescentes $90 \%$ dos respondentes possuem de 0 a 3 adolescentes (de 14 a 18 anos) compondo o grupo familiar no qual pertence $e$ no quantitativo de crianças, a opção de 0 a 3 anos ficou $60 \%$, a segunda opção de 4 a 6 anos ficou com $25 \%$. A terceira opção acima de 6 anos totalizou 15\%.

Ainda buscando traçar o perfil das famílias diagnosticou-se que, de acordo com as respostas, estão em sua maioria de 0 a 3 pessoas, com $85 \%$, a segunda maior opção foi de 4 a 6 pessoas com 15\%. A terceira opção, acima de 6 pessoas, não obteve nenhuma porcentagem. Dentre as famílias que fizeram parte da amostra, e que apresentaram alguns de seus membros como estudantes, a sua grande maioria foi de nível fundamental, seguido do nível médio. E a maioria, se não todos, são referentes às crianças e os adolescentes.

Na segunda parte do questionário, buscou-se entender qual tipo de moradia que 0 entrevistado e sua família residem, e de acordo com os dados colhidos, $90 \%$ dos respondentes residem em casa de alvenaria e $10 \%$ em barraco. As demais opções não foram marcadas.

Tabela 2: Tipo de Moradia

\begin{tabular}{|c|c|c|}
\hline Tipo de moradia & Quant. Absoluta & Quant. Percentual \\
\hline Alvenaria & 405 & $90,0 \%$ \\
\hline Barraco & 45 & $10,0 \%$ \\
\hline Pau a Pique & 0 & $0,0 \%$ \\
\hline Palafita & 0 & $0,0 \%$ \\
\hline TOTAL & 450 & $100,0 \%$ \\
\hline
\end{tabular}

Fonte: Os autores (2015)

Em sua grande maioria, com 90\%, as residências construídas/habitadas, são de alvenaria, isso resulta em maior conforto e qualidade de vida para os moradores, por se tratar de uma casa mais segura.
Objetivando entender ainda melhor a realidade dos moradores do bairro Esperança, foi perguntado aos entrevistados sobre o status das moradias, sendo os resultados apresentados na tabela 3.

Tabela 3: Tipo de Moradia

\begin{tabular}{|c|c|c|}
\hline Tipo de moradia & Quant. Absoluta & Quant. Percentual \\
\hline Própria & 337 & $75,0 \%$ \\
\hline Alugada & 45 & $10,0 \%$ \\
\hline Cedida & 23 & $5,0 \%$ \\
\hline Posse & 45 & $10,0 \%$ \\
\hline TOTAL & 450 & $100,0 \%$ \\
\hline
\end{tabular}

Fonte: Os autores (2015)

Observando os dados da tabela 3, verifica-se que $75 \%$ das famílias possuem casa própria, de alvenaria e com a composição familiar de 1 a 4 pessoas.

Constatando que $75 \%$ das famílias possuem suas casas próprias, qual a necessidade de desenvolver um programa social de financiamento para a casa própria? Ao se iniciar o desenvolvimento de um projeto de inclusão, deve-se conhecer o local e as demandas.

O tempo de moradia foi questionado, buscando-se estabelecer correlações com as pressões demográficas produzidas pela implantação do COMPERJ e impactos potenciais dessa pressão. 
Tabela 4: Tempo de Residência

\begin{tabular}{|c|c|c|}
\hline Tempo de residência & Quant. Absoluta & Quant. Percentual \\
\hline De 0 a 2 anos & 0 & $0,0 \%$ \\
\hline De 3 a 5 anos & 22 & $5,0 \%$ \\
\hline De 6 a 8 anos & 22 & $5,0 \%$ \\
\hline De 9 a 15 anos & 90 & $20,0 \%$ \\
\hline Acima de 15 anos & 316 & $70 \%, 0$ \\
\hline TOTAL & 450 & $100,0 \%$ \\
\hline
\end{tabular}

Fonte: Os autores (2015)

Verifica-se que em relação ao tempo de residência no Bairro, $70 \%$ indicaram residir a mais de 15 anos e entre 9 e 15 anos, cerca de $20 \%$ compõem o resultado.

Pode-se inferir que, considerando que as obras do COMPERJ se iniciaram em 2010, o processo gerador de pressão demográfica não influenciou à população do bairro, já que 90\% de seus moradores fixaram residência na localidade a mais de 9 anos, descartando o discurso geral de que o COMPERJ provocou pressões com aumento de população.

$\mathrm{Na}$ análise dos programas sociais implementados e em curso na comunidade, e se os mesmos têm abrangência e capacidade de atendimento, foi questionado ao entrevistado se este seria beneficiário de algum programa social, sendo os resultados apresentados na tabela 5 .

Tabela 5: Está sendo beneficiado

\begin{tabular}{|l|c|c|}
\hline Esta sendo beneficiado? & Quant. Absoluta & Quant. Percentual \\
\hline SIM & 293 & $65 \%$ \\
\hline NÃO & 158 & $35 \%$ \\
\hline TOTAL & 450 & $100 \%$ \\
\hline
\end{tabular}

Fonte: Os autores (2015)

De acordo com os resultados apurados, verifica-se que $65 \%$ dos pesquisados estão vinculados a algum tipo de programa social e cerca de $35 \%$ informaram que não são beneficiários. Assim, e de forma complementar, outro questionamento foi formulado a fim de identificar a qual programa estariam vinculados.

Tabela 6: Programas do Governo Federal que a família está inserida

\begin{tabular}{|l|l|l|}
\hline \multicolumn{1}{|c|}{ Programas inseridos Quant. Absoluta } & \multicolumn{1}{c|}{ Quant. Percentual } \\
\hline Bolsa Família & 205 & $70,0 \%$ \\
\hline Pró Jovem & 44 & $15,0 \%$ \\
\hline PETI & 44 & $15,0 \%$ \\
\hline NAPEM & 0 & $0,0 \%$ \\
\hline Brasil Carinhoso & 0 & $0,0 \%$ \\
\hline Outro & 0 & $0,0 \%$ \\
\hline TOTAL & 293 & $100,0 \%$ \\
\hline \multicolumn{2}{|c|}{ Fonte: Os autores (2015) }
\end{tabular}

Verifica-se nos resultados que o programa Bolsa Família é o mais acessado, com $70 \%$, das respostas, seguido pelo programa Pró jovem e PETI, ambos com 15\% das respostas. Não sendo indicados outros programas existentes na comunidade.
Questionamento complementar foi feito buscando a avaliação dos programas sociais desenvolvidos no bairro e sua efetividade enquanto proposta de atendimento de demandas e necessidades, sendo os resultados apresentados na tabela 7 . 
Tabela 7: Avaliação dos Programas Sociais

\begin{tabular}{|l|c|c|}
\hline \multicolumn{1}{|c|}{ Avaliação dos programas } & Quant. Absoluta & Quant. Percentual \\
\hline Boa & 113 & $25,0 \%$ \\
\hline Ótima & 0 & $0,0 \%$ \\
\hline Regular & 135 & $30,0 \%$ \\
\hline Ruim & 135 & $30,0 \%$ \\
\hline Péssima & 67 & $15,0 \%$ \\
\hline TOTAL & 450 & $100,0 \%$ \\
\hline
\end{tabular}

$\mathrm{Na}$ análise das repostas, verifica-se que as opções: regular, ruim e péssima corresponde a grande maioria das indicações, totalizando $75 \%$ de insatisfação em relação aos programas. Apenas 25\% indicaram como boa a avaliação dos programas sociais a que tem acesso.

Aqui verifica-se uma inconsistência quando a proposta de efetividade dos programas seria o pleno atendimento das demandas e o que se observou na prática é que a população acessa os programas, mas estes ainda não conseguem atender suas necessidades.

\section{RESULTADOS E DISCUSSÕES}

Observando os resultados que foram encontrados através da pesquisa de campo e buscando verificar a efetividade dos Programas de Inclusão Social desenvolvidos no Bairro Esperança, percebeu-se, que os programas, conseguem atender a uma parcela da população que de fato necessita, contudo, ainda deixa muito a desejar, pois de acordo com os dados, ainda existem muitas famílias não atendidas por programas de inclusão social.

Dentre os programas desenvolvidos na comunidade o mais abrangente é o Bolsa Família, inserido em $70 \%$ das famílias, contudo os moradores necessitam de ferramentas para alterarem suas realidades sociais. Este programa é de grande relevância, entretanto as famílias e seus membros precisam de mais.

Quanto aos programas desenvolvidos no bairro, foi observado o Minha Casa Minha Vida, em processo de construção, que atenderá cerca de 3.000 famílias e está sendo desenvolvido no bairro Esperança, por este está inserido em uma ZEIS, buscando desta forma, trazer dignidade aos moradores e retirando-os de áreas de risco, na comunidade existe apenas o risco social, risco ambiental ou natural não existe na localidade, tais como: enchentes, alagamentos, entre outros.

Contudo, apenas 25\% dos pesquisados informaram não possuir casa própria, assim torna-se questionável o programa Minha Casa Minha Vida neste bairro, além disso, cerca de $45 \%$ desta população (amostra), disse ter em média de 5 a 8 membros, e as casas do programa foram projetadas para famílias com 3.4 pessoas, desta forma as casas estarão fora dos padrões e não atenderão as necessidades destes moradores.

Deveria ter sido realizada uma análise do perfil da comunidade assim como de seus moradores, para então desenvolver um programa que atendesse as demandas locais. O programa que está sendo desenvolvido para atender as necessidades dos moradores locais, se tornará o motivo de migrações para o bairro de pessoas de outras localidades que serão beneficiadas sem terem real necessidade de ingresso no programa.

Ressalta-se assim que a necessidade de se conhecer amplamente o perfil da população e características de cada bairro permite ajustar melhor os programas de inclusão a serem desenvolvidos e que atendam às necessidades reais das comunidades atendidas.

\section{CONCLUSÕES E RECOMENDAÇÕES}

O estudo teve como foco, a comunidade Bairro Esperança (Reta Nova), considerada área de sub-normalidade e localizada no 1으. Distrito do Município de Itaboraí/RJ, verificado se a população está sendo inserida efetivamente a partir desses programas ou excluída de alguma forma e se os Programas de Inclusão Social chegam até eles na forma como são propostos, levando em conta que a análise das Políticas Públicas é o estudo do processo e não apenas das consequências resultantes das intervenções. 
A análise dos programas de inclusão social desenvolvidos no Bairro Esperança, comunidade que está inserida em uma ZEIS e de sua efetividade, permitiu estabelecer a relação entre a base da proposta geral do programa federal e a prática efetiva observada in loco no que se refere ao fomento ao desenvolvimento local proposto.

Através da pesquisa realizada com os moradores foi possível entender a dinâmica da comunidade e o perfil dos moradores, além de possibilitar a criação de uma ferramenta de pesquisa para obtenção de dados relevantes e criar indicadores para tal análise.

Através da pesquisa realizada em campo notou-se uma demanda relevante de uma parcela da população que necessita de atenção dos gestores, que devem ser amparados por programas de inclusão, visando seu desenvolvimento. Como visto durante o estudo, esta parcela da população, está sendo privado de seus direitos constitucionais de serem incluídos em uma sociedade e gozar de direito iguais aos demais.

Este estudo cumpriu o que foi proposto, os programas sociais desenvolvidos na comunidade existem, são poucos e não atendem a todos que necessitam deles. As pessoas que não estão no perfil do programa Bolsa Família, que atende $70 \%$ da amostra,

\section{REFERÊNCIAS}

[1] Carvalho, José Murilo de. Cidadania no Brasil: o longo caminho. Rio de Janeiro: Civilização Brasileira, 2002.

[2] Constituição Federal de 1988. Disponível em: <http:// www. planalto.gov.br/civil> Acesso em: 30/10/2014.

[3] Freitas. Neli. Política Pública e Inclusão: Análise e perspectivas Educacionais. 2010. Disponível em:<http://www.Ffc.br> Acessado em 01/06/2015.

[4] Fleury, Sônia. Política Assistencial: A Seguridade Social e os Dilemas da Inclusão Social. $2005 . \quad$ Disponível em :<http://www.app.ebape.fgv.br> Acessado em 01/06/2015.

[5] Ibge. Instituto Nacional de Geografia e Estatística. 2010.Disponível em:< http://www.ibge.gov.br> acessado em 28/10/2014. [6] Jornal O Globo. 2014. Disponível em:<http://www. Oglobo.globo.com> Acessado em 15/06/15.

[7] Itaboraí. LEl No. 54/2006 DE 26 DE Dezembro de 2006. Institui o Plano Diretor Municipal. estão ficando sem o atendimento de suas carências.

Através de políticas públicas voltadas para a inclusão social, desenvolvimento dos moradores e diminuição da pobreza e da fome, é possível alterar realidades, melhorar a qualidade de vida desses indivíduos, retirá-los da margem da sociedade e inseri-los nela.

De acordo com os dados da pesquisa, verifica-se que os projetos implantados na comunidade, atendem uma pequena parcela da população, contudo percebe-se que ainda grande demanda e que necessita de um olhar diferenciado dos gestores públicos.

As deficiências verificadas nos Programas desenvolvidos no Bairro Esperança estão relacionadas à falta de um diagnóstico mais amplo e abrangente do perfil local e ainda carecem de planejamento adequado para sua execução.

Este estudo não tem como objetivo findar a discussão sobre este assunto, mas sim contribuir para um entendimento inicial apresentando indicadores relevantes, quanto à dinâmica do bairro e o perfil de seus moradores, sendo assim uma proposta inicial para fundamentar novas discussões e estudos a serem realizados em futuro próximo pelos autores.

em:<http://www.itaboraí.org.br > acessado em 18/10/2014

[8] Meksenas, Paulo. Cidadania, Poder e Comunicação. 2002.Disponível em: <http://www.artigonal.br> Acessado em 15/05/15

[9] Politica Nacional para a Inclusão Social da População em Situação de rua. Disponível em: $<$ http://_www.recife.pe.gov.br>. Acessado em 21/04/15.

[10] Portal Brasil.Disponível em: http://www.brasil.gov.br> Acessado em 15/06/15.

[11] Sawaia, Bader. AS ARTIMANHAS DA EXCLUSÃO: Análise Psicossocial e Ética da Desigualdade Social. 2001.Disponível em: http:// www.Revispsi.UREJ> Acessado em 09/04/15.

[12] Souza. Celina. Estado da Arte da Pesquisa em Políticas Públicas. 2006.Disponível em:<http://www.igepri.org $>$ Acessado em 08/06/2015

[13] Sassaki. Romeu. Inclusão: Construindo uma Sociedade para Todos. 2006. Disponível em: <http:// www.scielo.br > Acessado em 08/06/15. 


\section{Bapítulo 6}

\section{REDE CAUSA JUSTA - FATORES CRÍTICOS DE SUCESSO DA REDE DE EMPREENDIMENTOS COMUNITÁRIOS DO MÉDIO E BAIXO RIO MADEIRA}

\section{Andressa Samara Masiero Zamberlan}

Mariluce Paes de Sousa

Resumo:A formação de redes como estratégia de cooperação e ação coletiva para o alcance de objetivos comuns tem sido mais frequentes nos últimos tempos, o que corrobora com vários estudos sobre estratégias e aspectos organizacionais. Observa-se com base na literatura que a formação de redes de relacionamentos dá-se por meio de processos que envolvem a formação, manutenção e resultado, sendo que estes podem ser afetados por fatores relacionais, organizacionais e ambientais, os quais são considerados como fatores críticos de sucesso. A metodologia aplicada a este artigo é analise de conteúdo utilizando os Fatores Críticos de Sucesso que são divididos nas seguintes dimensões: ambiente de negócios; aspectos antropológicos e socioculturais; políticas macroeconômicas e processo de formação propostas por Cândido e Abreu (2004) que totalizam 33 variáveis e o Relatório Síntese Projeto Agroindústrias para o Médio e Baixo Rio Madeira elaborado pelo IEPAGRO - Instituto de Estudos e Pesquisas Agroambientais e Organizações Sustentáveis serviu como base de pesquisa. Isto com a finalidade identificar e analisar os Fatores Críticos de Sucesso na criação da Rede Empreendimentos Comunitários do Médio e Baixo Rio Madeira, no Município de Porto Velho, Estado de Rondônia.

Palavras-Chave: Economia Solidária, Redes Solidárias e Empreendimentos Comunitários. 


\section{INTRODUÇÃO}

A motivação de indivíduos se unirem por objetivos e interesses coletivos, são denominadas redes, por sua vez estas se caracterizam pela interação das partes envolvidas. Para alcançar tais objetivos e interesses às redes compostas por empreendimentos, obedecem aos princípios da economia solidária, tais como: democracia, cooperação e igualitarismo, tendo o trabalho, e não o lucro, como foco das suas ações, na literatura são denominados de empreendimentos econômicos solidários (EES), representados por cooperativas, associações, empresas auto geridas e ainda grupos informais.

As redes de empreendimentos buscam garantir a todos os participantes da rede iguais condições de participar e decidir, sobre a sua produção, e nas demais esferas políticas da sociedade, visando combater toda forma de exploração de trabalhadores, enfatizando o valor da cidadania na busca do bem comum e da cooperação. A abordagem de redes é uma forma de examinar as organizações não como átomos - isolados e independentes umas das outras - mas como um conjunto imerso em contexto que, além do aspecto econômico, envolve também o histórico, político, cultural e social e que, por isso, apresenta motivações de diversas naturezas (GRANOVETTER, 1992).

Isto remete a um conjunto de fatores-chave em todo o processo de formação, os quais precisam ser observados como condição para a continuidade e o sucesso da ação, o que é denominado de Fatores Críticos de Sucesso - F.C.S, que Watson et al (1992), definem como sendo um conjunto de condições vitais de um dado projeto social, que quando falhas, aumentam a probabilidade de insucesso e, quando satisfatórias, assegurarão 0 alcance dos objetivos pretendidos. (CÂNDIDO, 2001).

Os fatores ambientais e organizacionais afetam a formação de relacionamentos cooperativos os quais são desenvolvidos por meio de um processo, portanto, a presença ou ausência desses fatores interferem no sucesso ou fracasso da cooperação. Cândido e Abreu (2004) considerando a importância de entender tais fatores propõem as seguintes categorias de análise: ambiente de negócios; aspectos antropológicos e socioculturais; políticas macroeconômicas e processo de formação. Os aspectos antropológicos e socioculturais têm por objetivo mostrar as interferências, trocas e interações humanas dentro de ambientes que se interligam, sem esquecer o processo de formação (aspectos relevantes da cultura) e as resultantes desses elementos.

Quanto as políticas macroeconômicas, o que se leva em consideração, é quem são os responsáveis por iniciativas, mecanismos e incentivos externos a rede, porém estes devem influir no comportamento, decisões, estratégias da iniciativa em questão. O processo de formação, nos remete as seguintes etapas, familiarização com conceitos, escolha de agentes, estrutura e arquitetura organizacional adotada.

As ideias de redes de empreendimentos comunitários surgem como uma opção no cenário atual buscando trazer desenvolvimento tanto em áreas urbanas como também em áreas rurais. Existe uma tendência maior voltada ao setor agrário, pois tem como objetivo fazer com que o pequeno produtor permaneça no campo e ainda aumente sua renda e melhore a qualidade de vida (ARAÚJO, 2009).

Para compreensão de tais fenômenos este estudo se propõe a analisar os fatores críticos de sucesso na criação da rede de empreendimentos comunitários no Médio e Baixo Rio Madeira - Rede Causa Justa, no município de Porto Velho, em Rondônia, que concentra 66 comunidades, divididas do ponto de vista geopolítico em 5 distritos, onde as atividades econômicas são desenvolvidas no nível primário, com uma produção predominantemente extrativista e com processos simples de manufatura, como é o caso da produção de farinha de mandioca.

Embora este quadro seja conhecido nas 3 esferas de poder em âmbito Municipal, Estadual e Federal, somente no ano de 2005 começa a receber maior atenção, quando surgem as primeiras movimentações para a construção das Usinas Hidrelétricas do Madeira. Pois, as exigências de ações mitigadoras estabelecidas no Plano Básico Ambiental - PBA, aprovado pelo Instituto Brasileiro de Meio-Ambiente - IBAMA, trazem propostas de criação de um Programa de Ações a Jusante das Usinas. Para atendimento ás premissas do plano foram desenvolvidas várias atividades, sustentadas por diagnósticos sobre a situação atual, expectativas e potencialidades produtivas, os quais subsidiaram as negociações dos 
consórcios construtores com as lideranças locais (PAES-DE-SOUZA, 2010).

No entanto, dado a complexidade da situação, o IBAMA solicitou outros estudos, sendo contratada a Universidade Federal de São Carlos para revisar o primeiro $\mathrm{PAB}$, no qual as empresas construtoras comprometeram-se a viabilizar a implementação de agroindústrias nos distritos, tendo como principal exigência que fosse garantida a sustentabilidade de tais empreendimentos. Logo, no PAB revisado pela UFSCar foi concebido um modelo de qualidade de vida ribeirinha. No entanto, para que o tal modelo fosse implementado, houve a necessidade de contratação de uma organização que operacionalizasse as ações ali prevista (PAES-DE-SOUZA, 2010)

Para realização desta atividade, a empresa responsável pela construção, a Santo Antônio Energia - SAE, contratou o Instituto de Estudos e Pesquisas Agroambientais e Organizações Sustentáveis - IEPAGRO para operacionalização do modelo concebido pela UFSCar.

Os resultados de tais estudos geraram uma base de dados organizada e sistematizada com plataforma articulada que demonstram a realidade das famílias, das organizações sociais, produtivas, e das comunidades como um todo, possibilitando com que os pesquisadores do IEPAGRO fizessem uma prospecção de uma rede de empreendimentos comunitários, a qual foi denominada de "Rede Causa Justa" em alusão a luta dos ribeirinhos por permanecerem em suas comunidades e ao papel de guardadores da floresta nos últimos dois séculos, tornando a região do Médio e Baixo Rio Madeira a área habitada mais preservada do Estado de Rondônia (IEPAGRO, 2010).

A proposição referida foi registrada em relatório, tendo sido publicado, constando na base de dados do IEPAGRO. O relatório foi entregue às autoridades estaduais e municipais, e também ao IBAMA. A partir destas informações e tendo em conta os aspectos geopolíticos, socioeconômicos e ambientais da região, alinha-se a seguinte questão de pesquisa: Quais os fatores críticos de sucesso na criação da rede de empreendimentos comunitários do Médio e Baixo Rio Madeira?

\section{REVISÃO DE LITERATURA}

A discussão de economia solidária, chamada também de Ecosol, surge quando o mundo adota um sistema econômico denominado capitalista, em que os meios de produção e distribuição são pautados na propriedade privada e com fins lucrativos, sendo assim, se trona necessário conhecer as origens teóricas da economia solidária.

O surgimento das concepções relacionadas à Ecosol provém do diálogo entre a sociologia e a economia, isso no final do século XIX e início do XX pelos clássicos da sociologia (GISLAIN \& STEINER, 1995; STEINER, 1999 apud AZAIS, 2009). Uma "nova" ciência, a sociologia econômica ou a socioeconomia, surgiu. Entre as temáticas abrangidas por este ramo da sociologia, a "economia solidária" vem ocupando lugar de destaque (AZAIS, 2009, p. 39).

De maneira concisa, pode-se dizer que a sociologia estuda a análise das interdependências entre os membros de um grupo, onde os atores são influenciados entre si podendo atuar de forma racional ou irracional. As Teorias econômicas ortodoxas, no entanto, afirmam que os atores são influenciados por outros atores e seus comportamentos são guiados pela racionalidade. Até recentemente a economia podia se resumir no trinômio, progresso técnico, acumulação de capital, crescimento de renda, repousando sobre o sistema de preços, porém hoje ela se tornou mais acessível, fazendo assim que exista um cruzamento entre as temáticas sociológicas e econômicas (AZAIS, 2009).

A fim de complementar, Azais, na mesma obra, retrata a posição de outros pensadores:

(...) o próprio Sismondi, já em 1819, nos Novos princípios de economia política, sensibilizado pela miséria social e pelas condições de trabalho da classe operária, opunha-se às funções autorreguladoras do mercado. Para ele, o homem - e não acumulação - fornece o objeto central da economia. Stuart Mill, na sequência de Sismondi, coloca o homem no cerne da economia. (...) O progresso não se resume no crescimento de bens disponíveis, é preciso que eles sejam bem distribuídos. Portanto, progresso econômico não é sinônimo de progresso social. Favorável a uma sociedade fundamentada em relações igualitárias entre operários e patrões, (...) Stuart Mill julga que o 
progresso depende da associação de interesses entre grupos sociais com anseios divergentes (...)(AZAIS, 2009, p. 41)

Considerando tais posições, embora a economia solidária ter ascendido recentemente nas discussões, ideias de união de interesses, maior igualdade entre as classes sociais já faziam parte de algumas teorias antigas. Sendo que tais teorias contemplam a analise do mercado econômico com um todo, onde não deixam o social a simples mercê das leis de mercado. Isso nos leva a dizer que a economia solidária é oposta a pensamentos econômicos ortodoxos.

Segundo Lévesque (2001) citado por Azais (2009), a sociologia econômica trata da ação econômica, de suas relações e processos de arranjos institucionais. Sendo que está cobre cinco campos de investigação: 1) o ator econômico e seus motivos de ação; 2) a estrutura social econômica; 3) os modos de regulamentação e de legitimação; 4) os efeitos da economia sobre a sociedade; e 5) as interações entre 0 desenvolvimento econômico e mudança social (LÉVESQUE et al. 2001, p. 47 apud AZAIS, 2009).

Alinha-se a seguir em quais aspectos a economia solidária difere, mesmo que minimamente, de economia social, para tanto, recorre-se a Harribey (2000) e Guélin (1998) citado por Lechat (2002) que definem economia social da seguinte maneira:

\begin{abstract}
"... tem uma abrangência normativa $e$ ideológica e tenta responder às necessidades reais das classes mais populares, seja para assegurar-se contra doença através de fundos de socorro antes da Previdência Social existir, para acessar ao crédito por meio de organismos de crédito cooperativo, ou para comprar bens junto a cooperativas de consumo, ou então para organizar-se em grupos produtores, como na agricultura (HARRIBEY, 2000, p. 11 apud LECHAT)."
\end{abstract}

Neste sentido Guélin vai mais além ao definir economia social, como:

"... ela é composto por organismos produtores de bens e serviços, colocados em condições jurídicas diversas no seio das quais, porém, a participação dos homens resulta de sua livre vontade, onde o poder não tem por origem a detenção do capital e onde a detenção do capital não fundamenta a aplicação dos lucros". (GUÉLIN,1998, p.13 apud LECHAT, 2002)

Considerando as contribuições e visando sintetizar a discussão a respeito da diferenciação dos termos economia solidária e economia social, recorre-se a uma matéria da revista Recma ${ }^{2}$, no seu editorial $A$ solidariedade em questão, de janeiro 2001, que estabelece uma nítida diferença entre economia social e economia solidária, pontuando que:

A solidariedade é problematizada, que etimologicamente, o termo é uma deformação da palavra latina solidum que, entre os jurisconsultos romanos, servia para designar a obrigação que pesava sobre os devedores quando cada um era responsável pelo todo (in solidum). A solidariedade, antes de ser um valor, é um fato e designa uma dependência recíproca. Uma outra concepção, normativa desta vez, faz da solidariedade um dever moral de assistência como já o preconizava o solidarismo de C. Gide no fim do século XIX. Como fato ou como dever, a solidariedade supõe um laço recíproco (e nisso se opõe à caridade, concebida como um dever unilateral). O dever moral de assistência, mas não a solidariedade como fato, supõe uma situação de desigualdade. Deste ponto de vista, a economia solidária apoia-se sobre uma economia de sujeitos desiguais, enquanto que a economia social é, pelos seus princípios e regras, uma economia de iguais. (LECHAT, 2002).

\subsection{TEORIA DE REDES: CONCEITOS E TIPOLOGIAS}

O debate literário sobre redes é vasto dentro do campo da Administração, a partir de autores como: Martes \& Bulgacov (2006), Balestrin \& Vargas (2004), Furlanetto (2001), Zawislak (1996, 2000 e 2001), Caglio (1998), Oliver e Ebers (1998). Tal discussão surge nos Estados Unidos e na Inglaterra nas décadas de 1970 e 1980, os estudos com enfoque em redes, porém no Brasil o

\footnotetext{
${ }^{2}$ Revista RECMA: Revue des études coopératives, mutualistes et associatives,fundada em 1921 e que tem por subtítulo: Revue internationale de l'économie sociale).
} 
interesse surge a partir da década de 1990. Os principais temas abordados por estes estudos de acordo com Martes \& Bulgacov:

Elaboração e fluxo de conhecimento, cooperação, confiança, desenvolvimento regional a partir de redes de pequenas e médias empresas, competitividade a partir das inter-relações de grandes corporações, em especial as alianças estratégicas, benefícios advindos da troca de informações, internacionalização de empresas, governança corporativa, entre outras (MARTES; BULGACOV et al. 2006, p. 13)

A fim de complementar as teorias a cerca de redes organizacionais, na figura 01, a seguir apresenta-se um quadro com autores que também apresentam definições, classificações e condições a cerca de redes.

Figura 01 - Quadro com Definições de Rede

\begin{tabular}{|c|c|}
\hline Autor & Definição \\
\hline Ernst (1994) & $\begin{array}{l}\text { - redes de fornecedores: envolvendo a subcontratação e acordos entre um } \\
\text { cliente e seus fornecedores de insumos intermediários para a produção; } \\
\text { redes de produtores: abrangendo todos os acordos de co-produção que } \\
\text { oferecem possibilidade a produtores concorrentes de juntarem suas capacidades de } \\
\text { produção e recursos financeiros/humanos com a finalidade de ampliar seus portfólios } \\
\text { de produtos, assim como sua cobertura geográfica; } \\
\text { - } \quad \text { redes de clientes: são os contratos e acordos firmados entre as indústrias e } \\
\text { distribuidores, canais de comercialização, revendedores com valor agregado e } \\
\text { usuários finais nos grandes mercados de exportação ou nos mercados domésticos; } \\
\text { - redes de coalizões-padrão: são formadas por potenciais definidores de } \\
\text { padrões globais com o objetivo explícito de prender tantas empresas quanto } \\
\text { possíveis a seu produto proprietário ou padrões de interface, } \\
\text { redes de cooperação tecnológica: com o objetivo explícito de facilitar a } \\
\text { aquisição de tecnologia para projetos e produção de produtos, capacitar o } \\
\text { desenvolvimento conjunto dos processos e da produção e, permitindo acesso } \\
\text { compartilhado a conhecimentos científicos genéricos e de Pesquisa e } \\
\text { Desenvolvimento (P \& D). }\end{array}$ \\
\hline $\begin{array}{c}\text { Garofoli } \\
\text { (1993) }\end{array}$ & $\begin{array}{l}\text { - } \quad \begin{array}{l}\text { redes hierarquizadas espacialmente descentralizadas, onde uma firma lidera } \\
\text { um conjunto de formas dispersas; }\end{array} \\
\text { redes hierarquizadas espacialmente centralizadas; } \\
\text { laços de cooperação entre firmas espacialmente centralizadas (distritos } \\
\text { industriais); } \\
\text { - } \quad \text { laços de cooperação entre firmas espacialmente descentralizadas (alianças } \\
\text { estratégicas). }\end{array}$ \\
\hline $\begin{array}{l}\text { Laumann, } \\
\text { Galaskiewicz } \\
\text { \& Mardsen } \\
\text { (1978) }\end{array}$ & $\begin{array}{l}\text { Baseia-se em dois princípios o da competição e cooperação: } \\
\text { - redes formadas pelo modo competitivo: as empresas mesmo pondo em } \\
\text { prática a cooperação, a ajuda mútua e o compartilhamento, são encaradas como } \\
\text { entidades que buscam suas metas particulares, procurando manter sua autonomia } \\
\text { nas suas operações e estratégias. } \\
\text { - } \quad \text { redes formadas pelo modo cooperativo: neste caso, as empresas envolvidas } \\
\text { têm seus objetivos particulares, mas têm a devida percepção de que, o benefício } \\
\text { será maior se juntas buscarem alcançar um objetivo maior e coletivo. }\end{array}$ \\
\hline
\end{tabular}

Fonte: Adaptado de Cândido, 2001.

\subsection{FATORES CRÍTICOS DE SUCESSO}

Nesta pesquisa a definição e delimitação de Fatores Críticos de Sucesso (FCS) seguiram a proposição de Cândido e Abreu (2004) os quais consideram que os FCS são percebidos a partir da existência de um conjunto de fatores-chave, que precisam ser observados como condição para a continuidade e o sucesso da ação. O atual cenário que ambienta o mundo dos negócios tem conduzido os setores e segmentos econômicos, juntamente com os seus agentes produtivos a buscarem a competitividade como estratégia para sua sobrevivência e desenvolvimento. Para o sucesso de qualquer empreendimento é necessário identificar quais as variáveis que podem causar o sucesso ou o insucesso de qualquer iniciativa. 
São considerados fatores críticos de relacionamentos cooperativos, os aspectos ambientais e organizacionais que podem estimular ou restringir um relacionamento, podendo influenciar a formação ou manter uma relação de cooperação (CÂNDIDO; ABREU, 2004; OLIVER, 1990).

A formação, desenvolvimento e manutenção de redes são influenciados por inúmeros fatores. Cândido e Abreu (2004) apresentaram uma lista de Fatores Críticos de Sucesso, que consideram "um conjunto de condições vitais de um dado projeto social, que quando falham aumentam a probabilidade de insucesso, e, quando satisfatórios, assegurarão $O$ alcance dos objetivos pretendidos." (CÂNDIDO e ABREU, 2004, p. 5)
Os fatores críticos para o sucesso de redes interorganizacionais, os quais são agrupados em quatro diferentes dimensões: i) ambiente de negócios; ii) aspectos antropológicos e socioculturais; iii) políticas macroeconômicas; e iv) processo de formação. Em cada uma delas os fatores críticos de sucesso são apresentadas em ordem de importância.

Os autores observam que para utilizar cada dimensão e variável como método de pesquisa, faz-se necessário que esteja claro o conceito a cerca de tal variável para assim poder identificar quais aspectos tem relação com as variáveis em questão.

$\mathrm{Na}$ sequência discorre-se sobre a definição de cada uma das dimensões tendo-se como base os estudos de Cândido (2001), como pode ser observado nas figuras a seguir:

Figura 02 - Dimensão Ambiente de Negócios

\begin{tabular}{|c|c|}
\hline Variável & Def \\
\hline $\begin{array}{l}\text { Competitividade } \\
\text { local }\end{array}$ & $\begin{array}{l}\text { A identificação de condições de desenvolvimento econômico da região, e por } \\
\text { consequência da rede a ser estudada, a partir da habilidade dos } \\
\text { empreendimentos inovarem e melhorar. }\end{array}$ \\
\hline $\begin{array}{l}\text { Prática } \\
\text { inovação }\end{array}$ & $\begin{array}{l}\text { A existência de um ambiente propício para á pratica da inovação, baseada na } \\
\text { cooperação e colaboração interorganizacional, partindo do princípio de que as } \\
\text { empresas participantes dependem umas das outras para poderem pôr em prática } \\
\text { o conjunto das suas operações e suas ações estratégicas individuais e coletivas. }\end{array}$ \\
\hline $\begin{array}{l}\text { Perfil das } \\
\text { empresas } \\
\text { locais; }\end{array}$ & $\begin{array}{l}\text { A existência de instituições e/ou pessoas responsáveis pelo processo tenham } \\
\text { conhecimento adequado do perfil das empresas localizadas na região. }\end{array}$ \\
\hline $\begin{array}{l}\text { Infraestrutura } \\
\text { física }\end{array}$ & $\begin{array}{l}\text { Existência de boas condições de infraestrutura físicas (elétricas, hidráulicas, } \\
\text { sanitárias e ambientais); de comunicação e informação e de transportes que } \\
\text { atendam as necessidades das empresas participantes da rede de } \\
\text { empreendimentos }\end{array}$ \\
\hline $\begin{array}{l}\text { Convivência } \\
\text { com a prática } \\
\text { cooperação e } \\
\text { competição }\end{array}$ & $\begin{array}{l}\text { Existência de um ambiente propício para a prática da cooperação e colaboração } \\
\text { entre as empresas participantes do agrupamento baseados em objetivos comuns } \\
\text { entre: empresas, o poder público e às instituições de apoio às atividades } \\
\text { empresariais na região }\end{array}$ \\
\hline $\begin{array}{l}\text { Formas de } \\
\text { comunicação }\end{array}$ & $\begin{array}{l}\text { A existência de múltiplos canais e formas diversas de comunicação entre os } \\
\text { participantes (interno-externos, público/privados), partindo do princípio de que esta } \\
\text { forma de atuação empresarial se desenvolve através de comunicações e } \\
\text { interações múltiplas, em torno de interesses e necessidades comuns e nos } \\
\text { relacionamentos entre os diversos participantes. }\end{array}$ \\
\hline $\begin{array}{l}\text { Participação de } \\
\text { instituições de } \\
\text { apoio. }\end{array}$ & $\begin{array}{l}\text { Participação de fornecedores especializados, fabricantes de produtos } \\
\text { complementares, prestadores de serviços especializados, envolvimento de } \\
\text { instituições públicas e privadas (universidades, centros de pesquisa, associações } \\
\text { comerciais e industriais, órgãos de normatização, etc.) }\end{array}$ \\
\hline
\end{tabular}

Esta dimensão é responsável por retratar o ambiente e os fatores de produção já existentes, ou ainda identificar o que está faltando ou é pouco desenvolvido quanto se tem uma rede ou pensa-se em implantar uma 
Figura 03 - Dimensão Políticas Macroeconômicas

\begin{tabular}{|c|c|}
\hline Variável & Descrição \\
\hline Estabilidade & $\begin{array}{l}\text { A existência de estabilidade nas políticas macroeconômicas do tipo: } \\
\text { estrutura do sistema tributário, condições do mercado de trabalho, normas } \\
\text { sobre a propriedade intelectual, conhecimentos acerca da capacidade da } \\
\text { absorção e utilização da capacidade de produção. }\end{array}$ \\
\hline $\begin{array}{l}\text { Planejamento } \\
\text { coordenação das } \\
\text { ações das instituições } \\
\text { de apoio }\end{array}$ & $\begin{array}{l}\text { A existência de uma política que promova o desenvolvimento de } \\
\text { programas voltados para articular o planejamento e coordenação das } \\
\text { ações das instituições locais do tipo: desenvolvimento de novas } \\
\text { tecnologias, regulação, treinamento, controle de qualidade, licenciamento, } \\
\text { financiamento, segurança do trabalho, controle ambiental. }\end{array}$ \\
\hline $\begin{array}{lr}\text { Independência } & e \\
\text { autonomia } & \text { das } \\
\text { empresas } & \end{array}$ & $\begin{array}{l}\text { Que as empresas participantes da rede sejam independentes, ou seja, as } \\
\text { empresas ao atuarem em rede, não significa que elas tenham de abrir mão } \\
\text { da sua autonomia. }\end{array}$ \\
\hline $\begin{array}{l}\text { Investimentos públicos } \\
\text { de apoio }\end{array}$ & $\begin{array}{l}\text { Que os investimentos públicos destinados ao estímulo à produção sejam } \\
\text { orientados para a criação de infraestrutura para a melhoria na prestação de } \\
\text { serviços públicos que atendam as demandas específicas da região e da } \\
\text { rede. }\end{array}$ \\
\hline $\begin{array}{l}\text { Formas } \\
\text { concorrência }\end{array}$ & $\begin{array}{l}\text { A existência de formas de concorrência e rivalidade saudável entre as } \\
\text { empresas localizadas na região e entre os participantes da rede }\end{array}$ \\
\hline $\begin{array}{l}\text { Mecanismos } \\
\text { fortalecer } \\
\text { relacionamentos } \\
\text { interações }\end{array}$ & $\begin{array}{l}\text { A existência de mecanismos organizacionais direcionados para o } \\
\text { fortalecimento dos relacionamentos e interações entre os diversos agentes } \\
\text { direta e indiretamente envolvidos com o conjunto das empresas da região }\end{array}$ \\
\hline $\begin{array}{lr}\text { Capacidade } & \text { de } \\
\text { mobilização, } & \text { Políticas } \\
\text { direcionadas } & \text { para o } \\
\text { fortalecimento } & \text { da } \\
\text { capacitação } & \\
\text { tecnológica } & \end{array}$ & $\begin{array}{l}\text { A existência de uma efetiva capacidade mobilizadora dos agentes e das } \\
\text { instituições públicas e privadas, especialmente as de cunho local e } \\
\text { microrregional }\end{array}$ \\
\hline $\begin{array}{lr}\text { Política de difusão de } \\
\text { tecnologias } & \text { de } \\
\text { informação } & \text { e } \\
\text { conhecimento } & \end{array}$ & $\begin{array}{l}\text { A existência de uma política de difusão de tecnologias de informação e } \\
\text { conhecimentos (TI's) para as empresas participantes da rede, que } \\
\text { possibilite troca e compartilhamento de informações sobre mercados, } \\
\text { tecnologias alternativas, novos insumos, novas técnicas mercadológicas, } \\
\text { de gerência financeira, etc }\end{array}$ \\
\hline $\begin{array}{l}\text { Integração das } \\
\text { políticas de apoio }\end{array}$ & $\begin{array}{l}\text { A integração de diferentes políticas (financeira, industrial, serviços, de C \& } \\
\text { T, educacional, etc.) postas em prática pelo poder público e instituições } \\
\text { privadas. }\end{array}$ \\
\hline $\begin{array}{l}\text { Estimulo a geração, } \\
\text { aquisição e difusão do } \\
\text { conhecimento }\end{array}$ & $\begin{array}{l}\text { O desenvolvimento de atividades de apoio à formação de ambientes } \\
\text { capazes de estimular a geração, aquisição e difusão de conhecimentos. }\end{array}$ \\
\hline $\begin{array}{l}\text { Nível de interação entre } \\
\text { os agentes envolvidos }\end{array}$ & $\begin{array}{l}\text { Desenvolvimento de modelos e sistemas visando a maior interação entre os } \\
\text { diversos agentes econômicos, técnico-científicos, políticos e reguladores } \\
\text { existentes na região. }\end{array}$ \\
\hline
\end{tabular}

Fonte: Adaptado de Cândido, 2001

Esta dimensão é representada pelo tamanho do mercado e toda sua dinâmica como o nível de sofisticação dos compradores e o como às empresas reagem a estas exigências, enfim tem por principal objetivo identificar as condições de mercado e demanda pelos produtos a serem ofertados pela rede. 
Figura 04 - Dimensão Processo de Formação

\begin{tabular}{|c|c|}
\hline Variável & Definição \\
\hline $\begin{array}{lr}\text { Potencial } & \text { para } \\
\text { prática } & \text { da } \\
\text { cooperação } & \end{array}$ & $\begin{array}{l}\text { O processo de formação deve ser focado em setores e atividades para as } \\
\text { quais as localidades e regiões já contem com algumas experiências anteriores }\end{array}$ \\
\hline $\begin{array}{l}\text { Vinculação a uma } \\
\text { política } \\
\text { desenvolvimento } \\
\text { regional }\end{array}$ & $\begin{array}{l}\text { O processo de formação e desenvolvimento de redes de empreendimentos } \\
\text { solidários e comunitários deve estar vinculado a uma política de } \\
\text { desenvolvimento regional que envolva diretamente apoio as redes atentando } \\
\text { para as potencialidades e os benefícios decorrentes da sua criação }\end{array}$ \\
\hline $\begin{array}{l}\text { Remoção } \\
\text { obstáculos, } \\
\text { restrições } \\
\text { limitações }\end{array}$ & $\begin{array}{l}\text { O processo precisa ser focado na remoção dos obstáculos e atenuação das } \\
\text { restrições e limitações para o funcionamento e desenvolvimento da rede. }\end{array}$ \\
\hline $\begin{array}{l}\text { Desenho das } \\
\text { fronteiras } \\
\text { organizacionais }\end{array}$ & $\begin{array}{l}\text { A existência de um adequado desenho das fronteiras organizacionais, } \\
\text { incluindo os diversos elos na cadeia produtiva }\end{array}$ \\
\hline $\begin{array}{l}\text { Familiarização com } \\
\text { os conceitos }\end{array}$ & $\begin{array}{l}\text { Familiarizar os componentes efetivos e potenciais da rede com os conceitos, } \\
\text { importância, e vantagens de atuar de forma conjunta e compartilhada com os } \\
\text { outros empreendimentos }\end{array}$ \\
\hline $\begin{array}{l}\text { Expressão dos } \\
\text { objetivos comuns }\end{array}$ & $\begin{array}{l}\text { A necessidade de que os participantes envolvidos diretos e indiretamente } \\
\text { tenham seus objetivos expressos explicitamente, a partir da existência de } \\
\text { objetivos comuns }\end{array}$ \\
\hline $\begin{array}{l}\text { Relacionamentos } \\
\text { voluntários } \\
\text { constantes }\end{array}$ & $\begin{array}{l}\text { Que as diversas formas de interligações e interações entre os diversos } \\
\text { componentes da rede sejam realizados através de relacionamentos } \\
\text { voluntários e constantes }\end{array}$ \\
\hline $\begin{array}{l}\text { Existência de lideres } \\
\text { capazes de } \\
\text { conduzir o processo }\end{array}$ & $\begin{array}{l}\text { A existência de líderes nos diversos níveis da rede, assumindo compromissos } \\
\text { e atuando como um referencial, com participação ativa na definição e } \\
\text { implementação das estratégias e operações e, principalmente no processo } \\
\text { decisório dos empreendimentos, tanto individual quanto coletivamente }\end{array}$ \\
\hline $\begin{array}{l}\text { Definição de uma } \\
\text { arquitetura } \\
\text { organizacional }\end{array}$ & $\begin{array}{l}\text { Definir uma arquitetura organizacional para o agrupamento que seja a mais } \\
\text { adequada ao contexto regional, definindo quais os papéis e atribuições de } \\
\text { cada um deles e, de como serão firmados e mantidos às relações de } \\
\text { dependência com os diversos agentes dentro da cadeia produtiva do } \\
\text { agrupamento. }\end{array}$ \\
\hline $\begin{array}{l}\text { Estratégias de } \\
\text { atuação e política } \\
\text { mercadológicas }\end{array}$ & $\begin{array}{l}\text { A estratégia mais indicada para o fortalecimento da rede deve ser inicialmente } \\
\text { atender as necessidades e os interesses do mercado interno e, a partir daí } \\
\text { buscar o mercado externo, realizando campanhas publicitárias em revistas } \\
\text { estrangeiras locais especializadas e publicações de circulação global; } \\
\text { participando de feiras e encontros de interesse. }\end{array}$ \\
\hline
\end{tabular}

Fonte: Adaptado de Cândido, 2001

Esta dimensão refere-se ao contexto institucional e cultural em que são criadas, organizadas e gerenciadas a rede, e a natureza da rivalidade entre dos empreendimentos que competem nos diversos segmentos de mercado 
Figura 05 - Dimensão Aspectos Antropológicos e Socioculturais

\begin{tabular}{|c|c|}
\hline Variável & Definição \\
\hline $\begin{array}{l}\text { Nível de } \\
\text { atividade } \\
\text { comunitária; }\end{array}$ & $\begin{array}{l}\text { Que nas áreas geográficas escolhidas como alvo para aplicação da rede existam } \\
\text { sistemas sociais que apresentem um certo nível de atividade comunitária, ou pelo } \\
\text { menos tendência para tanto }\end{array}$ \\
\hline História comum; & $\begin{array}{l}\text { Que as diversas partes componentes da rede tenham um mínimo de história } \\
\text { comum, podendo ser manifestada através de questões étnicas, históricas, de } \\
\text { valores, religiosas, preferências políticas, etc }\end{array}$ \\
\hline $\begin{array}{l}\text { Políticas de } \\
\text { conscientização } \\
\text { e socialização; }\end{array}$ & $\begin{array}{l}\text { A promoção de uma política de promoção, que cuide de aspectos relacionados à } \\
\text { socialização e conscientização dos seus membros, incluindo noções de } \\
\text { responsabilidade, compromisso, participação e consciência coletiva }\end{array}$ \\
\hline Apoio familiar; & $\begin{array}{l}\text { A existência de uma cultura empresarial que valorize os laços cooperativos e uma } \\
\text { tradição de apoio familiar a novos empresários }\end{array}$ \\
\hline $\begin{array}{lr}\text { Clima } & \text { de } \\
\text { confiança } & \text { e } \\
\text { identidade } & \\
\text { cultural. }\end{array}$ & $\begin{array}{l}\text { A existência de um ambiente que favoreça um clima de confiança e identidade } \\
\text { cultural que precisam ser estimulados e transmitidos a todos os agentes direta e } \\
\text { indiretamente envolvidos no processo }\end{array}$ \\
\hline
\end{tabular}

Fonte: Adaptado de Cândido, 2001

Cada um desses quatro fatores influencia a competitividade e todos se reforçam (ou enfraquecem) mutuamente. Isto é, existe uma forte sinergia entre eles, o conjunto das partes pode ser maior ou menor que a soma das mesmas. A vantagem competitiva baseada em uma só classe de fatores, ou em duas, geralmente mostra-se não sustentável ao longo do tempo, uma vez que os competidores acabam por superá-la rapidamente. (CÂNDIDO, 2001).

As dimensões e variáveis aqui apresentadas serão utilizadas para identificar os FCS na criação de uma rede de empreendimentos comunitários na região do Médio e Baixo Rio Madeira.

\section{PROCEDIMENTOS METODOLÓGICOS}

Esta pesquisa se caracteriza como uma análise de conteúdo, isto por meio de pesquisa documental e em base de dados

Figura 06 - FCS - Dimensões e variáveis

\begin{tabular}{|c|c|}
\hline Dimensão & Variável \\
\hline $\begin{array}{l}\text { Ambiente de Negócios na } \\
\text { Localidade }\end{array}$ & 07 \\
\hline Políticas Macroeconômicas & 11 \\
\hline Processo de Formação & 10 \\
\hline $\begin{array}{l}\text { Aspectos Antropológicos e } \\
\text { Socioculturais }\end{array}$ & 05 \\
\hline TOTAL & 33 \\
\hline
\end{tabular}

Fonte: Adaptado de Cândido, 2001. secundários, tendo como principal fonte o banco de dados do Instituto de Estudos e Pesquisas Agroambientais e Organizações Sustentáveis - IEPAGRO, que está disponível no endereço http://www.iepagro.org.br/editora.php. Foram efetuadas consultas aos instrumentos de pesquisas e relatórios com as evidencias e resultados dos estudos desenvolvidos pelo mesmo instituto.

Neste instrumento tomou-se conhecimento do contexto da Região do Médio e Baixo Rio Madeira, com detalhes identificados em relação as comunidades, as pessoas e o processo produtivo, o que está retratado em planilhas, gráficos, esquemas, quadros, tabelas, fotos.

O tratamento dos dados foi feito de acordo com a figura 06 abaixo, respeitando as dimensões e variáveis propostas por Cândido e Abreu (2004).

\section{APRESENTAÇÃO E ANÁLISE DOS RESULTADOS \\ 4.1 PROPOSTA DE CRIAÇÃO DA REDE CAUSA JUSTA}

A proposta da rede de empreendimentos para o médio e baixo Rio Madeira foi apresentada como resultado de um trabalho de pesquisa e acompanhamento realizado pelo IEPAGRO para atender demanda da empresa responsável pela construção da Hidrelétrica 
do Rio Madeira o Consórcio denominado Santo Antônio Energia - SAE.

A partir das ações desenvolvidas e visando a melhoria da qualidade de vida ribeirinha foi gerada a proposição de uma rede de empreendimentos comunitários, de forma a possibilitar maior sinergia entre as comunidades, convergência de organizações sociais de produção já existentes na região e ainda, o aproveitamento dos recursos naturais, cultura e práticas milenares dos extrativistas/produtores, de forma a promover a organização, processamento e comercialização da produção, estabelecendo um processo de coordenação entre os diversos empreendimentos.

Observa-se que a concepção da Rede, respeitou a realidade do médio e baixo rio madeira, sendo delimitadas na região as comunidades que sediaram os empreendimentos da rede, no entanto, beneficiando a todas com a criação da rede.
Segundo dados do mesmo instituto, a região do médio e baixo rio madeira concentra 66 comunidades, cujas principais são os distritos de: Cujubim Grande; São Carlos; Nazaré; Calama; e Demarcação, todos localizadas no Município de Porto Velho.

A proposta da rede de empreendimentos comunitários respeita a cultura local, o modo de produção já existente e tem a seguinte configuração: compõe-se, na fase inicial de 13 associações, uma cooperativa e um conselho de comunidades, incluindo uma central de comercialização já visando um sistema de logística de escoamento da produção. A proposição da rede de empreendimentos comunitários está pautada nos princípios de economia solidária, tais como, relações econômicas justas, sustentáveis e solidárias. A figura 23 de maneira simplificada demonstra o portfólio de produtos e seus derivados previstos para serem processados e comercializados pelos empreendimentos da rede.

Figura 08 - Produtos da Rede

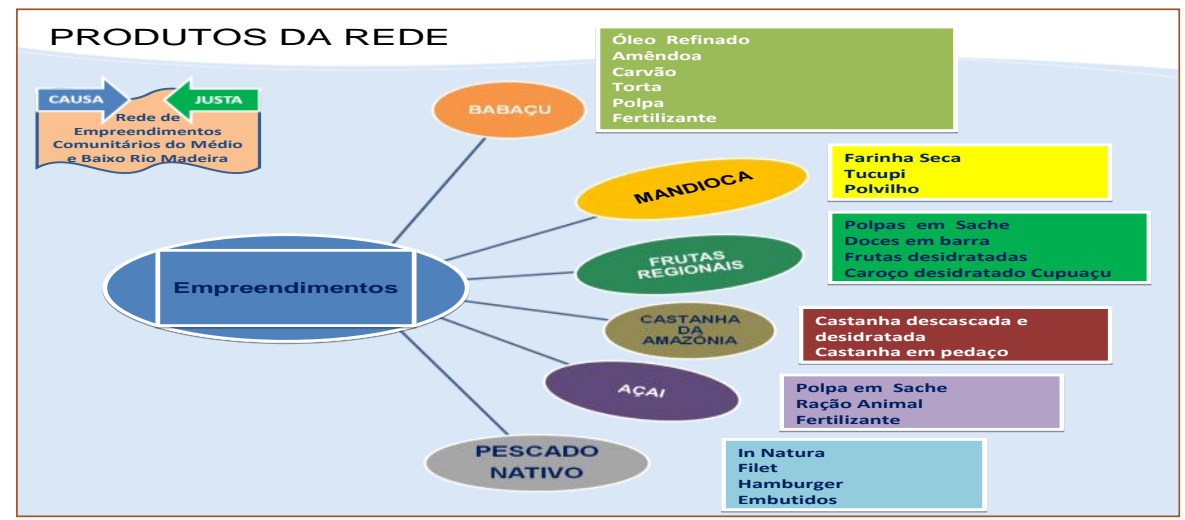

Fonte: IEPAGRO (2011)

A criação da Rede Causa Justa preconiza a organização de 13 empreendimentos comunitários tendo como base a instalação de micro-agroindústrias de processamento de produtos agroextrativistas, as quais terão a produção explorada pelas associações das comunidades, tendo a logística de transporte, comercialização e distribuição ao encargo da cooperativa do baixo madeira - COOMADE. As localidades para implantação das agroindústrias foram determinadas conforme inventário da produção, por exemplo, a comunidade que é produtora de frutas sediará a agroindústria de beneficiamento de frutas. A central de comercialização foi proposta com a finalidade de facilitar e melhorar o escoamento e comercialização dos produtos. Para organização da coleta e comercialização do pescado foi sugerido a criação de entrepostos a fim de melhorar o fluxo, conservação e distribuição do peixe, e ainda, a reforma do terminal pesqueiro para processamento e comercialização.

\subsection{FATORES CRÍTICOS DE SUCESSO NA CRIAÇÃO DA REDE DE EMPREENDIMENTOS COMUSNITÁRIOS DO MÉDIO E BAIXO RIO MADEIRA - CAUSA JUSTA}

Utilizando-se das referências das dimensões e variáveis propostas por Cândido e Abreu (2004), a partir de pesquisa documental, aliada as técnicas de análise de conteúdo, buscou-se identificar dentro da proposição da rede e realidade local quais variáveis podem 
ser consideradas como fator crítico de sucesso, com a análise, foi possível apontar os FCS para a criação da rede proposta, classificando-os como: FCS Positivo e FCS Negativo.

Considerou-se a classificação "FCS Positivo" quando a variável foi identificada na região de

Figura 19 - Ambiente de Negócios

\begin{tabular}{|l|l|l|}
\hline \multicolumn{2}{|c|}{ Dimensão Variável } & \multicolumn{1}{c|}{ Classificação dos FCS } \\
\hline \multirow{4}{*}{$\begin{array}{l}\text { Ambiente } \\
\text { Negócios }\end{array}$} & Competitividade local; & FCS Positivo \\
\cline { 2 - 3 } & Prática da inovação; & FCS Negativo \\
\cline { 2 - 3 } & Perfil das empresas locais; & FCS Positivo \\
\cline { 2 - 3 } & Infraestrutura física; & FCS Negativo \\
\cline { 2 - 3 } & $\begin{array}{l}\text { Convivência com a prática cooperação e } \\
\text { competição; }\end{array}$ & FCS Negativo \\
\cline { 2 - 3 } & Formas de comunicação; & FCS Negativo \\
\cline { 2 - 3 } & Participação de instituições de apoio. & FCS Negativo \\
\hline
\end{tabular}

Fonte: Desenvolvido pela autora

Partindo para a dimensão que trata das Políticas Macroeconômicas, a figura 20, das 11 variáveis utilizadas como parâmetro de pesquisa todas aparecem como fatores críticos de sucesso negativos, apesar da proposição da rede as condições que favorecem a sua instalação e FCS Negativo quando a variável não foi pontuada no relatório, sendo assim segue as figuras abaixo:

Figura 20 - Políticas Macroeconômicas

\begin{tabular}{|c|c|c|}
\hline Dimensão & Variável & $\begin{array}{l}\text { Classificação dos } \\
\text { FCS }\end{array}$ \\
\hline & Estabilidade & FCS Negativo \\
\hline & $\begin{array}{l}\text { Planejamento e coordenação das ações das } \\
\text { instituições de apoio }\end{array}$ & FCS Negativo \\
\hline & Independência e autonomia das empresas & FCS Negativo \\
\hline & Investimentos públicos de apoio & FCS Negativo \\
\hline & Formas de concorrência & FCS Negativo \\
\hline Políticas & $\begin{array}{l}\text { Mecanismos para fortalecer os relacionamentos e } \\
\text { interações }\end{array}$ & FCS Negativo \\
\hline Macroeconômicas & $\begin{array}{l}\text { Capacidade de mobilização, Políticas direcionadas } \\
\text { para o fortalecimento da capacitação tecnológica }\end{array}$ & FCS Negativo \\
\hline & $\begin{array}{l}\text { Política de difusão de tecnologias de informação e } \\
\text { conhecimento }\end{array}$ & FCS Negativo \\
\hline & Integração das políticas de apoio & FCS Negativo \\
\hline & $\begin{array}{l}\text { Estimulo a geração, aquisição e difusão do } \\
\text { conhecimento. }\end{array}$ & FCS Negativo \\
\hline & Nível de interação entre os agentes envolvidos & FCS Negativo \\
\hline
\end{tabular}

$\mathrm{Na}$ próxima dimensão, Processo de Formação, figura 21, apresenta a seguinte performance: 
Figura 21-Processo de Formação

\begin{tabular}{|c|c|c|}
\hline Dimensão & Variável & Classificação dos FCS \\
\hline \multirow{10}{*}{$\begin{array}{l}\text { Processo de } \\
\text { Formação }\end{array}$} & Potencial para prática da cooperação & FCS Negativo \\
\hline & $\begin{array}{l}\text { Vinculação a uma política de desenvolvimento } \\
\text { regional }\end{array}$ & FCS Negativo \\
\hline & Remoção aos obstáculos, restrições e limitações & FCS Negativo \\
\hline & Desenho das fronteiras organizacionais & FCS Positivo \\
\hline & Familiarização com os conceitos & FCS Negativo \\
\hline & Expressão dos objetivos comuns & FCS Positivo \\
\hline & Relacionamentos voluntários constantes & FCS Negativo \\
\hline & $\begin{array}{l}\text { Existência de lideres capazes de conduzir o } \\
\text { processo }\end{array}$ & FCS Negativo \\
\hline & Definição de uma arquitetura organizacional & FCS Positivo \\
\hline & Estratégias de atuação e política mercadológicas & FCS Negativo \\
\hline
\end{tabular}

Nesta dimensão das 10 variáveis, apenas três foram classificadas como um fator não critico de sucesso positivo a criação da proposta de rede estudada. Contudo na última dimensão, figura 22, Aspectos Antropológicos e Socioculturais, das 5 variáveis, apenas 2 foram apontadas como fator crítico de sucesso negativo a criação da rede estudada.

Figura 22 - Aspectos Antropológicos e Socioculturais

\begin{tabular}{|c|c|c|c|}
\hline Dimensão & & Variável & Classificação dos FCS \\
\hline \multirow{5}{*}{$\begin{array}{l}\text { Aspectos, } \\
\text { Antropológicos } \\
\text { Socioculturais }\end{array}$} & \multirow{5}{*}{ e } & Nível de atividade comunitária; & FCS Negativo \\
\hline & & História comum; & FCS Positivo \\
\hline & & $\begin{array}{l}\text { Políticas de conscientização e } \\
\text { socialização; }\end{array}$ & FCS Negativo \\
\hline & & Apoio familiar; & FCS Positivo \\
\hline & & Clima de confiança e identidade cultural. & FCS Positivo \\
\hline
\end{tabular}

Foram utilizadas como variáveis de pesquisa quatro dimensões, compostas por 33 variáveis, das quais somente 9 considera-se FCS positivo, ou seja, estas não se mostram como ameaça a criação da rede proposta, pois por meio do relatório estas já ficaram bem claras e concisas quanto a sua existência e aplicação de acordo com a definição proposta por Cândido (2001). No entanto, as demais, 24 variáveis, classificamse como FCS negativo, ou seja, existe no relatório trechos que tratam destas variáveis, porém o que é retratado contrariam as condições necessárias ao sucesso da criação da rede. Ressalta-se que as variáveis que se relacionam a participação, coordenação, integração, politicas e praticas oriundas do poder público, não são evidenciadas no relatório analisado.

O quantitativo de FCS positivos e Negativos encontra-se expostos na figura 23. 
Figura 23 - Classificação dos Fatores Críticos de Sucesso

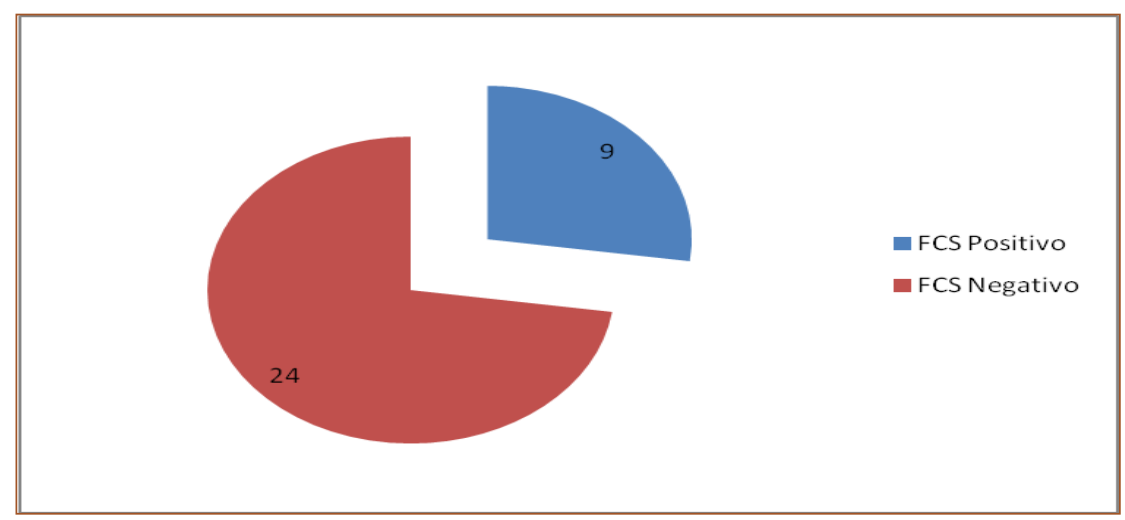

Fonte: Desenvolvido pela autora

Portanto, é possível afirmar que a criação da rede depende da atenção para mitigar alguns gargalos apresentados como fatores críticos de sucesso negativos a criação da rede, estes aqui já apresentados, que representam a maioria das variáveis pesquisadas.

\section{CONCLUSÕES}

O objetivo principal deste trabalho foi analisar os fatores críticos de sucesso relacionados à criação de uma rede de empreendimentos comunitários oriundos de uma proposta feita pelo IEPAGRO, apresentado em um denso relatório de pesquisa, esta rede nominada Causa Justa a qual se refere ao médio e baixo rio madeira.

Das 33 variáveis utilizadas como parâmetro de pesquisa, algumas, apenas 9 puderam ser classificadas como FCS Positivos, ou seja, contribuem para implementação da rede, estação apontadas como favoráveis a rede proposta. Sendo assim as restantes, 24 variáveis, aparecem como FCS Negativos, ou seja, são desfavoráveis a implementação da rede e estas devem ser os principais alvos de ações a fim de torná-las FCS positivos. Após a apresentação de todos os resultados, temos o seguinte a concluir, que a proposição da rede é viável e plenamente aplicável, a fim de melhorar a qualidade de vida da população do médio e baixo rio madeira, porém alguns aspectos devem ser tratados como prioridade e seriedade a fim de que a criação da rede seja possível.

Quando se fala em investimentos públicos, planejamento de ações das instituições de apoio, política de desenvolvimento regional, se tem uma situação delicada, porém indispensável, é possível afirmar isto porque a pesquisa apontou e a visitas também apontaram que atualmente a região é carente de serviços básicos como água tratada, coleta de lixo, energia elétrica, comunicação, educação, saúde estes apontados como essenciais para a instalação de agroindústrias nas comunidades, formando assim um gargalo a criação da rede, dai a confirmação nas falas dos responsáveis visitados que é necessário uma união dos poderes públicos a fim de sanar essas dificuldades para ai então poder-se capacitar a população que não deixa de ser um fator importante que pode levar ao insucesso da rede.

Apresentado aspectos de infraestrutura básica não se enquadram de forma ideal para a implantação das agroindústrias, se tem a questão do conhecimento da população local a ser envolvida neste processo, isso, pois, a proposta da rede foi inteira baseada na realidade das comunidades, em suas atividades habituais, culturas disponíveis na região e ainda o conhecimento tácito que os mesmo têm.

Contudo tal conhecimento mostrou-se insuficiente para que a proposta seja criada e assim seja rentável e estável, observou-se a grande necessidade da capacitação e formação da população, isso nos mais diversos aspectos, desde aspectos de higiene pessoal, processo produtivo, gestão, funcionamento da rede, atuação de cada um e ainda desenvolver as relações interpessoais afinal se trata de uma rede de empreendimentos comunitários. 


\section{REFERÊNCIAS}

[1] Amato Neto, J., Redes de cooperação produtiva e clusters regionais: oportunidade para as pequenas e médias empresas. São Paulo: Atlas, 2000.

[2] Araujo, Fernanda S. Economia Solidária e Autonomia: uma análise das relações sociais de produção em dois empreendimentos econômicos solidários de beneficiamento de pescado. Dissertação de M.Sc., Programa de Engenharia de Produção do Instituto Alberto Luiz Coimbra de PósGraduação e Pesquisa de Engenharia (PEP/COPPE/UFRJ). Rio de Janeiro, 2009.

[3] Azais, C. Economia Solidária ou Práticas Solidárias? Um questionamento a partir da sociologia econômica. Paper apresentado no I Congresso Internacional de sociologia Econômica e Finanças, São Carlos, 2006.

[4] Balestrin, A., \& Vargas, L. M. (2004). A dimensão estratégica das redes horizontais de PMEs: teorizações e evidências. Revista de Administração Contemporânea , 8 (Edição Especial), 203-227.

[5] Bardin, Laurence. Análise de conteúdo. Luís Antero Reto e Augusto Pinheiro (trad.). 3 ed. Lisboa: Edições 70, 2004.

[6] Cândido, Gesinaldo Ataíde. Fatores Críticos de sucesso no processos de formação, desenvolvimento e manutenção de redes interempresariais do tipo agrupamento industrial entre pequenas e médias empresas: um estudo comparativo de experiências brasileiras. Tese de doutorado em Engenharia da Produção Universidade Federal de Santa Catarina, Florianópolis, 2001.

[7] Cândido, G. A., \& Abreu, A. F. Fatores Críticos de sucesso no processos de formação, desenvolvimento e viabilização de redes organizacionais: um estudo exploratório. Encontro Nacional da Associação dos Programas de PósGraduação em Administração. Curitiba: ANPAD. 2004.

[8] Casarotto Filho, Nelson e PIRES, Luis Henrique. Redes de pequenas e médias empresas e desenvolvimento local: estratégias para a conquista da competitividade global com base na experiência italiana. São Paulo, Atlas, 1998.

[9] Cassiolato, J. E.; Lastres, H. M. M. O foco em arranjos produtivos e inovativos locais de micro e pequenas empresas. Rio de Janeiro: UFRJ/Ed. Relume Dumará, 2005

[10] .Cassiolato, J. E. e Lastres, H. M. "Inovação, Globalização e as Novas Políticas de Desenvolvimento Industrial e Tecnológico". In Cassiolato, J. E. e Lastres, H. M. M. (orgs.), Globalização e inovação localizada: experiências de sistemas locais no Mercosul. Brasília: IBICT/MCT, 1999.

[11] Castell, M. . A sociedade em rede. São Paulo: Paz e Terra. 1999.

[12] Cattani, Antônio (Org.). A outra economia. Porto Alegre: Veraz, 2003.

[13] Diniz, C.C. Desenvolvimento poligonal no Brasil: nem desconcentração nem contínua polarização, Nova Economia, v.3, n.1. Belo Horizonte, UFMG/FCE/DCE. 1995.

[14] França Filho, G; Laville, J. Economia Solidária uma abordagem internacional. Porto Alegre: Editora da UFRGS, 2004. 199p.

[15] França Filho, Genauto Carvalho de. Para um olhar epistemológico da administração: problematizando o seu objeto. In: IN: SANTOS, Reginaldo Souza (Org.). A Administração Política como campo do conhecimento. 1a ed. São Paulo Salvador: Mandacaru, 2004. p.119-143.

[16] Gaiger, Luiz Inácio. A solidariedade como alternativa econômica para os pobres. Contexto e Educação. Ijuí, v. 13, n. 50, p. 47-71, 1996.

[17] Gaiger, Luiz Inácio. Empreendimentos solidários: uma alternativa para a economia popular? In: . (org.). Formas de combate e de resistência à pobreza. São Leopoldo: Unisinos, p. 101-126. 1996.

[18] Galbraith, John Kenneth. Moeda: de onde veio, para onde foi. São Paulo, Livraria Pioneira Editora, 2. ed.1983.

[19] Garolofi, G. Endogenous development and souththern Europe. Aldershot: Averuby, 1992.

[20] Grandori, A., \& Soda, G. (1995). Inter-firm networks: antecedents, mechanisms and formas. Organizations Studies, 16 (2), 183-232.

[21] Granovetter, M. Econimic Action and Social Structure: The Problem of Embeddedness. American Journal of Sociology. 1992.

[22] Geiger, A. Elementos a serem considerados na análise da governança de aglomerados empresariais. Disponível em:<www.producao.ufrgs.br/.../85_elementos_da_ governanca.doc>. Acesso em 30 mai 2011.

[23] Gil, Antônio Carlos. Métodos e técnicas de pesquisa social. 5. ed. São Paulo: Atlas, 2007

[24] Gongalves, A. As comunidades utópicas e os primórdios do socialismo no Brasil, E-topia: Revista Electrónica de Estudos sobre a Utopia, n. 2 (2004). Disponível em: http://www.letras.up.pt/upi/utopiasportuguesas/etopia/revista.htm. Acesso em

[25] 10 out 2011.

[26] Guélin, André. L'invention de l'économie sociale. Paris: Econômica. 1998.

[27] Hall, R. H. Organizações: estruturas, processos e resultados. São Paulo: Prentice Hall. 2004.

[28] Harribey J.M.. "La financiarisation de l'économie et la création de valeur", Université Bordeaux IV, Doc. de Travail du C.E.D., $n^{\circ}$ 45.(2000)

[29] Humphrey, J. Schmitz, H. Developing Country Firms in the World Economy Governance and Upgrading in Global Value Chains. Institute of Development Studies: 2002. Disponível em: <http://www.ids.ac.uk/ids/global/vw.html>. Acesso em 30 mai 2011.

[30] lepagro. Relatório Síntese. Pré-projetos das Agroindústrias do Médio e Baixo Rio Madeira. Paes-de-Souza, M. Serra, N .E. M., Gil, J. IEPAGRO, Porto Velho, 2011.

[31] Lastres, H. M. M; Ferraz, J. C. Economia da informação, do conhecimento e do 
aprendizado. In: Lastres, H. M. M.; ALBAGLI, S. (Org.). Informação e globalização na era do conhecimento. Rio de Janeiro: Campus, 1999. p. 27-57.

[32] Laville, Jean-Louis (dir.). L'économie solidaire. Paris: Desclée de Brouwer. 1

[33] Lechat, Noëlle Marie Paule. As Raízes Históricas da Economia Solidária e seu Aparecimento no Brasil. Civitas - Revista de Ciências Sociais, 2002.

[34] Lechat, Noëlle Marie Paule. Economia social, economia solidária, terceiro setor: do que se trata?. Civitas - Revista de Ciências Sociais, 2002.

[35] Lisboa, A M. Socioeconomia solidária. Marco conceitual latino-americano. In: IX

[36] Encontro Nacional de Economia Política. Anais.. Uberlândia : Sociedade Brasileira de Economia Política, 2006. Disponível em http://www.ie.ufu.br/ix_enep_mesas/Mesa\%2029\%2 0\%20Economia\%20Pol\%C3\%ADtica\%20do\%20De senvolvimento\%20II/Socioeconomia\%20solid\%C3 \%A1ria.pdf Acesso em 10/11/2010.

[37] Mance, E. A. Consumo Solidário. In: CATTANI, Antônio David (org). A Outra Economia. Porto Alegre: Veraz Editores, 2000a. p. 44-49.

[38] Marconi, M. M.; Lakatos, E. M. Técnicas de pesquisa: planejamento e execução de pesquisas, amostragens e técnicas de pesquisa, elaboração, análise e interpretação de dados. São Paulo: Atlas, 1990

[39] Martes, Ana Cristina B.; Bulgacov, Sérgio et al. Apresentação: Fórum - Redes Sociais e Interorganizacionais. In Revista de Administração de Empresas, São Paulo, ERA Publicações, v. 46, ก. 3, 2006

[40]

eira, J. M.; Wanderley, C. A.; Silva, A. C. M.; Miranda, L. C. Indicadores de desempenho empresarial divulgados por empresas norteamericanas. Contabilidade Vista \& Revista, Belo Horizonte, v.14, n. 2, p. 85-103, ago. 2005. Disponível em: < http://www.face.ufmg.br/revista/index.php/contabili dadevistaerevista/article/view/220>. Acesso em 19 nov. 2011.

[41] Metello, Daniela Gomes. Os benefícios da associação em cadeias produtivas solidárias: o caso da Justa Trama - Cadeia Solidária do Algodão Agroecológico. Rio de Janeiro: 2007.

[42] Oliver, A., \& Ebers, M. Networking network studies: analysis of conceptual configurations in the study of inter-organizational relationships. Organization Studies , 19 (4), 459-583. 1998.

[43] Oliver, C. Determinantes of interorganizational relationships: integration and futures directions. Academy of Management Review , 15 (12), 241-265. 1990.

[44] Paes-de-Sousa, M. Pré-projetos das Agroindústrias do Médio e Baixo Rio Madeira. IEPAGRO, Porto Velho, 2010.

[45] Pinto, J.R.L. Economia solidária: de volta à arte da associação. Porto Alegre: Editora da UFRGS, 2006.
[46] Porter, M. E. Competição On competition: estratégias competitivas essenciais. Rio de Janeiro: Campus, 1999

[47] Razeto, Luis. Empresas de Trabajadores y Economía de Mercado. Disponível em: http://www.luisrazeto.net. Acesso em: 10 de março de 2012

[48] Razeto, Luis. Las Empresas Alternativas. Disponível em: http://www.luisrazeto.net. Acesso em: 11 de março de 2012.

[49] Razeto, Luis. Os Caminhos da Economia de Solidariedade. Disponível em: http://www.luisrazeto.net. Acesso em: 12 de março de 2012

[50] Razeto, Luís. Economia de solidariedade e organização popular. In: Moacir Gadotti (org.). Educação comunitária e economia popular. São Paulo: Cortez, p. 34-58. 1993.

[51] Ruduit, S., Relações interfirmas e emprego na rede de empresas: a experiência de externalização de uma empresa no setor de telecomunicações. Sociologias, n. 8. Porto Alegre, Jul/Dec 2002. Disponível em: http://www.scielo.br/scielo. php?pid=S151745222002000200015\&script=sci_arttext\&tlng=pt. Acesso em 13/11/2010.

[52] Santana, G.J. Problematizando a Economia Solidária. Paper apresentado no I Congresso Internacional de sociologia Econômica e Finanças, São Carlos, 2009.

[53] Smith, Adam. A Riqueza das Nações. Hemus, 3a ed. 2008, 440p. ISBN 85-289-0554-3 (edição resumida).

[54] Schmitz, H. and Nadvi, K. Institute of Development Studies, University of Sussex, UK. Clustering aAd industrialization: Introduction. Elsevier Science Ltd. 1999:v. 27, n. 9. Pp. 15031534

[55] Singer, P. Introdução à Economia Solidária. São Paulo: Perseu Abramo, 2002b.

[56] Singer, P. A recente ressurreição da economia solidária no Brasil. In: Produzir para viver: os caminhos da produção não capitalista. Rio de Janeiro: Civilização Brasileira, 2002 ${ }^{a}$.

[57] Singer, Paul. Globalização e Desemprego. 3aㅡ ed. São Paulo: Contexto, 1999.

[58] Silva Júnior, Jeová Torres. Gestão, Fato associativo e Economia Solidária: A experiência da ASMOCONP/ Banco Palmas. 2005. $98 \mathrm{f}$. Dissertação (Mestrado em Administração)-Escola de Administração, Universidade Federal da Bahia, Salvador, 2005

[59] Sousa Santos, B.; Rodriguez, C. Introdução: para ampliar o cânone da produção. In: SOUSA SANTOS, Boaventura. Produzir para viver: os caminhos da produção não capitalista. Rio de Janeiro: Civilização Brasileira, 2002.

[60] Sugden, R. Wilson, J. R. 'Economic Development in the Shadow of the Consensus: A Strategic Decision-Making Approach', Contributions to Political Economy, 21,111-134. 2002.

[61] Suzigan, W.; Furtado, J.; Garcia, R.; Sampaio, S.E.K. Sistemas locais de produção: mapeamento, tipologia e sugestões de políticas. 
Revista de Economia Política, v. 24, n. 4, p. 543562, 2004.

[62] Tauile, J. R.. Do socialismo de mercado à Economia Solidária. Economia
[63] contemporânea. Rio de Janeiro, 6(1): 107122, jan./jun.

2002.http://www.ie.ufrj.br/revista/pdfs/do_socialism o_de_mercado_a_economia_solidaria. pdf . Acesso em 13/11/2010 


\section{Capítulo 7}

\section{DESEMPENHO ORGANIZACIONAL E PRÁTICAS SUSTENTÁVEIS EM UMA EMPRESA DE TRANSPORTES DE CARGA}

\section{Cesar Mauricio Kulak}

Marcos de Castro

Marlete Beatriz Maçaneiro

Resumo: A sustentabilidade vem ganhando cada vez mais importância e espaço dentro das organizações sejam por iniciativa das próprias organizações ou por pressões exercidas por seus parceiros. E devido à pressão que as organizações vêm sofrendo para a adoção de práticas sustentáveis, esta pesquisa buscou medir o desempenho organizacional e as práticas de sustentabilidade em uma empresa de transportes na região centro sul do estado do Paraná. Para verificar o desempenho destas práticas, foi utilizado como ferramenta de análise o Balanced Scorecard, que se destaca por medir o desempenho da organização em suas quatro perspectivas (financeira, de clientes, de processos internos e de aprendizado e crescimento) aliando-as às praticas sustentáveis. O objetivo da pesquisa é identificar de que forma a organização está adotando as práticas de sustentabilidade por meio da ferramenta do Balanced Scorecard, desenvolvidos por Kaplan e Norton (1992) relacionados ao seu desempenho organizacional. A metodologia utilizada adotou uma abordagem qualitativa de estudo de caso em uma transportadora, sendo uma pesquisa descritiva obtida por meio de entrevistas semi-estruturadas, documentos e relatórios da organização. Os principais resultados do estudo possibilitaram identificar que a empresa se encontra num primeiro estágio com relação à sustentabilidade. Ela está desenvolvendo as suas práticas sustentáveis que iniciaram por meio da pressão exercida por seus clientes e que gradativamente começam a ser incorporadas por seus colaboradores e dirigentes, principalmente nas questões relacionadas à dimensão ambiental.

Palavras-chave: Sustentabilidade; Estratégia; Balanced Scorecard. 


\section{INTRODUÇÃO}

Atualmente, as organizações buscam cada vez mais vantagens competitivas dentro de um mercado que a cada dia fica mais acirrado, principalmente devido à globalização em que vivemos e da velocidade em que as transações acontecem diariamente. Além disso, é inegável a importância e o espaço que a sustentabilidade vem ganhando nos últimos anos. Aliado a esse crescimento e importância da sustentabilidade, outro fator que exerce forte pressão nas organizações também é o apelo que a sociedade exerce para a adoção das práticas de ações sustentáveis.

Para Munck (2013), as proposições de sustentabilidade ganharam destaque a partir do século XXI, em que a busca por uma evolução de uma sociedade mais igual, com preservação do meio natural e conquistas culturais são preservados para as futuras gerações, atendendo suas necessidades atuais sem sacrificar recursos existentes. O termo desenvolvimento sustentável ficou mundialmente conhecido em 1987 elaborado pela WCED - World Commission on Environment and Development, em que é definido como "o desenvolvimento que procura satisfazer as necessidades da geração atual, sem comprometer a capacidade das gerações futuras de satisfazerem as suas próprias necessidades" (WCED, 1987).

O campo da administração acompanha o desenvolvimento das organizações, e dentro dessa visão competitiva que rodeiam as empresas, está constantemente discutindo entre diversos assuntos também a questão da sustentabilidade como foco estratégico e de responsabilidade social e ambiental dentro das organizações. Aliado à pressão que as organizações sofrem da sociedade, uma das consequências é a de que aquelas mais estruturadas sejam as primeiras a serem inseridas na questão sustentável. Com isso, essas empresas começam a exigir de seus parceiros que também sejam sustentáveis, criando uma corrente de sustentabilidade, muitas vezes, fruto de pressões do mercado e da própria sociedade. Elkington (2012, p. 18) destaca algumas questões, como "quais formas de capital natural são afetadas pelas nossas atividades planejadas? Essas formas de capital são sustentáveis tendo em vista essas e outras pressões?".
Outro fator importante diz respeito à rastreabilidade de produtos, que muitas organizações exigem de seus parceiros para comprovar a prática de sustentabilidade, desde a origem dos produtos e matérias primas. Um exemplo são as indústrias, que buscam identificar a origem de seus produtos desde o plantio, para ter alto padrão de qualidade e comprovar a qualidade de seus produtos, desde a origem da matéria prima. Para comprovar a qualidade dos produtos, as exigências vão além da indústria, que exige de seus parceiros a qualidade pretendida para suas mercadorias.

Questões como, a origem dos produtos adquiridos dos fornecedores, além do fornecedor, já envolve outros agentes como o produtor rural, buscando a origem da matéria prima desde o produto selecionado para plantio, questionando se o produto é transgênico ou não? Qual o padrão exigido na empresa? Qual a forma de transporte da matéria prima? Existem riscos de contaminação? A transportadora da matéria prima faz uso das práticas sustentáveis? Quais são as práticas adotadas pela empresa de transportes para garantir a entrega do produto com a qualidade exigida? A empresa e seus parceiros possuem certificados de qualidade?

Diante das exigências sofridas pela organização e da importância que a sustentabilidade vem ganhando nos dias atuais, este estudo busca verificar o desempenho e as práticas de sustentabilidade adotadas pela organização, seja por iniciativa da empresa ou por pressão exercida de seus parceiros. Então surge a seguinte questão: qual a relação entre as práticas de sustentabilidade e o desempenho organizacional da empresa?

Para responder a essa questão, relacionando as práticas de sustentabilidade e o desempenho da organização, foi utilizado como instrumento de pesquisa o BSC Balanced Scorecard, em que "os objetivos e medidas focalizam o desempenho organizacional sob quatro perspectivas: financeira, do cliente, dos processos internos e de aprendizado e crescimento" Kaplan e Norton (1997 p. 8), formando suas quatro perspectivas. O objetivo da pesquisa é identificar como as práticas de sustentabilidade influenciam a organização com relação ao seu desempenho organizacional, utilizando o Balanced 
Scorecard e relacionando-o com as práticas de sustentabilidade.

Desta forma, o artigo está organizado da seguinte forma: introdução, que expõe o assunto de estudo, a fundamentação teórica, que trata da sustentabilidade e do Balanced Scorecard, que foi a ferramenta utilizada para medir as práticas sustentáveis da transportadora. A metodologia que foi utilizada nesta pesquisa, a descrição e análise dos resultados obtidos, e por fim, as considerações finais.

\section{REVISÃO DA LITERATURA}

\subsection{SUSTENTABILIDADE DESENVOLVIMENTO SUSTENTÁVEL ORGANIZACIONAL}

No mundo competitivo em que as organizações estão inseridas atualmente, cada vez mais elas buscam melhores formas de gerir seus negócios, com o objetivo de aumentar sua rentabilidade e ter vantagem competitiva sustentável. $\mathrm{Na}$ busca desses diferenciais, o desempenho das organizações acaba sendo o reflexo da forma como são administradas e isso reflete diretamente em seu desempenho e resultados. Aliado a isso, a sustentabilidade também vem ganhando seu espaço nas organizações. Dessa maneira, os gestores devem buscar maximizar o resultado sem deixar de levar em conta as questões sociais e ambientais, que envolvem a sustentabilidade, com enfoque na prosperidade econômica, na qualidade ambiental e na justiça social Elkington (2012).

Quando se fala em sustentabilidade, logo vêm em mente as questões ambientais. Com certeza a preservação da natureza e dos recursos naturais são essenciais, mas não é a única dimensão existente na sustentabilidade, as questões sociais e econômicas também fazem parte do ser sustentável. Gladwin (1995) destaca que o desenvolvimento sustentável é um processo de realização do desenvolvimento humano, e deve-se buscar esse desenvolvimento nas três dimensões da sustentabilidade. Para isso Elkington (2012) definiu o tripé da sustentabilidade, que aborda a sustentabilidade econômica, social e ambiental. Ele coloca a abordagem da sustentabilidade como algo que há tempos é conhecida como uma tentativa de harmonizar o pilar financeiro da sustentabilidade, com pensamento emergente sobre o pilar ambiental, o que tem sido complicado para muitas organizações.

A incorporação da sustentabilidade em meio à gestão empresarial vem impondo novas adequações às organizações, uma vez que pouco a pouco a gestão sustentável vem ganhando mais espaço na sociedade. Como uma organização pode ser sustentável e ao mesmo tempo gerar lucro para seus proprietários e acionistas? Talvez essa seja uma das principais preocupações dos empresários, inclusive daqueles que desconhecem o que realmente é sustentabilidade. Hopwood (2005) vê as mudanças através da gestão de cima para baixo, partindo das estruturas de tomada de decisão para que a sustentabilidade tenha maior importância em suas organizações.

Mas essa é uma tendência que está mudando, em que as organizações da atualidade, principalmente as grandes corporações, buscam melhorar seus resultados de forma sustentável. Elkington (2012) destaca que as organizações não tem mais como fugir da questão sustentável, não são apenas as grandes organizações que devem pensar sustentavelmente, por força da pressão exercida tanto pela sociedade como por grandes corporações. Seus parceiros sejam fornecedores, clientes, empreiteiros, prestadores de serviços, mais cedo ou mais tarde terão que se adaptar à questão sustentável, senão por iniciativa própria, a pressão do próprio mercado e da sociedade irá exigir que as empresas se adaptem a essa nova realidade chamada sustentabilidade.

A estratégia do desenvolvimento sustentável da organização deve atuar nas três dimensões da sustentabilidade: na dimensão econômica, social e ambiental. Deve buscar o equilíbrio dentro das três dimensões, como metas de ser ambientalmente responsável, socialmente justo e economicamente viável, conforme demonstra a Figura 1 que representa o Triple Bottom Line (TBL), desenvolvido por Elkington (2012): 
Figura 1: Triple Bottom Line.

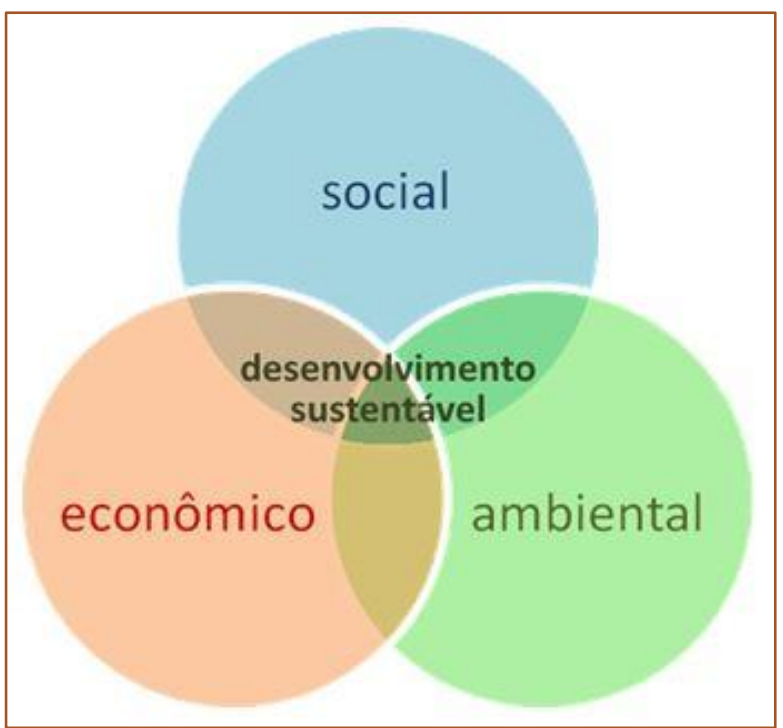

Fonte: adaptado de Elkington,( 2012).

Conforme Elkington (2012) demonstra por meio da TBL (Triple Bottom Line), o desenvolvimento sustentável de uma organização se dá por meio do conjunto das dimensões econômica, social e ambiental. Muitas vezes, as organizações podem trabalhar uma, duas ou até mesmo as três dimensões, mas de forma isolada, sem interligação entre elas, a qual realmente forma a sustentabilidade que as organizações tanto almejam.

Assim, para medir o desempenho da organização e relacionar com as práticas de sustentabilidade, foi utilizado como instrumento de desempenho o Balanced Scorecard (BSC), verificando dentro de suas quatro perspectivas, o que a organização trabalha em questões sustentáveis, que envolvem as dimensões econômica, social e ambiental.

\subsection{BALANCED SCORECARD (BSC)}

O Balanced Scorecard é um instrumento de medição e gestão de desempenho organizacional das empresas. É uma sigla que traduzida significa Indicadores Balanceados de Desempenho, foi desenvolvido em 1992 pelos professores da
Harvard Business School, Robert Kaplan e David Norton. Em um primeiro momento foi desenvolvido como um modelo para avaliação do desempenho organizacional e consequentemente se desenvolveu para uma metodologia de gestão estratégica, Kaplan e Norton (1997).

A metodologia do Balanced Scorecard, também conhecido pela sua sigla BSC, pressupõe que a gestão das empresas e seus indicadores de desempenho não devem se restringir apenas a informações econômicas e financeiras. Além dos resultados econômicofinanceiros, é necessário também monitorar o desempenho de mercado junto aos seus clientes, do desempenho dos processos internos da organização, de pessoas, inovação e tecnologia, em que esse conjunto de medidas pode alavancar o resultado das empresas. Kaplan e Norton (2004).

Para Kaplan e Norton (1997, p.8) "os objetivos e medidas focalizam o desempenho organizacional sob quatro perspectivas: financeira, do cliente, dos processos internos e de aprendizado e crescimento". Essas quatro perspectivas formam a estrutura do Balanced Scorecard, conforme pode ser verificado no Quadro 1. 
Quadro 1 - Quatro Perspectivas do Balanced Scorecard.

\begin{tabular}{|l|l|}
\hline \multicolumn{1}{|c|}{ Perspectiva } & \multicolumn{1}{|c|}{ Medidas Genéricas } \\
\hline Financeira & $\begin{array}{l}\text { Retorno sobre o investimento e valor } \\
\text { econômico agregado }\end{array}$ \\
\hline Do Cliente & $\begin{array}{l}\text { Satisfação, retenção, participação de mercado e } \\
\text { participação de conta }\end{array}$ \\
\hline Interna & $\begin{array}{l}\text { Qualidade, tempo de resposta, custo e } \\
\text { lançamentos de novos produtos }\end{array}$ \\
\hline Aprendizado e Crescimento & $\begin{array}{l}\text { Satisfação dos funcionários e disponibilidade } \\
\text { dos sistemas de informação }\end{array}$ \\
\hline
\end{tabular}

Fonte: (Kaplan e Norton, 1997 p. 44)

Para Kaplan e Norton (1997) O Balanced Scorecard reflete o equilíbrio entre objetivos de curto e de longo prazo, entre medidas financeiras e não financeiras, entre indicadores de tendências (leading) e ocorrências (lagging) e ainda entre as perspectivas internas e externas de desempenho. Garrison e Noreen (2001 p. 320) destacam que "a estratégia é basicamente uma teoria sobre como alcançar as metas da organização."

Kaplan e Norton (1997) detalham as quatro perspectivas do BSC, sendo que, a perspectiva financeira reflete as medidas financeiras que a organização almeja alcançar por meio de sua estratégia, porém ela irá demonstrar como os resultados se comportam com base no que aconteceu. Ela busca o retorno sobre o investimento, margem de contribuição, redução de custos, para melhoria do resultado financeiro. $\mathrm{Na}$ perspectiva dos clientes, a organização deve trabalhar o relacionamento com seus clientes, medindo questões como a satisfação, o que seus clientes esperam da organização, quais são suas expectativas. Essas questões tem o objetivo de aumentar mercado e angariar mais clientes, além de manter clientes atuais, de maneira que eles sejam fieis à organização. A perspectiva interna ou perspectiva dos processos internos, como o próprio nome diz, busca melhorar as questões internas da organização, como qualidade, inovação, serviços pós-vendas, melhorando questões internas que irão refletir no resultado da organização. E por fim, a perspectiva do aprendizado e crescimento que verifica principalmente a satisfação de seus colaboradores, que podem crescer junto com a organização, pois pessoas satisfeitas terão prazer em trabalhar para as organizações, acumulando conhecimento e aprendizado simultaneamente, tanto para a organização quanto para os próprios funcionários. Ainda Kaplan e Norton (1997, p. 49) destacam:

Os objetivos financeiros servem de foco para os objetivos e medidas das outras perspectivas do scorecard. Qualquer medida selecionada deve fazer parte de uma cadeia de relações de causa e efeito que culminam com a melhoria do desempenho financeiro. O scorecard deve contar a história da estratégia, começando pelos objetivos financeiros de longo prazo e relacionando-os depois à sequencia de ações que precisam ser tomadas em relação aos processos financeiros, dos clientes, dos processos internos e, por fim, dos funcionários e sistemas, a fim de que, a longo prazo, seja produzido o desempenho econômico desejado.

A figura 2 demonstra a visão estratégica com as quatro perspectivas do Balanced Scorecard desenvolvidas por Kaplan e Norton (1997). 
Figura 2: Visão e Estratégia.

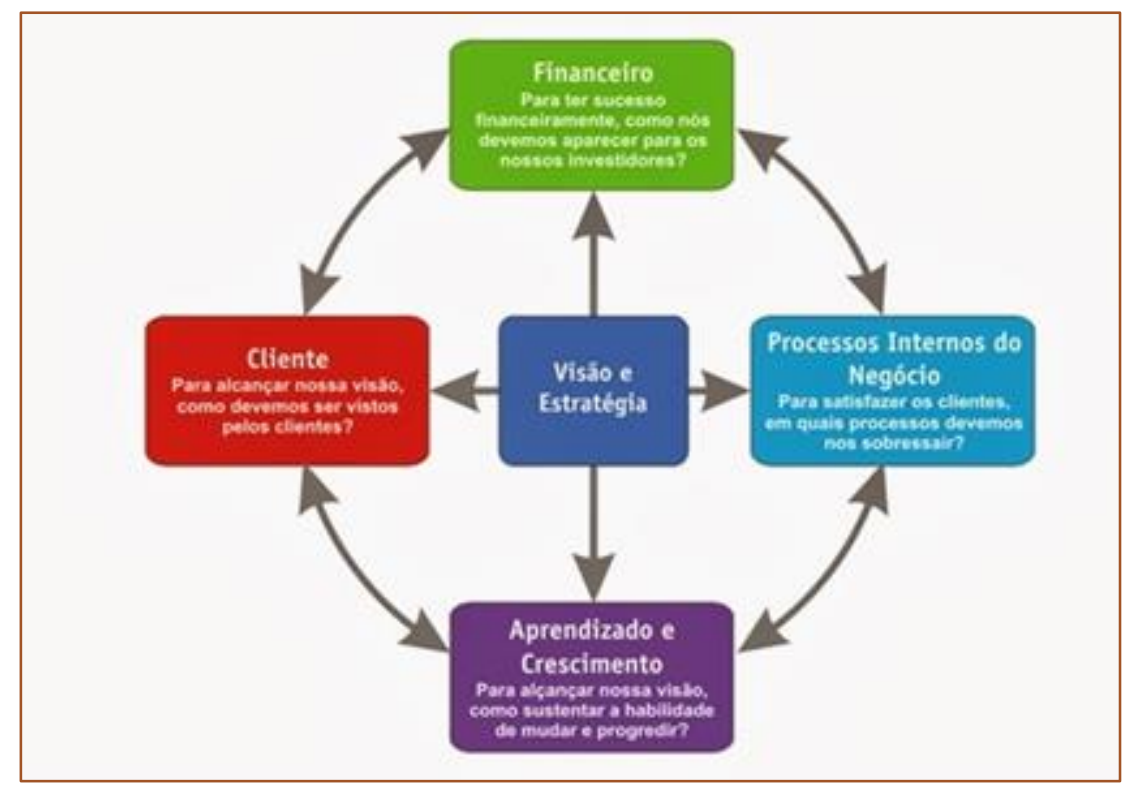

Fonte: adaptado de Kaplan e Norton, 1997

Para Garrison e Noreen (2001 p. 327): "O balanced scorecard é um sistema promissor de gestão das organizações. Consiste em um sistema integrado de medidas de desempenho, derivadas da estratégia da companhia e para dar suporte a ela." Dessa forma, fica clara a importância das quatro perspectivas, que no fim são essenciais para o sucesso da organização e consequentemente do alcance dos objetivos traçados.

\section{METODOLOGIA}

O presente estudo caracteriza-se como uma pesquisa com abordagem a qualitativa. A estratégia de pesquisa adotada foi o estudo de caso. A unidade de análise é de um caso único, com exploração específica no desempenho da organização e suas práticas de sustentabilidade. Para Yin (2010 p.39): "O estudo de caso é uma investigação empírica, que investiga um fenômeno contemporâneo e em seu contexto de vida real, especificamente quando os limites entre o fenômeno e o contexto não são claramente evidentes".

É uma pesquisa descritiva por meio de coleta de dados de relatórios e documentos da organização para posterior análise e interpretação. As técnicas utilizadas para a coleta de dados foram entrevistas, observação direta e consulta a documentos da empresa. A entrevista foi semi-estruturada, combinando perguntas abertas e fechadas para o informante discorrer sobre o assunto, com perguntas pré-determinadas, além de questões adicionais que surgiram no decorrer da entrevista, para melhor elucidar as questões referentes ao estudo. A observação direta ocorreu através de visitas à empresa nas entrevistas e na coleta de dados documentais, em que buscou verificar a execução das atividades relatadas por seus colaboradores.

A empresa pesquisada é uma empresa de pequeno porte, localizada na região centrooeste do Estado do Paraná. O número de funcionários é de cerca de 40 funcionários,. $\mathrm{Seu}$ principal cliente responde por aproximadamente noventa por cento de seu faturamento, que em média é de um milhão de reais por mês.

O estudo de caso foi realizado na transportadora de cargas, que por meio da competitividade existente no mercado e a crescente adoção das práticas de sustentabilidade pelas organizações, pressionaram a organização para adotar práticas sustentáveis em sua estratégia. O objetivo deste trabalho é identificar de que forma a organização está adotando estas práticas de sustentabilidade por meio da ferramenta do Balanced Scorecard, desenvolvidos por Kaplan e Norton (1992).

A análise dos dados foi realizada a partir da coleta das informações, por meio da análise de conteúdo, através dos documentos 
fornecidos pela organização, em conjunto com os dados das entrevistas e da observação direta nas visitas à organização, com o objetivo de validar os indicadores utilizados na transportadora, com as práticas sustentáveis.

\section{ANÁLISE DOS RESULTADOS}

O processo de análise de dados serviu para dar suporte ao desempenho da organização com relação as suas práticas sustentáveis. A descrição e análise dos resultados estão divididas em três subitens: no primeiro, está a missão visão e valores da organização, no segundo subitem os indicadores sob as quatro perspectivas do BSC e o terceiro subitem as perspectivas do BSC relacionadas com as práticas sustentáveis da organização.

\subsection{MISSÃO, VISÃO E VALORES}

A organização é uma empresa de transporte de carga, que depende basicamente de um cliente para a execução de seus trabalhos. A prestação de serviços ocorre desde 2004, atualmente conta com aproximadamente 30 caminhões em sua frota. Em 2015, começou a sofrer pressões de seu principal cliente para a prática de gestão dentro da organização, aliada a questões que também envolvem a sustentabilidade.

Com base nas exigências sofridas de seu cliente, um dos primeiros passos foi descrever por meio de seus gestores a missão, visão e valores da organização. A missão é uma declaração do propósito da empresa, definindo o que ela faz Padoveze (2011). A missão da transportadora é: Ser eficiente para os clientes através de melhorias contínuas em serviços e transportes rodoviários de cargas, somando para o desenvolvimento do contratante. Oferecendo soluções de transporte com qualidade e competência, visando a modernidade em procedimentos logísticos, garantindo a eficácia e conquistando confiança no transporte de seus produtos.

A visão diz respeito aonde a empresa quer chegar, o futuro que almeja alcança Padoveze (2011), a visão da transportadora é: Ser a principal e melhor empresa no transporte rodoviário de cargas na preferência dos clientes, aumentando continuamente os serviços garantindo qualidade e sendo responsiva. Os valores de uma organização são o conjunto de crenças e princípios que guiam a organização, Padoveze (2011). A transportadora tem como valores: Organização; Ética Profissional; Comprometimento; Respeito pelas Pessoas; Informação; Pontualidade; Qualidade; Consciência Ambiental e Social.

Após a descrição da missão, visão e valores, a organização passou a se preocupar em desenvolver os indicadores solicitados por seu cliente para medir o desempenho relacionado à prestação de serviços. Eles estão sendo trabalhados em conjunto pela transportadora e seu cliente e ainda estão em desenvolvimento. Como o Balanced Scorecard é o instrumento de análise para esses indicadores, eles foram distribuídos nas suas quatro perspectivas, conforme a perspectiva de cada indicador, analisando sua importância e atrelando às práticas sustentáveis da organização.

\subsection{OBJETIVOS E INDICADORES SOB QUATRO PERSPECTIVAS DO BSC}

Os objetivos da transportadora foram divididos dentro das quatro perspectivas do Balanced Scorecard, para avaliar o desempenho por meio dos indicadores e consequentemente mensurar esses indicadores com as possíveis práticas de sustentabilidade praticadas pela organização. Para Kaplan e Norton (1997), "O Balanced Scorecard deixa claro que as medidas financeiras e não-financeiras devem fazer parte do sistema de informações para funcionários de todos os níveis da organização".

A organização começou a se preocupar com as questões gerenciais e sustentáveis em 2015, principalmente pelo fato de receber forte pressão de seu principal cliente. Conforme Elkington (2012 p.33):

\footnotetext{
Recusar o desafio imposto pelos três pilares é correr o risco de extinção. Esse assunto não diz respeito somente a grandes organizações: estas serão forçadas a repassar a pressão, por meio de cadeia de fornecimento, para seus grandes e pequenos fornecedores e empreiteiros.
}

Os três pilares destacados por Elkington (2012) dizem respeito às questões econômicas, sociais e ambientais, que por força de pressão está sendo repassado para a organização em estudo. Dentre vários 
fatores cobrados pelo cliente, destacam-se controles que devem ser apresentados mensalmente pela organização por meio de indicadores. Essa cobrança foi uma exigência que a organização recebeu de seu principal cliente para poder continuar a prestar os serviços de transporte.

Contudo, é uma mudança de cultura dentro da organização e mudanças não se fazem de um dia para o outro. Os indicadores foram estabelecidos e alguns podem ser obtidos de maneira mais rápida, mas outros dependem de um pouco mais de trabalho para que sejam executados. É uma questão de adaptação e de algumas mudanças necessárias para essa nova realidade. A organização está trabalhando para ter todos os indicadores em mãos e, à medida que vai formatando esses indicadores, absorve essas novas exigências que o mercado impôs a sua cultura organizacional, tornando-se aos poucos mais uma atividade do dia a dia da organização.

Para este estudo, os controles de desempenho exigidos da organização foram divididos nas quatro perspectivas do Balanced Scorecard. O quadro 2 apresenta os indicadores de desempenho da Transportadora distribuídos dentro dessas perspectivas do Balanced Scorecard, que envolvem medidas financeiras e não financeiras, conforme a adequação de cada indicador a uma perspectiva.

Quadro 2 - Indicadores da Transportadora nas perspectivas BSC.

\begin{tabular}{|c|c|c|}
\hline Perspectiva & Objetivo & Indicador \\
\hline \multirow{2}{*}{ Financeira } & \% Custo de avarias no transporte & $\begin{array}{l}\mathrm{R} \$ \text { avarias transportes / } \\
\mathrm{R} \$ \text { total transportado }\end{array}$ \\
\hline & Faturamento por caminhão & $\begin{array}{l}\text { Faturamento por período / } \\
\text { № veículos }\end{array}$ \\
\hline \multirow{2}{*}{ Clientes } & Reclamações de clientes & № reclamações clientes \\
\hline & Avarias no transporte & $\begin{array}{l}\text { № transportes com avaria / } \\
\text { № total de transportes }\end{array}$ \\
\hline \multirow{9}{*}{$\begin{array}{l}\text { Processos } \\
\text { internos }\end{array}$} & Entregas no prazo & $\begin{array}{l}\text { № entregas realizadas dentro } \\
\text { prazo / Total entregas }\end{array}$ \\
\hline & Veículos disponíveis no prazo & $\begin{array}{l}\text { Veículos carregados no prazo } \\
\text { / total veículos carregados }\end{array}$ \\
\hline & Performance da frota & $\begin{array}{l}\text { № manutenção executados / } \\
\text { № manutenção planejada }\end{array}$ \\
\hline & Não conformidade $(\mathrm{NC})$ realizadas & $\begin{array}{l}\text { NC respondidas no prazo/ } \\
\text { NC totais }\end{array}$ \\
\hline & Veículos com idade inferior 5 anos & $\begin{array}{l}\text { Veículos }<5 \text { anos / } \\
\text { Total veículos }\end{array}$ \\
\hline & Ocorrência indisponibilidade rastreamento & № vezes sistema inoperante \\
\hline & Veículos controle emissão poluentes & $\begin{array}{l}\text { № veículos com controle de } \\
\text { poluentes / total veículos }\end{array}$ \\
\hline & Plano emergencial de riscos & $\begin{array}{lll}\begin{array}{l}\text { Existência } \\
\text { emergencial }\end{array} & \text { de } & \text { plano } \\
\end{array}$ \\
\hline & Investimentos programas sócio ambientais & $\begin{array}{l}\text { Investimento programas / } \\
\text { faturamento bruto }\end{array}$ \\
\hline \multirow{2}{*}{$\begin{array}{l}\text { Aprendizado e } \\
\text { crescimento }\end{array}$} & Horas de treinamentos & $\begin{array}{l}\text { № horas treinamento / } \\
\text { Total funcionários }\end{array}$ \\
\hline & Sugestões de melhoria & Sugestões implantadas \\
\hline
\end{tabular}

Fonte: elaborado pelo autor

Para a elaboração do quadro 2 e sua a distribuição dentro das perspectivas do BSC, foram elaboradas com base na consulta aos documentos da organização relacionadas aos itens de controle, e das entrevistas realizadas com o supervisor de logística e o gestor da 
organização para confirmação dos acompanhamentos realizados na empresa.

Na perspectiva financeira, conforme Kaplan e Norton (1997 p. 26), "as medidas financeiras de desempenho indicam se a estratégia de uma empresa, sua implementação e execução estão contribuindo para a melhoria dos resultados financeiros." Nessa perspectiva, a principal preocupação está em acompanhar os custos por avarias ocasionadas no transporte de cargas, e o faturamento por veículo, que faz a média do faturamento do período com relação à frota de veículos existente na organização. Para Kaplan e Norton (1997, p. 67): "A perspectiva dos clientes permite que as empresas alinhem suas medidas essenciais de resultados relacionadas aos clientes - satisfação, fidelidade, retenção, captação, e lucratividade - com segmentos específicos de clientes e mercado".

Com base nessa perspectiva, os indicadores controlados na organização, se referem às reclamações de clientes e o número de avarias no transporte que ocorreram em cada período. Nos dois indicadores são desenvolvidos planos de ação para solucionar os problemas ocasionados, tanto pelas reclamações quanto pelas avarias para que esses problemas não ocorram novamente.

A perspectiva dos processos internos é a que tem o maior número de indicadores na empresa em pesquisa. Kaplan e Norton (1997 p. 27) afirmam que "as medidas de processos internos estão voltadas para os processos internos que terão maior impacto na satisfação do cliente e na consecução dos objetivos financeiros da empresa." Ainda sobre processos internos Kaplan e Norton (1997, p. 97) destacam que:

\begin{abstract}
Para a perspectiva dos processos internos da empresa, os executivos identificam os processos mais críticos para a realização dos objetivos dos clientes e acionistas. As empresas costumam desenvolver objetivos e medidas para essa perspectiva depois de formular objetivos e medidas para as perspectivas financeiras e de cliente.
\end{abstract}

Analisando os indicadores de processos internos, a empresa possui inicialmente nove itens de controle nessa perspectiva. O primeiro indicador se refere a entregas no prazo, que mede o percentual de entregas atrasadas com relação ao total de entregas. Caso o veículo não cumpra o prazo, o atraso deverá ser justificado. O segundo indicador é o de veículos disponíveis no prazo, que diz respeito a programação de carregamento dos caminhões, com prazo estabelecido para embarque de mercadorias e a saída para o cliente. No terceiro indicador de percentual de performance da frota, estão as manutenções dos veículos. Todos os veículos da organização passam por manutenção preventiva. Para cada item existe uma quilometragem de revisão, como troca de óleo, troca de filtro de ar, filtro de direção hidráulica, caixa entre outros. Esse indicador mede os veículos que passaram por manutenção preventiva em relação ao total de veículos existentes.

Os relatórios de não conformidade (NC) medem as respostas em relação ao total de não conformidades (NC) do período. O indicador de número de veículos com idade inferior a 5 anos foi uma exigência para minimizar problemas, como quebra de veículos e possíveis atrasos na entrega de produtos. Porém, esse indicador obteve um prazo maior para se adequar, pois demanda um alto investimento e, além disso, está relacionado ao item de controle de manutenção preventiva, uma vez que os veículos que passam pela manutenção prévia tendem a rodar de forma similar aos veículos mais novos. $O$ indicador de percentual de ocorrência de indisponibilidade de sistema de rastreamento mede o tempo em que os veículos ficaram sem rastreabilidade. Todos os veículos da organização são rastreados e a organização está substituindo o sistema de rastreamento, para minimizar o problema de queda do atual sistema de rastreabilidade.

O indicador de percentual de veículos com controle de emissão de poluentes verifica o nível de poluição gerado pelos veículos da organização. Esses veículos tem controle de poluentes lançados no ambiente, por meio do tratamento multifuncional $\mathrm{CNHI}$ A550. A cada seis meses os veículos devem passar por esse controle. Outro indicador se refere ao plano emergencial de risco, que é um indicador especifico para riscos ambientais. Para isso, a empresa contratou um seguro com relação a riscos ambientais, para eventuais acidentes que possam causar danos à natureza. A organização também faz investimentos em programas sócio ambientais, principalmente relacionados às questões ambientais. Nos programas 
ambientais, a Transportadora trabalha em parceira com empresas de coleta de resíduos, para destinação dos resíduos gerados por suas atividades. Com relação ao óleo utilizado pelos caminhões, são todos armazenados em tambores, e uma empresa especializada com certificado ambiental, mensalmente, recolhe esse óleo para ser reprocessado, são os resíduos líquidos. Além disso, outra empresa também com certificado de coleta e transporte de resíduos é contratada para o recolhimento dos resíduos sólidos gerados pela transportadora, para que sejam dados os destinos ambientalmente corretos, tanto para os resíduos líquidos quanto para os sólidos. A empresa também utiliza cisterna para captação e utilização das águas da chuva, gerando economia em seus custos e contribuindo com o ambiente no reaproveitamento de água.

$\mathrm{Na}$ perspectiva de aprendizado e crescimento, Kaplan e Norton (1997) destacam que: "a quarta perspectiva do Balanced Scorecard, aprendizado e crescimento, identifica a infra-estrutura que a empresa deve construir para gerar crescimento e melhoria a longo prazo." Nessa perspectiva, a empresa trabalha com os indicadores de percentual de horas de treinamento, que mede o número de horas em treinamento dos funcionários com relação ao total de funcionários. Nos treinamentos, cabe destacar que todo motorista contratado pela empresa deve passar por um treinamento interno antes de qualquer viagem e, além do treinamento, recebe uma cartilha de como o motorista deve se comportar. Outro indicador se refere a sugestões de melhorias, em que a organização busca incentivar os seus colaboradores para compartilhar com questões que colaborem para as tarefas do dia a dia da empresa, com o objetivo de implantar as melhorias na organização.

Para Rezende (2011 p. 90) "O Balanced Scorecard proporciona desde a cobertura corporativa, com dinâmicas que envolvem toda a organização, até situações em que o acompanhamento é feito em pequena escala, por e para um grupo de indivíduos". Dessa forma, destaca-se a importância de cada um dos indicadores na busca de atingir cada uma das metas traçadas, como também do conjunto desses indicadores para a estratégia global da organização.
4.3. AS PERSPECTIVAS DO BSC EM RELAÇÃO ÀS PRÁTICAS SUSTENTÁVEIS DA ORGANIZAÇÃO

A organização passou a adotar índices de controle de atividades executadas, em virtude da pressão exercida pelo seu principal cliente, exigência que está vinculada à continuidade de prestação de serviços pela transportadora. Conforme Elkington (2012), as empresas pressionadas por diversas forças passam da visão focada exclusivamente na satisfação de interesses econômicos, para uma visão mais abrangente, levando em conta aspectos sociais e ambientais. Diante dessa exigência, o estudo dividiu esses indicadores dentro das quatro perspectivas do Balanced Scorecard, que envolvem medidas financeiras e não financeiras, identificando quais desses indicadores trabalham as questões sustentáveis dentro da organização.

$\mathrm{Na}$ perspectiva financeira, o principal foco está em obter resultados para a organização, no controle de avarias dos produtos. O indicador reflete não só financeiramente, como também ambientalmente, pois, quanto menos avarias, menor será o descarte de resíduos para o ambiente. Na perspectiva de clientes, o indicador de número de avarias está diretamente ligado ao indicador de custos de avarias, diferenciando-se pelo controle de quantidade de avarias, ao invés dos valores financeiros. As reclamações de clientes é um indicador mais genérico, em que deve ser analisado caso a caso, o qual pode ou não estar relacionado à questão sustentável. Como sugestão, as reclamações de clientes podem ser abertas em grupos de reclamações, para futuramente classificá-las e identificar as contribuições para as práticas sustentáveis.

A relação com as práticas sustentáveis da organização está principalmente na perspectiva de processos internos. Um dos indicadores dessa perspectiva se refere aos investimentos sócios ambientais, em que a organização trabalha com 0 descarte consciente do lixo produzido. Empresas especializadas e certificadas fazem a coleta dos resíduos, tanto líquidos quanto sólidos. Essa coleta pode ser comprovada por meio de documentos de certificações das empresas de coletas e notas fiscais de movimentação desses resíduos.

Ainda, a empresa faz uso sustentável das águas da chuva, que são armazenadas em 
cisternas e posteriormente reaproveitadas. As águas são utilizadas para lavar os caminhões, lavar o pátio da oficina, além das descargas dos banheiros. Após a utilização da água para lavar os caminhões e o pátio da oficina, essa água passa por filtragens antes de voltar para a natureza, por meio de três caixas que filtram as impurezas das águas, que só voltam ao ambiente natural após passar por esse processo. Periodicamente, são feitas análises para verificar a qualidade da água que está retornando à natureza e se está dentro dos padrões ambientalmente aceitos.

Dentro dessa mesma perspectiva, o índice de percentual de performance da frota também tem forte vinculo com a sustentabilidade, em que atinge vários objetivos ao mesmo tempo. Por meio de manutenções preventivas, que compõem esse indicador, os veículos circulam de forma mais confiável e diminuem as manutenções corretivas, gerando uma economia financeira. Além do fator financeiro, melhora o desempenho dos veículos, com maior quilometragem por litro de combustível, queimando menos combustíveis no ambiente. Também reduz o número de peças substituídas e diminui o risco de acidentes com produtos nas pistas e eventuais contaminações de córregos e rios, aumentando a garantia de desempenho no tempo de entrega das mercadorias.

A organização também possui controle de emissão de poluentes, por meio de um tratamento denominado multifuncional $\mathrm{CNHI} A$ 550, que é feito periodicamente em todos os veículos da frota. A empresa possui um plano emergencial de riscos, com contrato de seguro de cargas perigosas, para cobrir eventuais danos causados por acidentes com produtos transportados. Dentro desse plano, também estão incluídos os treinamentos dos motoristas para transportes de tais cargas. A empresa faz treinamentos obrigatórios para transporte dessas cargas e estão em estudo treinamentos adicionais englobados no plano emergencial de riscos.

$\mathrm{Na}$ perspectiva de aprendizado e crescimento, o principal indicador se refere ao treinamento de seus colaboradores. Todo motorista contratado pela empresa, faz um treinamento antes de sua primeira viagem. Após o treinamento, o colaborador recebe 0 manual de condutas, elaborado pela própria organização. Aos colaboradores das demais áreas são oferecidos treinamentos de acordo com a necessidade de cada atividade, previamente definidos.
$\mathrm{Na}$ questão social a organização não possui projetos sociais em que faz parte, mas faz constantes doações para a sociedade como igrejas e associações. Para Elkington (2012, p. 29):

\begin{abstract}
O sucesso futuro do mercado dependerá da capacidade de uma empresa individual (ou de toda a cadeia de valor) atingir simultaneamente não somente 0 pilar tradicional da lucratividade, mas também os dois novos pilares: um concentrado na qualidade ambiental e outro na justiça social. Portanto as empresas e seus comitês terão de pensar em termos dos três pilares da sustentabilidade.
\end{abstract}

Diante disso, a empresa em análise busca um novo modelo que as organizações estão se inserindo, além da busca de lucros e rentabilidade, também começa a se preocupar com aspectos sociais e ambientais, para garantia de seu futuro.

\section{CONCLUSÃO}

O objetivo deste estudo foi analisar as características das práticas sustentáveis da organização, por meio das quatro perspectivas do Balanced Scorecard. A pesquisa classificou esses indicadores dentro das perspectivas: financeira, de clientes, de processos internos e de aprendizado e crescimento. Após essa classificação, por meio da analise documental e de entrevistas com pessoas da organização e em alguns casos de verificação de procedimentos adotados, foi possível verificar que a organização se encontra no primeiro estágio com relação execução de práticas sustentáveis.

O principal motivo para o avanço das práticas sustentáveis da transportadora está na questão ambiental, como na coleta de resíduos líquidos e sólidos, no reaproveitamento da água das chuvas, na utilização dessa mesma água e tratamento para devolvê-la à natureza. Também cabe destacar as manutenções preventivas e o controle de poluentes feitos na frota da organização, que combina questão ambiental, agredindo menos a natureza, e a questão econômica, trazendo mais desempenho e economia nos veículos da organização. 
Na dimensão social não é possível identificar nenhum programa que esteja ligado diretamente com os indicadores dentro das perspectivas do Balanced Scorecard. Como questão social, a empresa faz frequentemente doações para entidades religiosas e associações, mas sem um projeto social especifico. Na dimensão econômica, pode-se perceber que algumas atividades executadas refletem nos resultados da organização. A mais evidente delas diz respeito a manutenção preventiva, que tem impacto significativo no resultado, diminuindo as manutenções corretivas e melhorando o desempenho na entrega de mercadorias, com menor risco de veículos e mercadorias parados.

A organização objeto deste estudo de caso começou a se preocupar com questões relacionadas à sustentabilidade, por meio da pressão exercida pelo seu principal cliente, em que a exigência do cumprimento dessas atividades está diretamente relacionada à continuidade de prestação de serviços de transportes. Assim, não se pode afirmar que a empresa aplica a sustentabilidade em suas três dimensões, pelo contrário, ela ainda está iniciando as práticas sustentáveis. Primeiro, para se adequar a exigências impostas por seu cliente, depois, o fato do mercado atual exigir essas práticas sustentáveis. Nesse sentido, a tendência é que a organização

\section{REFERÊNCIAS}

[1] Aligleri, L; Aligleri, L A; Kruglianskas, I. Gestão socioambiental: responsabilidade e sustentabilidade do negócio. São Paulo: Atlas, 2009.

[2] Aligleri, L. A adoção de ferramentas de gestão para a sustentabilidade e a sua relação com os princípios ecológicos nas empresas. 2011. 178 f. Tese (Doutorado em Administração)Universidade de São Paulo, São Paulo, 2011.

[3] Barbieri, J.C.; Cajazeira,J. E. R. Responsabilidade social empresarial e empresa sustentável. São Paulo: Saraiva, 2009.

[4] Dias, R. Gestão ambiental: responsabilidade social e sustentabilidade. São Paulo: Atlas, 2011.

[5] Elkington, J. Canibais com garfo e faca. São Paulo: Makron, 2012.

[6] Herrero Filho, E. Balanced Scorecard e a gestão estratégica - uma abordagem prática. Rio de Janeiro: Elsevier, 2005.

[7] Garrison, R. H.; Noreen, E. W. Contabilidade Gerencial. Rio de Janeiro: LTC, 2001.

[8] Gladwin, T. N., Kennelly, J. J.; Krause, T. $S$. Shifting Paradigms for Sustainable Development. assimile em sua cultura organizacional a importância de uma empresa trabalhar de forma sustentável.

Um ponto positivo destacado pela organização foi um contrato firmado com um novo cliente, a partir da apresentação do modelo que a empresa pretende seguir, com base nos indicadores citados neste trabalho. Os indicadores ainda estão em fase de implantação, mas já contribuíram no fechamento de contrato com um novo cliente, que representará aproximadamente dez por cento do faturamento total da empresa.

Com o passar do tempo a cultura organizacional da empresa vai se adaptando a essa nova realidade para que a organização trabalhe de forma sustentável dentro das três dimensões das práticas sustentáveis, como destaca Elkington(2012), sendo ambientalmente responsável, socialmente justo e economicamente viável.

A pesquisa apresenta suas limitações no estudo de caso, que foi em uma organização em estágio inicial de suas práticas sustentáveis. Outros estudos podem ser realizados na própria organização, para medir a evolução dessas práticas sustentáveis ou em outras empresas, que buscam aplicar as práticas sustentáveis dentro de suas organizações.

Academy of Management. v.20, n. 4, p. 874-907, 1995.

[9] Hopwood, M.; Mellor, M.; Obrien, G. Sustainable Development - Mapping Different Approaches. Sustainable Development. v. 13, n. 1, p. 38-52, 2005

[10] Kaplan, R. S.; Norton, D. P. A estratégia em ação: Balanced Scorecard. 9.ed. Rio de Janeiro: Campus, 1997.

[11] Kaplan, R. S.; Norton, D. P. Mapas estratégicos Balanced Scorecard: convertendo ativos intangíveis em resultados tangíveis. 4.ed. Rio de Janeiro: Campus, 2004

[12] Munck, L ; Bansi, A.C. ; Galleli-DIAS, B. ; Cella-De-Oliveira, F.A. Em busca da sustentabilidade organizacional : a proposição de um framework. Revista Alcance (Online), v. 20, p. 31-46, 2013.

[13] Munck, L; Borim-de-Souza, R.; Zagui, C. A gestão por competências e sua relação com ações voltadas à sustentabilidade. REGE, São Paulo, v. 19, n. 3, p. 377-394, jul./set, 2012.

[14] Munck, L. Gestão da sustentabilidade nas organizações: um novo agir frente à lógica das competências. São Paulo: Cengage Learning, 2013. 
[15] Padoveze, C.L. Controladoria estratégica e operacional - conceitos - estrutura - aplicação. São Paulo: Cengage Learning, 2011.

[16] Rezende, J.F.C. Balanced scorecard e a gestão do capital intelectual - alcançando a performance balanceada na economia do conhecimento. Rio de Janeiro: Elsevier, 2003.

[17] Sachs, I. Desenvolvimento includente, sustentável sustentado. Rio de Janeiro: Garamond, 2004.
[18] Yin, R.; Estudo de caso: planejamento e métodos. 4.ed. Porto Alegre: Bookman, 2006.

[19] World Commission On Environment And Development - Wced. Our commom future. Oxford: Oxford University Press, 1987.

[20] Zylbersztajn, D. Sustentabilidade e geração de valor: a transição para o século XXI. Rio de Janeiro: Elsevier, 2010. 


\section{Capítulo 8}

\section{CONSTRUCÃO PARTICIPATIVA DE INDICADORES DE SUSTENTABILIDADE COMO SUPORTE DE TOMADA DE DECISÃO PARA A QUALIDADE DE VIDA NAS COMUNIDADES EM LUANDA (ANGOLA): ESTUDO DE CASO NA CENTRALIDADE DO KILAMBA}

\section{Eduardo Lopes Marques \\ Lilhan Ferro de Souza Barbosa \\ Augusto Paulo Salelo José}

Resumo: O termo sustentabilidade, nos dias atuais, combina as relações existentes entre o meio ambiente, o meio econômico e o meio social. Nesta perspectiva, usam-se indicadores de sustentabilidade para desenhar um modelo de desenvolvimento de processos produtivos, bem como meio de monitoramento e comunicação para as práticas rumo ao desenvolvimento sustentável. Esta pesquisa foi desenvolvida com o objetivo de construir, com a colaboração dos moradores da cidade do Kilamba (Luanda- Angola), indicadores de sustentabilidade que poderão servir de suporte para definição de políticas públicas capazes de melhorar a qualidade de vida dos cidadãos. Para tanto combinou-se o desenvolvimento de um estudo documental e bibliográfico com a realidade local da comunidade, através da aplicação de questionários e utilização da escala de Linkert. Com isso, foi possível separar os indicadores em três grupos, correspondentes ao 1ํ Grau que ficou composto por todos os indicadores que obtiveram pontuação ponderada entre 0,9 e 0,8, este grupo ficou constituído de $46 \%$ de indicadores da Dimensão Social, 54\% da Ambiental e nenhum da Económica. Do 2ํGrau foram considerados os indicadores com pontuação entre 0,7 e 0,6, sendo que neste grupo $29 \%$ dos indicadores eram da Dimensão Social, 50\% da Ambiental e 21\% da Dimensão Econômica. No 3o e último Grupo estavam os indicadores menos pontuados, que obtiveram valores entre 0,5 e 0,4, sendo que ficou composto por $100 \%$ de indicadores da Dimensão Econômica. Da pesquisa verificou-se que aos habitantes da Cidade do Kilamba, houve redução nos riscos de saúde (Saúde), maior disponibilidade de serviços de educação (Educação), bem como o padrão de uma vida mais decente (Rendimentos), variáveis que impactam diretamente o IDH.

Palavras-Chave: Indicadores de Sustentabilidade, Construção Participativa, Qualidade de Vida. 


\section{1 - INTRODUÇÃO}

Tem-se o conhecimento que os indicadores de sustentabilidade são utilizados como ferramentas simplificadas de análise, monitoramento e comunicação, com o objetivo de avaliar determinado sistema no âmbito de uma realidade conceitual e, dessa forma, permitir a mensuração dos fenômenos complexos (CLARO e CLARO, 2004 apud CALLADO).

Assim, os Indicadores de Sustentabilidade constituem instrumentos importantes e mais adequados para que os gestores públicos possam avaliar e monitorar a sustentabilidade ambiental e planejar estratégias em prol da melhoria da qualidade de vida da população (SANTIAGO e DIAS, 2012).

Diante do exposto este artigo propôs como problema de pesquisa e, ainda, objetivo geral a ser cumprido, buscar compreender como se dá a construção de Indicadores de Sustentabilidade de forma participativa e que possam contribuir para estudos de avaliação de desempenho econômico e a qualidade de vida (bem-estar) na Centralidade do Kilamba (Luanda- Angola). Tendo como hipóteses a possibilidade de construção destes indicadores, em função das expectativas da população ou da não possibilidade de construção dos indicadores em decorrência da necessidade mais aprofundada por parte da comunidade sobre a temática Desenvolvimento Sustentável.

O artigo buscou mostrar a existência de uma relação positiva entre a aplicabilidade de Indicadores de Sustentabilidade vs Qualidade de Vida; Caracterizar a comunidade em estudo "Centralidade do Kilamba"; Aplicar inquérito, relevando aspectos económicos, sociais e ambientais, junto da comunidade; Destacar os melhores indicadores de acordo com a escala de Likert; Interpretar os resultados obtidos com a aplicação de inquérito.

Como justificativa para o desenvolvimento do trabalho tem-se em primeiro o fato da questão de sustentabilidade ser o termo diretor das práticas produtivas e de consumo tanto nas organizações como nas comunidades sociais, e pela preocupação que o Governo tem, desde o pós-guerra (2002), em atender as necessidades habitacionais, conjugado com as aspirações de qualidade de vida da população dos cidadãos. Além disso, a escolha da Centralidade do Kilamba fundamenta-se por ser um dos maiores projetos habitacionais já construídos na Província de Luanda.

Desta feita, definiu-se objetivos específicos capazes de responder ao objetivo geral da pesquisa, sendo que para o alcance de cada objetivo específico foi empregado o método mais adequado possível, a seguir: Para "Caracterizar a comunidade em estudo Centralidade do Kilamba" utilizou-se a técnica de pesquisa Participante, sendo que nesta fase a pesquisa foi realizada através de uma visita de campo, em termos de abordagem a pesquisa foi Qualitativa nesta fase. Com a técnica de pesquisa de campo foi possível "Aplicar inquérito, relevando aspectos económicos, sociais e ambientais, na comunidade" para coleta de informações junto aos residentes, que possibilitem a seleção de indicadores. $\mathrm{Na}$ sequência, através das técnicas Econométricas fez-se a Tabulação e cálculo no sistema SPSS dos dados do objetivo anterior, e trabalhá-los com técnicas econométricas. Quanto à abordagem, neste ponto a pesquisa foi Quantitativa e, com os dados no sistema SPSS poderemos "Destacar os melhores indicadores de acordo com a escala de Linkert". E por final foi feita a "Interpretação dos resultados obtidos com a aplicação de inquérito" de modo a entender o que sinalizam cada resultado obtido.

$\mathrm{Na}$ pesquisa, utilizou-se o método de amostragem não probabilística intencional, também chamada de amostragem por tipicidade. Ao final da pesquisa e, em função dos resultados, este estudo apresenta vias alternativas da atual tendência dos modelos de desenvolvimento nos projetos habitacionais, bem como melhoria na análise do desempenho económico das comunidades.

Sendo assim, este artigo está constituído por quatro capítulos, sendo o primeiro esta introdução, com uma análise geral do que será discutido, bem como os objetivos pretendidos com a pesquisa. De seguida, o trabalho apresenta a Revisão Bibliográfica, que aborda a discussão sobre a Sustentabilidade relacionada à Qualidade de Vida nas comunidades. O terceiro capítulo da pesquisa surge para caracterizar a Centralidade do Kilamba, apresentando as condições infra-estruturais naquela comunidade bem como suas fragilidades. No quarto e o último capítulo do trabalho, apresentam-se os Resultados da Pesquisa, conseguidos através dos questionamentos, 
via inquérito, aos moradores da Cidade do Kilamba, e também pela técnica de Observação.

Uma das principais limitações da pesquisa encontra-se no facto de a pesquisa ter construído os indicadores necessários a avaliação da Sustentabilidade, mas não ter calculado o índice de sustentabilidade que apresentasse 0 ponto de situação da comunidade.

\section{2- REFERENCIAL TEÓRICO}

As grandes transformações ocorridas na segunda metade do século XX aumentaram as dúvidas em relação ao futuro do Meio Ambiente. A ideologia do crescimento econômico não predominava somente nos sistemas de economia de mercado, como também, naqueles orientados por um sistema de planejamento centralizado, como é o caso da União Soviética. No mesmo período, era destaque a preocupação da relação homemnatureza em vários encontros acadêmicos, levando ao desenvolvimento de novas disciplinas como a Ecologia Cultural e Ecologia Humana, além das contribuições dos antropólogos marxistas relativamente ao tema (DIEGUES, 1992, p. 24).

A discussão em torno da temática ambiental evoluiu bastante levando o homem a encontrar novos métodos de relacionamento entre sociedade-ambiente, de modo a reduzir os impactos negativos gerados nos seus processos produtivos. (WEISACKER et al, 1995 ApudBELLEN, 2002, p. 5).

As primeiras reações quanto as questões ambientais foram lançadas pelo Clube de Roma, quando publicaram, em 1972, Os Limites do Crescimento (The limits to Growth, em inglês), que permitiu, no mesmo ano, a primeira grande discussão internacional na Conferência de Estocolmo sobre o Meio Ambiente Humano (MEADOWS, 1972 apud BELLEN, 2002, p. 8).

No ano de 1974, de uma reunião realizada pela UNCTAD (Conferência das Nações Unidas Sobre Comércio e Desenvolvimento) e pela UNEP (Programa do Meio Ambiente das Nações Unidas), resultou a Declaração de Cocoyok, um documento que contribui para abordagem da temática ambiental nas principais discussões a nível mundial. (CAVALCANTI et al, 1994).

Um ano depois, 1975, as conclusões da Declaração de Cocoyok foram aprofundadas pela fundação Dag-Hammarskjold que publicou um relatório com a colaboração de 48 países, juntamente com o Programa do Meio Ambiente das Nações Unidas e outras 13 Organizações da Organização das Nações Unidas, levando em causa a questão do poder e sua relação com a degradação ambiental, bem como realça um modelo de desenvolvimento a partir da mobilização das próprias forças capazes de alavancar uma mudança estrutural dos sistemas actuais (BELLEN, 2002, p. 9).

Na sequência, em finais da década de 80 e início dos anos 90, o termo Ecodesenvolvimento é substituído pelo Desenvolvimento Sustentável (DIAS e TOSTES, 2009). Foi realizada, no Rio de Janeiro em 1992, a Comissão Mundial para o meio Ambiente e Desenvolvimento, também conhecida como "Rio 92", presidida pela norueguesa Gro. Haalen Brundtland e Mansour Khalid, daí que o resultado do trabalho denominava-se Relatório Brundtland (BARBOSA, 2008). No relatório se encontram além do conceito de Desenvolvimento Sustentável (dos mais difundidos à nível mundial), questões sociais, destacando-se a preocupação com o uso da terra, sua ocupação, suprimento de água, abrigo e outros serviços sociais, educativos e sanitários, sem esquecer o processo administrativo e o crescimento urbano. Da conferência "Rio 92" ainda surge a Agenda 21, que firma o conceito de desenvolvimento sustentável incorporando em outras agendas mundiais de Desenvolvimento e de Direitos Humanos (BARBOSA, 2008).

A interligação entre o desenvolvimento sócioeconômico e as transformações no meio ambiente, durante décadas ignoradas, entrou no discurso oficial da maioria dos governos do mundo a partir da metade da década de 1990 (CAVALCANTI et al, 1994).

$\mathrm{Na}$ Comissão Mundial para o Meio Ambiente e o Desenvolvimento (CMMAD), também conhecida como Comissão de Brundtland, resultou um relatório onde ficou exposta uma das definições mais difundidas do Desenvolvimento Sustentável sendo aquele que atende as necessidades do presente sem comprometer as possibilidades de as gerações futuras atenderem suas próprias necessidades (BARBOSA, 2008). BELLEN (2004); GOODLAND e LEDOC (1987 apud BARONI) apresentam conceitos diferenciados de Desenvolvimento Sustentável, sem contudo perder a essência apresentada no conceito mais tradicional. 
Tabela 1: Esquema cronológico das manifestações internacionais em torno do Desenvolvimento Sustentável

\begin{tabular}{|c|c|}
\hline Ano & Organização \\
\hline 1972 & Clube de Roma - O limites do crescimento \\
\hline 1973 & Maurice Strong e lgnacy Sachs - Termo Econdesenvolvimento \\
\hline 1974 & UNCTAD e UNEP - Declaração de Cocoyok \\
\hline 1975 & Fundação Dag-Hammarskjold - Aprofundou a Declaração de Cocoyok \\
\hline 1987 & Relatório Bruntland da ONU - Conceito clássico do DS \\
\hline 1992 & Declaração do Rio - Agenda 21 \\
\hline 1993 & Publicação do Relatório Worldwich Institute \\
\hline
\end{tabular}

Fonte: Elaborada pelo autor

De maneira geral, espera-se que os novos modelos de Desenvolvimento Sustentável centrem-se na pessoa, tendo como preocupação inicial a incorporação de novas tecnologias, seguras na ótica ambiental, na programação de investimentos, e na busca de formas a refletir o risco da escassez de recursos ambientais para os futuros projetos (HAIA, 1992).

Com o lançamento do conceito de Desenvolvimento Sustentável viu-se a necessidade de construir mecanismos para sua mensuração, dado que estes também seriam mecanismos para promover a ação, monitorar o andamento, bem como avaliar o progresso rumo ao Desenvolvimento Sustentável (TAYRA e RIBEIRO, 2006, p. 86). Para o efeito, seleciona-se Indicadores de Sustentabilidade por constituir-se em ferramentas centrais que permitem um acompanhamento das principais variáveis de interesse de uma organização ou comunidade e possibilitam o planejamento das ações humanas ou institucionais, visando melhorias de desempenho (CALLADO, 2010, p. 3).

Uma pesquisa realizada por Callado (2010), com a pretensão de fazer o levantamento de indicadores de sustentabilidade utilizados em trabalhos empíricos e teóricos junto à especialistas, revelou que a maioria deles direcionam seus estudos nos parâmetros Ambientais, Sociais e Econômicos, sendo que outras dimensões desenvolvidas por alguns autores são apenas extensões dessas três dimensões.

A dimensão Ambiental da sustentabilidade consiste na manutenção das funções e componentes do ecossistema, via bases sustentáveis, vista como a capacidade que a natureza tem as condições de vida para os seres vivos. A dimensão Social é voltada ao equilíbrio social, tanto na vertente do desenvolvimento social, como socioeconômico, ou seja, um guia para humanização da economia, além da pretensão de desenvolver o tecido social nas suas vertentes humanas e culturais. E por último, a dimensão Econômica desenvolve o modo de gerenciamento dos recursos financeiros para o desenvolvimento sustentável, desta feita, o lucro deixa de ser somente medido em sua vertente financeira, levando-se em conta agora, as vertentes ambientais e sociais, o que potencializa tantos dos humanos como os meios não humanos de produção (MOURA, 2003; MAY et al., 2003 e DONAIRE, 1999 apud BORGES, 2013, p. 491 e 492).

Virgínia Marcelo et al. (2001) desenvolveram um estudo para construção participativa de indicadores de sustentabilidade da construção habitacional nas comunidades do Município de Santo André (Brasil). Os resultados permitiram apurar 30 indicadores, com maiores médias, que por sua vez, iriam compor um questionário a ser aplicado na comunidade na fase seguinte da pesquisa. Numa outra pesquisa, realizada por Krama (2009), com a necessidade de fazer uma análise comparativa entre os 27 Estados Brasileiros utilizando a ferramenta Painel de Sustentabilidade, buscou-se construir os Indicadores para a avaliação da sustentabilidade através da comparação dos dados baseado num único fator para todos os 
Estados. O filtro permitiu a seleção de seis indicadores para dimensão social, cinco para dimensão ambiental, e para as dimensões econômica e institucional foram selecionados dois para cada.

Os sistemas de indicadores de sustentabilidade podem ser avaliados por uma série de ferramentas já desenvolvidas para este processo. Dentre elas destacam-se três das ferramentas usadas para avaliar a sustentabilidade, sendo consideradas as principais, de acordo com Van Bellen (2003), através de uma pesquisa realizada junto a especialistas em estudos sobre o Desenvolvimento Sustentável.

Em primeiro tem-se a ferramenta Ecological Footprint Method, ou Método da Pegada Ecológica, foi desenvolvida por Wackernagel e Rees em 1996, traduzindo o espaço ecológico correspondente para sustentar um determinado sistema. Em segundo destaca-se o Painel de Sustentabilidade, que faz metáfora a um painel de automóvel, ou seja, um índice agregado de vários indicadores dentro de cada um dos blocos, que aos tomadores de decisão, em geral, a situação do progresso em direcção ao desenvolvimento sustentável (RABELO e LIMA, 2007; BELLEN, 2003). Por fim tem-se o Barômetro da Sustentabilidade, que foi desenvolvido por um grupo de especialistas ligados aos institutos Internacional Union for Conservation of Nature (IUCN) e International Development Research Centre (IDRC), sendo o principal dos pesquisadores Robert Prescott-Allen (PAULISTA et al., 2008, p. 193).

Pensar na Sustentabilidade do Desenvolvimento comunitário é fundamental, pois, políticas públicas não sustentáveis ao mesmo tempo em que degradam o homem e a sua qualidade de vida, baseadas em métodos insustentáveis de desenvolvimento só favorecem à degradação ambiental via exploração predatória dos recursos naturais e poluição ambiental causando impactos negativos nas condições de saúde da população (PELICIONE,1998, p. 28).

Atualmente, o conceito de qualidade de vida relaciona-se com a sustentabilidade, com a participação popular, em proteger os ecossistemas, com a satisfação das necessidades básicas dos cidadãos, com uma gestão baseada na solidariedade social, na visão holística dos problemas e na redução das iniquidades sociais (MENDES et al, 2001;
ROCHA et al, 2000; VALENTE, 2004; GOMES, 2000 apud MACHADO, 2010, p. 39).

Destas preocupações a questão da qualidade de vida que se busca para as comunidades aliada aos preceitos da Agenda 21, faz com que os indicadores se tornem os mecanismos mais adequados para $\mathrm{o}$ planejamento $\mathrm{e}$ gestão das cidades, quando elas se afirmam capazes de medir o Desenvolvimento e os problemas Sócio-Ambientais locais.

Por fim, para entender o comportamento de determinados fenômenos, na estatística usase a mensuração aplicada sobre uma amostra capaz de representar e permitir concluir sobre a população total. Nesta pesquisa, usou-se da escala de Likert na perspectiva de medir o nível de satisfação sobre os indicadores a serem selecionados. A Escala de Likert é um dos modelos mais utilizados e discutidos pelos pesquisadores, desenvolvido por Rensis Likert, em 1932, quando este tentou mensurar atitudes no contexto das ciências comportamentais (JÚNIOR e COSTA, 2014, p. 3). Segundo Cunha (2007, p. 24), as escalas do tipo Likert são compostas por conjuntos de frases ou itens que, para cada uma delas, pede ao inquerido que manifeste o seu grau de concordância desde o Discordo Totalmente (1 Ponto), até ao Concordo Totalmente (5, 7 ou 11 dependente dos graus definidos pelo pesquisador).

\section{3 - CARACTERIZAÇÃO DO LOCAL DE ESTUDO: CENTRALIDADE DO KILAMBA}

A cidade do Kilamba localiza-se aos quase 40 quilômetros a Sul do Centro da Capital (Luanda - Angola), sendo referenciada através do Estádio 11 de Novembro. O projeto que deverá ser desenvolvido em três fases na sua primeira fase comporta 115 edifícios, fazendo um total de 3.800 apartamentos das tipologias T3, T3+1 e T5. Os edifícios foram distribuídos em 24 Quarteirões, de A à Z, com exceção das letras $\mathrm{O}$ e I.

Três anos após a sua abertura ao público, a Centralidade do Kilamba hoje é habitada por família de poucos membros e uma forte presença da população jovem.

Com vista a garantir a manutenção e assistência técnica dos equipamentos no bairro urbano, foi construído em 2014 um centro de formação profissional que ministra cursos virados para as necessidades específicas da Cidade do Kilamba. 
O projeto que foi desenvolvido dentro dos esforços do executivo surgiu num primeiro momento como uma "boa nova" para muitos angolanos que a muito corriam atrás do sonho da casa própria. Tão logo, a desilusão ao quotidiano deste público-alvo, aquando da ivulgação dos primeiros preços dos apartamentos que variavam entre os USD 120 mil e 225 mil.

Uma característica interessante é que na centralidade do Kilamba encontram-se a concentração de trabalhadores de um mesmo setor de atividade num mesmo quarteirão, isto em decorrência de alguns privilégios a que algumas instituições se beneficiaram. No quarteirão $A$, por exemplo, é maioritariamente habitada por funcionários da Sonangol; o quarteirão $Q$ e $R$ habitadas por funcionários das Forças Armadas Angolanas (FAA); e muitos outros cidadãos que preferiram deixar suas antigas residências na Maianga, Cazenga, Viana, Cacuaco, hoje distribuídos nos vários pontos deste bairro urbanizado.

Figura 1: Vista Geodézica da Centralidade do Kilamba (Vista de Estradas)

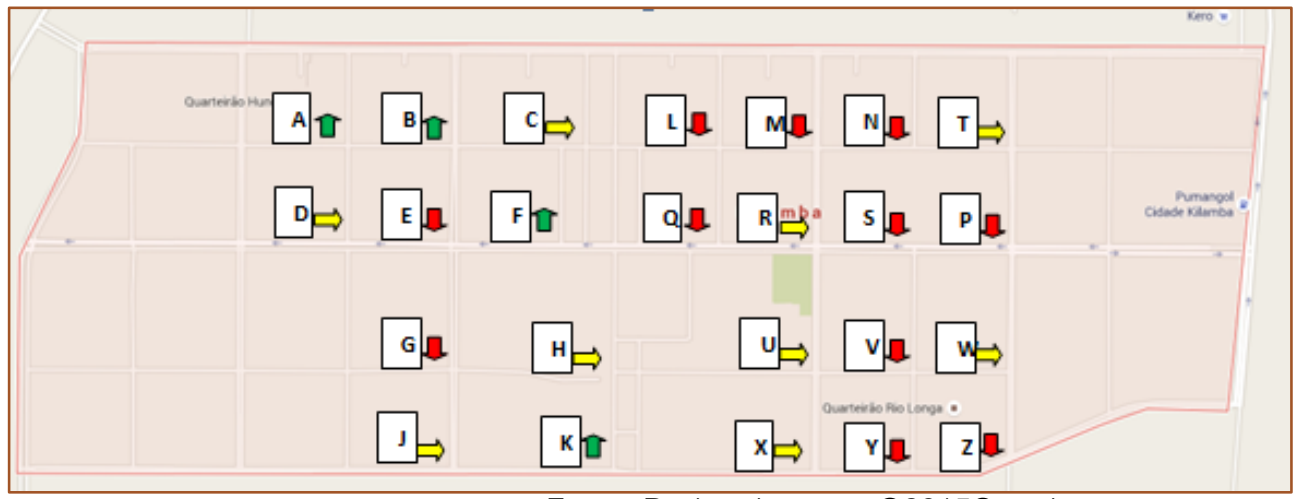

Legenda: UMenos
Crítico

$\Rightarrow$ Crítico

Muito Crítico

Fonte: Dados do mapa (02015Google

Com base na observação feita, para a descrição física da Centralidade, foi possível classificar o estado das condições dos quarteirões, tendo em conta dois aspectos fundamentais à saúde humana: Resíduos domésticos no quarteirão e o tratamento dos jardins.

Para o desenvolvimento deste tema foi realizado uma visita de campo, prestando especial atenção aos números de edifícios nos quarteirões, número de lojas que se traduzem nas disponibilidades de serviços aos moradores, a questão da educação, ou seja, que tipo de unidade de ensino existente, e para o lado ambiental o foco estava em como estão as condições de depósitos de lixo e o tratamento das zonas verdes. Da visita coletou-se a seguinte informação:

Quarteirão A - Este quarteirão possui um total de 26 Edifícios, sendo 15 da tipologia T3 (4 andares), 6 da tipologia T3 (8 andares), 3 de T3+1 e 2 Edifícios do tipo T5, bem como 14 lojas, 1 Creche e 1 Instituição de ensino superior. Quanto à questão do lixo neste quarteirão não se observou tanto lixo fora dos depósitos, comparativamente à outros, os espaços de jardins também têm sido bem aproveitado, a maioria deles, pelos moradores para o desenvolvimento de zonas verdes (Visitado à 01/09/2015 pelas 16h:10min).

Quarteirão B - Neste quarteirão há um total de 28 Edifícios, 19 do tipo T3 (4 andares), 4 T3 (8 andares), 3 T3+1 e 2 do tipo T5, tendo ainda 16 lojas e, semelhante ao anterior, 1 Creche e Instituição de ensino Superior. Também não foi detectado um excesso de lixo nas suas extremidades, estando todo em depósitos, e os espaços para jardinagem têm sido aproveitados de igual forma, pelos moradores (Visitado à 01/09/2015 pelas 16h:32min).

Quarteirão C- O quarteirão possui 35 Edifícios, constituído por 23 T3 (4 andares), 4 T3 (8 andares), 5 T3+1 e 3 T5, comportando ainda 16 lojas, 1 creche e 1 Instituto Médio. Verificou-se muito lixo no quarteirão e os depósitos já se encontravam cheios, obrigando os moradores a depositarem os resíduos no chão. Quanto aos espaços de jardins, os moradores são mais atenciosos aos jardins próximos dos seus edifícios (Visitado à 01/09/2015 pelas 16h:56min). 
Quarteirão D - Este possui 27 Edifícios, distribuídos em 15, 6, 4 e 2, nas tipologias T3 (4 andares), T3 (8 andares), T3+1 e T5 respectivamente. Encontra-se ainda a disposição do quarteirão 6 lojas, 1 Creche e 1 Escola de Ensino de Base. Nas extremidades do quarteirão há muito lixo e o tratamento dos jardins estão mais voltados para os espaços próximos dos Edifícios (Visitado à 01/09/2015 pelas $17 \mathrm{~h}: 17 \mathrm{~min})$.

Quarteirão E - Tem 19 Edifícios T3 (4 andares), 7 T3 (8 andares), 4 T3+1 e 2 Edifícios do tipo T5, totalizando 32 Edifícios à disposição do quarteirão, além de 1 Creche. Há muito lixo à volta do quarteirão, e não verifica uma preocupação com os espaços de jardinagem (Visitado à 01/09/2015 pelas 17h:35min).

Quarteirão F - Com um total de 28 Edifícios, deles 16 são do tipo T3 (4 andares), 7 são do tipo T3 (8 andares), 3 deles são T3+1 e 2 são T5, encontra-se ainda no quarteirão 1 Creche e 1 Instituto Médio. A situação do lixo não é tão grave comparado aos demais, verificou-se que há um sistema de separação dos resíduos domésticos neste quarteirão, e os jardins têm recebido devido tratamento. Neste quarteirão encontram-se o órgão administrativo da Centralidade com serviços como Emissão de Bilhete de Identidade, Conservatória de Registo Civil, e outros semelhantes (Visitado à 01/09/2015 pelas 18h:05min).

Quarteirão G - Existe um total de 32 Edifícios, sendo 20 T3 (4 andares), 4 T3 (8 andares), 4 $\mathrm{T} 3+1$ e 4 T5. Existe também 1 Creche, 1 Escola de Base e 8 lojas. Há muito lixo fora dos depósitos e neste quarteirão há também muito capim queimado, nos espaços que estariam destinados à prática de jardinagem (Visitado à 01/09/2015 pelas 18h:23min).

Quarteirão H - Tem 25 Edifícios no total, distribuídos em 19, 2, 2 e 2, nas tipologias T3 (4 andares), T3 (8 andares), T3+1 e T5, além comportar 14 lojas e 1 Creche. Existe lixo no chão em algumas zonas do quarteirão, os jardins são em algumas. Neste quarteirão encontra-se o estaleiro da CITIC-Constrution, e os mesmos ocupam 4 Edifícios da tipologia
T3 de 4 andares (Visitado aos 30/08/2015 pelas 13h:33min).

Quarteirão J - Este tem 17 Prédios do tipo T3 (4 andares), 6 do tipo T3 (8 andares), 4 Prédios T3+1 e 2 do tipo 5. Tem ainda 6 lojas, 1 Creche e 1 Escola de Base. No quarteirão foi detectado muito lixo, e os moradores têm maior preocupação com os jardins das proximidades dos seus ediicios (Visitado aos 30/08/2015 pelas $15 \mathrm{~h}: 16 \mathrm{~min})$.

Quarteirão K - Neste quarteirão existe 26 Edifícios, 15 deles são T3 (4 andares), 8 são T3 (8 andares), 2 são T3+1 e apenas 1 é da tipologia T5, mas o quarteirão tem 12 lojas, 1 Creche e 1 Escola de base. Não verificou tanto lixo no quarteirão e os seus jardins apresentavam-se saudáveis (Visitado aos 02/09/2015 pelas 10h:05min).

Quarteirão L - Com o total de 32 Edifícios distribuídos nas tipologias T3 (4 andares), T3 (8 andares), T3+1 e T5, sendo o número de Edifícios 19, 7, 4 e 2 respectivamente, o quarteirão possui além de 10 lojas 1 Creche. Observou-se muito lixo, inclusivo nos espaços para jardinagem. A Empresa Pública da Águas, E.P. (EPAL) e a Empresa de Distribuição de Electricidade, E.P. (EDEL) têm neste quarteirão seus postos instalados para servirem os seus serviços à todos moradores da Centralidade (Visitado aos 02/09/2015 pelas $10 \mathrm{~h}: 28 \mathrm{~min})$.

Quarteirão M - Possui 23 prédios, sendo 15 do modelo T3 (4 andares), 4 do modelo T3 (8 andares), 2 do tipo T3+1 e 2 do tipo T5. Comporta ainda 4 lojas, 1 Creche e 1 Instituto Médio. Há muito lixo no quarteirão e principalmente próximo da creche, nem se verifica alguma preocupação por parte dos moradores, quanto ao tratamento de Jardins (Visitado aos 02/09/2015 pelas 10h:52min).

Quarteirão N - Este possui 28 Edifícios, 16 T3 (4 andares), 7 T3 (8 andares), 3 T3+1 e 2 do modelo T5, encontrando-se ainda 8 lojas e 1 Creche. Verificou-se muito lixo no quarteirão e os depósitos cheios, obrigando os moradores a porem o lixo no chão. Não há um bom aproveitamento dos espaços de jardinagem (Visitado aos 18/08/2015 pelas 12h:50min). 
Quarteirão P - Com 23 Edifícios distribuídos em 15, 4, 2 e 2 pelas tipologias T3 (4 andares), T3 (8 andares), T3+1 e T5, o quarteirão possui também 8 lojas, 1 Creche e Escola de Base. O lixo encontra-se mal depositados, e há muito capim queimado nas terras para jardinagem (Visitado aos 18/08/2015 pelas 12h:40min).

Quarteirão Q - Neste existe 11 prédios T3 (4 andares), 5 T3 (8 andares), 2 prédios $\mathrm{T} 3+1 \mathrm{e}$ 2 T5, além de 8 loja, uma creche e uma escola de base. Neste quarteirão os depósitos estão saturados e os jardins não estão tratados (Visitado à 01/09/2015 pelas 17h:30min).

Quarteirão R - Tem 18 edifícios T3 (4 andares), 5 T3 (8 andares), 3 T3+1 e 3 edifícios T5. Existem 10 lojas à volta do quarteirão. Há pouco lixo neste, e os jardins têm sido tratados em sua maioria, importa ressaltar que neste quarteirão existe 1 único centro de saúdo que atende à todos moradores da centralidade (Visitado à 01/09/2015 pelas 18h:20min).

Quarteirão S - Num total de 24 edifícios, deles 14 T3 (4 andares), 5 T3 (8 andares), 3 T3+1 e 2 T5. O quarteirão $S$ tem 8 lojas, uma creche e uma escola de Base. Apresenta muito lixo em todo quarteirão e muito capim seco nos espaços reservados para jardim (Visitado aos 18/08/2015 pelas $13 \mathrm{~h}: 05 \mathrm{~min})$.

Quarteirão T - Este quarteirão tem 28 prédios das mesmas tipologias descriminadas anteriormente, distribuídas em 17, 6, 3 e 2 para cada uma delas. Tendo ainda 12 lojas e uma Creche. No quarteirão é visível foi encontrado os depósitos de lixo cheios e os jardins têm merecido especial atenção aqueles que estão mais próximos dos prédios (Visitado aos 18/08/2015 pelas 12h:24min).

Quarteirão U - É o segundo maior quarteirão da centralidade com 48 Edifícios no seu todo, tendo 5 da tipologia T5, 5 da tipologia $T 3+1$, 10 da tipologia T3 (8 andares) e 28 do modelo T3 (4 andares). O quarteirão possui ainda 12 lojas, uma creche e um Instituto Superior. Não se verificou uma quantidade de lixo fora do normal, e os jardins têm sido tratados neste quarteirão (Visitado aos 18/08/2015 pelas 14h:15min).

Quarteirão V - Tendo 19 prédios T3 (4 andares), 8 prédios T3 (8 andares), 4 do modelo T3+1 e 2 do tipo T5, 8 lojas, uma creche e uma Escola de Base. Não há tanto lixo, mas os jardins estão em péssimas condições (Visitado aos 16/08/2015 pelas 17h:13min).

Quarteirão W - Tem 33 edifícios, 17 deles T3 (4 andares), 10 T3 (8 andares), 3 do modelo $\mathrm{T} 3+1,3$ do tipo T5, 12 lojas, uma creche e uma Escola de Base. Não há tanto lixo no quarteirão, mas vê-se muito capim seco nos espaços de Jardinagem. Existe neste quarteirão Uma escola de condução, levando destaque por ser a única na centralidade (Visitado aos 16/08/2015 pelas 16h:55).

Quarteirão X - É o maior quarteirão do Kilamba, com 49 Edifícios distribuídos nas mesmas tipologias (T3 de 4 andares, T3 de 8 andares, T3+1 e T5), com as quantidades de $27,4,13$ e 5 respectivamente. O quarteirão apresenta também 8 lojas, uma creche e e um Instituto Médio. Os depósitos apresentam-se cheios dando a possibilidade de os moradores colocarem o lixo no chão (Visitado aos 18/08/2015 pelas 14h:36min).

Quarteirão Y - Tem 22 edifícios, sendo 12 T3 (4 andares), 5 T3 (8 andares), 3 T3+1 e 2 da tipologia T5, além de 8 lojas tem uma creche e um Instituto Médio. Há muito lixo no quarteirão e muitas crianças ao redor do mesmo, os moradores tiram o capim da terra mas deixam-no ali mesmo nos espaços de Jardinagem (Visitado aos 16/08/2015 pelas 16h:35min).

Quarteirão Z - O quarteirão tem 27 prédios, 15 T3 (4 andares), 8 T3 (8 andares), 2 T3+1 e 2 T5. Das suas infra-estruturas ainda é possível identificar 4 lojas e uma creche. Há bastante lixo acumulado no quarteirão e, não há o devido tratamento para os espaços de jardinagem (Visitado aos 16/08/2015 pelas 16h:10min).

A visita foi realizada de 16 de Agosto até 2 de Setembro do ano de 2015. Ressalta-se que existem outras infra-estruturas disponíveis em 
todos os quarteirões como Quilômetros de Estradas devidamente sinalizadas, e quadras desportivas para cada quarteirão.

\section{4 - RESULTADOS DA PESQUISA}

Na pesquisa foram aplicados um total de 110 inquéritos, nos 11 quarteirões que apresentaram uma situação crítica, com base no capítulo anterior, sendo distribuído igualitariamente 10 inquéritos para cada quarteirão, aplicados aos moradores, especificamente.

O primeiro grupo de perguntas no inquérito visava caracterizar a população em si, permitiu-nos apurar que $54 \%$ dos inqueridos eram pessoas do sexo Masculino e $46 \%$ Feminino.

Dos inqueridos 31 pessoas apresentaram idades compreendidas entre 20 à 25 anos de idade, sendo o primeiro grupo das classes, no segundo e maior grupo foram inqueridas 35 pessoas com idade entre 26 e 30 anos, e no menor grupo foram inqueridas 2 pessoas que apresentara-se ter mais de 50 anos de idade.

Durante a pesquisa bibliográfica foram selecionados os indicadores mais destacados por atuais pesquisadores na matéria, em conjunto que os indicadores apurados na fase de observação da comunidade em estudo, possibilitando a elaboração do inquérito com 38 indicadores das três dimensões base da sustentabilidade (Social, Ambiental e Económico).

Os moradores avaliaram esses indicadores através da escala de Likert tendo em conta a qualidade dos indicadores quanto a sua importância e relevância na definição de estratégia de gestão do condomínio público. Os inqueridos atribuíram valores de 1 a 5 , sendo 1 para quando discordassem totalmente da relevância do indicador, e 5 caso concordassem totalmente que o indicador deve ser considerado na tomada de decisão da gestão do condomínio.

Depois de avaliados os indicadores poderiam ter uma pontuação geral entre 0 à 1 , resultante da razão entre o somatório dos pontos realizados e os pontos máximos possíveis, os resultados foi conforme consta na tabela 2 a seguir

A dimensão social no inquérito foi avaliada no segundo grupo de questões, sendo que Os Serviços de Educação mereceu a maior pontuação por parte dos moradores, que deixaram em segundo lugar a disponibilidade de Meios de Transporte Públicos. Importa referir que o indicador com menor pontuação neste conjunto foi a Reintegração Social. (Conforme Gráfico 1 a seguir).

A sustentabilidade analisada na perspetiva social dá ênfase ao bem-estar do ser humano, as condições e os meios utilizados para melhorar a qualidade de vida, buscando o que é Socialmente Desejável com a máxima racionalização de recursos disponíveis. A construção desses indicadores e sua validação para avaliação da Qualidade de Vida não constitui uma solução aos diversos problemas sociais, mas sim um caminho para monitorar eficientemente o combate às condições de vida precárias como a fome, necessidade de habitação, desigualdades sociais e demais problemas contra ao bemestar humano. (Gráfico 2)

No terceiro grupo, os moradores avaliaram os indicadores na dimensão ambiental. Com a pretensão de chamar atenção a preocupação relativamente aos impactos das atividades humanas sobre o meio ambiente, dadas as necessidades humanas ilimitadas e recursos naturais limitados. Por esta razão, busca-se por processos produtivos capazes de reduzir a utilização dos combustíveis fósseis, diminuição da emissão de substâncias poluentes, adoção de políticas de conservação de energia e recursos, substituição de recursos não renováveis por renováveis e, de modo geral, aumentar a eficiência na utilização desses recursos naturais (BELLEN, 2002, p. 26, apud SACHS, 1997). Nesta dimensão, a Qualidade do $\mathrm{Ar}$ esteve no centro das preocupações levando a melhor, e os morados deixaram em último plano a Subsistência Alimentar, conforme o (Gráfico 3). 
Tabela 2: Pontuação obtida por indicador.

\begin{tabular}{|c|c|c|c|}
\hline Dimensão & № Ordem & INDICADORES & Pontuação \\
\hline \multirow{13}{*}{ SOCIAL } & 1 & 1- Infraestrutura & 0,85 \\
\hline & 2 & 2- Serviços de Educação & 0,89 \\
\hline & 3 & 3- Dispon. de Comércio e Serviços & 0,71 \\
\hline & 4 & 4 - Habitabilidade & 0,67 \\
\hline & 5 & 5- Mobilidade Pessoal & 0,69 \\
\hline & 6 & 6- Meios de Transporte Públicos & 0,86 \\
\hline & 7 & 7- Espaços Abertos e de Lazer & 0,66 \\
\hline & 8 & 8 - Segurança & 0,84 \\
\hline & 9 & 9- Reintegração Social & 0,61 \\
\hline & 10 & 10 - Participação na Tomada de Decisão & 0,71 \\
\hline & 11 & 11 - Religião & 0,81 \\
\hline & 12 & 12 - Acesso à informação & 0,69 \\
\hline & 13 & 13 - Iluminação Pública & 0,81 \\
\hline
\end{tabular}

\begin{tabular}{|c|c|c|c|}
\hline \multirow{19}{*}{ AMBIENTAL } & 1 & 14 - Tratamento dos Jardins & 0,72 \\
\hline & 2 & 15 - Paisagens Naturais & 0,67 \\
\hline & 3 & 16 - Subsistência Alimentar & 0,55 \\
\hline & 4 & 17 - Reutilização de Materias & 0,65 \\
\hline & 5 & 18 - Qualidade do ar & 0,90 \\
\hline & 6 & 19- Poluição dos motores a combustão & 0,74 \\
\hline & 7 & 20 - Qualidade das águas domésticas & 0,87 \\
\hline & 8 & 21 - Preservação da Camada do Ozônio & 0,73 \\
\hline & 9 & 22 - Biodiversidade & 0,62 \\
\hline & 10 & 23 - Prod. de Resíduos Sólidos Domésticos & 0,65 \\
\hline & 11 & 24 - Consumo de Energia nas Residências & 0,70 \\
\hline & 12 & 25 - Uso de Energia Renováveis & 0,73 \\
\hline & 13 & 26 - Uso racional de água & 0,83 \\
\hline & 14 & 27 - Uso racional de energia & 0,85 \\
\hline & 15 & 28 - Poluição Sonora & 0,75 \\
\hline & 16 & 29 - Colecta de Lixo & 0,87 \\
\hline & 17 & 30 - Higienização dos esgotos & 0,86 \\
\hline & 18 & 31 - Educação Ambiental & 0,69 \\
\hline & 19 & 32 - Legislação Ambiental local & 0,76 \\
\hline
\end{tabular}

\begin{tabular}{|l|l|l|r|}
\hline \hline & 1 & $33-$ Custo da Habitação & 0,58 \\
\cline { 2 - 4 } & 2 & $34-$ Modo de Pagamento & 0,51 \\
\cline { 2 - 4 } ECONÓMICO & 3 & $35-$ Renda Familiar & 0,65 \\
\cline { 2 - 4 } & 4 & $36-$ Oportunidade de emprego & 0,75 \\
\cline { 2 - 4 } & 5 & $37-$ Contribuição para Economia Local & 0,67 \\
\cline { 2 - 4 } & 6 & 38 - Taxas de Manutenção das Edificações & 0,57 \\
\hline
\end{tabular}


Gráfico 1: Indicadores da dimensão Social

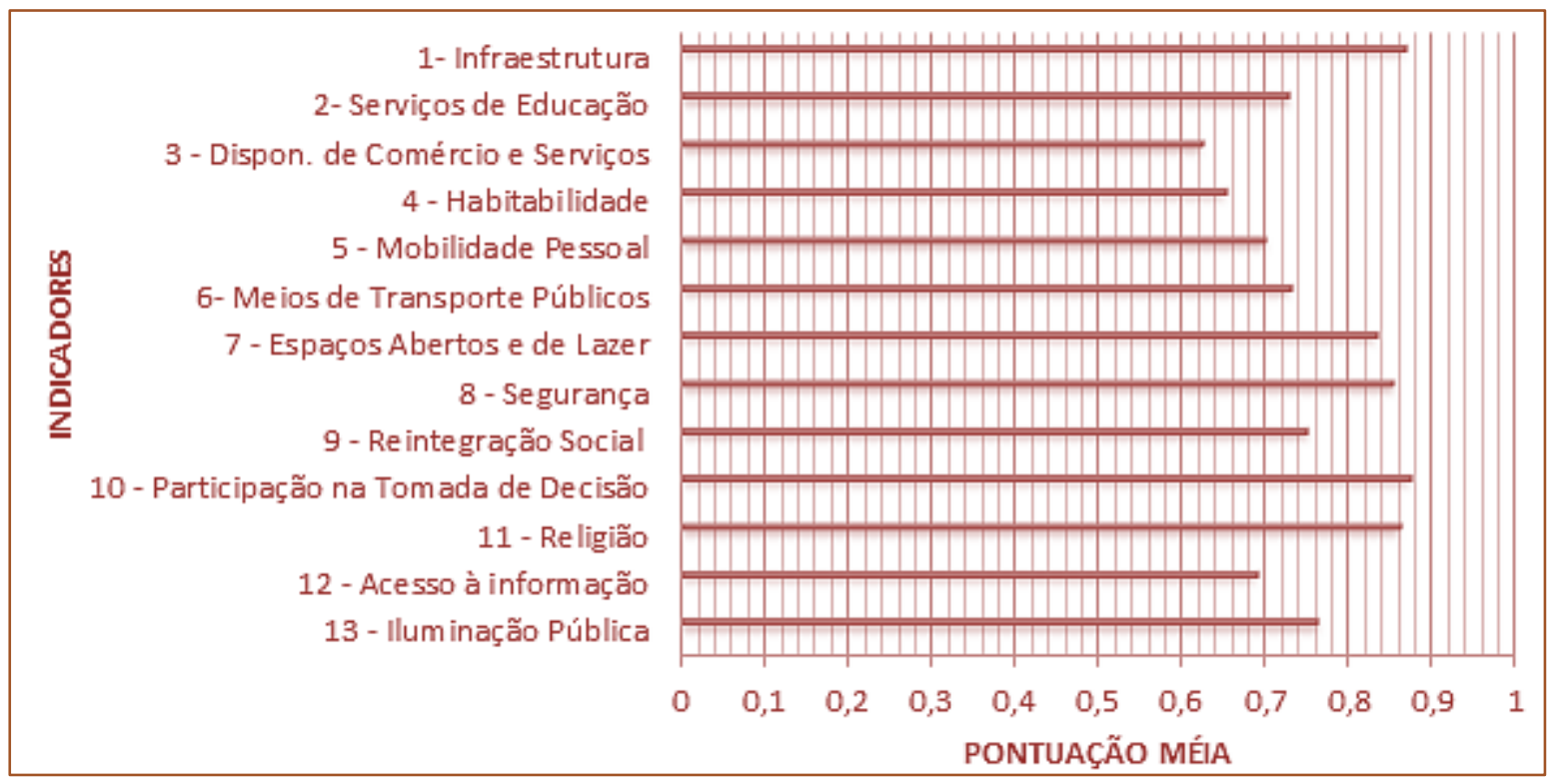

Gráfico 2: Indicadores da dimensão Ambiental.

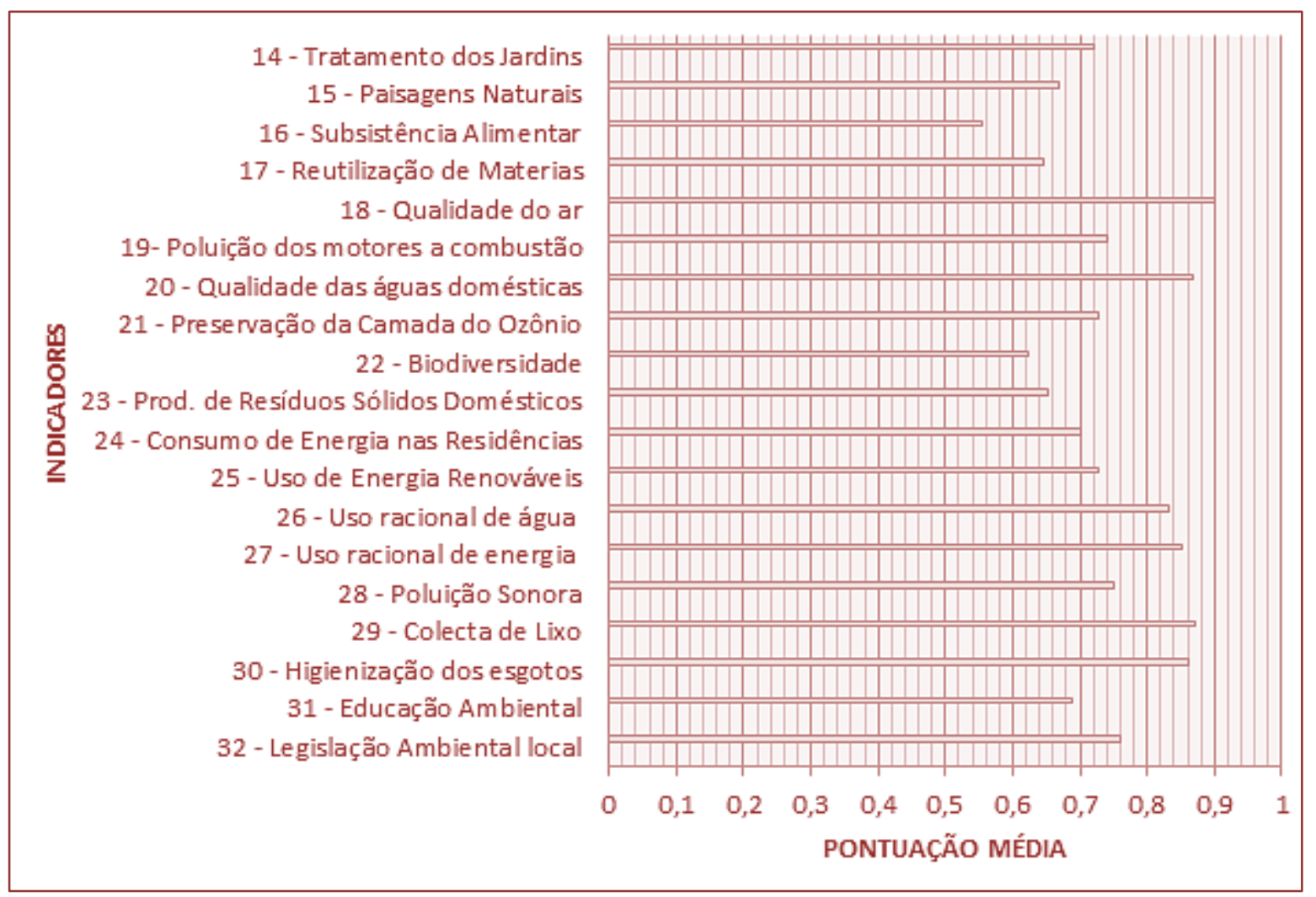

Os indicadores apresentados para esta dimensão do tripé foram, em sua maioria, definidos tendo em conta a realidade local, através da técnica de observação.
No desafio da busca por melhor qualidade de vida, há a necessidade de realçar, junto aos tomadores de decisão, a busca por modelos de desenvolvimento capazes de interligar e incorporar o crescimento económico, 
igualdade social, relações humanas mais fraternas e justas com a conservação de recursos naturais (PELICIONE, 1998, p. 21 apud DIAS, 1994).

O parâmetro ambiental apresenta-se o mais sensível dentre os três em estudo, pois, pelos seus indicadores, além de exercer forte influência sobre a saúde dos seres vivos, este está intrinsecamente ligada com a capacidade de regeneração dos recursos naturais explorados para 0 processo Gráfico 3: Indicadores da Dimensão Econômica.

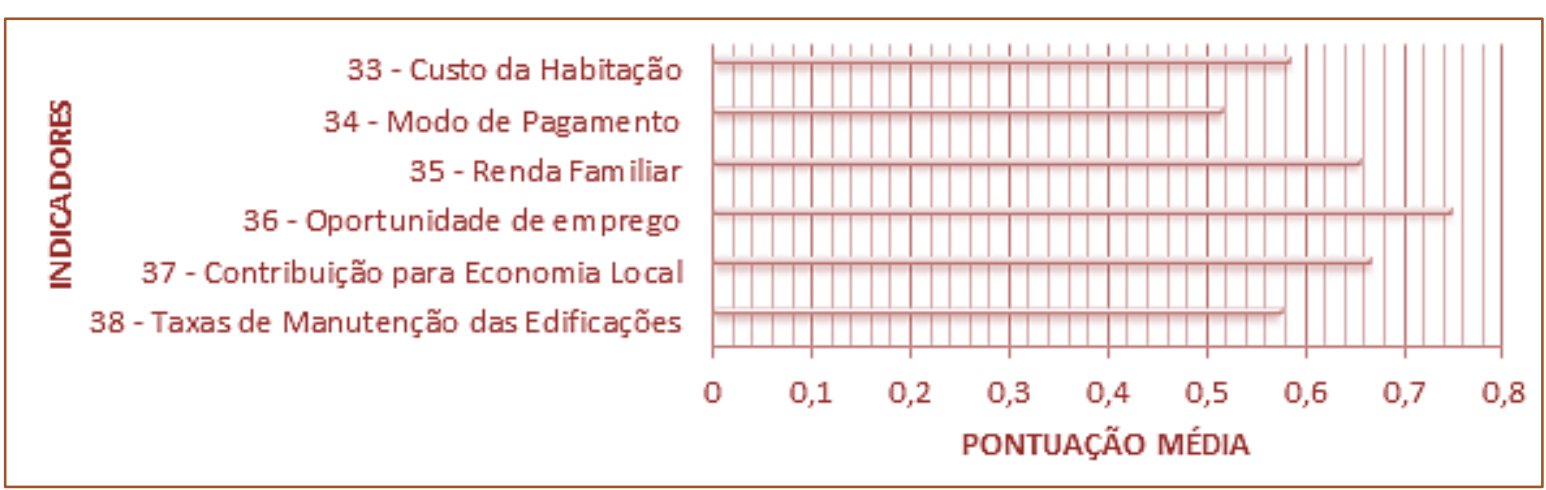

Esta dimensão busca por sistemas econômicos interligados, ou seja, demandando uma integração de setores capazes de promover o crescimento de longa duração, na mesma altura que lutam pelo equilíbrio regional.

A construção desses indicadores não é, portanto, uma garantia de sucesso aos programas de desenvolvimento comunitários, para que se caminhe com êxito rumo ao desenvolvimento sustentável é importante a definição clara do que se objetiva com tais programas e indicadores propostos. Deve-se ainda prezar pela qualidade dos indicadores, pois esta é condicionada das componentes na sua formulação e precisão da informação empregada (KEMERICH; RITTER; BORBA, 2014, p. 3726).

\section{5 - CONCLUSÕES}

Foi possível notar que a questão de sustentabilidade já é conceitualmente conhecida e discutida a sua aplicabilidade por alguns dos moradores da cidade do Kilamba, e sendo que muitos deles estão começando a experiência de ser chefe de família, a questão Social e especificamente os Serviços de Educação vivem nos centros das suas preocupações, dado que esta variável produtivo de bens e serviços para satisfação das necessidades humanas.

Tal fato, leva-nos à uma outra dimensão estudada no quarto grupo de questões no questionário aplicado. Aqui procurou medir o grau de satisfação quanto ao custo e modo de pagamento das habitações, relacionadas com a capacidade de renda de cada habitante naquela comunidade, e os resultados foram, conforme o gráfico a seguir: 
fundamental para a avaliação da Qualidade de Vida e o desenvolvimento Económico de uma nação.

Após identificação e classificação dos indicadores correspondentes as dimensões social, ambiental e econômica, bem como a influência que apresentam sobre a qualidade

\section{REFERÊNCIAS}

[1] Abreu, Saluana Rodrigues e Borges, Fabrício Quadros. Indicadores de Sustentabilidade Organizacional: estudo em um shopping center no estado do Pará. Economia e Administração, v. 12, no 5, p. 480-507, Out/Dez. 2013.

[2] Barbosa, Gisele Silva. O desafio do desenvolvimento sustentável. Visões, $4^{\mathrm{a}} \mathrm{Ed}$, Rio de Janeiro, v. 1, no 4, 11p, Jan/Jun. 2008.

[3] Baroni, Margaret. Ambiguidades e Deficiências do conceito de Desenvolvimento Sustentável. Administração de Empresas, São Paulo, v. 32, no 2, p. 14-24, Abr/Jun. 1992.

[4] Bellen, Hans Michael Van. Indicadores de Sustentabilidade: uma análise comparativa. 2002. 235p. Tese (Engenharia de Produção) Universidade Federal de Santa Catarina, Florianópolis, Nov. 2002.

[5] Bellen, Hans Michael Val. Desenvolvimento Sustentável: uma descrição das principais ferramentas de avaliação. Ambiente \& Sociedade, Campinas, v. VII, ํㅡㄴ 1, p. 67-88, Jan/Jun. 2003.

[6] Callado, Aldo Leonardo Cunha. Modelo de mensuração de sustentabilidade empresarial: uma aplicação em vinícolas localizadas na Serra Gaúcha. 2010. 215 f. Tese (Agronegócios) Universidade Federal do Rio Grande do Sul, Porto Alegre, 2010.

[7] Cavalcanti, Clóvis et al. Desenvolvimento e Natureza: estudos para uma sociedade sustentável. INPSO-Fundaj, Recife: 1994. 262 p.

[8] Claro, Priscila Borin de Oliveira e CLARO, Danny Pimentel. Sustentabilidade estratégica: existe retorno no longo prazo?. Administração, São Paulo, v. 49, no 2, p. 291-306, Abr/Mai/Jun. 2014.

[9] Conferência DAS Nações Unidas Sobre o Meio Ambiente e Desenvolvimento. Agenda 21. 1992. Brasília: Biblioteca Digital da Câmara dos Deputados, 1995.

[10] Cunha, Belinha Pereira da. e AUGUSTIN, Sérgio. Sustentabilidade Ambiental: estudos jurídicos e sociais. $2^{\mathrm{a}}$ Ed. Educs, Caxias do Sul, 2014.

[11] Cunha, Luísa Margarida Antunes Da. Modelos Rasch e Escalas de Likert e Thurstone na medição de atitudes. 2007. 78 f. Dissertação (Probabilidades e Estatística) - Universidade de Lisboa, Lisboa, 2007.

[12] Deponti, Cidonea Machado et al. Estratégia para construção de indicadores para avaliação da sustentabilidade e monitoramento de sistemas. Revista de Agroecologia e de vida e desenvolvimento econômico, sugere-se como passo seguinte ideal a construção de indicadores que mensurem a um só tempo e de forma integradora, o bemestar individual, o equilíbrio ambiental e desenvolvimento econômico, que seriam medidos por um IQV (Índice de Qualidade de Vida).

Desenvo/vimento Rural Sustentável, Porto Alegre, v. 3, no 4, p. 44-52, Out/Dez. 2002.

[13] Diegues, António Carlos S. Desenvolvimento Sustentável ou Sociedades Sustentáveis: da crítica dos modelos aos novos paradigmas. São Paulo em Perspectiva, São Paulo, v. 6, no 1, p. 22-29, Jan/Jun. 1992.

[14] Furtado, João Salvador. Indicadores de Sustentabilidade e Governança. Rev/nter, São Paulo, v. 2, no 1, p. 121-188, Fev. 2009.

[15] Guimarães, Roberto Pereira e Feichas, Susana Arcangela Quacchia. Desafios na construção de indicadores de sustentabilidade. Ambiente \& Sociedade, Campinas, v. XII, $\mathrm{n}$ ㄴ 2, $\mathrm{p}$. 307-323, Jul/Dez. 2009.

[16] Júnior, Severino Domingos da Silva e COSTA, Francisco José. Mensuração e Escalas de Verificação: uma Análise Comparativa das Escalas de Likert e Phrase Completion. 2014. PMKT Revista Brasileira de Pesquisa de Marketing, Opinião e Mídia. São Paulo, v. 15, p. 1 - 16, Mar/Jun. 2014

[17] Kemerich, Pedro Daniel da Cunha; Ritter, Luciana Gregory e Borba, Wiliam Fernando. Indicadores de Sustentabilidade Ambiental: métodos e aplicações. REMOA - Revista Monografias Ambientais. Santa Maria, v. 13, no 5, p. 3723-3736, Jun/Set. 2014.

[18] Krama, Márcia Regina. Análise dos indicadores de desenvolvimento sustentável no Brasil, usando a ferramenta Painel de Sustentabilidade. 2008. 185 f. Dissertação (Engenharia de Produção e Sistemas) - Pontíficia Universidade Católica do Paraná, Curitiba, Set. 2008.

[19] Machado, Laura. Índice de Mobilidade Sustentável para Avaliar a Qualidade de Vida Urbana: Estudo de caso Região Metropolitana de Porto Alegre - RMPA. 2010. 172 f. Dissertação (Planejamento Urbano e Regional) - Universidade Federal do Rio Grande do Sul, Porto Alegre, 2010. [20] Marcelo, Virginia Célia Costa; Vizioli, Simone Helena Tanoue; ANGILELI, Cecília Maria de Moraes e Menezes, Alessandra Aparecida da Silva. Indicadores de Sustentabilidade da Construção Habitacional nas Comunidades de Santo André (SP). Cadernos de Pós-Graduação em Arquitetura e Urbanismo. São Paulo, p. 204-237, Jan. 2009. Disponível em: http://www.mackenzie.br/dhtm/seer/index.php/cpga u

[21] Paulista, Geralda et al. Espaço emocional e indicadores de sustentabilidade. Ambiente \& 
Sociedade, Campinas, v. XI, nำ 1, p. 185-200, Jan/Jun. 2008.

[22] Pelicioni, Maria Cecília Focesi. Educação Ambiental, Qualidade de Vida e Sustentabilidade. Saúde e Sociedade, São Paulo, v. 7, no 2, p. 19-31. 1998.

[23] Programa das Nações Unidas Sobre O Meio Ambiente e Desenvolvimento. Caminhos para o Desenvolvimento Sustentável e Erradicação da Pobreza - Síntese para tomadores de decisão. 2011.

[24] Rabelo, Laudemira Silva e Lima, Patrícia Verónica P. Sales. Indicadores de Sustentabilidade: a possibilidade de mensuração do desenvolvimento sustentável. Rede, Fortaleza, v. 1, no 1, p. 55-76, Dez. 2007.

[25] Santiago, Leila Santos e DIAS, Sandra Maria Furiam. Matriz de Indicadores de Sustentabilidade para a gestão de resíduos sólidos urbanos. Eng Sanit Ambient. Campo Limpo, v. 17, no 2, p. 203-212, Abr/Jun. 2012.

[26] Tayra, Flávio e Ribeiro, Helena. Modelos de indicadores de sustentabilidade: Síntese e avaliação crítica das principais experiências. Saúde e Sociedade, São Paulo, v. 15, no 1, p. 8495, Jan/Abr. 2006.

[27] Veiga, José Eli da. Indicadores de Sustentabilidade. Revista de Economia Política, São Paulo, v. 29, no 4, p. 21-35, Fev. 2010. 


\section{Bapítulo 9}

\section{REFLEXO DAS INFORMAÇÕES CONTÁBEIS PELOS PRODUTORES DE LEITE \\ DA AGRICULTURA FAMILIAR NO MUNICÍPIO DE GUAPÓ - GO.}

\section{Matheus Silva Bastos}

\section{Lorena Nogueira de Souza}

Elizabeth Vieira Porto Pereira

Alexandre de Carvalho Paranaiba

\section{Jediel Teixeira Mendes}

Resumo: Este artigo tem por objetivo levantar as informações inerentes ao uso da temática contábil na agricultura familiar, em especial, a produtora de leite no município de Guapó - GO. Os dados colhidos através de uma pesquisa de campo, onde foram aplicadas dezessete questões e a análise dos dados evidenciou que mais da metade dos produtores utiliza de alguma forma de registro das próprias contas. Verificou-se, também, que existe uma grande resistência de tais produtores na adoção da contabilidade como ferramenta gerencial. E eles nem sempre sabem se com a atividade deles, obtiveram lucro ou prejuízo. O estudo, no caso, permitiu concluir que a resistência desses produtores no agronegócio ainda persistirá por um longo tempo se conscientizarem da necessidade e da importância da contabilidade na atividade rural.

Palavras-chave: Agronegócio, Agricultura Familiar, Contabilidade, Sustentabiidade, Viabilidade econômico financeira. 


\section{INTRODUÇÃO}

A agricultura familiar ocupa hoje grande destaque na economia brasileira, e, principalmente no estado de Goiás, com $80 \%$ das propriedades rurais, assim identificadas pelo IBGE, censo de 2006 e representa a maioria dos produtores rurais no Brasil, reunindo aspectos importantes, como, a família, o trabalho rurícola, a produção e as tradições culturais. Porquanto, a agricultura familiar é a em que, ao mesmo tempo a proprietária tem a posse da terra e também assume, nela, os trabalhos de produção agrícola.

De cada três propriedades rurais classificadas como de agricultura familiar, uma é produtora de alguma quantidade de leite no Brasil, o que demonstra a importância delas para tal segmento pois, a propriedade de agricultura familiar contribui para o abastecimento do mercado interno e até o externo.

A região Centro-Oeste é uma das que mais desenvolve a pecuária leiteira no âmbito da agricultura familiar. O município de Guapó GO, conforme o censo do IBGE (2006) conta com 466 propriedades rurais e que, em sua grande maioria, fazem parte da agricultura familiar, cuja atividade principal é a produção de leite.

Considerando-se o município de Guapó GO, verificou-se, pelo nível sócio-cultural dos produtores que há fragilidades e até mesmo resistência quanto ao uso de informações contábeis, o que demonstra que tais produtores ainda se encontram em uma zona desfavorável da informação contábil para uma tomada de decisão na gerência da propriedade, abstendo-se da característica e forma tradicional do manejo da propriedade, para, então, considerá-la como um local de atividade de uso próprio e de geração de receita.

Em tal sentido, ao observar um grupo social identificado, como agricultores familiares, é possível indagar sobre o uso das técnicas contábeis por eles utilizadas.

A contabilidade, por ser uma ciência social aplicada, utiliza de uma metodologia para "captar, registrar, acumular, resumir e interpretar os fenômenos que afetam as situações patrimoniais, financeiras e econômicas de qualquer entidade" (FEA/USP, 2010, p. 01).
Assim, a contabilidade rural tem como objetivo orientar o produtor rural no acompanhamento dos custos, das despesas e da rentabilidade, e, dessa maneira, o produtor pode minimizar ou eliminar desperdícios e melhorar a própria eficiência produtiva. As informações contábeis, também, auxiliam na redução dos custos e das despesas, para que, ao final do exercício, os lucros sejam apurados com confiança, ensejando que, num futuro próximo, se tomem as melhores decisões de negócio.

Os produtores de leite da agricultura familiar, na gestão do próprio negócio, mesmo sem ter uma contabilidade formalizada, fazem o uso de informações contábeis peculiares no mister que desenvolvem. De modo que, o controle do rebanho, da produção e da venda de leite ocorre por apontamentos em cadernetas, ou em simples cadernos de anotações. Assim, em sua grande maioria, os produtores acabam utilizando a informação contábil sem técnica de escrituração e sem uma estruturação ou nomenclaturas técnicas.

Pelo exposto até aqui, o presente artigo busca responder esta questão: Quais as fragilidades inerentes às informações contábeis utilizadas para o desempenho financeiro dos agricultores familiares produtores de leite no município de Guapó - GO?

Nesse contexto, o objetivo geral da pesquisa é o de levantar as informações inerentes ao uso da temática contábil na agricultura familiar no referido município, a fim de viabilizar a atividade leiteira. E, pelos objetivos específicos, apresentar e conceituar a agricultura familiar e a atividade leiteira, bem como; identificar a informação contábil caracterizada para as atividades zootécnicas, identificando os pontos frágeis no uso das informações contábeis pelos referidos produtores, verificando a inter-relação produtor-contabilidade e, ainda, evidenciar o uso ou não da contabilidade nas tomadas de decisões na propriedade rural.

Esse artigo se justifica pela necessidade de descobrir as fragilidades das informações contábeis, buscando o conhecimento de quais ferramentas contábeis são utilizadas por tais produtores, de modo a serem identificadas, para criar mecanismos e auxiliar no desempenho financeiro da dita produção. 


\section{REFERENCIAL TEÓRICO}

Os registros de informações existentes no século XXI podem ser utilizados como veículos de identificação e meios de captação de recursos das manifestações oriundas da esfera dos produtores de agricultura familiar e sua identidade, quando vista, sob a ótica do conhecimento contábil, são empíricos.

\section{CONTABILIDADE}

Nesse sentido, ao observar um grupo social identificado, como de agricultores familiares, é possível inquirir sobre o uso das técnicas contábeis utilizadas. A contabilidade, por ser uma ciência social aplicada, utiliza de uma metodologia para "captar, registrar, acumular, resumir e interpretar os fenômenos que afetam as situações patrimoniais, financeiras e econômicas de qualquer entidade" (FEA/USP, 2010, p. 01).

Além de fornecer as demonstrações contábeis básicas (balanço patrimonial e a demonstração do resultado do exercício). A contabilidade dispõe de um fluxo contínuo de informações sobre os mais variados aspectos da gestão financeira e econômica de uma entidade, proporcionando uma tomada de decisão mais segura, indicando a posição atual e o grau de acertos ou desacertos das decisões anteriores (FEA/USP, 2010).

\section{CONTABILIDADE RURAL}

Marion (2002, p. 25), por sua vez, afirma, em seu livro, "Contabilidade Rural", quanto à utilidade da Contabilidade, tendo como ponto de partida, o raciocínio geral que é responsável por identificações preliminares, onde é introduzido sua temática e posteriores, repassada e adequado a um grupo especifico de acordo com a necessidade e identidade dele, "quando aplicada a um ramo específico, normalmente é denominada de acordo com a atividade daquele ramo". Dessa forma, a Contabilidade Rural é uma contabilidade geral aplicada às empresas rurais que exploram a terra por meio do cultivo do solo, da criação de animais e da transformação de determinados produtos agrícolas.

A criação de animais que vivem em coletividade (rebanho) é a atividade da pecuária. A pecuária sempre esteve entre as principais atividades do setor rural. Todavia, é necessário desmistificar o termo pecuária, pois, ele não se aplica apenas à criação de gado. Nesse propósito, Crepaldi (1998, p. 197) afirma em sua obra "Contabilidade Rural" que o termo pecuária, também, se aplica a outros criatórios:

Quando se refere às atividades da pecuária, logo se faz associação com gado vacum (bois e vacas); entretanto, elas se referem à criação de gado em geral, ou seja, animais que vivem em coletividade (rebanho) quer seja bois e vacas, búfalos, carneiros, ovelhas e, entre outros, as aves que incluem frango, pato marreco, faisão, peru etc.

Marion (2002, p. 106) afirma que existem três tipos de atividades na pecuária bovina, a saber:

1. Cria: a atividade básica é a produção de bezerros que só serão vendidos após o desmame. Normalmente, a matriz (de boa fertilidade) produz um bezerro por ano.

2. Recria: a atividade básica é, a partir do bezerro adquirido, a produção e a venda do novilho magro para a engorda.

3. Engorda: a atividade básica é, a partir do novilho magro adquirido, a produção e a venda do novilho gordo.

A pecuária pode, também, se dedicar à produção de leite, de forma que, uma variante da função "cria", só com foco na produção leiteira, são mais valorizadas as "crias" fêmeas, haja vista a atividade fim, produção leiteira.

As atividades agrícolas subsidiam, ou podem ser os insumos que fomentam a pecuária no que tange à alimentação ou trato do próprio animal. Este elemento forma o custo final do produto que pode ser identificado como "culturas temporárias" e "culturas permanentes". Destarte, a classificação contábil está relacionada ao tipo e à atividade operacional da atividade agrícola.

Segundo o Pronunciamento Técnico CPC 29 (2009, p. 04) em suas definições relacionadas com a área agrícola determina que colheita "é a extração do produto de ativo biológico ou a cessação da vida desse ativo biológico". A partir deste conceito, Marion (2002) separa as culturas, como temporárias e permanentes, sendo as culturas temporárias as quais proporcionam apenas uma colheita, necessitando de um replantio após a colheita, consideradas na contabilidade como estoque. Já as culturas permanentes são denominadas 
assim, por estarem vinculadas ao solo e por terem seu tempo de vida útil mais longo, além de proporcionarem mais de uma colheita, deve-se escriturá-las, portanto, como imobilizado.

\section{AGRICULTURA FAMILIAR}

A identificação de um grupo social de agricultura familiar pode partir de vários conceitos que se reformulam no tempo. Por isso, a agricultura familiar, como objeto de estudo, tomou uma identidade no Brasil, a partir da Lei 11.326/2006, que, assim, a definiu, levando se em conta a identificação da área laborada e os componentes da propriedade. Mas, ao observar a estrutura e formação gestora, pode-se fazer uma indagação a cerca das propriedades consideradas, ou não, de agricultura familiar. Haja vista que muitas propriedades, não obstante a área do módulo rural, são geridas pela própria família possuidora.

A agricultura familiar contribui muitíssimo com a economia brasileira, ainda que um grupo de identidade heterogênica, participando efetiva e constantemente do desenvolvimento econômico e social do País. De tal forma, a agricultura familiar, a cada momento torna-se alvo de fortes argumentações, tanto na esfera social como na econômica.

Senão, veja-se a lição abaixo:

A agricultura familiar emerge como um sistema social complexo cuja diversidade Ihe confere variadas funções, que the permitem fazer múltiplas contribuições à sociedade brasileira. Por sua importância incontestável, a agricultura familiar esta incluída na definição das políticas públicas de vários países, embora não haja consenso internacional quanto ao significado do conceito de agricultura familiar. No caso brasileiro, com a política de inclusão social do governo, a agricultura familiar é considerada tanto como instrumento de desenvolvimento socioeconômico (como fonte de emprego e veículo de segurança alimentar, de qualidade do produto e de proteção ao meio ambiente) quanto como instrumento político de fortalecimento da democracia. (CRESTANA e SOUSA, 2006, p. 12).

O estudo de Crestana e Sousa, 2006, p. 13 apud IBGE, 2006 apontou que a agricultura familiar respondeu com 3,6\% do PIB brasileiro, em 2003. Somando-se aos 5,7\% da agricultura patronal, totalizando 9,3\% da participação da agropecuária no PIB nacional daquele ano.

O perfil da agricultura familiar é voltado para a distribuição e sistema produtivo. E, com isso, é evidente ressaltar que as vantagens e os incentivos para essa classe de produtores familiares são de suma importância para propiciar o desenvolvimento rural e o aumento da procura por semelhantes atividades.

\section{ASPECTOS LEGAIS DA AGRICULTURA FAMILIAR}

Na agricultura familiar, o método de produção é composto de forma simultânea entre gestão e trabalho, onde agricultores familiares conduzem o processo produtivo e utilizando de diferentes ideias, reforçando, assim, a diversificação no trabalho familiar.

O reconhecimento legal da Agricultura Familiar se deu com a Lei no 11.326, 24 de julho de 2006 - Lei da Agricultura Familiar que em seu art. $3^{\circ}$, considera agricultor familiar e empreendedor familiar rural aquele que pratica atividades rurais, atendendo, simultaneamente, aos seguintes requisitos:

- Não detenha, a qualquer título, área maior do que 4 (quatro) módulos fiscais;

- Utilize predominantemente mão de obra da própria família nas atividades econômicas do seu estabelecimento ou empreendimento;

- Tenha renda familiar predominantemente originada de atividades econômicas vinculadas ao próprio estabelecimento ou empreendimento;

- Dirija seu estabelecimento ou empreendimento com sua família.

E, para a valorização, modernização e, consequentemente, a profissionalização do sistema de produção, criou-se um programa para ampliar e fortalecer o ramo do agronegócio, gerando aumento de rendas e agregando valores aos produtores e às propriedades da agricultura familiar.

Mesmo com as dificuldades no início de implantação da legalidade, o Pronaf vem mostrando ser um grande estimulador à inclusão produtiva da agricultura familiar.

Guanziroli e Cardim (2000) afirmam que os agricultores familiares já demonstraram mais 
eficientes no uso do crédito rural que os agricultores patronais, pois, produzem mais com menores recursos.

As linhas de crédito dos bancos, para financiamento do agronegócio se tornou comum no Brasil, sendo que os grandes produtores dão, em garantia, as propriedades, as benfeitorias e maquinarias, enquanto, os produtores familiares têm, na própria produção, uma certeza de lucro para quitar as dívidas com o banco e, ainda, ver na sobra o fruto do esforço pessoal.

\section{PRODUÇÃO LEITEIRA}

No Brasil, a atividade leiteira é praticamente predominante em todas as regiões. $\mathrm{E}$, em cerca de 1,8 milhões propriedades rurais, $80 \%$ são de unidades familiares de produção. O potencial de empregabilidade da mão de obra da família é bastante considerável, levando em conta que, para cada $\cup \$ 2,500.00$ obtidos com a venda de leite e derivados, um posto de trabalho, permanente ou fixo, é gerado. (ALTAFIN et al, 2011).

A pecuária leiteira é uma das principais atividades desenvolvidas entre os agricultores familiares, e se faz presente em cerca de 36\% das propriedades classificadas como de economia familiar, contribuindo com $52 \%$ do valor bruto da produção agrícola.

Nas regiões Sul e Centro-Oeste, há um maior número de propriedades de agricultura familiar com a pecuária leitura. (GUANZIROLI E CARDIM, 2000).

De acordo com Nascimento et al (2009), os gestores da pecuária leiteira utilizam poucos recursos administrativos e não tem consciência da importância das ferramentas contábeis e como elas auxiliam no processo de decisão gestora. O planejamento estratégico no meio rural revela um campo de estudo incipiente, que apresenta importantes contribuições da prática administrativa, também, no universo rural.

No Brasil a pecuária leiteira pode ser classificada em dois tipos básicos, produtores especializados e produtores não especializados. Os produtores especializados são os produtores que apresentam como atividade principal a produção de leite, conseguida a partir de rebanho leiteiro especializado que apresenta tecnologia, diferenciação de produto. Os produtores não especializados são produtores que trabalham de maneira incipiente, com baixa tecnologia. E grande parte destes produtores considera o leite como "subproduto do bezerro de corte", a atividade leiteira apresenta-se como meio de subsistência e não empresarial. No aspecto financeiro estes produtores trabalham com baixos retornos agregados com pouco nível de investimentos na produção. (NASCIMENTO, et al, 2009, apud JANK \& GALAN, 1998).

A produção leiteira no Brasil, no período de 1996 a 2004, apresentou crescimento de 2,96\% ao ano, mesmo com a diminuição do número de vacas de ordenha. E, tal ocorrência se deu com o aumento da produtividade média por cabeça de vaca. Quando considerada a receita dos produtores, observou ganhos em volumes, mas o preço médio recebido não evoluiu na mesma proporção (NASCIMENTO, et al, 2009, apud PONCHIO, et al, 2005).

Estima-se que o setor envolva cerca de 3,6 milhões de pessoas, produzindo aproximadamente 25 bilhões de litros de leite por ano, provenientes de um dos maiores rebanhos do mundo. No período de 19952008, o produto lácteo nacional registrou um aumento $74,7 \%$ no volume de leite produzido (mil litros) e de $407,5 \%$ no valor da produção (IBGE, 2006).

\section{METODOLOGIA}

A pesquisa inerente à produção leiteira pela agricultura familiar do município de Guapó, GO, foi feita através da pesquisa de campo, na qual o grupo foi identificado e analisado em relação as identificações do uso da informação contábil, assim, definido por Severino (2007, p. 123):

$\mathrm{Na}$ pesquisa de campo, o objeto é abordado em seu meio ambiente próprio. A coleta de dados é feita nas condições naturais em que os fenômenos ocorrem, sendo assim diretamente observados, sem intervenção e manuseio por parte do pesquisador.

Abrange desde os levantamentos, que são mais descritivos, até estudos mais analíticos. 
Os procedimentos para a condução do estudo foi bibliográfico e o levantamento de dados, através de questionários.

A pesquisa bibliográfica foi um passo inicial para o estudo, buscando e utilizando livros e artigos para sustentar dados importantes relacionados à pesquisa.

O levantamento de dados sobre a fragilidade das informações contábeis foi obtido por meio de questionários, aplicados aos produtores de leite da agricultura familiar do município de Guapó - GO, angariando o conhecimento de quais ferramentas contábeis eles utilizam, de modo a identificar-Ihes as fragilidades.

Segundo Gil (2002, p.128), questionário é, "como a técnica de investigação composta por um número mais ou menos elevado de questões apresentadas por escrito às pessoas, tendo por objetivo o conhecimento de opiniões, expectativas, situações vivenciadas". Esse autor mostra que a maior vantagem desse tipo de instrumento é que ele consegue atingir um numero maior de pessoas, quando se utiliza de entrevistas, porque, além de obter respostas pontuais a perguntas específicas, pois, o ideal é que tais questionários contenham questões objetivas de múltipla escolha, onde o entrevistado marca apenas uma resposta como a correta para ele.

Lakatos e Marconi (2005) ressaltam que é preciso tomar alguns cuidados ao elaborar 0 questionário como: conhecimento do assunto, seleção de questões que sejam pertinentes para a pesquisa, limitado em extensão e finalidade, codificado a fim de facilitar a tabulação, indicação da entidade organizadora do questionário acompanhada por instrução e boa apresentação estética.

O questionário foi elaborado com questões fechadas, de forma que facilite a resposta do produtor rural pesquisado. Com relação à abordagem do problema, a pesquisa é qualitativa e quantitativa. A análise qualitativa proporcionou a análise dos dados, enquanto a pesquisa quantitativa proporcionou que os dados coletados fossem quantificados, organizados e demonstrados em tabelas.

A população da pesquisa são os produtores de leite da agricultura familiar localizados na zona rural do município de Guapó - GO, a 50 $\mathrm{km}$ da capital do Estado.

Amostra selecionada foi de 20 produtores.

\section{RESULTADOS E DISCUSSÕES}

Para analisar como a Contabilidade é percebida e praticada pelos agricultores familiares produtores de leite do município de Guapó - GO, foram entrevistados 20 produtores do universo de 466 propriedades existentes no município (IBGE, 2006).

A pesquisa foi realizada por meio da aplicação de um questionário que segue em anexo. A partir de sua análise buscamos evidenciar quanto ao conhecimento, uso, da informação contábil na agricultura familiar produtora de leite.

Os entrevistados correspondem a $65 \%$ são homens e 35\% são mulheres. $30 \%$ dos entrevistados possui idade acima dos 60 anos e $70 \%$ entre 36 a 59 anos. O grau de escolaridade revela $65 \%$ possuem apenas o primeiro grau. Ressalta-se que o estudo não determina se 0 agricultor sabe fazer o controle. Há casos presentes na pesquisa de que os agricultores com o ensino primário de $1^{\text {a }}$ à $4^{\mathrm{a}}$ Série Incompleto realiza o controle de suas produções e de agricultores com Ensino Médio Completo não fazem esse controle.

Tabela 1 - Tamanho das Propriedades

\begin{tabular}{|c|c|c|}
\hline Tamanho das Propriedades em Hectares & Quantidade & $(\%)$ \\
\hline Menos de 10 hectares & 4 & 20 \\
\hline 11 a 20 hectares & 7 & 35 \\
\hline 21 a 50 hectares & 7 & 35 \\
\hline 51 a 84 hectares & 1 & 5 \\
\hline 85 a 99 hectares & 0 & - \\
\hline Mais de 100 hectares & 1 & 5 \\
\hline Total & 20 & 100 \\
\hline
\end{tabular}

Fonte: os autores, 2015. 
Guanziroli e Cardim (2000), ao definirem o conceito de agricultura familiar determinam que para ser considerada como tal a propriedade deve estar dentro de um limite estabelecido, de até 4 módulos fiscais, para cada região do país, que no caso da região centrooeste em hectares, a média é de 84 ha. Mais precisamente no município de Guapó GO um módulo fiscal corresponde a 22 ha (LANDAU, et al, 2012).

Conforme a tabela 1 verificou-se que $20 \%$ dos agricultores possuem uma área de até 10 hectares. Um número significativo de agricultores, 35\% possui área entre 11 a 20 e hectares e mais 35\% possui área de 21 a 50 hectares. $5 \%$ representam os agricultores que possui área entre 51 a 84 hectares e 5\% mais de 100 hectares.

Quanto à identificação de um grupo para efeito legal, variações são consideradas quanto à cultura e a economia. Neste sentido ao ser observado na Lei 11.326/2006, onde se trata a questão de políticas públicas para atender as propriedades rurais de pequeno porte surge à identificação de Agricultura Familiar. No contexto desta lei criada como enredo para financiamento ao agricultor criaram-se condições de identificação no qual limita a participação do produtor pelos itens condicionados. Em seu art. 3ํㅡ da Lei 11.326/2006, considera agricultor familiar e empreendedor familiar rural aquele que pratica atividades rurais, atendendo, simultaneamente, aos quatros requisitos, citados anteriormente.

Verifica-se, conforme tabela 1, que apenas um agricultor possui, ou seja, 5\%, mais de 100 hectares o que pela legislação não se enquadra na agricultura familiar. Porém visto e questionado quanto ao grupo social, o agricultor tendo algumas características que não sejam linear a Lei 11.326/2006, fica descredenciado como agricultura familiar. Mas a de convir que já existam discussões quanto à sua classificação e identificação. Se o conceito de agricultura familiar está na arte de cultivar a terra, agricultura familiar é a família envolvida nesse processo de cultivo da terra. Assim mencionado por Lima et al (2006, p. 59) esclarece que "Agricultura familiar é hoje o que predomina no Brasil quando se refere aos que vivem no campo, que trabalham com a família, em pequenas áreas de terra ou não, produzindo prioritariamente para a reprodução da força de trabalho familiar".

Portanto, neste estudo mesmo que algum agricultor tenha sua propriedade superior aos 4 módulos ficais este será considerado como agricultura família, pois possui características que o identifique e o assegure no grupo, conforme foi citado acima por Lima et al.

Tabela 2 - Atividades realizadas na propriedade

\begin{tabular}{|c|c|c|}
\hline Atividades & Quantidade & $\%$ \\
\hline Produção de Leite & 20 & 57 \\
\hline Avicultura & 5 & 14 \\
\hline Suinocultura & 4 & 11 \\
\hline Piscicultura & 3 & 9 \\
\hline Vendas Internas (feiras) & 2 & 6 \\
\hline Arrendamento & 1 & 3 \\
\hline Total & 35 & 100 \\
\hline Fonte: os autores, 2015
\end{tabular}

$\mathrm{Na}$ tabela 2, evidenciou-se que, como objeto da pesquisa a produção de leite, todos os produtores pesquisados produzem leite e também optam por outras atividades. É muito comum na agricultura familiar o produtor trabalhar em sua propriedade com mais de uma atividade. As diversas atividades produzidas por esses agricultores é uma característica da pluriatividade. Conforme Schneider (2003, p. 112), define "Pluriatividade como um fenômeno através do qual membros das famílias que habitam no meio rural optam pelo exercício de diferentes atividades", que nada mais é, que a diversificação das atividades rentáveis do negócio. É através dela que os membros das famílias de agricultores, que residem no meio rural, optam pelo exercício de diferentes atividades, ou ainda, optam pelo exercício de atividades não agrícolas.

Observa-se na tabela 2 que em segundo lugar vem avicultura com 14\%, abaixo a 
suinocultura $11 \%$ e a piscicultura com $9 \%$, essas atividades é muito comum nas propriedades da região. Entre os pesquisados, $6 \%$ responderam que realizam feiras, onde vendem a produção da propriedade, já os outros agricultores vendem suas produções a leiteiros e queijeiros, profissionais que comercializam esses produtos no município. Apenas 1, ou seja, 3\% dos pesquisados, realiza o arrendamento de suas terras.

Tabela 3- Programa Nacional de Fortalecimento da Agricultura Familiar

\begin{tabular}{|c|c|c|}
\hline Questões & Quantidade & $(\%)$ \\
\hline Conhece & 10 & 50 \\
\hline Não conhece & 2 & 10 \\
\hline Já utilizou & 4 & 20 \\
\hline Atualmente é um beneficiário do programa & 4 & 20 \\
\hline Total & 20 & 100 \\
\hline
\end{tabular}

Fonte: os autores, 2015

Conforme tabela 3, apurou-se que 50\% dos entrevistados conhecem o Programa

Nacional de Fortalecimento da Agricultura Familiar (Pronaf), sendo uma medida do Governo Federal adotada em âmbito nacional para que atendesse as especificidades desse segmento.
$20 \%$ responderam que já utilizou e outros $20 \%$ atualmente é um beneficiário do programa. Apenas 10\% não o conhecem.

Desses $20 \%$ que já utilizou e os $20 \%$ que são beneficiários atualmente, perguntamos em que foi destinado o recurso financeiro. Conforme tabela 4, abaixo:

Tabela 4 - Em que foi destinado o recurso financeiro (PRONAF)?

\begin{tabular}{|c|c|c|}
\hline Respostas & Quantidade & $(\%)$ \\
\hline Vacas leiteiras & 7 & 88 \\
\hline Ordenha & 0 & - \\
\hline Piscicultura & 1 & 12 \\
\hline Maquinários & 0 & - \\
\hline Irrigação & 0 & - \\
\hline Outros & 0 & - \\
\hline Total & 8 & 100 \\
\hline \multicolumn{2}{|c|}{ Fonte: os autores, 2015 }
\end{tabular}

Observou-se que, $88 \%$ dos entrevistados responderam que o recurso financeiro foi gasto na compra de vacas leiteiras, que estão hoje em lactação e $12 \%$ em piscicultura.

Tabela 5 - Quanto à profissão contábil, considera necessária para atividade rural?

\begin{tabular}{|c|c|c|}
\hline Respostas & Quantidade & $(\%)$ \\
\hline Sim & 5 & 25 \\
\hline Não & 5 & 25 \\
\hline Às vezes & 10 & 50 \\
\hline Total & 20 & 100 \\
\hline \multicolumn{2}{|c|}{ Fonte: os autores, 2015} \\
\hline
\end{tabular}


Conforme a tabela 5, com esta pergunta evidenciou o quanto os agricultores familiares conhece ou não da profissão contábil. Evidenciou-se que $50 \%$ dos agricultores pesquisados responderam "às vezes" por considerar a profissão necessária somente para o cumprimento de suas obrigações fiscais, principalmente no momento do
Imposto Territorial Rural, declaração anual realizada nos meses de agosto a setembro, como forma de cumprir com as exigências do governo. E 25\% responderam que "sim", que a consideram importante, mas não manifestaram maiores apreços e $25 \%$ que "não" consideram necessária para a atividade desempenhada.

Tabela 6 - Utiliza a contabilidade como forma de controlar e organizar a propriedade?

\begin{tabular}{|c|c|c|}
\hline Respostas & Quantidade & $(\%)$ \\
\hline Sim & 0 & - \\
\hline Não & 20 & 100 \\
\hline Às vezes & 0 & - \\
\hline Total & 20 & 100 \\
\hline
\end{tabular}

Fonte: os autores, 2015

Constatou-se que ao serem questionados quanto à utilização da ferramenta contábil como forma de controle e organização na propriedade os agricultores foram unanimes em responder que "não" utilizam, conforme tabela. Percebe-se, no dialogo informal, nas respostas uma grande barreira quanto ao entendimento da palavra "contabilidade".
Não obstante e conforme tabela 7 , questionou-se sobre o controle de suas contas, se utiliza de alguma forma de registros. Observa-se que uma incoerência surgiu.

Tabela 7 - Quanto ao controle de suas contas, você utiliza alguma forma de registro?

\begin{tabular}{|c|c|c|}
\hline \multicolumn{1}{|c|}{ Respostas } & Quantidade & $(\%)$ \\
\hline Anotações em cadernos & 11 & 55 \\
\hline Anotações em livros diários & 0 & - \\
\hline Anotações em livros caixas & 0 & - \\
\hline Anotações em livros conta corrente & 0 & - \\
\hline Grava tudo na memória & 8 & 40 \\
\hline Utiliza de programa de gestão financeira & 0 & - \\
\hline Anoto, mas sem muita frequência & 1 & 5 \\
\hline Total & 20 & 100 \\
\hline
\end{tabular}

Fonte: os autores, 2015

A contabilidade tem suas normas baseadas na orientação, controle e registro dos atos e fatos ocorridos e praticados de qualquer natureza, ou seja, jurídica ou física.

Os agricultores percebem a contabilidade apenas de forma distante, ou seja, para eles os simples registros que são feitos em seus cadernos de anotações, mesmo que, seja sem muita frequência não são registros contábeis. Para Lima et al (2001), há um controle por parte dos agricultores familiares, porém realizado de maneira informal.

Conforme tabela $7,55 \%$ responderam que o controle de suas contas é registrado por meio de anotações em cadernos, utilizando um pequeno caderno espiral. $40 \%$ dos entrevistados responderam que grava tudo na memória. Conforme Lima et al (2001, p. 43) dizem: "Praticamente ninguém possui registro contábil das suas atividades. Todas as informações estão na memória do agricultor e 
dos demais membros da família". 5\% responderam que realizam anotações, mas sem muita frequência. $O$ qual entende-se ser insuficiente para determinar o resultado, seja ele positivo ou negativo.

Tabela 8- Ao fazer as anotações, elas ocorrem somente quando?

\begin{tabular}{|c|c|c|}
\hline Respostas & Quantidade & (\%) \\
\hline Efetua suas compras & 0 & 15 \\
\hline Efetua suas vendas & 3 & - \\
\hline Realiza um investimento & 0 & - \\
\hline Adquire um financiamento & 0 & - \\
\hline Todas as vezes que compra e vende & 0 & 45 \\
\hline Controle de recebimentos e pagamentos & 0 & - \\
\hline Todas as vezes que compra, vende e faz & 9 & 40 \\
\hline pagamentos & 0 & 100 \\
\hline Anota exclusivamente os documentos para declarar \\
o Imposto de renda, ITR
\end{tabular}

Fonte: os autores, 2015

$\mathrm{Na}$ tabela 8, quando questionado ao agricultor, se ao fazer as anotações elas ocorrem somente quando, 45\% responderam que todas as vezes que compra, vende e/ou faz pagamentos é realizado o registrado. Outros $15 \%$ responderam que essas anotações ocorrem somente quando efetua suas vendas. E 40\%, como já pode-se observar na tabela 10, não anota, grava tudo na memória, realizam o controle de maneira informal.

Tabela 9 - Na gestão do seu negócio, você?

\begin{tabular}{|c|c|c|}
\hline \multicolumn{1}{|c|}{ Respostas } & Quantidade & $(\%)$ \\
\hline Faz anotações para tomar decisões & 11 & 55 \\
\hline Tem dificuldades na tomada de decisões & 0 & - \\
\hline $\begin{array}{c}\text { Faz separação dos gastos pessoais dos gastos } \\
\text { do seu negócio }\end{array}$ & 1 & 5 \\
\hline Costuma realizar orçamentos & 6 & 30 \\
\hline Não souberam responder & 2 & 10 \\
\hline Total & 20 & 100 \\
\hline
\end{tabular}

Fonte: os autores, 2015

Observa-se na tabela 9, que 55\% dos agricultores entrevistados, na gestão do seu negócio, fazem anotações para tomar decisões. 5\% faz separação dos gastos pessoais dos gastos do seu negócio, 30\% responderam que costuma realizar orçamentos, levantando dados para a realização de sua produção, e 2 agricultores, ou seja, 10\% não souberam responder.

Constatou-se o desconhecimento da palavra "gestão", por parte de alguns agricultores, compreendendo mais a palavra "administração". 
Tabela 10 - Na criação do gado, o controle dos seus gastos com os animais são registrados?

\begin{tabular}{|c|c|c|}
\hline Respostas & Quantidade & $(\%)$ \\
\hline Sim & 4 & 20 \\
\hline Não & 13 & 65 \\
\hline Às vezes & 3 & 15 \\
\hline Total & 20 & 100 \\
\hline
\end{tabular}

Fonte: os autores, 2015.

Conforme tabela 10, ao se questionar, se os controles com os gastos dos animais são registrados, $65 \%$ responderam que não, $20 \%$ que sim e $15 \%$ às vezes.

Tabela 11 - Você controla o estoque de produtos e insumos?

\begin{tabular}{|c|c|c|}
\hline Respostas & Quantidade & $(\%)$ \\
\hline Sim & 5 & 25 \\
\hline Não & 13 & 65 \\
\hline Às vezes & 2 & 10 \\
\hline Total & 20 & 100 \\
\hline \multicolumn{2}{|c|}{ Fonte: os autores, 2015. }
\end{tabular}

Constatou-se, na tabela 11 , que $65 \%$ dos agricultores, questionados sobre o controle de estoque, responderam que não, $25 \%$ que sim e $10 \%$ às vezes realiza o controle de estoque dos produtos e insumos de sua produção.

Tabela 12- Você sabe se sua atividade deu lucro ou prejuízo?

\begin{tabular}{|c|c|c|}
\hline Respostas & Quantidade & $(\%)$ \\
\hline Sim & 15 & 75 \\
\hline Não & 1 & 5 \\
\hline Às vezes & 4 & 20 \\
\hline Total & 20 & 100 \\
\hline \multicolumn{2}{|c|}{ Fonte: os autores, 2015. }
\end{tabular}

Verificou-se, na tabela 12, quando questionado sobre a questão de saber se sua atividade deu lucro ou prejuízo, ou seja, se o agricultor consegue ou não saber o resultado do exercício, obteve-se um número expressivo, $75 \%$ afirmaram que sempre conseguem saber seu resultado, $20 \%$ responderam às vezes sabem o resultado, mas por não utilizar de nenhum registro ou ferramenta, fica com dúvidas quanto ao resultado. E 5\% não sabem quando obteve lucro ou prejuízo. Neste aspecto a contabilidade traz uma ferramenta com grande importância, como por exemplo, a demonstração do resultado do exercício (DRE), onde é confrontado todas as receitas menos as despesas e custos do período.

Tabela 13 - Você participa de eventos, palestras, cursos que tragam novidades para os produtores rurais?

\begin{tabular}{|c|c|c|}
\hline Respostas & Quantidade & $(\%)$ \\
\hline Sim & 5 & 25 \\
\hline Não & 15 & 75 \\
\hline Às vezes & 0 & - \\
\hline Total & 20 & 100 \\
\hline
\end{tabular}

Fonte: os autores, 2015. 
Constatou-se, na tabela 13, quando foi perguntado sobre a participação em eventos, palestras, cursos entre outros, $75 \%$ responderam que não participa, devido a não serem informados, demonstrando-se interesse em participar. $25 \%$ disseram que sim, sempre participa achando muito gratificante. Percebe- se 0 interesse desses agricultores em aprendizagem e em participar desses cursos. Um dos motivos pela qual os agricultores enfrentam dificuldades e obstáculos em controlar e apurar o resultado de suas produções é pela falta de conhecimento do assunto.

Tabela 14 - Como você decide em efetuar investimentos?

\begin{tabular}{|c|c|c|}
\hline Respostas & Quantidade & (\%) \\
\hline Consulto informações da contabilidade & 0 & 15 \\
\hline Consulto apenas minhas anotações & 3 & 45 \\
\hline Consulto minha família & 9 & 40 \\
\hline Não faço nenhuma consulta & 8 & 100 \\
\hline Total & 20 & \\
\hline
\end{tabular}

Fonte: os autores, 2015

$\mathrm{Na}$ tabela 14, foi questionado como o agricultor decide em efetuar investimentos em suas propriedades. Constatou-se que $45 \%$ dos pesquisados consulta a família na hora de efetuar investimentos, muito característico na agricultura familiar, onde todos os membros da família participam da produção e administração da propriedade. 40\% não faz nenhuma consulta, e 15\% consulta apenas suas anotações.

\section{CONSIDERAÇÕES FINAIS}

Conclui-se com base nos dados coletados e levantados que a metade dos agricultores considera a profissão contábil necessária somente para o cumprimento de suas obrigações fiscais, principalmente no momento da declaração do imposto territorial rural. A outra metade ficou dividida em não consideram a profissão necessária para atividade rural e os que responderam sim, porém não manifestaram maiores apreços. Com unanimidade os agricultores responderam que não utilizam da ciência contábil como forma de controlar e organizar sua propriedade. Da mesma forma, verificouse que cem por cento dos agricultores familiares produtores de leite do município de Guapó - GO ainda administra suas atividades na informalidade e/ou com anotações em um caderno.

Verificou-se também por meio da revisão da literatura que a contabilidade tem suas normas baseadas na orientação, controle e registro dos atos e fatos ocorridos e praticados por qualquer natureza, seja ela jurídica ou física. Da mesma forma, constatouse que cinquenta e cinco por cento dos agricultores utilizam como controle de suas contas o registro de anotações em pequenos cadernos espirais. Também responderam que essas anotações são para tomadas de decisões. Os que não utilizam este registro, suas informações estão gravadas na sua memória e de seus familiares.

Constatou-se também que os agricultores que possuem seus registros de anotações em cadernos elas ocorrem somente quando é realizado compra, venda e pagamentos. Sendo também somente quando são efetuadas suas vendas. Percebe-se que a maioria desses agricultores sabe quando sua atividade apresentou lucro ou prejuízo, embora não se utilizam diretamente da contabilidade.

Conclui-se, portanto, que ainda há uma resistência muito grande, por parte dos agricultores familiares produtores de leite em adotar a contabilidade como registro e ferramenta de administração. Neste contexto, entende-se que um trabalho realizado pela classe contábil seria útil para mostrar a estes agricultores a importância da contabilidade como ferramenta para administração de suas atividades, a fim de atingir um melhor desempenho financeiro de suas produções. 


\section{REFERÊNCIAS}

[1] Altafin, Iara (et. al). Produção Familiar de Leite no Brasil: Um estudo sobre os assentamentos de reforma agrária no Município de Unaí (MG). Revista UNI, Imperatriz - MA, ano 1, volume 1, p. 31-49, 2011.

[2] Brasil. Lei 11.326, de 24 de julho de 2006. Estabelece as diretrizes para a formulação da Política Nacional da Agricultura Familiar e Empreendimentos Familiares Rurais. Disponível em:<http://www.planalto.gov.br/ccivil_03/_Ato2004 2006/2006/Lei/L11326.htm> Acesso em: 15 ago. 2015.

[3] Comitê de Pronunciamentos Contábeis (CPC). Pronunciamento Técnico CPC

[4] 29 - Ativo biológico e produto agrícola. Conselho Federal de Contabilidade. Brasília, 2009. Disponível em: <http://www.cpc.org.br/CPC/DocumentosEmitidos/Pronunciamentos/Pronunciamento?ld=60 >. Acesso em: 27 set. 2015.

[5] Crepaldi, S. A. Contabilidade Rural: uma abordagem decisorial. 2 ed. São Paulo: Atlas, 1998.

[6] Crestana, S.; Sousa, I. S. F. Introdução. In: Sousa, I. S. F. (Ed.). Agricultura Familiar na dinâmica da pesquisa agropecuária. Brasília, DF: Embrapa Informação Tecnológica, 2006. p. 11-23.

[7] FEA/USP. Contabilidade Introdutória. 11 ed. São Paulo: Atlas, 2010.

[8] Guanziroli, C.; Cardim, S. E. (Coord.). Novo Retrato da Agricultura Familiar: O Brasil redescoberto. Brasília: Projeto de Cooperação Técnica Fao/Incra, fev/2000. 74 p. Disponível em: $<$ http://gipaf.cnptia.embrapa.br/publicacoes/artigos -e-trabalhos/censo-95-vfinal-2000.pdf. > Acesso em 20 de set. 2015.

[9] Gil, A. C. Como elaborar projetos de pesquisa. São Paulo: Atlas, 2002.

[10] Instiuito Brasileiro de Geografia e Estastítica (lbge), Censo Agropecuário 2006.

Disponível em:

<http://www.ibge.gov.br/home/estatistica/economia /agropecuaria/censoagro/brasil_2006/Bras il_censoagro2006.pdf>. Acesso em: 20 ago. 2015.

[11] Instiuito Brasileiro de Geografia e Estastítica. Cidades. Disponível em: $<$ http://cidades.ibge.gov.br/xtras/perfil.php?lang=\& codmun $=520920 \&$ search $=$ goiaslguapo $>$. Acesso em: 25 ago. 2015.

[12] Jank, Marcos Sawaya; GALAN Valter Bertini. Competitividade do sistema Agroindustrial do leite. 1998. In Programa de estudo dos negócios do sistema agroindustrial. Disponível em: http://www.fundace.org.br/leite/arquivos/projetos_pr iorizados/elaboracao_competitividad e_industrial/bibliot/vol_ii_Leite\%20Competitividade_ jank.pdf. Acesso em 26 set 2015.

[13] Lakatos, E. M.; Marconi, M. A. A metodologia científica. São Paulo: Atlas, 2005.

[14] Landau, Elena Charlote. et al. Variação geográfica do tamanho dos módulos fiscais no Brasil. Sete Lagoas: Embrapa Milho e Sorgo, 2012. Disponível

em <http://aiba.org.br/wpcontent/uploads/2014/12/Vari a\%C3\%A7\%C3\%A3o-Geogr\%C3\%A1fica-doTamanho-dosModulos-Fiscais-no-BrasilEmbrapa.pdf>. Acesso em: 15 nov. 2015.

[15] Lima, Arlindo Jesus Prestes de; et al. Administração da unidade de produção familiar: modalidades de trabalho com agricultores. 2 ed. Ijuí: Unijuí, 2001.

[16] Lima, J. R. T. de; et al. Extensão Rural, desafios de novos tempos. Agroecologia e sustentabilidade. Série: Educação e Economia Solidária. Bagaço, Recife, 2006.

[17] Marion, J. C. Contabilidade Básica. 8 ed. São Paulo: Atlas, 2007.

[18] Contabilidade

Rural: contabilidade agrícola, contabilidade da pecuária, imposto de renda pessoa jurídica. 7 ed. São Paulo: Atlas, 2002.

[19] Nascimento, Fabio Nunes (et. al). Planejamento Estratégico em uma Pequena Propriedade Produtora de Leite. SOBER Sociedade Brasileira de Economia, Administração e Sociologia Rural, Porto Alegre - RS, 2009. Disponível em: <http://www.sober.org.br/palestra/13/719. pdf>. Acesso em: 12 set. 2015 .

[20] Ponchio, Leandro Augusto; Gomes, Alexandre Lopes; Paz Erica da. Perspectivas de consumo de leite no Brasil. São Paulo: Cepea, julho 2005.

[21] Schneider, S. Teoria Social, Agricultura Familiar e Pluriatividade. Revista Brasileira de Ciências Sociais, São Paulo, v. 18, n. 51, p. 99-121, $2003 . \quad$ Disponível em <http://www.scielo.br/pdf/rbcsoc/v18n51/15988>. Acesso em: 20 nov. 2015.

[22] Severino, Antônio Joaquim. Metodologia do trabalho científico. 23 ed. São Paulo: Cortez \& Moraes, 2007. 


\section{Gapítulo 10}

\section{IMPACTO DO TELETRABALHO NA GESTÃO SOCIALMENTE RESPONSÁVEL DOS STAKEHOLDERS}

\section{Simone Metello de Mattos Castro}

\section{Tatiana Metello Castro}

Fernando Toledo Ferraz.

Resumo:O objetivo deste estudo é pesquisar o impacto do teletrabalho nas organizações, sob o ponto de vista da responsabilidade social na gestão dos stakeholders, analisando os resultados de sua adoção em termos sociais, ambientais e econômicos (triple bottom line). Para isto é feita uma ampla pesquisa bibliográfica em livros e periódicos nacionais e internacionais sobre o tema. Como resultados, são apresentados os benefícios e barreiras encontrados para cada tipo de stakeholder e são propostos indicadores econômicos, sociais e ambientais para avaliar o sucesso da adoção do teletrabalho em organizações.

Palavras-chave: Sustentabilidade. Teletrabalho. Gestão. Stakeholders. Responsabilidade Social. 


\section{OBJETIVO}

Nos últimos anos, os habitantes dos grandes centros urbanos têm sofrido com longos engarrafamentos para ir e vir de seus locais de trabalho. Os deslocamentos são lentos, custosos e estressantes. Além disso, há um aumento da emissão de gases poluentes no meio ambiente devido à quantidade de veículos que transitam nas vias públicas.

Por outro lado, o desenvolvimento da tecnologia da informação, com a proliferação do uso de computadores pessoais, da internet e do armazenamento de informações em servidores remotos, vem proporcionando flexibilização das estruturas organizacionais.

Nesse contexto, uma nova forma de trabalho vem ganhando destaque nas empresas: o teletrabalho. Segundo De Masi (2000), o teletrabalho pode ser entendido como um trabalho realizado longe dos escritórios empresariais e dos colegas de trabalho, com comunicação independente com a sede central do trabalho e com outras sedes, através de um uso intensivo das tecnologias da comunicação e da informação. De acordo com Mello (1999), o processo de teletrabalho surge como uma alternativa moderna de gestão empresarial para tornar as empresas mais competitivas e dinâmicas, diferentes daquelas acostumadas à estabilidade e à rotina do trabalho tradicional.

Como afirmou Teddy Wivel, sócio sênior da empresa Ernst and Young, "não é possível criar valor para os acionistas sem criar valor para os stakeholders" (Crowe, 1999). Assim, ao optar pela adoção do modelo de teletrabalho, a empresa deve estar atenta aos impactos que esta mudança pode acarretar para seus diferentes stakeholders sob a ótica do tripé da sustentabilidade (triple botton line), ou seja, analisando seus impactos financeiros, sociais e ambientais.

O presente artigo visa analisar as características, os benefícios e as barreiras na adoção do teletrabalho sob a ótica dos vários stakeholders impactados e, por fim, propor indicadores para avaliar o sucesso da adoção deste modelo de trabalho nas organizações.

\section{MÉTODO}

Este estudo foi desenvolvido através de pesquisas bibliográficas nacionais e internacionais sobre temas como teletrabalho, gestão de stakeholders, sustentabilidade e responsabilidade social. Através de um enfoque sistêmico como método de abordagem buscou-se compreender os fenômenos aqui pesquisados e a relação entre eles.

$\mathrm{Na}$ primeira fase deste estudo foi desenvolvida uma pesquisa bibliográfica sobre os benefícios e barreiras referentes à adoção do teletrabalho pelas organizações. Além da pesquisa nos livros citados nas referências bibliográficas, forma feitas pesquisas nas bases SCOPUS e na de Periódicos CAPES, utilizando-se as palavras chaves "telework" e "sustainability".

Ao final, com base nos os benefícios e barreiras levantados nas pesquisas bibliográficas foram propostos indicadores para avaliação do sucesso do modelo de teletrabalho, após sua implementação em organizações.

\section{RESULTADOS DA REVISÃO BIBLIOGRÁFICA}

\subsection{O TELETRABALHO}

$\mathrm{Na}$ base SCOPUS foram encontrados 202 artigos em periódicos ou conferências com a palavra chave "telework" no título do documento. Pelas publicações é possível supor que haja um crescente aumento de interesse pelo tema. 
Figura 01 - Evolução das publicações com "telework" no título na Base Scopus

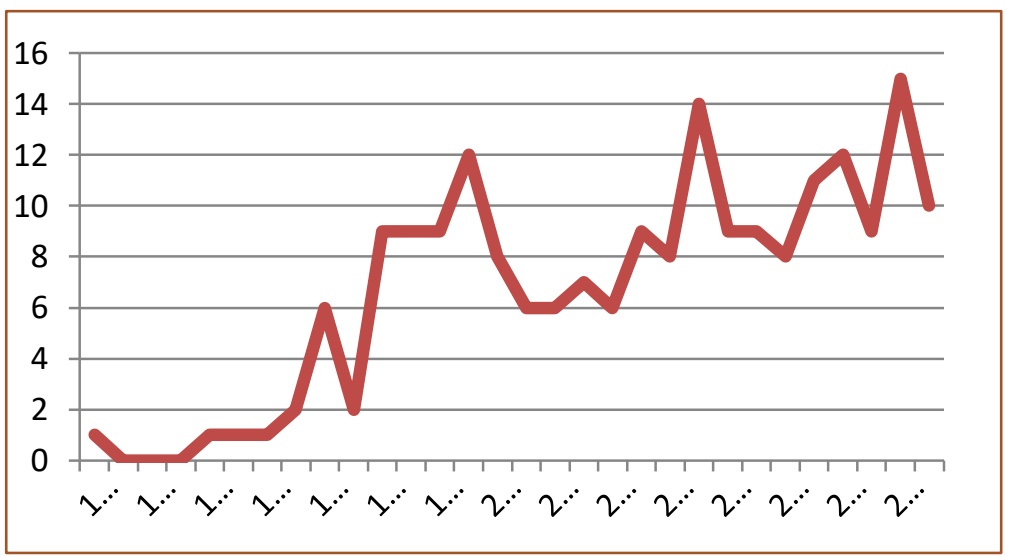

As áreas que mais têm publicado sobre o tema têm sido Ciências Sociais, Administração e Negócios, Ciências da Computação e Engenharia (entre 35 e 70 publicações cada uma) e logo em seguida
Psicologia, Medicina, Ciências da Decisão, Ciências Ambientais, Economia e Finanças e Ciências da Saúde num segundo grupo (entre 5 e 20 publicações cada).

Figura 2 - Publicação por área do conhecimento na Base Scopus com "telework" no título

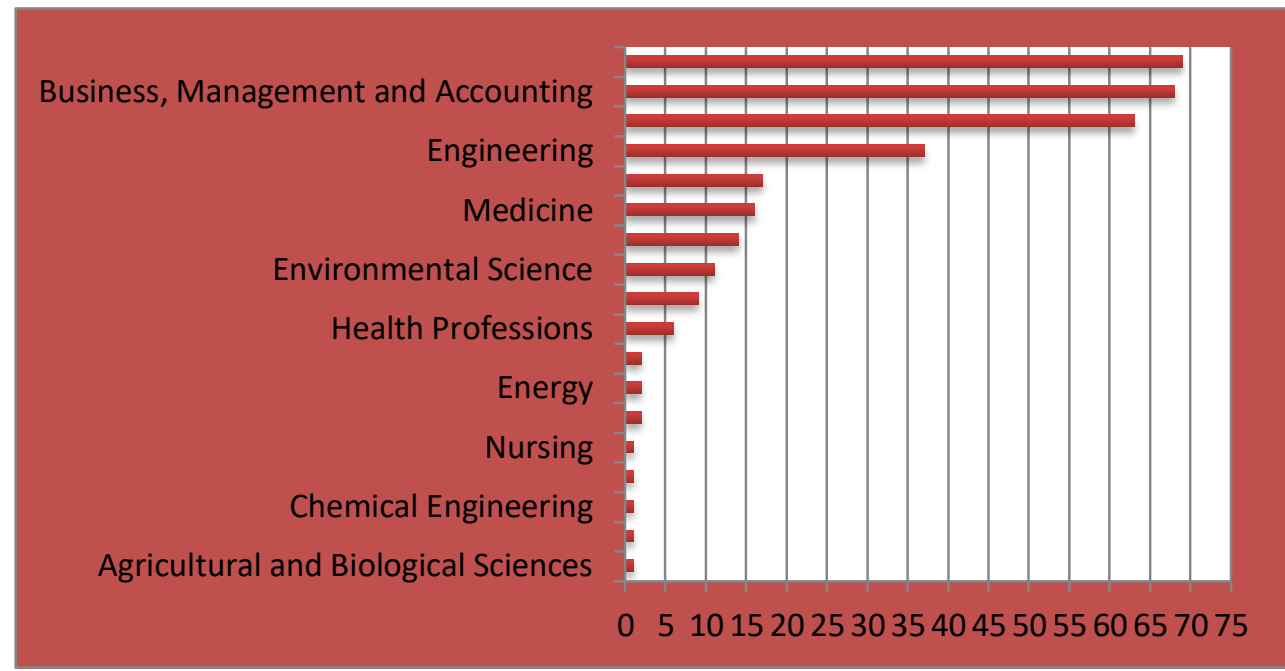

Ao relacionarmos o termo "telework" com "sustainability" há uma redução de publicações para um total de 5 , sendo as mesmas nos anos de 2006, 2008, 2011, 2013 e 2014.

Hynes (2014) faz uma revisão de políticas públicas relacionadas a transporte e gestão do trabalho com o argumento de que o teletrabalho pode contribuir para a crescente pressão dos transportes relacionados ao ir e vir para o trabalho de forma a reduzir a necessidades de viagens e, com isto, obter diversos efeitos positivos para a sustentabilidade. Os efeitos enfatizados, neste caso, relacionam-se mais estreitamente à dimensão ambiental do triple bottom line.

Basso et al (2013) endereçam especificamente a questão da relação entre o teletrabalho e a sustentabilidade e sugerem que o teletrabalho pode ser visto como uma oportunidade para se melhorar o desempenho empresarial no que tange à sustentabilidade. Sugerem também que há uma aparente distância entre o desempenho econômico das empresas e seu desempenho social e ambiental. Dessa forma o teletrabalho poderia 
ser uma oportunidade de se reduzir esta distância.

Rietveld (2011) por sua vez chama a atenção que, apesar da difusão da ideia de que o teletrabalho pode contribuir para a solução do consumo energético no trânsito e dos crescentes congestionamentos nos grandes centros urbanos, sua aplicação tem algumas questões ainda não muito bem resolvidas. Ele cita barreiras como organização interna das empresas, mudanças na responsabilidade social das empresas e, enfim, mudanças no estilo de vida e padrões de atividades dos trabalhadores.

Kawai (2008) investiga os efeitos de políticas urbanas baseadas em Tecnologias de Informação e Comunicação (TIC's) usando como referência um estudo de caso sobre a experiência de Loma Linda Connected Community Program (LLCCP). Este foi um caso de um programa de desenvolvimento municipal baseado em TIC's. O autor sugere que apesar do crescente reconhecimento do uso do teletrabalho para o desenvolvimento de comunidades sustentáveis, o conhecimento sobre projeto urbano e arquitetônico para suportar tais comunidades, ainda necessita desenvolvimento.

Reed et al (2006) trata da questão da ética relativa à utilização e adoção do teletrabalho pelas empresas. Eles se baseiam no trabalho de Yuthas e Dillard (1999) que desenvolvem a relação entre uma perspectiva de ética pósmoderna e a teoria de "stakeholders".

Segundo Bergum (2009), o teletrabalho é todo serviço executado por um empregado à distância, em caráter continuo, fora das instalações da empresa empregadora, utilizando-se do apoio e facilidades das tecnologias de informação e comunicação. De forma semelhante, a Organização Internacional do Trabalho (OIT) define que o teletrabalho pode ser entendido como o trabalho efetuado distante dos escritórios centrais, sedes ou dos locais físicos de produção e operação das empresas. Assim, os teletrabalhadores executam seu trabalho fora dos domínios da empresa empregadora, porém, mantem-se conectados com seus supervisores e demais colegas por meio das tecnologias de comunicação e informação.

De acordo com a Sociedade Brasileira de Teletrabalho e Teleatividades (SOBRATT), o teletrabalho também pode ser chamado de trabalho à distância ou trabalho remoto, entretanto não tem o mesmo significado do termo home office. Isso porque o teletrabalho não determina um local específico para trabalhar, pode ser desenvolvido no domicílio do trabalhador, em escritórios descentralizados da própria empresa, em áreas gratuitas ou pagas de utilização de computadores com acesso à Internet.

Em 2008, a SOBRATT realizou uma estimativa, a partir de dados de diferentes instituições, de que, naquele ano, o Brasil contava com aproximadamente 10 milhões e seiscentos mil teletrabalhadores, ou seja, cerca de 5\% da população brasileira. Essa estimativa não diferencia regiões ou estados do país e inclui todos os setores e áreas, bem como todos os tipos de teletrabalhadores: formais, informais, empregados ou por conta própria, autônomos, liberais, em tempo integral, parcial, complementar e eventual, numa ampla faixa etária que vai dos 18 aos 60 anos, com utilização de acesso à Internet de uma vez por semana a uma vez por dia, considerando-se a utilização de desktops, notebooks, handhelds, smartphones, com acesso discado e/ou banda larga, para trabalhos completos ou atividades parciais.

\subsection{A RESPONSABILIDADE SOCIAL EMPRESARIAL}

Atualmente, a Responsabilidade Social Empresarial (RSE) é vista como um fator de competitividade para os negócios e vai além do cumprimento das obrigações legais. Além de buscar bons resultados financeiros, as empresas devem considerar o impacto de suas atividades no meio ambiente e construir relações éticas e transparentes com seus stakeholders: clientes, funcionários, fornecedores, governo e sociedade. Assim, uma empresa socialmente responsável deve buscar atender ao tripé da sustentabilidade (triple bottom line). Deve buscar ter bons resultados em termos sociais, ambientais e econômicos (BROWN, 2006).

Sociais - Refere-se ao tratamento do capital humano da empresa ou sociedade.

Ambientais - Refere-se ao capital natural de uma empresa ou sociedade.

Econômico - Trata-se do lucro. É o resultado econômico positivo de uma empresa.

Existe uma vasta literatura sobre responsabilidade social empresarial, onde com frequência, especialmente no Brasil, a questão é vista como motivada pela filantropia 
ou idealismo ético. Porém, atualmente, a visão mais difundida para a responsabilidade social é a progressista, onde as ações são de interesse da própria empresa e beneficiam, de forma abrangente, diversos stakeholders da mesma. Nesta visão progressista, buscase além de maximizar os resultados produtivos e financeiros da empresa, dentro das regras legais, também resultados sociais e ambientais.

Em muitas situações, é do interesse das empresas a realização de ações sociais, pois melhoram a imagem da empresa perante seu mercado consumidor e a sociedade. Outro aspecto importante é a obtenção de financiamento por parte das empresas. Atualmente, para a liberação de financiamento, muitas instituições adotam princípios e padrões voltados para a promoção de uma maior responsabilidade social e ambiental, chamados de Princípios do Equador, lançados em 2003 (WRIGHT, 2012). A criação destes princípios é tida como uma das mais importantes iniciativas de governança ambiental do setor financeiro. Fornecem um direcionamento para a compreensão das funções, responsabilidades e impactos das instituições financeiras na governança ambiental global. Foram adotados por grande parte das instituições

Figura 3: Modelo da Teoria dos Stakeholders financeiras que operam no mercado de financiamento de projetos. Fortalecem a governança ambiental e social do financiamento de projetos em todos os setores da indústria e regiões geográficas. Neste contexto, para que o financiamento de qualquer projeto seja liberado, a instituições analisam o triple bottom line da sustentabilidade, ou seja, o que é esperado do projeto em termos sociais, ambientais e econômicos.

Nesta linha, a responsabilidade social empresarial passa a ser um importante instrumento gerencial para as empresas em um mundo cada vez mais competitivo.

\subsection{A GESTÃO PARA OS STAKEHOLDERS}

Segundo Freeman (2001), stakeholder é qualquer indivíduos ou grupo de indivíduos que obtém benefícios, é prejudicado ou têm seus direitos afetados (violados, restritos ou ignorados) pelas ações de uma organização. Assim, o autor aponta como principais stakeholders de uma organização seus gestores, proprietários, fornecedores, funcionários, clientes e a comunidade local da qual ela é parte integrante.

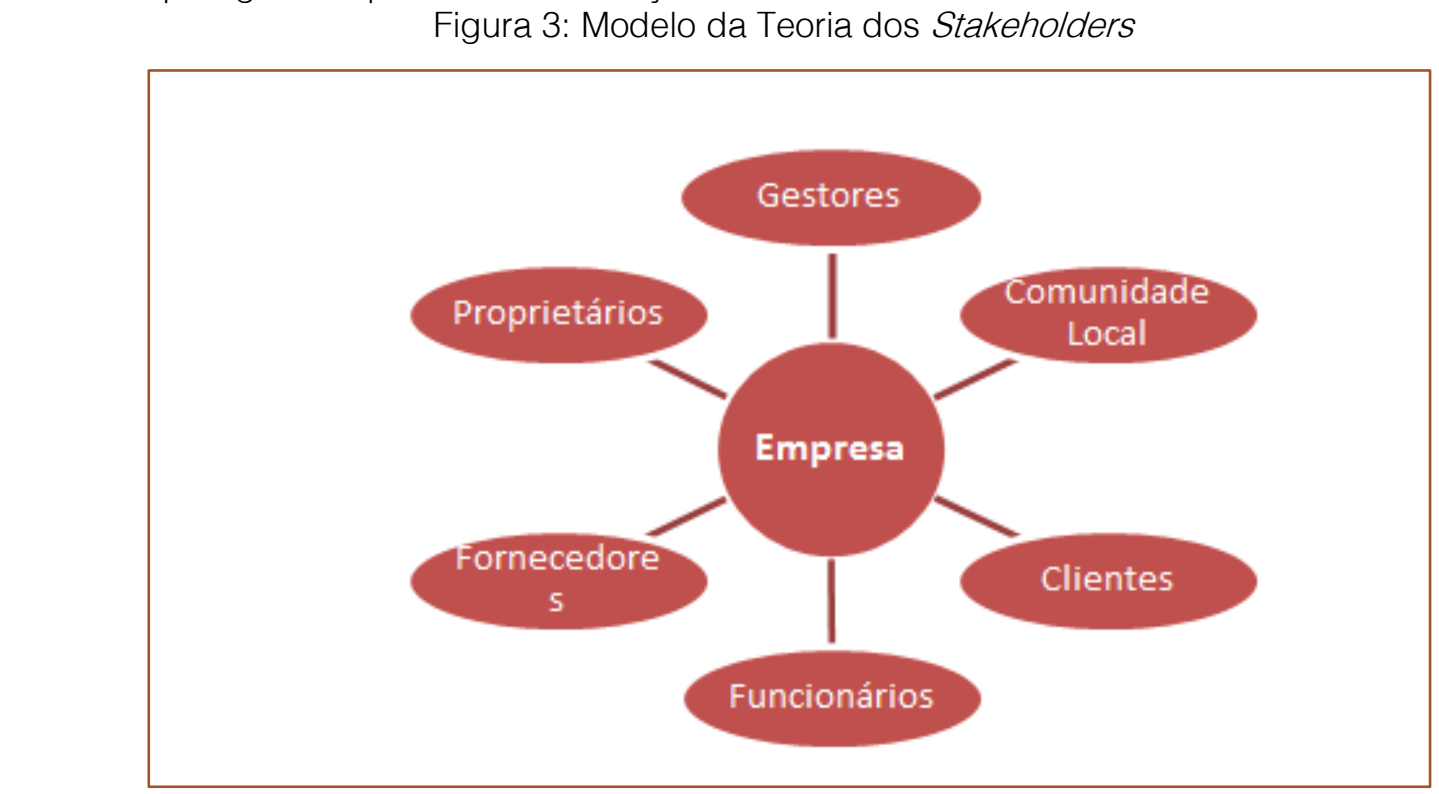

Fonte: Adaptado de Freeman (2001)

De acordo com esse modelo de Freeman (2001), os proprietários possuem, na forma de ações ou cotas, uma porção financeira da organização e esperam um retorno por essa aplicação. Eles podem tanto ser os próprios gestores e funcionários da empresa, como ocorre em negócios familiares, quanto acionistas de grandes corporações. 0 negócio deverá sempre buscar a maximização dos retornos para seus proprietários.

Os funcionários, por sua vez, têm seus empregos e grande parte de sua vida pessoal dependentes da organização. Eles são um 
recurso fundamental para o negócio, pois vendem sua força de trabalho em troca de salário, segurança, benefícios e satisfação pessoal. Dessa forma, a empresa deve preocupar-se em atender às expectativas de seus colaboradores de forma a preservá-los na organização e mantê-los motivados a desempenhar com excelência suas atividades.

Já os fornecedores, são essenciais para o sucesso da empresa devido ao impacto que o preço das matérias-primas provisionadas pode gerar no preço final do produto. Por outro lado, a organização é cliente de seu fornecedor e, assim, também é um stakeholder dele. Assim, há uma relação de dependência entre as partes e ambos podem triunfar ou naufragar juntos.

Em relação aos clientes, os mesmos trocam recursos com a empresa, recebendo seus produtos e serviços e oferecendo recurso financeiro fundamental à sobrevivência da organização. Desse modo, atender e mesmo superar suas expectativas é importante atribuição de qualquer negócio.

No que se refere à comunidade local no modelo de Freeman (2001), a mesma garante à empresa 0 direito de construir suas instalações, recebendo em troca benefícios como taxas e contribuições. Além disso, é importante que a organização zele pela comunidade, cuidando para mitigar quaisquer externalidades negativas que possa causar, como poluição e desmatamento, por exemplo, e empenhando-se na maximização das externalidades positivas.

É possível perceber, portanto, a importância de que a organização esteja atenta às relações da empresa com todos estes atores e a como mudanças na estrutura organizacional podem afetar positivamente ou negativamente cada um deles.

\section{TELETRABALHO NA GEStÃO DOS STAKEHOLDERS}

Segundo o Manual de Oslo (OCDE, 1997), a inovação organizacional é definida no como a implementação de um novo método organizacional nas práticas de negócios da empresa, na organização do seu local de trabalho ou em suas relações externas. Desse modo, implementação do teletrabalho em uma empresa pode ser considerada uma inovação organizacional, pois tem a capacidade de impulsionar mudanças nos processos do negócio e nas relações da empresa com seus stakeholders.

A seguir, são apresentados impactos do teletrabalho sobre vários stakeholders de uma empresa, encontrados na pesquiso bibliográfica deste estudo.

\subsection{GESTORES}

Segundo Pérez et al. (2002), a gestão feita com base nos resultados do funcionário e não no tempo que ele permanece no escritório é um dos fatores de sucesso do teletrabalho. Os autores ressaltam ainda vantagens da utilização desse modelo de trabalho relacionadas aos indicadores de turnover. Eles afirmam que a natureza flexível do teletrabalho, é reconhecida como um benefício incomparável pelos empregados. Desse modo, o recrutamento de novos funcionários e a retenção dos já pertencentes à organização requer menor esforço por parte dos gestores.

Além disso, de acordo com Pérez et al. (2002), o trabalho remoto também proporciona redução na taxa de absenteísmo dos colaboradores. Isso ocorre porque, não sendo necessário o esforço de deslocamento por parte do teletrabalhador, é possível realizar suas atividades ainda que não esteja se sentindo completamente bem, o que talvez se tornasse inviável caso ele devesse deslocar-se até o escritório da empresa. Também é possível se continuar a realizar o trabalho, mesmo com problemas meteorológicos ou nos transportes públicos.

Apesar das vantagens destacadas, Jardim (2003) afirma que o teletrabalho exige um maior grau de autonomia do trabalhador e nem todos os trabalhadores enquadram-se nessa modalidade de trabalho. Nesse contexto, Goulart (2009) explica que, para a implantação do modelo proposto para o teletrabalho é necessário conhecer o modelo de gestão da empresa, analisar as atividades realizadas por cada um dos cargos e respectivas características psicossociais dos empregados e capacitar o empregado para o eficaz cumprimento de suas atividades a serem realizadas remotamente.

Desse modo, considerando os aspectos do teletrabalho que afetam os gestores da organização podemos utilizar como indicadores do sucesso deste modelo de trabalho o turnover da empresa, sua taxa de 
absenteísmo e a produtividade dos funcionários.

\subsection{PROPRIETÁRIOS}

De acordo com Kobal et al. (2009), a adoção do teletrabalho pelas organizações pode proporcionar às mesmas benefícios como a diminuição dos custos com estrutura física e equipamentos, já que a empresa não precisará mais dispor de um local para abrigar esses colaboradores e nem mesmo de equipamentos para o desenvolvimento das funções, e o aumento da produtividade do funcionário. Nesse contexto, Pérez et al. (2002) apontam que o aumento da produtividade pode ocorrer devido a fatores como o aumento da motivação dos funcionários ou a estipulação de um sistema de pagamentos e recompensas relacionado ao desempenho dos colaboradores.

Já para Winter (2005), o aumento da produtividade é consequência de uma melhor administração do tempo por parte do funcionário, uma vez que ele não precisará mais realizar os deslocamentos entre a empresa e sua residência. Assim como Kobal et al. (2009), Winter (2005) ressalta a redução de custos nas organizações que adotam o teletrabalho, afirmando que as mesmas podem aproveitar benefícios como o de uma maior flexibilidade organizacional e maior flexibilidade econômica ao reduzirem seus custos com imobiliários e mão-de-obra, como vale-transporte, telefone, água, café, energia elétrica, dentre outros.

O teletrabalho, entretanto, também acarreta preocupações aos proprietários das organizações que o adotam. Dentre elas, pode-se destacar a redução da confiabilidade na segurança dos dados da empresa. Conforme explica Machado (2002), para desenvolver suas atividades, o funcionário se inter-relaciona com as atividades do sistema de informações de sua empresa, seja alimentando-o com novas informações, seja acessando as informações armazenadas. Assim, a possibilidade do acesso remoto aumenta os riscos à integridade, confidencialidade e disponibilidade das informações necessárias à manutenção das organizações. Além disso, a organização poderá ter que arcar com custos adicionais para aumentar a segurança e a confiabilidade da conexão entre o ambiente residencial e a rede corporativa, adotar ferramentas de comunicação unificada e hospedar suas aplicações corporativas, como e-mail e sharepoint, em estruturas de computação em nuvem, para obter um modelo de teletrabalho eficiente.

Desse modo, conforme a análise de Greco e Martins (2001), se por um lado o teletrabalho proporciona uma redução de custos de produção, por outro pode representar à organização riscos na segurança de suas informações, dado que o teletrabalhador passa a dispor de material corporativo fora do ambiente da empresa.

Assim, para medir os impactos que o teletrabalho ocasiona aos proprietários, são sugeridos como indicadores a produtividade dos funcionários, os custos com infraestrutura predial e de tecnóloga da informação (TI), além dos custos com horas extras.

\subsection{FORNECEDORES}

De acordo com Neely (2007), o sucesso de uma organização depende de sua habilidade para integrar as relações de sua rede de negócios e gerenciar estes relacionamentos. Desse modo, ao permitir uma maior dispersão geográfica dos colaboradores, o teletrabalho possibilita que a empresa se aproxime dos diferentes fornecedores que têm suas instalações distantes da organização, aumentado, assim, a integração da cadeia de suprimentos.

Além disso, a utilização de ferramentas de colaboração, muito adotadas pelos teletrabalhadores, também pode ser ampliadas de forma a englobar a cooperação com clientes e fornecedores. Nesse contexto, Coenen e Kok (2013) afirmam que a adoção do teletrabalho em projetos de desenvolvimento de novos produtos pode aumentar a colaboração entre a empresa e seus fornecedores, já que possibilita a integração de membros da equipe dispersos geograficamente. Desse modo, é possível agregar diferentes competências, imprimindo maior velocidade e qualidade ao desenvolvimento de produtos, o que trará benefícios para toda a cadeia de suprimentos.

O sucesso de uma maior integração na cadeia de suprimentos pode ser medido por meio de indicadores como a produtividade referente ao custo de desenvolvimento de novos produtos. 
Segundo Nilles (1997), quanto mais flexível o regime de trabalho em uma organização, maiores as chances de que seus funcionários permaneçam motivados para desempenhar suas tarefas de forma efetiva e orientada para os resultados. Com base nos estudos realizados por este e outros autores, Pérez et al. (2002) destacam os benefícios e as barreiras da adoção do teletrabalho do ponto de vista dos funcionários.

Tabela 1: Benefícios e barreiras do teletrabalho para os funcionários

\begin{tabular}{|c|c|}
\hline Benefícios & Barreiras \\
\hline Flexibilidade & Dificuldades organizacionais \\
\hline Autonomia & Dificuldades para trabalhar em equipe \\
\hline Liberdade pessoal & Percepção de perda de status \\
\hline Trabalho autônomo & Dificuldade de promoção \\
\hline Redução de custos & Problemas psicológicos \\
\hline Redução de problemas trabalhistas & \\
\hline Oportunidades aos portadores de \\
deficiência
\end{tabular}

Fonte: Adaptado de Pérez et al. (2002)

Em uma organização cuja gestão engloba a adoção do teletrabalho, seus funcionários poderão usufruir de maior flexibilidade de horário em sua jornada de trabalho, maior facilidade para conciliar sua vida pessoal e profissional e redução dos custos relacionados a transporte, estacionamento e vestuário. Além disso, é possível que haja uma maior autonomia do funcionário em relação às atividades desenvolvidas.

Conforme afirmam Greco e Martins (2001), no modelo de teletrabalho, o funcionário não precisará enfrentar a poluição das cidades, e eventualmente da própria empresa, nem o congestionamento do tráfego, o tempo nele perdido e os gastos de transporte. Assim, o teletrabalho possibilitará a redução ou eliminação do tempo de deslocamento para o local de trabalho, principalmente nos grandes centros urbanos, e o aumento da inserção de portadores de deficiência que possuam dificuldades de deslocamento no mercado de trabalho.

Por outro lado, algumas barreiras deverão ser superadas pelos funcionários de uma empresa que adote o teletrabalho. Dentre elas, podemos destacar o isolamento do empregado em relação aos demais colaboradores da organização. Isso poderá acarretar dificuldade na realização de trabalhos em equipe e na transferência de conhecimento entre os funcionários.

Segundo Jardim (2003), o teletrabalho pode ocasionar, ao funcionário, dificuldade de distinção entre a vida profissional e a vida particular, além de isolamento social, menor ajuda na execução do trabalho e menores possibilidades de ascensão na carreira profissional. Assim, ao limitar o convívio social do empregado, o teletrabalho poderá reduzir sua possibilidade de obtenção de promoções na carreira, já que seu trabalho poderá tornarse menos evidente, além de aumentar o risco de surgimento de problemas psicológicos provenientes do isolamento, como a depressão.

Além disso, Winter (2005) afirma que o teletrabalho pode ocasionar o aumento de horas trabalhadas em casa, na tentativa de se alcançar um objetivo determinado.

Dessa forma, os resultados obtidos com a utilização do teletrabalho podem ser medidos por meio de indicadores de satisfação dos funcionários, contratação de pessoas portadoras de necessidades especiais, taxa de acidentes de trabalho, taxa de acidentes de deslocamento, taxa de afastamentos por doenças e custos relacionados a questões trabalhistas e horas extras realizadas pelos funcionários.

\subsection{CLIENTES}

No que se refere ao atendimento aos clientes, Mello (2006) explica que a utilização do teletrabalho permite que as organizações trabalhem com equipes espalhadas pelo país ou pelo exterior, sem a necessidade de concentrá-las em um espaço físico determinado. Assim, é possível que a empresa esteja mais próxima de seus clientes geograficamente dispersos.

Isso pode ser observado no caso da empresa Ticket. De acordo com a resolução da SOBRATT (2013), a matriz da companhia em São Paulo possuía cerca de 800 colaboradores, sendo 150 no modelo home 
office. O estudo mostra que a adoção do teletrabalho permitiu à Ticket aumentar seu foco no cliente: maior proximidade e agilidade no atendimento aos clientes. Assim, conseguiu melhorar a rentabilidade da organização. Além disso, essa mudança possibilitou que a empresa atuasse em quatro novos territórios geográficos sem a necessidade de aumentar seu quadro de funcionários e ampliou a quantidade média de visitas aos clientes em 1,5 visitas ao dia.

É possível, portanto, mensurar o sucesso do teletrabalho no que tange aos clientes por meio da utilização de indicadores de satisfação dos clientes e produtividade referente à quantidade de vendas realizadas.

\subsection{COMUNIDADE LOCAL}

De acordo com Mello (2011), a utilização do teletrabalho nas organizações poderá proporcionar os seguintes benefícios à sociedade:

- Aumento na geração de empregos, devido ao menor custo de investimento em instalações físicas e infraestrutura urbana.

- Diminuição dos congestionamentos nas grandes cidades, principalmente em horários de grande fluxo de movimentação de pessoas e veículos.

- Redução da emissão de poluentes pelo consumo de energia de origem fóssil.

- Aumento da quantidade de empregos nas zonas rurais, uma vez que, com o uso da tecnologia, eles se tornam viáveis mesmo em locais remotos.

A resolução da SOBRATT (2013), por sua vez, divide os impactos do teletrabalho relacionados à sustentabilidade em três pilares fundamentais: economia, meio ambiente e sociedade.

No que se refere à sustentabilidade econômica, a resolução da SOBRATT (2013) explica que, de acordo com os estudos realizados, as empresas, a comunidade e os funcionários somariam ganhos de mais de US\$ 900 bilhões com a adoção do teletrabalho. Isso ocorreria devido a fatores como o aumento da produtividade, a economia em imóveis e custos relacionados ao absenteísmo e à rotatividade de pessoal.
Além disso, com a redução da quantidade de pessoal e de empregados circulando pela cidade e pelas estradas, os acidentes de trânsito e os custos deles decorrentes também seriam mitigados. A resolução SOBRATT (2013) afirma que, de acordo com um estudo publicado em 2013, pela Fundação Getúlio Vargas, os custos anuais de congestionamentos na cidade de São Paulo são estimados em $\mathrm{R} \$ 40$ bilhões.

Já na dimensão ambiental, assim como Winter (2005), a resolução da SOBRATT (2013) faz referência aos benefícios ambientais, ressaltando os menores índices de poluição decorrentes da redução dos congestionamentos do trânsito, $\mathrm{o}$ que contribui para a mitigação do efeito estufa e da poluição atmosférica.

Em relação à sustentabilidade social, os benefícios apontados são o aumento das oportunidades a pessoas portadoras de necessidades especiais, funcionários com filhos pequenos ou pais idosos, dentre outros. O menor número de pessoas circulando pelas ruas também tende a reduzir a criminalidade, principalmente nos grandes centros urbanos.

Além disso, o convívio à distância pode permitir que colaboradores sejam conhecidos por seus colegas primeiro por sua capacidade de trabalho, reduzindo, assim, a probabilidade de ocorrerem preconceitos baseados na aparência física ou comportamental dos mesmos.

No que se refere aos indicadores a serem utilizados para medir o impacto da adoção do teletrabalho na comunidade à qual uma organização pertence, pode-se considerar a pegada de carbono da empresa, a quantidade de funcionários contratados, a quantidade de empregados que vivem em zonas rurais e a quantidade de portadores de necessidades especiais.

\section{CONCLUSÕES SOBRE COMO AVALIAR O SUCESSO DO TELETRABALHO}

Considerando os aspectos descritos anteriormente, para medir o sucesso do teletrabalho diante dos impactos nos vários stakeholders e da visão do tripé da sustentabilidade são propostos os seguintes indicadores: 
Figura 4: Tripé da Sustentabilidade

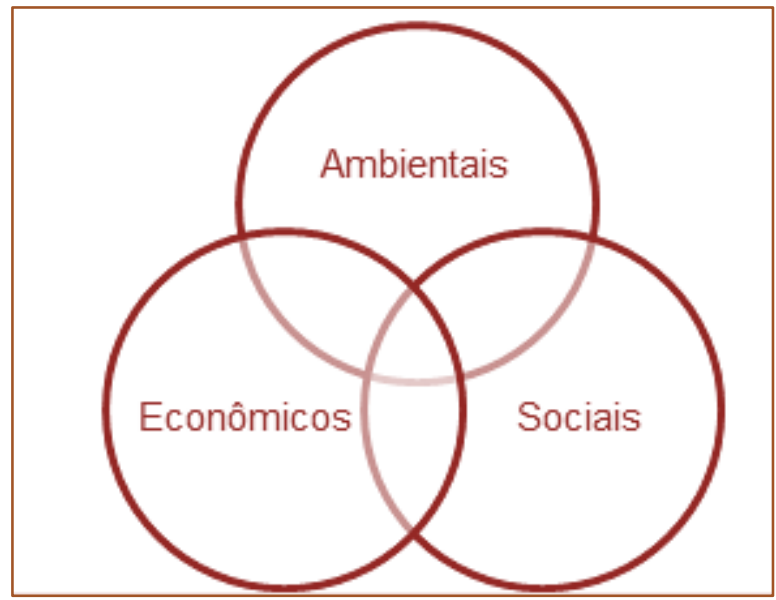

Fonte: Adaptado de Brown (2006)

\section{ECONÔMICOS}

- - Produtividade

- - Turnover

- $\quad$ - Custos com questões trabalhistas

- - Custos com acidentes de trabalho

- - Custos com horas extras

- - Custo com vale transporte

- - Absenteísmo

- - Custos com infraestrutura predial (aluguel, luz, água, etc)

- $\quad$ - Custos para implantar o teletrabalho

- - Custos por não cumprimento da cota de PCD ( pessoas com deficiência)

\section{SOCIAIS}

- - Satisfação dos funcionários

- - Afastamento por doença

- - Satisfação dos clientes

- - Quantidade de funcionários

- - Quantidade de funcionários vivendo em zonas rurais ou outras cidades

- Quantidade de funcionários portadores de necessidades especiais
AMBIENTAIS

- Quantidade de acidentes de trabalho

- Quantidade de acidentes de deslocamento

- - Pegada de carbono

- Kilometragem casa-trabalho

- Meio de transporte utilizado ( a pé. carro, ônibus, trem, metro, outros)

\section{CONSIDERAÇÕES FINAIS}

No desenvolvimento desse artigo, buscou-se analisar as características do teletrabalho e da teoria dos stakeholders proposta por Freeman (2007). Com base em tais informações e considerando a perspectiva do triple bottom line, foi possível propor indicadores que ajudem a mensurar o sucesso do teletrabalho nas empresas em que é adotado.

Desse modo, espera-se que tal estudo possa contribuir para a orientação de gestores no que se refere a decisões relativas ao teletrabalho em suas organizações e para a realização de futuras pesquisas que visem aprofundar o tema discutido. Nesse contexto, recomenda-se que novos estudos sejam realizados com o objetivo de realizar outras abordagens que não foram incluídas nesse artigo. Por exemplo, será oportuno analisar os impactos do teletrabalho em diferentes tipos de organizações. Seria possível também a realização de um estudo comparativo entre os indicadores de empresas semelhantes que adotem e que não adotem o teletrabalho. 


\section{REFERÊNCIAS}

[1] Bergum, S. Management of Teleworkers: managerial communication at a distance. Tukum Kauppakorkeakoulu, Turku School of Economics. Turku: Uniprint, 2009.

[2] Basso, R.B.F., Battistelle, R.A.G. \& Cavenaghi, $V$. Telework and management: Technology for a more sustainable environment, 22nd International Conference on Production Research, ICPR, 2013.

[3] Brown, D.; Dillard, J.; Marshall, R. S. Triple Bottom Line: A business metaphor for a social construct. Portland State University, School of Business Administration, 2006.

[4] Coenen, M. KOK, R.A. W. Workplace flexibility and new product development performance: the role of telework and flexible work schedules. Nijmegen: Radboud University Nijmegen, 2013.

[5] Crowe, R. Winning with integrity. Londres: The Guardian, 27 November 1999.

[6] De Masi, D. O ócio criativo. 1 ed. Rio de Janeiro: Sextante, 2000.

[7] Freeman, R. A stakeholder theory of the modern corporation. Perspectives in Business Ethics Sie, v. 3, p. 144, 2001.

[8] Freeman, E. R. Managing for Stakeholders. University of Virginia: Darden Business Publishing, 2007.

[9] Goulart, J. O. Teletrabalho: Alternativa de trabalho flexível. Brasília: Senac, 2009.

[10] Greco, M. A.; MARTINS, I. G. S. Direito e Internet: relações jurídicas na sociedade informatizada. São Paulo: Revista dos Tribunais, 2001.

[11] Hynes, M. Telework Isn't Working: A Policy Review. The Economic and Social Review, v. 45, n. 4, Winter, p. 579-602, 2014.

[12] Jardim, C. C. S. O teletrabalho e suas atuais modalidades. São Paulo: LTr, 2003.

[13] Kawai, Y. Work/life community by teleworkpossibilities and issues in the case of loma linda, Journal of Green Building, vol. 3, no. 2, pp. 128139, 2008.

[14] Kobal, F. V. G; AGNER, T.; OLIVEIRA, A. C. Vantagens e desvantagens do teletrabalho: uma pesquisa de campo em uma multinacional. Salvador: XXIX Encontro Nacional De Engenharia De Produção, 2009.

[15] Machado, C. S. Gerenciamento da segurança da informação em sistemas de teletrabalho. Florianópolis: Universidade Federal de Santa Catarina, 2002.

[16] Mello, A. A. O uso do teletrabalho nas empresas de call center e contact center multiclientes atuantes no brasil: estudo para identificar as forças propulsoras, restritivas e contribuições reconhecidas. São Paulo: Universidade de São Paulo, 2011.
[17] Mello, A. A. A virtualização de empresas: a prática do teletrabalho em uma organização privada. São Paulo: IX Semead - Administração no Contexto Internacional, 2006.

[18] Mello, A. A. Teletrabalho (telework): o trabalho em qualquer lugar e a qualquer hora. 1 ed. Rio de Janeiro: Qualitymark, 1999.

[19] Neely, A. Business performance measurement: unifying theory and integrating practice. 2 ed. Cambridge: Cambridge University Press, 2007.

[20] Nilles, J.M. Fazendo do Teletrabalho uma Realidade. Ed. Futura. São Paulo, 1997.

[21] Organização Internacional do Trabalho. Convenio sobre Teletrabajo. Revista de la OIT, Espanha. n. 44, out. 2002. Disponível em: $<$ http://international.vlex.com/vid/convenioteletrabajo-176950>. Acesso em: 20 jun. 2015.

[22] Organização para Cooperação E Desenvolvimento Econômico (OCDE). Manual de Oslo: diretrizes para coleta e interpretação de dados sobre inovação. Brasil: ARTI /FINEP, 1997.

[23] Pérez, M. P.; Sánchez, A. M.; Carnicer, P. $\mathrm{L}$. Benefits and barriers of telework: perception differences of human resources managers according to company's operations strategy. Zaragoza, Espanha: Technovation, 2002.

[24] Reed, A., Hunton, J. E., \& Norman, C. S. (2006). A postmodern stakeholder analysis of telework, Advances in Accounting Behavioral Research, Volume 9, 2006, Pages 209-235 doi:10.1016/S1475-1488(06)09008-9

[25] Rietveld, P. Telework and the transition to lower energy use in transport: On the relevance of rebound effects, Environmental Innovation and Societal Transitions, vol. 1, no. 1, pp. 146-151, 2011.

[26] Sociedade Brasileira de Teletrabalho E Teleatividades - Sobratt. <http://www.sobratt.org.br/> Acesso em: 20 out. 2014.

[27] Sociedade Brasileira de Teletrabalho E Teleatividades; Estudo de estratégias de gestão de mobilidade via teletrabalho e teleatividades no estado de São Paulo. Resolução SMA No 24 de 10 de abril de 2013

[28] Yuthas, K., Dillard, J.F. Ethical development of advanced technology: A postmodern stakeholder perspective. Journal of Business Ethics, 19 (1), pp. 35-49, 1999.

[29] Winter, V. R. L. Teletrabalho: uma forma alternativa de emprego. São Paulo: LTr, 2005.

[30] Wright, C. Global Banks, the Environment, and Human Rights: The Impact of the Equator Principles on Lending Policies and Practices. Global Environmental Politics, Volume 12, Number 1, February 2012, pp. 56-77. 


\section{Bapítulo 11}

\section{INTELIAGRI - SISTEMA INTELIGENTE PARA GESTÃO DO USO DE RECURSOS HIDRICOS E INSUMOS NA AGRICULTURA}

\section{Jose Airton Chaves Cavalcante Junior \\ Angel Ramon Sanchez Delgado \\ Maria Claudia Rodriguez \\ Jose Antonio Carlos Canedo de Medeiros}

Resumo: Com este trabalho objetivou-se desenvolver um modelo computacional inteligente denominado INTELIAGRI para ser aplicado ao agronegócio. Ele faz uso de uma rede neuronal artificial para determinar a produtividade de uma cultura em relação aos insumos utilizados, e de um algoritmo genético para a maximização da receita líquida com recursos limitados. Procurando-se fazer uma avaliação do modelo, realizamos uma experiência numérica com base nos dados apresentados na literatura para as culturas alface americana e meloeiro. Comparando os resultados obtidos com os apresentados de forma analítica, pode-se concluir que a ferramenta apresentada constitui uma alternativa confiável na tomada de decisões econômicas.

Palavras chave: inteligência artificial, função resposta, agronegócio, lâmina de água, dose de nitrogênio 


\section{INTRODUÇÃO}

Os economistas designam as relações existentes entre a produtividade e os fatores de produção pelo termo função produção ou resposta, definida como a relação física entre quantidades utilizadas de certo conjunto de insumos e as quantidades físicas máximas que se podem obter do produto, para uma dada tecnologia conhecida. Assim, para cada cultura existe a chamada função "produção-insumos-cultura", que é a resposta à utilização de determinados insumos necessários para seu desenvolvimento (por exemplo; água e nitrogênio), sendo esta resposta variável de acordo com cada tipo de cultura, solo e clima. O conhecimento da função de produção permite-nos saber quanto de água e nitrogênio utilizar para a produção demandada. Esta informação é fundamental para o agricultor, pois reduz seus custos e maximiza a produção.

O emprego das funções respostas à produção e receita líquida na análise dos resultados de experiências agrícolas é bastante difundido (Pereira et al, 2003, Frizzone et al., 2005, Monteiro et.al., 2006, Peixoto et.al., 2007, Marques Silva et.al., 2008, Carvalho et al., 2009, Dos Santos, J. L. C. et al., 2014, Delgado A. R. S. et al., 2014). Em geral, o problema é encontrar uma solução ótima da combinação insumo-produto, que maximize a produção e a receita líquida separadamente, sujeita às restrições de recursos pré-fixadas e a uma estrutura de custos e preços dada. Vamos supor que o benefício é proporcional ao preço da cultura vezes a produção em função da lâmina de água e do nitrogênio. Nesse caso, a receita líquida é o benefício menos o custo da água vezes a lâmina de água, menos o custo do nitrogênio vezes a correspondente dose, e o problema a ser tratado é a maximização da receita líquida com insumos (água-nitrogênio) limitados.

A água e o nitrogênio são fundamentais para o desenvolvimento das culturas, e quando são correlacionadas com a produção obtida, temse a função de produção água-nitrogêniocultura. Se estas funções fossem conhecidas com precisão, seria possível selecionar com exatidão o nível ótimo de água e nitrogênio para uma situação em particular; mas tais funções estão restritas a grandes variações dificultando as previsões. Variações climáticas, atributos físicos do solo, uniformidade de distribuição da água pelo sistema de irrigação e muitos outros fatores, tornam difícil prever a produtividade das culturas. Na prática se geram regressões lineares para representar "boas aproximações" das funções de produção. A qualidade do ajustamento, que indica a proporção de variação da função é indicada por uma unidade descritiva conhecida como coeficiente de determinação $\left(r^{2}\right)$.

O manejo adequado da água é fundamental, considerando que o setor agrícola é o maior consumidor de água e que os recursos hídricos são essenciais e estratégicos no desenvolvimento da agricultura. Segundo Figueiredo, et al.(2008), uma mudança fundamental deverá ocorrer nas práticas da irrigação nos próximos anos, em decorrência das pressões econômicas sobre os agricultores, da crescente competição pelo uso dos recursos e dos impactos ambientais da irrigação. Eles acham que tais fatores deverão motivar uma mudança do paradigma da irrigação, enfocando-se mais a eficiência econômica do que a demanda de água das culturas. Considerando que na atualidade os custos de adubação nitrogenada; especificamente nitrogênio ( $N$ ), são cada vez mais variáveis e que a demanda no Brasil cresce a cada dia, é necessário que sejam respeitadas as questões ambientais referentes à preservação dos solos, como peça fundamental para uma agricultura sustentável.

Neste artigo apresenta-se um modelo computacional inteligente denominado INTELIAGRI que maximiza a produção e a receita líquida (separadamente) em função da água e do nitrogênio, dentro de uma caixa bidimensional de restrições e baseado na construção de uma rede neuronal artificial (RNA) para determinar a produtividade de uma cultura em relação aos insumos utilizados, e de um algoritmo genético (AG) para a maximização da receita líquida com recursos limitados.

As redes neuronais artificiais são modelos de processamento computacional cujo princípio de funcionamento se baseia na forma com que os neurônios e suas associações com outros neurônios funcionam no cérebro humano (Braga et al., 2007, Liden, 2008). É uma forma de computação não algorítmica derivada de modelos matemáticos que tenta simular o funcionamento de neurônios biológicos (Coppin et al., 2012).

Os algoritmos genéticos (GAs) são métodos de otimização adaptativos inspirados nas 
idéias de Darwin sobre a seleção natural das espécies (Holland, 1975), e tem sido aplicado com sucesso na otimização de problemas complexos dos quais geralmente se tem pouca informação a priori, como por exemplo na minimização de problemas de programação polinomial e de otimização combinatória (Goldberg, 1989 e Michalewicz, 1999).

\section{MATERIAL E MÉTODOS}

As redes neuronais artificiais (RNA) são construídas a partir da interligação de um grande número de neurônio em que os neurônios podem ser organizados em uma ou mais camadas. As redes neuronais artificiais são classificadas em função da forma de conexão dos neurônios. Neste trabalho consideramos redes com alimentação para frente (feed-forward). Nestas redes, os neurônios são organizados em camadas e o sinal de entrada é propagado passando sucessivamente por todas as camadas até atingir a camada de saída produzindo um sinal de saída. Usamos redes de base radial (RBF) conforme mostrado na figura 1.

Figura 1 - Rede de Base Radial

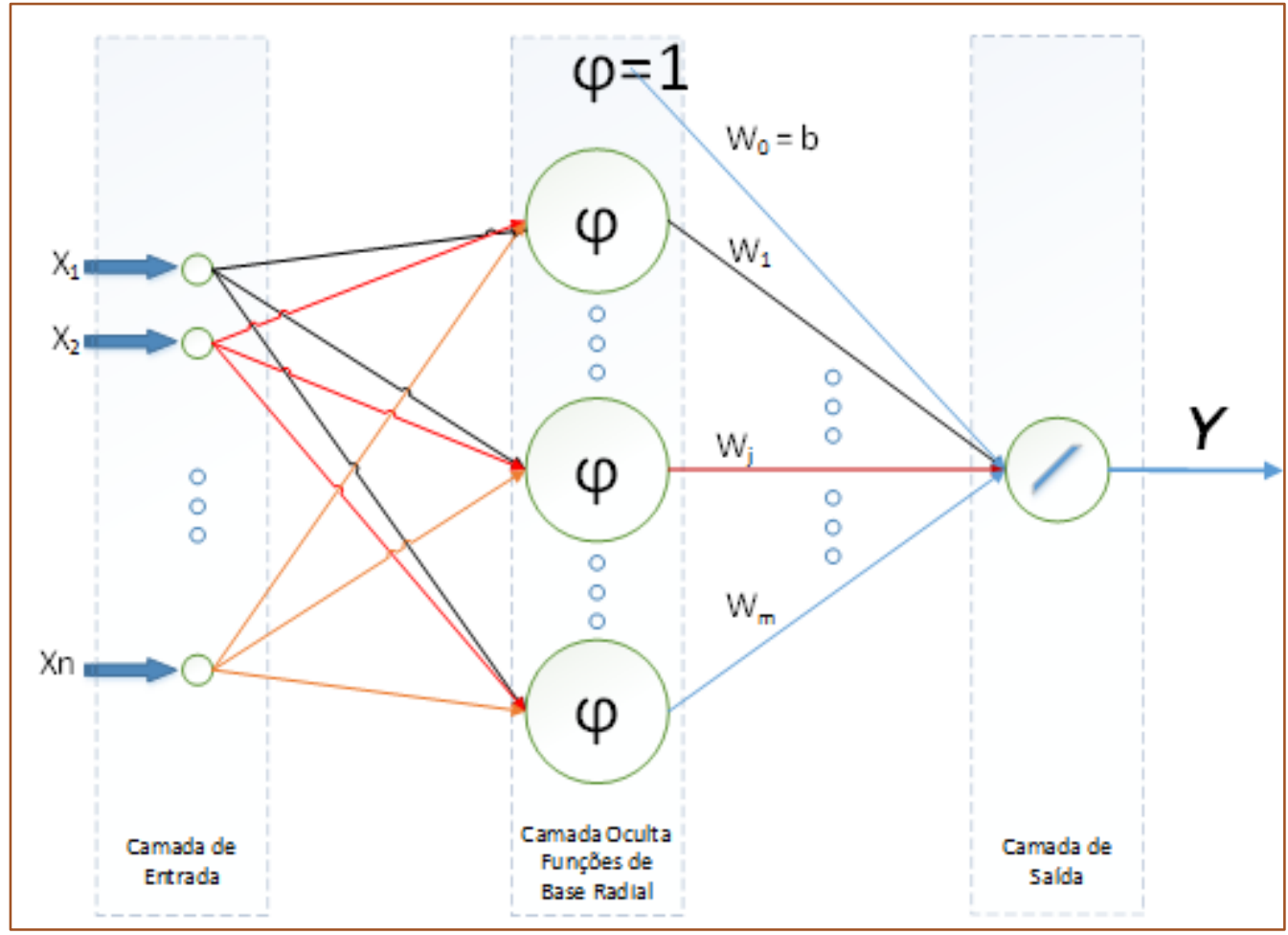

A camada de entrada tem a função de receber os dados e repassá-los a todos os nós da camada oculta. A camada oculta é responsável por fazer uma transformação não-linear do espaço de entrada enviando-os para a camada de saída. A dimensão do espaço oculto está relacionada com a capacidade da rede de aproximar um mapeamento entrada-saída; ou seja, quanto mais alta for a dimensão do espaço oculto, mais precisa será a aproximação. Finalmente a camada de saída, que é linear, produz como resposta da rede, uma combinação linear dos valores produzidos pela camada oculta.

O INTELIAGRI é um modelo baseado em redes neuronais artificiais e algoritmos genéticos cujo diagrama de blocos está representado na figura 2 . 
Figura 2 - Diagrama em blocos do INTELIAGRI

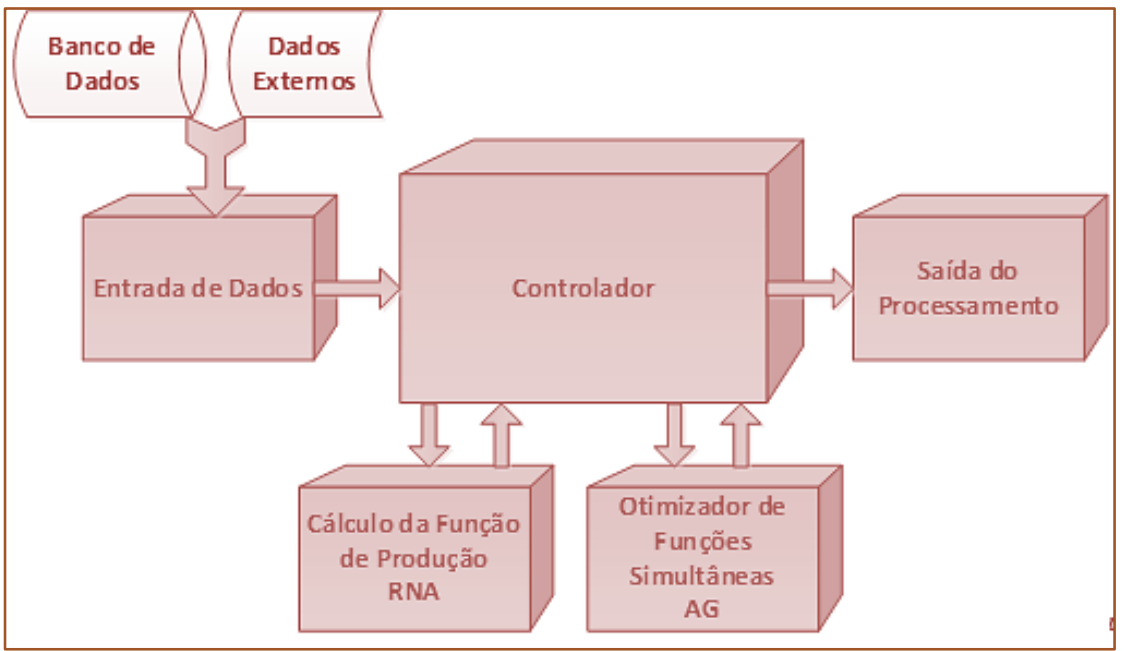

Para a rede resolver um problema de ajuste de curva em um espaço de alta dimensionalidade, "aprender" é equivalente a encontrar uma superfície em um espaço multidimensional que forneça o melhor ajuste para os dados de treinamento, observando que esta medida é feita em um sentido estatístico (interpolação de dados), neste objetivo usamos as redes neuronais.

A outra técnica de inteligência artificial utilizada neste trabalho, são os algoritmos genéticos (AG), serão usados para a maximização da receita líquida em função da água e o nitrogênio. Esta é uma técnica de otimização que irá buscar o ponto ótimo da função de produção (máximo ou mínimo); o resultado obtido é uma boa solução aproximada, isto é, com um erro baixo ou aceitável.

Os algoritmos genéticos fazem parte de conjunto de técnicas conhecidas como algoritmos evolucionários, sendo uma técnica de otimização inteligente baseada na metáfora do processo biológico da evolução natural (genética e seleção natural), são algoritmos estocásticos (probabilísticos), tanto na fase de inicialização da população quanto na fase de evolução (durante a seleção dos pais principalmente). Embora chamados de algoritmos, na verdade são heurísticas que não asseguram a obtenção do melhor resultado possível em todas as suas execuções, isto é, se não for o próprio ponto de ótimo estará na sua vizinhança (Linden, 2008).

Figura 3 - Esquema de funcionamento de um AG básico

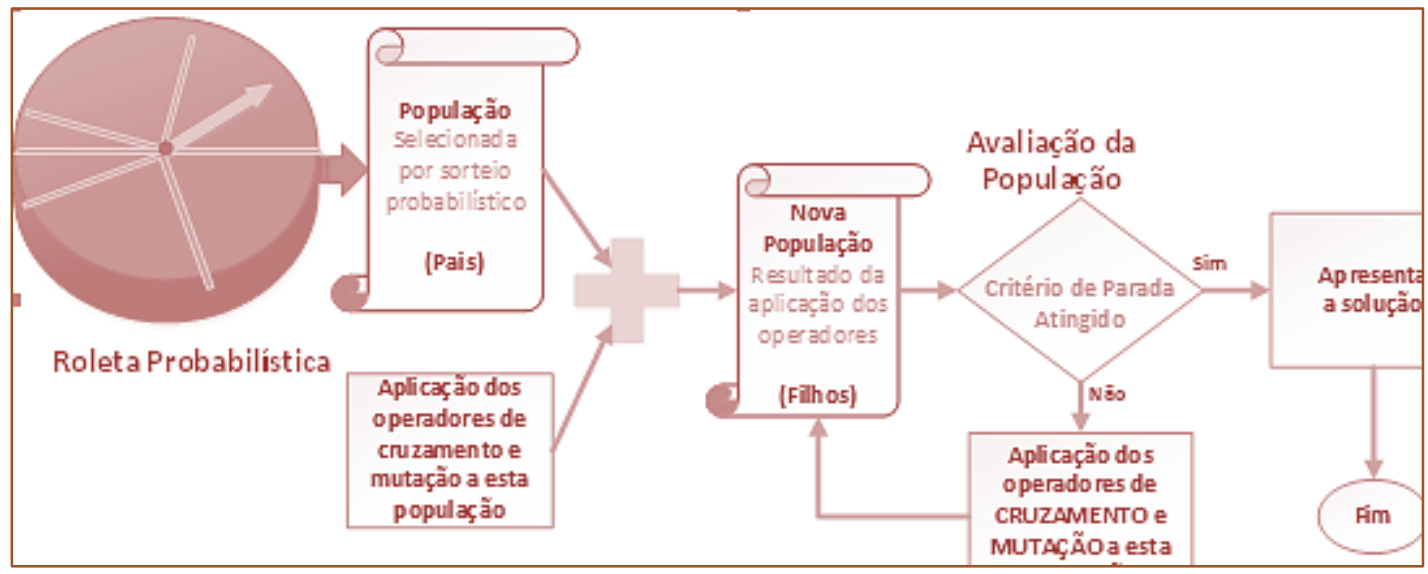


O algoritmo genético trabalha avaliando um conjunto de possíveis soluções simultaneamente (em paralelo), que chamamos de população; cada indivíduo que compõe a população é uma solução candidata e cada indivíduo tem um valor associado a ele que chamamos de fitness ou aptidão (um valor ou nota); que serve para medir a capacidade daquele indivíduo de resolver um determinado problema. Os operadores genéticos são aplicados sobre a população de tal modo que os mais aptos terão mais chance de sobreviver para constituir uma nova população (Goldberg, 1989).

Para testar o INTELIAGRI, foram selecionadas as culturas alface americana (Marques Silva et.al. 2008) (equação 1) e meloeiro (Monteiro et.al. 2007) (equação 2).

$$
\begin{aligned}
& y(w, n)=-12.490+388,1 w-6,02 n-1,042 w^{2} \\
& -0,04563 n^{2}+0,1564 w n
\end{aligned}
$$

Onde: $y(w, n)=$ Produtividade da alface americana em kg. $h a^{-1} ; r^{2}=0,8311$.

$w$ = Lâmina de água, em mm;

$n=$ Dose de nitrogênio, em $\mathrm{kg} \cdot h a^{-1}$

em que o domínio de $w$ e $n$ está restrito à caixa bidimensional $[0,250] \times[100,240]$.

e:

$y(w, n)=34,16737 n+70,77509 w-$ $0,05781 w^{2}-0,07612 n^{2}$

(2)

Onde: $y(w, n)=$ produtividade de meloeiro em kg.ha-1; $r^{2}=0,9962$

em que o domínio de $w$ e $n$ está restrito à caixa bidimensional :[0, 700]X[0, 350].

O preço adotado para alface americana foi de $R \$ 0,80 \mathrm{~kg}^{-1}$. O custo para água de $R \$ 0,44$ $m m^{*} \mathrm{ha}^{-1}$ e para nitrogênio $\mathrm{R} \$ 2,09 \mathrm{~kg}^{-1}$. Já para o melão foi calculado um preço de $\mathrm{R} \$ 0,40 \mathrm{~kg}^{-}$ 1 e de $\mathrm{R} \$ 0,134 \mathrm{~mm}^{*} \mathrm{ha}^{-1}$ para água. $\mathrm{Na}$ época, o preço do nitrogênio era $\mathrm{R} \$ 2,33 \mathrm{~kg}^{-1}$.
Note que o coeficiente de determinação $\left(r^{2}\right)$ da alface americana indica que $83,11 \%$ da variação do rendimento em função dos níveis de água e nitrogênio podem ser explicadas pela eq. 1. Analogamente para a cultura do melão, a eq. 2, indica 99,62\% de ajuste.

Segundo Frizzone, a agricultura irrigada frequentemente se defronta com funções de produção não lineares, indicando a obtenção de retornos decrescentes ao fator variável, e essas funções podem ser tratadas por aproximações lineares e a otimização pode ser feita utilizando-se a técnica de programação separável (PS). Essa abordagem permite transformar um problema de programação não linear em um problema de programação linear, possível de ser resolvido usando o conhecido método SIMPLEX (Frizzone et al., 2005). Na busca de técnicas não convencionais na otimização agrícola que trabalhem diretamente com a função objetivo (evitando, por exemplo, linearização por partes); Carvalho et al., 2009, Delgado \& Ventura, 2014 apresentaram procedimentos baseados no método barreira logarítmico (MBL).

\section{RESULTADOS E DISCUSSÃO}

A seguir apresentamos os resultados obtidos pelo INTELIAGRI que serão confrontados com o resultado obtido pelo método que utiliza programação separável (PS) (Marques e Monteiro, 2006 e 2008) e com o resultado obtido pelo Método de Barreira Logarítmica MBL (Delgado e Ventura, 2014), na otimização dos insumos - água e nitrogênio, nas culturas da alface americana e do meloeiro.

No módulo RNA do INTELIAGRI, os dados utilizados serviram para traçar a função de produção das culturas em relação aos insumos de água e nitrogênio. A seguir, na figura 4, é apresentada a tela do INTELIGRI, no treinamento de uma RNA mostrando a curva de aprendizado da RNA para a alface americana. 
Figura 4 - Treinamento de uma RNA - Curva de aprendizagem da RNA para Alface Americana

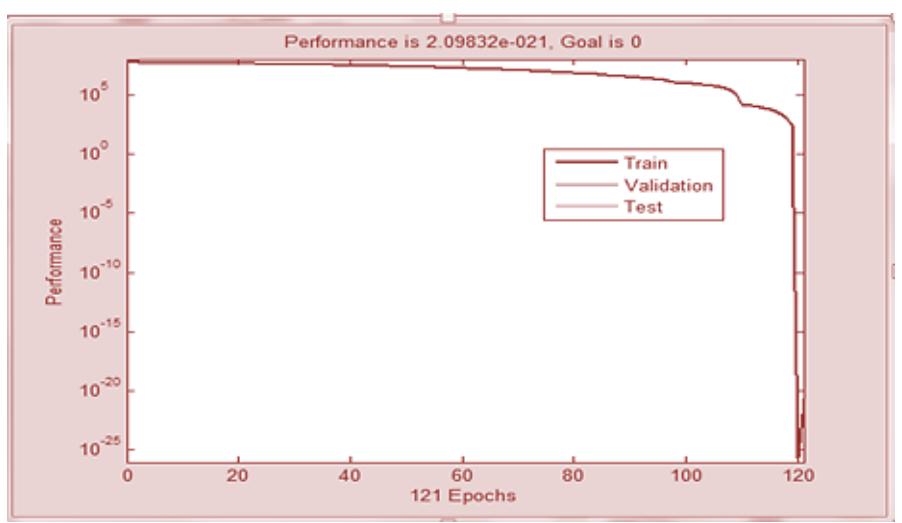

A figura 5 apresenta três gráficos que correspondem respectivamente: (a) dados de produção experimental (Marques Silva, 2008), (b) curva de produção para a alface americana obtida computacionalmente pelo INTELIAGRI, e (c) mostra o erro entre os dados de produção e a função de produção.

Figura 5 - Função de Produção da Alface Americana - (a) original, (b) obtida computacionalmente e (c) erro

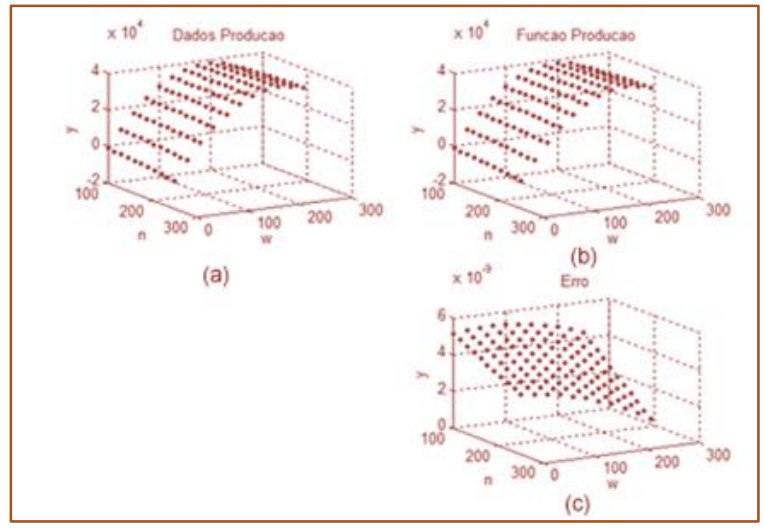

Para maximização da receita líquida na produção da cultura alface americana, o INTELIAGRI obteve um valor da produtividade máxima de $26.903 \mathrm{~kg}$. ha ${ }^{-1}$, com 199,55 $\mathrm{mm} \cdot \mathrm{ha}^{-1}$ de água e 234,96 kg. ha ${ }^{-1} \mathrm{de}$ nitrogênio e receita líquida de $R \$ 20.931$ por hectare com 203,98 mm. ha ${ }^{-1}$ de água e 240 kg. ha-1 de nitrogênio (ver Figura 6). Os resultados são compatíveis com os obtidos em Marques Silva et.al. (2008), onde foi registrada uma produtividade de 26.959,93 kg. ha-1 com 205,26 mm de água e 257,14 kg. $\mathrm{ha}^{-1}$ de nitrogênio. 
Figura 6 - Resultados do AG na otimização da receita líquida da cultura de alface americana (a) Função de produção; (b) Trajetória de otimização do AG; (c) Função receita líquida e (d) Trajetória do AG para máxima receita líquida.

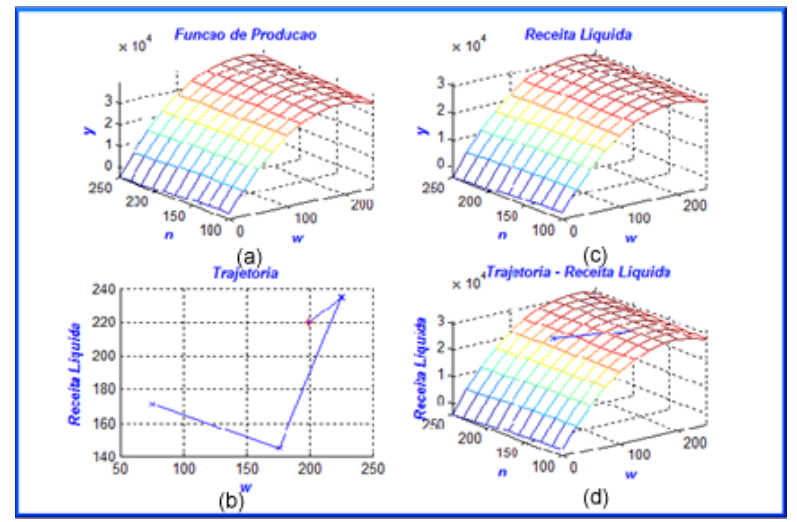

A seguir na tabela 1, apresentamos um comparativo entre os valores obtidos (Lâmina

de Água e Dose de Nitrogênio) com os métodos.

Tabela 1: Comparativo entre métodos para a alface americana.

\begin{tabular}{|l|l|l|l|} 
& Inteliagri & Mbl & Ps \\
\hline Água $\left(\mathrm{mm}_{\mathrm{ha}}{ }^{-1}\right)$ & 199,55 & 204,99 & 205,26 \\
\hline Nitrogênio $\left(\mathrm{Kg}^{-h^{-1}}\right)$ & 234,96 & 249,99 & 257,14 \\
\hline Agua e Nitrogênio & - & $2,72 \%$ e $6,40 \%$ & $2,86 \%$ e $9,44 \%$ \\
\hline
\end{tabular}

$\mathrm{Na}$ última linha da tabela tem-se o comparativo entre INTELIAGRI e os dois outros modelos, em termos percentuais, para a lâmina de água e dose de nitrogênio, respectivamente. Note-se que os valores encontrados são próximos nos três modelos, mantendo uma equivalência nos resultados, como era de se esperar.
Da mesma forma que no caso da alface americana, foi feita a análise dos resultados obtidos com a aplicação do INTELIAGRI para o meloeiro. A figura 7 a seguir apresenta a tela do INTELIGRI, no treinamento de uma RNA mostrando a curva de aprendizado da RNA para o meloeiro.

Figura 7 - Treinamento de uma RNA - Curva de aprendizagem da RNA para o Meloeiro.

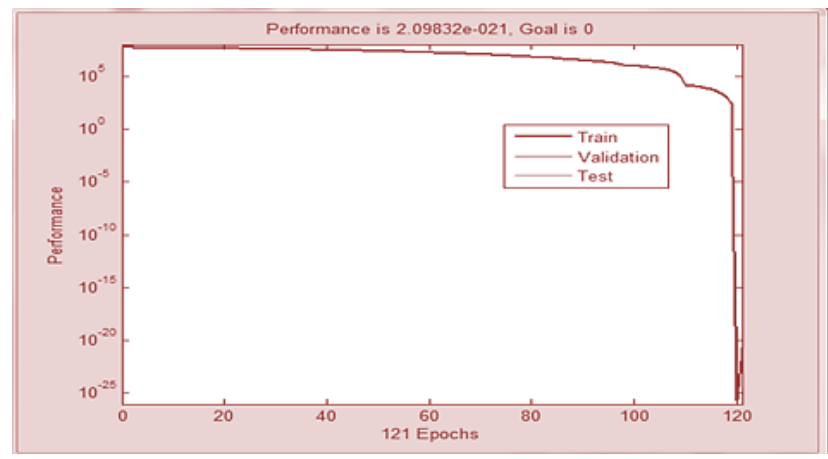


A figura 8 apresenta três gráficos que correspondem respectivamente: (a) dados de produção experimental (Marques Silva, 2008), (b) curva de produção para o meloeiro obtida computacionalmente pelo INTELIAGRI, e (c) mostra o erro entre os dados de produção e a função de produção.

Figura 8 - Função de Produção do Meloeiro - (a) original, (b) obtida computacionalmente e (c) erro

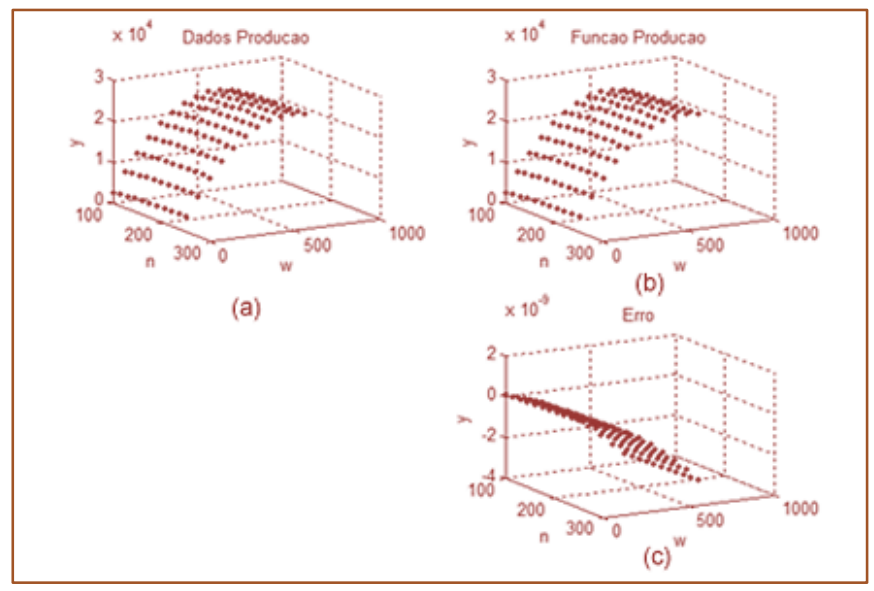

Para maximização da receita líquida para a produção do Meloeiro, o INTELIAGRI obteve um valor da produtividade máxima. 25.467 ha $^{-}$ 1 e uma receita líquida de $R \$ 9.546,96 \mathrm{ha}^{-1}$ com $630,11 \mathrm{~mm} \cdot$ ha $^{-1}$ de água e $234,97 \mathrm{~kg} \cdot \mathrm{ha}^{-1}$ de nitrogênio (figura 9). Os resultados também são compatíveis com os obtidos em Monteiro et.al. (2008), onde foi registrada uma produtividade de $25.384,30 \mathrm{~kg}$. ha ${ }^{-1} \mathrm{com}$ $609,20 \mathrm{~mm}$ de água e 186,23 kg. ha-1 de nitrogênio.

Figura 9 - Resultados do AG na otimização da receita líquida da cultura do meloeiro: (a) Função de produção;

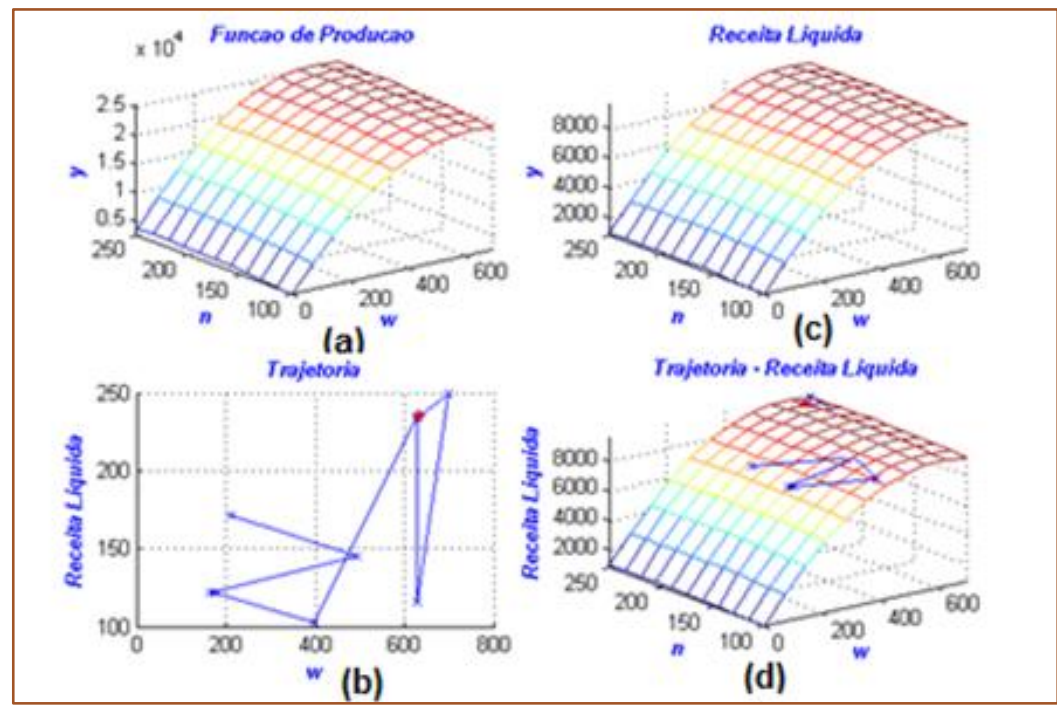

(b) Trajetória de otimização do AG; (c) Função receita líquida e (d) Trajetória do AG para máxima receita líquida.
A seguir na tabela 2 apresentamos um comparativo entre os valores obtidos (Lâmina de Água e Dose de Nitrogênio) com os métodos. Novamente que os valores encontrados são próximos nos três modelos, 
Tabela 2: Comparativo entre métodos para o meloeiro

\begin{tabular}{|c|c|c|c|}
\hline & Inteliagri & Mbl & Ps \\
\hline Água $\left(\mathrm{mm} \mathrm{ha}^{-1}\right)$ & 630,11 & 612,30 & 609,20 \\
\hline Nitrogênio $\left(\mathrm{Kg}^{-1} \mathrm{ha}^{-1}\right)$ & 234,97 & 224,30 & 186,23 \\
\hline Agua e Nitrogênio & - & $2,83 \%$ e $4,54 \%$ & $3,31 \%$ e $20 \%$ \\
\hline
\end{tabular}

\section{CONCLUSÕES}

1. Partindo da premissa de que a administração de atividades agropecuárias (Agronegócios) requer conhecimentos técnicos e financeiros, não distribuídos de forma igualitária entre pequenos, médios e grandes produtores rurais, o acesso a um sistema operacional de fácil utilização, favoreceria a inclusão digital no campo associada à otimização dos recursos.

2. Em situações onde a tomada de decisão está relacionada com a alocação de recursos limitados, o INTELIAGRI favorece a racionalidade do agricultor, pois auxilia na otimização da produção e receita líquida agrícola com recursos limitados.

3. O presente trabalho, através do uso de técnicas de inteligência artificial, quais sejam as redes neuronais e algoritmos genéticos, culminou com o desenvolvimento de uma ferramenta computacional e sua aplicação na solução de problemas de otimização do uso de insumos na agricultura e maximização da receita líquida para o produtor rural. Para testar e validar o modelo desenvolvido foram utilizadas massas de dados advindas do trabalho de outros pesquisadores disponíveis na literatura.

4. Os resultados obtidos mostraram que - INTELIAGRI atendeu aos objetivos propostos, indicando que essa ferramenta computacional inteligente pode ser utilizada para a otimização do uso de recursos hídricos e insumos com o aumento da receita líquida, tendo sido testado e validado através de comparação com os trabalhos de Marques e Silva (2008) e de Ventura e Sanchez (2009), na otimização das culturas da alface americana e do meloeiro.
5. A utilização das ferramentas de Inteligência Artificial usadas pelo INTELIAGRI permite a sua aplicação na otimização de culturas usando diversos insumos, podendo trabalhar com funções de produção ndimensionais, mesmo que estas apresentem descontinuidades, sem aumentar a complexidade do seu algoritmo.

6. O desenvolvimento de códigos computacionais com base no INTELIAGRI, em parcerias com cooperativas agrícolas, pode contribuir para o avanço na disponibilização de ferramentas para auxílio do planejamento ótimo de plantios pelo aumento da eficiência do uso da água e insumos, e, em geral ao fortalecimento tecnológico da agricultura irrigada.

7. Como trabalhos futuros pretende-se realizar experimentos com outras culturas levando em conta um número maior de insumos e a determinação dos parâmetros desses insumos para o ponto de produção ótima.

\section{AGRADECIMENTOS}

Os autores deste trabalho agradecem ao Programa de Pós graduação em Ciência, Tecnologia e Inovação em Agropecuária PPGCTIA/UFRRJ - Brasil, na figura da coordenadora Lucia Helena dos Anjos e corpo docente, à Capes pelo patrocínio às atividades desta pesquisa possibilitando o intercâmbio junto à "Universidad Nacional de Rio Cuarto" (UNRC) - Argentina e à própria UNRC por todo apoio prestado durante a realização desta pesquisa e ao seu corpo docente também. 


\section{REFERÊNCIAS}

[1] Braga, A.P.; Carvalho, A.P. de L. F.; Ludermir, T. B. Redes Neuronais Artificiais: Teoria e Aplicações. $2^{\underline{a}}$ edição. Rio de Janeiro, editora LTC, 2007, 226 p.

[2] Beale, M. H.; Hagan, M. T.; Demuth, H. B. Neural Network Toolbox - User Guide R2011b, EUA, Mathworks Inc. 2011, 404 p.

[3] Carvalho, D. F.; Delgado, A. R. S.; Oliveira, R. F.; Silva, W. A.; Forte, V. L.; Maximização da produção e da receita agrícola com limitações de água e nitrogênio utilizando método de pontos interiores. Engenharia Agrícola, Jaboticabal, v.29, n.2, p.321-327, 2009.

[4] Coppin, B. Inteligência Artificial, Rio de Janeiro, RJ, editora LTC, 2012, 636 p.

[5] Delgado, A. R. S., Ventura Drumond, S.; Experiência numérica na maximização da produção e receita agrícola do meloeiro e da alface americana. Pesq. Oper. Para o Desenvolvimento, v.6, n.3, p.332-342, 2014.

[6] Dos Santos Júnior J. L. C., Frizzone, J. A., Da Silva Paz, V. P.; Otimização do uso da água no perímetro irrigado Formoso aplicando lâminas máximas de água. Irriga, Botucatu, v.19, n.2,p. 196-206, 2014

[7] Figueiredo Garcia De, M.; Frizzone, J. A.; Pitelli, M. M.; Rezende R.; 2008. Lâmina ótima de irrigação do feijoeiro, com restrição de água, em função do nível de aversão ao risco do produtor. Acta Sci. Agron., Maringá, v.30,n.1,p. 81-87, 2008.

[8] Frizzone, J. A.; Andrade Junior, A. S. de; Souza, J. L. M. de; Zocoler, J. L.; Planejamento da irrigação. Análise de decisão de investimento. 1. Ed. Brasília: Embrapa Informação Tecnológica, 627 p., 2005.

[9] Goldberg, D. E., Genetic Algorithms in Search, Optimization an Machine Learning, Addison Wesley Publishing Company, USA, 1989
[10] Holland, J. H., Adaptation in Natural and Artificial Systems, University of Michigan Press, USA, 1975

[11] Liden, R. Algoritmos Genéticos - Uma importante ferramenta da inteligência computacional. 2a $2^{\underline{a}}$ ed. Rio de Janeiro, editora Brasport, 2008, 428 p.

[12] Marques Silva, P. A.; Pereira Magela, G.; Reis, R.; Lima, L. A.; Taveira J. H.; Função de resposta da alface americana aos níveis de água e adubação nitrogenada. Ciênc. Agrotec., v. 32, n.4, p.1266-1271, 2008.

[13] Michalewicz, Z., Genetic Algorithms + Data Structures = Evolution Programs, Springer, NY, USA, 1999

[14] Monteiro, R. O. C.; Colares, D. S.; Costa T. R. N.; Leão, M. C. S.; de Aguiar, J. V.; Função de resposta do meloeiro a diferentes lâminas de irrigação e doses de nitrogênio. Hortic. Bras. v. 24, n. 4, p.455-459, 2006

[15] Monteiro, R. O. C.; Nonato Távora, R.; Leão, M. C. S.; de Aguiar, J. V.; Aspectos econômicos da produção de melão submetido a diferentes lâminas de irrigação e doses de nitrogênio. Irriga, Botucatu, v.12, n.3, p.364-376, 2007.

[16] Peixoto de Castro R.; Nonato Távora, R.; DA Silva Clemente A. L.; Gomes Filho, R.; Modelos de decisão para otimização econômica do uso da água em áreas irrigadas da fazenda experimental Vale do Curu, Pentecoste-CE. Irriga, Botucatu, v.12, n.3, p.377-392, 2007.

[17] Pereira, O. C. N.; Bertonha, A.; Freitas, P. S. L. de; Gonçalves, A. C. A.; Rezende, R.; Silva, F. A. da; 2003. Produção de alface em função de água e nitrogênio. Acta Scientiarum Agronomy, Maringá, v. 25, n.2, p. 381-387, 2003. 


\section{Bapítulo 12}

\section{APROVEITAMENTO DE ENERGIA EÓLICA EM UMA ACADEMIA DE GINÁSTICA NA CIDADE DE CABO FRIO}

\section{Filipe Borges de Oliveira \\ Josaura de Oliveira Leite \\ Leonardo Rafael Brum}

Resumo: Este projeto monográfico visa mostrar uma abordagem total sobre energia eólica e suas características no Brasil e no mundo. Uma das iniciais formas de energia conhecida, o vento já era concentrado para mover barcos à vela de pano em 3.500 a.C.. Em terra os primeiros moinhos de vento talvez tenham surgidos na Pérsia por volta de 700 d.C. As pás rodavam horizontalmente e eram ligadas diretamente a pedras de moenda que fragmentavam grãos. A força do vento também é utilizada para irrigar terras áridas e drenar alagados, e ainda como fonte alternativa de energia para gerar eletricidade. Tendo como objetivo geral, a implantação desse tipo de captação de energia através de ventos para a cidade de Cabo Frio, uma vez que esta se mostra favorável climaticamente falando, por apresentar ao longo do ano, uma grande quantidade de ventos suficientes para a distribuição de energia à toda população deste município. Como questão norteadora, pergunta-se se seria possível junto à academia em cabo frio e no meio ambiente e, por que não, junto à ampla, disponibilizar tal equipamento e beneficiar a população com tamanha tecnologia retirada dos ambientes naturais da cidade? Uma vez que a energia eólica no Brasil é tão pouco aproveitada. 


\section{I - INTRODUÇÃO}

Nomeia-se energia eólica a energia cinética presente nas massas de ar em movimento (vento). Sua aplicação acontece através do câmbio da energia cinética de transporte em energia cinética de rotação, com o trabalho de turbinas eólicas, também chamadas aerogeradores, para gerar a eletricidade, ou cataventos (e moinhos), para serviços mecânicos como bombeamento d'água.

Bem como a energia hidráulica, a energia eólica é usada há milhares de anos com as mesmas intenções, a saber: bombeamento de água, trituramento de grãos e outros empregos que englobam energia mecânica. Para gerar a eletricidade, as primeiras tentativas apareceram no final do século XIX, porém apenas um século após, com o conflito internacional do petróleo (década de 1970), é que teve importância e investimentos satisfatórios para viabilizar o desenvolvimento e aproveitamento de equipamentos em tamanho comercial.

A primeira turbina eólica comercial conectada à rede elétrica pública foi montada em 1976, na Dinamarca. Recentemente, houve mais de 30 mil turbinas eólicas em atividade no mundo. Em 1991, a Associação Européia de Energia Eólica instituiu como propostas a construção de $4.000 \mathrm{MW}$ de energia eólica na Europa até o ano 2000 e $11.500 \mathrm{MW}$ até o ano 2005. Essas e outras propostas estão sendo desempenhadas bem antes do aguardado (4.000 MW em 1996, 11.500 MW em 2001). As propostas recentes são de $40.000 \mathrm{MW}$ na Europa até 2010. Nos Estados Unidos, o parque eólico que há é de mais ou menos 4.600 MW instalados e com um desenvolvimento por ano em torno de $10 \%$. Considera-se que em 2020 o mundo terá 12\% da energia originada pelo vento, com uma competência instalada de mais de 1.200GW (WINDPOWER; EWEA; GREENPEACE, 2003; WIND FORCE, 2003).

Atuais desenvolvimentos tecnológicos (sistemas desenvolvidos de transmissão, ótima aerodinâmica, estratégias de domínio e operação das turbinas etc.) têm minimizado custos e aperfeiçoado a atuação e a confiança dos equipamentos. O valor dos equipamentos, que era um dos relevantes obstáculos a aplicação comercial da energia eólica, diminuindo-se consideravelmente nas últimas duas décadas. Projetos eólicos em 2002, usando atualizadas turbinas eólicas em condições adequadas, apresentaram custos na ordem de 820/kW instalado e produção de energia a 4 cents/kWh (EWEA; GREENPEACE, 2003).

\subsection{TEMA}

O aproveitamento deste tipo de energia decorrente dos avanços tecnológicos do setor contribuiu bastante para a definição deste tema como um trabalho de estudo em fase do término do curso de graduação de Engenharia de produção. Com isso, o foco desse projeto é ressaltar a importância do uso da energia renovável neste início do século $X X I$ e demonstrar o diferencial da energia proveniente dos ventos.

\subsection{PROBLEMA}

Para justificar o desenvolvimento de energias do tipo "renováveis" podemos analisar, primeiramente, a atual dependência que temos de recursos energéticos nãorenováveis que pela estimativa se pode prever a futura escassez que haverá dos mesmos. Outro fator importante é a busca permanente de novas opções tecnológicas energéticas que não geram degradação da atmosfera, do solo, de recursos hídricos e do meio ambiente de uma maneira geral, sempre levando em conta as fontes de energia intermináveis que temos no planeta e questiona-se o porquê da energia eólica no Brasil ser tão pouco aproveitada e porque se deve mudar isso.

\subsection{OBJETIVOS DA PESQUISA}

Este trabalho tem como objetivo a análise do aproveitamento da energia eólica numa academia de ginástica que como todas as demais energias possuem certas vantagens e desvantagens; o que a faz diferente não é só um fato ou outro, é o conjunto como um todo. Além de esta ser uma fonte de energia renovável, ela pode ser utilizada para o fornecimento de energia para pequenas populações onde não há um acesso de energia direto e também não necessita de grandes investimentos.

\subsubsection{OBJETIVO GERAL}

Este trabalho tem como objetivo geral analisar o aproveitamento da energia eólica numa academia de ginástica, que como todas as 
demais energias possuem certas vantagens e desvantagens, pois além de ser uma fonte de energia renovável, ela pode ser usada para o abastecimento de energia para pequenas populações onde não há um acesso de energia direto e também não necessita de grandes investimentos.

\subsubsection{OBJETIVOS ESPECÍFICOS}

Como objetivos específicos:

- Estudar regiões no Brasil e na Região litorânea, Cabo Frio que utilizam a energia eólica:

- Verificar climas favoráveis para a implantação da energia renovável;

- Avaliar a implantação do equipamento na região dos lagos em uma academia de ginástica.

\subsection{CONTRIBUIÇÃO CIENTÍFICA}

Hoje em dia, na grande maioria dos casos, o uso da energia eólica acontece com o intuito de gerar energia elétrica para, provavelmente, bombear água, aquecer ambientes, ligar várias máquinas, moer grãos, usos domésticos ou de pequenas empresas, entre outros. Isso acontece pelo fato da eletricidade ser uma maneira muito cômoda e usual de distribuição de energia.

Com esse estudo pormenorizado, contribuirá de forma positiva na aquisição e implantação do equipamento de energia eólica quando pesquisado as regiões brasileiras e especialmente na validação deste na região litorânea, mais especificamente em academia de ginástica na cidade de Cabo Frio.

\subsection{ASPECTOS ENVOLVIDOS \\ METODOLÓGICOS}

Nesta seção serão mostradas as etapas que serão utilizadas para esta pesquisa de ordem quali-quantitativa e descrever a aplicação das etapas do modelo que será utilizado, definindo um referencial de partida acerca do tema escolhido.

Pesquisa de caráter quanti-qualitativa com o objetivo em explicar por meio de observação de local e estrutura apropriados para a realização da implantação do equipamento eólica na região litorânea, mais precisamente, em uma academia localizada em Cabo Frio.
A pesquisa será exploratória, explicativa e descritiva e, do ponto de vista da sua natureza é aplicada.

Foi realizado o levantamento bibliográfico para um aprofundamento sobre o tema, tendo como cenário virtual os sites de buscas como - Google Acadêmico, sites específicos sobre o tema e acervos de obras bibliográficas no espaço temporal entre 2000 a 2012 na qual no ano de 2000 foram os mais pesquisados, seguindo uma ordem de exposição ao meio eletrônico ao relacionar este periódico ao Atlas. Pesquisas feitas recentemente também foram publicadas, porém com a data ao que consta de 2000, 2003 e 2012 no referencial bibliográfico.

\section{2 - REFERENCIAL TEÓRICO}

\subsection{MAS AFINAL, O QUE É ENERGIA EÓLICA?}

A energia eólica é a energia adquirida pelo movimento do ar (vento). É uma grandiosa fonte de energia, renovável, limpa e podendo estar presente em todos os lugares.

Foram criados na Pérsia no séc. $V$ os moinhos de vento e eram utilizados para bombear água para irrigação. Os mecanismos fundamentais de um moinho de vento não modificaram desde esse tempo: o vento alcançava uma hélice que ao movimentar-se girava um eixo que impulsionava uma bomba (gerador de eletricidade).

\subsection{ORIGEM}

Os ventos são produzidos pela diferença de temperatura da terra e das águas, das planícies e das montanhas, das regiões equatoriais e dos pólos do planeta Terra.

A abundância de energia presente no vento varia de acordo com as estações do ano e as horas do dia. A descrição de um lugar e a rugosidade do solo também têm bastante interferência na repartição de presença dos ventos e de sua agilidade em um local. Além disso, a quantia de energia eólica que se retira numa região se sujeita das características de função, altura de operação e lacuna horizontal dos sistemas de conversão de energia eólica estabelecidos. A avaliação necessita do potencial de vento em uma região é o primeiro e essencial passo para o aproveitamento do recurso eólico como fonte de energia. 
Para a análise do potencial eólico de uma região é preciso a coleta de dados dos ventos com exatidão e qualidade, capaz de providenciar um mapeamento eólico da região.

As hélices de uma turbina de vento são desiguais aos das lâminas dos antigos moinhos, pois são mais aerodinâmicas e eficientes. As hélices têm o formato de asas de aviões e usam a mesma aerodinâmica. As hélices em movimento acionam um eixo que está conexo à caixa de mudança. Por meio de uma série de engrenagens a velocidade do eixo de rotação cresce. O eixo de rotação está ligado ao gerador de eletricidade que com a rotação em alta velocidade gera energia.

Um aero-gerador incide num gerador elétrico movimentado por uma hélice, que por sua vez é movimentada pela força do vento. A hélice pode ser notada como um motor a vento, cuja quantidade de energia que pode ser produzida pelo vento depende de quatro fatores: da abundância de vento que passa pela hélice, do diâmetro da hélice, da dimensão do gerador e do proveito de todo o sistema.

\subsubsection{VENTOS E MEIO AMBIENTE}

A energia eólica é denominada a energia mais limpa do planeta, estando disponível em vários lugares e em diferentes magnitudes, uma boa opção às energias não-renováveis.

\subsubsection{O VENTO E A ENERGIA EÓLICA}

$O$ vento é o ar em circulação por causa do aquecimento diferente da superfície da terra pelo sol. O solo e a atmosfera recebem mais calor solar junto ao Equador do que nas regiões polares. Mesmo dessa maneira, as regiões equatoriais não ficam mais quentes a cada ano, nem as polares ficam mais frias. É a movimentação do ar ao redor da terra que suaviza a temperatura extrema e gera ventos na superfície tão proveitosos para a produção de energia.

Como todos os gases, o ar se espalha ou estende de volume quando aquecido, e contrai e diminui de volume quando se resfria. No ambiente o ar quente é mais leve e menos pesado do que o ar frio e se ergue a altas altitudes quando intensamente acalorado pelo sol. O ar aquecido perto do Equador correrá para cima, e então, no sentido dos pólos onde o ar junto a superfície é mais frio. As regiões terrestres adjacentes aos pólos agora possuem mais ar, pressionando-as, e o ar da área mais fria tende a desligar dessas áreas e movimentarem-se no curso do Equador.

Muita energia está sendo invariavelmente transferida do sol para a superfície terrestre, portanto, somente ventos das camadas atmosféricas mais baixas são acessíveis para converter a sua energia.

\subsubsection{COMO FUNCIONA A ENERGIA EÓLICA?}

O vento contorna uma hélice gigante ligada a um gerador que gera eletricidade. Quando vários mecanismos como esse - conhecido como turbina de vento - são conectados a uma central de transmissão de energia, temse uma central eólica. A quantidade de energia gerada por uma turbina varia conforme o tamanho das suas hélices e, claro, do conjunto de ventos na região em que está instalada. Engana-se quem pense que o ideal é contar simplesmente com ventos fortes. "Além da velocidade dos ventos, é importante que eles sejam regulares, não sofram turbulências e nem estejam sujeitos a fenômenos climáticos como tufões", diz o engenheiro mecânico Everaldo Feitosa, vicepresidente da Associação Mundial de Energia Eólica.

O Brasil tem um dos maiores potenciais eólicos do planeta e, apesar de hoje o vento ser responsável por míseros 29 megawatts (MW) dos cerca de 92 mil MW fixados no país, há planos pretensiosos para explorar essa fonte de energia. Amparado no Programa de Incentivo às Fontes Alternativas de Energia (Proinfa), difundido pelo Ministério de Minas e Energia, o Brasil pretende chegar, em 2008, cerca de $1.500 \mathrm{MW}$ produzidos pelo vento um terço disso será instalado no Ceará e deve suprir mais da metade da demanda do estado.

O que dificulta a instalação de mais centrais eólicas ainda é o valor. O valor da energia produzida por uma central eólica está entre $60 \%$ e $70 \%$ a mais que a mesma quantidade produzida por uma usina hidrelétrica. Por outro lado, a energia do vento tem o grande proveito de ser inesgotável e causar muito pouco impacto ao ambiente.

\subsection{A ENERGIA EÓLICA NO BRASIL}


Com um nível de consumo equiparado ao da Itália e da Espanha, o Brasil é atualmente o $12^{\circ}$ maior consumidor de energia do mundial. $\mathrm{Na}$ maior parte dos casos, o emprego da energia eólica incide com o propósito de gerar eletricidade para, provavelmente, usos caseiros ou de empresas de pequeno porte, sovar grãos, ligar diferentes maquinários, aquecer ambientes, bombeamento de água, entre outros. Isso acontece pelo fato da eletricidade ser utilizado frequentemente na distribuição de energia.

Ainda que a aplicação dos recursos eólicos tenha sido cometido tradicionalmente com o emprego de cata-ventos multipás para bombear água, algumas avaliações concisas de vento, desempenhadas de modo recente em vários locais da região brasileira, apontam a existência de um imenso potencial de energia eólica ainda não especulado.

Grande atenção tem sido conduzida para o estado do Ceará, pelo fato de ter sido uma das primeiras regiões a desempenhar plano de recenseamento do potencial de energia eólica por meio de aferição de vento com modernos sensores especiais. Contudo, não foi somente na costa do Nordeste que âmbitos de amplo potencial eólico foram encontrados. Por exemplo, uma central de energia eólica está funcionando, em Minas Gerais, desde 1994, numa área distante (mais de $1000 \mathrm{~km}$ da costa), com perfeitas condições de vento.

A capacidade construída no Brasil está acima de 20 MW, com turbinas eólicas de médios e grandes portes vinculados ao circuito elétrico. Do mesmo modo, existem dezenas de turbinas eólicas de pequeno porte funcionando em locais isolados da rede convencional para aplicações diversas, tais como eletrificação, carregamento de baterias, bombeamento, e telecomunicações.
Pelo aspecto econômico e ambiental a llha de Fernando de Noronha no estado de Pernambuco contribui de forma positiva para a implantação de energia eólica. Aspecto econômico - Pelo fato de ser uma ilha, o fornecimento de energia elétrica é realizado através do diesel transportado do continente, tornando o abastecimento muito oneroso. Referente ao aspecto ambiental - com uma natureza vasta e exuberante, a brisa do mar e o vento constante.

Desde julho de 1992, a turbina que trabalha na Ilha de Fernando de Noronha, apresenta potência nominal de $75 \mathrm{Kw}$, diâmetro do rotor de $17 \mathrm{~m}$ (3 pás) e uma torre de $23 \mathrm{~m}$ de altura.

\subsection{DISPONIBILIDADE DE RECURSOS}

A estimativa do potencial eólico de uma região exige tarefas metódicas de coleta e pesquisa de dados sobre a atividade do vento, sua a velocidade e o regime.

Em regra, uma estimativa estrita exige recenseamentos específicos, mas dados coletados em aeroportos, estações meteorológicas e outros aproveitamentos semelhantes podem ministrar uma primeira avaliação do potencial bruto ou teórico da aplicação da energia do vento.

A fim de que a energia eólica seja qualificada tecnicamente aproveitável, é obrigatório que sua densidade seja maior ou igual a 500 $\mathrm{W} / \mathrm{m} 2$, a uma altura de $50 \mathrm{~m}$, o que requer uma velocidade menor do vento de 7 a $8 \mathrm{~m} / \mathrm{s}$ (GRUBB; MEYER, 1993). Segunda a Organização Mundial de Meteorologia, em apenas $13 \%$ da camada terrestre o vento descreve uma velocidade média igual ou superior a $7 \mathrm{~m} / \mathrm{s}$, a uma altura de $50 \mathrm{~m}$. Essa dimensão modifica demais entre regiões e continentes, atingindo a $32 \%$ na Europa Ocidental, como apontado na Tabela 1.

Tabela 1 Distribuição da área de cada continente segundo a velocidade média do vento

\begin{tabular}{|c|c|c|c|c|c|c|}
\hline \multirow{3}{*}{ Regiäo/Continente } & \multicolumn{6}{|c|}{ Velocidade do Vento $(\mathrm{m} / \mathrm{s})$ a $50 \mathrm{~m}$ de Altura } \\
\hline & \multicolumn{2}{|c|}{6,4 a 7,0} & \multicolumn{2}{|c|}{7,0 a 7,5} & \multicolumn{2}{|c|}{7,5 a 11,9} \\
\hline & $\left(10^{:} \mathrm{km}\right)$ & (\%) & $\left(10^{i} \mathrm{~km}\right)$ & (\%) & $\left(10^{\circ} \mathrm{km}\right)$ & (\%) \\
\hline África & 3.750 & 12 & 3.350 & 11 & 200 & 1 \\
\hline Austrália & 850 & 8 & 400 & 4 & 550 & 5 \\
\hline América do Norte & 2.550 & 12 & 1.750 & 8 & 3.350 & 15 \\
\hline América Latina & 1.400 & 8 & 850 & 5 & 950 & 5 \\
\hline Europa Ocidental & 345 & 8.6 & 416 & 10 & 371 & 22 \\
\hline Europa Ocidental \& ex-URSS & 3.377 & 15 & 2.260 & 10 & 1.146 & 5 \\
\hline Ásia (excluindo ex-URSS) & 1.550 & 6 & 450 & 2 & 200 & 5 \\
\hline Total do Globo & 13.650 & 10 & 9.550 & 7 & 8.350 & 6 \\
\hline
\end{tabular}

Fonte: GRUBB, M. J; MEYER, N. I. Wind energy: resources, systems and regional strategies. In: JO-HANSSON, T. B. et. al. Renewable energy: sources for fuels and electricity. Washington, D.C.: Island Press, 1993p. 
Apesar de tudo, avalia-se que o potencial eólico bruto no mundo seja da classe de 500.000 TWh por ano. Devido, não obstante, a advertências socioambientais (existência de áreas densamente povoadas e/ou industrializadas e outras restrições naturais, como regiões muito montanhosas, por exemplo), apenas 53.000 TWh (cerca de 10\%) são qualificados tecnicamente aplicáveis (Tabela 2). Ainda assim, esse potencial líquido satisfaz a cerca de quatro vezes o consumo de energia elétrica no mundo.

Tabela 2 Estimativas do potencial eólico mundial

\begin{tabular}{|c|c|c|c|c|}
\hline Regiāo & $\begin{array}{l}\text { Porcentagem } \\
\text { de Terra } \\
\text { Ocupada* }\end{array}$ & $\begin{array}{l}\text { Potencial } \\
\text { Bruto } \\
\text { (TWh/ano) }\end{array}$ & $\begin{array}{l}\text { Densidade } \\
\text { Demográfica } \\
\text { (hab/km;) }\end{array}$ & $\begin{array}{c}\text { Potencial } \\
\text { Ĺquido } \\
\text { (TWh/ano) }\end{array}$ \\
\hline Africa & 24 & 106.000 & 20 & 10.600 \\
\hline Austrália & 17 & 30.000 & 2 & 3.000 \\
\hline América do Norte & 35 & 139.000 & 15 & 14.000 \\
\hline América Latina & 18 & 54.000 & 15 & 5.400 \\
\hline Europa Ocidental & 42 & 31.400 & 102 & 4.800 \\
\hline Europa Ocidental \& ex-URSS & 29 & 106.000 & 13 & 10.600 \\
\hline Ásia (exduindo ex-URSS) & 9 & 32.000 & 100 & 4.900 \\
\hline Total do Globo"* & 23 & 498.400 & . & 53.000 \\
\hline
\end{tabular}

Fonte: GRUBB, M. J; MEYER, N. I. Wind energy: resources, systems and regional strategies. In: JO-HANSSON, T. B. et. al. Renewable energy: sources for fuels and electricity. Washington, D.C.: Island Press, 1993p. ( $\left.{ }^{*}\right) \mathrm{Em}$ relação ao potencial bruto; ${ }^{* *}$ Excluindo-se Groenlândia, Antártida, a maioria das ilhas e os recursos offshore.

Nos inícios dos anos 1990, os primeiros anemógrafos computadorizados e sensores especiais para energia eólica foram montados no Ceará e em Fernando de Noronha (PE), Brasil. Houve a possibilidade de determinar 0 potencial eólico e a instalação das primeiras turbinas eólicas do brasileira como consequência dessas avaliações na região.

\subsubsection{POTENCIAL EÓLICO BRASILEIRO}

Diversos estudos apontam projeções extremamente significativas, ainda que haja divergências entre instituições e especialistas na avaliação da força dos ventos no Brasil. Antigamente, as avaliações eram da prescrição de $20.000 \mathrm{MW}$. Nos dias atuais a maior parte dos estudos aponta projeções maiores que 60.000 MW. Essas divergências derivam, sobretudo, da carência de informações (subsídios da superfície) e das diferentes metodologias empregadas. ${ }^{4}$

\footnotetext{
${ }^{4}$ Também o conceito de potencial eólico pode ser interpretado de diferentes maneiras, devido à complexidade na determinação das restrições técnico-econômicas e, principalmente, socioambientais ao aproveitamento eólico.
}

Em diversas partes do mundo, assim como no Brasil, quase não existem estudos de vento com características para uma estimativa do potencial eólico. Os primeiros aparelhos sensórios especializados para energia eólica foram estabelecidos no Ceará e em Fernando de Noronha, no estado de Pernambuco, somente no princípio dos anos 90. Os bons resultados alcançados com aquelas avaliações beneficiaram a decisão exata do potencial de energia eólica daquelas localidades e a instalação de aerogeradores. Alguns estados do Brasil transcreveram as pesquisas do Ceará e de Pernambuco e principiaram projetos de recenseamento de estudos dos ventos.

A primeira versão do Atlas Eólico da Região Nordeste foi publicada em 1998, com apoio da ANEEL e do Ministério de Ciência e Tecnologia - MCT, o Centro Brasileiro de Energia Eólica - CBEE, da Universidade Federal de Pernambuco - UFPE. O prosseguimento desse trabalho resultou no Panorama do Potencial Eólico no Brasil, conforme Figura 3. 
Figura 3 - Velocidade média anual do vento a 50m de altura

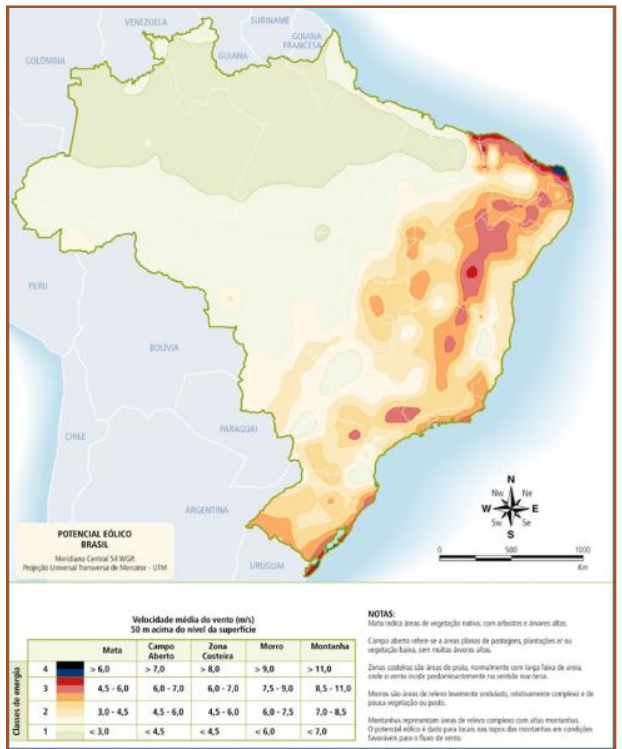

Fonte: FEITOSA, E. A. N. et al. Panorama do Potencial Eólico no Brasil. Brasília: Dupligráfica, 2003. (adaptado)

Os recursos correspondentes na legenda da Figura 3 fazem menção à velocidade média do vento e energia eólica média a uma altura de $50 \mathrm{~m}$ acima da superfície para cinco categorias topográficas diferenciadas: zona costeira - extensão praiana, normalmente com ampla faixa de areia, onde o vento prevalece do sentido mar-terra; campo aberto - locais planos de pastagens, plantações e lou vegetação baixa com poucas árvores altas; mata - áreas de vegetação natural com arbustos e árvores altivas, porém de baixa densidade, espécie terreno que acarreta mais obstruções ao curso de vento; morro - locais de relevo ligeiramente sinuoso, relativamente complexo, sem muita vegetação ou pasto; montanha - locais de relevo complexo, com montanhas altivas.
A classe 1 que se encontra na legenda mostra territórios de baixo potencial eólico, de pouca ou nenhuma importância para o aproveitamento da energia dos ventos.

As classes 2 e 3 podem ser favoráveis ou desfavoráveis, sujeitos as situações topográficas. Por exemplo: um local de classe 3 no interior do Maranhão (mata) descreve somente valores entre 4,5 e $6 \mathrm{~m} / \mathrm{s}$, enquanto que um local da mesma classe 3 na costa do Nordeste (zona costeira) pode ter velocidades médias anuais entre 6,5 e $8 \mathrm{~m} / \mathrm{s}$. A classe 4 concebe aos melhores locais para emprego da energia eólica no país.

A disposição das velocidades de vento e regiões topográficas usadas no mapa é apresentada na Tabela 3.

Tabela 3 Definição das Classes de Energia

\begin{tabular}{|c|c|c|c|c|c|c|c|c|c|c|}
\hline \multirow[b]{2}{*}{ Classe } & \multicolumn{2}{|c|}{ Mata } & \multicolumn{2}{|c|}{ Campo aberto } & \multicolumn{2}{|c|}{ Zona costeira } & \multicolumn{2}{|c|}{ Morios } & \multicolumn{2}{|c|}{ Montanhas } \\
\hline & $v_{m}(m / s)$ & $E_{m}(W / m ;)$ & $V_{m}(m / s)$ & $E_{m}(W / m i)$ & $V_{m}(m / s)$ & $E_{m}(W / m)$ & $v_{m}(m / s)$ & $E_{m}(W / m)$ & $v_{m}(m / s)$ & $E_{m}(W / m)$ \\
\hline 4 & $>6$ & $>200$ & $>7$ & $>300$ & $>8$ & $>480$ & $>9$ & $>700$ & $>11$ & $>1250$ \\
\hline 3 & $4,5-6$ & $80-200$ & $6-7$ & $200-300$ & $6,5-8$ & $250-480$ & $7,5-9$ & $380-700$ & $8.5-11$ & $650-1250$ \\
\hline 2 & $3-4,5$ & $25-80$ & $4,5-6$ & $80-200$ & $5-6.5$ & $100-250$ & $6-7,5$ & $200-380$ & $7-8.5$ & $300-650$ \\
\hline 1 & $<3$ & $<25$ & $<4,5$ & $<80$ & $<5$ & $<100$ & $<6$ & $<200$ & $<7$ & $<300$ \\
\hline
\end{tabular}

Fonte: FEITOSA, E. A. N. et al. Panorama do Potencial Eólico no Brasil. Brasília: Dupligráfica, 2003. 
Ainda em termos de áreas no Brasil, outro estudo valioso, foi publicado pelo Centro de Referência para Energia Solar e Eólica CRESESB/CEPEL. Versa-se do Atlas do Potencial Eólico Brasileiro, onde os resultados estão disponíveis no seguinte endereço eletrônico:

www.cresesb.cepel.br/atlas_eolico_brasil/atla s-web.htm. Nesse curso apreciou-se um potencial eólico brasileiro da ordem de 143 GW. Há também outras pesquisas específicas por unidades da Federação, realizadas por iniciativas locais.

\subsection{ENERGIA EÓLICA NO CONTEXTO DO SETOR ELÉTRICO BRASILEIRO}

Ainda é pouco expressiva a participação da energia eólica para transformação em energia elétrica no país. Em setembro de 2003 havia apenas 6 centrais eólicas funcionando no Brasil como mostrado na Tabela 4.

Tabela 4 Centrais eólicas em operação no Brasil - situação em setembro de 2003

\begin{tabular}{|c|c|c|c|c|}
\hline Nome da Usina & $\begin{array}{r}\text { Potência } \\
(\mathrm{kW})\end{array}$ & Muniápio - UF & $\begin{array}{l}\text { Destino } \\
\text { da Energia }\end{array}$ & Proprietánio \\
\hline Eólica & 75 & Ferrando de Noronha - PE & SP & $100 \%$ para Companhia Energética de Pernambuco \\
\hline Eólica de Bom Jardim & 600 & Bom lardim da Serra - $\mathbf{X}$ & PIE & 100\% para Parque Élico de Santa Catarina Ltda. \\
\hline Eólica de Fernando de Norcriha & 225 & Ferrnando de Noronha - PE & PIE & $100 \%$ para Centro Brasileiro de Energia Eólica - FADENJFPE \\
\hline Eólica de Prainha & 10.000 & Aquiraz-CE & PIE & $100 \%$ para Wobben Wind Power Indístria e Comércio Lteda. \\
\hline Eólica de Taiba & 5.000 & 5äo Gonçalo do Amarante - CE & PIE & 100\% para Wobben Wind Power Indústria e Comério Ltata. \\
\hline Eólica Olinda & 225 & Olinda - PE & PIE & $100 \%$ para Centro Brasileiro de Energia Eólica - FADENFPE \\
\hline $\begin{array}{l}\text { Élica-Elétrica Experimental } \\
\text { do Morro do Camelinho }\end{array}$ & 1.000 & Gouveia - MG & $5 P$ & 100\% para Companhia Energética de Minas Gerais \\
\hline Eólico - Elétrica de Palmes & 2.500 & Palmas - PR & PIE & 100\% para Centrais Eólicas do Paraná Ltuda. \\
\hline Mucuripe & 2.400 & Fortaleza - CE & PIE & 100\% para Wobben Wind Power Indústria e Comércio Ltuda. \\
\hline
\end{tabular}

Fonte: agência nacional de energia elétrica - aneel. Banco de informações de geração - big. 2003. Disponível em: www.aneel.gov.br/15.htm

Portanto, os incentivos em vigor para o setor elétrico brasileiro deverão despertar o interesse de empreendedores. Evidencia-se, aqui, o Programa de Incentivo às Fontes Alternativas (PROINFA). Outro fator relevante, como apoio, é a probabilidade de se complementar a geração hidrelétrica e a geração eólica, já que o mais alto potencial eólico, na região Nordeste, acontece no período de menor disponibilidade hídrica, conforme mostrado na Figura 3.

Figura 3 - Hidrelétrica e eólica complementaridade entre a geração

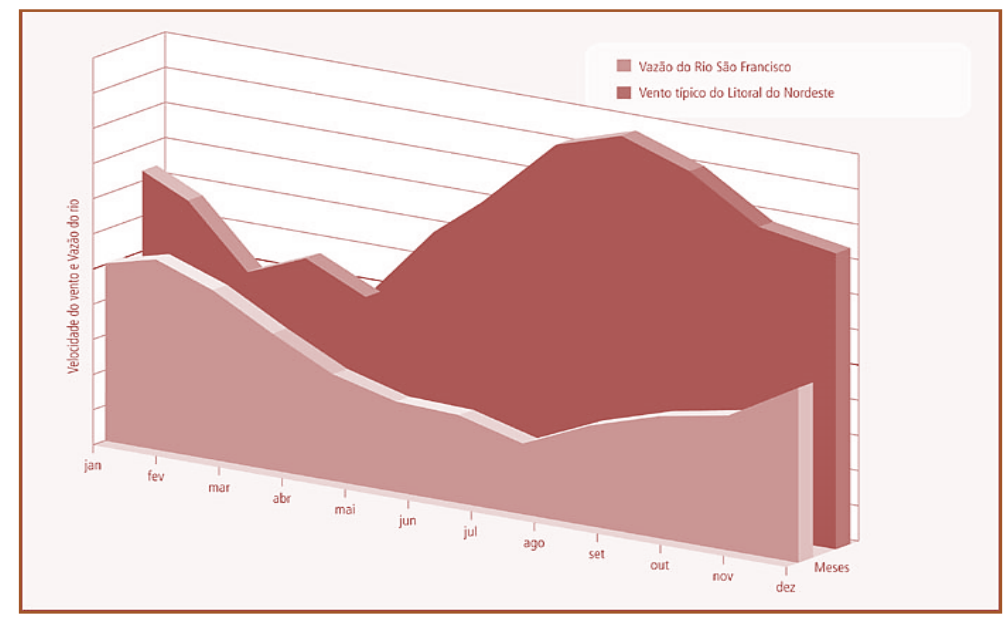

Fonte: centro brasileiro de energia eólica - cbee / ufpe. 2000. Disponível em: www.eolica.com.br. 


\subsection{IMPACTOS SOCIOAMBIENTAIS}

A geração de eletricidade através de aerogeradores compõe uma opção para diferentes condições de demanda. As pequenas centrais podem abastecer pequenos lugarejos afastados da rede, colaborando para a técnica de globalização do atendimento. As centrais de grande porte apresentam potencial para dar atendimento uma expressiva parcela do Sistema Interligado Nacional (SIN) com interessantes vantagens: cooperando para a diminuição da emissão de poluentes pelas centrais térmicas; reduzindo a necessidade da instalação de grandes reservatórios; e diminuindo o risco promovido pela sazonalidade das chuvas, à luz da complementaridade mencionada anteriormente.

Tendo em vista o contexto do meio ambiente, observa-se que é extremamente recomendável este tipo de energia para todos os países, em qualquer região, já que é uma energia limpa, renovável, não danifica a camada de ozônio, não há influência no aquecimento global, além de não intervir com grande impacto nas regiões em que é implantada, já que quase toda a área onde foi implantada pode ser reaproveitada para outros propósitos, como por exemplo, para pecuária e agricultura.

Apesar de as usinas eólicas não emitirem poluentes atmosféricos e não queimarem combustíveis fósseis, estas centrais podem ocasionar impactos tanto sociais quanto ambientais. Os impactos sonoros e visuais são os principais transtornos socioambientais das centrais eólicas.

Os impactos sonoros ocorrem por causa do ruído dos rotores e modificam conforme as especificações dos equipamentos (ARAÚJO, 2000). De acordo com o autor, os aerogeradores de múltiplas pás são ineficientes e os ruídos são mais fortes que as turbinas de hélices de velocidade mais rápida. Com a finalidade de não prejudicar a população vizinha, o nível de ruído dos aerogeradores deve satisfazer às normas e padrões constituídos pela legislação vigente.

Os impactos visuais são decorrentes da concentração de torres e aerogeradores, principalmente no caso de centrais eólicas com numerosas turbinas, também denominadas como fazendas ou parques eólicas.
Outra desvantagem das instalações de turbinas eólicas é a possibilidade de intervenções eletromagnéticas, que podem ocasionar transtornos nos sistemas de comunicação e transmissão de dados (rádio, televisão etc.) (TAYLOR, 1996). Segundo este autor, essas intervenções modificam bastante, de acordo com localização da montagem da usina e suas especificações técnicas, em particular o material utilizado na fabricação das pás. Também a possível intervenção nas rotas migratórias de aves precisa ser devidamente analisada nos estudos e relatórios de impactos ambientais (EIA/RIMA).

\subsection{IMPACTOS E PROBLEMAS}

Ainda que não queimem combustíveis fósseis e não lancem poluentes, fazendas eólicas não são completamente carentes de impactos ambientais. Elas mudam paisagens com suas torres e hélices e podem ameaçar pássaros se instaladas em rotas de migração. Enviam um certo grau de ruído (de baixa freqüência), que pode gerar algum incômodo. Além disso, podem causar interferência na transmissão de televisão.

O custo dos geradores eólicos poderá ser elevado, porém o que ser verá a seguir, não é o custo o problema, pois os valores são acessíveis á todos os meios. E as plantas eólicas têm um retorno financeiro a um curto prazo.

Outro problema que poderia até ser mencionado é que a questão dos ventos em que algumas regiões não é constante, ou a intensidade é muito fraca, adquirindo-se pouca energia ou quando ocorrem chuvas muito fortes, há desperdício de energia. Porém, a realidade é outra uma vez em que a inovação dos equipamentos se renovam, há a possibilidade sim que se manter essa energia por muitos tempo através de um sistema de bateria que é implantado.

\section{3 - ESTUDO DE CASO EM CABO FRIO - RJ}

\subsection{A CIDADE DE CABO FRIO - UM BREVE HISTÓRICO}

O processo que iniciou a ocupação da sede da cidade foi à decorrência da rápida transformação funcional ocorrida nos últimos quarenta anos, durante os quais o pequeno núcleo pesqueiro e salineiro se transformou em relevante centro turístico do município. O núcleo de Cabo Frio encontra-se em área de 
topografia plana, com pequenas elevações, tendo sido seu crescimento fortemente condicionado pela presença do canal que liga a Lagoa de Araruama ao mar, cortando a cidade.

Um clima excelente, com tantas belezas naturais e das vias de fácil acesso, nada mais natural do que a cidade ser descoberta por turistas, principalmente cariocas e mineiros que fixaram residências de veraneio na região, dessa forma aumentando as expectativas para economia local.

Reconhecida tanto no âmbito nacional e quanto internacionalmente é uma cidade badalada por suas praias tranquilas e aprazíveis, tendo a Praia do Forte a mais famosa. É o ponto de convergência para muitas cidades que disponham de melhorias vias de acesso. Sua ligação com o Rio de Janeiro é facílima. As estradas são em qualidade e quantidade bem planejadas, havendo trecho privatizado com boa manutenção.

O sol brilha em média 315 dias por ano, numa temperatura que varia entre $40^{\circ}$ na época do verão e $16^{\circ}$ no inverno. O clima é úmido e quente. Os fatores responsáveis pela frequência e intensidade do vento nordeste, que sopra quase o ano inteiro e afasta as nuvens carregadas são pouquíssima chuva, muito calor e baixa umidade do ar. Acrescente a isso as águas frias da ressurgência e está formado um legítimo sistema de ar condicionado natural que ameniza o calor do verão e, dando lugar ao vento sudoeste, suaviza o frio no inverno.

\subsubsection{CARACTERÍSTICAS GEOGRÁFICAS}

O município de Cabo Frio está situado na região litorânea a 155 km da capital do Rio de Janeiro. Suas características geográficas podem ser observadas no quadro 1.

Quadro 1: Características geográficas da cidade de Cabo Frio

\begin{tabular}{|l|c|}
\hline Área & $410.415 \mathrm{Km}^{2}$ \\
\hline População & 186.227 hab. (IBGE 2010) \\
\hline Densidade & 453,75 hab./Km² \\
\hline Altitude & 4 metros \\
\hline Clima & Tropical litorâneo \\
\hline Fuso horário & UTC-3 \\
\hline \multicolumn{2}{|c|}{ Fonte: IBGE-2010 } \\
\hline
\end{tabular}

A cidade é arranjada com construções de estruturas baixas e com edificações de no máximo seis andares. É composto de térreo, pilotis, quatro pavimentos e uma cobertura como ordena a lei 109, de 16 de novembro de 1979. Nos arredores, fora do centro cidade, existem sítios e fazendas com vegetação rasteira e com algumas atividades agropecuárias. Avaliando a resistência do sistema dos ventos, toda obstáculo que impede, desvia e que diminui ou aumenta a passagem do ar.

A mudança da velocidade coma altura, a rugosidade do solo, que é caracterizada pela vegetação, aproveitamento da terra, estrutura das construções, a presença de barreiras nas adjacências e o relevo que pode implicar na aceleração ou desaceleração da passagem do fluxo de ar, são fatores que terão influencia no regime dos ventos e resultando na propensão de geração de energia.
A velocidade média do vento em Cabo Frio é maior que $6 \mathrm{~m} / \mathrm{s}$, levando em consideração que a turbina eólica do projeto comece a produzir energia, a velocidade do vento deve ser a partir de $3 \mathrm{~m} / \mathrm{s}$, conclui-se que há a possibilidade da instalação do aerogerador.

\subsubsection{CUSTO DO EQUIPAMENTO}

Avaliando o grande potencial eólico que há no Brasil, é possível gerar eletricidade a custos concorrentes com centrais termoelétricas, nucleares e hidroelétricas.

Apreciações dos recursos eólicos examinados em vários locais do Brasil, mostram a possibilidade de produção elétrica com custos em torno de US\$ 70 - US\$ 80 por MWh.

O custo da energia elétrica produzida por meio de novas usinas hidroelétricas erguidas 
na região amazônica será bem mais alto que os custos das usinas instaladas até hoje.

De acordo com a ELETROBRÁS quase 70\% dos projetos prováveis deverão ter custos de produção maiores do que a energia produzida por turbinas eólicas. Outra vantagem das centrais eólicas relacionadas às usinas hidroelétricas é que uma boa área preenchida pela central eólica pode ser utilizada (para agricultura, pecuária, etc.) ou preservada como habitat natural (CBEE, 2012).

\subsubsection{SISTEMAS DE ENERGIA EÓLICA}

Um sistema eólico é composto por diversos fatores que devem trabalhar em harmonia de modo a oferecer um maior efeito final. Para resultado de estudo geral da conversão eólica devem ser avaliados os seguintes componentes:

- Vento: Disponibilidade energética do local destinado à instalação do sistema eólico.

- Rotor: Responsável por transformar a energia cinética do vento em energia mecânica de rotação.
- Transmissão e Caixa Multiplicadora: Responsável por transmitir a energia mecânica entregue pelo eixo do rotor até a carga. Alguns geradores não utilizam este componente; neste caso, o eixo do rotor é acoplado diretamente à carga.

- Gerador Elétrico: Responsável pela conversão da energia mecânica em energia elétrica.

- Mecanismo de Controle: Responsável pela orientação do rotor, controle de velocidade, controle da carga, etc.

- Torre: Responsável por sustentar e posicionar o rotor na altura conveniente.

- Sistema de Armazenamento: Responsável por armazenar a energia para produção de energia firme a partir de uma fonte intermitente.

- Transformador: Responsável pelo acoplamento elétrico entre o aerogerador e a rede elétrica.

Figura 4 - Exemplo de uma instalação eólica.

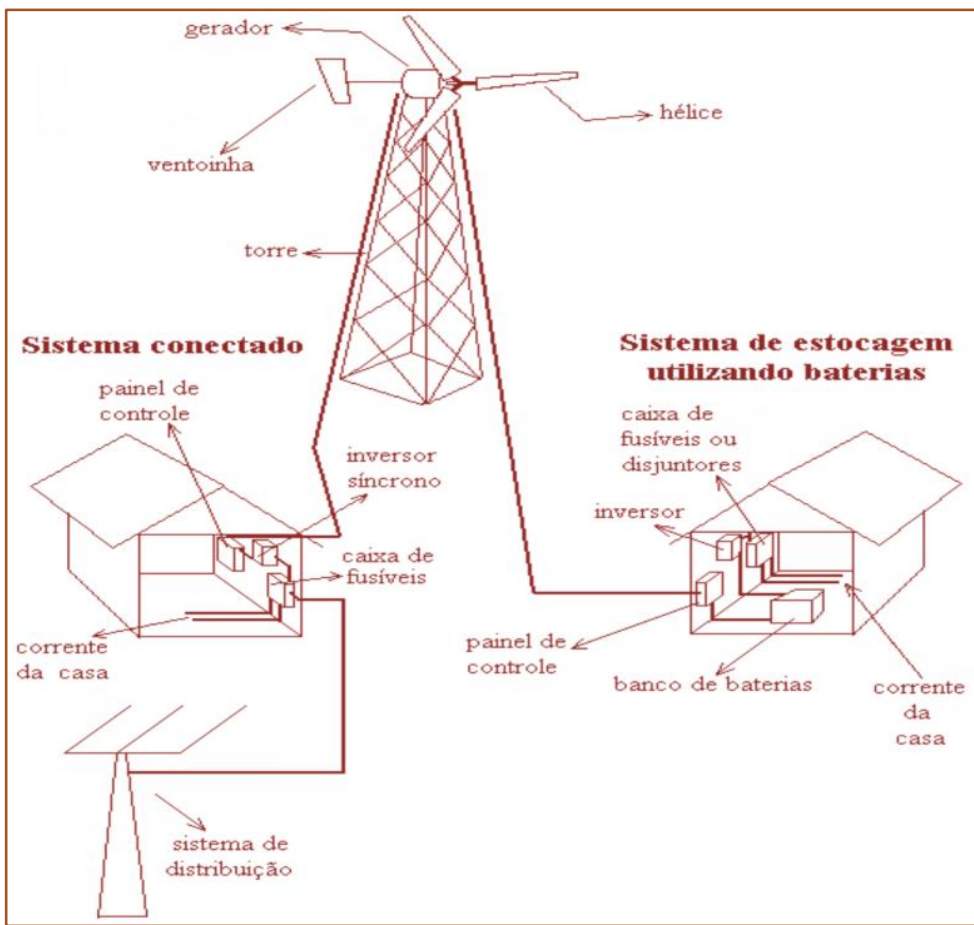

Fonte: http://www. portalsaofrancisco.com.br/alfa/energia-eolica/energia-eolica-14.php 


\subsection{ANÁLISE DE VIABILIDADE DA ENERGIA EÓLICA NA ACADEMIA}

A academia na qual se pretende implantar a energia eólica está localizada na Região dos Lagos, mais precisamente em Cabo Frio onde se fez um estudo acerca da área.

A área onde está localizada a academia, possui características promissoras para a implantação de aproveitamento de energia eólica, podendo aumentar a perspectiva de viabilidade do projeto à esta pesquisa. A academia se encontra numa zona aberta, há $600 \mathrm{~m}$ da orla praiana em torno existem construções baixas, fatores esses que proporcionam o alto fluxo do vento, assim, estabelecendo área apropriada para a instalação do aerogerador. Outro fator é altura da instalação da turbina, pois quanto mais alta a altura da torre, menores serão as barreiras para o fluxo do vento, e isso poderá aumentar a rentabilidade da implantação do projeto eólico.

Para se ter ou tiver uma ideia sobre o local, iniciar-se a detalhes e custos da academia.

O quadro 2 indica os aparelhos elétricos utilizados e a quantidade de horas em funcionamento. A tabela 6 indica o consumo de energia da academia no período de 1 ano.

A academia possui: 2 aparelhos de ar condicionados, um na sala I para spinning e outra na sala II para ginástica e lutas onde são utilizados na maior parte do tempo: $5 \mathrm{X}$ por semana (segunda a sexta) em horários alternativos, totalizando 8 horas de uso alternados diários na sala I e 4 horas na sala II. Os demais aparelhos são utilizados de acordo com a necessidade dos alunos e funcionários. Aos sábados a academia está em funcionamento das 09:00 ao 12:00.

Quadro 2 - Elementos que compõem a academia

\begin{tabular}{|c|c|c|}
\hline Esteira elétrica & 04 & $07: 00$ às 11:00 \\
\hline Televisão & 01 & $07: 00$ às 11:00 \\
\hline Bebedouro & 02 & $07: 00$ às 11:00 \\
\hline Lanchonete & 02 & $07: 00$ às 11:00 \\
\hline Geladeira vertical & 01 & $07: 00$ às 11:00 \\
\hline Geladeira horizontal & 01 & $07: 00$ às 11:00 \\
\hline Chuveiro elétrico & 01 & $07: 00$ às 11:00 \\
\hline Bomba d'água & 01 & $07: 00$ às 11:00 \\
\hline Luz & 20 & $07: 00$ às 11:00 \\
\hline Ventiladores & 10 & $07: 00$ às 11:00 \\
\hline Ar condicionado & 2 & $07: 00$ às 11:00 \\
\hline
\end{tabular}

Fonte: pesquisa de campo feita em agosto

De acordo com o parâmetro entre consumo da energia elétrica e o número de clientes, percebe-se que o consumo de energia elétrica aumenta na mesma proporção em relação ao número crescente de alunos, é uma ocorrência sazonal. A procura de pessoas para atividade física acontece no verão e no inverno há uma diminuição dessa demanda. O mesmo ocorre com o consumo da energia elétrica na academia. Resultando numa variação do custo da capacidade de energia ao longo do ano mostrado na tabela 5. Possuindo ainda para cálculos de gastos com energia elétrica convencional: 
Tabela 5 - Consumo de energia elétrica da Academia de outubro de 2011 a setembro de 2012

\begin{tabular}{|c|c|c|c|c|}
\hline Série & Mês & Ano & Valor Wh & Valor $\mathrm{R} \$$ \\
\hline 1 & 10 & 2011 & 228 & $1.424,47$ \\
\hline 2 & 11 & 2011 & 245 & $1.503,75$ \\
\hline 3 & 12 & 2011 & 266 & $1.521,72$ \\
\hline 4 & 01 & 2012 & 289 & $1.620,00$ \\
\hline 5 & 02 & 2012 & 281 & $1.730,72$ \\
\hline 6 & 03 & 2012 & 317 & $1.878,80$ \\
\hline 7 & 04 & 2012 & 281 & $1.743,62$ \\
\hline 8 & 05 & 2012 & 252 & $1.655,87$ \\
\hline 9 & 06 & 2012 & 252 & $1.612,99$ \\
\hline 10 & 07 & 2012 & 228 & $1.428,74$ \\
\hline 11 & 08 & 2012 & 228 & $1.456,78$ \\
\hline 12 & 09 & 2012 & 233 & $1.539,39$ \\
\hline Total & & & & $19.116,85$ \\
\hline
\end{tabular}

Fonte: Academia - Histórico do consumo de energia elétrica (Outubro de 2011 a Setembro de 2012)

Tabela 6 - Média do Consumo de energia elétrica anual da academia

\begin{tabular}{|c|c|cr|}
\hline Série & Valor Wh & \multicolumn{2}{c|}{ Valor } \\
\hline 1 & 228 & $\mathrm{R} \$$ & $1.424,47$ \\
\hline 2 & 245 & $\mathrm{R} \$$ & $1.503,75$ \\
\hline 3 & 266 & $\mathrm{R} \$$ & $1.521,72$ \\
\hline 4 & 289 & $\mathrm{R} \$$ & $1.620,00$ \\
\hline 5 & 281 & $\mathrm{R} \$$ & $1.730,72$ \\
\hline 6 & 317 & $\mathrm{R} \$$ & $1.878,80$ \\
\hline 7 & 281 & $\mathrm{R} \$$ & $1.743,62$ \\
\hline 8 & 252 & $\mathrm{R} \$$ & $1.655,87$ \\
\hline 9 & 252 & $\mathrm{R} \$$ & $1.612,99$ \\
\hline 10 & 228 & $\mathrm{R} \$$ & $1.428,74$ \\
\hline 11 & 228 & $\mathrm{R} \$$ & $1.456,78$ \\
\hline 12 & 233 & $\mathrm{R} \$$ & $1.539,39$ \\
\hline Total & 3100 & $\mathrm{R} \$$ & $19.116,85$ \\
\hline Média & 258,3333333 & $\mathrm{R} \$$ & $1.593,07$ \\
\hline
\end{tabular}

Fonte: Academia - Histórico do consumo de energia elétrica (Outubro de 2011 a Setembro de 2012)

Por apresentar um gasto maior pelos equipamentos e aparelhos na academia, foi feito um levantamento acerca de gastos onde podemos concluir que, com a viabilidade em colocar em funcionamento a energia eólica no local, mais especificamente no terreno desocupado e livre situado atrás da academia e faz parte desta, a economia é visivelmente incrível, uma vez que, o consumo elevado tem em média anual de 258,3 Wh o que equivale a um custo da mensal em tono de $R \$ 1.593,07$, como apresentado na tabela X. O custo da energia produzida pelos aerogeradores concentra-se no investimento inicial, uma vez que para a operação e manutenção os custos são muito baixos, em torno de $2 \%$ do custo total. Além de utilizar a energia renovável e limpa, a academia ganha novos aspectos e maior volume de clientes.

Em termos comparativos com outro tipo de energia alternativa e renovável, como exemplo a energia solar, o preço estimado do $\mathrm{MW} / \mathrm{h}$ gerado por uma usina solar oscila atualmente entre $R \$ 300,00$ e $R \$ 500,00$ enquanto as eólicas já alcançam valores na casa dos $\mathrm{R} \$$ 100. Além de outro dado econômico, a concessionária de energia elétrica no Brasil determina as tarifas residenciais de $\mathrm{R} \$ 400,00$ a $\mathrm{R} \$ 600,00 / \mathrm{KWh}$, enquanto com a energia eólica a tarifa é estabelecida a $\mathrm{R} \$ 300 / \mathrm{KWh}$, já é uma boa justificativa para a utilização desse tipo de energia limpa. 


\section{CONCLUSÃO}

De acordo com a pesquisa realizada neste estudo concluiu-se que a construção do sistema energia eólica ocorre do grande investimento em tecnologia. A utilização de novos materiais, novos métodos de planejamento e cálculo, os desenvolvimentos em aerodinâmica, o lançamento de materiais compostos, novas fibras e resinas mais resistentes, o grande progresso da eletrônica são os principais fatores que colaboram para que as turbinas tenham melhor desempenho, sejam mais seguros e mais baratos. Ou seja, tornando-se um excelente empreendimento em diversos aspectos.

Notou-se que alguns impactos negativos foram desfeitos com o decorrer do projeto e os pontos positivos foram fortalecidos favorecendo a sua aprovação.

A torre do projeto possui $15 \mathrm{~m}$, portanto o som não vai causar transtornos na vizinhança, evitando o impacto sonoro. E coma essa altura evita-se o contato com fios elétricos situados na rua.

Outro ponto negativo é o impacto visual que pode causar estranheza por quem passa pelo local, porém, nos dias atuais há o respeito com a sustentabilidade, acarretando maior credibilidade, chamando atenção e tornandose um diferencial, podendo atrair um número maior de clientes para academia. Assim resultando num consumo consciente coletivo.

Não há a preocupação em ser ultrapassado com as pilhas de combustível ou com a técnica da bomba hidroelétrica porque 0 mecanismo não necessita de baterias,

\section{REFERÊNCIAS}

[1] Agência Nacional De Energia Elétrica ANEEL. Banco de Informações de Geração - BIG. 2003. Disponível em: www.aneel.gov.br/15.htm.

[2] Ampla Energia e Serviço Elétrico. Disponível em: www.ampla.com. Acesso em 10 ago. 2012.

[3] Araújo, M. S. M. Relatório de análise do Mecanismo de Desenvolvimento Limpo: MDL: estudos de caso. Rio de Janeiro: Coppe, Ufrj, 2000. 122 p.

[4] Araújo, T.S. Fontes alternativas de energia para a agricultura. Curso de especialização por tutoria à distância, 1985.

[5] Boyle, G. (Ed.). Renewable energy: power for a sustainable future. Oxford: Oxford University Press, 1996. estando todo o sistema ligado à concessionária AMPLA.

Em relação aos aspectos geográficos foi comprovado que a cidade de Cabo Frio possui excelentes condições climáticas, ventos sopram ao longo de todas as estações do ano, é uma região litorânea, além de o terreno ser apropriado para a instalação da turbina eólica.

Observando as perspectivas econômicas, o valor do custo da implantação do produto é de $R \$ 20.000,00$. Observando o gasto de consumo de energia da academia (quadro 2 ), o total do gasto em um ano é de $\mathrm{R} \$ 19.116,85$. Sendo a média anual de $\mathrm{R} \$ 1.593,07$ (tabela $Y$ ). É fácil notar que em termos financeiros fica bastante viável, tendo um retorno do investimento em curto prazo de 18 meses, além dos gastos com a manutenção serem escassos, pois já está incluso no valor inicial do empreendimento. Passando esse período de menos de dois anos, o proprietário terá uma economia bastante significativa.

O aproveitamento da energia eólica na academia em Cabo frio comporta numerosos benefícios referentes às energias tradicionais em função do seu maior desenvolvimento. É uma fonte inesgotável, não produz resíduo e nem lança gases poluentes.

Conclui-se que todas as condições são favoráveis ao projeto de aproveitamento de energia eólica torna-se viável para a academia de Cabo frio, ressaltando as expectativas sobre a responsabilidade social empresarial.

[6] Canoaseólica. Disponível em: www.canoaseolica.com.br. Acesso em 10 out.2012 [7] Centro Brasileiro de Energia Eólica - CBEE / UFPE. 2000. Disponível em: www.eolica.com.br. Acesso em: 22 de mar. 2012.

[8] Centro de Referência Para a Energia Solar e Eólica Sérgio de Salvo Brito - CRESESB. 2000. Disponível em: www.cresesb.cepel.br/cresesb.htm. [9] Energia do Vento e da água. Energia. São Paulo, gecho, 1994 64p.

[10] European Wind Energy Association (EWEA); Greenpeace. Wind force 12: a blueprint to achieve $12 \%$ of the world's electricity from wind power by 2020. London: ewea, 2003. Disponível em: $\quad<$ http://www.ewea.org/documents/WF122004_eng.pdf>. Acesso em: 31 maio 2005.

[11] Feitosa, E. A. N. et al. Panorama do Potencial Eólico no Brasil. Brasília: Dupligráfica, 2003. 68p. 
[12] Goldenberg, José. Energia no Brasil. São Paulo, 1976.

[13] Grubb, M. J; Meyer, N. I. Wind energy: resources, systems and regional strategies. In: JOHANSSON, T. B. et. al. Renewable energy: sources for fuels and electricity. Washington, D.C.: Island Press, 1993p.

[14] Kranert. Energia Eólica. Energia, v-4, n23, p 24-30, 1982.

[15] Memória Da Eletricidade. Primeira turbina eólica de Fernando de Noronha: 2000.

[16] Nascimento, J. B. Energia Eólica no Brasil e no mundo - uma visão geral, (tese de doutorado em andamento - 1996).

[17] OIL\&Gas. $2012 . \quad$ Disponível em:www.rioegas.com.br. Acesso em 10 out.2012

[18] Silva Júnior, César; Sasson, Sezar; Bedaque, Paulo Sérgio. Entendendo a natureza. O mundo em que vivemos. 1a ed., 1992.
[19] Stoner, Carol Hupping. A produção de sua própria energia I. - Manual prático de energias renováveis, 1976.

[20] Taylor, D. Wind energy. In: BOYLE, G. (Ed.). Renewable energy: power for a sustainable future. Oxford: Oxford University Press, 1996. cap. 7, p. 267-314.

[21] Wobben. 2003. Disponível em: www.wobben.com.br/Espanhol/usinas.htm.

[22] Wind directions. [London]: EWEA, v. 20, may 2000.

[23] Windpower monthly news magazine. [Knebel]: Windpower Monthly, v. 16, 2000.

[24] Wikipédia. Cabo Frio. Disponível em:< http://pt.wikipedia.org/wiki/Cabo_Frio>. Acesso em 15 mar. 2012. 


\section{Bapítulo 13}

\section{AVALIACÃO DA QUALIDADE ACÚSTICA PRÉ-OCUPACÃO PARA O SISTEMA DE PISO EM AMBIENTE CONSTRUİDO DE UM APARTAMENTO RESIDENCIAL EM NITERÓI-RJ}

\section{Wlander Belem Martins}

\section{Helton Luiz Santana Oliveira}

\section{Pedro Vieira de Souza Junior.}

Resumo:O presente trabalho trata da avaliação do nível de conforto acústico em ambiente construído do sistema de piso de apartamentos para fins residenciais, na fase pré-ocupação, isto é, anterior à sua ocupação definitiva, antes que elementos de mobiliário que modificam as características acústicas do ambiente sejam introduzidas em seu interior. Atualmente, face ao forte crescimento da ocupação imobiliária de grande parte das cidades brasileiras, este tema tem ganho cada vez mais importância na vida urbana, o que se evidencia principalmente pelos registros de incômodos de habitantes desses apartamentos residenciais em relação ao ruído proveniente do pavimento superior. Dentre as possíveis razões para este fenômeno tem-se a redução das espessuras de piso e não adoção de soluções construtivas adequadas, seja por mero desconhecimento dos projetistas, seja por não exigência do futuro habitante, ou por simples adoção de estratégias equivocadas de racionalização e redução de custos pelo construtor sem a real consideração dos benefícios de médio e longo prazo de técnicas construtivas e materiais adequados. Este trabalho pretende com o emprego da metodologia do estudo de caso verificar em que medida um imóvel residencial construído segundo padrões clássicos distancia-se dos preceitos estabelecidos na NBR-15575 (ABNT, 2013), com relação ao desempenho acústico do sistema de piso de seus elementos construtivos em termos de segurança, habitabilidade e sustentabilidade. A pesquisa de campo deuse num imóvel recentemente edificado em Niterói-RJ. A geração dos sinais sonoros padronizados empregados nos ensaios de campo foi efetuada com o emprego do equipamento Tapping Machine e com um Medidor de Nível de Pressão Sonora. Verificou-se com o trabalho que os valores encontrados para o nível de pressão padronizado estão dentro dos limites estabelecidos pela norma para o desempenho mínimo.

Palavras-Chave: Desempenho acústico, Qualidade acústica, Sistema de Piso. 


\section{INTRODUÇÃO}

As empresas que atuam na construção civil hoje, em função das mudanças ocorridas nesses últimos anos, estão buscando alternativas para se tornarem mais competitivas. Diante desse quadro, elas estão buscando racionalizar os métodos, processos e sistemas construtivos empregado com o objetivo principal de diminuição dos custos. Essa racionalização construtiva leva a uma adequação tecnológica e de mudanças organizacionais dos processos tradicionais de construção (BARROS, 1998). Essas mudanças construtivas podem refletir em redução de espessuras de paredes e pisos resultando numa perda de desempenho e da qualidade acústica das edificações (REZENDE, 2014).

Diversas fontes geram ruído nas edificações, tais como as aéreas e as estruturais. Podemse considerar como aéreas: o som gerado por vozes, buzinas, tráfego urbano e, como estruturais: o impacto em pisos causados por quedas de objetos, móveis sendo arrastados no pavimento superior e os sistemas hidrossanitários, que são transmitidos através do próprio sistema de piso e dos elementos laterais ou paredes NBR 15575-3 (ABNT, 2013).

\section{OBJETIVO}

O objetivo deste artigo é avaliar os índices estabelecidos pela norma de desempenho de edificações no Brasil, a NBR 15575-3 (ABNT, 2013), apresentado um estudo de caso através do ensaio de um sistema de piso de um imóvel residencial construído segundo padrões clássicos, e comparando com os critérios de classificação estabelecidos pela norma brasileira.

\section{METODOLOGIA}

Os ensaios para coleta de dados foram realizados conforme as recomendações das normas ISO 140-7 (ISO,1998), ISO 717-2 (ISO,2013 e ISO 10052 (ISO,2004), cujo detalhamento é apresentado a seguir

\subsection{MEDIÇÕES DE ACORDO COM A ISO 140- 7 E ISO 10052}

As medições dos níveis de pressão sonora foram realizadas utilizando filtros de bandas de oitava e, foi adotado o tempo de um minuto para a leitura dos níveis de pressão sonora.

Conforme NBR 15575 (ABNT, 2013), a metodologia de medição especificada nas normas ISO 140-7 (ISO,1998) e ISO 10052 $(I S O, 2004)$ estão baseadas na emissão de ruído de impacto, através da utilização da Tapping Machine padronizada, instalada no recinto superior (emissor), e a medição do nível de pressão sonora em bandas de frequência sendo feita no recinto subjacente (receptor). Ao nível efetivamente medido se processa uma correção, segundo as condições acústicas do recinto receptor, obtido com o cálculo do tempo de reverberação, que proporcionam o Nível de Pressão Sonora de Impacto Padrão Ponderado ( $\left.L_{n T, w}^{\prime}\right)$.

Para o ensaio do ruído de impacto do piso foi posicionada a Tapping machine em 4 diferentes pontos, distribuídos no piso do pavimento superior (emissor), conforme norma ISO 140-7 (ISO,1998). As medições do nível de ruído de impacto foram efetuadas, para cada posição da máquina, em 4 posições do equipamento de medição do nível de pressão sonora no ambiente inferior ao piso ensaiado (receptor), num total de 72 registros para cada ponto, sendo obtida a média para cada frequência em cada ponto. $\mathrm{O}$ equipamento de medição foi instalado em tripé a 1,2 m do piso, a uma distância mínima entre posições de 0,7 $\mathrm{m}$ e, entre paredes de $0,5 \mathrm{~m}$. 
Figura 1. Esquema de medição de ruído de impacto utilizando a Tapping machine

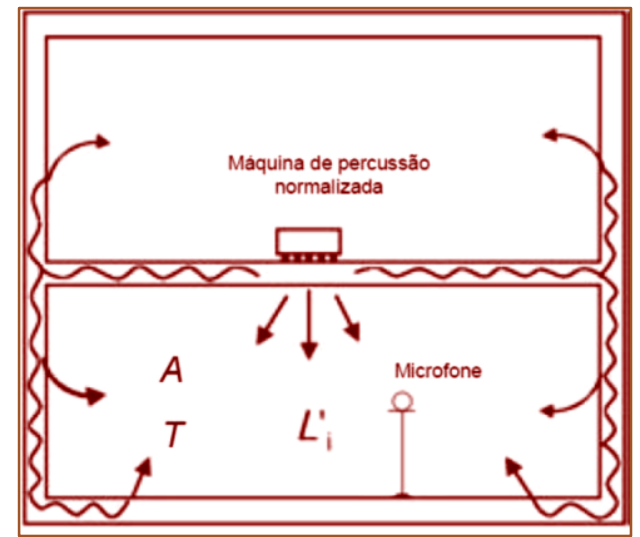

A determinação do nível de pressão sonora por impacto padronizado em cada frequência

se dá pela fórmula a seguir:

$$
L_{n T}^{\prime}=L_{i}-10 \times \log \left(\frac{T}{T_{0}}\right) \mathrm{dB}
$$

Onde:

Li é o nível de pressão sonora no piso do ambiente que está sendo excitado pela Tapping Machine $[\mathrm{dB}]$;

T é tempo de reverberação (RT60) medido no piso do ambiente [s];

$T_{0}$ é o tempo de reverberação de referência $(0,5 s)$ [s].

Os tempos de reverberação utilizados no cálculo do nível de pressão sonora padronizado foram estimados conforme os materiais das superfícies absorventes do ambiente estudado e calculados segundo as médias de Sabine e Eyring. Foi também levado em consideração no cálculo o coeficiente de absorção sonora do ar, considerando a umidade da cidade de $60 \%$ e a temperatura de $25^{\circ} \mathrm{C}$.

\subsection{MEDIÇÃO DE ACORDO COM A ISO 717-2}

Após obtidos os L'nT para cada frequência, é necessário transformá-los em um único valor de acordo com a ISO 717-2 (ISO,2013). Para isso, a curva de L'nt obtida na medição de campo deve ser ajustada à curva de valores de referência para ruído de impacto em bandas de oitava encontrada na ISO 717-2 (ISO,2013).

Através do ajuste, os desvios desfavoráveis são utilizados para que se encontre o número único. A soma dos desvios desfavoráveis, segundo a medição em bandas de oitava, é de $10 \mathrm{~dB}$. O ajuste que mais se aproximar deste somatório será utilizado para a obtenção do número único, que no caso se refere a frequência de $500 \mathrm{~Hz}$ (PARMANEN, 1988).

\subsection{OBJETOS DE ESTUDO}

Os ensaios experimentais utilizados neste trabalho referem-se à avaliação do desempenho do piso de um imóvel residencial construído segundo padrões clássicos, cujos sistemas construtivos são compostos por materiais usualmente utilizados na construção civil. Os ensaios foram realizados entre dois pavimentos, sendo ambas situações, sala sobre sala.

No quadro 1, estão descritas as características dos sistemas construtivos do imóvel. 
Quadro 1. Características dos sistemas construtivos e cômodo ensaiado

\begin{tabular}{|c|c|c|c|c|}
$\begin{array}{c}\text { Constituição } \\
\text { do piso }\end{array}$ & Espessura total & $\begin{array}{c}\text { Área do piso } \\
{\left[\mathrm{m}^{2}\right]}\end{array}$ & $\begin{array}{c}\text { Volume de superfície } \\
\text { do ambiente receptor } \\
{\left[\mathrm{m}^{3}\right]}\end{array}$ & $\begin{array}{c}\text { Pé direito do } \\
\text { ambiente receptor } \\
{[\mathrm{m}]}\end{array}$ \\
\hline Cerâmico & $\begin{array}{c}16 \mathrm{~cm} \text { com } \\
\text { contra piso }\end{array}$ & 88,4 & 43,2 & 2,5 \\
\hline
\end{tabular}

\subsection{EQUIPAMENTOS}

Os equipamentos utilizados na realização das medições foram:

- Medidor de Nível de Pressão Sonora do fabricante Larson Davis, modelo 831;

- Calibrador de Nível de Pressão Sonora tipo 1 do fabricante Larson Davis;

- Tapping Machine do fabricante Look Line, modelo EM50;

Foi feito uma medição de ruído de fundo no ambiente receptor em duas posições, para que, caso necessário, fossem efetuadas as correções necessárias nos níveis de ruído medidos no pavimento receptor.

\section{ANÁLISE DE RESULTADOS}

4.1 CÁLCULO DO TEMPO DE REVERBERAÇÃO DO AMBIENTE RECEPTOR

No cálculo das estimativas de tempo de reverberação leva-se em consideração as propriedades sono absorventes dos diferentes materiais construtivos empregados no ambiente receptor, que são apresentados na tabela 1, bem como seus parâmetros dimensionais característicos, mais especificamente: áreas das superfícies de absorção e o volume total do ambiente, que são apresentados na tabela 2. Segundo Beranek (2006) existem vários métodos que podem ser empregados para tais estimativas e, neste trabalho adotou-se uma média entre as estimativas pelo método de Sabine (equação 1) e o método de Eyring (equação 2), apresentadas respectivamente, a seguir:

$$
\begin{aligned}
& R T_{60}=0,161 \times \frac{v}{\sum_{i=1}^{n}\left(s_{i} \times \alpha_{i}\right)+(4 \times m \times V)}[\mathrm{s}] \\
& R T_{60}=0,161 \times \frac{V}{\sum_{i=1}^{n}\left[-S_{i} \times \ln \left(1-\alpha_{i}\right)\right]+(4 \times m \times V)}[\mathrm{s}]
\end{aligned}
$$

Onde:

V: Volume geométrico interno total do ambiente em estudo $\left[\mathrm{m}^{3}\right]$;

$S_{\mathrm{i}}$ : Área plana da superfície de absorção sonora $\left[\mathrm{m}^{2}\right]$;

$\mathrm{m}$ : Coeficiente de absorção sonora pelo ar atmosférico interno do ambiente $\left[\mathrm{m}^{-1}\right]$;

$\alpha_{\mathrm{i}}$ : Coeficiente de absorção sonora do material de construção da superfície por banda de oitava [1];

$\mathrm{RT}_{60}$ : Tempo de reverberação do ambiente em estudo [s] 
Tabela 1 - Coeficientes de Absorção Sonora dos materiais em Banda de Oitava - $\alpha$ [1]:

\begin{tabular}{|c|c|c|c|c|c|c|}
\hline & \multicolumn{6}{|c|}{ Frequências em Bandas de Oitavas [Hz] } \\
\hline & 125 & 250 & 500 & 1.000 & 2.000 & 4.000 \\
\hline Cerê & 0,01 & 0,01 & 0,01 & 0,02 & 0,02 & 0,02 \\
\hline Madeira envernizada & 0,05 & 0,05 & 0,03 & 0,03 & 0,03 & 0,03 \\
\hline Esquadria convencional c & 0,35 & 0,25 & 0,18 & 0,12 & 0,07 & 0,04 \\
\hline Bloco de concreto $p$ & 0,10 & 0,05 & 0,06 & 0,07 & 0,09 & 0,08 \\
\hline Gesso em placas (teto) & 0,02 & 0,02 & 0.03 & 0,03 & 0,05 & 0,05 \\
\hline
\end{tabular}

Fonte: Carvalho, 2010.

Tabela 2 - Absorção sonora das superfícies por bandas de Oitavas: Si.ai [m2]

\begin{tabular}{|c|c|c|c|c|c|c|c|}
\hline \multicolumn{2}{|l|}{ Componente de Superfície } & \multicolumn{6}{|c|}{$\begin{array}{l}\text { Frequências em Bandas de Oitavas } \\
{[\mathrm{Hz}]}\end{array}$} \\
\hline & & 125 & 250 & 500 & 1.000 & 2.000 & 4.000 \\
\hline Área física de piso plano $\left[\mathrm{m}^{2}\right]$ & 17,27 & 0,17 & 0,17 & 0,17 & 0,35 & 0,35 & 0,35 \\
\hline $\begin{array}{l}\text { Área física de portas de madeira: } 3 \times(2,1 \times \\
\qquad 0,7)+1 \times(2,10 \times 0,8)\left[\mathrm{m}^{2}\right]\end{array}$ & 6,09 & 0,30 & 0,30 & 0,18 & 0,18 & 0,18 & 0,18 \\
\hline $\begin{array}{l}\text { Área física de porta de correr envidraçada: } \\
\qquad 1 \times(1,5 \times 2,5)\left[\mathrm{m}^{2}\right]\end{array}$ & 3,75 & 1,31 & 0,94 & 0,68 & 0,45 & 0,26 & 0,15 \\
\hline $\begin{array}{l}\text { Área física de Paredes (descontadas as } \\
\left.\text { cavidades de portas e janelas) [ } \mathrm{m}^{2}\right]\end{array}$ & 44,04 & 4,40 & 2,20 & 2,64 & 3,08 & 3,96 & 3,52 \\
\hline Área física de teto plano $\left[\mathrm{m}^{2}\right]$ & 17,27 & 0,35 & 0,35 & 0,52 & 0,52 & 0,86 & 0,86 \\
\hline Área total de absorção sonora [m²] & 88,41 & & & & & & \\
\hline Volume geométrico interno total $\left[\mathrm{m}^{3}\right]$ & 43,17 & & & & & & \\
\hline Absorção sonora pelas superfícies [ $\mathrm{m}^{2}$.Sabine] & & 6,54 & 3,96 & 4,19 & 4,58 & 5,62 & 5,06 \\
\hline
\end{tabular}

Na tabela 3, são apresentados os coeficientes de absorção sonora do ar segundo Harris (1966), assim como são apresentados os valores da absorção pelo ar e a absorção total, que inclui as parcelas devidas às superfícies do ambiente construído e mais o ar que ocupa internamente este espaço.

Tabela 3 - Absorção sonora pelo ar e total em bandas de Oitavas.

\begin{tabular}{|c|c|c|c|c|c|c|c|}
\hline & \multicolumn{7}{c|}{ Frequências em Bandas de Oitavas [Hz] } \\
\hline $\begin{array}{c}\text { Coeficiente de absorção sonora pelo ar }\left[\mathrm{m}^{-1}\right] \\
\text { @ UR=60\% e T=25ㄷ }\end{array}$ & 0,0000 & 0,0000 & 0,0000 & 0,0010 & 0,0022 & 0,0055 \\
\hline Absorção sonora pelo ar [m².Sabine] & 0,00 & 0,00 & 0,00 & 0,17 & 0,38 & 0,95 \\
\hline Absorção sonora total [m².Sabine] & 6,54 & 3,96 & 4,19 & 4,41 & 5,24 & 4,11 \\
\hline
\end{tabular}

Tabela 4 - Estimativas dos tempos de reverberação (RT60) por diferentes métodos e coeficiente de absorção médio (amédio) por bandas de oitava.

\begin{tabular}{|c|c|c|c|c|c|c|}
\hline & \multicolumn{5}{c|}{ Frequências em Bandas de Oitavas [Hz] } \\
\hline & 125 & 250 & 500 & 1.000 & 2.000 & 4.000 \\
\hline RT60_Calculado por Sabine [s] & 1,06 & 1,75 & 1,66 & 1,58 & 1,33 & 1,69 \\
\hline Coeficiente de absorção sonora médio: $\alpha_{\text {médio }}$ & 0,07 & 0,05 & 0,05 & 0,05 & 0,06 & 0,06 \\
\hline RT60_Calculado por Eyring [s] & 1,03 & 1,72 & 1,62 & 1,43 & 1,13 & 1,13 \\
\hline RT60_Médio (Sabine e Eyring) [s] & 1,04 & 1,74 & 1,64 & 1,50 & 1,23 & 1,41 \\
\hline
\end{tabular}


Logo, foram adotados para estimar os tempos de reverberação por bandas de oitavas do ambiente estudado valor médio apresentado na última linha da tabela 4 , que são obtidos pelo cálculo das médias entre a estimativa segundo o método de Sabine e a estimativa segundo o método de Eyring.

Tabela 5 - Posição 1 da Tapping machine no ambiente emissor

\begin{tabular}{|c|c|c|c|c|c|c|c|c|c|}
\hline$f[\mathrm{~Hz}]$ & TR [s] & Curva Std & L'nT [dB] & Delta & Parcelas & $\begin{array}{c}\text { Std } \\
\text { Deslocada }\end{array}$ & Delta & Parcelas & Patamar \\
\hline 125 & 1,04 & 86 & 55,7 & $-30,3$ & 0 & 75,09 & $-19,37$ & 0 & 73,09 \\
\hline 250 & 1,74 & 86 & 61,8 & $-24,2$ & 0 & 75,09 & $-13,31$ & 0 & 73,09 \\
\hline 500 & 1,64 & 84 & 64,4 & $-19,6$ & 0 & 73,09 & $-8,65$ & 0 & 73,09 \\
\hline 1000 & 1,50 & 81 & 63,4 & $-17,6$ & 0 & 70,09 & $-6,74$ & 0 & \\
\hline 2000 & 1,23 & 68 & 67,1 & $-0,9$ & 0 & 57,09 & 10,00 & 10,0 & \\
\hline & & \multicolumn{2}{|c|}{ Deslocar } & $-10,9$ & 0,0 & & & 10,0 & Ok \\
\hline
\end{tabular}

Figura 2. Gráfico para obtenção do valor único em $500 \mathrm{~Hz}-$ Valor único $=73,9 \mathrm{~dB}$

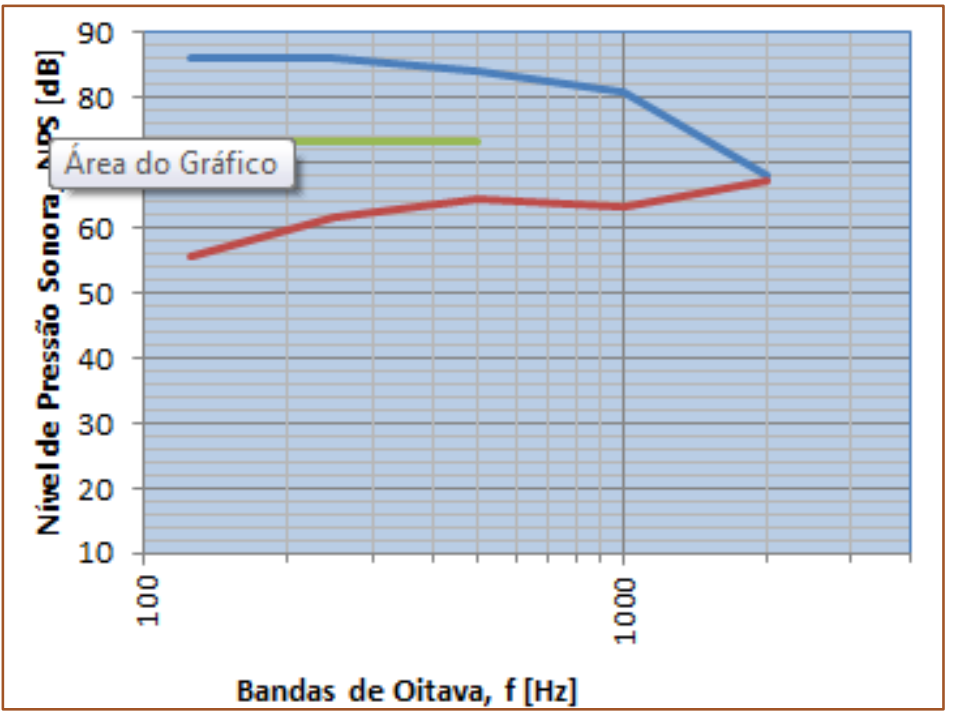

Quadro 2. Classificação do nível de desempenho na posição 1

\begin{tabular}{|l|l|}
\hline Classificação iso 717-2 & Classificação nbr 15575 \\
\hline$L^{\prime} n T, w=73,9$ & Nível de Desempenho Mínimo \\
\hline
\end{tabular}

Tabela 3. Posição 2 da Tapping machine no ambiente emissor

\begin{tabular}{|c|c|c|c|c|c|c|c|c|c|c|}
\hline$f[\mathrm{~Hz}]$ & $T R[s]$ & Curva Std & $L^{\prime} \mathrm{nT}[\mathrm{dB}]$ & Delta & Parcelas & Std Deslocada & \multicolumn{2}{c|}{ Delta } & \multicolumn{2}{c|}{ Parcelas Patamar } \\
\hline 125 & 1,04 & 86 & 55,0 & $-31,0$ & 0 & 77,22 & $-22,25$ & 0 & 75,22 \\
\hline 250 & 1,74 & 86 & 60,8 & $-25,2$ & 0 & 77,22 & $-16,46$ & 0 & 75,22 \\
\hline 500 & 1,64 & 84 & 65,4 & $-18,6$ & 0 & 75,22 & $-9,85$ & 0 & 75,22 \\
\hline 1000 & 1,5 & 81 & 64,8 & $-16,2$ & 0 & 72,22 & $-7,44$ & 0 & \\
\hline 2000 & 1,23 & 68 & 69,2 & 1,2 & 1,2 & 59,22 & 10,00 & 10,0 & \\
\hline & & & Deslocar & $-8,8$ & 1,2 & & & 10,0 & Ok \\
\hline
\end{tabular}


Figura 3. Gráfico para obtenção do valor único em $500 \mathrm{~Hz}$ - Valor único= 75,2 dB

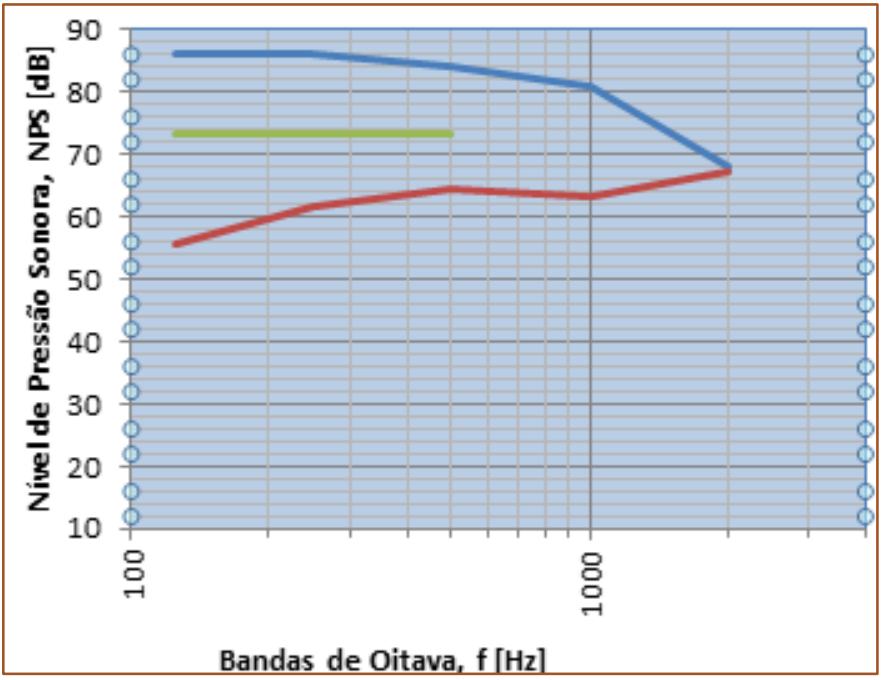

Quadro 3. Classificação do nível de desempenho na posição 2

\begin{tabular}{|l|l|}
\hline Classificação iso 717-2 & Classificação nbr 15575 \\
\hline$L^{\prime} n T, W=75,2$ & Nível de Desempenho Mínimo \\
\hline
\end{tabular}

Tabela 4. Posição 3 da Tapping machine no ambiente emissor

\begin{tabular}{|c|c|c|c|c|c|c|c|c|c|}
\hline $\mathrm{f}[\mathrm{Hz}]$ & $\mathrm{TR}[\mathrm{s}]$ & Curva Std & L'nT [dB] & Delta & Parcelas & $\begin{array}{c}\text { Std } \\
\text { Deslocada }\end{array}$ & Delta & $\begin{array}{c}\text { Parcela } \\
\text { s }\end{array}$ & $\begin{array}{c}\text { Patama } \\
r\end{array}$ \\
\hline 125 & 1,04 & 86 & 55,2 & $-30,8$ & 0 & 71,92 & $-16,67$ & 0 & 69,92 \\
\hline 250 & 1,74 & 86 & 60,5 & $-25,5$ & 0 & 71,92 & $-11,46$ & 0 & 69,92 \\
\hline 500 & 1,64 & 84 & 62,6 & $-21,4$ & 0 & 69,92 & $-7,35$ & 0 & 69,92 \\
\hline 1000 & 1,5 & 81 & 62,0 & $-19,0$ & 0 & 66,92 & $-4,91$ & 0 & \\
\hline 2000 & 1,23 & 68 & 63,9 & $-4,1$ & 0,00 & 53,92 & 10,00 & 10,0 & \\
\hline & & & Deslocar & $-14,0$ & 0,0 & & & 10,0 & Ok \\
\hline
\end{tabular}

Figura 4. Gráfico para obtenção do valor único em $500 \mathrm{~Hz}$ - Valor único= 69,9 dB

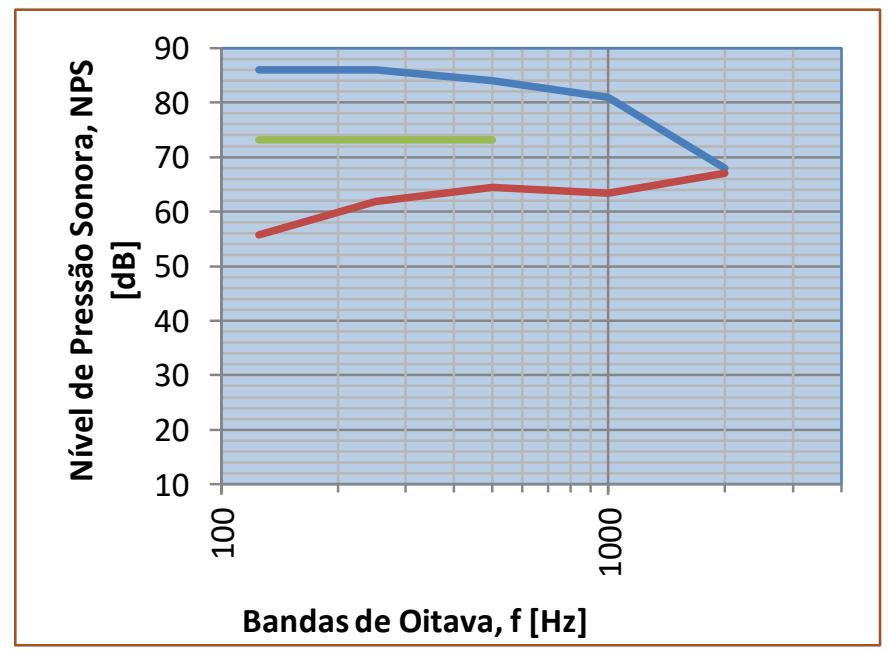


Quadro 4. Classificação do nível de desempenho na posição 3

\begin{tabular}{|l|l|}
\hline Classificação iso 717-2 & Classificação nbr 15575 \\
\hline L'nT,w 69,9 & Nivel de Desempenho Mínimo \\
\hline
\end{tabular}

Tabela 5. Posição 4 da Tapping machine no ambiente emissor

\begin{tabular}{|c|c|c|c|c|c|c|c|c|c|}
\hline $\mathrm{f}[\mathrm{Hz}]$ & $\mathrm{TR}[\mathrm{s}]$ & Curva Std & L'nT [dB] & Delta & Parcelas & Std Deslocada & Delta & Parcelas & Patamar \\
\hline 125 & 1,04 & 86 & 50,9 & $-35,1$ & 0 & 72,72 & $-21,80$ & 0 & 70,72 \\
\hline 250 & 1,74 & 86 & 59,9 & $-26,1$ & 0 & 72,72 & $-12,81$ & 0 & 70,72 \\
\hline 500 & 1,64 & 84 & 60,7 & $-23,3$ & 0 & 70,72 & $-10,05$ & 0 & 70,72 \\
\hline 1000 & 1,5 & 81 & 62,9 & $-18,1$ & 0 & 67,72 & $-4,79$ & 0 & \\
\hline 2000 & 1,23 & 68 & 64,7 & $-3,3$ & 0,0 & 54,72 & 10,00 & 10,0 & \\
\hline & & & Deslocar & $-10,9$ & 0,0 & & & 10,0 & Ok \\
\hline
\end{tabular}

Figura 5. Gráfico para obtenção do valor único em 500Hz - Valor único= 70,7 dB

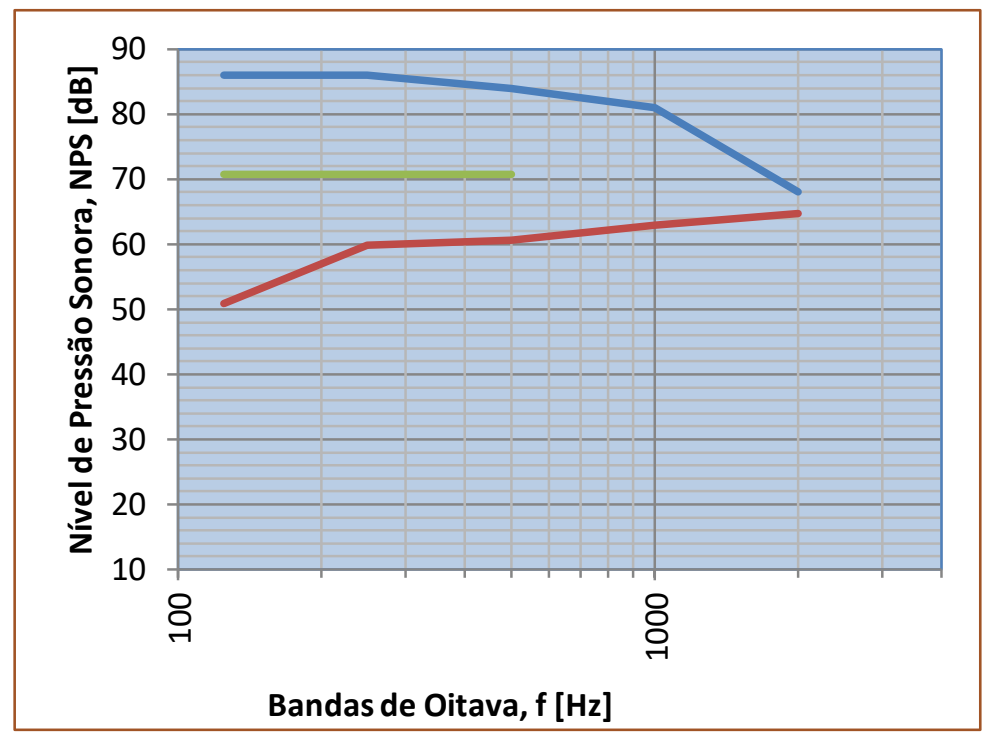

Quadro 5. Classificação do nível de desempenho na posição 4

\begin{tabular}{|l|c|}
\hline Classificação iso $717-2$ & Classificação nbr 15575 \\
\hline L'nt, $w=70,7$ & Nível de desempenho mínimo \\
\hline
\end{tabular}

\section{CONCLUSÕES}

Através dos resultados obtidos nos ensaios experimentais, foi possível avaliar os critérios estabelecidos pela norma brasileira ABNT NBR 15575 (ABNT, 2013).

Quanto ao desempenho acústico para isolamento de impacto do sistema de pisos deste imóvel residencial em Niterói, RJ, e levando-se em consideração que na construção do prédio não foram levadas em conta os requisitos da Norma 15575 (ABNT, 2013), pode-se observar que para o sistema construtivo, os valores encontrados para o $L_{n T, w}$ estão dentro dos limites estabelecidos pela norma brasileira para o Desempenho Mínimo que é no intervalo de até $80 \mathrm{~dB}$.

Segundo a ABNT (2013), o requisito mínimo para isolamento de ruído de impacto entre unidades é reconhecidamente insuficiente para prover o desejável conforto aos usuários. Portanto, recomenda-se, sempre que possível, o desempenho Intermediário ou Superior, seja pela aplicação de contrapisos flutuantes ou por sistemas de lajes mais robustos. 
Espera-se que a publicação da Norma de Desempenho ABNT NBR 15575 ocorrida em julho de 2013 promova uma mudança de atitude pelas empresas de construção civil, pois a partir de agora os consumidores de imóveis poderão exigir das construtoras os requisitos mínimos de desempenho ao logo da vida da unidade habitacional. Caso não sejam atendidos, poderão exigir, amparados

\section{REFERÊNCIAS}

[1] Associação Brasileira de Normas Técnicas (ABNT), 2013. NBR 15575-3: Edificações habitacionais - Desempenho.

[2] Barros, M. M. S. B. Racionalização dos métodos, processos e sistemas construtivos. Comissão de Pesquisa do Departamento de Construção Civil. Escola Politécnica da Universidade de São Paulo. São Paulo, 1998.

[3] Beranek, L. L. Analysis of Sabine and Eyring equations and their application to concert hall audience and chair absorption. The Journal of the Acoustical Society of America, v. 120, n. 3, p. 1399-1410, 2006.

[4] Bistafa, S. R. Acústica aplicada ao controle do ruído. São Paulo: Edgard Blucher, 2009.

[5] Carvalho, R..P. Acústica Arquitetônica. 2. Ed. Brasília: Thesaurus, 2010.

[6] Ferraz, R., 2008. Atenuação de Ruído de Impacto em Pisos de Edificações de Pavimentos Múltiplos. Dissertação (Mestrado em Engenharia de Estruturas) - Programa de Pós-Graduação em Engenharia de Estruturas, Universidade Federal de Minas Gerais, Belo Horizonte. na norma técnica, o cumprimento dos requisitos de desempenho acústico.

Uma mudança de paradigma é esperada a partir da publicação da norma, pois será necessária uma nova metodologia de projeto que exigirá um nível de conhecimento maior por parte dos construtores que o atual, principalmente quanto aos requisitos relacionadas ao desempenho acústico.

[7] Harris, C. M. Absorption of sound in air versus humidity and temperature. The Journal of the Acoustical Society of America, v. 40, n. 1, p. 148-159, 1966

[8] International Organization for Standardization (ISO), 1998. ISO 140-7: Acoustics: Measurement in of sound in buildings and of building elements. Part 7: Field measurements of impact sound insulation of floors. Genève, Switzerland.

[9] 1996. ISO 717-2: Acoustics: Rating of sound insulation in buildings and of building elements. Genève, Switzerland.

[10] 2004. ISO 10052: Acoustics: Field measurements of airborne and impact sound insulation and of service equipament sound Survey method. Genève, Switzerland.

[11] Permanen J. Principles of Constructing a short test method for impact sound insulation measurements 181-194. Technical Research Centre of Finland, Laboratory of Heating and Ventilation, SF-02150 Espoo, Finland, 1988.

[12] Rezende, J.B. de, Rodrigues, F. C., Vecci, M. A. M. Uma análise de critérios de desempenho acústico para sistemas de piso em edificações. Juiz de Fora, MG, maio 2014. p. 28-30. 


\section{Bapítulo 14}

\section{A RESPONSABILIDADE SOCIAL MARKETING SOCIAL NAS ORGANIZAÇÕES}

\section{Filipe de Castro Quelhas}

Resumo: Muitas vezes as organizações confundem o marketing social com filantropia. Hoje,a gerência por intenções já não encontra mais espaço no mercado. Com o crescimento do Terceiro Setor - tanto em volume de recursos financeiros quanto em relevância social e política - e sua consequente profissionalização, as modernas técnicas de gestão dos negócios foram, pouco a pouco, incorporadas à área social. A sociedade também espera e cobra resultados concretos efetivos capazes de transformar organizações e pessoas carentes em cidadãos que exercitem seus direitos fundamentais. O marketing social com base na responsabilidade social pode chegar a construir em longo prazo um valor diferencial para a marca e uma vantagem competitiva para as empresas. Hoje em dia existem conhecimentos e técnicas para organizar e colocar em prática programas efetivos de mudança social em qualquer área de assunto social, tanto local quanto nacional. Originar a mudança social que melhore a vida é um desafio das campanhas sociais e o objetivo do marketing social.

Palavras-chave: Responsabilidade Social Empresarial, Marketing Social, Organizações. 


\section{INTRODUÇÃO}

\subsection{CONSIDERAÇÕES INICIAIS}

A economia no país e no mundo passou por várias transformações nos últimos anos. Neste novo contexto social de informações e de negócios em escala global, de novas técnicas administrativas e de inovações tecnológicas, surgiram também outros modelos de produtividade, de competitividade e também outros valores passaram a fazer parte dos objetivos das organizações.

Durante anos acreditou-se que o crescimento econômico por si só proporcionaria melhores condições de vida para a sociedade, porém as carências e desigualdades sociais continuaram presentes na sociedade. $O$ fortalecimento da cidadania e da afirmação dos direitos coletivos desencadeou uma preocupação com a atuação empresarial no que diz respeito ao social, estreitando assim a relação entre empresas e sociedade. As empresas passaram a atuar como agentes transformadoras contribuindo para a melhoria da qualidade de vida da sociedade.

Observa-se uma crescente participação das organizações no desenvolvimento daquilo que é de interesse social, ou seja, na saúde, educação, cultura, meio ambiente, assistência social, etc.

A sociedade está cada vez mais consciente de seus direitos exigindo das empresas uma postura mais participativa no que diz respeito aos problemas sociais. Deste modo as empresas têm se preocupado em arcar com as responsabilidades em relação a seus funcionários, clientes, fornecedores, acionistas, à comunidade onde atuam e ao meio ambiente. Esta atitude pode se tornar o fator determinante do sucesso mercadológico, devido a atual dificuldade de criar um diferencial competitivo.

O sucesso da empresa e o aumento de seu faturamento podem estar relacionados com o que a sua imagem sugere para o consumidor. Portanto, ser uma empresa socialmente responsável, valorizar os princípios éticos e morais e divulgar suas atividades sociais são fatores estratégicos e indispensáveis para se ter acesso a novos mercados. As empresas que utilizarem de maneira inteligente as suas atuações sociais em suas estratégias de comunicação utilizando-se do marketing social estarão um passo à frente, diferenciando seus produtos, aumentando as vendas e fidelizando clientes.
2 REFERENCIAL TEÓRICO

\subsection{RESPONSABILIDADE SOCIAL EMPRESARIAL}

Diante das diversas mudanças ocorridas no contexto de atuação das organizações, o ambiente externo passou a ser considerado à medida que na administração desenvolveu-se o entendimento de que o desempenho dos sistemas organizacionais dependeria de outros elementos, além das suas ações específicas. As organizações passaram a ser vistas como sistemas abertos.

Segundo Chiavenato (2000), as organizações operam dentro de um contexto do qual dependem para sobreviver, manter-se e desenvolver. Os recursos e as informações necessárias para o funcionamento das organizações são obtidos do ambiente e para ele dirigem o resultado das suas operações. Como sistemas sociais abertos, atuam num ambiente dinâmico permeado por interrelações entre vários agentes ou grupos sociais, tais como: os trabalhadores diretos, os clientes, fornecedores, os acionistas, instituições financeiras, o governo, comunidade local e o meio ambiente natural.

Para Duarte e Dias (1985), a empresa não existe no vácuo, ela integra um macrosistema social no qual seus principais componentes são representados pela sociedade, economia, meio ambiente natural, a ciência e a tecnologia, ou seja, está submetida a um conjunto de relações.

Portanto, se antes os executivos podiam tomar decisões sem se preocupar com a influência e os reflexos do meio ambiente externo, hoje, a complexidade do ambiente de negócios e as rápidas transformações que nele ocorrem faz com que os administradores considerem nas suas decisões internas, as influências vindas do ambiente externo. Os reflexos das mudanças ocorridas nas últimas décadas marcaram as organizações e a sociedade de uma forma geral.

De acordo com Duarte e Dias (1985), à medida que o ambiente se transforma, mudam os valores culturais, padrões de comportamento e surgem novas expectativas para o papel das organizações. A sustentabilidade das organizações passa a depender de sua flexibilidade em aceitar novos paradigmas.

A preocupação com os efeitos sociais e ambientais das atividades de empresas, bem como os valores éticos e morais, gera muitas 
discussões e tem levantado várias questões no meio empresarial.

Drucker (1999) salienta que não se pode afirmar que uma empresa tenha como responsabilidade apenas 0 desempenho econômico; mas este é sua primeira responsabilidade. A empresa que não trabalha para obter lucro pelo menos igual ao custo do seu capital é irresponsável, pois desperdiça recursos da sociedade. Segundo o autor, seria justo que os mesmos grupos de liderança que foram responsáveis pelo êxito em prover as quantidades para a vida assumam agora a responsabilidade de prover também a qualidade da vida. A responsabilidade seria então algo a ser incorporado após as necessidades econômicas estarem razoavelmente satisfeitas.

"As organizações na sociedade de Organizações têm responsabilidade de encontrar um enfoque para os problemas sociais básicos que estejam de acordo com suas competências e que, certamente, converta os problemas sociais em oportunidades para a organização." (Peter Drucker. Sociedade Pós-Capitalista. São Paulo: Pioneira, 1994, p. 114.)

A visão tradicional da empresa como instituição apenas econômica, orientada para a maximização de lucros, que não considera os aspectos sociais e políticos que influenciam $\mathrm{o}$ ambiente de negócios na tomada de decisão, passa a ser agora questionada pela sociedade. Nenhuma organização deve perder o foco da lucratividade, entretanto, o econômico deve aliar-se ao social, contribuindo assim para a criação de valores superiores para seus colaboradores, transformando o lucro em conseqüência natural de suas atividades.

O Instituto Ethos (2015) caracteriza da seguinte forma a ação socialmente responsável das empresas:

A responsabilidade social das empresas tem como principal característica a coerência ética nas práticas e relações com seus diversos públicos, contribuindo para o desenvolvimento contínuo das pessoas, das comunidades e dos relacionamentos entre si e com o meio ambiente. Ao adicionar às suas competências básicas e conduta ética e socialmente responsável, as empresas conquistam o respeito daspessoas e das comunidades atingidas por suas atividades, o engajamento de seus colaboradores e a preferência dos consumidores.

A essência da doutrina da Responsabilidade Social sob o ponto de vista empresarial, na concepção de Duarte e Dias (1985), está baseada em três pressupostos básicos: primeiro, ampliação do alcance da responsabilidade da empresa, que não mais se limita aos interesses dos acionistas; segundo, a mudança da natureza das responsabilidades que ultrapassam o âmbito legal e envolvem as obrigações morais ditadas pela ética; terceiro, a adequação às demandas sociais mais atuantes e exigentes. Todas as organizações precisam ter bem claro, para si e para seus empregados, o conceito de Responsabilidade Social, buscando ter consciência sobre os reais efeitos de sua atividade na sociedade e no meio ambiente, e de seus impactos nos planos local, regional e nacional. A Responsabilidade Social é um exercício da cidadania corporativa, e as empresas que querem transmitir uma imagem ética e moral podem, futuramente, ser beneficiadas pelas suas atitudes, por exemplo, através da prática da Responsabilidade Social, como estratégia de valorização de produtos e serviços e estratégias sociais de desenvolvimento da comunidade (MELO NETO e FROES, 1999). Para a empresa, a estratégia de valorização de produtos ou serviços, além de prezar pela qualidade, prima pelo status de produtos e serviços socialmente corretos. E a estratégia social de desenvolvimento da comunidade pode inserir a organização como um agente do desenvolvimento local, através do apoio de outras entidades comunitárias e do próprio governo. As entidades que praticam a Responsabilidade Social compõe o chamado Terceiro Setor, que Fernandes (1994, p.21) resume como sendo um composto de organizações sem fins lucrativos, criadas e mantidas pela ênfase na participação voluntária, num âmbito não-governamental, dando continuidade às práticas tradicionais de caridade, filantropia e do mecenato e expandindo o seu sentido para outros domínios, graças, sobretudo, à incorporação do conceito de cidadania e de suas múltiplas manifestações na sociedade civil.

A importância da sociedade civil para o desenvolvimento do Terceiro Setor, conforme Fernandes (1994) está ligada à interação das empresas privadas com a sociedade, respeitando a legislação criada pelo Estado. Assim, surgem as Organizações da 
Sociedade Civil (OSCs) que se preocupam com os interesses coletivos. Percebe-se que a sociedade deixa de esperar atitudes do Estado e busca, através de voluntários, comunidades de bairros, fundações e associações, resolverem os problemas que seriam de alçada do governo. A expressão Terceiro Setor deriva da idéia de que a sociedade civil é dividida em Primeiro Setor Estado, Segundo Setor - mercado ou empresas privadas e Terceiro Setor - "um espaço de participação e experimentação de novos modos de pensar e agir sobre a esfera social" (CARDOSO, 1997, p.12). O Terceiro Setor engloba organizações com objetivos sociais, ao invés de econômicos, e que têm grande influência nas inovações sociais como serviços para pessoas carentes e deficientes, pesquisa científica, grupos de apoio a dependentes químicos, entre outros. Segundo Melo Neto e Froes (1999, p. 23-24), a economia deste setor não gira em torno de indicadores econômicos, mas de indicadores socioeconômicos, internos e externos. Elas não distribuem os lucros a seus proprietários, não estão sujeitas a controle político direto e possuem independência para definir seu próprio futuro.

Esse autor também afirma que o Terceiro Setor deixou de ser visto como um opositor ao governo e ao mercado para ser considerado como seu cooperador. Um exemplo claro disso no Brasil foi a criação do Programa Comunidade Solidária, onde voluntários atendem necessidades específicas de algumas comunidades em conjunto com o governo.

Fica evidente que a Responsabilidade Social Empresarial apresenta-se como um conceito cada vez mais importante para o campo de estudo da administração, pouco a pouco vem ganhando espaço e avança como campo de estudos em prol dos negócios e da sociedade, exercendo impactos nos objetivos, estratégias e no próprio conceito de empresa.

\subsubsection{VANTAGENS E DESVANTAGENS DA RESPONSABILIDADE SOCIAL}

A Responsabilidade Social não se restringe apenas à organização, mas envolve toda a sua área de influência e seus funcionários, caracterizando-se como um modo da empresa ser competitiva, conquistar e ampliar o mercado. Isso porque a Responsabilidade Social não pode ser destacada como uma ação caridosa ou como uma filantropia isolada, motivada por umsentimento de culpa provindo da utilização dos recursos da sociedade, ou por iniciativa unilateral do empresário, mas, sim, alinhada aos objetivos da empresa, que devem contemplar a responsabilidade social (ORCHIS et al., 2002).

\subsubsection{VANTAGENS E MOTIVAÇÃO DA RESPONSABILIDADE SOCIAL}

A motivação não se dá apenas por bondade e nem só por interesse. Uma série de fatores vem levando as organizações a aumentarem sua participação na área social. Ela está baseada na questão humanitária, em valores como solidariedade e preocupação com o bem comum, sempre presente no ser humano. A pressão da sociedade também é um peso. Cada vez mais percebe-se que o governo não vai resolver sozinho todos os problemas sociais, por isso as empresas entenderam que têm que dar sua contribuição. Entretanto, fica evidente que a prática da responsabilidade social também é bom para os negócios, trazendo vários benefícios para a própria empresa. Alguns desses benefícios podem se traduzidos em vantagens como:

1. Fidelização de clientes; 2. Segurança patrimonial e dos funcionários; 3. Atração e retenção de talentos profissionais; 4. Menor ocorrência de controles e auditorias de órgãos externos; 5. Aumento da produtividade; 6 . Melhoria nas relações com os órgãos governamentais e comunidade; 7 . Fortalecimento da marca e imagem da organização.

Segundo Orchis et al. (2002), a prática da Responsabilidade Social de forma correta pode melhorar o desempenho e a sustentabilidade da empresa a médio e longo prazos, proporcionando, dentre outros fatores, valor agregado à imagem corporativa da empresa; motivação do público interno; posição influente nas decisões de compras; vantagem competitiva; influência positiva na cadeia produtiva; reconhecimento dos dirigentes como líderes empresarias e melhoria do clima organizacional.

\subsubsection{DESVANTAGENS RESPONSABILIDADE SOCIAL}

Melo Neto e Froes (1999) esclarece que a partir do momento em que a empresa deixa de cumprir com as suas obrigações sociais 
em relação aos seus empregados, comunidade, fornecedores, acionistas, clientes e parceiros, ela perde o seu capital de Responsabilidade Social, a sua credibilidade, prejudica sua imagem e ameaça a sua reputação. No âmbito interno pode ocorrer a deterioração do clima organizacional, a desmotivação generalizada, o surgimento de conflitos, greves e paralisações, baixa produtividade e aumento de acidentes de trabalho. No âmbito externo, podem ocorrer prejuízos maiores como: acusações de injustiça social; boicote de consumidores; reclamações dos fornecedores e revendedores; queda nas vendas; gastos extras com passivo ambiental e até mesmo risco de falência.

\section{2 ÉTICA EMPRESARIAL}

Sempre que falamos de Responsabilidade Social, nos deparamos com a palavra ética. A palavra ética vem do grego ethos, que significa analogamente "modo de ser" ou "caráter".

Segundo Vázquez (1999, p.23-24):

A ética é a teoria ou ciência do comportamento moral dos homens em sociedade, ou seja, é a ciência de uma forma específica do comportamento e seu objeto de estudo é constituído por vários tipos de atos humanos: os atos conscientes e voluntários dos indivíduos que afetam outros indivíduos, determinados grupos sociais ou a sociedade em seu conjunto.

Agir de acordo com os preceitos éticos, sem dúvida, norteia as ações de grande parte das organizações, sobretudo porque é fácil ser ético quando não há dificuldades envolvidas ou quando as ações de uma empresa transcorrem normalmente. Entretanto, alerta Stanton et al (2001), "o desafio começa quando nem tudo vai bem - quando surge a pressão. Essas pressões surgem em todos os aspectos da vida, e o marketing não é uma exceção". Apesar disto, os bons profissionais devem ser capazes de distinguir entre o que é ético e o que não é, e agir de acordo com isso, independente das conseqüências. Os valores morais de um grupo ou organização define o que é ser ético para si e a partir daí, elaboram rígidos códigos que identificam atitudes específicas como antiéticas e descrevem os padrões que os membros da organização devem atingir.
As empresas, explica Kotler (2000), precisam adotar e disseminar um código escrito de ética, construir a tradição do comportamento ético e responsabilizar plenamente pela observação de diretrizes éticas e legais. Uma organização que age com princípios de ética tem legitimidade para exigir de seus funcionários comportamentos adequados aos preceitos definidos. Portanto a inclusão dos aspectos éticos às práticas empresariais tipicamente enfocam os contextos de justiça e do que é certo e/ou errado. Daí surgem os códigos de éticas, direcionados à conduta dos empregados, comunidade, meio ambiente, acionistas, clientes, ciência e tecnologia, que decorrem de programas alicerçados na prevenção, detecção e punição de violações dos padrões delimitados, os quais são designados para incutir a responsabilidade pessoal e o comportamento ético.

Galbraith (1996) aborda esta questão de forma ainda mais clara quando afirma que: o sistema econômico só funciona eficazmente dentro de regras de condutas firmes. A primeira é a honestidade comum - a verdade deve ser transmitida como informação essencial aos investidores, ao público em geral e aos consumidores.

Uma empresa é considerada ética se cumprir com todos os compromissos éticos que tiver, se adotar uma postura ética como estratégia de negócios, ou seja, agir de forma honesta com todos aqueles que têm algum tipo de relacionamento com ela, ou seja, os stakeholders.

Sendo assim, podemos afirmar que responsabilidade social e ética empresarial são equivalentes. A empresa que pratica responsabilidade social é aquela que responde à situação social na qual está inserida, consciente que está no seu papel de agente da sociedade.

A ausência de parâmetros éticos podem por em perigo a sobrevivência das empresas, deste modo, a empresa que quiser competir com sucesso nos mercados nacional e mundial, terão que manter uma sólida reputação de comportamento ético. 


\subsection{REFLEXÕES SOBRE O MARKETING $\mathrm{SOCIAL}$}

A Responsabilidade Social Corporativa tem sido disseminada entre várias empresas, através de instrumentos como selos, certificações e a divulgação pela mídia das ações sociais de empresas responsáveis. Para a difusão dessas ações sociais as organizações podem lançar mão do Marketing Social, que tem um caráter fundamental para a formação da imagem da instituição.

\subsubsection{CONCEITOS DE MARKETING E MARKETING SOCIAL}

Para um melhor entendimento de marketing social é importante definir, primeiramente, o que é marketing utilizando um enunciado clássico de Kotler (1992):

Marketing é um processo social e gerencial pelo qual indivíduos e grupos obtêm o que necessitam e o que desejam através da criação, oferta e troca de produtos de valor com outros. Esta definição baseia-se nos seguintes conceitos centrais: necessidades, desejos e demandas; produtos (bens, serviços e Marketing Social de idéias); valor, custo e satisfação; troca e transações; relacionamentos e redes; mercados; e empresas e consumidores potenciais.

Segundo Kotler e Roberto (1992) Marketing social é uma estratégia de mudança de comportamento. Ele combina os melhores elementos das abordagens tradicionais da mudança social num esquema integrado de planejamento e ação, além de aproveitar os avanços na tecnologia das comunicações e na capacidade do marketing.

Portanto o marketing social apropria-se de técnicas de marketing de negócios adaptando-as e colocando-as a serviço da promoção e difusão das inovações sociais, do desenvolvimento e bem estar social. Ele redescobre o consumidor por meio do diálogo interativo, o que gera condições para que se construa o processo de reflexão, participação e mudança social. Os resultados são mensuráveis pelos seus efeitos e avaliados por sua efetividade.

A empresa deve identificar a causa de interesse social mais relevante para seu público objetivo e que seja coerente com os valores da marca, este é o maior problema das empresas, porque se o consumidor não se identificar com a campanha, poderá haver uma recusa do produto.

\subsubsection{OBJETIVOS DO MARKETING SOCIAL}

Formação de mercado futuro: projetos sociais focados em melhores condições de vida e redução da pobreza podem fazer com que os beneficiados sejam futuros fiéis consumidores; Garantia de share no mercado: Uma vez que a utilização do marketing social traz visibilidade, imagem positiva e mídia espontânea, esta ferramenta auxilia a manutenção do share da marca ou da empresa; Proteção contra ações negativas de consumidores: Consumidores podem acionar sozinhos ou em grupos, empresas que venham a ser consideradas irresponsáveis socialmente; Mídia espontânea: Projetos sociais despertam atenções da mídia, geram uma grande oportunidade gratuita de publicidade com uma credibilidade; Atrair e reter clientes: Um grande número de pesquisas no mundo inteiro vem revelando que há um crescente número de consumidores que dão preferência, no momento da compra, a produtos e serviços de empresas vistas como socialmente responsáveis; Atrair investidores: Existem evidências que muitos investidores individuais e institucionais são atraídos por empresas guiadas por estratégias de Marketing Social; Melhor qualidade de vida, maior produtividade e melhores produtos: Fazendo da comunidade um lugar melhor para se viver, a empresa terá um lugar melhor para fazer negócios. Uma comunidade saudável é um lugar melhor para vender seus produtos, para instalar seu escritório, para se estabelecer. Também estará indiretamente melhorando a qualidade de vida de seus colaboradores e parceiros, permitindo uma maior motivação e melhor produtividade; Dedução Fiscal: Muito embora a maioria das empresas que se realizam programas de Marketing Social afirme que um tratamento mais ameno do físico não é o seu objetivo ao iniciar uma ação desta natureza, este aspecto não pode ser ignorado, principalmente num país com uma carga tributária tão elevada quanto o Brasil. É preciso não se esquecer que, por um bom tempo, a idéia de empresas adotando práticas de responsabilidade social era encarada apenas como uma forma de fugir dos impostos. Ainda existe certa preocupação com a "Pilantropia" empresarial, como ficou conhecida a prática de usar o bem como escudo para grossa sonegação de 
impostos; Tornar forte e protegida a imagem da marca e sua reputação: No mundo globalizado a imagem de marca e sua reputação está entre os ativos mais valiosos de uma empresa. Ações de Marketing Social são altamente visíveis para os consumidores, permitindo fortalecer ou degradar a imagem de uma empresa; Diferenciação do produto ou da marca: Os produtos do mercado moderno estão próximos da similaridade, tanto pela tecnologia aplicada quanto na qualidade tornando-os um Commoditie, empresas que estão focadas em ações sociais diferenciam-se dos concorrentes. "As empresas sabem da importância da formação de uma marca, mesmo elas tendo uma "missão" e uma visão", elas não passam de uma série de declarações indiferenciadas de "direitos" e não transmitem a idéia de um verdadeiro "sistema de crenças", capaz de engajar e motivar não só seus consumidores diretos, mas também todos que estão ligados a elas, de alguma forma. Se for feito com integridade e compromisso, o Marketing Social pode oferecer as tais empresas uma solução a esse desafio emergente de formação da marca.

Podemos deduzir que o papel-chave das comunicações é fazer a promessa ganhar força como manifestação de uma marca, e a maior parte dos investimentos em propaganda e relações públicas destina-se a isso. O Marketing Social é umas das formas mais poderosas de se fazer à promessa de uma marca.

\subsubsection{FATORES DE RISCO}

Em contrapartida, existem riscos e cuidados que devem ser considerados na aplicação do Marketing Social para evitar o desgaste da imagem da empresa:

Seleção das entidades: Falta de critério na seleção da organização; Ex: associar-se a entidades que obtêm vantagens fiscais em nome de uma causa pública, mas que de fato representam interesses particulares (possuem uma imagem negativa).

Ações de curto prazo: Ações de curto prazo podem ser danosas, pois os aplausos virão somente após o reconhecimento dos resultados, e resultados demoram anos para se conseguir;
Destinar o orçamento de um projeto para apenas uma entidade: Beneficiar apenas uma entidade na sua campanha de solidariedade significa explicitamente recusar todas as outras. Para elas, quem apóia uma, pode também apoiar outras.

Conduta contraditória das ações: A criação de uma imagem ética e solidária comunicada, aos, funcionários, fornecedores, e, clientes,precisa, ter, correspondência, na prática. Portanto, passa, a, ser, mais, visado, e, cobrado, qualquer,comporta- mento contraditório à imagem criada, pode ter repercussão negativa, tanto interna como externamente. Por exemplo: se a empresa se empenhar em um projeto social, deve também se preocupar com a poluição ambiental que pode vir a causar, nunca deve tratar seus funcionários de forma desumana, etc. Portanto, a empresa deve tomar cuidado antes de começar sozinha ou simplesmente incumbir uma agência de propaganda a fazer um projeto social, sem que ela tenha experiência nesta área.

\subsubsection{O MARKETING SOCIAL E A RESPONSABILIDADE SOCIAL}

A grande diferença entre o Marketing Social e a Responsabilidade Social é que o Marketing Social tem como objetivo a mudança de comportamento da sociedade para com o bem-social utilizando ferramentas mercadológicas e técnicas de Marketing, a responsabilidade social é a preocupação que as empresas, pessoas e governo têm pelo social. A responsabilidade veio para ficar e tem se transformado em um novo critério de excelência e qualidade para as empresas.

Resultando que, conceitualmente certo ou errado, o Marketing passou a fazer parte do jargão administrativo, comercial, político e até filantrópico do país.

Por falar em filantrópico é preciso também que seja utilizado com eficácia, o que equivale a dizer que as instituições que o adotam como modelo social, deverá repensar estes modelos, por um autossustentável, já que hoje o mercado não aceita empresas que não busquem lucro, seja quantitativo ou lucrosocial. Com relação ao Marketing social as instituições que o adotam com técnica ou filosofia mercadológica devem aprender a explorar as usas potencialidades como um conjunto de instrumentos que, acima de tudo, 
contribui para o bem-social e como conseqüência para o aumento de sua produtividade e rentabilidade.

Esse conceito, conforme Kotler (1992) é uma orientação da administração que visa a proporcionar satisfação do cliente e o bemestar do consumidor final em longo prazo, como a solução para satisfazer aos objetivos e as responsabilidades da organização.

Algumas premissas subjacentes ao conceito:

- A missão principal da organização é criar clientes satisfeitos e saudáveis e contribuir para a qualidade de vida;

- A organização $\begin{gathered}\text { procura } \\ \text { constantemente melhores produtos, }\end{gathered}$ definidos em termos de atração e benefícios para os clientes. Está pronta a promover os benefícios que são do interesse dos consumidores, mesmo se eles não estiverem conscientes disso;

- A organização evita aqueles produtos que não se enquadram dentro dos melhores interesses do cliente;

- Os consumidores apoiarão aquelas organizações que demonstrarem preocupação para com a sua satisfação e bem-estar social, formando o conceito do consumidor responsável;

A responsabilidade do Marketing social exige a inclusão de quatro considerações na tomada de decisão:

a) desejo dos consumidores;

b) interesses dos consumidores;

c) exigências das empresas;

d) bem-estar social.

Kotler (1992) coloca que o marketing social é uma estratégia de mudança de comportamento. Ele combina os melhores elementos das abordagens tradicionais da mudança social em um esquema integrado de planejamento e ação, além de aproveitar os avanços na tecnologia das comunicações e na capacidade do Marketing.

Somente poderá ser implementado o marketing social em uma organização quando existir uma mudança de comportamento internamente aos valores e cultura da empresa com base nos princípios éticos e de responsabilidade social em todo seu processo produtivo, administrativo e comercial para que possa refletir externamente no mercado como imagem de marca por meio do Marketing social (Kotler, 1992).

\subsection{5 ÁREA DE ATUAÇÃO DO MARKETING SOCIAL}

O Conceito de Marketing Social pressupõe que a organização deve inicialmente determinar as necessidades, desejos e interesses dos mercados-alvo, e em seguida proporcionar a satisfação desejada de maneira mais eficiente do que os concorrentes, de forma a melhorar o bemestar do consumidor e da sociedade. Dessa forma o Marketing social é a modalidade de ação mercadológica institucional que tem por objetivo atenuar ou eliminar problemas sociais, carências da sociedade relacionadas principalmente com questões de higiene, saúde pública, trabalho, educação, habitação, transporte e nutrição. A natureza do problema social é a base do trabalho do Marketing social, como:

Qualidade de vida; Capacitação pessoal; Convivência social; Sobrevivência. O Marketing Social que busca melhorar o nível da qualidade de vida de um povo tem seus programas voltados principalmente à área da saúde, com o objetivo de reduzir índices de mortalidade infantil, incrementar as condições de atendimento médico (quantidades de leitos hospitalares e de médicos por habitantes) e dos serviços públicos (água e esgoto).

A capacitação de pessoal tem seus programas voltados para atender aqueles que apresentam dificuldades, ou algum tipo de deficiência e que precisam de atendimento diferenciado, especializado - deficiências físicas, psicológicas ou técnica.

O Marketing Social procura também melhorar os padrões de convivência social, com programas voltados para a harmonia de interesse entre os diversos grupos sociais:

Racismo; Gangues; Tráficos de Drogas; Marginalização da população carente.

As situações de risco à vida é mais um foco do Marketing Social, uma vez que busca oferecer condições de prevenção, correção, recuperação e eliminação dos fatores que colocam a vida em perigo.

Alguns exemplos: 
- Epidemias (Dengue, Cólera, Aids). Programas de prevenção à gravidez na adolescência;

- Programas de recuperação de jovens infratores;

Nem mesmo o plano de Marketing social mais bem elaborado pode ter êxito no sentido de conseguir adoções de seu produto social se não for bem implantado. $E$ isso, acontece na maioria dos projetos de Marketing social. Muitas vezes uma campanha de Marketing Social é organizada dentro de uma estrutura já existente. A preocupação da organização é com o lucro quantitativo, com o fortalecimento da sua marca perante seu público-alvo, ou ainda quando precisam fazer algo para reparar a sociedade por algum prejuízo que a empresa tenha causado ao ambiente ou à comunidade.

Além de seduzirem consumidores e funcionários, as chamadas campanhas de Marketing Social passaram a atrair a atenção do mercado financeiro, tradicionalmente insensível aos apelos aparentemente emocionais.

O que se tem notado é que grandes investidores institucionais no mundo inteiro começam a prestar atenção às atividades sociais e ambientais das empresas na hora de definir quais delas merecem receber dinheiro.

Social não é despesa nem custo, é investimento. Deve ser feita uma análise sem impulsos ideológicos e fundamentadas em bases empíricas de verificação do seu impacto para o crescimento econômico e diminuição das desigualdades sociais. Dessa forma, este documento traz algumas reflexões sobre as contribuições dos investimentos sociais para a melhoria das condições econômicas do país, e apresenta alguns exemplos sobre como o investimento social resulta em lucros econômicos tangíveis para toda a sociedade.

Muitas vezes, as organizações confundem o Marketing Social como sendo filantropia, ou seja, amor à humanidade, pois o atendimento à área social, no passado, era feito por senhoras da sociedade que, realizando obras sociais, exercitavam sua vocação filantrópica. Hoje, a gerência por intenções já não encontra mais espaço no mercado. Com o crescimento do Terceiro Setor - tanto em volume de recursos financeiros quanto em relevância social e política e sua conseqüente profissionalização - as modernas técnicas de gestão dos negócios foram, pouco a pouco, incorporadas à área social.

Não muito antes de conceito de Marketing tornar-se amplamente aceito por muitas empresas, ele recebeu muita oposição. Por mais de 30 anos, os críticos têm persistentemente dito que o Marketing ignora a responsabilidade social. Isto é, embora o conceito de Marketing possa ajudar uma organização a atingir seus objetivos, ele pode, ao mesmo tempo, encorajar ações que firam os melhores interesses da sociedade.

De um ponto de vista, essas acusações são verdadeiras. Uma empresa pode satisfazer seus consumidores totalmente; objetivando conforme seu processo almejar um lucro enorme, enquanto por outro lado, pode afetar a sociedade. Para ilustrar: uma fábrica de papel poderia estar oferecendo aos seus clientes de jornal uma impressão de qualidade por um preço razoável, mas para fazer isso ela estaria poluindo o ar e a água próximos à fábrica.

Contudo, esse não precisa ser o caso. A responsabilidade social de uma empresa pode ser totalmente compatível com o conceito de Marketing. A compatibilidade depende de duas coisas: quão amplamente uma empresa percebe seus objetivos de Marketing e quanto tempo ela pretende esperar para atingir seus objetivos. Uma empresa que estende suficientemente as dimensões de tempo e de abrangência dos seus objetivos de Marketing para atender suas responsabilidades sociais está praticando o que se tornou conhecido como conceito de Marketing de Responsabilidade Social.

O trabalho em estudo está voltado para o empreendedor e gestor social, oferecendo a ele uma base conceitual acerca do Marketing Social. Considera-se que essa área do conhecimento ainda é relativamente nova, no Brasil. Sem dúvida, isso justifica a discussão de alguns conceitos básicos, de modo a auxiliar os gestores de programa sociais a melhor entender os princípios e métodos que norteiam essa inovadora forma de abordagem das questões sociais. O Marketing social não se restringe à mera transposição dos métodos e técnicas do Marketing comercial para a área social. Seu conceito e definição mostram uma nova forma de ver e entender as questões sociais, daí originando-se novos métodos e estratégias de intervenção. O Marketing social 
é uma tecnologia de gestão do processo de transformação social.

\subsection{BALANÇO SOCIAL}

O Balanço Social caracteriza-se pela demonstração das práticas de responsabilidade social, ou seja, por meio desse instrumento a empresa torna pública as ações sociais que empreende com os seus diversos parceiros: empregados, comunidade, meio ambiente, entre outros.

As definições atualmente disponíveis para o instrumento Balanço Social, sua evolução e práticas já adotadas em outros países e mesmo no Brasil são apresentadas neste capítulo. A palavra balanço, aplicada na linguagem corrente, conforme Mosimann et al (1989), é extensiva a toda forma de inventário num dado momento, de um conjunto qualquer de elementos considerados como positivos e de outro considerado como negativos. Dessa forma, faz-se balanço da situação política, do dia a dia, da saúde, etc.

Na contabilidade, o termo tem sido utilizado tanto para designar o período em que se faz o levantamento dos fatos de natureza contábil da entidade, como, também, para denominar todas as demonstrações econômicofinanceiras de uma empresa, em uma determinada data, ou somente uma delas: o Balanço Patrimonial.

De acordo com Mosimann et al (1989), a partir da metade deste século, uma associação dos referidos vocábulos introduziu a expressão Balanço Social, tendo em vista que as numerosas pressões sociológicas influenciadas pela ação dos sindicatos, das organizações de consumidores, pelos movimentos ecológicos etc., cada vez mais estabeleceram a idéia de que a entidade empresa não era somente um agente econômico na missão de produzir riqueza, mas que ela era um ente social que devia prestar contas do seu impacto sobre a sociedade em geral e das relações nascidas do trabalho.

As empresas que praticam a Responsabilidade Social encontraram no Balanço Social uma forma de divulgar as suas ações com relação a seus funcionários, comunidade e meio ambiente. Esse balanço é um documento divulgado anualmente pela empresa, como uma forma de comprovar sua atuação no campo social.
Segundo Kroetz (2000), o balanço social visa demonstrar os impactos sofridos e causados pela entidade em relação aos ambientes social e ecológico, identificando a qualidade das relações organizacionais com seus empregados, com a comunidade e com o meio ambiente, quantificando as sempre que possível.

Muitas empresas começaram a divulgar o balanço social principalmente para tornar público o que elas têm feito na área social, pois perante seus clientes isto se torna um fator importante na decisão de compra de seus produtos ou serviços, e também pode ser um diferencial perante seus concorrentes, acionistas, investidores e funcionários. Dessa maneira, a empresa que cumpre seu papel social aumenta a capacidade de atrair maior quantidade de consumidores (CAMARGO et al., 2001).

O balanço social pode também ser utilizado como uma fonte de marketing para a empresa, pois a sua divulgação funciona como um instrumento de publicidade, constando à política da empresa, a forma como é administrada e quais são os fatores que ela preza. Pode funcionar como uma publicidade da empresa, sendo um aspecto de extrema relevância que pode seduzir empresários e o público em geral (KROETZ, 2000).

\section{$\begin{array}{lll}2.6 & \text { INSTITUTO } & \text { ETHOS }\end{array}$ RESPONSABILIDADE SOCIAL}

O Instituto Ethos de Empresas e Responsabilidade Social é uma das principais referências no assunto, no Brasil. Idealizado por empresários e executivos oriundos do setor privado, foi criado com a missão de mobilizar, sensibilizar e ajudar as empresas a gerir seus negócios de forma socialmente responsável, tornando-as parceiras na construção de uma sociedade sustentável e justa. Seus 1245 associados - empresas de diferentes setores e portes - têm faturamento anual correspondente a cerca de $35 \%$ do PIB brasileiro e empregam em torno de dois milhões de pessoas, tendo como característica principal $\mathrm{o}$ interesse em estabelecer padrões éticos de relacionamento com funcionários, clientes, fornecedores, comunidade, acionistas, poder público e com o meio ambiente.

O Instituto Ethos é um pólo de organização de conhecimento, troca de experiências e 
desenvolvimento de ferramentas que auxiliam as empresas a analisar suas práticas de gestão e aprofundar seus compromissos com a responsabilidade corporativa. É hoje uma referência internacional no assunto e desenvolve projetos em parceria com diversas entidades no mundo todo.

O Instituto Ethos trabalha em cinco linhas de atuação:

1. ampliação do movimento de responsabilidade social empresarial (sensibilização e engajamento de empresas em todo o Brasil, articulação de parcerias, sensibilização da mídiapara o tema da RSE (Responsabilidade Social Empresarial), coordenação da criação do comitê brasileiro do Global Compact etc);

2. aprofundamento de práticas em RSE (Indicadores Ethos de RSE - incluindo versões para micro e pequenas empresas e alguns setores da economia -, Conferência Nacional anual para mais de 1 mil participantes, constituição de redes de interesse, promoção da publicação de balanços sociais e de sustentabilidade, produção de publicações e manuais práticos);

3. influência sobre mercados e seus atores mais importantes no sentido de criar um ambiente favorável à prática da RSE (desenvolvimento de critérios de investimentos socialmente responsáveis com fundos de pensão no Brasil, desenvolvimento de programa de políticas públicas e RSE, participação em diversos conselhos governamentais para discussão da agenda pública brasileira).

4. Articulação do movimento de RSE com políticas públicas:

a) desenvolvimento de políticas para promover a RSE e desenvolver marcos legais;

b) promoção da participação das empresas na pauta de políticas públicas do Instituto Ethos;

c) fomento à participação das empresas no controle da sociedade, por meio de acompanhamento e cobrança das responsabilidades legais, transparência governamental e conduta ética;

d) divulgação da RSE em espaços públicos e eventos; e) estruturação de processos de consulta a membros e parceiros da companhia.

5. Produção de informação (pesquisa anual Empresas e Responsabilidade Social Percepção e Tendências do Consumidor, produção e divulgação de conteúdo e um site de referência sobre o tema na internet, coleta e divulgação de dados e casos das empresas, promoção do intercâmbio com entidades internacionais líderes no tema da responsabilidade social).

\subsubsection{INDICADORES ETHOS DE} RESPONSABILIDADE SOCIAL

No Brasil, o Instituto Ethos de Empresas e Responsabilidade Social desenvolveu um instrumento de acompanhamento e monitoramento das práticas de responsabilidade social empresarial, utilizado como um instrumento de auto-avaliação. O questionário de avaliação da empresa está dividido em sete grandes temas:

- valores e transparência;

- público interno;

- meio ambiente;

- fornecedores;

- consumidores/clientes;

- comunidade;

- governo e sociedade.

Esses sete temas são avaliados por meio de dois grupos de indicadores. O primeiro grupo avalia o estágio atual de determinada prática de responsabilidade social, enquanto o segundo utiliza indicadores que contêm elementos de validação e de detalhamento do estágio de responsabilidade social identificado pela empresa.

Analisando-se os indicadores propostos pelo Instituto Ethos conclui-se que:

a operacionalização dos indicadores é de fácil interpretação e aplicação e constitui-se através da autoavaliação; os resultados permitem a melhoria da tomada de decisão no investimento social; foco da autoavaliação está no comportamento adotado pela empresa. 


\section{COSIDERAÇÕES FINAIS}

A partir deste estudo, pode-se afirmar que a Responsabilidade Social está predominantemente direcionada a uma atitude e a um comportamento empresarial ético e responsável. Nesta abordagem prevalece 0 que denominamos de "responsabilidade ética". É o dever e compromisso da empresa em assumir uma atitude transparente, responsável e ética em suas relações com os seus diversos públicosalvo (governo, clientes, fornecedores, comunidade, etc.). As organizações buscam na Responsabilidade Social benefícios como o reforço de sua imagem e, dependendo dos resultados dos projetos sociais por ela financiados, a empresa pode torna-se mais conhecida e vender mais. A marca, os seus produtos e serviços podem ganhar maior visibilidade. Os clientes podem orgulhar - se de comprar produtos ou contratar serviços de uma empresa com elevada Responsabilidade Social. Os seus funcionários orgulham-se e sentem-se motivados em trabalhar nessa empresa. Com relação aos fornecedores, podem sentir-se motivados a trabalhar como parceiros de uma empresa dessa natureza.

\section{REFERÊNCIAS}

[1] Chiavenato, Idalberto. Administração dos novos tempos. Rio de Janeiro: Campus, 2000.

[2] Camargo, Mariângela Franco et al. Gestão do terceiro setor no Brasil: estratégia de captação de recursos para organizações sem fins lucrativos. São Paulo: Futura, 2001.

[3] Cardoso, Ruth. Fortalecimento da sociedade civil - $3^{\circ}$ Setor: Desenvolvimento social sustentado. Rio de Janeiro: Paz e Terra, 1997.

[4] Drucker, Peter. Sociedade Pós-Capitalista. São Paulo: Pioneira, 1994.

[5] Duarte, Glenso D; DIAS, José Maria A. M. Responsabilidade social: a empresa hoje. Rio de Janeiro: Livros Técnicos e Científicos, 1985.

[6] Fernandes, Rubem César. Privado porém público. Rio de janeiro: Relume-Dumará, 1994.

[7] Froes, César; Melo Neto, Francisco Paulo de. Responsabilidade social \& cidadania empresarial: a administração do terceiro setor. Rio de Janeiro: Qualitymark, 1999.

[8] Galbraith, John Kenneth. A era da incerteza. São Paulo: Pioneira, 1996. INSTITUTO ETHOS.
Os concorrentes podem reconhecer o ganho de valor dessa empresa. É o uso da cidadania empresarial como vantagem competitiva. O governo e a sociedade civil podem tornar-se parceiros desta empresa em seus empreendimentos sociais. E, como resultado final, a longo prazo pode-se obter um sensível aumento nas vendas, a empresa pode fortalecer a sua imagem, ganhar respeito e confiabilidade e assegurar a sua autopreservação.

\section{CONCLUSÃO}

Conclui-se que o marketing social está sendo utilizado como uma estratégia empresarial e também como um meio que estabelece formas de divulgação das ações sociais empresariais, comunicando-as a toda a rede de interessados na empresa direta ou indiretamente. Dessa maneira, as organizações praticantes da Responsabilidade Social através do marketing social podem conseguir sustentabilidade para sobrevivência, permanência e destaque no mercado onde atuam.

Disponível em < http://www.ethos.org.br>. Acesso em: 11 outubro de 2015.

[9] Kotler, Philp. Administração de Marketing. São Paulo: Prentice Hall, 2000.

[10] Kotler, Philip; Roberto, Eduardo L. Marketing social: estratégias para alterar o comportamento público. São Paulo: campus, 1992.

[11] Kroetz, César Eduardo Stevens. Balanço Social: teoria e prática. São Paulo: Atlas, 2000.

[12] Mattar, F. N. Pesquisa de Marketing. São Paulo: Atlas, 1995.

[13] Mosimann, Clara P. et al. O Balanço Social, São Paulo: FEA-USP, 1989. ORCHIS, Marcelo A. et al. Responsabilidade social das empresas: a contribuição das universidades. São Paulo: Petrópolis, 2002.

[14] Stanton, Willian J. et al. Marketing. São Paulo: Makron Books, 2001.

[15] Vazquez, A. S. Ética. Tradução de João Dell'Anna. 23a ed. Rio de Janeiro: Civilização Brasileira, 1999. 


\section{Bapítulo 15}

\section{ANÁLISE DA FUNCÃO DE DESPESA EDUCACÃO NOS MUNICÍPIOS DE RONDÔNIA COM MELHOR ÍNDICE FIRJAN DE DESENVOLVIMENTO MUNICIPAL}

\section{Alexandre de Freitas Carneiro}

Josias da Silva Nogueira

Sérgio Candido de Gouveia Neto

José Arilson de Souza

Resumo: Este estudo tem por objetivo analisar as aplicações de recursos na função de governo Educação dos municípios de Rondônia, de acordo com as seguintes questões de pesquisa: quais municípios apresentam mais regularidade de gastos com a função de despesa Educação?; qual o nível de correlação existente entre as despesas executadas na função Educação, dos municípios, no período de 2009 a 2014, e as receitas executas no mesmo período?; quais municípios apresentaram maior e menor aplicação de recursos na função de despesa Educação em relação ao total de despesas executadas?; qual a subfunção de maior predominância nos municípios investigados? O método é o estatístico com abordagem descritiva. Os dados foram coletados no sítio do Siope, do Sistn, da Fimbra e do Tribunal de Contas da União. Analisaram-se os 15 melhores municípios no ranking do Índice Firjan de Desenvolvimento Municipal por meio da estatística descritiva e inferencial. O município que apresentou melhor a correlação foi Vilhena e a pior, Teixeirópolis. O município de Chupinguaia foi o que mais aplicou na educação: $43,71 \%$ do seu orçamento total. O estudo é de interesse tanto para gestores públicos, em especial aos conselhos municipais de educação, quanto para a sociedade interessada no controle social da Educação Básica.

Palavras-chave: Educação; Função de despesa pública; Gastos públicos; Municípios.

1 - Artigo publicado na sua primeira versão no XIII Congresso Nacional de Excelência em Gestão \& IV INOVARSE - Responsabilidade Social Aplicada. Rio de Janeiro, setembro, 2017.

2 - Artigo publicado na segunda versão traduzida para língua inglesa na Review of Research, Índia, vol. 7 , issue 1, october, 2017 (com a devida autorização do Editor para a publicação na versão em língua portuguesa no capítulo deste livro). 


\section{INTRODUÇÃO}

Este estudo enquadra-se na área da gestão pública no âmbito das 28 funções de governo, especificamente a função de Educação, que é um serviço público importante para formação e desenvolvimento do cidadão. As subfunções da Educação são: Ensino Fundamental, Ensino Médio, Ensino Profissional, Ensino Superior, Ensino Infantil, Educação de Jovens e Adultos e Educação Especial. Os gastos sociais relacionados a essa função precisam ter maior acompanhamento, inclusive por meio de controle social, de discussões e de controles por meio de participação social nas decisões de políticas públicas, ampliando os espaços dos conselhos municipais de educação (DIAS; MATOS, 2012).

Dessa forma, o problema de pesquisa deste trabalho está relacionado às aplicações de recursos na função de governo Educação nos municípios de Rondônia, entre 2009 e 2014. O estudo se justifica devido à reconhecida importância da problemática do controle social exercido pelo cidadão sobre gestão da educação municipal. Esse controle é exercido, por exemplo, quando a sociedade analisa o perfil dos gastos públicos, verificando se eles crescem à medida que há aumento das receitas. Para além disso, nos últimos cinquenta anos, no Brasil, houve uma diminuição da desigualdade de oportunidades educacionais no nível da Educação Básica e ganhos de acessibilidade muito altos, segundo pesquisas de Ribeiro, Ceneviva e Brito (2015). Essa mudança justifica mais pesquisas para verificar a aplicação de recursos na Educação Básica, subfunção obrigatória para os municípios.

O estudo pode também auxiliar avaliações e análises por parte dos membros dos conselhos municipais da educação e a redefinição de políticas públicas pelos gestores na elaboração dos orçamentos públicos para os anos seguintes. Segundo Gohn (2011), os conselhos gestores na área educacional são inovações recentes e constituem um espaço real de mais participação. Portanto, pesquisas analíticas nesse campo constituem contribuições importantes. Elas podem contribuir, ainda, para um contexto de aprendizagem política (policy learning) (HOWLETT; RAMESH; PERL, 2013).

O objetivo geral é analisar as aplicações de recursos na função de governo Educação dos municípios de Rondônia, entre 2009 e 2014, e, especificamente, responder às questões norteadoras: quais municípios apresentam mais regularidade de gastos com a função de despesa Educação?; qual o nível de correlação existente entre as despesas executadas na função Educação, no período de 2009 a 2014, e as receitas executas no mesmo período pelos municípios?; quais municípios apresentaram maior e menor aplicação de recursos na função de despesa Educação em relação ao total de despesas executadas?; qual a subfunção de maior predominância nos municípios investigados?

Além desta introdução, 0 artigo está estruturado em outras quatro seções. Nas seções 2, 3 e 4, a fundamentação teórica abrange, respectivamente, gestão e políticas públicas em educação, orçamento e estudos anteriores; a seção 5 trata do método de pesquisa; a seção 6 , da descrição dos resultados; e, por fim, na seção 7, são apresentadas a síntese, a análise e as considerações finais.

\section{GESTÃO PÚBLICA E POLÍTICAS PÚBLICAS DE EDUCAÇÃO}

O artigo 1. da Lei de Responsabilidade Fiscal (LRF) expressa que: "Esta Lei estabelece normas de finanças públicas voltadas para a responsabilidade na gestão fiscal, com amparo no Capitulo II do Titulo VI da

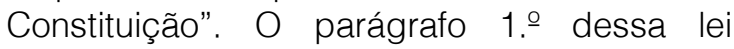
pressupõe que uma gestão com responsabilidade fiscal deva ser planejada e transparente, prevenindo os riscos de desvios de verbas que deixam as contas públicas desiquilibradas, mediante o cumprimento de metas de resultados entre receitas e despesas e a obediência a limites e condições. Os pilares dessa norma são o planejamento, o controle, a transparência e a responsabilidade.

Segundo Oliveira (2012), para que não se verifiquem abusos por parte dos governos e para que o Estado não tenha interesses clientelistas, existe a importância do controle das políticas públicas. Segundo esse autor, se de um lado as empresas privadas se adequam a um mercado tão concorrido e a consumidores sempre mais exigentes, por outro lado, os governos têm a função de servir a população com prestação de serviços. As regras e controles são importantes, mas devem ser simples, de fácil entendimento e menos burocráticas para que a eficiência e a 
qualidade dos serviços públicos sejam prioritárias (OLIVEIRA, 2012).

Esse marco regulatório, a LRF, que objetiva evitar desvios na aplicação dos recursos públicos, precisa ser revisado para que o foco não recaia somente nas formalidades, que são excessivas e dificultam a eficiência administrativa. Atualmente, a população espera cada vez mais eficiência por parte do Estado no oferecimento de um serviço público de qualidade e eficiente, além de obedecer à legislação (OLIVEIRA, 2012).

Há dois tipos de políticas públicas: as finalísticas (Saúde, Educação) e as de gestão, que são as que dizem a respeito ao planejamento, ao controle, à organização, ao orçamento, às finanças, à contabilidade, ao pessoal, à tecnologia, à logística, a aspectos jurídicos. As políticas públicas de gestão também incluem as políticas de atendimento ao cidadão, como a gestão para resultados (OLIVEIRA, 2012). Segundo Oliveira (2012, p. 61), "a gestão pública engloba todas as políticas setoriais do governo, por isso é importante se ter um serviço público de qualidade e eficiência".

As políticas públicas de gestão capacitam os governos para que tenham melhores formas de como administrar os recursos públicos e avaliar a sua aplicação e os resultados alcançados. Não bastam as políticas de gestão estar somente no papel; é importante implantar e executar o que foi planejado - isso depende da capacidade de cada governo (OLIVEIRA, 2012).

O debate sobre gestão pública é um assunto que não tem despertado tanto interesse por parte da população em geral, que acaba por priorizar as políticas finalísticas (Saúde, Educação), cujo impacto no dia a dia da sociedade é mais evidente (OLIVEIRA, 2012). Oliveira (2012) afirma que é importante que se discutam publicamente os interesses da população com a intenção de atender ao cidadão e às empresas com eficiência, qualidade e transparência. Um problema muito sério no Brasil é a falta de projetos e de investimentos de médio e longo prazo, visto que os políticos sempre pensam no seu próprio mandato, a fim de conseguir que o mesmo grupo continue no poder. Para isso também contribui o fato de que sociedade é imediatista e quer ver resultados (OLIVEIRA, 2012).

Secchi (2013) define "políticas públicas" como formas criadas para se enfrentar um problema público. No Brasil, não é bem claro para as pessoas o que são políticas públicas. Para Secchi (2013), a "política pública" (public policy) está relacionada a decisões e a ações tomadas a partir de orientações. Existem dificuldades quanto a quem estabelece as políticas públicas. Há duas abordagens: a estatista ou estadocêntrica, que defende que a exclusividade de estabelecimento de política pública é do Estado, e a abordagem multicêntrica ou policêntrica, que considera tanto o estado, quanto organizações não governamentais, organizações privadas, organismos multilaterais e redes de políticas públicas como protagonistas no estabelecimento das políticas públicas (SECCHI, 2013).

E o que é fazer política pública? Para Secchi (2013), quando os governos são omissos em relação a problemas públicos verifica-se uma falta de políticas públicas para se resolver certo problema público. Para a resolução de um problema público, importa saber sobre as atribuições econômicas do Estado. Giacomoni (2012) descreve três funções econômicas estatais: a) função alocativa, que tem o intuito de promover ajustamentos na alocação de recursos, nos quais os bens públicos ofertados são produzidos tanto por repartições públicas, quanto por empresas privadas; b) função distributiva, que promove ajustamentos na distribuição de renda, o que é viabilizado pelo orçamento público; e c) função estabilizadora, que é a mais moderna das três funções e, a partir dos anos trinta, ganhou importância ao combater os efeitos da depressão. A política de estabilização tem o orçamento público como importante instrumento.

Tratando de política pública, no contexto proposto neste estudo, é importante indagar o que vem a ser qualidade na educação pública. Segundo Chirinéa e Brandão (2015), o Estado entende ela está relacionada apenas a conhecimentos e habilidades que podem ser mensuráveis por meio de testes, como referencial de qualidade, como o do Índice de Desenvolvimento da Educação Básica (IDEB). Para esses autores, tal indicador não leva em consideração as peculiaridades de cada região, município e escola em seus respectivos contextos e especificidades. Deve-se, assim, aliar a avaliação externa à autoavaliação da escola. Essa autoavaliação pode ter como parâmetro, entre outros, o escopo da presente pesquisa. 
No quadro 1, apresentam-se as principais normas nacionais relativas às políticas públicas educacionais.

Quadro 1 - Política Nacional da Educação.

\begin{tabular}{|c|c|}
\hline Legislação & Conteúdo \\
\hline $\begin{array}{l}\text { Constituiçã } \\
\text { o Federal } \\
\text { (CF/88) }\end{array}$ & $\begin{array}{l}\text { Artigos } 205 \text { a 2014; art. 214. A Lei estabelecerá o plano nacional de educação, de } \\
\text { duração plurianual, visando à articulação e ao desenvolvimento do ensino em seus } \\
\text { diversos níveis e à integração das ações do poder público que conduzam à: I - } \\
\text { erradicação do analfabetismo; II - universalização do atendimento escolar; III - } \\
\text { melhoria da qualidade do ensino; IV - formação para o trabalho; V - promoção } \\
\text { humanística, científica e tecnológica do País. }\end{array}$ \\
\hline $\begin{array}{l}\text { Lei de } \\
\text { Diretrizes e } \\
\text { Bases } \\
\text { (LDB) }\end{array}$ & $\begin{array}{l}\text { Lei n. 9.394, de } 20 \text { de dezembro de 1996; art. 9. A União incumbir-se-á de: I - } \\
\text { elaborar o Plano Nacional de Educação, em colaboração com os Estados, o Distrito } \\
\text { Federal e os Municípios; Art. 10. Os Estados incumbir-se-ão de: I - organizar, } \\
\text { manter e desenvolver os órgãos e instituições oficiais dos seus sistemas de ensino; } \\
\text { Parágrafo único. Ao Distrito Federal aplicar-se-ão as competências referentes aos } \\
\text { Estados e Municípios. Art. 11. Os municípios incumbir-se-ão de: I - organizar, } \\
\text { manter e desenvolver os órgãos e instituições oficiais dos seus sistemas de ensino, } \\
\text { integrando-os às políticas e planos educacionais da União e dos Estados; } \\
\text { Parágrafo único. Os Municípios poderão optar, ainda, por se integrar ao sistema } \\
\text { estadual de ensino ou compor com ele um sistema único de educação básica. }\end{array}$ \\
\hline $\begin{array}{l}\text { Plano } \\
\text { Nacional } \\
\text { da } \\
\text { Educação } \\
\text { (PNE) }\end{array}$ & $\begin{array}{l}\text { O PNE, aprovado em } 9 \text { de janeiro de } 2001 \text { como a Lei n. }{ }^{\circ} \text { 10.172, realiza um } \\
\text { diagnóstico da realidade do sistema educacional em todo território brasileiro, nos } \\
\text { diferentes níveis e modalidades de ensino, e estabelece algumas diretrizes e metas } \\
\text { a serem cumpridas em um período de dez anos, caracterizando-se como uma } \\
\text { política de Estado mais permanente. O Plano de Desenvolvimento da Educação } \\
\text { (PDE), apresentado ao país em abril de } 2007 \text { como um projeto federal, tem como } \\
\text { objetivo promover maiores investimentos na Educação Básica, Educação } \\
\text { Profissional e Ensino Superior. O plano conta com mais de } 40 \text { ações que incidem } \\
\text { sobre os mais variados aspectos da educação em seus diversos níveis e } \\
\text { modalidades. É um plano de governo que visa operacionalizar uma política de } \\
\text { Estado, o PNE. }\end{array}$ \\
\hline
\end{tabular}
Fonte: Dados da pesquisa, 2016, grifos nossos.

Howlett, Ramesh e Perl (2013, p. 201) discutem o conceito de "aprendizagem política" (policy learning) na avaliação de políticas públicas, que é um processo resultado de um "ciclo de tentativa de resolução de problemas", da "análise reiterada" e da "experimentação de soluções" (p. 5). Na construção de políticas públicas, devem-se avaliar as consequências para ajustar as metas ou as técnicas da política a novas informações, ao se verificarem as consequências de políticas passadas, na base de "tentativa e erro", com vistas a implementar e a conquistar os objetivos desejados (HOWLETT; RAMESH; PERL, 2013). Isso significa rever as políticas educacionais a cada ciclo ou exercício financeiro, as após ações efetivadas.

\section{ORÇAMENTO E GASTO PÚBLICO EM EDUCAÇÃO}

A Portaria $n .0^{\circ}$ 42/99 atualiza a discriminação da despesa pelas funções de que tratam o inciso I do $\S 1 .^{\circ}$ do art. 2.. $\mathrm{e}$ o $\S 2 . \circ$ do art. 8., ambos da Lei n. ${ }^{\circ} 4.320$, de 17 de março de 1964. Essa portaria estabelece os conceitos de função, subfunção, programa, projeto, atividade, operações especiais e dá outras providências. O art. 1. dessa portaria afirma no $\S$ 1.o.: "Como função, deve entender-se o maior nível de agregação das diversas áreas de despesa que competem ao setor público".

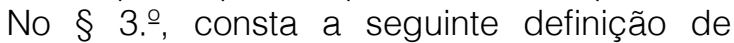
subfunção: "representa uma partição da função, visando a agregar determinado subconjunto de despesa do setor público". De acordo com o $\S 4$. - " "as subfunções poderão ser combinadas com funções diferentes daquelas a que estejam vinculadas, na forma do Anexo a esta Portaria".

A referida portaria estrutura as despesas públicas em 28 funções: administrativa, saúde, educação, segurança pública, saneamento, assistência social, agricultura, 
trabalho, energia, etc. A função Educação é dividida nas subfunções que mostra o quadro
2.

Quadro 2 - Subfunções da função Educação.

\begin{tabular}{|l|l|}
\multicolumn{1}{|c|}{ Função } & \multicolumn{1}{c|}{ Subfunções } \\
\hline \multirow{4}{*}{ 12 Educação } & 361-Ensino Fundamental \\
\hline & 362-Ensino Médio \\
\cline { 2 - 2 } & 363-Ensino Profissional \\
\cline { 2 - 2 } & 364-Ensino Superior \\
\cline { 2 - 2 } & 365-Ensino Infantil \\
\cline { 2 - 2 } & 366-Educação de Jovens e Adultos \\
\cline { 2 - 2 } & 367-Educação Especial \\
\hline & Fonte: Portaria n.o 42/99, MPOG.
\end{tabular}

Essas funções e subfunções compõem um dos relatórios da LRF e o orçamento público anual. Crepaldi e Crepaldi (2015) definem o orçamento como uma ferramenta de planejamento das ações do Poder Executivo, prevista e autorizada pelo Poder Legislativo por certo período. Segundo esses autores, o orçamento público compreende todas as receitas e os gastos previstos e fixados que o governo tem direito de executar dentro do mesmo exercício financeiro. As despesas públicas são as aplicações, em dinheiro, ou reconhecimento de dívidas por parte do agente público competente, tendo por objetivo uma finalidade de interesse público, autorizado pelo Poder Legislativo (CREPALDI; CREPALDI 2015). Uma das classificações orçamentárias da despesa é a por categorias econômicas, que são divididas em despesas correntes e despesas de capital. Aquelas estão relacionadas ao custeio e estas, aos investimentos.

Conforme afirmam Baleeiro e Machado Segundo (2015), em relação à despesa pública, o governo deve se inspirar, no princípio da máxima vantagem social, ao se orientar em "como obter o máximo de eficiência e de conveniência social com o mínimo de sacrifício pecuniário correspondente" (p. 88), na ocasião, por exemplo, de se decidir construir ou ampliar escolas.

Esse custeio e investimentos da Educação são demonstrados no relatório da execução orçamentária, conforme o artigo 165. ${ }^{\circ}$ da CF/88, assim como também nos balanços do poder público estabelecidos no artigo $72 . .9$ da Lei de Diretrizes e Bases da Educação (LDB), Lei $n^{\circ}$. 9.394/96 (CREPALDI; CREPALDI, 2015). São demonstrados, ainda, em relatórios da LRF. A CF/88, no artigo 212.․․ estabelece que:

A União aplicará, anualmente, nunca menos de dezoito por cento, e os Estados, o Distrito Federal e os Municípios vinte cinco por cento, no mínimo, da receita resultante de impostos, compreendida a proveniente de transferências, na manutenção e desenvolvimento do ensino.

A figura 1 mostra como são distribuídas as origens dos recursos para o custeamento dos serviços públicos em Educação Básica. 
Figura 1 - Origens e aplicações de recursos na educação.

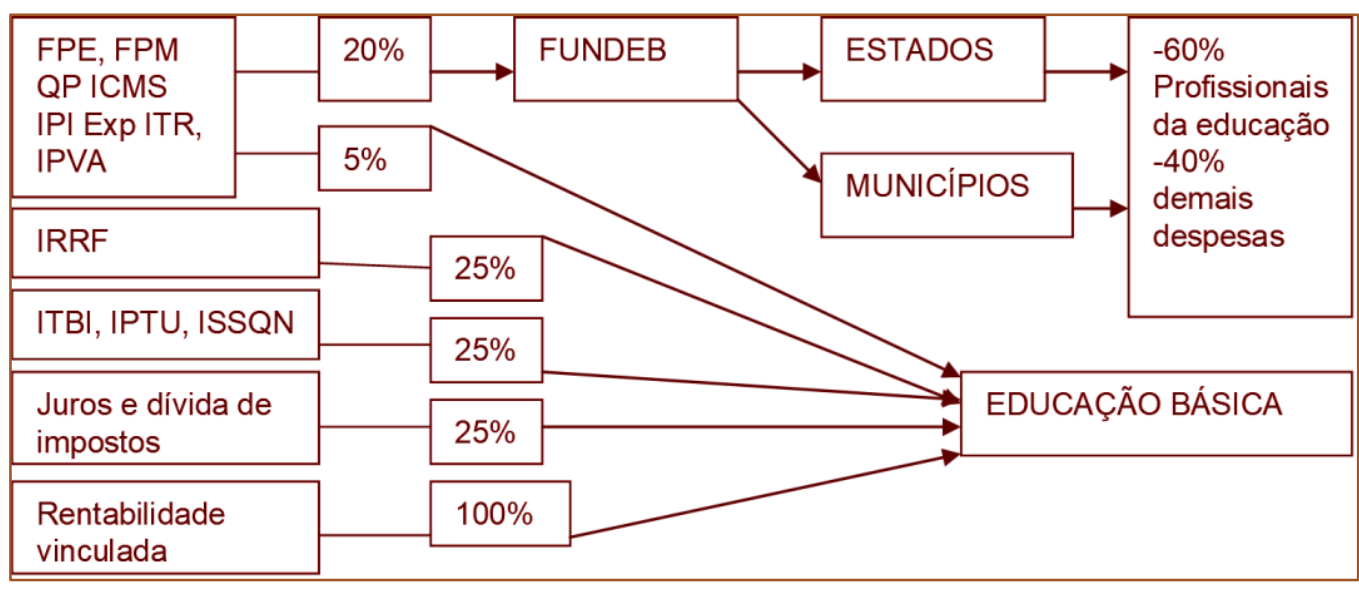

Fonte: Andrade, 2013, p. 220.

Se não houver a comprovação da aplicação de $25 \%$ dos recursos na Educação, poderá haver intervenção do Estado nos Municípios (CF/88, art. 34, inciso VII), assim como a rejeição de contas do gestor pelos Tribunais de Contas jurisdicionados (ANDRADE, 2013). É importante que a população se atenha aos impostos que paga para obter serviços públicos, avaliando a qualidade deles. Os demonstrativos que fazem a apuração dos gastos na manutenção e no desenvolvimento do ensino são padronizados por deliberação dos Tribunais de Contas. Segundo Cury (2011, p. 125), o "Fundeb tornou-se uma nova política necessária para corrigir os defeitos do Fundef e propiciar a abertura de formas de regime de cooperação federativa".

Testes e análises realizadas por Araújo (2016, p. 88) confirmam que os cinco primeiros anos de existência do Fundeb, que substituiu o Fundef, "apresentam uma tendência à melhoria nos indicadores de desigualdade territorial e os dados indicam que a responsabilidade desta melhora, pelo menos de forma mais significativa, está relacionada às políticas redistributivas federais", ou seja, à alteração dessa política de fundos da educação. Isso implica a diminuição das desigualdades territoriais na área educacional, tendo em vista o fato de que o país convive com desigualdades regionais. No entanto, o passo mais à frente na forma de raciocinar o financiamento educacional é o CAQi (Custo Aluno - Qualidade inicial), que foi transformado em parecer do Conselho Nacional de Educação pela Câmara de Educação Básica (CNE/CEB n. ${ }^{\circ}$ 08/2010) para estabelecer normas para aplicação do inciso IX do artigo 4.ำ da LDB (ARAÚJO, 2016).

Especificamente, o que pode ser considerado gasto na Manutenção e Desenvolvimento do Ensino - MDE, bem como o que não pode está determinado nos artigos 70 e 71 da LDB, conforme mostra o quadro 3. 
Quadro 3 - Despesas consideradas e não consideradas para a Educação pública.

\begin{tabular}{|c|c|}
\hline $\begin{array}{l}\text { Art. } 70 \text {. Considerar-se-ão como de manutenção } \\
\text { e desenvolvimento do ensino as despesas as } \\
\text { despesas realizadas com vista à consecução } \\
\text { dos objetivos básicos das instituições } \\
\text { educacionais de todos os níveis, } \\
\text { compreendendo as que se destinam a: }\end{array}$ & $\begin{array}{l}\text { Art. } 71 \text {. Não constituirão despesas de } \\
\text { manutenção e desenvolvimento do ensino } \\
\text { aquelas realizadas com: }\end{array}$ \\
\hline $\begin{array}{l}\text { I - remuneração e aperfeiçoamento do pessoal } \\
\text { docente e demais profissionais da educação; } \\
\text { II - aquisição, manutenção, construção e } \\
\text { conservação de instalaçôes e equipamentos } \\
\text { necessários ao ensino; } \\
\text { III - uso e manutenção de bens e serviços } \\
\text { vinculados ao ensino; } \\
\text { IV - levantamentos estatísticos, estudos e } \\
\text { pesquisas visando precipuamente ao } \\
\text { aprimoramento da qualidade e à expansão do } \\
\text { ensino; } \\
\text { V - realização de atividades-meio necessárias } \\
\text { ao funcionamento dos sistemas de ensino; } \\
\text { VI - concessão de bolsas de estudos a alunos } \\
\text { de escolas públicas e privadas; } \\
\text { VII - amortização e custeio de operações de } \\
\text { créditos destinadas a atender ao disposto nos } \\
\text { incisos deste artigo; } \\
\text { VIII - aquisição de material didático-escolar e } \\
\text { manutenção de programas de transporte } \\
\text { escolar. }\end{array}$ & 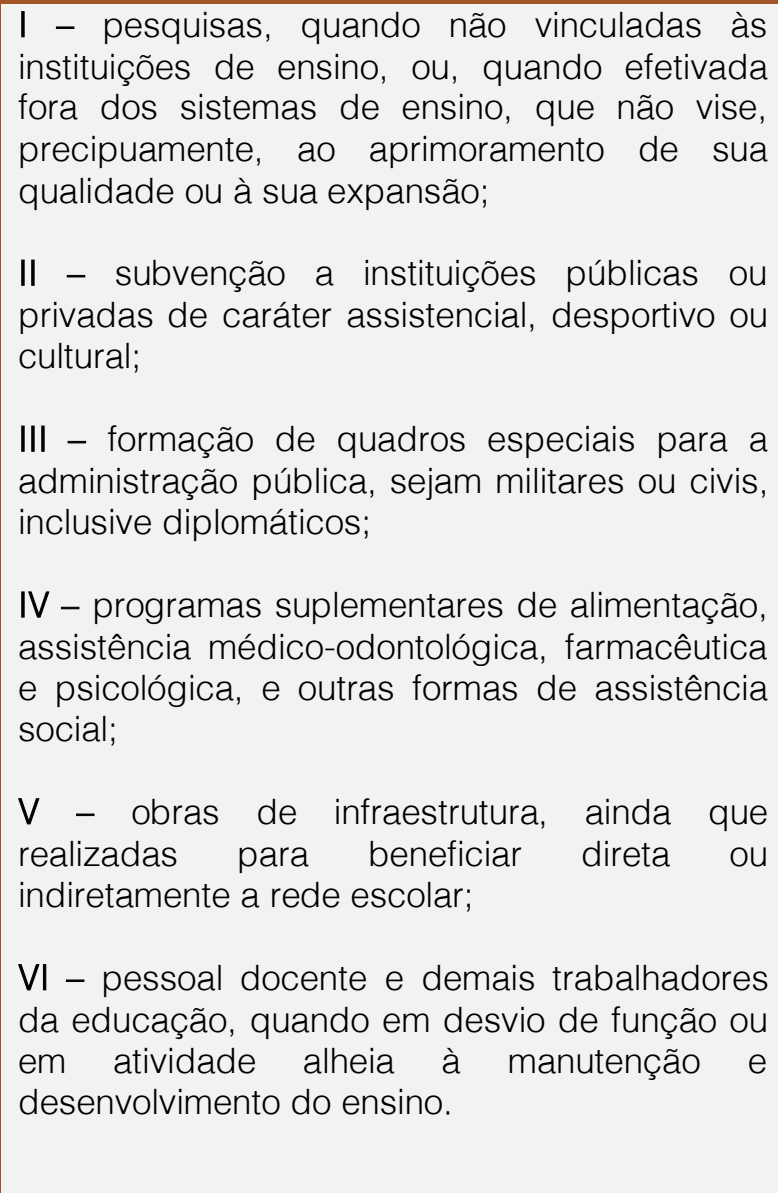 \\
\hline
\end{tabular}

Fonte: Lei n. ${ }^{\circ} 9.394 / 96$ (LDB).

\section{ESTUDOS RECENTES}

Alguns estudos recentes sobre a avaliação ou análise da educação pública estão apresentados resumidamente no quadro 4, com os objetivos e as principais conclusões.
Percebeu-se uma tendência nos estudos para a aplicação da Análise Envoltória de Dados para avaliar a eficiência dos gastos com a Educação pública. 
Quadro 4 - Estudos recentes sobre a análise da Educação pública.

\begin{tabular}{|c|c|c|}
\hline Autores & Objetivos/problema de pesquisa & Principais conclusões \\
\hline $\begin{array}{l}\text { Scarpin et } \\
\text { al, (2012) }\end{array}$ & $\begin{array}{l}\text { Analisar a eficiência dos recursos públicos } \\
\text { direcionados à educação nos municípios } \\
\text { do estado de Santa Catarina. }\end{array}$ & $\begin{array}{l}12 \% \text { dos municípios catarinenses são eficientes em } \\
\text { seus gastos com Educação e os menores } \\
\text { municípios tendem a ser os mais eficientes. }\end{array}$ \\
\hline $\begin{array}{l}\text { Borges; } \\
\text { Pereira, } \\
\text { (2014) }\end{array}$ & $\begin{array}{l}\text { Verificar a influência da educação fiscal } \\
\text { sobre a eficiência da gestão recursos pela } \\
\text { administração pública municipal. }\end{array}$ & $\begin{array}{l}\text { Foi rejeitada a hipótese principal de que o nível de } \\
\text { educação fiscal do cidadão em instrumento de } \\
\text { controle social influencia a eficiência da gestão } \\
\text { pública e aumenta o nível de transparência. }\end{array}$ \\
\hline $\begin{array}{l}\text { Sousa, } \\
\text { W. D. } \\
\text { et } \\
(2015)\end{array}$ & $\begin{array}{l}\text { Avaliar os gastos com o ensino } \\
\text { fundamental, analisando a eficiência e } \\
\text { eficácia na utilização dos recursos } \\
\text { públicos destinados aos municípios do } \\
\text { Espírito Santo. }\end{array}$ & $\begin{array}{l}16 \text { municípios alcançaram a eficiência máxima na } \\
\text { alocação dos recursos. Há indícios da existência } \\
\text { de um relacionamento estatisticamente significativo } \\
\text { entre o Índice de Desenvolvimento Humano } \\
\text { Educação, a eficiência na aplicação dos recursos } \\
\text { públicos e o alcance da meta do IDEB. }\end{array}$ \\
\hline $\begin{array}{l}\text { Silva, A. } \\
\text { B. et al } \\
\text { (2015) }\end{array}$ & $\begin{array}{l}\text { Identificar os municípios que } \\
\text { apresentaram os melhores e piores níveis } \\
\text { de eficiência técnica na aplicação de } \\
\text { recursos públicos em Educação. }\end{array}$ & $\begin{array}{l}5 \% \text { dos municípios são tecnicamente eficientes e } \\
16 \% \text { são fortemente ineficientes. Evidenciou-se } \\
\text { baixo nível de eficiência. Sugeriu-se modificar as } \\
\text { políticas públicas e selecionar estratégias para } \\
\text { alcançar metas previamente mensuradas. }\end{array}$ \\
\hline $\begin{array}{l}\text { Silva, M. } \\
\text { C. et al } \\
(2015 a)\end{array}$ & $\begin{array}{l}\text { Avaliar se os municípios de São Paulo, Rio } \\
\text { de Janeiro e Belo Horizonte foram } \\
\text { eficientes na gestão dos recursos do } \\
\text { ensino fundamental de forma a provocar } \\
\text { mudanças ou se permaneceram na inércia } \\
\text { social nos anos de divulgação do IDEB. }\end{array}$ & $\begin{array}{l}\text { RJ e BH foram eficientes e em SP não houve } \\
\text { efetividade na política de ensino fundamental } \\
\text { (inércia social) no ano de } 2011 \text {. }\end{array}$ \\
\hline $\begin{array}{l}\text { Silva, M. } \\
\text { C. et al } \\
(2015 b)\end{array}$ & $\begin{array}{l}\text { Avaliar se as políticas públicas funcionais } \\
\text { implementadas no município de São } \\
\text { Paulo, no período de } 2002 \text { a } 2012 \text {, } \\
\text { representaram efetividade social. }\end{array}$ & $\begin{array}{l}\text { Para a função Educação, houve efetividade social } \\
\text { no ano de } 2005 \text {. }\end{array}$ \\
\hline $\begin{array}{l}\text { Theiss, V. } \\
\text { et al } \\
\text { (2015) }\end{array}$ & $\begin{array}{l}\text { Analisar a alocação de recursos } \\
\text { econômicos e externalidades positivas na } \\
\text { educação de países da América Central, } \\
\text { do Sul e México. }\end{array}$ & $\begin{array}{l}\text { O Brasil encontra-se entre os países que obtiveram } \\
\text { eficiência máxima. Cuba obteve a menor eficiência. } \\
\text { Existe diferença de eficiências na alocação de } \\
\text { recursos econômicos em relação ao incremento } \\
\text { das externalidades positivas na educação dos } \\
\text { países analisados. }\end{array}$ \\
\hline $\begin{array}{l}\text { Santos, } \\
\text { Gomes e } \\
\text { Ervilha } \\
\text { (2015) }\end{array}$ & $\begin{array}{l}\text { Avaliar o desempenho do governo na } \\
\text { primeira fase do Plano Mineiro de } \\
\text { Desenvolvimento Integrado, considerando } \\
\text { os princípios de equidade e eficiência. }\end{array}$ & $\begin{array}{l}\text { O estado avançou no sentido de melhorar a } \\
\text { eficiência e os indicadores educacionais. }\end{array}$ \\
\hline $\begin{array}{l}\text { Tarda e } \\
\text { Rodrigues } \\
\text { (2015) }\end{array}$ & $\begin{array}{l}\text { Analisar a relação entre educação e } \\
\text { crescimento econômico na Região } \\
\text { Administrativa de Campinas. }\end{array}$ & $\begin{array}{l}\text { Comprovaram-se a validade da hipótese, } \\
\text { evidenciando a relação positiva do capital físico, } \\
\text { trabalho e gastos com educação com o PIB. }\end{array}$ \\
\hline $\begin{array}{l}\text { Santos, } \\
\text { Carvalho } \\
\text { e Barbosa } \\
(2016)\end{array}$ & $\begin{array}{l}\text { Analisar a eficiência dos gastos } \\
\text { municipais em Educação, considerando o } \\
\text { ensino fundamental, no contexto dos } \\
\text { municípios do Seridó Potiguar para o ano } \\
\text { de 2013. }\end{array}$ & $\begin{array}{l}\text { Evidenciaram-se três rankings de eficiência, os } \\
\text { quais evidenciaram os municípios mais e menos } \\
\text { eficientes nos seus gastos com educação. }\end{array}$ \\
\hline $\begin{array}{l}\text { Silva Filho } \\
\text { et } \\
(2016)\end{array}$ & $\begin{array}{l}\text { Avaliar e eficiência na alocação dos } \\
\text { gastos públicos com educação (ensino } \\
\text { fundamental) nos Colégios Militares do } \\
\text { Exército entre os anos de } 2009 \text { e } 2011 \text {. }\end{array}$ & $\begin{array}{l}\text { Em 2009, } 58,34 \% \text { dos colégios foram considerados } \\
\text { eficientes e, em } 2011 \text {, apenas } 30 \% \text {. Os autores } \\
\text { destacaram ainda que os colégios que } \\
\text { apresentaram maior alocação de recursos não } \\
\text { necessariamente se mostraram eficientes, } \\
\text { indicando a necessidade de uma melhor gestão } \\
\text { dos recursos. }\end{array}$ \\
\hline
\end{tabular}

Fonte: Dados da pesquisa, 2016. 


\section{PROCEDIMENTOS METODOLÓGICOS}

\subsection{CARACTERIZAÇÃO DO MÉTODO}

Vergara (2016) propôs dois critérios para a definição do tipo de pesquisa: quanto aos fins e quanto aos meios. Este projeto classifica-se, quantos fins, como descritivo e aplicado e, quanto aos meios, como documental. A abordagem é mista, mas com predominância do tipo qualitativa. Justifica-se uma abordagem mais qualitativa pelo fato de a preocupação ser a interpretação, em vez da medição (MARTINS; THEÓPHILO, 2007). Pelo critério de Gil, (2011) o método é o estatístico e o delineamento é a pesquisa documental.

\subsection{TÉCNICA DE COLETA E ANÁLISE DOS DADOS}

Os dados relativos às receitas e às despesas públicas foram coletados nos sítios do Siope, do Sistn, do Fimbra e do Tribunal de Contas do Estado de Rondônia. Os documentos obtidos para a análise foram os relatórios da LRF, contidos no Relatório Eesumido da
Execução Orçamentária (RREO). A análise dos dados foi realizada por meio de ferramentas estatísticas do XLSTAT, suplemento do Microsoft Excel ${ }^{\circledR}$. Foi utilizada a estatística descritiva para apoiar uma interpretação subjetiva (VERGARA, 2016) e a estatística inferência: a média, o desviopadrão, a variância, o coeficiente de correlação e de determinação de Pearson ( $r$ e $r^{2}$ ) e o teste $t$ de Student. Também foram analisadas as variações da despesa por função Educação e suas subfunções, em relação aos totais das receitas e das despesas. Para a análise da correlação, as variáveis independentes foram as receitas totais orçamentárias e as variáveis dependentes, as despesas da função Educação, pois, conforme Silva (2012, p.18), "arrecada-se para gastar" e "espera-se que o governo ao arrecadar mais possa, também, investir mais no cumprimento de suas funções". No quadro 5, são detalhadas as questões de pesquisa para a análise.

Quadro 5 - Questões de pesquisa detalhadas.

- Quais municípios do estado de Rondônia apresentam maior regularidade e menor regularidade de gastos com a função de despesa Educação?

- Qual a subfunção de maior média e de maior regularidade?

- Qual a subfunção de menor média e de menor regularidade?

- Qual o nível de correlação existente entre as despesas executadas na função Educação dos municípios, no período de 2009 a 2014, e as receitas executas no mesmo período?

- Existe correlação geral entre todas as receitas e todas as despesas somados os municípios (teste $t$ de Student)?

- Quais municípios obtiveram maior e menor aplicação de recursos na função de despesa Educação em relação ao total do orçamento públiç?

Fonte: Elaboração própria.

Para interpretar os coeficientes de correlação, utilizaram-se as escalas conforme a tabela 1. Para eliminar o efeito da inflação sobre as contas públicas, utilizou-se o Índice Geral de Preços Disponibilidade Interna (IGP-DI) utilizada pela Secretaria do Tesouro Nacional (STN) para atualizar os valores das demonstrações contábeis públicas (SILVA, 2012), corrigidos para moeda de 2014. 
Tabela 1 - Escalas para análise da correlação.

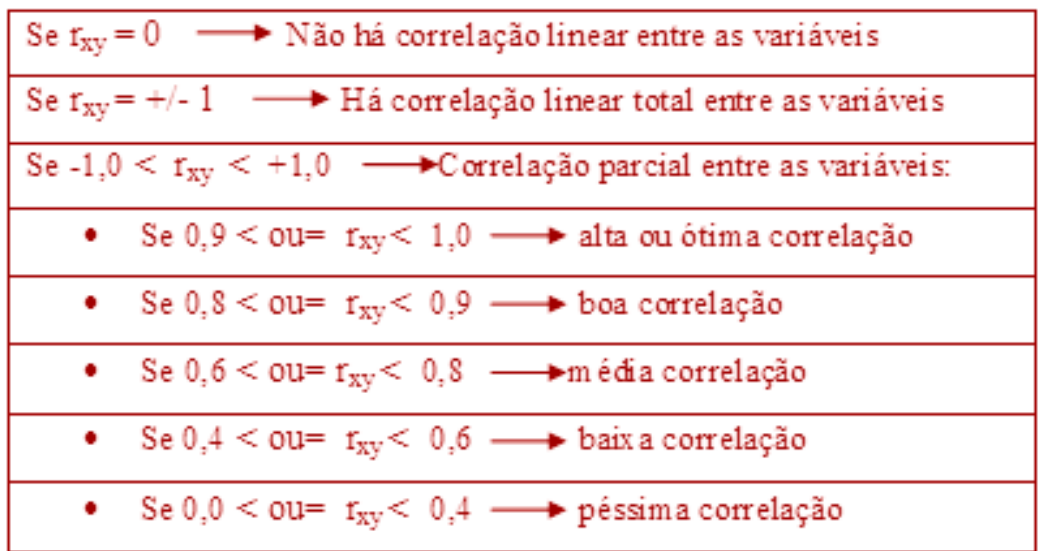

Fonte: Martins e Domingues, 2011, p. 487

\subsection{AMOSTRA}

A amostra da pesquisa foram os 15 melhores municípios do ranking do Índice Firjan de Desenvolvimento Municipal (IFDM). Trata-se de um estudo do Sistema Firjan que acompanha anualmente o desenvolvimento socioeconômico de todos os mais de cinco mil municípios brasileiros em três áreas de atuação: Emprego \& Renda, Educação e Saúde. Criado em 2008, ele é estabelecido, exclusivamente, com base em estatísticas públicas oficiais, disponibilizadas pelos ministérios do Trabalho, Educação e Saúde (SISTEMA FIRJAN, 2014). A tabela 2 apresenta os 15 municípios de Rondônia com melhores índices no ranking IFDM do estado. Os dados atuais foram publicados em 2014, referentes ao ano base 2011.

Tabela 2 - Ranking IFDM dos municípios de Rondônia.

\begin{tabular}{|c|c|c|c|c|c|c|c|}
\hline \multicolumn{2}{|c|}{ Ranking IFDM Geral } & \multirow{2}{*}{ UF } & \multirow{2}{*}{ Município } & \multirow{2}{*}{ IFDM } & \multirow{2}{*}{$\begin{array}{c}\text { Emprego \& } \\
\text { Renda }\end{array}$} & \multirow{2}{*}{ Educação } & \multirow{2}{*}{ Saúde } \\
\hline Nacional & Estadual & & & & & & \\
\hline $456^{\circ}$ & $1^{0}$ & RO & Vilhena & 0,7856 & 0,7648 & 0,7759 & 0,8161 \\
\hline $1106^{\circ}$ & $2^{0}$ & RO & Porto Velho & 0,7325 & 0,8279 & 0,6458 & 0,7239 \\
\hline $1116^{\circ}$ & $3^{0}$ & RO & Ariquemes & 0,7318 & 0,6529 & 0,7148 & 0,8277 \\
\hline $1227^{\circ}$ & $4^{0}$ & RO & Cacoal & 0,7242 & 0,6764 & 0,7080 & 0,7882 \\
\hline $1496^{\circ}$ & $5^{0}$ & RO & Chupinguaia & 0,7065 & 0,6534 & 0,7289 & 0,7372 \\
\hline $1689^{\circ}$ & $6^{0}$ & RO & Pimenta Bueno & 0,6958 & 0,6341 & 0,7588 & 0,6946 \\
\hline $1827^{\circ}$ & $7^{0}$ & RO & Ji-Paraná & 0,6884 & 0,7453 & 0,6786 & 0,6413 \\
\hline $2195^{\circ}$ & $8^{\circ}$ & RO & Santa Luzia D'Oeste & 0,6666 & 0,6151 & 0,7046 & 0,6802 \\
\hline $2618^{\circ}$ & $9^{\circ}$ & RO & Jaru & 0,6440 & 0,6447 & 0,6995 & 0,5877 \\
\hline $2706^{\circ}$ & $10^{\circ}$ & RO & Rio Crespo & 0,6395 & 0,5746 & 0,5593 & 0,7847 \\
\hline $2736^{\circ}$ & $11^{\circ}$ & RO & Buritis & 0,6383 & 0,5060 & 0,5849 & 0,8240 \\
\hline $2737^{\circ}$ & $12^{\circ}$ & RO & Teixeirópolis & 0,6383 & 0,5058 & 0,7516 & 0,6575 \\
\hline $2890^{\circ}$ & $13^{\circ}$ & RO & Ouro Preto do Oeste & 0,6299 & 0,5692 & 0,7203 & 0,6001 \\
\hline $2995^{\circ}$ & $14^{\circ}$ & RO & Itapuã do Oeste & 0,6235 & 0,5940 & 0,5481 & 0,7286 \\
\hline $3075^{\circ}$ & $15^{\circ}$ & RO & Rolim de Moura & 0,6185 & 0,5925 & 0,6952 & 0,5679 \\
\hline
\end{tabular}

Fonte: Sistema Firjan, 2014. 
6 APRESENTAÇÃO E ANÁLISE DOS RESULTADOS

\subsection{ESTATÍSTICA DESCRITIVA}

Com o intuito de responder às questões detalhadas da pesquisa, foram considerados, para analise dos dados, a média, o desviopadrão e a variância dos 15 municípios. $\mathrm{Na}$ tabela 3, são apresentados os dados estatísticos da função Educação geral.

Tabela 3 - Função Educação dos municípios.

\begin{tabular}{|c|c|c|c|}
\hline Municípios de ro & Média & Desvio-padrão & Variância \\
\hline 1 Santa Luzia do Oeste & 3.528.625,90 & $315.290,40$ & $99.408 .037 .213,36$ \\
\hline 2 Teixeirópolis & $4.152 .198,13$ & $579.416,29$ & $335.723 .242 .316,76$ \\
\hline 3 Jaru & $25.679 .002,45$ & $689.712,20$ & 475.702.914.740,10 \\
\hline 4 Rio Crespo & $3.773 .836,17$ & $830.845,77$ & $690.304 .692 .914,80$ \\
\hline 5 Buritis & $18.992 .497,13$ & $858.871,21$ & 737.659.748.846,41 \\
\hline 6 Itapuã do Oeste & $7.297 .200,63$ & $925.494,67$ & $856.540 .392 .452,86$ \\
\hline 7 Chupinguaia & $8.807 .837,76$ & $1.523 .645,33$ & $2.321 .495 .094 .497,89$ \\
\hline 8 Pimenta Bueno & $16.248 .862,43$ & $1.771 .635,59$ & $3.138 .692 .649 .502,44$ \\
\hline 9 Ouro Preto do Oeste & $20.449 .203,26$ & $1.781 .056,28$ & $3.172 .161 .482 .418,20$ \\
\hline 10 Rolim de Moura & $19.533 .253,96$ & $2.538 .242,00$ & $6.442 .672 .439 .961,90$ \\
\hline 11 Ji-Paraná & $32.588 .600,36$ & $2.901 .514,02$ & 8.418.783.606.965,04 \\
\hline 12Cacoal & $31.013 .991,35$ & $3.583 .046,46$ & $12.838 .221 .916 .477,40$ \\
\hline 13 Ariquemes & $56.180 .214,69$ & $3.881 .738,34$ & 15.067.892.558.273,60 \\
\hline 14 Vilhena & $40.375 .598,49$ & $5.646 .871,70$ & $31.887 .159 .990 .389,60$ \\
\hline 15 Porto Velho & $219.511 .143,44$ & $38.798 .058,19$ & 1.505.289.319.203.150,00 \\
\hline TOTAL & $508.132 .066,14$ & $66.625 .438,45$ & $1.591 .771 .737 .970 .120,00$ \\
\hline
\end{tabular}

Para responder ao questionamento de quais municípios apresentam mais regularidade de gastos com a função de despesa educação, verificam-se aqueles municípios que apresentam menor desvio-padrão e variância. Santa Luzia do Oeste tem o menor desviopadrão e a menor variância, portanto é o mais regular na aplicação dos recursos na educação. Teixeirópolis e Jaru são os segundo e terceiro mais regulares, respectivamente. A capital Porto Velho é o município menos regular, embora tenha a melhor média de aplicações de recursos.

$\mathrm{Na}$ tabela 4, apresentam-se a média e desviopadrão por subfunção dos gastos com a educação nos municípios.

Tabela 4 - Análise da função Educação por subfunção.

\begin{tabular}{|lrr|}
\hline \multicolumn{1}{|c|}{ SUBFUNÇÕES } & \multicolumn{1}{c|}{ MÉDIA } & DESVIO-PADRÃO \\
\hline Fundamental & $407.791 .960,17$ & $45.167 .166,76$ \\
Ensino Médio & $705.085,47$ & $936.534,14$ \\
Ensino Profissional & $127.642,33$ & --- \\
Ensino Superior & $993.759,42$ & $623.469,96$ \\
Ensino Infantil & $70.236 .832,42$ & $28.876 .893,21$ \\
Jovens e Adultos & $15.622 .145,32$ & $9.109 .370,17$ \\
Educação Especial & $3.317 .500,22$ & $1.833 .637,99$ \\
\hline \hline
\end{tabular}


As subfunções Ensino Fundamental e Ensino Infantil foram as que obtiveram maiores desvio-padrão e, portanto, são menos regulares. Entre todas as subfunções, com a excepção das de Ensino Fundamental e Ensino Infantil, a subfunção Jovens e Adultos é a que teve a maior média e o Ensino Profissional, a menor. A Educação de Jovens e Adultos obteve o maior desvio-padrão, e, portanto, mostrou-se menos regular. O Ensino Superior é mais regular por ter o menor desvio-padrão.

A tabela 5 apresenta os municípios com maiores e menores médias e desvio-padrão por subfunção.

Tabela 5 - Descrição de qual município foi mais e menos regular por subfunção.

\begin{tabular}{|c|c|c|c|c|}
\hline \multirow{2}{*}{ SUBFUNÇÕES } & \multicolumn{2}{|c|}{ MÉDIA } & \multicolumn{2}{|c|}{ DESVIO-PADRÃO } \\
\hline & MAIOR & MENOR & MAIOR & MENOR \\
\hline Fundamental & Porto Velho & Santa Luzia do Oeste & Porto Velho & Santa Luzia do Oeste \\
\hline Ensino Médio & Cacoal & Rio Crespo & Cacoal & Rio Crespo \\
\hline Ensino Profissional & Vilhena & Pimenta Bueno & --- & --- \\
\hline Ensino Superior & Jarú & Vilhena & Ji-Paraná & Rio Crespo \\
\hline Ensino Infantil & Porto Velho & Teixeirópolis & Porto Velho & Santa Luzia do Oeste \\
\hline Jovens e Adultos & Porto Velho & Teixeirópolis & Porto Velho & Pimenta Bueno \\
\hline Educação Especial & Ariquemes & Teixeirópolis & Porto Velho & Teixeirópolis \\
\hline
\end{tabular}

O município de Santa Luzia do Oeste foi o mais regular com gastos no Ensino Fundamental e Ensino Infantil, pois foi o que apresentou o menor desvio-padrão. Porto Velho foi o que mais aplicou recursos nessas subfunções, porém mostrou-se o menos regular, pois teve o maior desvio-padrão.

\subsection{ESTATÍSTICA INFERENCIAL}

Nesta seção, é analisada a correlação entre as despesas executadas na função Educação nos municípios e as receitas executas no mesmo período. $\mathrm{Na}$ tabela 6 , são evidenciados os coeficientes de correlação e de determinação de Pearson referentes ao município de Vilhena.

Tabela 6 - Índice de Correlação - município de Vilhena.

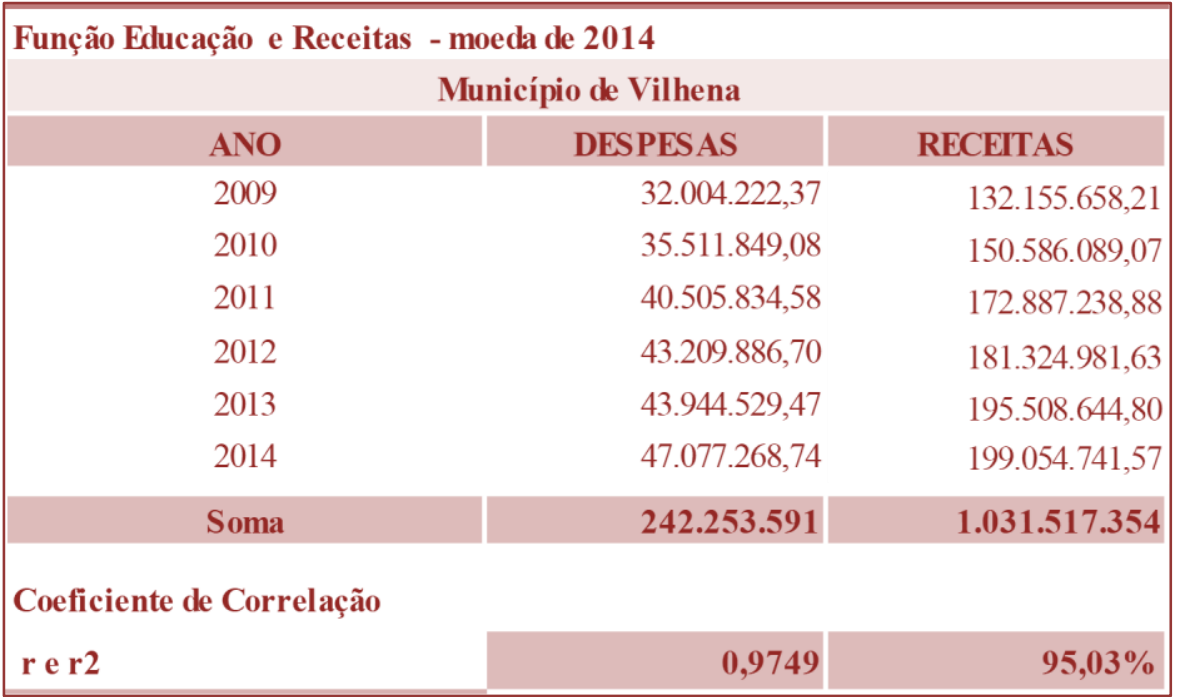

O coeficiente de correlação ( $r$ de Pearson) foi de 0,9749 e o coeficiente de determinação $\left(r^{2}\right)$ foi de $95 \%$. A correlação é positiva e alta.
Pode-se entender que, à medida que as receitas executadas aumentam, há um aumento das despesas na função Educação 
no mesmo sentido. O $r^{2}$ evidencia que 95\% das variações das despesas com Educação podem ser explicadas pelas variações nas receitas.

O município, além de ser o melhor do ranking estadual do Índice Firjan, é o melhor nas três áreas de atuação: Emprego \& Renda, Educação e Saúde. Vilhena também apresentou o melhor nível de correlação da amostra. Na tabela 7, apresentam-se os scores dos municípios.

Tabela 7 - Índices de correlação dos municípios.

\begin{tabular}{|c|c|c|c|}
\hline \multirow{3}{*}{ MUNICÍPIOS } & \multicolumn{3}{|c|}{ ANÁLIS E DA CORRELAÇÃO ENTRE DES PES A E RECETTA } \\
\hline & \multicolumn{2}{|c|}{ COEFICIENTES } & \multirow{2}{*}{$\begin{array}{l}\text { Interpretação do } \\
\text { Coeficiente de } \\
\text { Correlação }\end{array}$} \\
\hline & Correlação & Determinação & \\
\hline Vilhena & 0,9749 & $95,03 \%$ & Alta \\
\hline Porto Velho & 0,8901 & $79,22 \%$ & Boa \\
\hline Ariquemes & 0,5457 & $29,78 \%$ & Baixa \\
\hline Cacoal & 0,8056 & $64,90 \%$ & Boa \\
\hline Chupinguaia & 0,2658 & $7,06 \%$ & Pés sima \\
\hline Pimenta Bueno & 0,8697 & $75,63 \%$ & Boa \\
\hline Ji-Paraná & 0,9670 & $93,51 \%$ & Alta \\
\hline Santa Luzia D'Oeste & $-0,6146$ & $37,78 \%$ & Média/n egativa \\
\hline Jaru & 0,8244 & $67,97 \%$ & Boa \\
\hline Rio Crespo & 0,8798 & $77,40 \%$ & Boa \\
\hline Buritis & 0,6876 & $47,28 \%$ & Média \\
\hline Teixeirópolis & $-0,1784$ & $3,18 \%$ & Péssima / n egativa \\
\hline Ouro Preto do Oeste & 0,8403 & $70,61 \%$ & Boa \\
\hline Itapuã do Oeste & 0,9171 & $84,10 \%$ & Alta \\
\hline Rolim de Moura & 0,7009 & $49,13 \%$ & Média \\
\hline
\end{tabular}

Dois municípios apresentaram correlação negativa. Teixeirópolis apresentou um coeficiente de correlação ( $r$ de Pearson) de 0,1784 e o de determinação $\left(r^{2}\right)$, de 3,18\%. Trata-se de uma orrelação negativa e péssima. Pode-se entender que, à medida que as receitas executadas aumentam, não há um aumento das despesas na função Educação no mesmo sentido. O $\mathrm{r}^{2}$ evidencia que somente $3 \%$ das variações das despesas com Educação podem ser explicadas pelas variações nas receitas, no sentido contrário.

Dos que apresentaram correlação positiva, Chupinguaia obteve o menor score. Três municípios do interior obtiverem maior score que a capital Porto Velho. Segundo Martins e Domingues (2011), o fato de se apresentar uma correlação baixa não se deve descartar as variáveis de estudo. Para esses autores, "um coeficiente de correlação linear baixo indica apenas que não há uma grande semelhança de comportamento linear entre as variáveis de estudo" (p. 487). Por isso, devem-se estudar outros tipos de relações entre as variáveis, como por exemplo a do teste $t$ de Student. Entretanto, para aplicá-lo, deve-se ter pelo menos uma quantidade maior de amostras (maior número de anos) ou garantir que a população tenha distribuição normal (LEVIN; FOX, 2004).

O ranking dos municípios com melhor correlação das receitas e das despesas de governo Educação é o seguinte: Vilhena, JiParaná, Itapuã do Oeste, Porto Velho, Rio Crespo, Pimenta Bueno, Ouro Preto do Oeste, Jaru, Cacoal, Rolim de Moura, Buritis, Ariquemes, Chupinguaia, Teixeirópolis e Santa Luzia D'Oeste.

Na tabela 8 apresentam-se os resultados do teste $t$ de Student. Nesse teste, somaram-se todas as despesas dos municípios e também todas as receitas, ou seja, procurou-se verificar se há correlação geral entre essas variáveis. Verificou-se que há correlação em todos os anos analisados. 
Tabela 8 - Resultado do Teste t para correlação entre as variáveis despesas.

\begin{tabular}{|c|c|c|c|c|c|}
\hline Ano & $\mathrm{n}$ & gl & $\mathrm{t}$ tabelado & t calculado & Conclusão \\
\hline 2009 & 15 & 13 & 2,16 & 26,250 & t calculado> t tabelado - há correlação \\
\hline 2010 & 15 & 13 & 2,16 & 33,690 & t calculado> t tabelado - há correlação \\
\hline 2011 & 15 & 13 & 2,16 & 39,114 & t calculado> t tabelado - há correlação \\
\hline 2012 & 15 & 13 & 2,16 & 41,629 & t calculado> t tabelado - há correlação \\
\hline 2013 & 15 & 13 & 2,16 & 38,928 & t calculado> t tabelado - há correlação \\
\hline 2014 & 15 & 13 & 2,16 & 50,986 & t calculado> t tabelado - há correlação \\
\hline
\end{tabular}

Fonte: LEVIN; FOX, 2004. Teste $t$ - Intervalo de confiança de $95 \%$ com $5 \%$ de erro (0,25 para cada lado).

\subsection{RANKING DO ORÇAMENTO EM EDUCAÇÃO}

A tabela 9 traz informações sobre os recursos que os municípios de Rondônia aplicaram na função de despesa Educação em relação ao total do Orçamento Geral, no exercício de 2014, e mostra quais municípios obtiveram maior e menor aplicação de recursos por ordem de percentual.

Tabela 9 - Aplicação na função Educação em relação ao Orçamento Geral - 2014.

\begin{tabular}{|clrrrr|}
\hline ORDEM & \multicolumn{1}{|c}{ MUNICÍPIOS } & \multicolumn{2}{c|}{ ORÇAMENTO } & \multicolumn{1}{c|}{ EDUCAÇÃO } & \multicolumn{1}{c|}{$\%$} \\
1 & Chupinguaia & $\mathrm{R} \$$ & $25.472 .637,86$ & $11.134 .866,78$ & 43,71 \\
2 & Itapuã do Oeste & $\mathrm{R} \$$ & $20.057 .944,00$ & $8.390 .244,85$ & 41,83 \\
3 & Rio Crespo & $\mathrm{R} \$$ & $12.500 .000,00$ & $4.496 .384,16$ & 35,97 \\
4 & Ariquemes & $\mathrm{R} \$$ & $176.792 .884,00$ & $58.759 .698,42$ & 33,24 \\
5 & Buritis & $\mathrm{R} \$$ & $57.366 .283,13$ & $18.518 .372,12$ & 32,28 \\
6 & Ouro Preto do Oeste & $\mathrm{R} \$$ & $66.098 .925,25$ & $21.197 .482,10$ & 32,07 \\
7 & Jaru & $\mathrm{R} \$$ & $81.389 .146,56$ & $25.720 .043,12$ & 31,60 \\
8 & Teixeirópolis & $\mathrm{R} \$$ & $14.129 .266,46$ & $4.376 .781,02$ & 30,98 \\
9 & Pimenta Bueno & $\mathrm{R} \$$ & $63.489 .000,00$ & $18.136 .486,61$ & 28,57 \\
10 & Rolim de Moura & $\mathrm{R} \$$ & $92.726 .506,86$ & $23.577 .101,55$ & 25,43 \\
11 & Vilhena & $\mathrm{R} \$$ & $191.139 .171,54$ & $47.077 .268,74$ & 24,63 \\
12 & Santa Luzia D'Oeste & $\mathrm{R} \$$ & $15.124 .200,00$ & $3.373 .461,56$ & 22,31 \\
13 & Cacoal & $\mathrm{R} \$$ & $158.381 .000,00$ & $35.300 .213,69$ & 22,29 \\
14 & Porto Velho & $\mathrm{R} \$$ & $1.218 .553 .812,00$ & $257.128 .169,58$ & 21,10 \\
15 & Ji-Paraná & $\mathrm{R} \$$ & $183.365 .151,26$ & $36.371 .574,15$ & 19,84 \\
& SOMA & RS & $\mathbf{2 . 3 7 6 . 5 8 5 . 9 2 8 , 9 2}$ & $\mathbf{5 7 3 . 5 5 8 . 1 4 8 , 4 5}$ & 24,13 \\
\hline
\end{tabular}

Proporcionalmente, os municípios que mais aplicaram foram municípios de menor orçamento, como Chupinguaia e Itapuã do Oeste, que aplicaram $43,71 \%$ e $41,83 \%$, respectivamente, do total do orçamento. $\mathrm{O}$ município de Porto Velho tem maior orçamento, mas proporcionalmente em relação ao total do orçamento é um dos que menos aplicaram, juntamente com os municípios maiores, com exceção de Ariquemes que aplicou 33,24\%. Rio Crespo possui o menor orçamento, mas é terceiro na aplicação em Educação.

Verifica-se que possuir maior parcela de aplicação em Educação em relação ao orçamento geral não que significa que o município apresentará boa correlação das mesmas aplicações em relação às receitas. Vilhena vinha apresentando os melhores scores, mas nesse ranking ocupa a 11. posição.

\section{SÍNTESE, ANÁLISE E CONSIDERAÇÕES FINAIS}

O objetivo da pesquisa foi analisar as aplicações de recursos na função de governo Educação dos municípios de Rondônia, no período de 2009 a 2014. As respostas às 
Quadro 6 - Síntese das repostas às questões de pesquisa.

\begin{tabular}{|c|c|}
\hline Questões & Respostas \\
\hline $\begin{array}{l}\text { Quais municípios do Estado de Rondônia } \\
\text { apresentam maior regularidade e menor } \\
\text { regularidade de gastos com a função de } \\
\text { despesa Educação? }\end{array}$ & $\begin{array}{l}\text { Santa Luzia do Oeste é o município mais regular } \\
\text { e Porto Velho, o menos regular. }\end{array}$ \\
\hline $\begin{array}{l}\text { Qual a subfunção de maior média e de maior } \\
\text { regularidade? }\end{array}$ & $\begin{array}{l}\text { Ensino Fundamental é a que apresentou maior } \\
\text { média e Ensino Superior é o mais regular. }\end{array}$ \\
\hline $\begin{array}{l}\text { Qual a subfunção de menor média e de menor } \\
\text { regularidade? }\end{array}$ & $\begin{array}{l}\text { Ensino Profissional é a que teve menor média e } \\
\text { o Ensino Fundamental, a menor regularidade. }\end{array}$ \\
\hline $\begin{array}{l}\text { Qual o nível de correlação existente entre as } \\
\text { despesas executadas na função Educação nos } \\
\text { municípios no período de } 2009 \text { a } 2014 \text { e as } \\
\text { receitas executadas no mesmo período? }\end{array}$ & $\begin{array}{l}\text { Três municípios obtiveram correlação positiva e } \\
\text { alta; seis obtiveram correlação positiva e boa; } \\
\text { dois obtiveram correlação positiva e média; um } \\
\text { obteve correlação positiva e baixa; um obteve } \\
\text { correlação positiva e péssima; um obteve } \\
\text { correlação negativa e média; e um obteve } \\
\text { correlação negativa e péssima. }\end{array}$ \\
\hline $\begin{array}{l}\text { Existe correlação geral entre todas as receitas } \\
\text { e todas as despesas somados os municípios } \\
\text { (teste } t \text { de Student)? }\end{array}$ & $\begin{array}{l}\text { Há correlação geral em todos os anos } \\
\text { analisados. }\end{array}$ \\
\hline $\begin{array}{l}\text { Quais municípios obtiveram maior e menor } \\
\text { aplicação de recursos na função de despesa } \\
\text { Educação em relação ao total do orçamento } \\
\text { público? }\end{array}$ & $\begin{array}{l}\text { Chupinguaia é o que mais aplicou na função } \\
\text { Educação em relação ao total do orçamento } \\
\text { público e Ji-paraná o que menos aplicou. }\end{array}$ \\
\hline
\end{tabular}

Depois de coletados e computados os dados, percebe-se que os municípios menores foram os que mais aplicaram na educação em relação ao total do orçamento. Destacam-se Chupinguaia e Itapuã do Oeste, que aplicaram $43,71 \%$ e $41,83 \%$ do total do orçamento. Em um estudo feito por Scarpin et al (2012), os menores municípios tendem a ser mais eficientes.

Possuir maior parcela de aplicação em Educação em relação ao orçamento geral não significa que o município apresentará boa correlação. O município de Teixeirópolis, que aplicou 30,98\% do orçamento na educação, apresentou correlação negativa e péssima; já o município de Vilhena, que aplicou na Educação 24,63\% do total do orçamento, foi o que teve melhor correlação, positiva e alta, dos gastos na Educação.

Os municípios têm aplicado proporcionalmente bem o total do orçamento. Isso não significa que foram eficientes ou que obtiveram boa correlação dos gastos em relação às receitas. Silva Filho et al (2016) destacam a necessidade de uma melhor gestão dos recursos. Contudo, para que esses recursos aplicados na educação se transformem num serviço público de qualidade e eficiência são importantes a implantação e a execução de políticas públicas, projetos, estratégias e bons investimentos. É o que a população espera de uma boa gestão dos governantes: que os projetos e políticas públicas tenham efetividade social, mudanças para melhor. 0 país tem de certa forma avançado nos últimos anos, mas é importante que esse avanço não pare ou retroceda.

Diante da crise econômica e social que o país esta passando, com uma economia fragilizada, aumento do desemprego. Por meio de ma gestão eficiente dos gastos com bons projetos e políticas públicas, a Educação terá um grande desenvolvimento. Foi o que fizeram os países desenvolvidos, que investem fortemente na Educação há décadas. Uma população com bom nível educacional possibilita mais chances de os gestores serem capacitados e competentes e, assim, serão altas as chances de que façam uma boa gestão.

Espera-se que este estudo possa auxiliar os gestores a avaliarem e analisarem a elaboração de políticas públicas. As recomendações de ordem prática são para a observância do princípio e cálculo da máxima 
vantagem social, conforme o entendimento de Baleeiro e Machado Segundo (2015), e do princípio da aprendizagem política (policy learning), segundo Howlett, Ramesh e Perl (2013).

Recomendam-se, ainda, pesquisas de conteúdo das ações na função de despesa

\section{REFERÊNCIAS}

[1] Andrade, N. A. Contabilidade pública na gestão municipal: métodos com base nas normas brasileiras de contabilidade aplicadas ao setor público (NBCASP) e nos padrões internacionais de contabilidade. 5. ed. São Paulo: Atlas, 2013.

[2] Araújo, L. O CAQi e o novo papel da União no financiamento da educação básica. Jundiaí: Paco Editorial, 2016.

[3] Baleeiro, A.; Machado Segunddo, H. B. Uma introdução à ciência das finanças: 19. ed. Rio de Janeiro: Forense, 2015.

[4] Brasil. Lei $n .9$ 9.394, de 20 de dezembro de 1996. Estabelece as diretrizes e bases da educação nacional. Brasília, 2007.

[5] Ministério do Planejamento, Orçamento e Gestão - MPOG. Portaria n. 42, de 14 de abril de 1999. Disponível em: <ftp://ftp.fnde.gov.br/web/siope/leis/P42_MPOG_14 -04-1999.pdf>. Acesso em: 15 fev. 2017.

[6] Borges, E. F.; Pereira, J. M. Educação fiscal e eficiência pública: um estudo das suas relações a partir da gestão de recursos municipais. Revista de Educação e Pesquisa em Contabilidade, Brasília, v. 8, n. 4, p. 437-453, out./dez., 2014.

M.: Brandao, C. F. O $\frac{\text { Chirinea, }}{\text { Ideb como política de }}$ de regulação do Estado e legitimação da qualidade: em busca de significados. Ensaio: aval.pol.públ.Educ. [online]. v. 23, n. 87, p. 461484, abr./jun., 2015.

[8]

Crepaldi, S. A.; Crepaldi, G. S. Orçamento público: planejamento, elaboração e controle. São Paulo: Saraiva, 2013.

[9] Cury, C. R. J. Federalismo político e educacional. In: FERREIRA, N. S. C. (org.). Políticas públicas e gestão da educação: polêmicas, fundamentos e análises. 2. ed. Brasília: Liber Livro Editora, 2011.

[10] Dias, R.; MATOS, F. Políticas públicas: princípios, propósitos e processos. São Paulo: Atlas, 2012.

[11] Giacomoni, J. Orçamento público. 16. ed. São Paulo: Atlas, 2012.

[12] Gil, A. C. Métodos e técnicas de pesquisa social. 6. ed. São Paulo: Atlas, 2011.

[13] Gohn, M. G. Conselhos gestores e participação sociopolítica. 4. ed. São Paulo: Cortez, 2011. (Coleção questões de nossa época; v. 32).

[14] Howlett, M.; Ramesh, M.; Perl, A. Política pública: seus ciclos e subsistemas: uma abordagem integral. Trad. Francisco G. Heidemann. Rio de Janeiro: Elsevier, 2013.
Educação dos exercícios analisados e dos seguintes ampliando, a análise de todos os municípios, bem como uma pesquisa estatística com o objetivo de analisar a eficiência desses recursos pelo método da Análise Envoltória de Dados.

[15] Levin, J.; Fox, J. A. Estatística para ciências humanas. São Paulo: Pearson Education, 2004.

[16] Martins, G. A.; Theóphilo, C. R. Metodologia da investigação científica para ciências sociais aplicadas. São Paulo: Atlas, 2007. [17] Martins, G. de A.; Domingues, O. Estatística geral e aplicada. 4. ed. São Paulo: Atlas, 2011.

[18] Oliveira, R. Gestão pública: democracia e eficiência: uma visão prática e política. Rio de Janeiro: FGV, 2012

[19] Procopiuck, M. Políticas públicas e fundamentos da administração pública: análise e avaliação, governança e redes de políticas, administração judiciária. São Paulo: Atlas, 2013.

[20] Ribeiro, C. C.; Ceneviva, R.; Brito, M. M. A. Estratificação educacional entre jovens no Brasil: 1960 a 2010. In: Arrecthe, M. (org.). Trajetórias das desigualdades: como o Brasil mudou nos últimos cinquenta anos. São Paulo: Editora Unesp; CEM, 2015.

[21] Santos, Y. D.; Carvalho, J. R. M.; Barbosa, M. F. N. Análise da eficiência dos gastos com educação no ensino fundamental nos municípios do Seridó Potiguar. Revista Ambiente Contábil, Natal, v. 8, n. 2, p. 287-308, jul./dez., 2016.

[22] Santos,A. C.; Gomes, A. P.; Ervilha, G. T. Eficiência e desigualdade em educação no estado de Minas Gerais: uma análise da primeira etapa do PMDI. Planejamento e Políticas Públicas, n. 45, jul./dez., 2015.

[23] Scapin, J. E.; Macêdo, F. F. R. R.; Starosky Filho, L.; Rodrigues Junior, M. M. Análise da eficiência dos recursos públicos direcionados à educação: estudo nos municípios do Estado de Santa Catarina. Revista Gestão Públicas: Práticas e Desafios, Recife, v. III, n.ำ 6, dez., 2012.

[24] Secchi, L. Políticas públicas: conceitos, esquemas de análise, casos práticos. 2. ed. São Paulo: Cengage Learning, 2013.

[25] Silva, A. B. et al. Accountability para a gestão de verbas da educação pública em municípios brasileiros: análise com envoltória de dados (DEA). Revista Iberoamericana de Contabilidad de Gestión, v. XIII, n. 26, jul./dec., 2015.

[26] Silva Filho, G. M. et al. Análise da eficiência nos gastos públicos com educação fundamental nos colégios militares do exército em 2014. Revista Evidenciação Contábil \& Finanças, João Pessoa, v. 4, n. 1, p. 50-64, jan./abr., 2016.

[27] Silva, M. C. Demonstrações contábeis públicas: indicadores de desempenho e análise. São Paulo: Atlas, 2012. 
[28] Silva, M. C. et al. Avaliação da função educação nos municípios de São Paulo, Rio de Janeiro e Belo Horizonte: mudança ou inércia social. ConTexto, Porto Alegre, v. 15, n. 29, p. 1729, jan./abr., 2015a.

[29] Silva, M. C. et al. Avaliação de políticas públicas funcionais do município de São Paulo. 2002 - 2012. Revista de Administração e Contabilidade, Feira de Santana, v. 7, n. 3, p. 6685, set./dez., 2015b.

[30] SISTEMA FIRJAN. Índice Firjan de Desenvolvimento Municipal (2014). Disponível em: $<$ http://www.firjan.org.br/ifdm/>. Acesso em: 05 mar. 2017.

[31] Souza, W. D. et al. Análise dos gastos na alocação dos recursos públicos destinados ao ensino fundamental dos municípios do Espírito Santo. In: IX Congresso ANPCONT, Anais... Curitiba - PR, Associação Nacional de Programas de Pós-Graduação em Ciências Contábeis, 2015.

[32] Tarda, K. B.; Rodrigues, R. V. A influência dos gastos em educação no crescimento econômico da Região Administrativa de Campinas. Estudo \& Debate, Lajeado, v. 22, n. 2, p. 07-31, 2015.

[33] Theiss, V. et al. Eficiência na alocação dos gastos públicos na educação. Revista de Gestão e Contabilidade da UFPI, v. 2, n. 1, jan./jun., p. 4-17, 2015.

[34] Vergara, S. C. Projetos e relatórios de pesquisa em administração. 16. ed. São Paulo: Atlas, 2016. 


\section{Gapítulo 16}

APLICAÇÃO DO SISTEMA CONTÁBIL GERENCIAL
AMBIENTAL (SICOGEA): ANÁLISE EM UMA INSTITUIÇÃO
AUTÁRQUICA FEDERAL - RIO DE JANEIRO - RJ

Igor Laguna Vieira

Elmo Rodrigues da Silva

Resumo: Este artigo tem como objetivo apresentar os resultados de um estudo qualitativo sobre avaliação da sustentabilidade ambiental em uma autarquia federal localizada no município do Rio de Janeiro, tendo como modelo o Sistema Contábil Gerencial Ambiental (SICOGEA) - Geração 2. Para avaliar a sustentabilidade na autarquia estudada foi utilizada uma lista de verificação contendo 124 questões estruturadas dirigidas aos gestores da autarquia. Esse levantamento de dados foi complementado com trabalho de campo, por meio de observações in loco. Como resultado, constatou-se um índice geral de sustentabilidade ambiental de 43,19\%, sendo atribuído um conceito "regular" pelo método utilizado. Conclui-se que há deficiências na gestão ambiental da organização, demonstrando que práticas mais sustentáveis devem ser incentivadas.

Palavras-chave: SICOGEA; Contabilidade Ambiental; Sistemas de Gestão Ambiental; Sustentabilidade Ambiental; Gestão Pública. 


\section{INTRODUÇÃO}

O século XX foi palco de mudanças significativas no modo de vida humana. Com o desenvolvimento econômico e tecnológico, houve o aumento na demanda por recursos naturais e, consequentemente, da poluição ambiental. Foi a partir dos anos 1960 que se intensificou a pressão da sociedade para tentar impedir a destruição ao nível planetário, que pode levar, em curto prazo, a destruição da biodiversidade e da própria espécie humana.

A partir da década de 1970, a questão ambiental foi pauta de grandes eventos internacionais, destacando-se a Conferência das Nações Unidas sobre o Meio Ambiente Humano, em junho de 1972, em Estocolmo e a conferência posterior, em 1992, popularmente denominada "Rio 92". Dentre outros fatos importantes nestes eventos, surgiu a Agenda Ambiental para o Século XXI e o conceito de desenvolvimento sustentável, visto como uma forma de desenvolvimento que permita que gerações atuais e vindouras possam ter garantida a qualidade de vida, sem que o novo modelo de produção e consumo adotado a partir do século XX leve necessariamente a uma intensa decadência ambiental (VAN BELLEN, 2004).

As organizações, sejam elas públicas ou privadas, possuem um papel importante nesse contexto voltado para a busca da sustentabilidade ambiental. $\mathrm{O}$ setor empresarial, por exemplo, ao otimizar o uso de recursos naturais e tecnologias mais avançadas em seus processos produtivos, podem evitar desperdícios e poluição, contribuindo com uma melhor gestão ambiental. Além disso, tendem a reduzir custos e aumentar a competitividade da organização (DOMENICO et al., 2015). De certa forma, a estratégia dos negócios ditos sustentáveis pode se traduzir na entrega de produtos que buscam atender as necessidades dos consumidores e provoquem menos danos ao meio ambiente.

Por outro lado, na gestão ambiental pública é necessária a atuação de seus órgãos, não somente regulando e fiscalizando, mas também atuando ativamente no processo de preservação do meio ambiente, assumindo um compromisso social e ambiental (CHAVES et al, 2013). Neste sentido, o setor governamental deveria ser proativo em relação a questões ambientais, por ser ele responsável pela política e controle ambiental do país.
Observa-se que parte da sociedade vem exigindo mais transparência das organizações públicas e privadas, demandando meios de avaliar a sua contribuição ao desenvolvimento sustentável. Nessa perspectiva, a Contabilidade Ambiental objetiva mensurar a relação entre empresa e meio ambiente, gerando informações que contribuam com o processo decisório da gestão ambiental, além de permitir maior fiscalização e controle das atividades produtivas (SOUZA; UHLMANN; PFITSCHER, 2015).

Este artigo visa apresentar os resultados de um estudo qualitativo que teve como objetivo avaliar a sustentabilidade de uma autarquia federal, localizada no município do Rio de Janeiro. Do ponto de vista metodológico, o estudo possui uma abordagem qualitativa e descritiva. Para a escolha do método de avaliação da sustentabilidade da instituição foi feita uma pesquisa bibliográfica. O Sistema Contábil Gerencial Ambiental - SICOGEA - foi selecionado para o estudo. Este sistema foi desenvolvido por Pfistcher (2004), a partir do método GAIA criado por Lerípio (2001). O SICOGEA encontra-se em sua terceira geração, após modificações propostas por Nunes (2010) e Uhlmann (2011). Para efeitos deste estudo preliminar foi utilizada a segunda geração do SICOGEA.

A relevância deste estudo está na possibilidade de contribuir com o aperfeiçoamento do modelo utilizado ao ser aplicado em um caso prático, o que poderá, por conseguinte, em termos de sua sustentabilidade ambiental, promover a melhoria da gestão na instituição estudada, ao minimizar os impactos negativos de suas atividades, além de diminuir seus custos.

Inicialmente é apresentado o embasamento teórico do estudo que deu origem ao artigo. Em seguida é abordada a metodologia utilizada e, posteriormente, apresentados os resultados, discussões, conclusões e referências.

\section{REFERENCIAL TEÓRICO}

No referencial utilizado para o estudo abordou-se os eixos teóricos: Sistemas de Gestão Ambiental, Contabilidade Ambiental, Gerenciamento de Aspectos e Impactos Ambientais (GAIA), Sistema Contábil Gerencial Ambiental (SICOGEA) e Agenda Ambiental da Administração Pública (A3P), que serão tratados a seguir. 


\subsection{SISTEMAS DE GESTÃO AMBIENTAL}

Um SGA pode ser definido como "conjunto de procedimentos para gerir ou administrar uma organização, de forma a obter o melhor relacionamento com o meio ambiente" (TINOCO; KRAEMER, 2011, p. 101).

Já a ISO 14001:2015 define um SGA como "parte do sistema de gestão usado para gerenciar aspectos ambientais, cumprir requisitos legais e outros requisitos, e abordar riscos e oportunidades" (ABNT, 2015, p. 2).

Em ambos os conceitos é possível perceber que um SGA visa, portanto, reduzir ou eliminar os impactos ao meio ambiente, por meio de ações preventivas ou ações mitigadoras. A ISO 14001:2015 ainda traz questões de cumprimento da legalidade, ressaltando as oportunidades para as organizações que implantam um SGA. Tais sistemas permitem ainda identificar o nível de sustentabilidade ambiental das empresas, registrando os pontos falhos e, consequentemente, auxiliando a tomada de decisão, conciliando as gestões do meio ambiente e a administrativa.

Nas próximas seções serão apresentados dois SGA's: os métodos GAIA e SICOGEA, sendo este último derivado do primeiro.

\subsection{CONTABILIDADE AMBIENTAL}

Devido ao aumento da preocupação em relação a questões ligadas à área ambiental, o tema passou a se relacionar com quase todas as áreas do conhecimento humano, dentre elas a econômica, em particular no que diz respeito à Contabilidade Ambiental. Tal especialidade é responsável pelo registro do patrimônio ambiental da sociedade, identificando e interpretando dados, fazendo o registro dos eventos ambientais, chamados Ativos e Passivos Ambientais (SOUZA; UHLMANN; PFITSCHER 2015).

A contabilidade ambiental objetiva registrar as transações das organizações que impactem o meio ambiente, assegurando que: os custos, os ativos e os passivos ambientais estejam contabilizados de acordo com os princípios fundamentais da contabilidade ou, em caso de ausência de tais princípios, com as práticas normalmente aceitas no mundo dessa ciência; e o desempenho ambiental seja suficientemente transparente aos usuários da informação contábil (BERGAMINI JUNIOR, 1999).

Com as rápidas e constantes transformações econômicas, num cenário de recursos naturais cada vez mais escassos, a contabilidade ambiental não deve ser vista como mera fornecedora de dados, mas sim como uma ferramenta auxiliar na tomada de decisões.

São três usuários básicos para o uso de tais informações: o governo, as empresas e a sociedade. O governo pode se beneficiar para gerencias as contas públicas e para o seu processo orçamentário e de planejamento, com ênfase nos propósitos sociais mais amplos. As empresas podem mensurar o patrimônio ambiental e a eficiência de sua utilização pela empresa, fornecendo informações econômicas e financeiras sobre a proteção, preservação e recuperação ambiental aos gestores. A sociedade pode monitorar as ações empresariais em torno das questões ambientais, selecionando aquelas que julgam serem as mais ambientalmente corretas (COSTA; MARION, 2007).

\subsection{GERENCIAMENTO DE ASPECTOS E IMPACTOS AMBIENTAIS - GAIA}

O método GAIA (Gerenciamento de Aspectos e Impactos Ambientais) é um instrumento, criado por Lerípio (2001), que visa à melhoria do desempenho ambiental das organizações e o alcance da sustentabilidade. Possui como objetivo auxiliar as organizações a evidenciar impactos ambientais.

O GAIA tem como princípios: proporcionar às organizações o atendimento à legislação, a melhoria contínua e a prevenção da poluição a partir de atividades focalizadas no desempenho ambiental e na sustentabilidade, tomando como elementos fundamentais do processo a organização e as pessoas por meio de suas relações com o meio ambiente (LERÍPIO, 2001).

Para isso, é estruturado de forma que permita avaliar o desempenho ambiental e a sustentabilidade das empresas, baseado nos aspectos dos seus processos produtivos, organizacionais e na percepção ambiental das pessoas envolvidas no processo de construção de um Sistema de Gestão Ambiental (COSTA, 2007).

O sistema GAIA possui três fases: "sensibilização", "conscientização" e "capacitação e qualificação". A primeira fase, de sensibilização, compreende a sustentabilidade, a estratégia e o comprometimento ambiental do negócio. $\mathrm{Na}$ segunda fase, de conscientização, estão focados os aspectos ambientais, isto é, se os 
processos de produção podem causar danos ambientais, identificando também o ciclo de vida dos produtos. E a última fase, de capacitação e qualificação, envolve as possibilidades de aperfeiçoar os produtos e serviços entregues ao consumidor (COELHO; DOMENICO; PFITSCHER, 2011).

\subsection{SISTEMA CONTÁBIL GERENCIAL AMBIENTAL - SICOGEA}

Por não conter informações contábeis em sua metodologia, o método GAIA deu origem ao SICOGEA, desenvolvido por Pfitscher (2004), o qual adicionou a contabilidade ao meio ambiente, a fim de analisar a sustentabilidade nas organizações com o auxílio dessa ciência (BARBOSA, 2014).

O SICOGEA surgiu com a ideia de auxiliar os processos produtivos, com controle e prevenção, valorizando as atitudes ambientais dos gestores para mostrar sua representatividade em termos de benefícios e gastos ambientais, além de verificar os seus impactos. O SICOGEA é dividido em três etapas, quais sejam: i) integração da cadeia produtiva, ii) gestão e controle ecológico e iii) gestão da contabilidade e controladoria ambiental, sendo que cada uma dessas etapas possui várias fases (PFITSCHER, 2004).

Nunes (2010) propôs adaptações e melhoria ao SICOGEA, obtendo a segunda geração do método. As principais mudanças sugeridas pelo SICOGEA - Geração 2 foram: alteração na estrutura da lista de verificação; lista dividida por grupos-chave e subgrupos; inclusão de questões-chave nos itens da lista; forma de respostas de 0 (zero) a 5 (cinco); atribuição de pontos diferentes por questão, a critério do analista; inclusão de planilha de ponderação; outra estrutura de indicadores; inclusão de duas fórmulas para identificar os índices de eficiência dos itens; e sugestão de estrutura do 5W2H para as aplicações futuras.

A ferramenta $5 \mathrm{~W} 2 \mathrm{H}$ é uma espécie de checklist utilizada para garantir que os gestores e colaboradores conduzam processos sem dúvidas. Os $5 \mathrm{~W}$ correspondem às seguintes palavras do inglês: What (o que); Who (quem); Where (onde); When (quando) e Why (por que). Os 2H são: How (como) e How Much (quanto custa) (CANDELORO, 2008).

Para o índice geral de sustentabilidade, temse o valor variando de 0 a $100 \%$, atribuindo-se então um conceito (NUNES, 2010).

UhImann (2011) analisou O SICOGEA geração 2, sugerindo melhorias ao sistema, dando origem ao SICOGEA - geração 3. Não houve alteração na estrutura do SICOGEA Geração 2 excluindo ações, nem houve mudança na metodologia de cálculo dos índices de sustentabilidade ambiental, não havendo mudanças na fase de avaliação da sustentabilidade ambiental. Houve a inserção e a reorganização de outras ações, com vistas a potencializar os resultados e a facilitar a aplicação do sistema.

O

Quadro 1 resume as principais diferenças na etapa de avaliação de sustentabilidade da primeira geração do SICOGEA para as segunda e terceira gerações.

Quadro 1 - Evolução da avaliação de sustentabilidade no SICOGEA

\begin{tabular}{|c|c|c|}
\hline ITENS & SICOGEA-Geração 1 & SICOGEA - Geração 2 e 3 \\
\hline $\begin{array}{c}\text { Escala para } \\
\text { enquadramento das } \\
\text { respostas da lista de } \\
\text { verificação }\end{array}$ & $\begin{array}{c}\text { 3 níveis: Adequada - A; Deficitária - } \\
\text { D; Não se adapta - NA }\end{array}$ & níveis: 0 a 5 e NA - não se aplica \\
\hline $\begin{array}{c}\text { Índice geral de } \\
\text { sustentabilidade }\end{array}$ & $\frac{\text { Total de questões A x 100 }}{\text { Total de Questões - NA }}$ & $\begin{array}{c}\text { Pontos possíveis } \\
\text { Pontos Alcançados }\end{array}$ \\
\hline $\begin{array}{c}\text { Avaliação de } \\
\text { Sustentabilidade } \\
\text { Ambiental }\end{array}$ & $\begin{array}{c}\text { Inferior a 50\% - Deficitária } \\
\text { Entre 51 e 70\% - Regular } \\
\text { Mais de 71\% - Adequada }\end{array}$ & $\begin{array}{c}\text { Entre 21 e 40\% - Fraca } \\
\text { Entre 41 e 60\% - Regular } \\
\text { Entre 61 e 80\% - Boa } \\
\text { Superior a 80\% - Ótima }\end{array}$ \\
\hline $\begin{array}{c}\text { Possibilidade de } \\
\text { atribuição de peso às } \\
\text { questões }\end{array}$ & Não & Sim \\
\hline
\end{tabular}

Fonte: adaptado de Pfitscher (2004), Nunes (2010) e UhImann (2011) 


\subsection{AGENDA AMBIENTAL ADMINISTRAÇÃO PÚBLICA (A3P)}

Na gestão pública atual, dentre os aspectos a serem tratados, tem-se a questão da sustentabilidade ambiental. Para exemplificar, pode-se citar: o uso eficiente da água e da energia, a coleta seletiva de materiais recicláveis, o consumo responsável de produtos e serviços, entre outros.

Nesse sentido, o Ministério do Meio Ambiente (MMA) desenvolveu em 1999, ainda como projeto, a Agenda Ambiental na Administração Pública (A3P). Buscava-se revisar padrões de produção e consumo, além da adoção de novos referenciais de sustentabilidade ambiental nas instituições da administração pública. Dois anos mais tarde a A3P consolidou-se como programa, com o objetivo de construir de uma nova cultura institucional nas organizações públicas (MMA, 2009).

A A3P possui cinco objetivos básicos, a saber: (i) sensibilização dos gestores públicos quanto às questões socioambientais; (ii) promoção do uso racional de recursos naturais e economia dos gastos institucionais; (iii) contribuição para a revisão dos padrões de produção e consumo, assim como adoção de novos referenciais na administração pública; (iv) redução do impacto socioambiental provocado pelas atividades cotidianas; e (v) melhoria da qualidade de vida (MMA, 2009).

Para o cumprimento de seus objetivos, a A3P foi estruturada em seis eixos temáticos, apontados

no

Quadro 2, com seus fundamentos básicos:

\section{Quadro 2 - Eixos Temáticos da A3P}

\begin{tabular}{|c|c|}
\hline Eixos Temáticos & Fundamentos \\
\hline $\begin{array}{l}\text { Uso Racional dos Recursos } \\
\text { Naturais e Bens Públicos }\end{array}$ & $\begin{array}{l}\text { Usar racionalmente os recursos naturais e bens públicos significa utilizá-los } \\
\text { evitando o seu desperdício. Este eixo trata do uso racional de energia, água e } \\
\text { madeira, além do consumo de matérias de expediente, como papel, copos } \\
\text { plásticos e outros. }\end{array}$ \\
\hline $\begin{array}{l}\text { Gestão Adequada dos } \\
\text { Resíduos Gerados }\end{array}$ & $\begin{array}{l}\text { A gestão adequada dos resíduos passa pela adoção da política dos 5R's: } \\
\text { Repensar, Reduzir, Reutilizar, Reciclar e Recusar. Prioritariamente deve-se } \\
\text { pensar em reduzir o consumo e combater o desperdício, para só então } \\
\text { destinar adequadamente o resíduo gerado. }\end{array}$ \\
\hline $\begin{array}{l}\text { Qualidade de Vida no } \\
\text { Ambiente de Trabalho }\end{array}$ & $\begin{array}{l}\text { A qualidade de vida no ambiente de trabalho busca facilitar e satisfazer as } \\
\text { necessidades do trabalhador, por meio de ações que visem seu } \\
\text { desenvolvimento pessoal e profissional. }\end{array}$ \\
\hline Sensibilização e Capacitação & $\begin{array}{l}\text { A sensibilização visa estabelecer a responsabilidade socioambiental no corpo } \\
\text { de servidores. A capacitação busca contribuir para o desenvolvimento de } \\
\text { competências institucionais e individuais para que os servidores desenvolvam } \\
\text { atitudes, visando a melhoria de suas atividades. }\end{array}$ \\
\hline Licitações Sustentáveis & $\begin{array}{l}\text { A administração pública deve buscar a responsabilidade socioambiental nas } \\
\text { suas compras. Licitações sustentáveis são importantes para a preservação } \\
\text { ambiental e apresentam uma melhor relação custo/benefício a médio ou longo } \\
\text { prazo quando se comparam às que se valem apenas do menor preço. }\end{array}$ \\
\hline Construções Sustentáveis & $\begin{array}{l}\text { Construção sustentável é um conceito que denomina um conjunto de } \\
\text { medidas adotadas durante todas as etapas da obra que visam a } \\
\text { sustentabilidade da edificação. Através da adoção dessas medidas é } \\
\text { possível minimizar os impactos negativos sobre o meio ambiente além de } \\
\text { promover a economia dos recursos naturais e a melhoria na qualidade de } \\
\text { vida dos seus ocupantes. }\end{array}$ \\
\hline
\end{tabular}

Fonte: Adaptado de MMA (2009 e 2017b)

\subsubsection{PILAR LEGAL DA A3P}

A legislação ambiental brasileira, sustentáculo da sustentabilidade no país, prevê a manutenção e conservação do meio ambiente, assim como observa a indispensabilidade em adotar uma nova ética social. Almeja ainda a racionalidade da dimensão econômica, buscando à manutenção do equilíbrio ecológico, garantia da saúde, qualidade de vida e bem-estar econômico, social e ambiental do povo brasileiro. A questão ambiental é parte da agenda pública, exigindo a complementaridade e a interação entre as mais diversas ações do poder público, que possibilitarão o desenvolvimento sustentável do país (MMA, 2009). O Quadro 3 expõe as principais legislações que embasam a A3P: 
Quadro 3 - Principais Legislações que embasam a A3P

\begin{tabular}{|c|c|}
\hline Norma Legal & Conteúdo \\
\hline Lei n. 6.938/81 & $\begin{array}{l}\text { Institui a Política Nacional do Meio Ambiente. Considerada um } \\
\text { marco histórico no desenvolvimento do direito ambiental, a lei } \\
\text { estabelece definições legais sobre os seguintes temas: meio } \\
\text { ambiente, degradação da qualidade ambiental, poluição, poluidor } \\
\text { e recursos ambientais. Entre os muitos avanços visando a proteção } \\
\text { ambiental destaca-se na Lei a exigência de Estudo prévio de } \\
\text { Impacto Ambiental (EIA) e o seu respectivo relatório (RIMA). }\end{array}$ \\
\hline Constituição Federal de 1988 & $\begin{array}{l}\text { O artigo } 225 \text { afirma o direito da sociedade a um meio ambiente } \\
\text { ecologicamente equilibrado e afirma que cabe à coletividade e ao } \\
\text { poder Público defendê-lo e preservá-lo. }\end{array}$ \\
\hline Lei n.. 9.605/98 & $\begin{array}{l}\text { Lei dos crimes ambientais. Dispõe sobre a proteção efetiva do } \\
\text { meio ambiente. }\end{array}$ \\
\hline Decreto $n$. $=5.940 / 2006$ & $\begin{array}{l}\text { Estabelece a exigência de separação dos resíduos recicláveis dos } \\
\text { órgãos e entidades da administração pública federal direta e } \\
\text { indireta, e sua destinação às associações e cooperativas dos } \\
\text { catadores de materiais recicláveis. }\end{array}$ \\
\hline Lei n. $=12.187 / 2009$ & Institui a Política Nacional de Mudanças Climáticas. \\
\hline Lei $n .912 .349 / 2010$ & $\begin{array}{l}\text { Altera a Lei } n^{\circ} \text { 8.666/93 (a Lei das licitações). A promoção do } \\
\text { desenvolvimento nacional sustentável se torna objetivo das } \\
\text { licitações. }\end{array}$ \\
\hline Lei n.o 12.305/2010 & Institui a Política Nacional de Resíduos Sólidos (PNRS). \\
\hline $\begin{array}{llr}\text { Instrução } & \text { Normativa } & \text { n. } \\
1 / 2010 \text { do } & \text { Ministério do } \\
\text { Planejamento Orçamento e } & \text { Gestão (MPOG) } \\
\text { Ge }\end{array}$ & $\begin{array}{l}\text { Estabelece critérios de sustentabilidade ambiental na aquisição de } \\
\text { bens, contratação de serviços ou obras na Administração Pública } \\
\text { Federal. }\end{array}$ \\
\hline Lei n. $.12 .462 / 2011$ & Estabelece o Regime diferenciado de contratações públicas. \\
\hline $\begin{array}{l}\text { Recomendação CONAMA n.ำ } \\
\text { 12/2011 }\end{array}$ & $\begin{array}{l}\text { Indica aos órgãos e entidades do Sistema Nacional do Meio } \\
\text { Ambiente (Sisnama) a adoção de normas e padrões de } \\
\text { sustentabilidade. }\end{array}$ \\
\hline Decreto $n . \stackrel{0}{7.746 / 2012}$ & $\begin{array}{l}\text { Determina a adoção de iniciativas, dentre elas a A3P, referentes ao } \\
\text { tema da sustentabilidade pelos órgãos e entidades federais bem } \\
\text { como suas vinculadas. }\end{array}$ \\
\hline $\begin{array}{l}\text { Instrução Normativa } \\
\text { 10/2012 do MPOG }\end{array}$ & $\begin{array}{l}\text { Estabelece as regras para elaboração dos Planos de Gestão de } \\
\text { Logística Sustentável pela administração pública federal bem como } \\
\text { suas vinculadas. }\end{array}$ \\
\hline
\end{tabular}

Fonte: adaptado de MMA (2017a)

\section{METODOLOGIA}

Este estudo pode ser classificado como descritivo, quanto aos objetivos; como pesquisa de campo, quanto às fontes de dados; e como estudo de caso, quanto aos procedimentos de coletas de dados. Já a sua abordagem é qualitativa (SANTOS, 2015).

A pesquisa ocorreu na sede de uma autarquia federal, localizada no Rio de Janeiro/RJ. São duas edificações localizadas na mesma rua, com área total edificada de aproximadamente de nove mil $\mathrm{m}^{2}$, onde trabalham 385 servidores e 130 trabalhadores terceirizados (manutenção, limpeza, recepção e segurança). O órgão foi escolhido pelo fácil acesso aos pesquisadores. Uma observação importante: o órgão ainda não aderiu à A3P.

\subsection{MÉTODOS E MATERIAIS}

Para avaliar a sustentabilidade na autarquia em questão foi utilizado uma lista de verificação baseada na proposta de Nunes (2010), quando do desenvolvimento do SICOGEA - geração 2. A lista possui 124 questões, que foram respondidas com o auxílio de sete gestores do órgão e verificações in 10co. A pesquisa ocorreu no período de 10/03/2017 a 07/04/2017. A lista agrupa-se em quatro áreas, num total de sete critérios, sendo mostrados no Quadro 4 
Quadro 4 - Áreas e critérios avaliados pelo SICOGEA

\begin{tabular}{|l|l|}
\hline \multicolumn{1}{|c|}{ ÁREA } & \multicolumn{1}{c|}{ CRITÉRIOS } \\
\hline \multirow{3}{*}{ Produção } & Processos de Produção \\
\cline { 2 - 3 } & Fornecedores \\
\cline { 2 - 2 } & Manutenção \\
\hline \multirow{2}{*}{ Recursos Humanos } & Equipe de Colaboradores \\
\cline { 2 - 2 } & Gestão da Instituição \\
\hline Marketing & Responsabilidade Socioambiental \\
\hline Finanças & Contabilidade Gerencial e Auditoria \\
\hline \multicolumn{2}{|c|}{ Fonte: adaptado de Nunes (2010) } \\
\hline
\end{tabular}

Os dados foram tabulados, com respostas variando de 0 a 5 para cada questão, sendo:

- 0 - para itens em que não se demonstra nenhum investimento/controle sobre o tema avaliado;

- 1 - para itens em que se demonstra algum investimento/controle sobre o tema avaliado;

- 2 - para itens em que se demonstra investimento/controle um pouco maior que o item anterior sobre o tema avaliado;

- 3 - para itens em que se demonstra investimento/controle um pouco maior que o item anterior sobre o tema avaliado;

- 4 - para itens em que se demonstra investimento/controle quase que total sobre o tema avaliado e;

- 5 - para itens em que se demonstra investimento/controle total sobre o tema avaliado.

Há ainda a alternativa NA - Não se Aplica, para os itens em que não se atribui a possibilidade de haver questionamentos que enquadrariam na entidade pesquisada. É possível também atribuir pesos para cada questão (pontos possíveis), sendo esses a critério do pesquisador, que não devem ser divulgados ao respondente.

No caso desta pesquisa foi atribuído peso dois às questões diretamente ligadas aos eixos da A3P. Por "diretamente" entende-se aqueles questionamentos cujo tema está dentro dos objetivos pregados na Cartilha da A3P, do MMA (2009). Já para as questões que não foram explicitamente tratadas em tal cartilha foi atribuído peso um.

Para calcular sustentabilidade ambiental utiliza-se a seguinte fórmula: Índice geral de sustentabilidade $=$ pontos alcançados $/$ pontos possíveis (NUNES, 2010).

Após a obtenção dos resultados, é possível analisá-los conforme o índice geral de sustentabilidade encontrado, de acordo com o

\section{Quadro 5:}

Quadro 5 - Índice Geral de Sustentabilidade

\begin{tabular}{|l|l|l|}
\hline \multicolumn{1}{|c|}{ Resultado } & \multicolumn{1}{|c|}{ Sustentabilidade } & \multicolumn{2}{c|}{ Desempenho: controle, incentivo, estratégia } \\
\hline Inferior a 20\% & Péssimo - "P" & $\begin{array}{l}\text { Grande impacto pode estar sendo causado ao meio } \\
\text { ambiente }\end{array}$ \\
\hline Entre 21 e 40\% & Fraco - "F" & $\begin{array}{l}\text { Pode estar causando danos, mas surgem algumas poucas } \\
\text { iniciativas }\end{array}$ \\
\hline Entre 41 e 60\% & Regular - "R" & Atende somente à legislação \\
\hline Entre 61 e 80\% & Bom - "B" & $\begin{array}{l}\text { Além da legislação, surgem alguns projetos e atitudes que } \\
\text { buscam valorizar o meio ambiente }\end{array}$ \\
\hline Superior a 80\% & Ótimo - "O" & $\begin{array}{l}\text { Alta valorização ambiental com produção ecológica e } \\
\text { prevenção da poluição }\end{array}$ \\
\hline
\end{tabular}

Ao ser analisado o índice de sustentabilidade ambiental, é verificado qual o comprometido da instituição com a sociedade e o meio ambiente. 
Após a aplicação da lista de verificação de Nunes (2010), os dados foram analisados e foi constatado um índice de sustentabilidade ambiental geral de $43,19 \%$ na autarquia pesquisada. O critério "Contabilidade Gerencial e Ambiental" foi aquele que obteve o melhor índice de sustentabilidade ambiental

Tabela 1 mostra os resultados obtidos para cada áreas e seus respectivos critérios, bem
(80,91\%), sendo o único "ótimo" recebido pela instituição. Já o mais mal avaliado em relação a sua sustentabilidade ambiental foi o critério "Manutenção" (15,00\%), apresentando conceito "fraco".

A

- resultado geral da avaliação de sustentabilidade na autarquia:

Tabela 1 - Avaliação de Sustentabilidade da autarquia estudada

\begin{tabular}{|c|c|c|c|c|}
\hline \multirow{2}{*}{ Áreas e critérios } & \multirow{2}{*}{ Pontos possíveis } & \multirow{2}{*}{ Pontos obtidos } & \multicolumn{2}{|c|}{ Sustentabilidade } \\
\hline & & & Resultado & Avaliação \\
\hline Produção & 330 & 73 & $22,12 \%$ & Fraco \\
\hline Processos de Produção & 150 & 28 & $18,67 \%$ & Péssimo \\
\hline Fornecedores & 100 & 33 & $33,00 \%$ & Fraco \\
\hline Manutenção & 80 & 12 & $15,00 \%$ & Péssimo \\
\hline Recursos Humanos & 410 & 195 & $47,56 \%$ & Regular \\
\hline Equipe de Colaboradores & 190 & 91 & $47,89 \%$ & Regular \\
\hline Gestão da Instituição & 220 & 104 & $47,27 \%$ & Regular \\
\hline Marketing & 90 & 49 & $54,44 \%$ & Regular \\
\hline Responsabilidade Socioambiental & 90 & 49 & $54,44 \%$ & Regular \\
\hline Finanças & 110 & 89 & $80,91 \%$ & Ótimo \\
\hline Contabilidade Gerencial e Auditoria & 110 & 89 & $80,91 \%$ & Ótimo \\
\hline Total Geral & 940 & 406 & $43,19 \%$ & Regular \\
\hline
\end{tabular}

O critério "Processos de Produção" indica que a instituição não faz campanhas de uso racional de combustível, papel e demais materiais de consumo, como prega a $\mathrm{A} 3 \mathrm{P}$ em seu eixo de "Uso Racional do Recursos Naturais e Bens Públicos". Também não faz a coleta seletiva, o que contraria além da A3P a legislação vigente (Decreto 5.940/2006). O órgão estudado também não possui uma Comissão Interna de Prevenção de Acidentes - CIPA, citada na cartilha da A3P do MMA (2009) como fundamental em seu eixo "Qualidade de Vida no Ambiente de Trabalho". A iniciativa que aparece com melhor avaliação nesse critério é o uso racional da água.

O critério "Fornecedores" apresentou um índice de sustentabilidade ambiental de $33,00 \%$ (fraco), alcançado apenas 33 pontos dos 100 possíveis. Pela lista de verificação é possível perceber que não há preocupação com relação ao comportamento ambiental dos fornecedores. As poucas questões bem avaliadas são aquelas em que há exigência legal, como é o caso do decreto 5.450/2005, que regulamentou o pregão eletrônico para aquisição de bens e serviços.

Pelo critério "Manutenção" é possível perceber que a escolha das empresas que realizam a manutenção predial e veicular não possui qualquer apelo ambiental, bem como a compra de materiais de limpeza. A autarquia ainda não monitora os níveis de poluição sonora, luminosidade, poluição do ar e ergonomia de equipamentos no ambiente interno, contrariando a A3P, em seu eixo "Qualidade de Vida no Ambiente de Trabalho".

No critério "Equipe de Colaboradores" obtevese um índice de sustentabilidade ambiental de $47,27 \%$, observando-se ausência de ações de capacitação e conscientização dos servidores em relação a questões ambientais, de saúde e segurança do trabalho, contrariando o eixo "Sensibilização e Capacitação" da A3P. Nas questões relacionadas à qualidade de vida, no que tange a segurança financeira de seus servidores, observa-se que boa parte das ações baseia-se em legislações, tais como o pagamento de auxílio creche, auxílio alimentação e previdência privada, não sendo políticas oriundas da instituição. Uma ação do órgão que pode se ressaltar como positiva é a existência de um plano de saúde de gestão própria, exclusivo para funcionários do órgão. O critério "Gestão da Instituição" foi considerado regular, obtendo um índice de 
47,27\%. Para as questões não direcionadas diretamente para a área ambiental, a autarquia demonstrou ter certo controle. Porém em relação ao meio ambiente, a instituição carece de políticas que o relacionem à sua gestão, não possuindo sequer profissionais especialistas na área ambiental para conduzir tais ações. Além disso, o órgão não obteve nos últimos anos premiações ou reconhecimento pela sua atuação ambiental, não aplica recursos em projetos ambientais para sua sede, não possui um SGA implantado e nem possui um plano de qualidade ambiental. Como ponto positivo estão os investimentos em pesquisas ambientais que ocorrem nos institutos subordinados ao órgão pesquisado, citados no planejamento estratégico da instituição.

No critério "Responsabilidade Socioambiental", foi obtido um índice de $54,44 \%$, conceito regular. É possível observar que é escassa a relação da autarquia com a sociedade, podendo ser melhorada. O fato de canais de relacionamento serem disponibilizados não é suficiente para que tal relação ocorra de forma veemente. Seria possível implantar, por exemplo, programas de educação nas escolas para explicar a importância da energia nuclear, mostrando também seus riscos e possíveis impactos na saúde e no meio ambiente.

No critério "Contabilidade Geral e Auditoria" foi obtido o único conceito "ótimo" da instituição, com um resultado de 80,91\%. Pelos resultados é possível verificar que o órgão não sofreu multas nem pagou indenizações ambientais nos últimos anos. Como no critério "Gestão da Instituição", pode-se afirmar que o setor responsável pela contabilidade possui uma gestão controlada de suas obrigações.

No geral, o índice de sustentabilidade calculado para a autarquia federal à luz do SICOGEA - geração 2 ficou em 43,19\%, considerado como "regular", dizendo que a instituição apenas atende a legislação, o que pôde ser observado na prática, já que a maior parte das iniciativas ambientais surgem devido à obrigação legal de sua implantação. Ainda assim é possível perceber que mesmo ações obrigatórias pela legislação, como a coleta seletiva solidária, por exemplo, não foram implantadas pelo órgão.

\section{CONCLUSÕES}

Este estudo teve como objetivo avaliar a sustentabilidade na sede de uma autarquia federal à luz do SICOGEA - Geração 2, mais especificamente da primeira fase da terceira etapa do método (fase chamada "Investigação e Mensuração").

Por meio da coleta de dados da lista de verificação e sua análise, foi constatado um índice de sustentabilidade ambiental de $43,19 \%$ para o órgão pesquisado, conceito considerado como "regular". Embora haja legislações que não estejam sendo cumpridas, as ações que surgem são oriundas de obrigação legal, o que vai ao encontro ao "atende somente à legislação", desempenho relacionado ao conceito obtido.

Foi possível perceber que o critério da área de "Finanças", "Contabilidade e Auditoria", foi aquele que apresentou 0 melhor desempenho. Em contrapartida, os grupos relacionados à área de "Produção" foram aqueles que mais contribuíram para a redução do desempenho, sendo eles: "Processos de Produção", "Fornecedores" e "Manutenção".

Os resultados mostram a deficiência da gestão ambiental na organização, que deve incentivar mais práticas que reduzam possíveis impactos que estão sendo causados pela sua atividade.

Dentre as limitações da pesquisa, pode-se citar que ela fica sujeita à avaliação dos respondentes, bem como a lista de verificação utilizada e seus critérios. Destacase ainda que os resultados apresentados nesta pesquisa se restringem ao órgão estudado, não podendo ser generalizados para as outras unidades do órgão, tampouco demais organizações públicas.

Para futuras pesquisas, sugere-se a proposição de um plano de gestão ambiental para o órgão, estendendo a lista de verificação aplicada nesta pesquisa a outros momentos, a fim de traçar uma evolução da sustentabilidade ambiental na autarquia à luz do SICOGEA - Geração 2. Pode-se ainda aplicar o método em outros órgãos públicos, comparando os seus resultados.

Uma sugestão de melhoria ao SICOGEA seria criar listas de verificação padronizadas, já com pesos definidos para as questões, separados por atividade econômica. Dessa forma, acredita-se que a subjetividade do pesquisador seria minimizada e tornaria os resultados mais comparáveis. 


\section{REFERÊNCIAS}

[1] Associação Brasileira DE Normas Técnicas. NBR ISO 14001: Sistemas de gestão ambiental - Requisitos com orientações para uso. Rio de Janeiro: ABNT, 2015.

[2] Barbosa, Neuzaí Marreiros. Análise da sustentabilidade ambiental na justiça federal do Amazonas: estudo de caso usando um sistema contábil gerencial ambiental. 2014. $130 \mathrm{f}$. Dissertação (Mestrado) - Curso de Pós-graduação em Contabilidade e Controladoria, Faculdade de Estudos Sociais, Universidade Federal do Amazonas, Manaus, 2014.

[3] Bergamini Junior, Sebastião. Contabilidade e Risco Ambientais. Rio de Janeiro: Revista do BNDES, 1999.

[4] Candeloro, Raúl. Não tenha dúvidas: Método 5W2H. 2008. Disponível em: $<$ http://www. portaldomarketing.com.br/Artigos 1/Na o_tenha_duvidas_metodo_5w2h.htm >. Acesso em: $1 \overline{5}$ abr. 2017

[5] Chaves, Leonardo Corrêa et al. Gestão ambiental e sustentabilidade em instituições de ensino superior: construção de conhecimento sobre o tema. Revista Gestão Universitária na América Latina - Gual, Florianópolis, v. 6, n. 2, p.33-54, 29 abr. 2013. Universidade Federal de Santa Catarina (UFSC). http://dx. doi.org/10.5007/1983-4535.2013v6n2p33.

[6] Coelho, Eduardo; Domenico, Daniela di; Pfitscher, Elisete Dahmer. Análise de sustentabilidade ambiental: estudo de caso em uma fábrica de estofados. Revista de Informação Contábil, Recife, v. 6, n. 1, p.66-84, jan./mar. 2011.

[7] Costa, Maria Isabel Lopes da. Avaliação Ambiental de micro e pequenas empresas industriais do Arranjo Produtivo Local TêxtilConfecção do Município de Petrópolis-RJ. 2007. 196 f. Dissertação (Mestrado) - Curso de Pósgraduação em Engenharia Ambiental, Centro de Tecnologia e Ciências, Universidade Estadual do Rio de Janeiro, Rio de Janeiro, 2007.

[8] Costa, Rodrigo Simão da; MARION, José Carlos. A uniformidade na evidenciação das informações ambientais. Revista Contabilidade \& Finanças, São Paulo, v. 18, n. 43, p.20-33, abr. 2007. Fapunifesp (SciELO). http://dx.doi.org/10.1590/s151970772007000100003.

[9] domenico, Daniela di et al. Análise de sustentabilidade ambiental: estudo de caso em uma indústria de eletrodomésticos. Contexto, Porto Alegre, v. 15, n. 31, p.24-37, set./dez. 2015.

[10] LERÍPIO, Alexandre de Ávila. GAIA: um método de gerenciamento de aspectos e impactos ambientais. 2001. 172 f. Tese (Doutorado) - Curso de Engenharia de Produção, Universidade Federal de Santa Catarina, Florianópolis, 2001.
[11] MMA. A história da A3P. 2017a. Disponível em: <http://www.mma.gov.br/destaques/item/8852>. Acesso em: 15 abr. 2017.

[12] Agenda Ambiental na Administração Pública. 5. ed. Brasília: Ministério do Meio Ambiente, 2009. 100 p.

[13] Construções Sustentáveis. 2017b.

Disponível em: <http://www.mma.gov.br/component/k2/item/10317 -eixos-temáticos-construções-sustentáveis>. Acesso em: 29 abr. 2017.

[14] Nunes, João Paulo de Oliveira. Um aporte ao sistema contábil gerencial ambiental: elaboração e aplicação parcial do novo sistema em clínica hospitalar. 2010. 243 f. Dissertação (Mestrado) - Curso de Programa de Pós-graduação em Contabilidade, Centro Socioeconômico, Universidade Federal de Santa Catarina, Florianópolis, 2010.

[15] Pfitscher, Elisete Dahmer. Gestão e sustentabilidade através da contabilidade e controladoria ambiental: estudo de caso na cadeia produtiva de arroz ecológico. 2004. 252 f. Tese (Doutorado) - Curso de Programa de Pós Graduação em Engenharia de Produção, Universidade Federal de Santa Catarina, Florianópolis, 2004.

[16] Santos, Antonio Raimundo dos. Metodologia Científica: A construção do conhecimento. 8. ed. Rio de Janeiro: Lamparina, 2015 .

[17] Souza, Vanessa Duarte de; UHLMANN, Vivian Osmari; PFITSCHER, Elisete Dahmer. Sustentabilidade ambiental em instituição de ensino: Aderência à Agenda Ambiental de Administração Pública. Revista Perspectivas Contemporâneas, Campo Mourão, v. 10, n. 1, p.126-145, jan./abr. 2015.

[18] Tinoco, João Eduardo Prudêncio; KRAEMER, Maria Elisabeth Pereira. Contabilidade e Gestão Ambiental. 3. ed. São Paulo: Atlas, 2011.

[19] Uhlmann, Vivian Osmari. Contribuições ao desenvolvimento do Sistema Contábil Gerencial Ambiental - geração 2: proposição da terceira geração do método. 2011. 128 f. Dissertação (Mestrado) - Curso de Programa de Pós-graduação em Contabilidade, Universidade Federal de Santa Catarina, Florianópolis, 2011.

[20] Van Bellen, Hans Michael. Desenvolvimento Sustentável: Uma Descrição das Principais Ferramentas de Avaliação. Ambiente \& Sociedade, São Paulo, v. 7, n. 1, p.67-88, jan./jun. 2004. 


\section{Gapítulo 11}

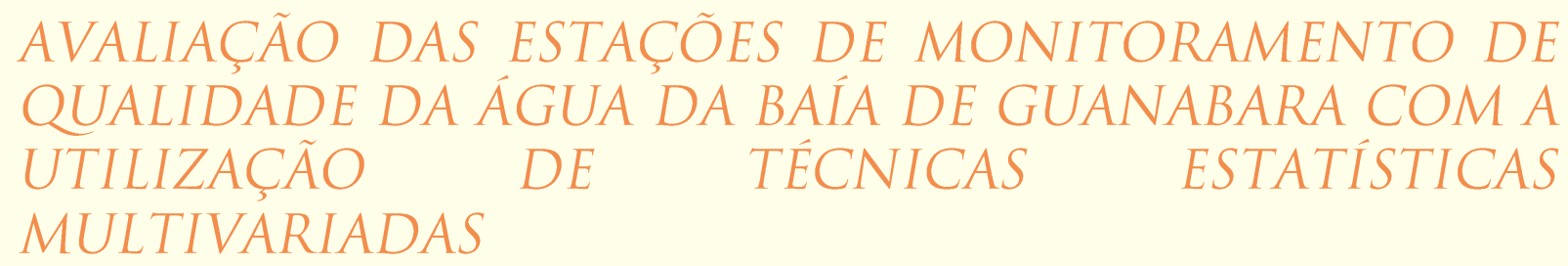

Raquel Emerick Pereira Mencarini

Maria José de Oliveira Cavalcanti Guimarães

Lidia Yokoyama

Resumo: O presente trabalho tem como objetivo otimizar, através do uso de técnicas estatísticas multivariadas, o monitoramento sistemático da qualidade da água da Baía de Guanabara, com vistas a estabelecer uma gestão adequada dos recursos hídricos. O período de estudo abordado foi de 2010 a 2016, por dispor de dados representativos em quantidade satisfatória para se obter resultados consistentes. Inicialmente definiu-se a área de estudo, selecionando-se 14 estações de amostragem frequentemente monitoradas pelo Instituto Estadual do Ambiente (INEA) em seu Plano de Monitoramento de Qualidade da Água. Foram selecionados 13 parâmetros de qualidade da água acompanhados através deste Plano de Monitoramento, quais sejam: Coliformes Termotolerantes, Condutividade, Demanda Bioquímica de Oxigênio, Fósforo Total, Nitrato, Nitrito, Nitrogênio Amoniacal, Oxigênio Dissolvido, Ortofosfato Dissolvido, $\mathrm{pH}$, Salinidade, Temperatura e Turbidez, cujos dados de monitoramento foram previamente analisados e organizados, objetivando-se a aplicação de técnicas estatísticas multivariadas com o software Statistical Package for the Social Sciences (IBM ${ }^{\circledR}$ SPSS ${ }^{\circledast}$ Statistics 19). A Análise Fatorial/Análise de Componentes Principais foi aplicada às medianas padronizadas dos dados de monitoramento das estações de monitoramento, identificando-se as relações existentes entre elas e, consequentemente, verificando-se que as mesmas podem ser agrupadas em setores com qualidade de água semelhante, tornando possível uma redução na quantidade de pontos de amostragem monitorados.

Palavras-chave: Monitoramento ambiental, Qualidade da água, Baía de Guanabara, Estatística Multivariada, Análise Fatorial/Análise de Componentes Principais 


\section{INTRODUÇÃO}

De acordo com Cameron e Pritchard (1963), "estuário é uma porção de água costeira, parcialmente rodeada de terra, com comunicação livre com o mar, pelo menos intermitentemente, estendendo-se para o interior do rio até ao limite de influência da maré e onde a água do mar é diluída por água doce proveniente do escoamento de origem terrestre".

A Baía de Guanabara é circundada pela região metropolitana do Rio de Janeiro, que é caracterizada por uma alta densidade demográfica e onde se encontra o segundo parque industrial do Brasil. Além disso, esta baía banha diretamente os municípios de Niterói, São Gonçalo, Itaboraí, Guapimirim, Magé, Duque de Caxias e Rio de Janeiro.

De acordo com a literatura, a qualidade de água deste estuário vem sofrendo grande depleção. Desde o início da década de 1980, podem ser observados sérios problemas de poluição decorrentes do crescimento urbano desordenado aliado à implementação de complexos industriais, quais sejam:

(i) alterações no contorno original das ilhas, decorrente de sucessivos aterros;

(ii) aumento nas taxas de assoreamento;

(iii) destruição da vegetação de manguezal; e

(iv) lançamento de esgotos domésticos, resíduo urbano e de despejos industriais, causando poluição por matéria orgânica, metais de alta toxicidade, fenóis, micropoluentes orgânicos, óleos e graxas (EMGEPRON, 2003).

Os desafios emblemáticos e urgentes para a gestão sustentável dos recursos hídricos estão ancorados em função de demandas crescentes para o abastecimento humano e para a conservação da qualidade ambiental, fatores fundamentais para a saúde e a qualidade de vida de populações urbanas e rurais (GUEDES et al., 2011), sendo conveniente identificar e prevenir as principais fontes de poluição, bem como obter dados para uma efetiva gestão (MOURA et al., 2010).

Assim, a atividade de monitoramento de um corpo hídrico é fundamental para a formação de uma base de dados que permita seu melhor conhecimento e uma adequada gestão dos recursos hídricos (FRANÇA, 2009). A quantificação da carga poluidora que aporta a um corpo d'água é um elemento fundamental para qualquer manejo que objetive a conservação e o uso sustentável da água. Através da análise integrada entre os dados de qualidade da água e as características de uso e ocupação do solo em uma bacia hidrográfica, juntamente com a distribuição da população urbana e a disponibilidade de infraestrutura urbana e industrial, torna-se possível definir relações de causa e efeito entre as condições de ocupação do estuário e a qualidade da água.

Apesar de, em termos gerais, os indicadores típicos que influenciam a química aquática serem bem conhecidos - processos naturais (clima, precipitação, erosão, intemperismo, geologia, tipo de solo), influências antropogênicas (atividades urbanas, industriais e agrícolas) e aumento da exploração dos recursos hídricos, a forma com a qual eles interagem e o resultado desta interação em nível regional são difíceis de predizer e generalizar, uma vez que os resultados diferem de local para local. O conhecimento destas interações é essencial para o planejamento regional, para o manejo sustentável dos recursos hídricos naturais e para a proteção ambiental. Os parâmetros físicos, químicos e biológicos que caracterizam a qualidade das águas sofrem grandes variações no tempo e no espaço. Tendo em vista estas variações espaciais e temporais na hidroquímica de um estuário, surge a necessidade de estudos e investimentos para o acompanhamento da qualidade das águas nas diferentes regiões de interesse (TRINDADE, 2013).

Programas de monitoramento de qualidade da água são primordiais para um melhor entendimento sobre o comportamento de um corpo hídrico (FRANÇA, 2009). O Ministério do Meio Ambiente define o monitoramento ambiental como "o conhecimento $e$ acompanhamento sistemático da situação dos recursos ambientais dos meios físico e biótico, visando à recuperação, melhoria ou manutenção da qualidade ambiental", a qual "está relacionada ao controle de variáveis ambientais, que se alteram, seja em função das ações antrópicas, seja em função de transformações naturais" (MMA, 2009).

Para uma interpretação ecológica da qualidade das águas superficiais e/ou para estabelecer um sistema de monitoramento, faz-se necessária a utilização de métodos simples que forneçam informações objetivas e interpretáveis seguindo para critérios próprios 
considerando as características peculiares dos recursos hídricos. Neste aspecto, o uso de índices de qualidade de água é uma tentativa geralmente usada em programas de monitoramento de águas superficiais para prever através de informações resumidas, a possível deterioração dos recursos hídricos no estuário ou ao longo do tempo (BARROS et al., 2010). No entanto, o monitoramento de corpos d'água por longos períodos e em várias estações de amostragem produz um banco de dados grande e complexo, contendo diversos tipos de parâmetros de qualidade da água. Isto dificulta a análise e interpretação dos dados para se extrair informações compreensíveis e representativas, de grande utilidade para a gestão adequada para a manutenção da qualidade da água, sendo muitas vezes subutilizados.

A avaliação dos dados de qualidade da água envolve uma grande quantidade de variáveis, cuja interpretação se torna difícil e dispendiosa. Uma das diversas técnicas de análise de dados é a análise multivariada, que corresponde a um grupo de técnicas estatísticas que buscam relacionar as variáveis pesquisadas, permitindo a identificação dos possíveis fatores ou fontes responsáveis pelas variações na qualidade da água da bacia hidrográfica. A complexidade matemática por trás destes métodos é facilmente ocultada nos softwares estatísticos, cujas técnicas computacionais vêm cumprindo o papel de reduzir a grande quantidade de dados sem a perda de informação, bem como o estudo da associação e correlação entre as variáveis (BARROS et al., 2010; MOURA et al., 2010).

Métodos estatísticos multivariados são uma excelente ferramenta exploratória para a interpretação destes complexos conjuntos de informações. Diversos trabalhos empregaram algumas destas técnicas (Análise de Agrupamentos, Análise Discriminante e Análise de Componentes Principais/Análise Fatorial) para alcançar diferentes objetivos: extrair informações sobre as similaridades e as diferenças entre períodos e pontos de amostragem da qualidade da água; reconhecer os parâmetros responsáveis pelas variações e tendências espaciais e temporais desta qualidade; identificar as fontes de poluição de diferentes pontos de um corpo d'água; identificar e analisar as relações entre química da água, uso e ocupação do solo e geologia (TRINDADE, 2013).
Dentre estas técnicas multivariadas, as que têm se mostrado mais adequadas no tratamento de dados de qualidade da água são a Análise de Componentes Principais $(A C P)$ e a Análise Fatorial (AF) em razão do tipo de resultado que fornecem, notando-se a preferência de muitos autores por estes tipos de análises em estudos neste âmbito (FRANÇA, 2009). A ACP e a AF são capazes de reduzir consideravelmente os dados, além de descrever a variabilidade de todo o conjunto com apenas poucos componentes principais/fatores, sem perder muita informação, percebendo-se a grande utilidade destas técnicas nas análises de qualidade da água. Elas possibilitam a identificação dos parâmetros com maior contribuição para as variações temporais e espaciais da qualidade da água, e o agrupamento das variáveis estudadas de acordo com suas características comuns ajuda na interpretação dos dados. Dessa forma, a ACP/AF é uma ferramenta útil para identificar as fontes de poluição de pontos de monitoramento e ajudar na tomada de decisão para controle desta poluição (TRINDADE, 2013).

Em pesquisa na literatura, foram encontrados alguns trabalhos sobre a qualidade da água da Baía de Guanabara, sendo a maioria de pequena abrangência, durante períodos de tempo não suficientes. Contudo, o aspecto mais importante neste sentido é que em nenhum deles foi realizada uma abordagem estatística mais aprofundada para tratamento e interpretação dos dados, apesar de a própria Resolução CONAMA no 357/05 (BRASIL, 2005) dispor em seu Parágrafo $2^{\circ}$, Artigo 8-, Capítulo III, que "os resultados do monitoramento deverão ser analisados estatisticamente e as incertezas de medição consideradas". Diante deste cenário, percebeu-se a importância de otimizar, através do uso de técnicas estatísticas multivariadas, o monitoramento sistemático da qualidade da água da Baía de Guanabara, de forma a subsidiar uma gestão sustentável adequada deste estuário.

\section{OBJETIVO}

O presente trabalho tem como objetivo geral otimizar, através do uso de técnicas estatísticas multivariadas, o monitoramento sistemático da qualidade da água da Baía de Guanabara, com vistas a estabelecer uma gestão adequada dos recursos hídricos. Para isso, faz-se necessário identificar as possíveis 
relações existentes entre as variáveis, de forma a se propor uma possível redução da quantidade de estações de monitoramento e/ou da frequência de amostragem, reduzindo custos e tempo gasto em campanhas de monitoramento e análises laboratoriais.

\section{METODOLOGIA}

\subsection{DEFINIÇÃO DA ÁREA DE ESTUDO}

Para a realização deste trabalho, foi utilizada a base de dados do Plano de Monitoramento de Qualidade da Água do INEA, através do qual é realizado o acompanhamento periódico de 21 estações de monitoramento da Baía de Guanabara. No entanto, face à indisponibilidade de dados completos de todo o período estudado, visto que alguns pontos de amostragem foram implantados no ano de 2012, foram consideradas somente 14 destas estações, cujas identificações e respectivas localizações são apresentadas na Figura 1.

Figura 1. Mapa de Localização das Estações de Monitoramento da Baía de Guanabara

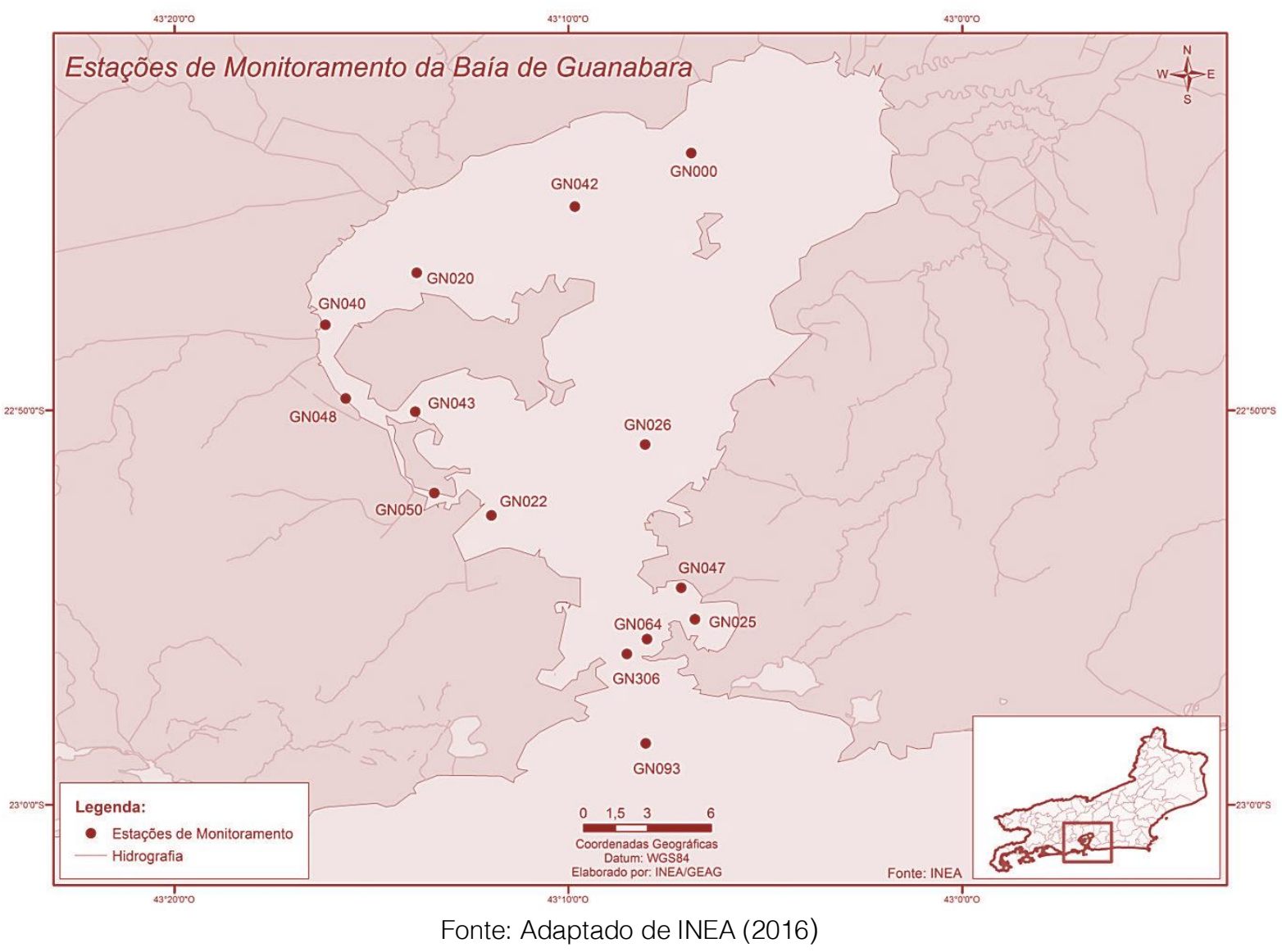

\subsection{AMOSTRAGEM}

De acordo com INEA (2012), as coletas de amostras das baías são planejadas para ter sua realização nas marés de quadratura vazante, a fim de se obter conhecimento do impacto proveniente da bacia drenante.

Todas as amostras foram coletadas e preservadas conforme preconizado no Guia Nacional de Coleta e Preservação de Amostras (BRANDÃO et al., 2011).

\subsection{PARÂMETROS MONITORADOS}

De um total de 15 parâmetros analisados no Plano de Monitoramento de Qualidade da Água do INEA, foram selecionados 13 por serem aqueles cujo monitoramento foi ininterrupto durante o período de avaliação, quais sejam: Coliformes Termotolerantes, Condutividade, Demanda Bioquímica de Oxigênio, Fósforo Total, Nitrato, Nitrito, Nitrogênio Amoniacal, Oxigênio Dissolvido, 
Ortofosfato Dissolvido, $\mathrm{pH}, \quad$ Salinidade, Temperatura e Turbidez.

Todos os parâmetros foram analisados na GELAB - Gerência de Laboratórios do INEA,

Tabela 1. Métodos de ensaio adotados para os parâmetros monitorados

\begin{tabular}{|c|c|c|}
\hline Parâmetro & Método & Referência \\
\hline Coliformes Termotolerantes & Tubos múltiplos & SM 9221 E2 \\
\hline Condutividade & Condutimétrico & SM 2510 \\
\hline $\mathrm{DBO}$ & Incubação (5 dias - $20^{\circ} \mathrm{C}$ ) / Titulométrico & SM 5210 \\
\hline Fósforo Total & Digestão oxidativa / Colorimétrico & SM 4500-P \\
\hline Nitrato & Cromatografia iônica & SM 4110 \\
\hline Nitrito & Cromatografia iônica & SM 4110 \\
\hline Nitrogênio Amoniacal & Fenato & $\mathrm{SM} 4500-\mathrm{NH}_{3}$ \\
\hline Oxigênio Dissolvido & Iodométrico modificado pela azida & SM 4500-O \\
\hline Ortofosfato Dissolvido & Cromatografia iônica & SM 4110 \\
\hline $\mathrm{pH}$ & Potenciométrico & SM 4500- $\mathrm{H}^{+}$ \\
\hline Salinidade & Condutimétrico & SM 2520 \\
\hline Temperatura & Termômetro de imersão (campo) & SM 2550 \\
\hline Turbidez & Nefelométrico & SM 2130 \\
\hline
\end{tabular}

Legenda: SM - Standard Methods (APHA, 2012)

\subsection{BASE DE DADOS}

O levantamento de dados foi realizado através de consulta ao banco de dados do INEA, que monitora, através da sua Gerência de Avaliação da Qualidade da Água (GEAG), as estações de amostragem da Baía de Guanabara.

As amostragens realizadas pelo órgão ambiental são executadas de acordo com um planejamento sistemático, respeitando-se frequências pré-estabelecidas, que condicionam o número de resultados de cada variável de qualidade de água para cada ponto de coleta.

A base de dados utilizada neste trabalho foi organizada a partir do conjunto de dados disponíveis de cada uma das estações de com exceção da Temperatura, cuja análise foi realizada em campo, através de métodos normalizados, conforme sintetizado na Tabela 1. 
Tabela 2. Medianas dos dados de monitoramento de qualidade da água da Baía de Guanabara no período de 2010 a 2016

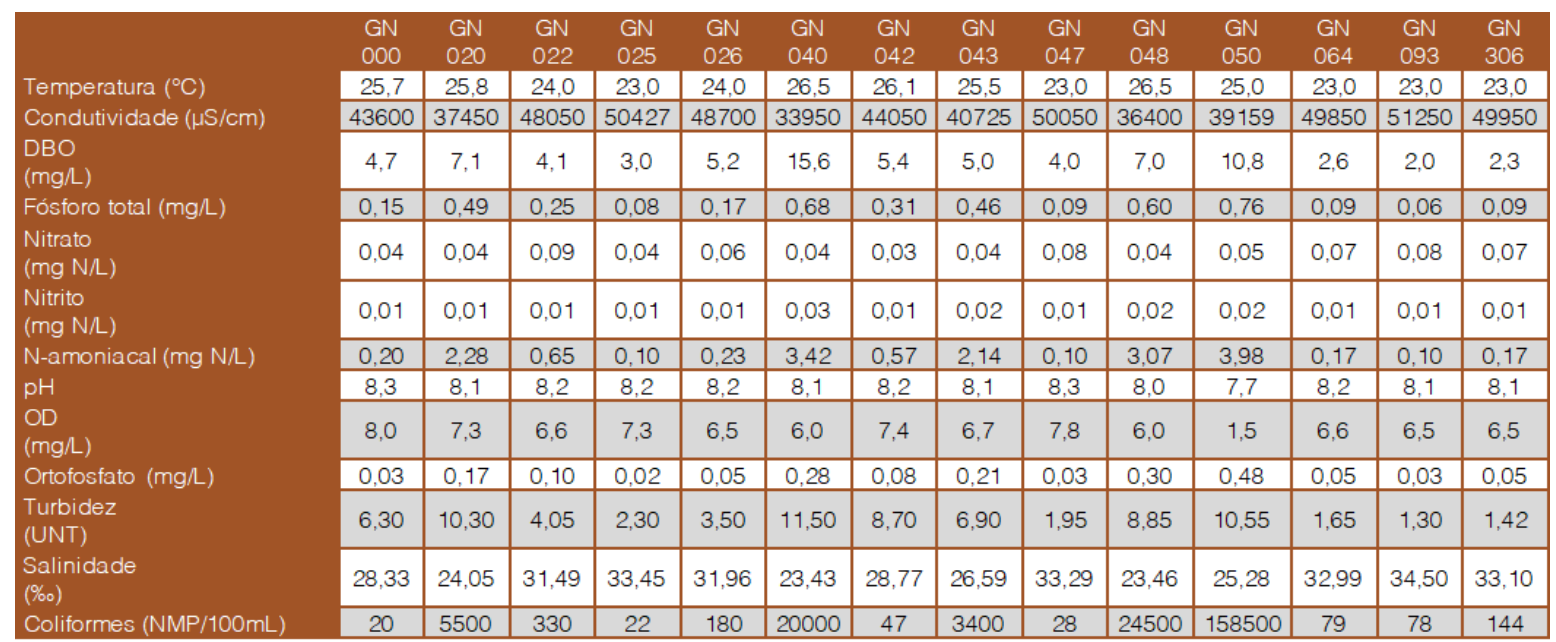

\subsection{APLICAÇÃO DOS MÉTODOS ESTATÍSTICOS MULTIVARIADOS}

Previamente à aplicação dos métodos estatísticos multivariados, a fim de se evitar erros de classificação resultantes da diferente ordem de grandeza tanto do valor numérico quanto da variância das variáveis analisadas, foi realizada a padronização dos dados da Tabela 2.

Em seguida, foi extraída a matriz de correlação das variáveis, a partir da qual podem ser observadas as variáveis mais significativas na avaliação da qualidade da água, sendo as mais expressivas aquelas que possuem maiores valores de coeficiente de correlação com o maior número de variáveis.

A próxima etapa foi a aplicação da Análise Fatorial propriamente dita, utilizando-se a Análise de Componentes Principais como método de extração dos fatores. As variáveis analisadas foram as estações de monitoramento e as observações foram as medianas dos dados de monitoramento relativos a cada parâmetro de qualidade da água. Para tanto, foi utilizado o software Statistical Package for the Social Sciences $\left(\right.$ IBM $^{\circledR}$ SPSS $^{\circledR}$ Statistics 19), o qual já possui em seu pacote as funções pré-programadas. Visando a simplificação da estrutura fatorial e, consequentemente, uma melhora significativa da interpretação, através da redução de algumas das ambiguidades que frequentemente acompanham a análise preliminar, foi aplicado o método de rotação fatorial ortogonal Varimax. A rotação fatorial redistribui a variância dos primeiros fatores para os últimos, obtendo-se pesos altos para cada variável em um único fator e pesos baixos ou moderados nos demais fatores (FRANÇA, 2009; HAIR JR. et al., 2009).

Figura 2. Diagrama esquemático da metodologia adotada

\begin{tabular}{|c|c|c|c|}
\hline $\begin{array}{c}\text { Seleção e } \\
\text { Organização } \\
\text { de Dados }\end{array}$ & $\begin{array}{c}\text { Padronização } \\
\text { dos Dados }\end{array}$ & $\begin{array}{c}\text { Confecção da } \\
\text { Matriz de } \\
\text { Correlação }\end{array}$ & AF/ACP \\
\hline
\end{tabular}




\section{RESULTADOS}

Através da matriz de correlação (Tabela 3) podem ser observadas as correlações existentes entre as 14 variáveis. Foram destacadas as melhores correlações, ou seja, aquelas com valor absoluto superior a 0,7 , já sendo possível se observar algumas tendências, as quais serão confirmadas pela Análise Fatorial/Análise de Componentes Principais. De antemão, pode-se afirmar que variáveis com correlações positivas possivelmente se encontrarão no mesmo grupo de qualidade de água, e aquelas com correlações negativas, em grupos antagônicos.

Tabela 3. Matriz de correlação das variáveis

\begin{tabular}{|c|c|c|c|c|c|c|c|c|c|c|c|c|c|c|}
\hline & GNOOO & GN020 & GN022 & GN025 & GN026 & GN040 & GN042 & GN043 & GN047 & GN048 & GN050 & GN064 & GN093 & GN306 \\
\hline GNOOO & 1,000 & & & & & & & & & & & & & \\
\hline GN020 & $-0,303$ & 1,000 & & & & & & & & & & & & \\
\hline GN022 & 0,496 & $-0,689$ & 1,000 & & & & & & & & & & & \\
\hline GN025 & 0,580 & $-0,813$ & 0,942 & 1,000 & & & & & & & & & & \\
\hline GN026 & 0,638 & $-0,774$ & 0,954 & 0,968 & 1,000 & & & & & & & & & \\
\hline GNO40 & $-0,564$ & 0,852 & $-0,774$ & $-0,898$ & $-0,816$ & 1,000 & & & & & & & & \\
\hline GN042 & 0,792 & 0,113 & 0,353 & 0,285 & 0,405 & $-0,203$ & 1,000 & & & & & & & \\
\hline GN043 & $-0,380$ & 0,767 & $-0,300$ & $-0,560$ & $-0,515$ & 0,658 & 0,040 & 1,000 & & & & & & \\
\hline GN047 & 0,612 & $-0,805$ & 0,919 & 0,989 & 0,959 & $-0,878$ & 0,264 & $-0,575$ & 1,000 & & & & & \\
\hline GN048 & $-0,560$ & 0,864 & $-0,666$ & $-0,860$ & $-0,807$ & 0,881 & $-0,163$ & 0,895 & $-0,862$ & 1,000 & & & & \\
\hline GN050 & $-0,842$ & 0,515 & $-0,463$ & $-0,661$ & $-0,622$ & 0,715 & $-0,443$ & 0,646 & $-0,708$ & 0,782 & 1,000 & & & \\
\hline GN064 & 0,498 & $-0,845$ & 0,956 & 0,991 & 0,961 & $-0,893$ & 0,215 & $-0,525$ & 0,972 & $-0,826$ & $-0,578$ & 1,000 & & \\
\hline GN093 & 0,476 & $-0,841$ & 0,952 & 0,981 & 0,952 & $-0,889$ & 0,229 & $-0,511$ & 0,949 & $-0,813$ & $-0,547$ & 0,994 & 1,000 & \\
\hline GN306 & 0,462 & $-0,848$ & 0,955 & 0,982 & 0,950 & $-0,892$ & 0,201 & $-0,510$ & 0,955 & $-0,812$ & $-0,544$ & 0,997 & 0,998 & 1,000 \\
\hline
\end{tabular}

Para a determinação do número de fatores a serem extraídos, foram adotados dois critérios: o de Kaiser (ou da Raiz Latente), que considera significantes apenas os fatores que possuem autovalores maiores que 1 , e o do Scree Plot, que é o gráfico dos autovalores em relação ao número de fatores em sua ordem de extração, sendo a forma da curva resultante usada para avaliar o ponto de corte. Mediante isto, foram extraídos três fatores com autovalores superiores a 1
(Critério de Kaiser): o primeiro, o segundo e o terceiro fatores explicam, respectivamente, cerca de $74 \%, 12,7 \%$ e 9,2\% da variância total e, juntos, aproximadamente $96 \%$ da variância total. O número de fatores extraídos foi confirmado através do Scree Plot. a mudança da curvatura se deu no quarto fator, devendo-se extrair o número de fatores à esquerda do ponto de inflexão, ou seja, três (Figura 3). 
Figura 3. Scree Plot

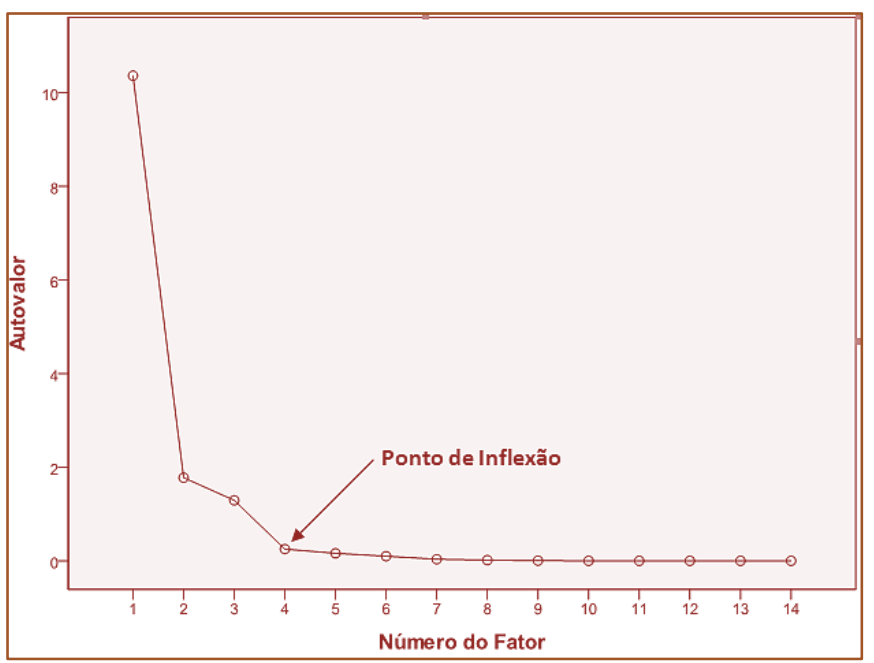

No entanto, a fim de melhorar a distribuição das cargas fatoriais, que se encontravam se necessária a aplicação da rotação fatorial concentradas no primeiro fator (Tabela 4), fezortogonal Varimax.

Tabela 4. Matriz de cargas fatoriais

\begin{tabular}{|c|c|c|c|}
\hline \multirow{2}{*}{ Variável } & \multicolumn{3}{|c|}{ Fator } \\
\hline & 1 & 2 & 3 \\
\hline GN025 & 0,985 & $-0,033$ & 0,137 \\
\hline GN047 & 0,978 & $-0,014$ & 0,084 \\
\hline GN064 & 0,971 & $-0,123$ & 0,204 \\
\hline GN026 & 0,961 & 0,073 & 0,194 \\
\hline GN093 & 0,961 & $-0,128$ & 0,226 \\
\hline GN306 & 0,960 & $-0,151$ & 0,228 \\
\hline GN040 & $-0,931$ & 0,080 & 0,104 \\
\hline GN048 & $-0,914$ & 0,104 & 0,361 \\
\hline GN022 & 0,896 & 0,011 & 0,435 \\
\hline GN020 & $-0,856$ & 0,419 & 0,160 \\
\hline GN050 & $-0,736$ & $-0,388$ & 0,463 \\
\hline GN042 & 0,312 & 0,899 & 0,144 \\
\hline GNOOO & 0,643 & 0,718 & $-0,193$ \\
\hline GN043 & $-0,658$ & 0,222 & 0,675 \\
\hline
\end{tabular}

Após a rotação, a variância explicada acumulada manteve-se a mesma de antes da rotação (96\%), havendo, porém, uma melhor distribuição da variância explicada entre os três fatores, bem como das cargas fatoriais das variáveis (Tabela 5). O primeiro fator agora explica 53,7\% da variância total, o segundo fator $24,4 \%$ e o terceiro fator $17,7 \%$. Foram retidas em cada fator as variáveis com cargas superiores a 0,7 , tendo sido adotado este critério conservador face à grande dimensão da área de estudo e à natureza dinâmica e não linear do sistema estuarino (OUYANG, 2005). 
Tabela 5. Matriz de cargas fatoriais após a rotação

\begin{tabular}{|c|c|c|c|}
\hline Variável & \multicolumn{3}{|c|}{ Fator } \\
\hline GN022 & 0,964 & $-0,059$ & 0,245 \\
\hline GN306 & 0,946 & $-0,298$ & 0,120 \\
\hline GN093 & 0,940 & $-0,295$ & 0,141 \\
\hline GN064 & 0,935 & $-0,318$ & 0,150 \\
\hline GN025 & 0,893 & $-0,364$ & 0,244 \\
\hline GN026 & 0,879 & $-0,284$ & 0,336 \\
\hline GN047 & 0,856 & $-0,403$ & 0,263 \\
\hline GN040 & $-0,734$ & 0,553 & $-0,197$ \\
\hline GN020 & $-0,718$ & 0,631 & 0,146 \\
\hline GN043 & $-0,244$ & 0,938 & $-0,013$ \\
\hline GN048 & $-0,592$ & 0,770 & $-0,183$ \\
\hline GN050 & $-0,284$ & 0,676 & $-0,608$ \\
\hline GN042 & 0,135 & 0,147 & 0,941 \\
\hline GN000 & 0,275 & $-0,336$ & 0,882 \\
\hline
\end{tabular}

Contudo, algumas variáveis (GN040, GN020, GN048 e GN050) apresentaram cargas cruzadas (destacadas em vermelho - Tabela 5), cuja diferença é inferior a 0,2 entre os fatores, fazendo-se necessária uma avaliação complementar através de gráficos de cargas fatoriais, a fim de se eliminar tais ambiguidades, obtendo-se assim uma completa compreensão dos resultados obtidos.

Nas Figuras 4, 5, 6 e 7 são apresentados os gráficos das cargas fatoriais dos três primeiros fatores. No gráfico da Figura 4, as variáveis (estações de amostragem) são posicionadas de acordo com sua carga fatorial nos três fatores extraídos após a rotação Varimax. Através dele, pode-se observar que elas se distribuem de forma definida entre três grupos distintos, o que pode ser confirmado nos gráficos de cargas fatoriais de cada fator (Figuras 5, 6 e 7). No primeiro fator, nota-se que as cargas de maior valor positivo correspondem aos pontos de monitoramento GN022, GN025, GN026, GN047, GN064, GN093 e GN306. Já no segundo fator, as estações de amostragem GN020, GN040, GN043, GN048 e GN050 apresentam as cargas mais elevadas. O Fator 3 é representado pelos pontos de coleta GN042 e GN000, os quais nele possuem as maiores cargas positivas.

Avaliando-se os dados de monitoramento do período estudado e comparando-os aos resultados obtidos, é possível depreender que tais grupos correspondem a categorias de qualidade da água: no Fator 1 encontram-se os pontos com melhor qualidade de água; o Fator 2 compreende os pontos com pior qualidade de água; e o Fator 3 representa os pontos com qualidade de água regular. 
Figura 4. Cargas fatoriais dos três fatores e agrupamento dos pontos de amostragem em função da qualidade da água

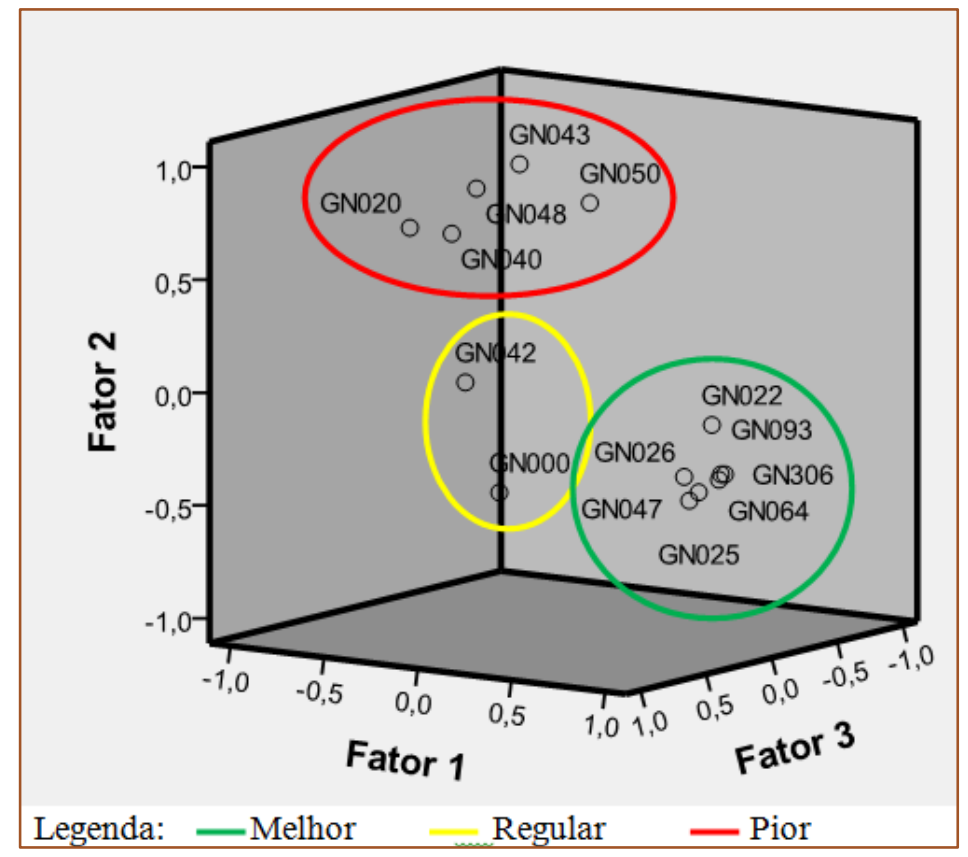

Figura 5. Cargas fatoriais do primeiro fator

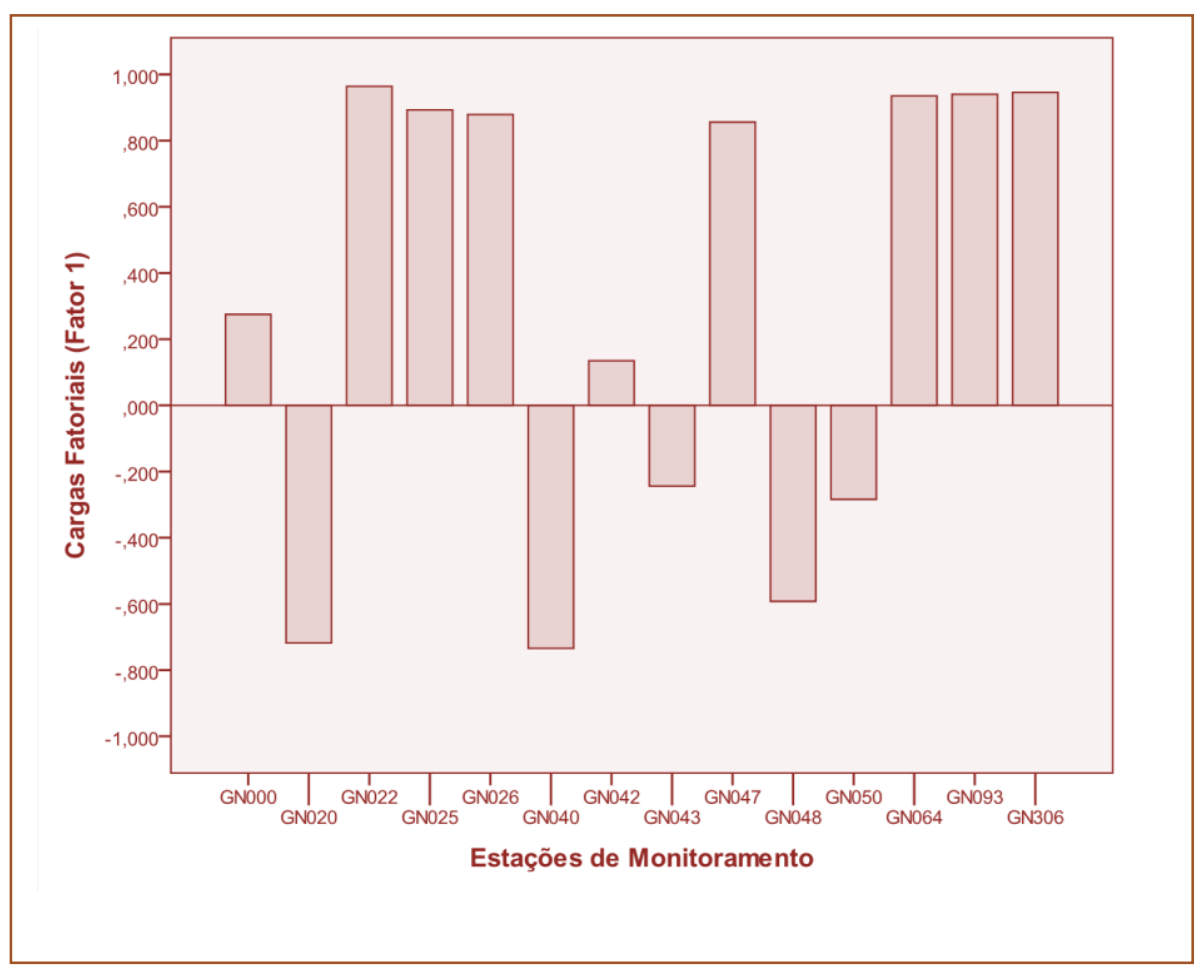


Figura 6. Cargas fatoriais do segundo fator

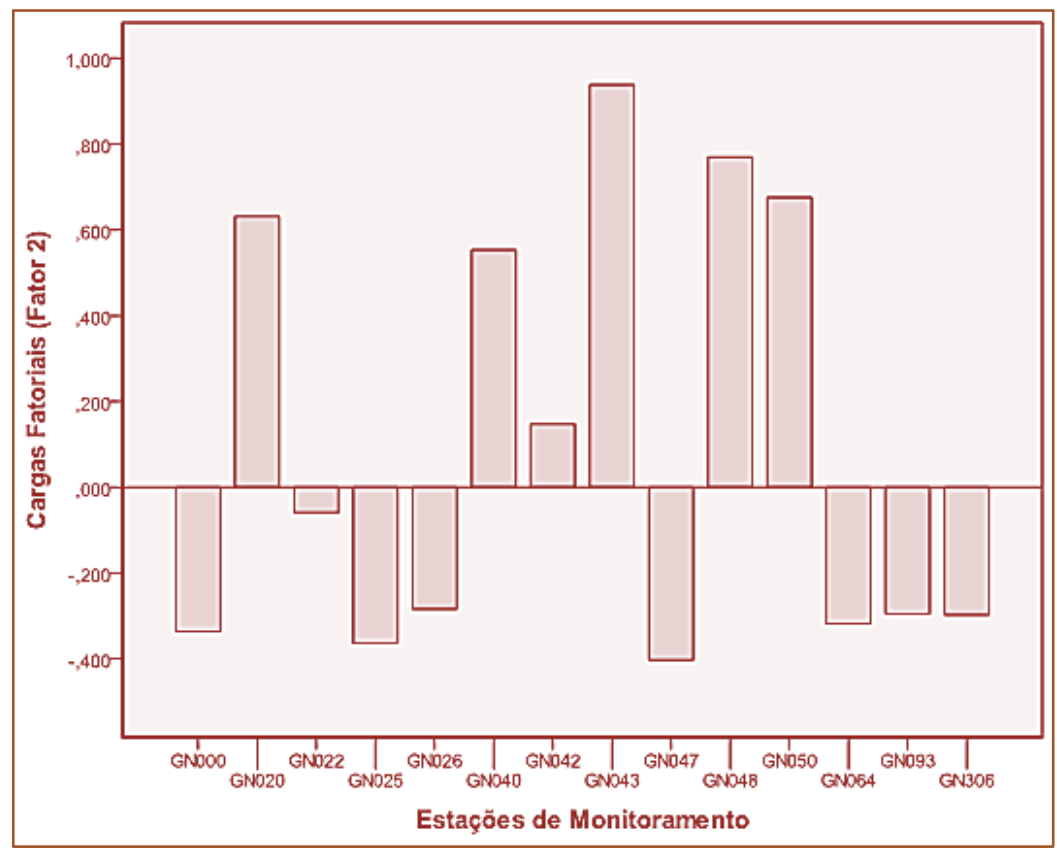

Figura 7. Cargas fatoriais do terceiro fator

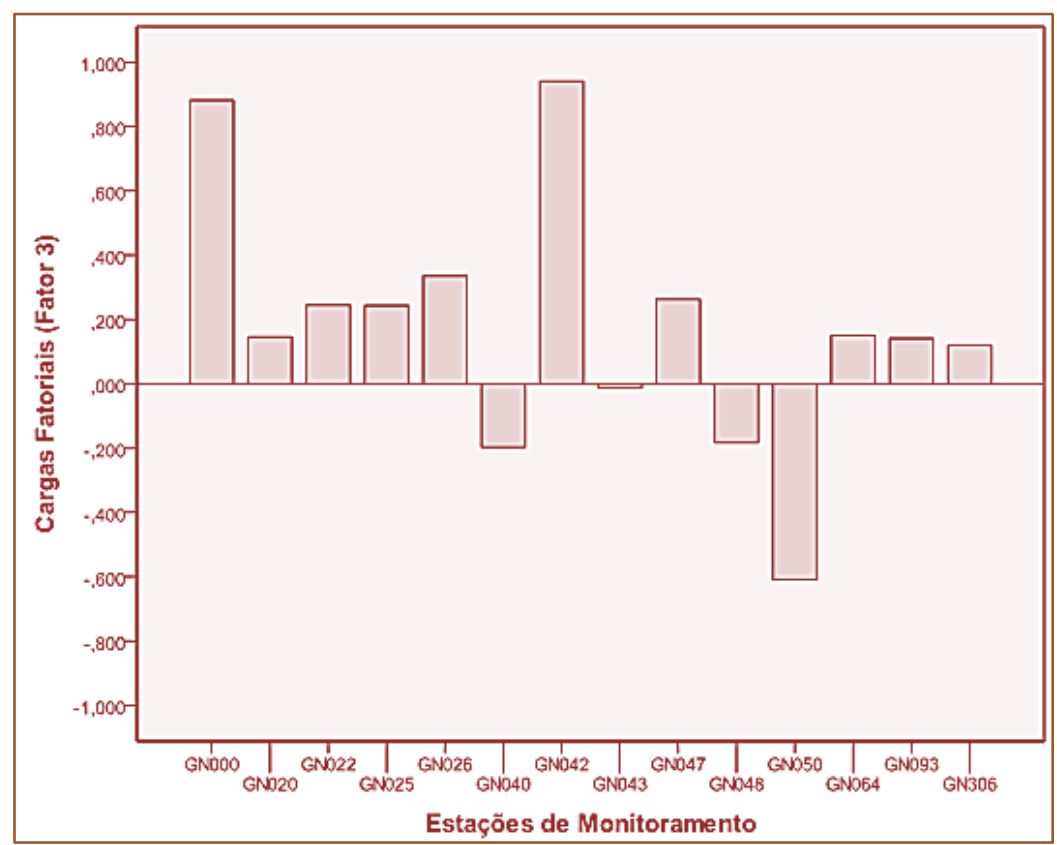

Com a definição da distribuição das variáveis entre os fatores, foi possível setorizar a Baía de Guanabara em função da qualidade de água, como mostrado na Figura 8. 
Figura 8. Setorização da Baía de Guanabara em função da qualidade da água

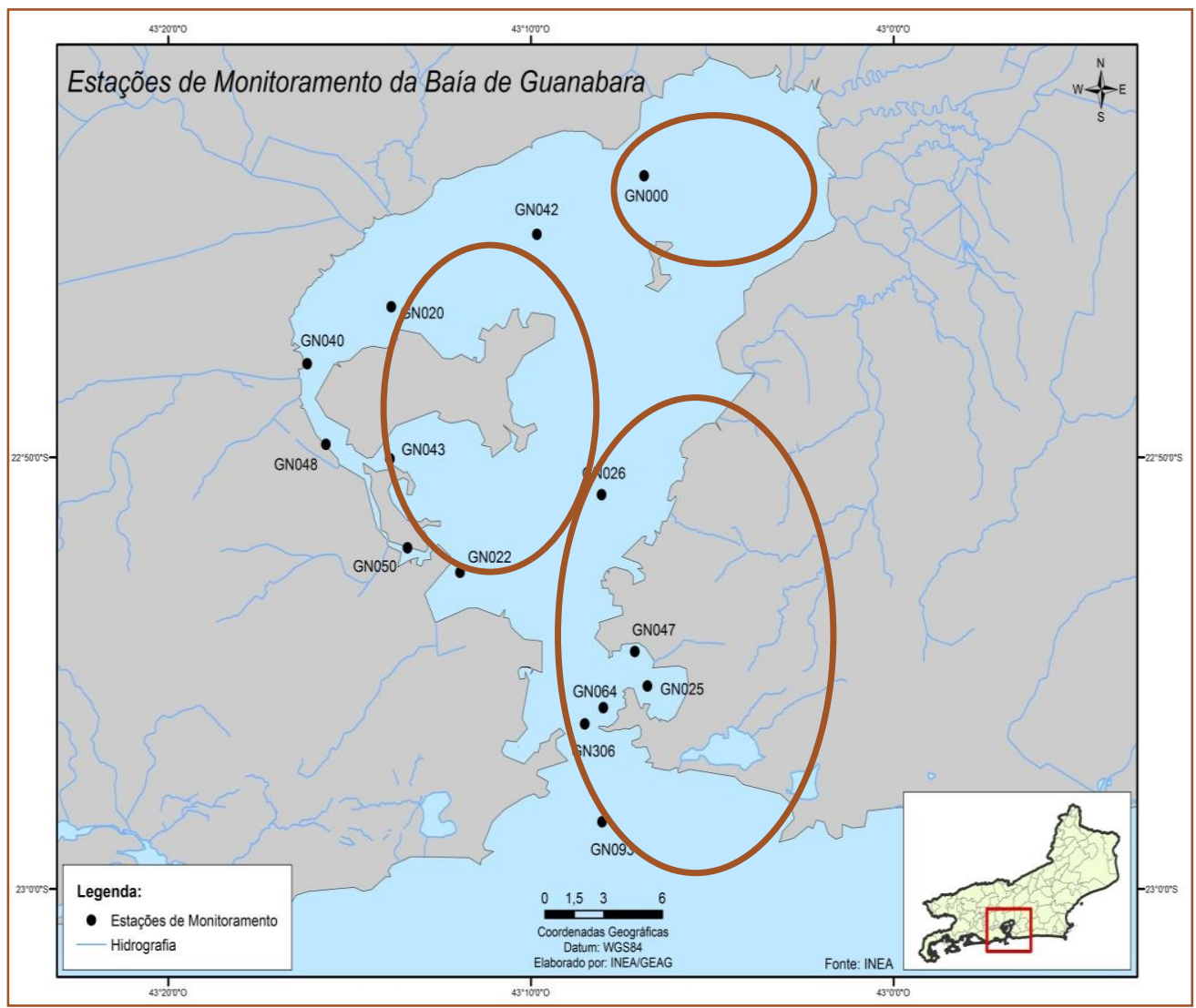

Na Área Noroeste encontra-se a água de pior qualidade, devido aos lançamentos extremamente altos de efluentes brutos ou parcialmente tratados provenientes das áreas residenciais de baixa renda ao norte do município do Rio de Janeiro. Essa região também recebe uma carga considerável proveniente das indústrias da Baixada Fluminense (FEEMA, 1998). Observa-se um gradiente decrescente de poluição na direção da Área Norte, em que a qualidade da água é regular. A Área Central sofre a influência de uma carga poluidora afluente menor e, por ser forte a influência das correntes de marés, apresenta água de melhor qualidade, assim como a Área de Entrada da Baía, em que ocorrem as trocas com o mar e renovação das águas do estuário. Esta setorização facilita a compreensão dos fenômenos poluidores, possibilitando uma redução do número de pontos e da frequência de amostragem, de forma a otimizar o monitoramento sem que haja prejuízos na qualidade da informação.

A fim de validar os resultados obtidos através da Análise Fatorial/Análise de Componentes Principais (AF/ACP), foi realizada uma comparação dos mesmos com o Índice de Conformidade (IC), instrumento adotado pelo INEA para descrever as condições das águas da Baía de Guanabara (Tabela 6). Para o seu cálculo, são utilizados cinco parâmetros ambientais de relevância para a qualidade de água quanto relacionados ao despejo doméstico, privilegiando-se também aqueles cujos padrões estão descritos na Resolução CONAMA 357/2005, sendo eles: Coliformes Fecais, Oxigênio Dissolvido, Fósforo Total, Nitrato e Nitrogênio Amoniacal (SOARES et al., 2012). O percentual de desvio em relação ao padrão gera uma classificação de conformidade em quatro categorias: Satisfatório, Regular, Ruim ou Péssimo. 
Tabela 6. Comparação dos resultados da AF/ACP com o Índice de Conformidade

\begin{tabular}{|l|c|c|}
\hline Ponto de monitoramento & AF/ACP & IC \\
\hline GN000 & Regular & Satisfatório \\
\hline GN020 & Pior & Péssimo \\
\hline GN022 & Melhor & Regular \\
\hline GN025 & Melhor & Satisfatório \\
\hline GN026 & Melhor & Satisfatório \\
\hline GN040 & Pior & Péssimo \\
\hline GN042 & Regular & Regular \\
\hline GN043 & Pior & Ruim \\
\hline GN047 & Melhor & Satisfatório \\
\hline GN048 & Pior & Péssimo \\
\hline GN050 & Pior & Péssimo \\
\hline GN064 & Melhor & Satisfatório \\
\hline GN093 & Melhor & Satisfatório \\
\hline GN306 & Melhor & Satisfatório \\
\hline
\end{tabular}

Observou-se que em todos os pontos de amostragem os resultados obtidos neste trabalho foram condizentes com o Índice de Conformidade, com exceção dos pontos GN000 e GN022. Uma explicação para esta discrepância é o fato de se ter utilizado um número maior de parâmetros de qualidade da água na execução deste trabalho em relação ao Índice de Conformidade, proporcionando assim uma análise mais abrangente e precisa.

\section{CONSIDERAÇÕES FINAIS}

A Baía de Guanabara, um dos palcos dos Jogos Olímpicos de 2016, vem sofrendo grande degradação ao longo das últimas décadas face ao aumento demográfico desordenado, sem a coleta e o tratamento adequado dos despejos domésticos, e devido também ao grande parque industrial instalado nos municípios que a circundam. Apesar de todo o aporte de investimentos que tem sido feito tanto pelo Governo quanto pela iniciativa privada visando a sua recuperação, ainda não se pôde observar uma mudança significativa no cenário de poluição que marca este corpo hídrico, face à grande deterioração a que foi submetido por tantos anos.

O monitoramento ambiental realizado pelo Instituto Estadual do Ambiente (INEA) fornece informações de extrema relevância para a gestão dos recursos hídricos da Baía de Guanabara, possibilitando a identificação dos principais poluentes e demais fatores contribuintes para a qualidade da água deste estuário. No entanto, visando a otimização deste monitoramento foi utilizada a Análise Fatorial/Análise de Componentes Principais, método estatístico multivariado amplamente empregado neste âmbito por permitir uma melhor compreensão da estrutura de dados e das relações existentes entre as variáveis.

Como resultado, obteve-se a classificação dos pontos de monitoramento em grupos de qualidade da água e sua consequente setorização, o que possibilita a realização de um monitoramento mais frequente somente de algumas estações de amostragem de cada grupo, e com menor frequência um monitoramento mais abrangente, efetuandose a coleta de todos os pontos. Esta estrutura obtida foi validada através de comparação com o Índice de Conformidade adotado pelo INEA, confirmando assim sua confiabilidade. Com isto, haveria uma redução significativa dos custos envolvidos na amostragem e na realização das análises laboratoriais, tendo como resultado uma gestão ambiental mais eficiente da Baía de Guanabara. 


\section{REFERÊNCIAS}

[1] Apha - American Public Health Association. Standard Methods for the Examination of Water and Wastewater. Maryland: United Book Press, 2012. 22ª ed., 1496 p.

[2] Barros, E.C.M.; Alcântara, L.O.; Santos, M.R.P.; Buarque, H.L.B.; Gomes, R.B. Análise estatística multivariada de dados de qualidade da água da Lagoa da Parangaba, Fortaleza, Ceará, Brasil. In: V Congresso de Pesquisa e Inovação da Rede Norte Nordeste de Educação Tecnológica. Maceió : Connepi, 2010. Disponível em: www.connepi.ifal.edu.br. Acesso em: 01 dez. 2014.

[3] Brandão, C. J. et al. Guia nacional de coleta e preservação de amostras: água, sedimento, comunidades aquáticas e efluentes líquidos. São Paulo : CETESB; Brasília : ANA, 2011. 326 p. Disponível em: www.ana.gov.br. Acesso em: 01 nov. 2014

[4] Brasil. Resolução CONAMA no 357, de 17 de março de 2005. Dispõe sobre a classificação e diretrizes ambientais para o enquadramento dos corpos de água superficiais, bem como estabelece as condições e padrões de lançamento de efluentes. Diário Oficial da União, Poder Executivo, Brasília, DF, no 053, 18 mar. 2005, p. 58-63.

[5] Cameron, W. M.; Pritchard, D. W. Estuaries. In: HILL, M.N. [ed.]. The Sea. Ideas and Observations on Progress in the Study of the Seas. New York : Wiley \& Sons, 1963, v. 2, p. 306-324.

[6] Emgepron - Empresa Gerencial de Projetos Navais. Baía de Guanabara: Monitoramento e prevenção da poluição hídrica. Rio de Janeiro : EMGEPRON, 2003. 32p. Disponível em: www.mma.gov.br. Acesso em: 30 set. 2016.

[7] Feema - Fundação Estadual de Engenharia do Meio Ambiente. Qualidade de Água da Baía de Guanabara (1990/1997). Programa de Despoluição da Baía de Guanabara/Programas Ambientais Complementares. Rio de Janeiro : Feema, 1998. 100 p.

[8] França, M. S. Análise estatística multivariada dos dados de Monitoramento de qualidade de água da bacia do alto Iguaçu: uma ferramenta para a gestão de recursos hídricos. 2009. 150 p. Dissertação (Mestrado em Engenharia de Recursos Hídricos e Ambiental) - Programa de Pós-Graduação em Engenharia de Recursos Hídricos e Ambiental, Universidade Federal do Paraná, Curitiba.
[9] Guedes, H.A.S.; Silva, D.D.; Ribeiro, C.B.M.; MATOS, A.T.; Elesbon, A.A.A.; Silva, B.M.B.; Gomes, C.R.; LISBOA, L.; MARTINS, V.S. Avaliação da qualidade da água do Médio Rio Pomba (MG) utilizando Análise de Agrupamento. In: XIX Simpósio Brasileiro de Recursos Hídricos. Maceió : $\mathrm{ABRH}, 2011$. Disponível em: www.abrh.org.br. Acesso em: 01 dez. 2014.

[10] Hair JR., J. F.; Anderson, R. E.; Tatham, R. L.; Black, W. C. Análise multivariada de dados. Porto Alegre : Bookman, 2009. 6ª ed., 688 p.

[11] Inea - Instituto Estadual do Ambiente. Plano de Monitoramento da Qualidade de Água. Rio de Janeiro : Inea, 2012. 113 p.

[12] Inea - Instituto Estadual do Ambiente. Disponível em: www.inea.rj.gov.br. Acesso em: 15 out. 2016.

[13] Mma - Ministério do Meio Ambiente. Programa Nacional do Meio Ambiente II - PNMA II, Fase 2, 2009 - 2014. Componente desenvolvimento institucional: Subcomponente monitoramento ambiental. Brasília : MMA, 2009. 17 p. Disponível em: www.mma.gov.br. Acesso em: 23 nov. 2014

[14] Moura, L.H.A.; Boaventura, G.R.; Pinelli, M.P. A qualidade de água como indicador de uso e ocupação do solo: Bacia do Gama - Distrito Federal. Química Nova, v. 33, n. 1, p. 97-103, 2010.

[15] Ouyang, Y. Evaluation of river water quality monitoringstations by principal component analysis. Water Research, v. 39, p. 2621-2635, 2005.

[16] Soares, F. F. L.; Souza, F. J.; Rodrigues, L. F. T.; Silva, L. D. O.; Pessoa, M. A. R.; Soares, M. F.; DOMINGOS, P. Uso de índices descritivos e preditivos para diagnóstico de corpos d'água. Revista Ineana, v. 1, n. 1, p. 31-45, 2012.

[17] Trindade, A.L.C. Aplicação de técnicas estatísticas para avaliação de dados de monitoramento de qualidade das águas superficiais da porção mineira da Bacia do Rio São Francisco. 2013, 165 p. Dissertação (Mestrado em Saneamento, Meio Ambiente e Recursos Hídricos) - Programa de Pós-Graduação em Saneamento, Meio Ambiente e Recursos Hídricos, Escola de Engenharia, Universidade Federal de Minas Gerais, Belo Horizonte. 


\section{Bapítulo 18}

\section{AVALIACÃO DE TECNOLOGIAS DE TRATAMENTO PARA FRAÇÃO ORGÂNICA DE RESİDUOS SÓLIDOS URBANOS}

\section{Felipe Barbosa Cordeiro}

Maria José de Oliveira Cavalcanti Guimarães

\section{Juacyara Carbonelli Campos}

Resumo: Conciliar a gestão adequada dos resíduos sólidos urbanos (RSU) com tecnologias que recuperem a energia presente nos resíduos, reduzam a emissão dos gases causadores do efeito estufa (GEE) e contribuam para o aumento da vida útil de aterros sanitários é uma das necessidades da sociedade moderna. O principal aspecto negativo da disposição em aterros sanitários é que, mesmo com os sistemas de coleta e queima do biogás gerado, uma parcela significativa deste gás não é captada pelo sistema, sendo então emitida para a atmosfera. Em função disso, é possível evidenciar a importância da diminuição na disposição de materiais orgânicos em aterros sanitários, culminando na necessidade de buscar formas eficazes para o tratamento da fração orgânica dos RSU, contribuindo tanto para a redução da emissão de gases causadores do efeito estufa, como para um aumento do tempo de vida útil de um aterro sanitário. Neste trabalho, é mostrado o gerenciamento de resíduos em alguns países e as tecnologias disponíveis para o tratamento da fração orgânica dos RSU, com ênfase nos pontos fortes e fracos de cada tecnologia.

Palavras chave: Resíduos Sólidos Urbanos, Fração Orgânica, Tecnologias e Gases do Efeito Estufa. 


\section{INTRODUÇÃO}

O Worldwatch Institute, com sede em Washington, disse em um comunicado à imprensa que a prosperidade e a urbanização podem resultar em um volume de resíduo sólido urbano (RSU) de 2,6 bilhões de toneladas em 13 anos, em comparação com os 1,3 milhões de toneladas no ano de 2012. Isso poderia desafiar a gestão ambiental e de saúde pública nas cidades do mundo (Allan Gerlat, 2012).

A lista dos 10 principais países geradores de RSU inclui quatro nações em desenvolvimento (Brasil, China, Índia e México), em parte devido ao tamanho de suas populações urbanas e, em parte, porque seus habitantes estão prosperando e adotando estilos de vida de alto consumo. Os Estados Unidos lideram o mundo em geração de RSU com cerca de 621.000 toneladas por dia. A China é um segundo relativamente próximo, com cerca de 521.000 toneladas. Os Estados Unidos geram quase sete vezes mais resíduos urbanos do que a nação na décima posição, a França (Allan Gerlat, 2012).

A gestão dos resíduos sólidos no Brasil tem sido historicamente tratada como questão sanitária e de saúde pública. Apenas mais recentemente sua gestão tem sido entendida enquanto tema transversal, devido à sua relação potencial com projetos de biogás visando a redução de emissão de gases efeito estufa e geração de energia (PROBIOGÁS, 2015).

Como exemplo, a Política Nacional de Resíduos Sólidos (PNRS) introduziu importantes conceitos e regulamentações, que se fundamentam, basicamente, no aproveitamento integral das frações que compõem os RSU antes de sua disposição final, seja por meio da reciclagem, metanização, compostagem ou logística reversa. Por si só, esta determinação já muda os paradigmas da atual gestão de resíduos no país, pautada em contratos de longo prazo onde resíduo vale o quanto pesa, de maneira indiscriminada, o que tem favorecido o aterramento de material de imenso potencial energético (PROBIOGÁS, 2015).

A Lei que institui a política nacional de resíduos sólidos - Lei 12.305/2010 estabelece a obrigatoriedade da coleta seletiva e determina que apenas os rejeitos devem ser encaminhados a aterros sanitários (regra que ficou conhecida no país como o "fim dos lixões"). Tais elementos reforçam o grande desafio, enfrentado pelo Brasil, de ampliar os níveis de tratamento dos esgotos sanitários e dos resíduos sólidos urbanos (PROBIOGÁS, 2015).

É importante salientar que a metanização, conversão de resíduos orgânicos em metano, vem se destacando mundialmente como alternativa tecnológica para valorização energética da fração orgânica dos resíduos sólidos urbanos (FORSU), tendo obtido sucesso com a sua aplicação em distintos tipos de resíduos e efluentes em todo o mundo. Especialmente nos países europeus, a consolidação desta tecnologia foi necessariamente acompanhada da regulamentação dos mercados associados à geração de energia e renda a partir dos resíduos orgânicos e seus subprodutos biogás e biossólido (agrícola ou energético) o que é fundamental para que esta tecnologia estabeleça também no Brasil (PROBIOGÁS, 2015)

Por meio deste raciocínio, está em fase de instalação na Estação de Transferência de Resíduos no bairro do Caju, operada pela Companhia Municipal de Limpeza Urbana (COMLURB), na cidade do Rio de Janeiro, um projeto que tem por objetivo o desenvolvimento de uma tecnologia nacional de metanização da fração orgânica dos resíduos sólidos urbanos (FORSU), denominada "Túneis de Metanização de Batelada Sequenciais" (TMBS). De acordo com PROBIOGÁS (2015), essa tecnologia, primeira a nível nacional, além dos benefícios da estabilização da fração orgânica, tem como objetivo o tratamento de resíduos com baixo índice de segregação de impróprios, o que é uma realidade brasileira. Dentre outros benefícios, ela visa solucionar os problemas relativos à acumulação dos materiais sedimentáveis, reduzir os custos relacionados aos sistemas de introdução e extração do material a ser tratado, propiciar a introdução de materiais com percentual elevado de impróprios, minimizar o tempo de póstratamento do material digerido (compostagem) e otimizar a produção de biogás.

Com isso, conciliar a gestão adequada dos RSU com tecnologias que recuperem a energia presente nos resíduos, reduzam a emissão dos gases causadores do efeito estufa (GEE) e contribuam para o aumento da vida útil de aterros sanitários é uma das necessidades da sociedade moderna. O principal aspecto negativo da disposição em 
aterros sanitários é que, mesmo com os sistemas de coleta e queima do biogás gerado, uma parcela significativa deste gás não é captada pelo sistema, sendo então emitida para a atmosfera.

Em função disso, é possível evidenciar a importância da diminuição na disposição de materiais orgânicos em aterros sanitários, culminando na necessidade de buscar formas eficazes para o tratamento da fração orgânica dos RSU, contribuindo tanto para a redução da emissão de gases causadores do efeito estufa, como para um aumento do tempo de vida útil de um aterro sanitário.

\section{OBJETIVO}

O objetivo geral deste trabalho é estudar as tecnologias disponíveis para o tratamento da fração orgânica dos resíduos sólidos urbanos, a fim de evitar sua disposição final sem um prévio tratamento, resultando na redução da emissão de gases causadores do efeito estufa e da quantidade de resíduos dispostos em aterros sanitários.

\section{METODOLOGIA}

O método para o desenvolvimento do presente trabalho consistiu na pesquisa de literatura técnica em sites com acervos técnicos como o Science Direct, por exemplo, tendo MSW ou Municipal Solid Waste, como principais palavras chave, além de materiais técnicos cedidos pela empresa Methanum e pela Prefeitura do Rio de Janeiro

\section{PANORAMA DO TRATAMENTO DOS RSU \\ 4.1 BRASIL}

Como exemplo no Brasil, será descrito neste item o Plano Municipal de Gestão Integrada de Resíduos Sólidos (PMGIRS) a ser implementado na cidade do Rio de Janeiro de 2017 a 2020, visto ser o local onde será instalado o projeto piloto de metanização evidenciado neste trabalho.

A Lei Federal no 12.305, de 02.08.2010, que instituiu a Política Nacional de Resíduos
Sólidos, regulamentada pelo Decreto Federal no 7.404, de 23.12.2010, reforçou a exigência de elaboração pelos municípios dos seus respectivos Planos, inclusive como condição para terem acesso a recursos federais, através de incentivos e financiamentos.

No município do Rio de Janeiro, a exigência de elaboração do Plano surgiu com a edição da Lei Municipal no 4.969, de 03.12.2008, que dispõe sobre objetivos, instrumentos, princípios e diretrizes para a Gestão Integrada de Resíduos Sólidos no âmbito do Município do Rio de Janeiro, estabelecendo em seu art. 6으 que cabe ao Município elaborar o seu Plano de Gestão Integrada de Resíduos Sólidos, sendo que o Decreto Municipal $n^{\circ}$ 31.416, de 30.11.2009, fez como exigência adicional a necessidade de se considerar, quando da elaboração do mencionado Plano, os objetivos de redução de emissões de Gases de Efeito Estufa - GEE na Cidade do Rio de Janeiro.

Em adição, encontra-se em vigor a Lei Municipal de Mudanças Climáticas, instituída pela Lei Municipal no 5.248, de 27.01.2011, que estabelece em seu artigo 6o, as metas de redução de emissões antrópicas de GEE para o Município do Rio de Janeiro: ano de 2016 redução de $16 \%$ e ano de 2020 - redução de $20 \%$ das emissões.

De acordo com o Inventário de Emissões de GEE do Rio (2012), o setor de resíduos é forte emissor de gás metano $\left(\mathrm{CH}_{4}\right)$, que apresenta potencial de aquecimento global 21 vezes maior que o gás dióxido de carbono $\left(\mathrm{CO}_{2}\right)$. $\mathrm{O}$ setor de resíduos somado ao de transportes contribuem com $41 \%$ das emissões de metano, razão pela qual o PMGIRS deve considerar a necessidade da redução desses gases.

Segundo os dados da COMLURB relativos ao ano de 2014, os resíduos coletados na cidade do Rio de Janeiro e encaminhados às unidades de recebimento do sistema público municipal atingiram a média de 9.227 t/dia, montante este que abrange a totalidade de tipos de resíduos sólidos, conforme explicitado na Tabela 1 e na Figura 1. 
Tabela 1 - Resíduos sólidos encaminhados às unidades de disposição final do sistema público da Cidade do Rio de Janeiro

\begin{tabular}{|c|c|c|}
\hline \multirow{2}{*}{ Tipo de Residuo } & \multicolumn{2}{|c|}{ Quantidades } \\
\hline & t/dia & $\%$ \\
\hline LIXO DOMICILIAR & 4.900 & 53,11 \\
\hline LXX PÚBLICO & 2.832 & 30,69 \\
\hline REMOÇÃO GRATUITA & 193 & \\
\hline $\begin{array}{l}\text { EMERGÊNCIA } \\
\text { RESÍDUOS DE SERVIÇOS DE SAÚDE } \\
\text { OUTROS }\end{array}$ & $\begin{array}{r}303 \\
2 \\
140\end{array}$ & 6,91 \\
\hline TOTAL DE COMPETÊNCIA MUNICIPAL & 8.370 & 90,71 \\
\hline GRANDES GERADORES, INCLUINDO RCC & 857 & 9,29 \\
\hline TOTAL DO MUNICÍPIO INCLUINDO GG & 9.227 & 100,00 \\
\hline
\end{tabular}

(Fonte adaptada: PMGIRS, 2016).

Figura 1 - Resíduos encaminhados aos aterros municipais (\%) (

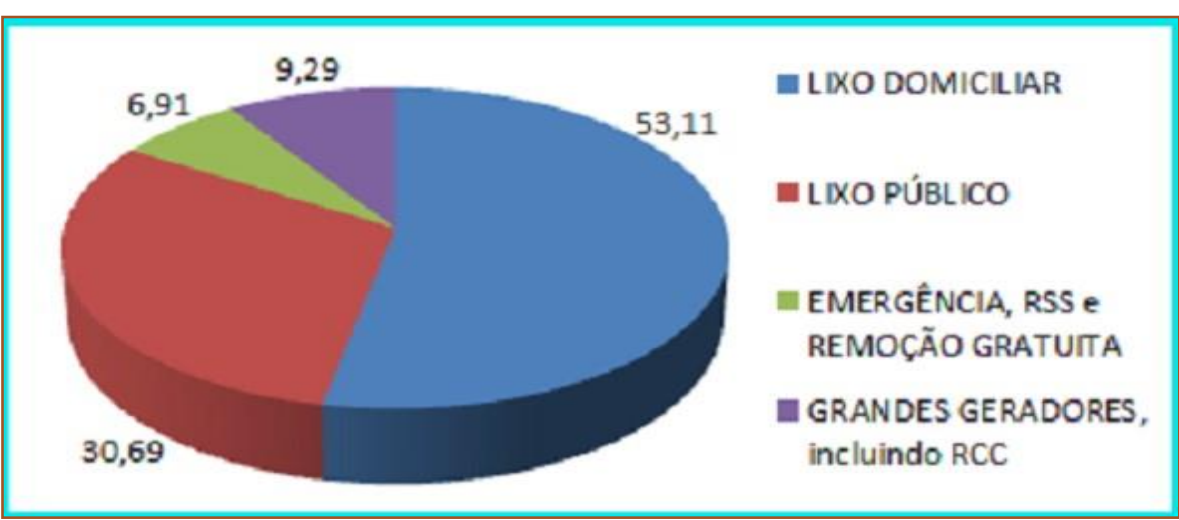

Fonte adaptada: PMGIRS, 2016).

Considerando-se a população estimada em 2014 pela Fundação Instituto Brasileiro de Geografia e Estatística - IBGE para a cidade 6.453.682 habitantes - chega-se aos seguintes valores per capita:

- $1.43 \mathrm{~kg} / \mathrm{hab} / \mathrm{dia}$, considerando o total de resíduos da cidade;

- $0,76 \mathrm{~kg} / \mathrm{hab} / \mathrm{dia}$, considerando apenas o lixo domiciliar.

A maior fração do RSU é de característica ORGÂNICA e está concentrada no fluxo da Coleta Domiciliar. É a mais danosa ao meio ambiente por gerar chorume, gás de efeito estufa e outros efeitos nocivos.

O Centro de Tratamento de Resíduos CTRRio, em Seropédica, inaugurado em 20 de abril de 2011, foi implantado em uma área de
220 hectares, passando a receber gradativamente os resíduos gerados na cidade do Rio de Janeiro, e com isto, viabilizando o processo de desativação do Aterro Metropolitano de Jardim Gramacho AMJG, em Duque de Caxias, encerrado em junho de 2012.

No decorrer de 2014, esta unidade recebeu, em média, 9.227 toneladas de lixo por dia do município do Rio de Janeiro, que podem ser assim resumidas:

- Lixo domiciliar (4.900 t/dia) que, acrescido do lixo público coletado (2.832 t/dia), alcançou o total de 7.732 t/dia;

- Demais resíduos de competência municipal (remoção gratuita, atendimento a emergência, remoção de resíduos dos 
serviços municipais de saúde, entre outros de origem menos relevante) que somaram 638 t/dia;

- Resíduos de grandes geradores, aí incluídos os resíduos da construção civil, que atingiram o total de 857 t/dia.

O biogás, atualmente gerado na ordem de $3.400 \mathrm{Nm}^{3} / \mathrm{h}$ (81.600 Nm³/dia), é encaminhado para queima em flare, tendo previsão de seu aproveitamento para geração de energia ou comercialização. No processo de queima em flare, o metano presente no biogás é transformado em gás carbônico, que é 21 vezes menos poluente do que o gás metano, proporcionando uma redução significativa de emissões de gases do efeito estufa.

A exigência de encaminhamento futuro de apenas rejeitos aos aterros sanitários, conforme preconiza a PNRS, aponta para a identificação de alternativas de tratamento da parcela orgânica do lixo, que poderá ser através de unidades descentralizadas de compostagem ou de biodigestores com aproveitamento energético, entre outras. Com isso, existe um projeto piloto de Biometanização, em fase de implantação, na unidade operacional da COMLURB, no bairro do Caju.

\subsection{RSU NO JAPÃO}

Segundo Yamamoto (2002), um resíduo, especialmente o de cozinha, é geralmente degradável e causa problemas, tais como doenças infecciosas, vermes, poluição da água e mau cheiro.

No Japão, o processo de incineração foi considerado o principal sistema de eliminação de resíduos sólidos do século passado e o aterro foi apenas um sistema secundário, usado principalmente para receber resíduos. Tal como outros países, os aterros de resíduos sólidos foram tratados apenas como locais de despejo, sem qualquer controle, mesmo após a Segunda Guerra Mundial. Assim, como resultado da preocupação crescente com o ambiente e as dificuldades na construção de novos aterros, que era causada pela reação contrária dos residentes (NIMBY - not in my backyard), a redução da quantidade de resíduos a serem depositados em aterros tornou-se uma meta urgente na gestão de resíduos, tanto a nível local como governo nacional (Tanaka et. al., 2005).

As tendências recentes na estratégia de aterro nos países desenvolvidos são a aeração e menos conteúdo orgânico nos resíduos. No Japão, a incineração de RSU tem sido a estratégia nacional desde a primeira lei moderna de resíduos sólidos em 1900, e os conteúdos incombustíveis são removidos na fonte antes da incineração. A separação na fonte entre resíduos combustíveis e incombustíveis é comumente praticada em municípios no Japão. O Japão está liderando o mundo em estratégias de aterro sustentável que promovem a estabilização e o pós-uso da terra (Tanaka et. al., 2005).

Segundo Tanaka et. al. (2005), no Japão, em média, cada cidadão contribuía com 0,6 kg por dia para a coleta de resíduos, ou 1,1 kg, quando os resíduos comerciais e empresariais eram incluídos. Contudo, em 2000, devido à prática comum de prétratamento para reduzir a quantidade de rejeitos, o total de resíduos depositados em aterros diminuiu para 0,23 kg por pessoa por dia, tendo contribuição do aumento da taxa de incineração e da reciclagem ativa de resíduos de embalagens (garrafas de vidro, latas de aço / alumínio e plásticos).

\subsection{RSU NA EUROPA}

A utilização de processos de metanização para tratamento de resíduos orgânicos pode ser considerada como a maior evolução europeia na gestão de resíduos durante as duas últimas décadas, marcadas pela expansão da tecnologia para a valorização da FORSU, particularmente nos últimos 10 anos (DE BAERE e MATTHEEUWS, 2008). Atualmente, essas tecnologias vêm dominando uma significativa parcela do mercado europeu na área de tratamento e valorização de resíduos, principalmente em países como Alemanha, Suécia, França, Espanha e Itália (PROBIOGÁS, 2015).

Segundo Schu (2008), as primeiras plantas demonstrativas das tecnologias de metanização seca atualmente disponíveis no mercado foram instaladas em 1984 - a primeira unidade foi construída na cidade de Gent, na Bélgica, em 1984, com tecnologia Dranco. Posteriormente, em 1988, na cidade de La Buisse, na França, foi construída a primeira planta com tecnologia Valorga.

Em 1990, a Europa dispunha de apenas três plantas industriais para a metanização de resíduos orgânicos, provendo uma capacidade instalada de 87.000 ton/ano. 
Entretanto, seguiram-se duas décadas que representaram a consolidação da metanização na Europa que, em 2010, já contabilizava 171 plantas, atingindo a capacidade total instalada de 5.204 .000 ton/ano, o que representou um acréscimo de quase $6.000 \%$ em um período de 20 anos (DE BAERE e MATTHEEUWS, 2008).

De modo geral, a ampliação na utilização de processos anaeróbios na Europa pode ser atribuída, basicamente, a fatores como os elevados preços da energia e incentivos governamentais para o setor; às restrições ambientais para a disposição de matéria orgânica em aterros sanitários; e às dificuldades na implantação de novos aterros ou na expansão das áreas existentes. De acordo com Kelleher (2007), uma parte significativa do interesse europeu na implantação de unidades de metanização da FORSU se deve em função da implementação da Diretiva Europeia 1999/31 relativa à deposição de resíduos em aterros sanitários. Essa diretiva, alterada pelo Regulamento (CE) 1882/2003 do Parlamento Europeu e do Conselho, estabeleceu que os Estados Membros da União Europeia reduzissem gradativamente a concentração de RSU biodegradáveis a serem destinados aos aterros, sendo que a matéria orgânica remanescente deveria sofrer algum processo de estabilização. A aplicação desta normativa nos países membros se dá através de decretos ou de leis locais. Por exemplo, em Portugal, através do Decreto de Lei 183/2009, onde se estabeleceu que até julho de 2013 os RSU biodegradáveis destinados a aterro sanitário deveriam ser reduzidos para 50\% da quantidade total, em peso, dos RSU biodegradáveis produzidos em 1995 e, que até julho de 2020, esse percentual seja de $35 \%$.

\section{TECNOLOGIAS PARA O TRATAMENTO DA FORSU}

\subsection{PROCESSO DRANCO}

O sistema Dranco é um processo de digestão anaeróbia termofílico via seca. O reator é de único estágio, fluxo contínuo, vertical, de formato cilíndrico e fundo cônico, tendo seu design similar a um silo de armazenamento.

O processo de alimentação ocorre uma vez ao dia, via bombas similares às utilizadas no bombeamento de concreto, introduzindo o material na parte superior do reator e a extração pela base, promovendo um fluxo descendente do material. O sistema de mistura dispensa agitadores mecânicos, sendo realizado por recirculação do material em digestão, processo esse que ocorre geralmente de forma contínua. Durante esse processo, o resíduo a ser alimentado é misturado ao material em digestão em proporções de até 6:1 (material digerido: resíduo fresco).

De acordo com informações obtidas na página web da empresa, atualmente existem 27 plantas construídas ou em construção com esta tecnologia na Europa e na Ásia (Fonte: http://www.ows.be/biogas-

plants/references/?dranco=refhouseholdwaste-dranco, 2017).

\subsection{PROCESSO AXPO KOMPOGAS}

O sistema Kompogas é um processo de digestão anaeróbia via seca, majoritariamente operado na faixa termofílica $\left(55-60^{\circ} \mathrm{C}\right)$. O reator é de único estágio, fluxo pistão com alimentação semicontínua, horizontal de formato retangular e fundo cilíndrico ou totalmente cilíndrico, construído em concreto armado ou aço.

De acordo com informações da empresa, atualmente, existem 50 plantas em execução ou operação com a tecnologia Kompogas. (Fonte: http://www.hzinova.com/cms/en/home?page_id=9, 2017).

\subsection{PROCESSO VALORGA}

O sistema Valorga é um processo de digestão anaeróbia via seca, majoritariamente operado na faixa mesofílica, sendo o reator de único estágio, fluxo semicontínuo, vertical, de formato cilíndrico, construído em concreto armado. O sistema de alimentação é realizado de forma semicontínua com a introdução do material via bombas similares às utilizadas para bombeamento de concreto.

De acordo com informações da empresa, atualmente existem 27 plantas no mundo com tecnologia Valorga. (Fonte: http://www.valorgainternational.fr/fr/pag8REFERENCES.html, 2017).

\subsection{O PROCESSO LARAN (EX-LINDE-BRV)}

O sistema Laran, originalmente conhecido como Linde-BRV, é um processo de digestão 
anaeróbia via seca, que pode operar nas faixas termofílica ou mesofílica, com reator de único estágio, fluxo pistão semicontínuo, horizontal de formato retangular, construído em concreto armado (PROBIOGÁS, 2015).

O sistema Laran trata diversos tipos de resíduos com elevado teor de sólidos, aceitando resíduos orgânicos de poda, agrícolas, de indústrias, além de FORSU. O processo de agitação é realizado com o auxílio de pás rotatórias perpendiculares às paredes laterais do reator, fixados em eixos perpendiculares ao fluxo do material em digestão. Em 2008, existiam 21 plantas construídas ou em construção com essa tecnologia no mundo (PROBIOGÁS, 2015).

\subsection{SISTEMA DE GARAGEM (TÚNEIS DE METANIZAÇÃO)}

O sistema de metanização tipo garagem se caracteriza pela sua construção em forma de túneis, ou garagens, operando em bateladas sequenciais, esvaziados e alimentados com FORSU. Trata-se de um processo de digestão anaeróbia via extrasseca, operado na faixa mesofílica, sendo o reator disposto na horizontal, de formato retangular, construído geralmente em concreto armado (PROBIOGÁS, 2015).

O sistema de alimentação e extração é realizado via pá carregadeira. Como sistema auxiliar, realiza-se a recirculação do lixiviado, que é direcionado a um reator de líquido para posterior reintrodução no processo, via aspersão no material em digestão (PROBIOGÁS, 2015).

O grande diferencial deste sistema é a possibilidade de utilização de resíduo com elevado teor de impróprios (plásticos, vidros, madeira pedras e outras). Devido ao fato do reator ser continuamente aberto para remoção do material digerido, não há possibilidade de acúmulo de impróprios no seu interior, fato que ocorre com frequência nas tecnologias de fluxo pistão e prejudica o funcionamento (PROBIOGÁS, 2015).

Em adição, podem-se enumerar as seguintes vantagens e desvantagens das tecnologias secas (PROBIOGÁS, 2015):

Processo Dranco - Vantagens: Agitação via recirculação por bombas hidráulicas; Inexistência de elementos internos ao reator, reduzindo problemas e demanda de manutenção; Existência de departamento de pesquisa e desenvolvimento competente, ativo em publicações e melhorias de processo. Desvantagens: Necessidade de correção do teor de matéria seca com adição de insumos que necessitam ser adquiridos (normalmente terras diatomáceas); Necessidade de constante recirculação do material em digestão para impedir a sedimentação dos mesmos; Sistema de introdução do material via bombas do tipo pistão, que necessitam limpeza manual diária; Níveis muito altos de impurezas no RSU exigem pré-tratamento.

Processo Kompogas - Vantagens: Sistema de agitação eficiente, apesar da presença de elementos mecânicos internos; Experiência no mercado; Experiência com diferentes tipos de substratos. Desvantagens: Sistema de agitação mecânico e interno ao reator, sendo que a manutenção dos mesmos requerem a interrupção do processo; Possibilidades de falhas no sistema de extração, sendo necessário um procedimento manual de desobstrução da tubulação; Níveis muito altos de impurezas no RSU exigem pré-tratamento.

Processo Valorga - Vantagens: Engenharia do reator permite a instalação de plantas com elevada capacidade instalada; Agitação pneumática, sem elementos mecânicos; Maior simplicidade construtiva que as tecnologias secas tradicionais. Desvantagens: Sistema de agitação via injeção de biogás comprimido na parte inferior, demandando limpeza manual diária para desobstrução dos canais de injeção; Necessidade de constante recirculação do material em digestão, para impedir a sedimentação dos mesmos; Sistema de introdução do material via bombas do tipo pistão, que necessitam limpeza manual diária; Níveis muito altos de impurezas no RSU exigem pré-tratamento.

Processo Laran - Vantagens: Sistema de extração eficiente; Experiência no mercado. Desvantagens: Sistema de agitação mecânico e interno ao reator, sendo que a manutenção dos mesmos requerem interrupção do processo; Sistema de extração por bomba de vácuo, necessitando tanques e equipamentos adicionais; Níveis muito altos de impurezas no RSU exigem pré-tratamento.

\section{CONCLUSÕES}

Face ao exposto, é possível evidenciar que as tecnologias secas de fluxo contínuo ou semicontínuo apresentam problemas operacionais 
relacionados à acumulação de materiais sedimentáveis impróprios ao processo de digestão anaeróbia (pedra, vidro, plástico, etc.) no interior do biodigestor. Tal fato prejudica a eficiência operacional das plantas e compromete as estruturas dos componentes do sistema, podendo culminar na falha e interrupção do processo.

\section{RFERÊNCIAS}

[1] Allan Gerlat, Study: Municipal Solid Waste Generation Could Double by 2025, Waste 360, jul 30, 2012. Disponível em: <http://www.waste360.com/research-andstatistics/study-municipal-solid-waste-generationcould-double-2025>. Acesso em: 30/04/2017.

[2] DE Baere, L.; Mattheeuws, B. State-of-theart 2008 - Anaerobic Digestion of Solid Waste. Waste Management World. v.9, N. 4, 2008.

[3] Hitachi Zosen. Disponível em: $<$ http://www.hz-

inova.com/cms/en/home?page_id=9>. Acesso em: 30/04/2017

[4] Kelleher, M. Anaerobic Digestion Outlook for Msw Streams, BioCycle, Vol. 48, N. 8, p. 51, 2007.

[5] Ministério das Cidades, PROBIOGÁS, O ESTADO DA ARTE DA TECNOLOGIA DE METANIZAÇÃO SECA, 2015. Disponível em: $<$ http://www.cidades.gov.br/images/stories/Arquivo sSNSA/probiogas/probiogas-metanizacaorsu.pdf>. Acesso em: 30/04/2017.
Não obstante, a tecnologia extresseca de "Túneis de Metanização" não apresenta esses problemas operacionais comuns em plantas com tecnologia seca, que devem ser considerados em avaliações para a implantação de um projeto desse tipo em países onde não se pratica a segregação na fonte de Resíduos Sólidos Urbanos.

[6] Organic Waste Systems. Disponível em: http://www.ows.be/household_waste/dranco/>. Acesso em: 30/04/2017.

[7] Prefeitura da Cidade do Rio de Janeiro, Plano Municipal de Gestão Integrada de Resíduos Sólidos - PMGIRS da Cidade do Rio de Janeiro 2017-2020, 28/11/2016.

[8] Schu, K. Anaerobic Digestion of Waste: Problems with Contraries and Innovative Solutions. SECOND INTERNATIONAL SYMPOSIUM ON ENERGY FROM BIOMASS AND WAST, Veneza, 2008.

[9] Tanaka, B.; Tojo, Y.; Matsuto, T.; J Mater Cycles Waste Manag. Past, present, and future of MSW landfills in Japan, 2005.

[10] Valorga International. Disponível em: < http://www.valorgainternational.fr/fr/>. Acesso em: 30/04/2017.

[11] Yamamoto, O. Proceedings of International Symposium on Environmental Pollution Control and Waste Management. Solid waste treatment and disposal experiences in Japan, p.417-424, 2002. 


\title{
Bapítulo 19
}

\section{CONFLITOS NA PRESTACÃO DE SERVICOS PÚBLICOS EM ÁREAS DE PROTECÃO PERMANENTE (APPS) - UMA ANALISE A PARTIR DO MUNICIPIO DE ITABORAI/RJ}

\author{
Pando Angeloff Pandeff \\ Alexandre de Vasconcellos Faria \\ Louise Angeloff \\ Kely Betânia Abrão Borges
}

Resumo: O presente estudo promove uma análise dos conflitos estabelecidos em áreas de APP (Áreas de Proteção Permanente), em especial sob a ótica de residentes que necessitam de serviços públicos fornecidos pelas concessionárias de energia entre outras e as bases legais de proteção das APPs. Buscou-se identificar os principais fatores geradores dos conflitos e a efetiva proteção do ambiente, considerando-se para tal, áreas urbanas já antopizadas por ocupação das FMPs (Faixas Marginais de Proteção) decorrentes da incapacidade do ente público em regular o uso e ocupação do solo em seu território. O acesso aos serviços públicos essenciais é garantia constitucional, mas o que se observa no cotidiano é o aumento crescente dos conflitos entre a necessidade da população e a resistência das concessionarias em fornecer tais serviços. O método de pesquisa utilizado foi o bibliográfico associado a um estudo de caso comparativo tendo como base o município de Itaboraí/RJ. Os resultados indicam que vários são os fatores contribuintes para que os conflitos se estabeleçam, cuja grande maioria e originados na própria administração pública, que autoriza construções e fornece o habite-se sem considerar as restrições em se tratando de áreas de APP e FMP, levando as concessionárias a demandarem dos moradores, autorizações específicas para os imóveis receberem os serviços, em cumprimento da legislação protetiva, recaindo assim o ônus sobre a população e levando os conflitos ate as esferas judiciais. O estudo é fruto de monografia apresentada no curso de Direito da Faculdade Itaboraí - Rede CNEC, em continuidade a outros correlatos em desenvolvimento no Município.

Palavras chave: APP. Conflitos. Itaboraí/RJ. Serviços Públicos. 


\section{INTRODUÇÃO}

A Constituição Federal de 1988 (CF-88) garante, em seu artigo 225, que o meio ambiente ecologicamente equilibrado é um bem de uso comum de toda a população brasileira, que é essencial à uma qualidade de vida sadia e atribui, ainda, ao poder público e a toda a coletividade o dever de preservá-lo e defendê-lo para as futuras gerações, bem como para a presente geração.

Ainda sob a ótica da CF-88 verifica-se que com a Emenda Constitucional no 26/2000, que trouxe alterações ao artigo 6 o da Constituição Federal, o direito à moradia ficou garantido enquanto direito social.

Dessa forma, fica evidenciado que a busca pela justiça social deve-se se pautar também na busca para que todos tenham acesso à moradia, ficando atribuído, portanto, ao poder público o dever de promover o referido acesso à moradia por meio de políticas de habitação social, devendo, para tal, promover o desenvolvimento urbanístico planejado, a fim de promover em conjunto, políticas ambientais de restauração, preservação e equilíbrio ecológico.

A Constituição trata também da prestação de serviços públicos como dever do Estado, e de prestá-los diretamente, por concessão ou por permissão, sendo para o presente estudo destacada a prestação do serviço de fornecimento de energia elétrica, água e esgoto.

Assim, no contexto do direito aos serviços e a prestação efetiva dos mesmos à população é que se instalam os conflitos, sendo estes, fruto do aumento populacional que aumenta a pressão sobre os espaços urbanos com maior demanda por moradias e consequentemente por mais serviços públicos, gerando assim mais pressão sobre o ambiente, em um ciclo vicioso de eventos que dão base para a ocorrência de conflitos ou ampliação destes.

Outro aspecto relevante que contribui para os conflitos e o desrespeito à norma Constitucional prevista no artigo 225 é o desenvolvimento urbano sem planejamento e sem estudos efetivos dos impactos ambientais pode ocasionar, onde se verifica não só o surgimento de moradias que ocupam irregularmente determinadas áreas consideradas protegidas, mas a anuência do Poder Público que concede autorização para construção sem verificar as restrições ambientais existentes como também as moradias que são construídas de forma irregular por famílias consideradas em risco social, mas que necessitam de uma moradia que atenda suas condições mínimas de existência e dignidade.

Estas residências, não poucas vezes, acabam por ser construídas em locais classificados como: Áreas de Proteção Permanentes (APPs), o que acaba por gerar problemas e conflitos envolvendo os três segmentos representativos da sociedade: público, privado e social.

O Novo Código Florestal de 2012 (Lei 12.651/12) em seu artigo $3^{\circ}$ inciso II, faz a previsão legal das APPs, que são áreas protegidas e que tem por fim, entre outros aspectos, a preservação de recursos hídricos, em especial nos espaços urbanos.

Para tanto faz previsão das Faixas Marginais de Proteção (FMPs) e respectivos afastamentos das APPs para edificações, devendo estar há pelo menos 30 metros de afastamento, a contar da margem do rio ou córrego, sendo ressalvados, em áreas já antropizadas, cujo afastamento mínimo previsto é de 15 metros, aceitável afastamento menor com base na legislação estadual e em áreas urbanas densamente povoadas.

Nesse contexto, tem-se que, construções que necessitam de serviços públicos como: energia elétrica, entre outros, estando estas construções situadas em áreas consideradas protegidas por Lei, à primeira vista, podem apresentar algum impedimento para as concessionárias de serviços públicos prestem seus serviços nessas áreas, sob pena de multa e outras sanções legais.

Verifica-se no cotidiano das demandas que, o cidadão requer a prestação do serviço público à concessionária e esta por sua vez nega alegando estar impedida pela legislação em função da área ser uma APP, solicitando assim ao requerente, autorização do órgão ambiental competente para que o serviço seja fornecido e dessa forma estabelecendo o impasse que acaba sendo levado às esferas judiciais para dirimir a questão.

$\mathrm{Na}$ medida em que as Políticas de Ordenamento Territorial não são eficazes, o que se verifica é o crescente assentamento de famílias às margens de rios e córregos, agravando ainda os riscos à saúde e aumentando a pressão sobre o ambiente, e consequentemente aumentando os conflitos já 
estabelecidos, evidenciado assim o desrespeito ao cumprimento das previsões legais, e nesse caso, o principal agente gerador dos conflitos é o próprio poder público.

Em todas as bases legais que versam sobre habitação e desenvolvimento urbano em APPs, verifica-se a intenção de preservação ambiental, permitindo-se a ação humana de forma sustentável, a fim de promover a recuperação da vegetação, fauna e flora local, porém, o que se observa no cotidiano é que $\mathrm{O}$ ambiente natural acaba por ser pressionado além de sua capacidade de suporte pela inobservância plena dos preceitos legais.

Dessa forma o estudo foca no crescente número de demandas judiciais no tocante de conflitos entre moradores que construíram suas residências, devidamente autorizadas pelo poder público, em APPs que já antropizadas, com inúmeras outras moradias com fornecimento de energia e que quando solicitaram serviço de instalação de medidores, tiveram seu pedido negado pela concessionária, recorrem ao judiciário em última instância.

O estudo busca assim apresentar alternativas para os conflitos evidenciados, tomando como base comparativa o Município de Itaboraí/RJ e contribuir para encaminhamento de demandas futuras.

\section{OBJETIVOS}

\subsection{OBJETIVO GERAL}

Analisar os conflitos estabelecidos quando da necessidade de prestação de serviços públicos em áreas de APP e a efetividade das soluções conduzidas pelo executivo municipal.

\subsection{OBJETIVOS ESPECÍFICOS}

- Promover revisão de literatura identificando os principais conceitos norteadores do estudo e bases legais associadas.

- Desenvolver estudo de caso sobre os conflitos estabelecidos em áreas de APP quando da demanda de serviços públicos.

- Identificar como os conflitos se estabelecem e as ações desenvolvidas para a solução destes.
- Promover comparação entre as demandas, os conflitos e as bases legais vigentes.

- Com base nos resultados obtidos, apresentar proposições para a melhoria na prestação dos serviços e redução de conflitos.

\section{METODOLOGIA}

A metodologia utilizada para o desenvolvimento do estudo foi a pesquisa bibliográfica de forma a definir conceituar os principais conteúdos apresentados sendo utilizada literatura específica a partir de livros e publicações especializadas, Legislação vigentes no âmbito federal, estadual e municipal e relatórios oficiais.

De forma complementar foi desenvolvido estudo de caso comparativo a partir do Município de Itaboraí/RJ onde se apresentam situações que configuram os conflitos nas APPs, sendo para tanto desenvolvidas observações em campo e utilizadas imagens geo referenciadas do aplicativo Google Earth associado à base de dados da hidrografia municipal.

Com base nos resultados obtidos foi possível caracterizar conflitos e identificar os fatores geradores destes comparando a realidade local observada e as previsões legais, permitindo assim, nas conclusões do estudo, inferir soluções possíveis e legais para os conflitos atuais e futuros.

\section{DESENVOLVIMENTO}

\subsection{SERVIÇOS PÚBLICOS OU CONCEDIDOS}

A Constituição Brasileira de 1988 trouxe a previsão legal para que o Estado preste serviços públicos. Tal prestação deve ocorrer por meio de permissão ou concessão. E ainda, poderá os serviços públicos serem prestados diretamente pelo Estado.

\footnotetext{
Art. 175. Incumbe ao Poder Público, na forma da lei, diretamente ou sob regime de concessão ou permissão, sempre através de licitação, a prestação de serviços públicos (CONSTITUIÇÃO FEDERAL, 1988).
}

O parágrafo único do mesmo artigo indica que a lei deverá dispor, entre outros aspectos, 
sobre os direitos dos usuários e sobre a obrigação dos prestadores de serviços públicos de prestarem um serviço adequado.

Neste sentido é possível observar a regularização dos serviços públicos no Código de Defesa do Consumidor (CDC) (Lei 8.078/90) e na Lei ํo: 8.897/95.

O CDC traz em seu artigo $3^{\circ}$, parágrafo $2^{\circ}$ a definição de serviços, ora seja, "qualquer atividade fornecida no mercado de consumo, mediante remuneração, inclusive as de natureza bancária, financeira, de crédito e securitária, salvo as decorrentes das relações de caráter trabalhista" inserindo assim a ideia de serviços.

Ainda em seu artigo 4, o CDC define as diretrizes pela qual a política nacional das relações de consumo devem se guiar, destacando-se entre os princípios elencados no referido artigo, o previsto no inciso VII, que diz que a racionalização e a melhoria dos serviços públicos é um dos princípios norteadores da política nacional das relações de consumo.

Pode-se observar que o CDC, com base no ordenamento constitucional contido no inciso primeiro do parágrafo único do artigo 175 da Constituição Federal, faz a regulamentação do direito do usuário do serviço público por parte dos prestadores de serviços públicos, ou mesmo o próprio poder público, quando na qualidade de prestador direto de serviço público, se norteie pela busca por uma constante melhoria nos serviços prestados.

De forma complementar, a Lei no: 8.078/90 sobre serviços públicos em seu artigo 22 traz o seguinte texto:

\begin{abstract}
Art. 22. Os órgãos públicos, por si ou suas empresas, concessionárias, permissionárias ou sob qualquer outra forma de empreendimento, são obrigados a fornecer serviços adequados, eficientes, seguros e, quanto aos essenciais, contínuos (CDC - LEI 8.078/90).
\end{abstract}

Essa Lei traz definições e exemplificações do que são serviços adequados e do que são direitos dos usuários, de acordo com o parágrafo $2^{\circ}$ do artigo $6^{\circ}$ da referida Lei: "serviço adequado é o que satisfaz as condições de regularidade, continuidade, eficiência, segurança, atualidade, generalidade, cortesia na sua prestação e modicidade das tarifas.".

Na análise do artigo 7ํ e 7-A da Lei 8.987/95 que dispõe sobre o rol de direitos ao usuário, bem como suas obrigações, os direitos elencados seguem uma tendência que preza pela adequação dos serviços, transparência, informação, concorrência entre prestadores sempre que possível, escolha entre datas de vencimento, entre outros. Já no quesito obrigações do usuário, destaca-se a obrigação de informar ao poder público as irregularidades e ilícitos praticados pelos prestadores, bem como o dever de preservar os bens públicos meios de prestação dos serviços públicos.

Assim, conceitualmente é possível definir serviços públicos como sendo aqueles serviços que o Estado avocou para si a responsabilidade de prestá-los diretamente ou mediante concessão e/ou permissão, uma vez que entende-se que, sua natureza é essencial para suprir uma necessidade da coletividade. Para assegurar uma melhor qualidade de vida de seu povo, para garantia da dignidade da pessoa humana e salvaguardar o direito do Estado sobre determinadas áreas de atuação mercadológica essencial para a segurança nacional.

Embasando esse entendimento, Filho (2008, p.305) e Meirelles (2008, p.333) diz que serviços públicos são:

Toda atividade prestada pelo Estado ou por seus delegados, basicamente sob o regime de direito público, com vistas a satisfação de necessidades essências e secundárias da coletividade.

Serviço público é todo aquele prestado pela Administração ou por seus delegados, sob normas e controles estatais, para satisfazer a necessidades essências ou secundárias da coletividade ou simples conveniências do Estado.

É possível perceber que há uma consonância entre os doutrinadores no sentido de que a objetividade dos serviços públicos é satisfazer as necessidades coletivas.

E neste sentido, uma vez que a CF-88 faz previsões de que um meio ambiente ecologicamente equilibrado é um direito de todos, e que é essencial a uma qualidade de vida sadia, atribuindo ainda, tanto à 
coletividade como ao Poder Público, a responsabilidade de defendê-lo e preservá-lo, evidenciam-se as obrigações dos prestadores de serviço público nesse sentido e também de garantir os direitos dos usuários dos serviços públicos e que necessitam suprir suas necessidades básicas previstas por Lei.

\subsection{O CONFLITO}

A palavra conflito indica que sobre determinado ponto de interesse, objeto, local, ou qualquer tipo de coisa tangível ou não, há uma tensão ocasionada por forças antagônicas e/ou divergentes.

Para o Direito Ambiental conflito significa a disputa entre no mínimo três esferas (Poder Público, Iniciativa Privada e Social) sobre o mesmo ponto de interesse.

O dicionário Houaiss (2009, p.520) define conflito da seguinte forma:

\section{n. substantivo masculino}

1 profunda falta de entendimento entre duas ou mais partes.

2 Derivação: por extensão de sentido. Choque, enfrentamento.

3 Derivação: por extensão de sentido. Discussão acalorada; altercação.

4 Derivação: por analogia. Ato, estado ou efeito de divergirem acentuadamente ou de se oporem duas ou mais coisas.

5 Rubrica: administração. Contestação recíproca entre autoridades pelo mesmo direito, competência ou atribuição [...]

Do ponto de vista do conflito, o estudo analisa o contexto onde o Poder Público tem o dever de promover um meio ambiente ecologicamente equilibrado, porém, por a incapacidade de efetivar uma política de ordenamento territorial e políticas de habitação que atendam as demandas crescentes, somados a falta de efetiva fiscalização, permite que as faixas marginais de Proteção de rios, córregos e nascentes sejam ocupadas e ali se instalem comunidades que, para a garantia da dignidade da pessoa humana, precisam ter acesso aos serviços públicos essenciais.

\subsection{A AREA DE PRESERVAÇÃO PERMANENTE (APPS)}

O Novo Código Florestal Brasileiro (Lei $n^{\circ}$ 12.651/2012) tem por função a regulamentação legal das florestas e demais tipos de vegetação, de forma que a lei as considera bens de interesse da comunidade, em consonância com 0 dispositivo Constitucional previsto no artigo 225.

Assim, o novo código legal, prevê ainda o uso sustentável das florestas, bem como um conjunto harmônico entre preservação ambiental e desenvolvimento econômico, como se observa no Art. 1 ㅇe em destaque:

\begin{abstract}
Art. 1-A. Esta Lei estabelece normas gerais sobre a proteção da vegetação, áreas de Preservação Permanente e as áreas de Reserva Legal; a exploração florestal, o suprimento de matéria-prima florestal, o controle da origem dos produtos florestais e o controle e prevenção dos incêndios florestais, e prevê instrumentos econômicos e financeiros para $\mathrm{o}$ alcance de seus objetivos (CODIGO FLORESTAL BRASILEIRO - LEI 12.651/12)
\end{abstract}

Nesse contexto, as Áreas de Preservação Permanente (APPs), são áreas de interesse ambiental que tem por natureza jurídica a de limitação administrativa, ou seja, ainda que propriedades situadas em APPs sejam transferidas, a obrigação permanece vinculada ao bem imóvel.

O conceito de APPs está definido no artigo 3은 inciso II da Lei $n^{\circ}$ 12.651/2012, que segue:

\footnotetext{
II - Área de Preservação Permanente APP: área protegida, coberta ou não por vegetação nativa, com a função ambiental de preservar os recursos hídricos, a paisagem, a estabilidade geológica e a biodiversidade, facilitar o fluxo gênico de fauna e flora, proteger o solo e assegurar o bem-estar das populações humanas.
}

O Código Florestal de 1934 não fazia uma previsão específica de área de preservação permanente, sua menção era sobre florestas protetoras. A grande diferença entre o código de 1934 e o atual de 2012 é que o dispositivo contemporâneo faz a previsão de que as 
áreas de preservação permanente possam ser cobertas por vegetação nativa ou exótica.

A lei determinou para as APPs, a função ambiental de garantir o equilíbrio ecológico previsto no artigo 225 da Constituição Federal, onde se verifica que a intenção foi o de preservar não somente os recursos hídricos, mas também a biodiversidade e fluxo gênico de fauna e flora. Todos os bens apontados pelo artigo estão intrinsecamente ligados, sendo, portanto, impossível relativizar o bem ambiental ante a sua função.

As APPs podem ser localizadas em propriedades privadas ou em propriedades públicas, rural ou urbana, coberta de vegetação nativa ou exótica.

Quanto a propriedade a qual encontra-se situada em APPs, ante a natureza de limitação administrativa, não onera o Estado a efetuar a desapropriação e consequente indenização ao proprietário.

A limitação administrativa imposta ao proprietário, possuidor ou ocupante, pessoa física ou jurídica, de direito privado ou público, é a de manter a vegetação nativa ou exótica.

Nos casos em que acontecer a supressão da vegetação em APPs, o proprietário, possuidor ou ocupante deve efetuar a recomposição da vegetação. Porém existem ressalvas, sendo possível legalmente, mediante prévia autorização pelo órgão competente, o uso sustentável das áreas protegidas (SIRVINSKAS, 2015)

Nesse contexto, o Novo Código Florestal faz previsão para apenas três possibilidades para desmatamento em APPs: Utilidade pública, interesse social e/ou atividades de baixo impacto ambiental.

Por interesse social, considera-se atividades de obras para melhoria de infraestrutura para serviços públicos de transporte, saneamento, energia, radiodifusão, telecomunicações, entre outros.

$\mathrm{Na}$ categoria de interesse social aponta-se a infraestrutura pública para prática de esportes, lazer, atividades educacionais e culturais. Assim como regularização de assentamentos ocupados por população de baixa renda.

Quanto as atividades de baixo impacto ambiental, configura-se pela abertura de trilhas para ecoturismo e outras atividades correlatas e que possam ser realizadas de forma sustentável.

Dessa forma e independentemente do motivo que ocasionou a supressão da vegetação, esta precisa ser previamente autorizado pelo órgão ambiental competente.

\subsection{BASES LEGAIS PARA AS APPS}

A primeira base legal para a constituição de áreas de preservação está na Constituição Federal de 1988, em seu artigo 225. Observase no referido dispositivo o ordenamento do legislador constituinte de que o Poder Público tem o dever de proporcionar um ambiente ecologicamente equilibrado, sendo este artigo da CF-88 o ponto de partida para a estruturação legal do Direito Ambiental brasileiro, pois faz as previsões quanto ao dever do poder público defender e preservar o meio ambiente.

Assim, verifica-se que já no $\S 1^{\circ}$, III, do art. 225, é atribuído ao poder público o dever de, para assegurar a efetividade do caput do próprio artigo, definir os componentes que devem ser protegidos em todo o território nacional, inclusive as APPs, que tiveram sua regulamentação no Novo Código Florestal.

O artigo 1-A da lei $n=12.651 / 2012$, determina que se estabeleçam as normas gerais sobre as APPs, sendo então definidas no artigo $3^{\circ}$ inciso II:

II - Área de Preservação Permanente APP: área protegida, coberta ou não por vegetação nativa, com a função ambiental de preservar os recursos hídricos, a paisagem, a estabilidade geológica e a biodiversidade, facilitar o fluxo gênico de fauna e flora, proteger o solo e assegurar o bem-estar das populações humanas;

Já o artigo 4ํ do Código Florestal cria um rol de áreas estabelecidas como APPs, definindo parâmetros que devem ser observados para a identificação dessas áreas, sendo estes:

As faixas marginais de qualquer curso d'água natural perene e intermitente, com exceção dos cursos d'água efêmeros, devendo ser observado para se configurar uma APP, a determinação de sua extensão e a largura dos cursos d'água.

Seguindo alíneas do inciso I do artigo $4^{\circ}$ da Lei $n^{\circ}$ 12.651/2012, as extensões da área 
protegida referente à largura do curso d'água são definidas da seguinte forma:

I - as faixas marginais de qualquer curso d'água natural perene e intermitente, excluídos os efêmeros, desde a borda da calha do leito regular, em largura mínima de:

a) 30 (trinta) metros, para os cursos d'água de menos de 10 (dez) metros de largura;

b) 50 (cinquenta) metros, para os cursos d'água que tenham de 10 (dez) a 50 (cinquenta) metros de largura;

c) 100 (cem) metros, para os cursos d'água que tenham de 50 (cinquenta) a 200 (duzentos) metros de largura;

d) 200 (duzentos) metros, para os cursos d'água que tenham de 200 (duzentos) a 600 (seiscentos) metros de largura;

e) 500 (quinhentos) metros, para os cursos d'água que tenham largura superior a 600 (seiscentos) metros;

O art.4, II faz as previsões legais para as APPs situadas no entorno de lagos e lagoas naturais, seguindo o mesmo padrão dos cursos d'água, onde as dimensões, neste caso, do lago ou lagoa vai determinar a extensão da área protegida.

II - as áreas no entorno dos lagos e lagoas naturais, em faixa com largura mínima de:

a) 100 (cem) metros, em zonas rurais, exceto para o corpo d'água com até 20 (vinte) hectares de superfície, cuja faixa marginal será de 50 (cinquenta) metros;

b) 30 (trinta) metros, em zonas urbanas;

E no art. 6 se estipula que, a interesse social, o chefe do executivo, poderá declarar como APP as áreas cobertas por floresta ou demais formas de vegetação que cumpram ao menos uma das finalidades elencadas nos incisos do referido artigo.

Com base na exposição inicial o estudo se foca nas seções seguintes sobre as questões e conflitos no âmbito do município de Itaboraí/RJ.

\subsection{CARACTERISTICAS GERAIS DO MUNICÍPIO DE ITABORAÍ/RJ}

O município de Itaboraí é localizado na região metropolitana do Estado do Rio de Janeiro, com uma extensão territorial de 430,374km², sendo limitado pelos municípios de Tanguá, Cachoeiras de Macacú, Guapimirim, São Gonçalo e Maricá (IBGE, 2016).

Sua população atual estimada pelo IBGE a partir do Censo 2010 é de 230.786 habitantes para o ano de 2016 (IBGE Cidades, 2016) e a sua realidade econômica gira, principalmente entorno do comércio e serviços, observando o trabalho manufaturado de cerâmicas, bem como agropecuária extensiva, apicultura e fruticultura.

Quanto ao relevo, o município conta com bairros localizados em locais mais altos, como o distrito de Sambaetiba, que fica na área da Serra do Barbosão, onde Itaboraí faz divisa com Tanguá e o distrito de Pacheco, que faz a divisa com Maricá na área da Serra do Lagarto.

O restante do território é composto por planícies, com poucas ondulações, onde se encontram os rios e córregos do município, estes confluem para a Baía de Guanabara porque uma parcela do território do município tem uma leve inclinação para a Baía.

Quanto a vegetação, o município conta com pastos, mangues, brejos e mata de encosta, esta última só é possível observar nas regiões mais altas do município, como nas serras do Barbosão e do Lagarto.

No ano de 2006 o município foi escolhido para sediar o COMPERJ - Complexo Petroquímico do Estado do Rio de Janeiro, sendo até então o maior empreendimento individual da Petrobrás, orçado inicialmente em US\$ 8,4 bilhões, sendo as obras iniciadas no ano de 2008 com a terraplenagem do terreno - área de 45 milhões de metros quadrados, gerando impactos sobre a bacia hidrográfica, alterando a drenagem e ainda sendo fator gerador do aumento da população flutuante.

A demanda por mão de obra para o processo de construção acarretou em um contingente de trabalhadores da ordem de 35.000 até início de do ano de 2014, influenciando a economia local e regional e ampliando os problemas relacionados a moradias e aumentando a pressão sobre a infraestrutura urbana. Mesmo com a paralisação das obras, parte desse contingente de trabalhadores permaneceu no município sem vínculos formais de trabalho, o que acarretou maior pressão sobre as áreas já sensíveis classificadas como em risco social 
(ITABORAÍ, 2016).

O COMPERJ não é o único elemento responsável pelo aumento da pressão sobre o ambiente e a bacia hidrográfica com consequente aumento da pressão sobre as APPs, porém, sendo o empreendimento responsável pelo o aumento da população flutuante, e este acarretou em aumento do número de residências em áreas de APPs.

Por outro lado, a incapacidade do executivo municipal em garantir que regras mínimas de uso e ocupação do solo fossem cumpridas ao longo dos anos contribuiu significativamente para ampliar o número de edificações, consequentemente ampliando os conflitos quando os serviços públicos são demandados pela população.

\subsection{CONFLITOS PERCEBIDOS NA PRESTAÇÃO DE SERVIÇOS}

Considerando que cabe ao Estado a prestação dos serviços públicos, de forma direta ou indireta, é esperado que esses serviços sejam prestados de forma adequada e segura, e que sejam melhorados continuamente, com bases nos parâmetros legais.

No contexto da prestação de serviços públicos e em particular sob a ótica do fornecimento de energia elétrica, objeto da análise comparativa para os conflitos em APPs, a ANEEL (Agência Nacional de Energia Elétrica) divulgou em 17/03/2016 um ranking das empresas prestadoras desse serviço, estando a concessionária Ampla (hoje ENEL) responsável pelo fornecimento de energia para grande parte dos municípios fluminenses, entre os quais Itaboraí.

Ainda sobre o fornecimento de energia elétrica cabe destacar o Programa Nacional de Universalização do Acesso e Uso da Energia Elétrica (Luz Para Todos) do Governo Federal, em conjunto com os Governos Estaduais e a iniciativa privada. O programa foi instituído em 2003, pelo Decreto oㅡ 4.873 de 11 de novembro de 2003 e teve por escopo combater a exclusão elétrica no país, promovendo a universalização do acesso e uso da energia elétrica e ainda amortizar o impacto tarifário oriundo das obras necessárias.

Com base no exposto, ao se analisar os aspectos da prestação de serviços no município de Itaboraí a partir das observações de campo e análise de imagens, é possível verificar que a realidade não corresponde os previsto nos princípios legais, sendo aplicável tanto para os serviços prestados diretamente pelo ente público quanto para aqueles que são prestados pela iniciativa privada através de permissão e/ou concessão.

No plano municipal verifica-se, com base nos relatórios do SNIS (Sistema Nacional de Informações de Saneamento) para o ano de 2016 e dados do TCE-RJ (2015), que os serviços públicos em geral atendem parcialmente à população e privilegiam áreas centrais em detrimento de áreas do município localizadas na periferia, evidenciando a grande desigualdade social existente, com populações residindo em áreas onde os serviços são cada vez mais precários e sem a presença efetiva do estado na regulação do uso e ocupação do solo, sendo justamente nestas comunidades onde estão concentrados a maior parcela dos conflitos que são objeto do estudo.

Buscando caracterizar esses conflitos, inicialmente faz-se necessário analisar 0 município sob a ótica de seu território e bacia hidrográfica, ressaltando que a abordagem sobre os conflitos tem seu recorte nas demandas de energia elétrica da população cujas residências estão situadas em áreas de APP e onde as concessionárias alegam não poder prestar o serviço por limitação legal.

$\mathrm{Na}$ figura 1 pode-se verificar inicialmente que o município se estende até a Baía de Guanabara, para onde os rios e córregos que integram a bacia hidrográfica da região fluem.

As divisas do município são com os municípios de Tanguá a leste, Cachoeiras de Macacu ao norte e nordeste, Guapimirim ao noroeste, São Gonçalo ao Oeste e Maricá ao Sul. 
Figura 1: Território do Município de Itaboraí e municípios limítrofes

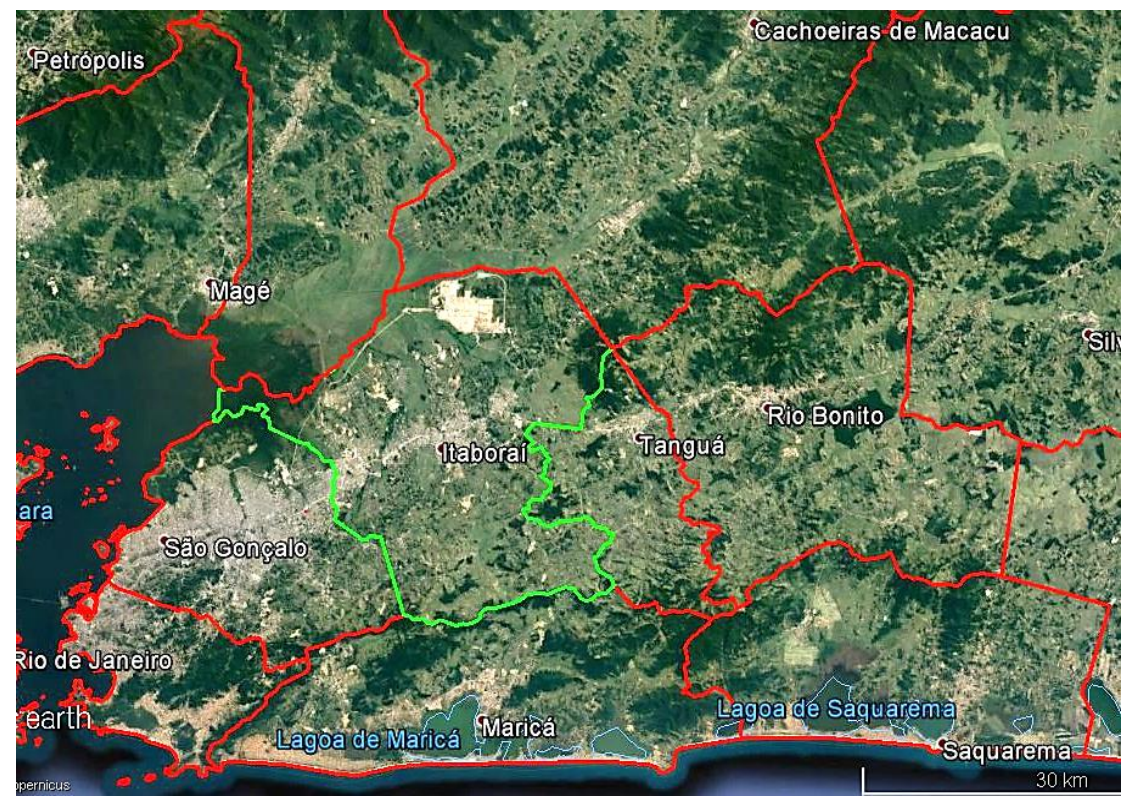

Fonte: Google Earth (2016)

Caracterizados os limites territoriais, destacase a hidrografia municipal com os principais rios que integram a bacia e os diversos rios e córregos de menor vazão e contribuintes da mesma bacia, configurando-se assim nas bases dos conflitos analisados e sua natureza de APP, onde a atenção do ente público se verifica ineficaz no contexto do planejamento urbano, uma vez que essas áreas tem o caráter de proteger e preservar matas ciliares e os recursos hídricos do entorno e margens de rios e córregos.
Os dois principais rios que cortam o município são: rio Macacu, que nasce na Serra dos Órgãos, em Cachoeiras de Macacu e deságua na Baía de Guanabara e o rio Caceribú que nasce na Serra do Sambê, no município de Rio Bonito e se integra ao rio Caceribú após retificação para a Estação de Captação de água da CEDAE que integra o sistema Imunana-laranjal, desaguando também na baia de Guanabara. Outros contribuintes importantes são os rios: Vargem, Ingá e Aldeia (Figura 2).

Figura 2: Estrutura geral da bacia hidrográfica do Município de Itaboraí

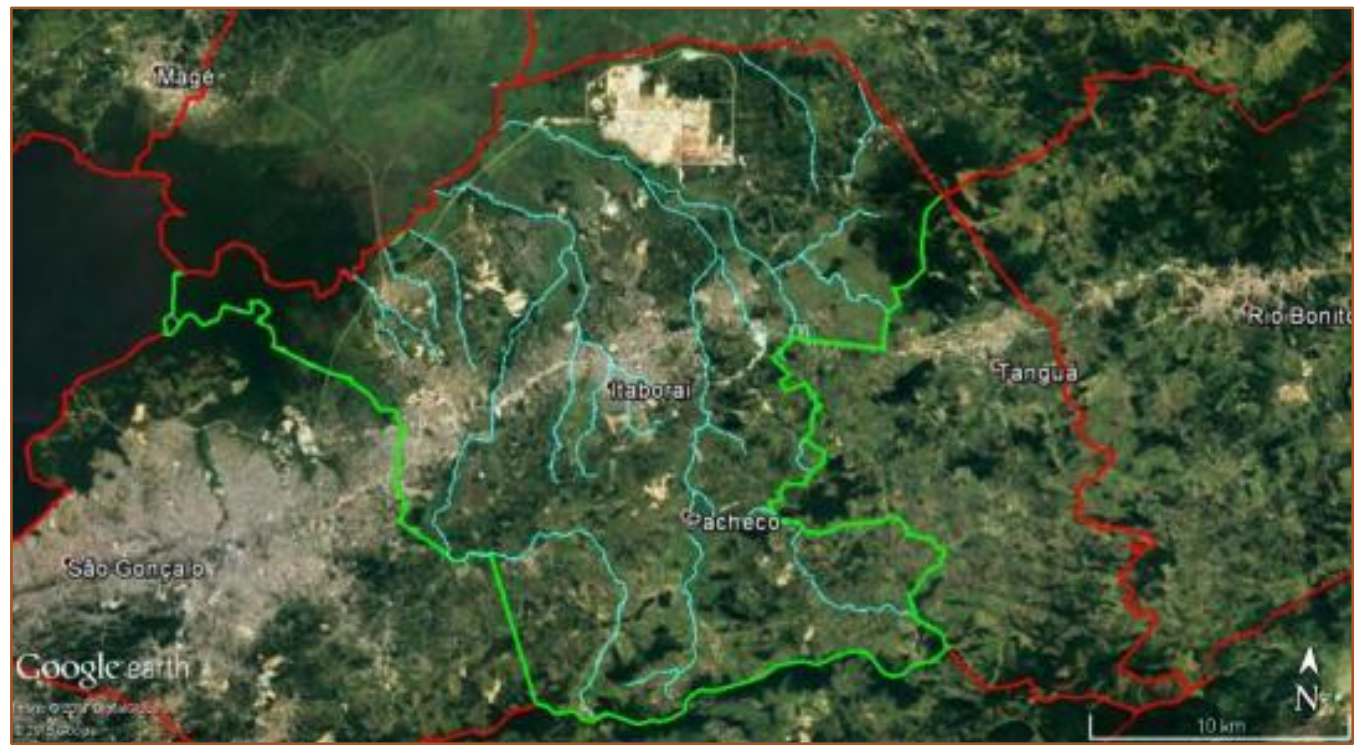

Fonte: Google Earth (2016) 
A figura 3 se detalha a hidrografia do município para permitir o entendimento sobre os aspectos que envolvem as áreas de APP, uma vez que estes cortam quase a totalidade do território municipal e áreas muitas vezes densamente povoadas.

Figura 3: Hidrografia Detalhada do Município de Itaboraí

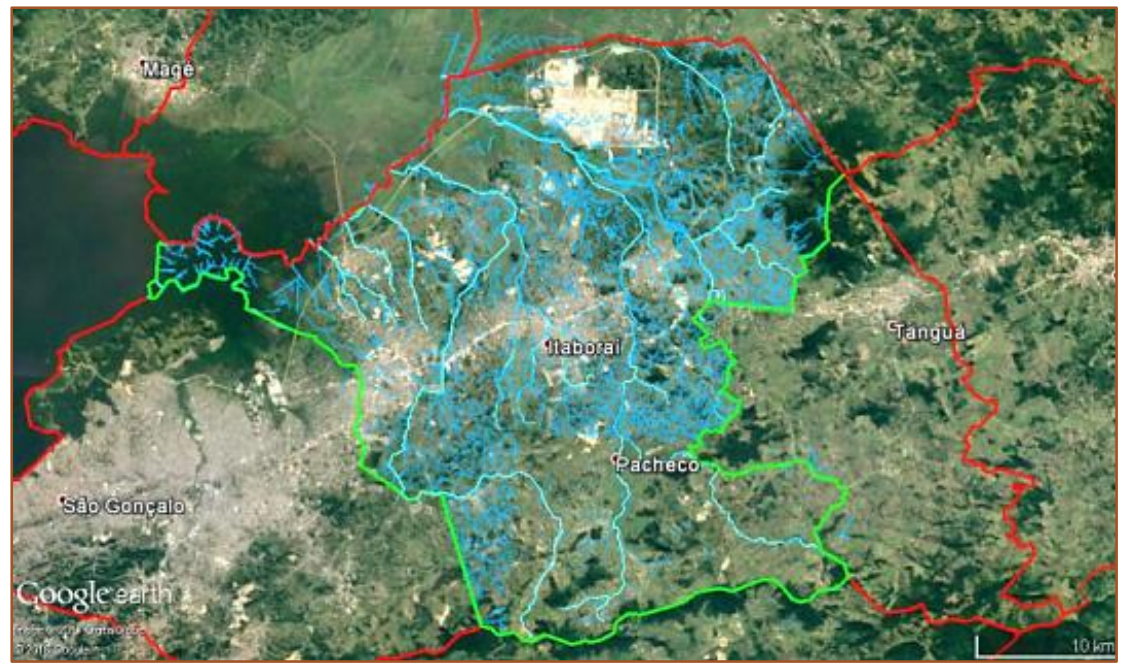

Fonte: Google Earth (2016)

Uma vez detalhada a hidrografia municipal, passa-se a análise dos fatores geradores dos conflitos entre as demandas dos residentes pelo fornecimento de energia elétrica e instalação de respectivos medidores pela concessionária e a negativa da mesma que alega construções em áreas de APP e portanto havendo impedimento legal.

Esse quadro envolve ainda a inobservância do executivo municipal que autoriza certas construções sem levar em conta as restrições legais para os casos de proximidade com APPs, bem como não é eficaz na fiscalização de edificações irregulares.

No primeiro caso analisado, trata-se de assentamentos marginais ao Rio Vargem, que corta o município de sul a norte em quase sua extensão total, sendo formado quando o Canal Fazendinha encontra com o Rio Caluge (figura 4). Verifica-se a grande concentração de edificações que não atendem ao afastamento mínimo do curso d'água, mas que tiveram seus medidores instalados. Hoje quando a concessionária é demandada, esta nega a instalação alegando ser área de APP e assim estabelecendo o conflito.

Figura 4: Formação Rio Vargem e Comunidade Rato Molhado

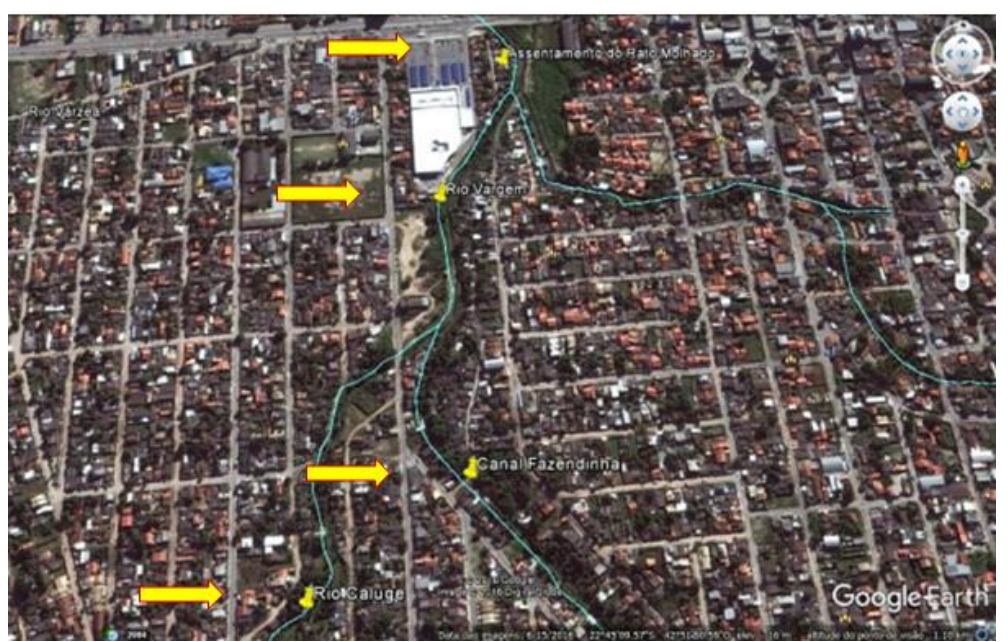

Fonte: Google Earth (2016) 
$\mathrm{Na}$ figura 4 verificar-se destaque para um assentamento subnormal denominada "Rato Molhado" ao lado de um grande empreendimento comercial localizado no centro do 1․ distrito do município e às margens da principal rodovia que corta 0 mesmo e a proximidade das edificações, agravada pela formação de um ângulo mais acentuado no traçado do rio até atravessar a rodovia, levando a uma proximidade maior dessas edificações com o rio.

Figura 5: Detalhe da Comunidade do Rato Molhado e proximidade com a APP

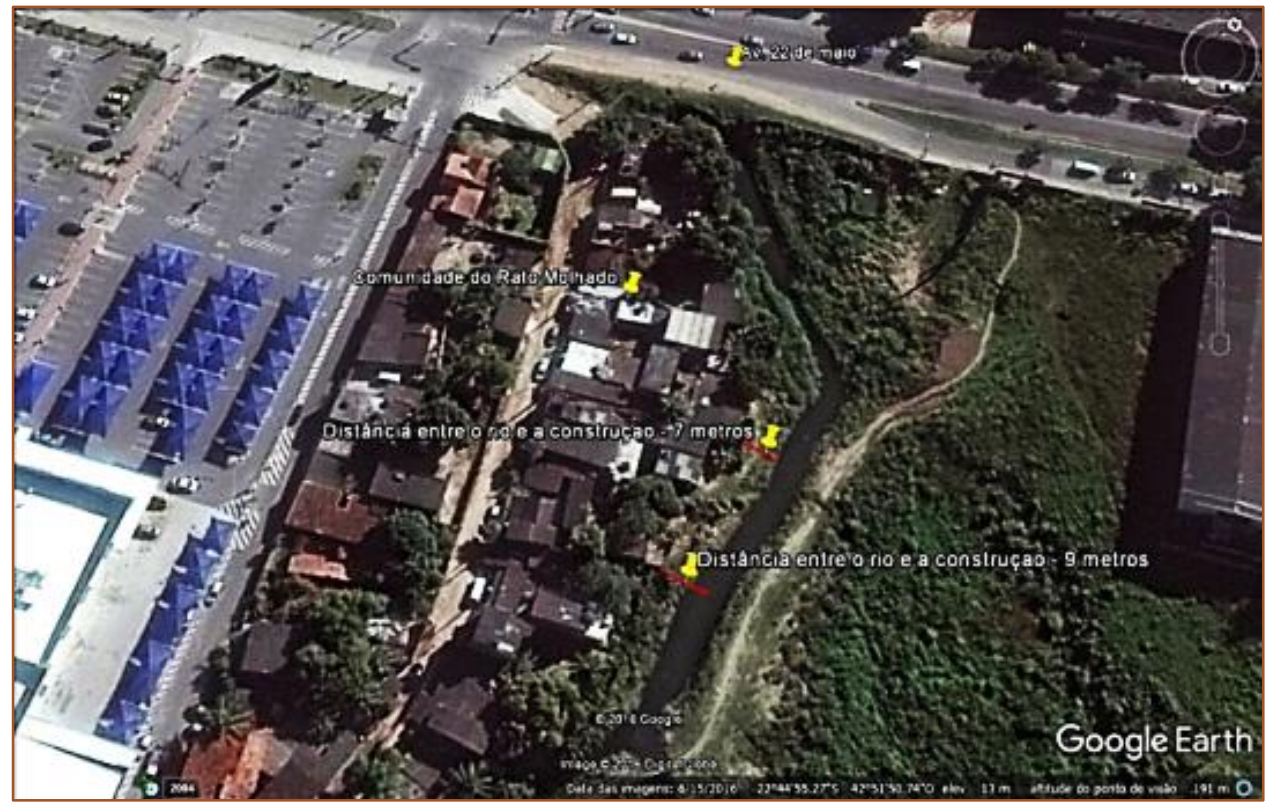

Fonte: Google Earth (2016)

Nas figuras 5 é possível observar em detalhe que a comunidade do Rato Molhado fica entre o Rio Vargem e um grande empreendimento comercial e às margens de uma rodovia. Sendo a área central do município, a localidade é uma das muitas que carecem de serviços públicos básicos e onde se configuram conflitos com as APPs.

Verifica-se que o afastamento mínimo do corpo hídrico não foi respeitado como indicado, com edificações construídas com afastamentos que variam entre 7 e 9 metros. A legislação estabelece que em áreas antropizadas, o afastamento mínimo deve ser de 15 metros.

Ressalta-se que a localidade é servida por rede de energia elétrica a pelo menos 15 anos, tendo as edificações consentimento do executivo municipal para serem construídas, caracterizando assim claro descumprimento das bases legais em relação as APPs.

Outro aspecto de destaque é que, novas edificações na mesma área já servida por redes de energia elétrica e que solicitaram instalação de medires para regularizarem o fornecimento de energia, tiveram seu pedido negado pela concessionária que alegou estarem em área APP, devendo assim terem autorização do órgão ambiental competente, estabelecendo-se aqui mais um conflito entre os atores sociais.

O segundo caso analisado está localizado no bairro de Marambaia, na divisa entre os municípios de Itaboraí com São Gonçalo, por onde passa o rio Caceribú, segundo o mapeamento da bacia hidrográfica, e onde foi construído um condomínio que ocupa as duas margens do rio que faz a divisa dos municípios, onde parte de sua área está no município de Itaboraí e outra parte no município de São Gonçalo.

Esse caso e a área conflitante merece atenção especial justamente por ser a divisa do município, havendo, portanto, conflito de interesse público dos dois municípios sobre aquela área e ainda a intervenção do Ministério público Estadual e da concessionária de energia.

Neste caso, é importante observar, que o conflito de competência, de acordo com STJ 
e a doutrina majoritária, adota-se a teoria do interesse preponderante, o que significa dizer que aquele que tiver maior interesse sobre a área, terá a competência para legislar e/ou expedir licenças ambientais.

Porém, no caso em questão, sendo impossível definir qual município tem maior interesse sobre a área, ou sofre maior impacto ambiental, cabe a esfera imediatamente superior, no caso o Estado do Rio de Janeiro, a competência sobre a área, inclusive para aplicar sanções ou concessões de licenças.

Figura 6: Área do condomínio Marambaia e o corpo hídrico que define a fronteira intermunicipal

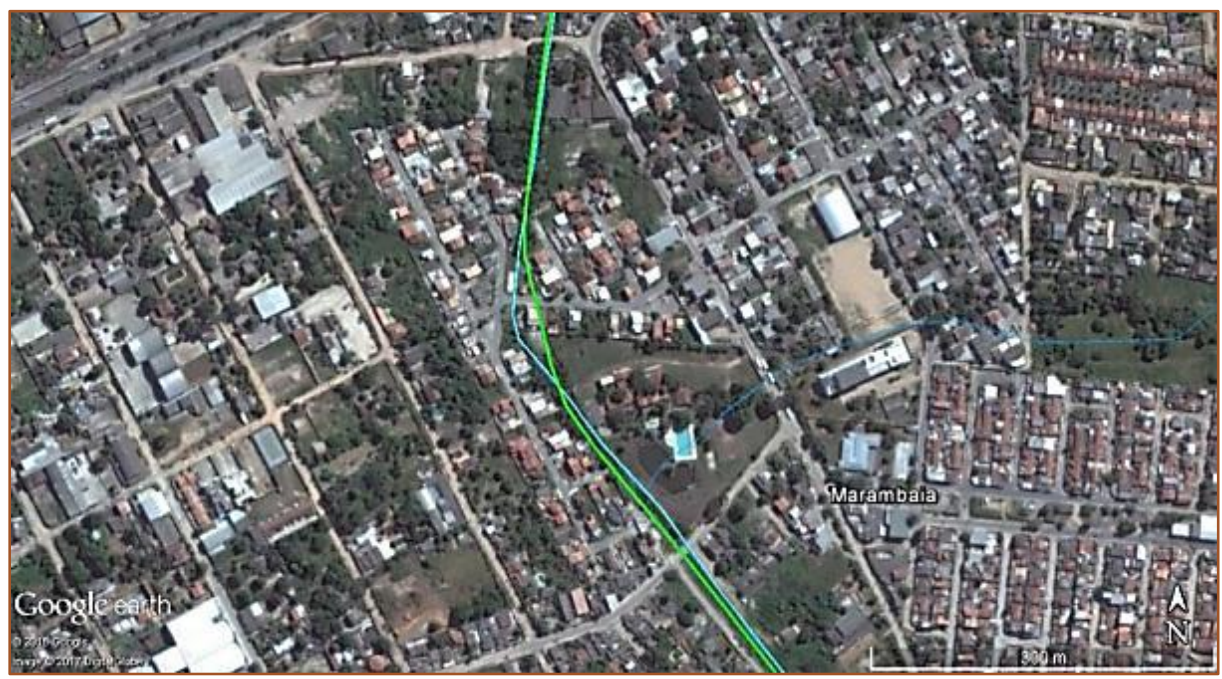

Fonte: Google Earth (2016)

Como se observa no detalhe na figura 7 , verifica-se a proximidade com a APP, trechos de intervenção sobre o corpo hídrico (ponte) e consequentemente a impossibilidade de proteção necessária pela não observância dos afastamentos como determina a legislação face ao estabelecimento das faixas marginais de proteção.

Figura 7: Área do condomínio Marambaia

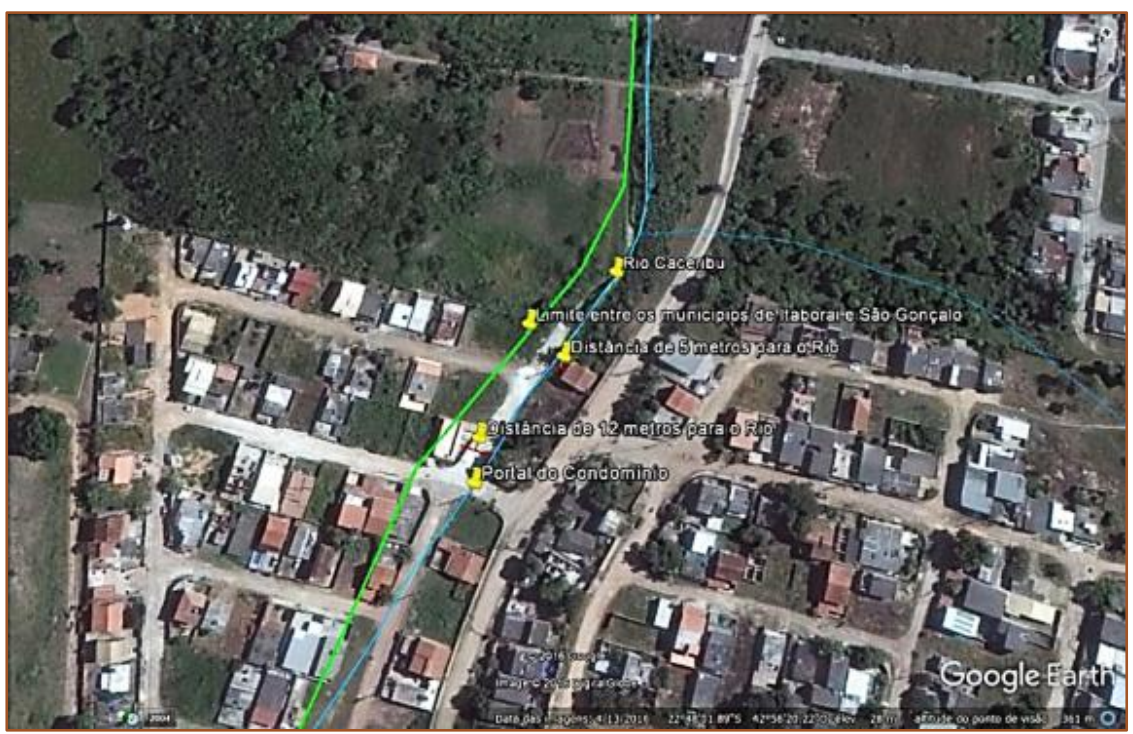

Fonte: Google Earth (2016) 
A traçado em verde, considerados pequenas diferenças dos dados de georeferenciamento indica o limite entre os municípios de Itaboraí, à direita, e de São Gonçalo, à esquerda. Já o traçado em azul indica o corpo hídrico que marca a divisa de municípios, no caso o Rio Caceribú como indicado na base de dados consultada. As demais indicações em vermelho mostram o afastamento entre o rio e as edificações, que variam entre 5 e 8 metros no máximo na maioria dos casos e em alguns casos, o limite do terreno das residências fica às margens do corpo hídrico onde se construíram muros de contenção.

Nesse contexto, primeiro questionamento recai sobre a responsabilidade do licenciamento ambiental, uma vez que o condomínio teve autorização de construção, sendo clara a supressão de vegetação para a construção do mesmo e o desrespeito aos limites de afastamento mínimo para garantir a proteção da APP.

Outro aspecto recai sobre o fornecimento de energia elétrica, considerando que 0 condomínio é atendido por rede de fornecimento, a concessionaria não poderia ter instalado medidores e fornecido o serviço sem prévia autorização do órgão competente, que no caso em particular, o órgão estadual, por conta da esfera de competência. Neste caso, a concessionária teve duas opções: ligar, por conta própria, a pedido do consumidor, e assumir o risco de receber sanções ambientais, ou não fazer a ligação e esperar a demanda judicial promovida pelo consumidor ser concluída, uma vez que não teve seu direito de acesso ao serviço público de energia atendido inicialmente.

Agravando esse quadro, hoje a concessionária nega a instalação de medidores para novas edificações no condomínio, sob alegação de estar a mesma em uma APP, configurando um contra senso da postura até então adotada, que por analogia deveria instalar medidores solicitados uma vez que inúmeros outros já estão ali instalados.

\section{RESULTADOS E DISCUSSÕES}

Os resultados do estudo indicam para uma clara dissonância entre o previsto nas bases legais que regem as APPs e respectivas FMPs e seu cumprimento, e a realidade do cotidiano da prestação dos serviços públicos, concomitante como à proteção ao meio ambiente no município de Itaboraí.

Os serviços públicos devem ser prestados objetivando o bem coletivo por essência e quanto à proteção do meio ambiente, a legislação é clara quando indica que as áreas no entorno de rios, cursos d'água, lagoas, são classificadas como APPs, possuindo natureza jurídica de limitação administrativa, significando dizer que o uso da propriedade fica afetado pelo interesse público.

Todavia, o que foi observado no contexto das APPs em território municipal, é totalmente contrário ao previsto nos dispositivos legais. Apesar da legislação municipal, estadual e federal versar sobre preservação e uso sustentável da natureza, na realidade cotidiana dos casos observados o que se verifica é o crescimento urbano de forma desordenada, a falta de planejamento para expansões, falta de efetividade de fiscalização das ocupações irregulares e ainda a própria contribuição negativa do executivo municipal que autoriza a construção de edificações sem respeitar os preceitos legais para APPs quando não se trata de empreendimentos de médio porte, contribuindo para ampliação dos conflitos.

Nos casos analisados, observou-se que o poder público, através de suas equipes técnicas, ou não conhece a legislação, ou a ignora para atender interesses alheios aos preceitos legais, não sendo concebível que qualquer órgão ambiental ou não, tanto municipal quanto estadual tenha promovido o licenciamento ambiental para construção de empreendimentos, sendo gerador de conflitos quando se trata da prestação de serviços à população.

A legislação abre exceções para a supressão da vegetação, para o uso das APPs, inclusive para habitação. Porém, ao se observar o rol de exceções, percebe-se que o cotidiano das ações que envolvem a questão do ordenamento territorial e o uso e ocupação do solo não é uma exceção, uma vez que qualquer intervenção em APPs, deve considerar o interesse social e ambiental coletivo.

Dentre os inúmeros conflitos identificados, o conflito mais comum em APPs envolve o interesse pessoal do indivíduo em ter a energia elétrica, o interesse privado da concessionária em não infringir a lei ambiental, o interesse público que autorizou a edificação e o interesse coletivo de ter um meio ambiente ecologicamente equilibrado. 
Assim, os conflitos dessa natureza culminam no sistema judiciário para que este cumpra sua função jurisdicional, o que também configura-se como serviço público, e a quem cabe decidir sobre a instalação dos medidores ou não, destacando-se ainda que, durante um processo judicial longo, outras edificações são erguidas e novos pedidos de ligação de energia elétrica ocorrem, seguindo o mesmo caminho até que chegue ao sistema judiciário, em um ciclo vicioso que se perpetua.

\section{CONCLUSÕES DO ESTUDO}

Uma vez observados os parâmetros legais que definem a política pública quanto a tutela ambiental, bem como o regimento e a função dos serviços públicos, entendendo também a função social da propriedade e as limitações administrativas impostas a esta por conta das APPs, ao comparar com a realidade municipal, é possível concluir que existe uma grande lacuna entre a aplicação efetiva das bases legais e a realidade do cotidiano das demandas da sociedade quanto ao bem ambiental.

Sendo a proposta do estudo analisar os conflitos estabelecidos na prestação de serviços públicos em Áreas de Proteção Permanente (as APPs), verifica-se a incapacidade efetiva do poder público cumprir o comando constitucional do Art. 225 e do que Preceitua o Novo Código Florestal, cabendo então rever as políticas públicas referentes à prestação dos serviços no que tange à proteção do meio ambiente.

Ao se buscar entendimento para os fatores geradores dos conflitos foi possível associar o crescimento populacional a falta de políticas e ações urbanísticas e de ordenamento territorial capazes de conciliar as demandas

\section{REFERÊNCIAS}

[1] Carvalho Filho, José dos Santos. Manual de Direito Administrativo. 20 $0^{\mathrm{a}} \mathrm{Ed}$. Rio de Janeiro: Lumen Juris, 2008.

[2] Meirelles, Hely Lopes. Direito Administrativo Brasileiro. 34aㅡ Ed. São Paulo: Malheiros, 2008.

[3] Brasil. CONSTITUIÇÃO DA REPÚBLICA FEDERATIVA DO BRASIL 1988. Disponível em: $<$ http://www.planalto.gov.br/ccivil_03/constituicao/c onstituicaocompilado.htm $>$. Acesso em: $18 / 03 / 2017$ ambientais e o uso do território, carecendo então ao poder público não exatamente da falta de um plano diretor, ou de um eficiente zoneamento urbano, sendo em essência, a falta de planejamento e capacidade efetiva de fiscalização.

Em relação aos serviços prestados pelas concessionárias de energia, verifica-se uma busca constante destas por estarem amparadas na legislação de forma a evitar sanções pelos órgãos ambientais, mas que por outro lado leva ao entendimento de que uma simples análise jurídica sobre as demandas envolverem APPs em áreas urbanas poderia dirimir muitos dos conflitos, adotando-se a analogia em áreas onde o serviço já estiver sendo prestado, considerando-se para tanto o impacto insignificante a ser causado com a instalação de mais um medidor em uma área já antropizada.

Quanto as APPs mais afetadas pelas atividades humanas, verifica-se que a construção de edificações regulares ou não, estas ocorrem sem respeitar o afastamento indicado pela legislação e com anuência ou omissão do executivo municipal.

Dessa forma, uma solução plausível seria a instalação de passeios públicos e plantio de espécies nativas na faixa paralela ao passeio e nas proximidades do corpo hídrico como forma de evitar construções irregulares nas faixas marginais de proteção, garantindo a proteção adequada do corpo hídrico.

O estudo não pretende encerrar as discussões sobre o tema, sendo base para o desenvolvimento de novas pesquisas na busca de soluções para os conflitos identificados.

[4] Brasil. Lei n. 8078 de 11/09/1990. Dispõe sobre a proteção do consumidor. Disponível em: $<$ http://www.planalto.gov.br/ccivil_03/leis/L8078.ht m>. Acesso em: 20/09/2016

[5] Brasil. Lei n. 12.685 de 25/05/2012. Novo Código Florestal. Disponível em: <http://www.planalto.gov.br/ccivil_03/_ato20112014/2012/lei//12651.htm>. Acesso em: 15/08/2016

[6] Ibge Cidades. Dados Estatísticos Municipais. Disponível em: <http://cidades.ibge.gov.br/xtras/perfil.php?lang=\& codmun=330190\&search=rio-de-janeirolitaborai $>$. 
Acesso em: 21/03/2017

[7] Houaiss, Antônio. Novo Dicionário Houaiss da Língua Portuguesa. São Paulo: Objetiva, 2009.

[8] Sirvinskas, Luís Paulo. Manual de Direito Ambiental. 13를. Ed. São Paulo: Saraiva 2015.
[9] TCE-RJ. Tribunal de Contas do Estado do Rio de Janeiro. Estudo Socioeconômico 2015: Itaboraí. Disponível em: $<$ http://www.tce.rj.gov.br/web/guest/estudossocioeconomicos1>. Acesso em: 13/10/2016. 


\section{Bapítulo 20}

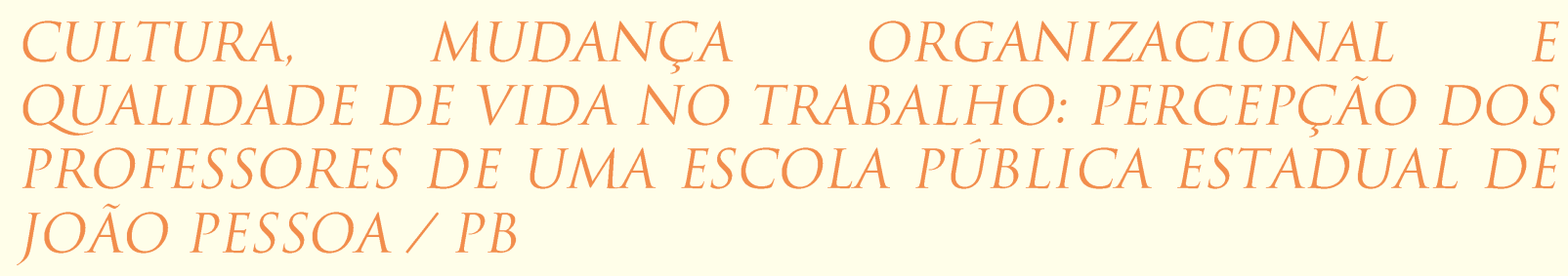

Amanda Raquel França Filgueiras D’Amorim

Ramon Schnayder de França Filgueiras D`Amorim

Luciene Laranjeira Diniz

Tulio Gonzaga Brandão de Mendonça

Resumo: O objetivo deste trabalho foi apontar as relações existentes entre cultura, mudança organizacional e qualidade de vida segundo professores de uma escola da rede estadual localizada em João Pessoa / PB. É indiscutível a relevância do papel do professor para formação de uma sociedade. Contudo, a cultura que predomina na escola, as mudanças que ocorrem na organização escolar e a Qualidade de Vida no Trabalho (QVT), podem definir fatores da vida do professor. Trata-se de uma pesquisa descritiva com abordagem quantitativa. Traz como instrumento de coleta de dados o questionário com questões subjetivas. Concluise que a temática em análise, segundo as respostas dos professores envolvidos na pesquisa, possui favoráveis níveis de relação, destacando satisfatórios índices de delineamento na pesquisa.

Palavras-Chave: Cultura Organizacional. Mudança Organizacional. Qualidade de Vida. Educação. 


\section{INTRODUÇÃO}

O fenômeno político-social chamado globalização, bem como as novas tecnologias da informação, proporcionou uma verdadeira revolução mundial no que diz respeito à transformação de paradigmas em vários segmentos (QUADROS, 1999). Esses elementos impactam a cultura organizacional e revelam outras questões de suma importância para se fazer uma análise sobre o assunto. É interessante perceber como esses elementos estão interligados e são até certo ponto de vista dependentes entre si. Pois quando o alicerce cultural é abalado, ocorre uma resposta quase que premente como reação; essa resposta nada mais é que uma transformação da realidade anteriormente conhecida até então. "A cultura organizacional especifica a identidade da organização. É construída ao longo do tempo e serve de chave para distribuir diferentes coletividades" (SROUR, 2005, p. 212). Por esta razão, (GORESKE, 2007), afirma que as organizações que enfrentam situações de turbulência e crises, tendem a passar pelo processo de mudança organizacional, onde a cultura tradicional é rapidamente modificada.

Sendo assim, toda mudança organizacional é fruto de uma estrutura cultural remodelada. Por esta razão, esta mudança demandará tempo para assimilação da mesma, e, por conseguinte, trará mudanças positivas ou negativas para a qualidade de vida no trabalho. Acerca desse assunto, Salles e Boas (2006) entende que a mudança significa desconstruir aprendizados que se passaram anos para construir e essa desconstrução pode gerar conflitos, desentendimentos e precisa de grande empenho dos envolvidos. A mudança é essencial para o desenvolvimento de uma organização. No entanto, quando o sentido da palavra mudar volta-se para pessoas, seus valores e suas crenças, o esforço torna-se de ampla significância.

Em síntese, esse processo ocorre de maneira ordenada, e pode ser identificado da seguinte maneira: a cultura tradicional sofre transformações, ocorrem mudanças em vários sentidos fazendo com que as pessoas tenham que se adequar aos novos formatos do ambiente de trabalho, e finalmente, a qualidade de vida no trabalho (QVT) é afetada trazendo resultados positivos e negativos para os trabalhadores.
Diante desse cenário de mudanças, modernização das organizações em geral, o relacionamento entre empregado, gestor e organização deve ser compreendido como algo determinante e vital para o sucesso de toda e qualquer ação. Contudo, esse relacionamento e suas particularidades, bem como, as novas rotinas, deve voltar-se diretamente para o bem estar do empregado. Pois, isso gera motivação e consequentemente benefícios e avanços no processo de trabalho.

Entretanto, o termo qualidade de vida no trabalho (QVT) nunca foi tão usado quanto nas últimas décadas. A QVT é algo que há muito tempo tornou-se preocupação na vida daqueles que defendem os direitos dos trabalhadores. Segundo Rodrigues (1994, p.76 apud SANTOS; SCHEIDT JUNIOR 2013, p. 6), "a qualidade de vida no trabalho tem sido uma preocupação do homem desde o início de sua existência com outros títulos em outros contextos, mas sempre voltada para facilitar ou trazer satisfação e bem estar ao trabalhador na execução de sua tarefa".

Sendo assim, Maximiano (2000, p. 498) que afirma que "a QVT baseia-se em uma visão integral das pessoas, que é o chamado enfoque biopsicossocial". O enfoque biopsicossocial das pessoas origina-se da medicina psicossomática, que propõe a visão integrada, ou holística, do ser humano. A visão do autor supracitado resume bem a sugestão hodierna para a QVT, pois assume um compromisso integral com o trabalhador rompendo as fronteiras do ambiente de trabalho e atingindo a vida social, a saúde física e emocional, bem como a motivação.

A proposta desta pesquisa é pertinente e significativa, pois tem como objetivo geral apontar as relações existentes entre cultura, mudança organizacional e qualidade de vida segundo professores de uma escola da rede estadual localizada em João Pessoa/PB/Brasil. Para atingir a finalidade da pesquisa e obter dados atuais e precisos, foi utilizado como recurso para extração das informações deste estudo de caso, um questionário com perguntas pertinentes ao assunto em questão. Com as respostas obtidas pela aplicação do questionário, foi possível assim fazer a análise e interpretação dos dados que serviram de base para o presente artigo.

Portanto, este trabalho oferece a possibilidade de identificar e analisar como a 
relação entre cultura, mudança organizacional e qualidade de vida é observada por professores que atuam no ensino médio. As contribuições desse trabalho são notáveis devido a sua singularidade na área educacional. Podendo assim, proporcionar uma visão de como anda essa temática na visão escolar, servindo para uma possível orientação e contribuindo a cerca de aperfeiçoamento da classe docente na temática proposta. Para os gestores organizacionais, é de suma importância a reflexão sobre o assunto aqui proposto, para que, depois de analisar os possíveis comportamentos e perfis de alguns professores em relação à resistência, aceitação e contribuição para a transformação da cultura organizacional, bem como também, a relação das mudanças com a qualidade de vida dos professores. O estudo de caso apresentado nesta pesquisa proporciona dados consistentes que servirão de modelo e reflexão sobre posturas e realidade atual a cerca da temática apresentada.

\section{MATERIAL E MÉTODOS}

A metodologia é um processo que envolve etapas, técnicas, ferramentas, métodos distintos, porém direcionados para um determinado fim, um único objetivo. Reafirmando esse pensamento, Oliveira (2003, p. 45) dispõe que:

A metodologia engloba todos os passos realizados para a construção do trabalho científico, que vai desde a escolha do procedimento para obtenção de dados, que perpassa pela identificação do(s) método(s), técnica(s), materiais, instrumentos de pesquisa, definição da amostragem/universo, até a categorização e análise dos dados coletados.

Sendo assim, os métodos a serem percorridos nos estudos variam de acordo com o enfoque dado por cada pesquisador.

\subsection{CARACTERIZAÇÃO DA PESQUISA}

No que diz respeito à abordagem do problema essa pesquisa é quantitativa haja vista a liberdade de utilizarmos indicadores quantitativos.
Vale ressaltarmos que utilizamos a relação quantitativa pela possibilidade de enquadramento de dados passíveis a categorização por meio de tabelas, evidenciados estatisticamente. Para Fachin (2003, p. 78), a variável quantitativa "[...] é determinada em relação aos dados ou proporção numérica. Porém, a atribuição numérica não deve ser ao acaso, porque a variação de uma propriedade não é quantificada cientificamente".

Segundo a tipologia da pesquisa, o estudo se enquadra no nível descritivo, revelando características de determinado grupo ou fenômeno. Assim, a pesquisa descritiva "Tem como objetivo a descrição das características de determinada população ou fenômeno, bem como o estabelecimento de relações entre variáveis e fatos" (MARTINS, 2000, p. 28).

Enquadra-se nesse grupo, pesquisas que buscam levantar opiniões e posturas de determinada população ou comunidade, identificando as relações entre as variáveis. Conforme Gil (2002, p. 42) afirma:

\begin{abstract}
As pesquisas descritivas têm como objetivo primordial a descrição das características de determinada população ou fenômeno ou, então, o estabelecimento de relações entre variáveis. [...] e uma de suas características mais significativas está na utilização de técnicas padronizadas de coleta de dados, tais como o questionário e a observação sistemática.
\end{abstract}

Portanto, na pesquisa descritiva, "não há a interferência do investigador, que apenas procura descobrir, com o necessário cuidado, a frequência com que o fenômeno acontece" (OLIVEIRA, 1997, p. 128). Dessa forma, buscamos sem interferência identificar, as características do grupo determinado, entendendo o sentido perceptivo do tema proposto.

\subsection{SUJEITOS DA PESQUISA}

A pesquisa tem como sujeitos os professores de nível médio de uma instituição pública escolar da cidade de João Pessoa - Paraíba. Partindo de princípios éticos e solicitações dos envolvidos, o anonimato da instituição foi preservado. 
O universo da pesquisa foi constituído por (29) professores. Todavia nossa amostra constitui-se de (15) professores (52\% do universo), haja vista que apenas esse total respondeu ao questionário.

\subsection{INSTRUMENTO DE COLETA DE DADOS}

Para coleta de dados, utilizamos como instrumento o questionário contendo questões objetivas. Essa escolha foi ancorada em Oliveira (1997, p. 165) que salienta o questionário como:

[...] um instrumento que serve de apoio ao pesquisador para a coleta de dados e apresenta os seguintes aspectos: a) É a espinha dorsal de qualquer levantamento; b) Precisa reunir todas as informações necessárias, nem mais e nem menos; c) Cada levantamento é uma situação nova; d) Necessidade da preparação da amostra (conhecer estatística); e) Linguagem adequada, certa dose de visão psicológica introspectiva para apanhar o pensamento das pessoas; f) Possuir imaginação; g) Experiência; h) Conhecimento.

O questionário foi estruturado em cinco partes: Parte I - Perfil sociodemográfico e profissionais dos professores (4 perguntas); Parte II - Cultura Organizacional (3 perguntas); Parte III - Mudança Organizacional (3 perguntas e 1 subdivisão); Parte IV - Qualidade de vida no trabalho (QVT) (10 perguntas e 1 subdivisão); e Parte V Relação da Temática: Cultura organizacional, mudança organizacional e qualidade de vida no trabalho (1 pergunta). O questionário sobre qualidade de vida fora baseado pelo instrumento de Furlanetto (2008).

\section{RESULTADOS E DISCUSSÃO}

Os resultados apresentados são baseados na amostra dos (15) professores, quanto à primeira parte do questionário aplicado, onde aborda a identificação do sexo, idade, tempo de trabalho na instituição e formação, segue tabela (1) a seguir:

Tabela 1 - Representação de Indicadores Sociodemográfico e Profissional

\begin{tabular}{|c|c|c|}
\hline Sexo & \multicolumn{2}{|c|}{ Fr } \\
\hline Feminino & 6 & $40 \%$ \\
Masculino & 9 & $60 \%$ \\
\hline Idade & $\mathrm{Fr}$ & $\%$ \\
\hline 20 a 30 anos & 3 & $20 \%$ \\
30 a 40 anos & 6 & $40 \%$ \\
Mais de 40 anos & 6 & $40 \%$ \\
\hline Tempo de trabalho na instituição & $\mathrm{Fr}$ & $\%$ \\
\hline Menos de 1 ano & 0 & $0 \%$ \\
1 a 5 anos & 6 & $30 \%$ \\
5 a 10 anos & 3 & $40 \%$ \\
\hline Mais de 10 anos & 6 & $\%$ \\
\hline Formação & $\mathrm{Fr}$ & $33 \%$ \\
\hline Licenciatura & 5 & $40 \%$ \\
Especialização & 6 & $27 \%$ \\
Mestrado & 4 & $0 \%$ \\
\hline Doutorado & 0 & \\
\hline
\end{tabular}

Fonte: Dados da Pesquisa, 2017.

Em síntese, o perfil dos trabalhadores da educação envolvidos no estudo quanto ao sexo, revela que os professores do sexo masculino compreendem maior número sendo $60 \%$ dos envolvidos, enquanto que $40 \%$ declaram ser do sexo feminino. Mostrando que a tradição da profissão do professor ser predominantemente feminina está em transformação, já se observa um avanço no número de professores do sexo masculino atuando na educação básica.

Em relação à faixa etária, idade mediana entre os 30 e 40 anos e mais de 40 anos, configuram o mesmo percentual, ambas são de $40 \%$. No entanto, a faixa de 20 a 30 anos tem o menor n'mero 20\%. Demonstrando assim, certo desinteresse da classe mais 
jovem pela profissão de professor, devido ao número reduzido.

Em se tratando do tempo de trabalho na instituição atuante, $40 \%$ dos professores envolvidos na pesquisa estão entre 1 a 5 anos no local. Aqueles que possuem mais de 10 anos lecionando na organização educacional, também representam $40 \%$. No entanto, 30\% afirmaram está na escola entre 5 e 10 anos. Nenhum dos envolvidos se enquadram na faixa de menos de 1 ano de trabalho na instituição pesquisada.

Quanto à formação dos envolvidos, 40\% dos professores possuem especialização, $27 \%$ possuem mestrado, 33\% possuem apenas licenciatura. Porém, nenhum dos envolvidos afirmou ter doutorado.

A partir dessas informações, ressalta-se que mesmo diante das dificuldades enfrentadas pelos profissionais da educação, a busca pela atualização e aquisição de novas competências está sendo levada em consideração, tendo em vista que apenas a minoria dos professores concluiu somente uma licenciatura. Souza (2007, p. 45) reafirma tal questão abordando que "A formação continuada de Professores é necessária para que os docentes construam uma preparação profissional para ler o mundo, junto com os outros e principalmente com os seus alunos". Portanto, esse interesse em buscar novos conhecimentos a cerca de novas práticas educacionais, só trás benefícios para o processo de ensino/aprendizagem na escola dos envolvidos.

$\mathrm{Na}$ segunda parte do questionário, o foco voltou-se para a cultura organizacional e assim, os dados apresentados na tabela (2) foram:

Tabela 2 - Representação de Indicadores Cultura Organizacional

\begin{tabular}{|c|c|c|}
\hline \multicolumn{2}{|c|}{$\mathrm{Fr}$} & $\%$ \\
\hline $\begin{array}{c}\text { Agente que contribui para formar a cultura } \\
\text { organizacional na instituição }\end{array}$ & 15 & $100 \%$ \\
Sim & 0 & $0 \%$ \\
Não & $\mathrm{Fr}$ & $\%$ \\
\hline Cultura organizacional da instituição pertencente & 9 & $60 \%$ \\
influencia a forma de trabalho & 0 & $0 \%$ \\
Sim & 6 & $40 \%$ \\
Não & $\mathrm{Fr}$ & $\%$ \\
Moderadamente & 4 & $27 \%$ \\
Cultura organizacional predominante na instituição de & 1 & $7 \%$ \\
atuação ajuda no desempenho de suas atividades & 10 & $66 \%$ \\
\hline Sim & Não & \\
\hline Moderadamente &
\end{tabular}

Fonte: Dados da Pesquisa, 2017.

Com relação aos dados obtidos na pesquisa referente à cultura organizacional, todos os entrevistados demonstraram que participam ativamente na formação da cultura organizacional da instituição que leciona. Isso revela que os referidos professores têm conhecimento sobre o assunto e assumiram uma postura de mudança, pois todos os envolvidos (15 professores) 100\% afirmaram contribuir na formação da cultura do seu local de trabalho.

Ao que se refere á influência da cultura organizacional na forma de trabalho dos professores, o resultado foi que $60 \%$ entendem que a cultura predominante influência sua forma de trabalhar, enquanto $40 \%$ afirmaram que essa influência existe, só que de forma moderada. Nenhum concorda que não exista influência da cultura da organização em seu modo de trabalho.

O indicador avaliado sobre a cultura organizacional de seu ambiente de trabalho, ajudar no desempenho de suas atividades, obteve-se que $66 \%$ dos informantes diz que essa relação acontece, mas em níveis de moderados, $27 \%$ afirmam expões apenas que ajuda no desempenho de suas atividades. Mas, $7 \%$ dos envolvidos discordam desse fator, e entende que não trás benefícios no seu desempenho.

Assim, os professores envolvidos na pesquisa entendem que a cultura organizacional da instituição na qual pertencem, possui características positivas para o delineamento de seu trabalho. Concordando com Freitas (2007 apud MARANHÃO, 2012, p. 24) quando 
diz que "[...] a cultura é uma ferramenta capaz de auxiliar processos de adequação e mudanças em termos organizacionais". Sendo assim, podemos entender que todo processo de inovação dentro de uma organização, aqui enfatizados na área de educação, passa pela cultura.
$\mathrm{Na}$ terceira parte do questionário o assunto abordado foi à mudança na organização, e então foram dadas as respostas, conforme a tabela (3) a seguir:

Tabela 3 - Representação de Indicadores Mudança Organizacional

\begin{tabular}{|c|c|c|}
\hline $\begin{array}{l}\text { Enfrentou mudança na cultura organizacional na } \\
\text { instituição de atuação }\end{array}$ & $\mathrm{Fr}$ & $\%$ \\
\hline $\begin{array}{r}\text { Sim } \\
\text { Não }\end{array}$ & $\begin{array}{l}7 \\
8\end{array}$ & $\begin{array}{l}47 \% \\
53 \%\end{array}$ \\
\hline $\begin{array}{l}\text { Nível da mudança organizacional enfrentada, caso } \\
\text { respondeu sim ao item anterior (7 professores) }\end{array}$ & $\mathrm{Fr}$ & $\%$ \\
\hline $\begin{array}{c}\text { Baixa } \\
\text { Média } \\
\text { Grande } \\
\text { Intensa }\end{array}$ & $\begin{array}{l}1 \\
5 \\
1 \\
0\end{array}$ & $\begin{array}{l}14 \% \\
72 \% \\
14 \% \\
0 \%\end{array}$ \\
\hline Reação às mudanças na organização de atuação & $\mathrm{Fr}$ & $\%$ \\
\hline $\begin{array}{l}\text { Resistência: dificuldade de aceitar novos padrões } \\
\text { Interação: Participa do processo de transformação } \\
\text { Naturalidade: facilidade de aceitar mudanças }\end{array}$ & $\begin{array}{l}3 \\
3 \\
9\end{array}$ & $\begin{array}{l}20 \% \\
20 \% \\
60 \%\end{array}$ \\
\hline $\begin{array}{c}\text { Avaliação quanto ás mudanças na instituição que } \\
\text { leciona }\end{array}$ & $\mathrm{Fr}$ & $\%$ \\
\hline $\begin{array}{c}\text { Necessárias: mudanças geram equilíbrio na } \\
\text { organização } \\
\text { Desnecessárias: não há necessidade de mudanças }\end{array}$ & $\begin{array}{c}14 \\
1\end{array}$ & $\begin{array}{c}93 \% \\
7 \%\end{array}$ \\
\hline
\end{tabular}

Fonte: Dados da Pesquisa, 2017

Ao que concerne os indicadores de mudança na organização, constatamos de imediato que houve pouca diferença entre os que sentiram mudanças na cultura organizacional (53\%) dos que não sentiram essa mudança (47\%), podendo este fato está ligado ao tempo de serviço na instituição.

Concernente ao nível de impacto dessa mudança, relacionados aos professores que responderam ter enfrentado alguma mudança na organização (7 professores), $72 \%$ destes sentiram que a mudança ocorrida foi nível médio, $14 \%$ que a mudança foi de nível baixo, $14 \%$ que a mudança foi de nível grande. Porém nenhum dos envolvidos encarou as mudanças ocorridas como de nível intenso.

Quanto ao indicador de reação às mudanças, $60 \%$ dos professores afirmaram encarar as mudanças com naturalidade, 20\% resistem às mudanças, e aqueles que destacaram participar do processo de mudança também compreendem $20 \%$ dos envolvidos.

Voltando-se para avaliação das mudanças se são de caráter necessário ou não, 93\% dos professores entendem como mudanças necessárias, 93\%, enquanto que $7 \%$ dos participantes, apenas (1) professor observa a mudança como algo desnecessário.

Neste ponto, podemos afirmar que os professores entrevistados encaram de forma positiva as mudanças organizacionais, e não resistem a seu processo. Diante disso, podemos compreender que é possível investir em políticas públicas de modelos e ferramentas educacionais para mudanças significativas, a fim de gerar melhorias nas formas de trabalho do educador.

Dessa forma, os professores corroboram da ideia de Wood Jr. (1995, p. 190 apud GORESKE, 2007, p. 6) quando define mudança organizacional, sendo: "Qualquer transformação de natureza estrutural, estratégica, cultural, tecnológica, humana ou de qualquer outro componente, capaz de gerar impacto em partes ou em conjunto da organização", pois apontam em sua maioria, que as mudanças são necessárias e vistas com naturalidade, por serem fatores reais na vivência do trabalho. Também é preciso focar o fator resistência, como destaca Dent e Golberg (1999 apud GORESKE, 2007, p. 8) quando "sugerem que os agentes de 
mudança ao propor a mudança considerem a existência de resistência e então inclua tal circunstância no planejamento para criar mecanismos de trabalhá-la". O quantitativo que resiste a mudança, mesmo sendo em porcentagem inferior, faz parte do processo.
Na quarta parte do questionário, a qualidade de vida no trabalho foi analisada conforme a visão dos professores em análise, como segue na tabela (4) abaixo:

Tabela 4 - Representação de indicadores qualidade de vida no trabalho - QVT

\begin{tabular}{|c|c|c|}
\hline Nível de qvt no ambiente de trabalho & $\overline{\mathrm{Fr}}$ & $\%$ \\
\hline Ruim & 2 & $13 \%$ \\
\hline Regular & 7 & $47 \%$ \\
\hline Bom & 6 & $40 \%$ \\
\hline Ótimo & 0 & $0 \%$ \\
\hline Condições de trabalho no ambiente de atuação & $\mathrm{Fr}$ & $\%$ \\
\hline Satisfatórias & 4 & $27 \%$ \\
\hline Insatisfatórias & 5 & $33 \%$ \\
\hline Regulares & 5 & $33 \%$ \\
\hline Ruins & 1 & $7 \%$ \\
\hline Qvt imposta pelo trabalho tem influênciado em sua saúde & $\mathrm{Fr}$ & $\%$ \\
\hline Sim & 10 & $67 \%$ \\
\hline Não & 5 & $33 \%$ \\
\hline $\begin{array}{c}\text { Em que nível, caso respondeu sim ao item anterior (10 } \\
\text { professores) }\end{array}$ & Fr & $\%$ \\
\hline Moderado & 5 & $50 \%$ \\
\hline Intenso & 4 & $40 \%$ \\
\hline Raro & 1 & $10 \%$ \\
\hline como analisa sua atuação no trabalho & fr & $\%$ \\
\hline Boa & 12 & $80 \%$ \\
\hline Ótima & 1 & $7 \%$ \\
\hline Regular & 2 & $13 \%$ \\
\hline tem dificuldade com alunos indisciplinados & $\mathrm{fr}$ & $\%$ \\
\hline $\operatorname{sim}$ & 6 & $40 \%$ \\
\hline Não & 9 & $60 \%$ \\
\hline Sente-se realizado atuando com sua profissão de professor & Fr & $\%$ \\
\hline $\operatorname{Sim}$ & 8 & $53 \%$ \\
\hline Não & 7 & $47 \%$ \\
\hline Parãmetro de equilibrio - trabalho, família e vida pessoal & $\mathrm{Fr}$ & $\%$ \\
\hline Ruim & 0 & $0 \%$ \\
\hline Regular & 6 & $40 \%$ \\
\hline Satisfatório & 7 & $47 \%$ \\
\hline Ótimo & 2 & $13 \%$ \\
\hline Valorização da sociedade diante de sua profissão & $\mathrm{Fr}$ & $\%$ \\
\hline Ruim & 7 & $47 \%$ \\
\hline Regular & 7 & $47 \%$ \\
\hline Satisfatório & 1 & $7 \%$ \\
\hline Ótimo & 0 & $0 \%$ \\
\hline Nível de stress durante suas atividades profissionais & $\mathrm{Fr}$ & $\%$ \\
\hline Alto & 6 & $40 \%$ \\
\hline Baixo & 2 & $13 \%$ \\
\hline Moderado & 7 & $47 \%$ \\
\hline Regular & 0 & $0 \%$ \\
\hline $\begin{array}{l}\text { relacionamento com demais funcionários no ambiente de } \\
\text { trabalho }\end{array}$ & fr & $\%$ \\
\hline Ótimo & 4 & $27 \%$ \\
\hline Bom & 11 & $73 \%$ \\
\hline Regular & 0 & $0 \%$ \\
\hline Ruim & 0 & $0 \%$ \\
\hline Péssimo & 0 & $0 \%$ \\
\hline
\end{tabular}

Fonte: Dados da Pesquisa, 2017. 
Ao forcarmos o nível de QVT dos professores, $47 \%$ responderam ser regular, $401 \%$ afirmaram ter um nível bom, 13\% disseram ter um nível ruim, e nenhum respondeu possuir ter um ótimo padrão de qualidade de vida no trabalho.

Com relação às condições de trabalho, os professores ofereceram respostas desanimadoras, 33\% responderam que possuem condições de trabalho regular, a classe que respondeu que o nível é insatisfatório também compreende 33\%, aqueles que acreditam ter condições satisfatórias de trabalho são apenas $27 \%$. E ainda, $7 \%$ (1) dos professores respondeu que as condições de trabalho são ruins.

Os professores revelaram ainda que a QVT tem influenciado em sua saúde, pois, 67\% dos entrevistados responderam positivamente, apenas 33\% não acreditam nessa relação. Dos (10) professores que disseram que QVT afeta sua saúde, 50\% afirma que esse fato acontece de forma moderada, $40 \%$ de forma intensa e apenas $10 \%$ (1) professor acredita que ocorre de forma rara. Revelando que a maioria dos professores envolvidos na pesquisa sentem os reflexos da QVT de forma intensa ou moderada.

Quanto à atuação do professor, a maioria $(80 \%)$, afirmaram ter uma boa atuação, $13 \%$ descreveram sua atuação como regular e apenas $7 \%$ julgaram ser ótima sua atuação profissional. Isso pode ter relação direta com as condições de trabalho oferecidas, bem como, com a qualidade de vida do ambiente que lecionam.

Com respeito à dificuldade de lidar com alunos indisciplinados, $60 \%$ afirma não ter essa dificuldade. No entanto, $40 \%$ dos envolvidos possuem dificuldades de lidar com esse tipo de aluno.

No que concerne à realização profissional, $53 \%$ disseram ser realizados na profissão de professor, enquanto $47 \%$ dos professores não se sentem realizados com sua profissão. Revelando um número expressivo de insatisfeitos com a profissão.

Voltando-se ao parâmetro de equilíbrio entre trabalho, família e vida pessoal, 47\% estabelecem essa relação como satisfatória, 40\% como regular, 13\% como ótima e nenhum dos pesquisados acredita possuir um parâmetro de equilíbrio ruim. Assim, podemos entender que a maioria estar conseguindo equilibrar trabalho, família e vida pessoal.

Ao que se refere à valorização da profissão diante da sociedade, $47 \%$ acreditam ser de cunho regular, aqueles que acham que a valorização está no parâmetro ruim compreendem também 47\%, apenas 7\% (1 professor) considera o nível de valorização satisfatório e nenhum acredita ser de nível ótimo a valorização diante da sociedade.

Em se tratando do nível de stress durante atividades profissionais, $47 \%$ afirmaram que 0 nível de stress enfrentado é moderado, 40\% responderam que o nível de stress sofrido é alto, $13 \%$ expuseram que o nível baixo, nenhum dos envolvidos estabelecem o nível de stress como sendo regular. Isso revela que fatores anteriores citados na pesquisa corroboram para esse favorável nível de stress enfrentados pelos professores em suas atividades educacionais.

No que diz respeito ao relacionamento com os demais funcionários no ambiente de trabalho, o resultado foi que $73 \%$ dos envolvidos apresentaram ter um bom relacionamento, $27 \%$ afirmaram ter um ótimo relacionamento, não sendo pontuados os níveis de relacionamento, regular, ruim e péssimo por nenhum dos professores da pesquisa.

Assim esses indicadores demonstram possuir fatores negativos quanto à desvalorização da profissão do professor, a problemática das condições de trabalho, o estresse em sala de aula, a saúde afetada, aspectos que refletem diretamente na qualidade de vida dos envolvidos na pesquisa. A classe estudada passa a maior parte do tempo em seu local de trabalho, formando cidadãos, desempenhado suas funções, contribuindo para o desenvolvimento da sociedade. Aspectos como bem estar, condições de trabalho, garantia de saúde física e psicológica, dentro outros devem estar em sintonia e em pleno funcionamento para que haja um equilíbrio e um contínuo progresso, nesse caso na organização educacional.

Sobre isso, Limongi-França e Rodrigues (2007, p. 156 apud MARANHÃO, 2012, p. 56) discorrem:

Qualidade de vida no trabalho é uma compreensão abrangente e comprometida das condições de vida do trabalho, que inclui aspectos de bem-estar, garantia da saúde e segurança física, mental e social e 
capacitação para realizar tarefas com segurança e bom uso da energia pessoal.

Portanto, o avanço da organização deve ser pensando tendo o funcionário como fator principal, pois todo o bom desempenho da organização depende da qualidade das atividades destes, que no caso da organização em análise é a escola.
Na quinta parte do questionário foi analisada a relação, segundo visão dos professores em questão, entre a cultura da organização, mudança organizacional e qualidade de vida no trabalho, como revela a tabela (5) em sequência:

Tabela 5 - Indicadores da Relação Entre Cultura Organizacional, Mudança Organizacional e Qualidade de Vida no Trabalho

\begin{tabular}{|c|c|c|}
\hline $\begin{array}{c}\text { A mudança na organização altera a cultura da } \\
\text { organização e afeta a qualidade de vida no trabalho } \\
\text { do professor }\end{array}$ & $\mathrm{Fr}$ & $\%$ \\
\hline $\begin{array}{c}\text { Não } \\
\text { Moderadamente } \\
\text { Intensamente } \\
\text { Raramente }\end{array}$ & $\begin{array}{c}0 \\
11 \\
4 \\
0\end{array}$ & $\begin{array}{c}0 \% \\
73 \% \\
27 \% \\
0 \%\end{array}$ \\
\hline
\end{tabular}

Com respeito à relação entre a cultura da organização, mudança organizacional e QVT, $73 \%$ dos professores afirmam ocorrer essa relação de forma moderada, $27 \%$ acreditam que ocorre de forma intensa. Nenhum dos pesquisados concorda que a relação exista de modo raro, nem tão pouco que não aconteça.

Assim os professores entendem que existe uma relação significativa, pois, quando ocorre a mudança na organização, consequentemente existe alteração na cultura da organização e inevitavelmente afeta a qualidade de vida no trabalho. Pode-se entender essa relação, quando Goreske (2007, p. 7) afirma: "a mudança nas pessoas e na cultura da organização que provoca alterações nos comportamentos, atitudes, expectativas, aspirações, necessidades, que afetam a cultura organizacional". Portanto, essas alterações alteram também a qualidade de vida no trabalho, podendo ser de cunho positivo ou negativo.

\section{CONCLUSÃO}

A cultura organizacional muda através das mudanças nas organizações e por sua vez, altera a qualidade de vida no trabalho dos envolvidos.

Este trabalho pretendeu apontar as relações existentes entre a cultura da organização, mudança organizacional e qualidade de vida no trabalho na percepção dos professores de uma escola da rede estadual na cidade de João Pessoa - Paraíba.

Contextualizada nesta pesquisa e mais especificamente na área educacional, essa temática apresentou-se de modo mais detalhado, a fim de que as organizações pudessem constatar sua real importância.

Os dados obtidos na pesquisa revelam que os professores contribuem para a formação da cultura organizacional, a maioria tem seu trabalho influenciado por ela e afirmam que a cultura organizacional predominante ajuda no desempenho de suas atividades. Observam as mudanças na organização (escola) como necessárias e naturais.

A maioria dos professores diz ter um nível regular de QVT, e declaram que as condições de trabalho são de insatisfatórias para regulares. Ainda, expõem que esse processo influência em sua saúde de intenso para moderado, gerando um quadro de estresse moderado. Enfatizam possuir boa atuação em sala de aula, e que não passam por dificuldades com alunos indisciplinados. No entanto, a grande parte dos professores envolvidos na pesquisa, não são realizados com a profissão. E entendem que o nível de valorização de sua profissão diante da sociedade vai de regular a ruim. Porém, conseguem atingir um equilíbrio satisfatório 
entre trabalho, família e vida pessoal e um bom relacionamento com os demais profissionais no ambiente de trabalho.

Contudo, compreende-se que a mudança organizacional altera a cultura organizacional e esta, afeta de forma significativa a qualidade de vida do professor de forma moderada.

De modo geral, as relações da temática apresentam fatores favoráveis. No entanto, suas dimensões negativas são preocupantes, visto que podem comprometer o serviço oferecido, ou seja, a educação.

Sendo assim, esses dados são importantes para as organizações principalmente as educacionais, a fim de analisarem as

\section{REFERÊNCIAS}

[1] [Andrade, Érika; Andrade, Virgínia. Estudo da relação entre cultura organizacional e qualidade de vida no trabalho: estudo de caso ampla e energisa. In: CONGRESSO NACIONAL DE EXCELÊNCIA EM GESTÃO, 6, Niterói, 2010. Anais... Niterói, 2010.

[2] Bergue, Sandro Trescastro. Cultura e mudança organizacional. Florianópolis: UFSC, 2010.

[3] Bosi, Alfredo. Dialética da colonização. São Paulo: Companhia das Letras, 1996.

[4] Eagleton, Terry. A ideia de cultura. $2^{\underline{a}}$ ed. São Paulo: UNESP, 2011.

[5] Fachin, Odília. Fundamentos de metodologia. 4.ed. São Paulo: Saraiva, 2003.

[6] Furlanetto, Solange Maria. Qualidade de vida no trabalho: A percepção dos servidores da prefeitura municipal de Porto Alegre. $112 f$. Especialização. (MBA em Gestão Pública). Instituto Brasileiro de Gestão de Negócios, Faculdade IBGEN, 2008.

[7] GIL, Antonio Carlos. Como elaborar projetos de pesquisa. 4.ed. São Paulo: Atlas, 2002.

[8] Goreske, Andréia Madeira. Mudança organizacional - Capacidade de adaptação. Revista do Granbery, 1 - 272, Semestre 2, 2007.

[9] Gorzoni, Patrícia Miola. Cultura Organizacional e Qualidade de Vida no Trabalho: Estudo com funcionários de um restaurante fastfood. 209f. Dissertação. (Mestrado - Programa de Pós-Graduação em Engenharia de Produção e área de concentração em economia, organização e gestão do conhecimento) - Escola de Engenharia de São Carlos, Universidade de São Paulo, 2010.

[10] Maranhão, Marise Leal. Cultura Organizacional e práticas de Qualidade de Vida no Trabalho: um estudo de múltiplos casos em palcos organizacionais de restaurantes do Recife - PE. 134f. Dissertação (Mestrado Profissional em Gestão Empresarial) - Centro de Pesquisa e Pós- estratégias melhorando os pontos fortes e corrigindo os pontos fracos, para que não comprometa ainda mais o desenvolvimento e desempenho da escola, e consequentemente, os resultados no ensino/aprendizagem.

Portanto, as mudanças devem ser pensadas antes de serem impostas, a cultura da organização por sua vez, só é alterada através das mudanças na organização, e a QVT só é alterada seja de forma positiva ou negativa, se as mudanças de fato ocorrerem. Para que haja a transformação de modo significativamente positivo na QVT, é preciso o foco da mudança estar no profissional da educação e em sua atuação no ambiente escolar.

Graduação em Administração, Faculdade Boa Viagem, Recife, 2012.

[11] Martins, Gilberto de Andrade. Manual para elaboração de monografias e dissertações. 2.ed. São Paulo: Atlas, 2000.

[12] Maximiano, Antonio César Amaru. Teoria geral da administração: da escola cientifica à competitividade na economia globalizada. 2.ed. São Paulo: Atlas, 2000.

[13] Oliveira, Maria Marly. Como fazer projetos, relatórios, monografias, dissertações e teses. Recife: Bagaço, 2003.

[14] Oliveira, Silvio Luiz. Tratado de metodologia cientifica: projetos de pesquisa, TGI, TCC, monografias, dissertações e teses. São Paulo: Pioneira, 1997.

[15] Quadros. Terezinha. Globalização, Novas Tecnologias, Educação e Trabalho: uma reflexão sobre a possibilidade de superação da exclusão. NUPPEAD, 1999. Disponível em:<http://www.uesc.br/cpa/artigos/globalizacao_n ovas_tecnologias_educacao_trabalho.pdf >. Acesso em: 18 Ago. 2014.

[16] Santos, Maria José Pereira dos; SCHEIDT JUNIOR, Ademar Silva. A qualidade de vida no trabalho - QVT e sua influência na retenção de talentos numa empresa atacadista em Guarujá Mirim / Rondônia. In: CONGRESSO NACIONAL DE EXCELÊNCIA EM GESTÃO, 9, Niterói, 2013. Anais... Niterói, 2013.

[17] Silva, Kalina Vanderlei; SILVA, Maciel Henrique. Dicionário de Conceitos Históricos. São Paulo: Contexto, 2006.

[18] Salles, Maria Aparecida Magalhães; Boas, Ana Alice Vilas. Contribuições da Mudança de Foco da Cultura Organizacional para a Qualidade de Vida no Trabalho: da Produção para Pessoas. In: Simpósio DE Excelência EM Gestão E Tecnologia, 2, Niterói, 2006. Anais... Niterói, 2006. [19] Srour, Robert Henry. Poder, cultura e ética nas organizações: o desafio das formas de gestão. Rio de Janeiro: Elsevier, 2005. 


\section{Gapítulo 21}

\section{GESTÃO DE RESIDUUS DE SERVIÇO DE SAÚDE: UMA ABORDAGEM TECNICA INCINERAÇÃO}

\section{Débora Batista de Farias}

Avenilson Gomes da Trindade

Luis Carlos Ufei Hassegawa

Aloir Pedruzzi Junior

Jonimar da Silva Souza

Nubiana de Lima Irmão Pedruzzi

Resumo: A produção de resíduos ao longo da história da humanidade vem crescendo a cada ano. O crescimento da população pode ser citado como um dos motivos desse acontecimento, fator que exige maior quantidade de matérias-primas e também de meios para a destinação desses materiais. Nesse Cenário a atividade hospitalar é responsável pela geração de grandes quantidades de resíduos de serviços de saúde (RSS), que promovem impactos consideráveis à natureza e à coletividade, caso tenham uma precária e indevida disposição final, sem o tratamento adequado. Diante desse contexto a presente pesquisa tem como objetivo discutir acerca da implantação de um empreendimento de incineração de resíduos sólidos de saúde. A pesquisa em pauta é do tipo exploratória, com uma abordagem qualitativa, essa pesquisa encontrou sua base em autores que já possuem produções acerca da temática. Essas produções foram elencadas, lidas, analisadas e, por fim, selecionadas a partir da relevância que demonstraram à temática. Através da pesquisa, Foi possível concluir que para o gerenciamento de RSS, é necessário o uso de técnicas desenvolvidas com competência e menor agressividade ao meio ambiente, sentido pelo qual a incineração aparece como o principal e menos agressivo à natureza.

Palavras-chave: Planejamento. Gerenciamento. Resíduos Sólidos de Saúde. 


\section{INTRODUÇÃO}

A produção de resíduos ao longo da história da humanidade vem crescendo a cada ano. O crescimento da população pode ser citado como um dos motivos desse acontecimento, fator que exige maior quantidade de matériasprimas e também de meios para a destinação desses materiais. No início da humanidade, os primeiros habitantes produziam resíduos em pequenas quantidades e em composição facilmente absorvida pelo meio ambiente (TCHOBANOGLOUS, 2006).

Nas últimas décadas, com a entrada da temática ambiental na pauta dos grandes debates mundiais, a gestão de resíduos tornou-se uma das principais questões a serem discutidas e solucionadas. Atualmente, os aterros sanitários são os principais meios de utilização para o descarte de resíduos sólidos na maioria das cidades brasileiras. Os populares lixões e aterros não dispõem de um conjunto de sistemas necessários para a proteção do bioma e da saúde pública (ABRELPE, 2011).

Contudo, o uso desses aterros não configura uma solução para os problemas de tratamento de resíduos sólidos, haja vista que um erro no manuseio pode acarretar impactos ambientais como a poluição do ar, do solo e dos recursos hídricos. A geração de energia por meio do uso de fontes renováveis com baixo impacto à natureza e a criação de instrumentos para um eficaz aproveitamento na destinação de resíduos sólidos urbanos são práticas incentivadas por órgãos ambientais do governo.

A incineração configura-se como uma das possibilidades de tratamento dos resíduos sólidos urbanos de modo ambientalmente correto. De acordo com Tchobanouglous (2006) pode ser definida como o processamento térmico em que os resíduos sólidos são oxidados com quantidade de oxigênio em excesso. Esse processo de tratamento de resíduos possui inúmeras vantagens, como a redução imediata do volume e do peso dos materiais a serem incinerados, colaborando para o fim dos aterros sanitários, conforme Kreith (2014).

A atividade hospitalar é responsável pela geração de Resíduos de Serviços de Saúde (RSS), que promovem impactos consideráveis à natureza e à coletividade, caso tenham uma precária e indevida disposição final, sem o tratamento adequado (FERREIRA, 2005).
Nesse cenário, a incineração possui maior aplicabilidade para 0 tratamento desses resíduos. Porém, tendo em vista os equipamentos, na maioria antigos, sem manutenção e controle de emissão de poluentes, a aceitação desse tratamento suscita debates em que se encontram opiniões contrárias e favoráveis. Para o debate sobre essa temática, a presente pesquisa tem como objetivo principal discutir acerca da implantação de um empreendimento de incineração de resíduos sólidos de saúde.

\section{METODOLOGIA}

A presente pesquisa se caracteriza do tipo exploratória, que segundo GIL (2007), possibilita a consideração dos mais variados aspectos relativos ao fato estudado. Com uma abordagem qualitativa, a pesquisa encontrou sua base em autores que já possuem produções acerca da temática. Essas produções foram elencadas, lidas, analisadas e, por fim, selecionadas a partir da relevância que demonstraram à temática.

\section{ANÁLISES E DISCUSSÕES}

Considerando a complexidade do serviço a ser prestado pelo empreendimento, é imprescindível que se planeje adequadamente todos os pontos fundamentais para a composição do negócio. O Plano de Negócios é "um documento que descreve (por escrito) quais os objetivos de um negócio e quais passos devem ser dados para que esses objetivos sejam alcançados, diminuindo os riscos e as incertezas. Um plano de negócio permite identificar e restringir seus erros no papel, ao invés de cometê-los no mercado", como afirma Rosa (2007, p. 59).

Nesse documento, constarão, por exemplo, esclarecimentos pertinentes ao capital para implantação do empreendimento, para a compra de equipamentos, para a manutenção diária e mensal dos equipamentos, além daquele necessário para a remuneração aos funcionários das áreas clínica, administrativa e operacional. Também nele, constarão informações referentes aos investimentos, riscos e planos que a empresa deseja por em prática.

Nesse sentido, inúmeras tecnologias são desenvolvidas para o tratamento de diversos 
tipos e formas de resíduos. As unidades de tratamento, geralmente, utilizam processos de incineração de resíduos sólidos, líquidos e lamas, de acordo com Poletto (2008, p. 31).

O planejamento é o meio pelo qual todo empreendimento deve ser concretizado. Desde os anos 2000, com o crescimento populacional e a mudança do cenário financeiro e político, que possibilitou grandes aberturas de créditos a empresas de pequeno, médio e grande porte, o sonho de muitas pessoas em abrirem suas respectivas empresas, veio de tornando realidade.

Para a concretização das idéias, o planejamento, o conhecimento sobre o cenário mercadológico e a organização para a construção de um roteiro de ação é fundamental a fim de que o sucesso seja alcançado. O Plano de Negócio ajudará na percepção da viabilidade do negócio e na busca por informações mais detalhadas acerca do cenário em que se pretende atuar: os produtos e serviços a serem oferecidos, os clientes, os concorrentes, os fornecedores e, sobretudo os pontos fortes e pontos fracos do empreendimento.

Os Resíduos de Serviço de Saúde são uma fonte de risco à saúde e ao meio ambiente, devido à falta de adoção de procedimentos técnicos adequados ao manuseio de resíduos sólidos e líquidos gerados como materiais biológicos contaminados, objetivos perfurocortantes, peças anatômicas, substancias tóxicas inflamáveis e radioativas.

\subsection{CONCEITUAÇÃO}

Os Resíduos de Serviço de Saúde são uma espécie da categoria de resíduos sólidos. De acordo com a Associação Brasileira de Normas e Técnicas (ABNT 2010), por meio da NBR 1004:2004, o conceito de resíduo sólido por ser definido como "resíduos nos estados sólido e semi-sólido, resultantes de atividades de origem industrial, hospitalar, comercial, agrícola, de serviços e varrição" (NBR 1004, 2010, p. 39). Nessa classe ainda são incluídos os lodos advindos de sistemas de tratamento de água, os gerados em equipamentos e instalações de controle de poluição, além de determinados líquidos cujas características não permitam de serem lançados na rede pública de esgoto ou corpos de água, ou ainda exijam soluções técnicas e economicamente viáveis em face à melhor tecnologia possível. O resíduos sólidos são divididos em três classes: Resíduos Perigosos, Não-inerte e Inertes (Quadro 1).

\section{Quadro 1 - Classificação dos Resíduos Sólidos}

\begin{tabular}{|c|c|c|}
\hline Classificação & Definição & Exemplos \\
\hline $\begin{array}{c}\text { CLASSE I } \\
\text { Resíduos Perigosos }\end{array}$ & $\begin{array}{c}\text { São aqueles que apresentam } \\
\text { periculosidade ou, uma das } \\
\text { características: inflamabilidade, } \\
\text { corrosividade, reatividade, toxidade } \\
\text { ou patogenicidade. }\end{array}$ & $\begin{array}{c}\text { Lixo hospitalas contaminantes, } \\
\text { produtos químicos de indústria, } \\
\text { óleos, cinzas de metais } \\
\text { preciosos, pilha, bateria e } \\
\text { pesticida. }\end{array}$ \\
\hline $\begin{array}{l}\text { CLASSE II } \\
\text { Não-inerte }\end{array}$ & $\begin{array}{c}\text { São aqueles que apresentam } \\
\text { propriedades: combustibilidade, } \\
\text { biodegradabilidade ou solubilidade } \\
\text { em água. }\end{array}$ & $\begin{array}{l}\text { Resto de alimentos, papel, } \\
\text { palha de aço, agulhas, latas e } \\
\text { fiação elétrica. }\end{array}$ \\
\hline $\begin{array}{l}\text { CLASSE III } \\
\text { Inertes }\end{array}$ & $\begin{array}{l}\text { São aqueles que não se degradam } \\
\text { ou não se decompõem quando } \\
\text { disposto no solo (se degradam } \\
\text { muito lentamente), sendo muitos } \\
\text { destes resíduos recicláveis. }\end{array}$ & $\begin{array}{l}\text { Tijolos, plásticos, borracha, } \\
\text { entulhos de demolição, pedras } \\
\text { e areias retiradas de } \\
\text { escavações. }\end{array}$ \\
\hline
\end{tabular}

Fonte: Elaborado com base na NBR no 10004:2004 


\subsection{GERENCIAMENTO}

O conceito de gerenciamento de resíduos de serviço de saúde pode ser definido como o conjunto de procedimentos de gestão que são planejados e implementados com bases científicas e técnicas normativas e legais visando à diminuição da produção de resíduos e promoção de um encaminhamento seguro e eficiente. A gestão desses resíduos representa a proteção dos trabalhadores, a preservação da saúde pública, dos recursos naturais e do meio ambiente como um todo. Esse gerenciamento é composto por diversas etapas de planejamento dos recursos físicos, dos recursos naturais e da capacitação dos recursos envolvidos no manuseio dos RSS. É obrigação de todo gerador de resíduos de serviço de saúde, a elaboração de um Plano de Gerenciamento de Resíduos de Saúde (PGRSS), com base nas características e na classificação dos resíduos que são produzidos no estabelecimento, elencando os parâmetros de manejo dos RSS.

De acordo com a Organização PanAmericana de Saúde (OPAS) e com a Organização Mundial da Saúde (OMS), o gerenciamento dos RSS abrange procedimentos que devem ser implantados da geração à disposição final. Nesse processo devem ser verificadas as questões técnicas, normativas e legais, visando à diminuição da produção e à proteção dos trabalhadores que manuseiam esses materiais, além da preservação da saúde pública da população, dos recursos naturais e do meio ambiente (CENTRO PANAMERICANO, 1997)

Os resíduos produzidos pelo National Taiwan University Hospital (NTUH) foram submetidos à avaliação por Li e Jenq (1993) por meio de um tratamento de incineração. Os resultados alcançados mostram que os resíduos continham 38\% de umidade e um poder calorífico de $3.400 \mathrm{kcal} / \mathrm{kg}$, compreendidos entre $34 \%$ de carbono e $15 \%$ de oxigênio. Os sistemas de tratamento de resíduos são influenciados diretamente pelas características físico-químicas, pois essas estão relacionadas ao poder calorífico (MATTIOLI; SILVA, 2012).

Apesar disso, a separação desses resíduos é de fundamental importância, pois determina para que a destinação final dos RSS seja feita de maneira adequada. Assim, a decisão sobre quais alternativas podem ser utilizadas para o tratamento dos resíduos selecionados, fazendo assim, com que os equipamentos e técnicas utilizadas sejam mais convenientes (SCHNEIDER; ALDART; GASTALDELLO, 2012).

De acordo com a resolução no 358 do Conselho Nacional do Meio Ambiente (CONAMA, 2005) e com a Agência Nacional de Vigilância Sanitária (ANVISA) os RSS são classificados em cinco grupos, tendo como parâmetro para essa classificação as características e os riscos oferecidos pelo material (Quadro2).

Quadro 2 - Classificação da Periculosidade dos Resíduos Sólidos

\begin{tabular}{|l|l|}
\hline \multicolumn{1}{|c|}{ Classificação Definição } \\
Grupo A & $\begin{array}{l}\text { Resíduos com a possível presença de agentes } \\
\text { biológicos devido a suas características de maior } \\
\text { concentração de vírus pode conter significativo } \\
\text { risco de infecção. }\end{array}$ \\
\hline Grupo B & $\begin{array}{l}\text { Resíduos que contém substâncias químicas que } \\
\text { apresentam risco à saúde pública ou ao meio } \\
\text { ambiente, dependendo as características como } \\
\text { inflamabilidade, corrosividade, reatividade } \\
\text { toxidade. }\end{array}$ \\
\hline
\end{tabular}


Quadro 2 - Classificação da Periculosidade dos Resíduos Sólidos (continuação)

\begin{tabular}{|l|l|}
\hline Classificação & \multicolumn{1}{|c|}{ Definição } \\
Grupo C & $\begin{array}{l}\text { Todo material que é resultado de atividades } \\
\text { humanas que envolvam rádio nuclídeos em } \\
\text { quantidade superior a do limite de eliminação } \\
\text { que as normas da Comissão Nacional de Energia } \\
\text { Nuclear (CNEN) estipulam. }\end{array}$ \\
\hline Grupo D & $\begin{array}{l}\text { São os resíduos que não representam um risco } \\
\text { biológico, químico ou radiológico de } \\
\text { contaminação à saúde ou ao meio ambiente, } \\
\text { sendo possível a equiparação aos resíduos } \\
\text { domiciliares. }\end{array}$ \\
\hline \multirow{3}{*}{ Grupo E } & $\begin{array}{l}\text { Constituído por materiais perfuro-cortantes ou } \\
\text { escarificantes, a exemplo de lâminas de } \\
\text { barbeação, escalpes, agulhas, ampolas de vidro, } \\
\text { brocas, limas endodônticas, pontas } \\
\text { diamantadas, lâminas de bisturi, lancetas, tubos } \\
\text { capilares, micro pipetas, lâminas e lamínulas, } \\
\text { espátulas e quaisquer utensílios de vidros que } \\
\text { possam quebrar no laboratório - pipetas, tubos } \\
\text { de coletas sanguíneas e placas de Petri - além } \\
\text { de outros do gênero. }\end{array}$ \\
\hline
\end{tabular}

Fonte: elaborado com base na Resolução no 358 do Conselho Nacional do Meio Ambiente (CONAMA, 2005)

\subsection{INCINERAÇÃO}

Configura-se como uma das técnicas de maior tecnologia do mercado na atualidade. Detalhadamente, denomina o processo de queima de materiais em alta $\left(900^{\circ} \mathrm{C}\right)$ numa mistura com ar durante um tempo prédeterminado. Em casos de incineração de lixo, os compostos orgânicos são reduzidos aos constituintes mineiras, principalmente o dióxido de carbono gasoso e vapor d'água e sólidos inorgânicos.

De acordo com a resolução $n^{\circ}$ 5/93 do CONAMA, não é obrigatória a incineração de lixo hospitalar como meio de tratamento do lixo, apesar de esse método ser considerado por grande parte de especialistas na área como a forma mais indicada para o tratamento e a disposição de resíduos de serviço de saúde.
A instalação de um incinerador deve ser precedida por uma análise repleta de cuidados, como conhecimento das características do lixo a ser incinerado e das consequências de uma inadequada realização dessa técnica. Para que se adeque aos níveis de controle de emissões na atmosfera, o processo de incineração ocorre em duas fases: combustão primária e combustão secundária. A duração da combustão primária é estimada entre 30 a 120 minutos, com uma temperatura que varia entre 500 a $800^{\circ} \mathrm{C}$. Nessa fase ocorre a secagem, o aquecimento, a liberação das substancias voláteis e a transformação do resíduo remanescente em cinzas, gerando o material particulado. 
Figura 1 - Exemplo de Incinerador de Resíduos

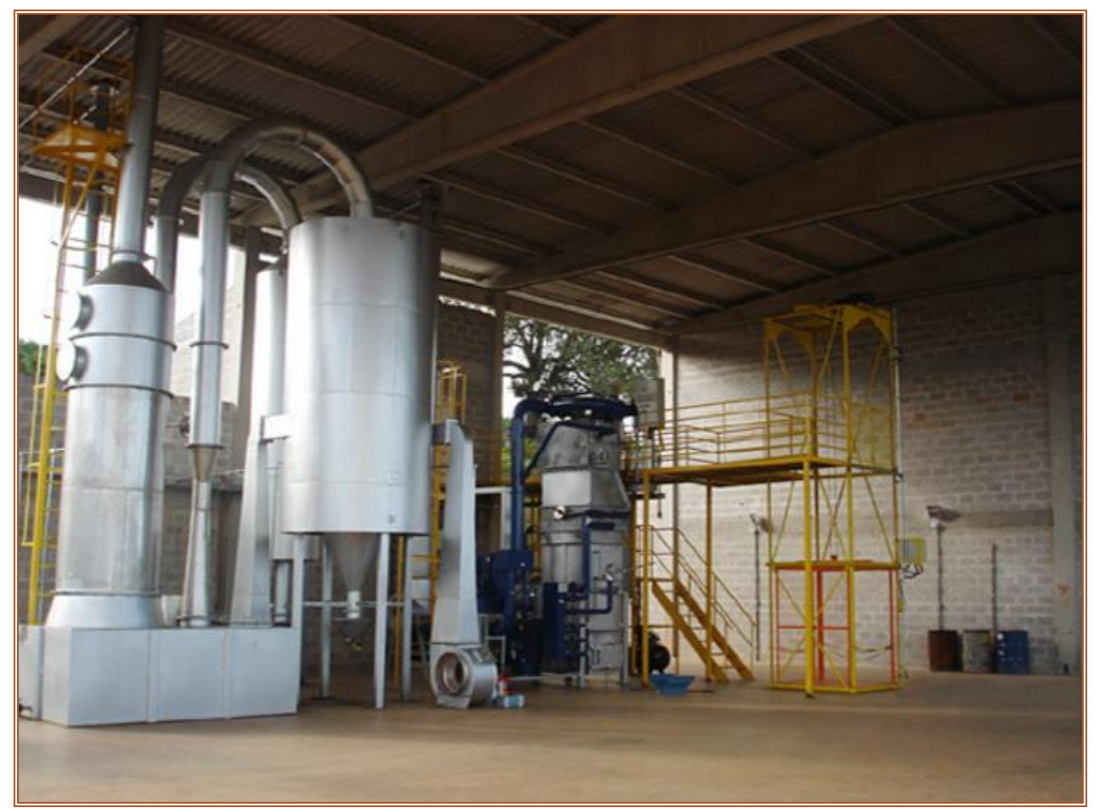

Fonte: autores.

$\mathrm{Na}$ combustão secundária, os gases, os vapores e o material particulado, liberados anteriormente, são soprados ou succionados para câmeras de combustão secundária ou pós-combustão, local em que permanecem por aproximadamente dois segundos, sob uma temperatura de $1000^{\circ} \mathrm{C}$, fazendo com que, nessa fase, ocorra a distribuição das substancias voláteis e parte do material particulado.

Rego (2014, p. 42) lista os níveis a serem estritamente obedecidos para a adequada combustão dos resíduos: a temperatura, que deve estar entre $800^{\circ} \mathrm{C}$ e $1000^{\circ} \mathrm{C}$; o tempo de retenção de aproximadamente dois segundos, expondo os materiais a chama, realizando a queima; a turbulência que promove contato das partículas com o oxigênio necessário a queima; a disponibilidade de oxigênio nas taxas determinadas ao processo, a fim do asseguramento da completa distribuição dos resíduos, inclusive os subprodutos formados, a exemplo dos dioxina e PCB's.

De acordo com o IPT/CEMPRE (Instituto de Pesquisas Tecnológicas e Compromisso Empresarial para Reciclagem, 1995), a classe dos metais é redistribuída para a corrente gasosa e outra parte continua nas cinzas podendo ser recuperada para a reciclagem. As cinzas desses metais, após submetidas a análises, são dispostas em aterros Classe I ou II em observância à classificação final. Um dos fatores interferentes na operação de um incinerador que pode resultar em poluição ambiental e ineficiência na distribuição dos micro-organismos são, por exemplo, gradientes de temperatura ocasionados pelo uso intermitente; velocidades lineares que excedem aos critérios de temperatura que são causados pela operação inadequada; proteção de micro-organismos quando, por exemplo, são cobertos por camadas de lixo úmido, não possibilitando que haja a combustão efetiva dos resíduos, de acordo com o que afirma a CETESB (1991).

$\mathrm{Na}$ incineração, os custos para o tratamento de RSS são elevados, possivelmente devido às exigências ambientais como a depuração dos gases (MORA, 1996). De acordo com o IPT/CEMPRE (1995), os custos iniciais para a aquisição de incineradores diminuem à medida que aumenta a capacidade do equipamento em realizar os serviços de incineração.

Com a realização das leituras referente à temática, no quadro 3 foi possível listar as vantagens e desvantagens que o processo de incineração pode ocasionar desde que seja realizado como processo de tratamento e/ou disposição final de resíduos de serviço de saúde. 
Quadro 03 - Vantagens/Desvantagens da Realização de Incineração de RSS

\begin{tabular}{|c|c|}
\hline Vantagens & Desvantagem \\
\hline $\begin{array}{l}\checkmark \quad \text { Possibilidade de uso para todos os } \\
\text { tipos de resíduos infectantes, até mesmo } \\
\text { alguns resíduos especiais, sem a realização de } \\
\text { segregação intra-hospitalar; }\end{array}$ & $\begin{array}{l}\checkmark \quad \text { As dificuldades de controle dos } \\
\text { efluentes gasosos, sendo possível a emissão de } \\
\text { dioxinas; }\end{array}$ \\
\hline $\begin{array}{l}\checkmark \quad \text { A redução significativa de peso e de } \\
\text { volume (próximos a } 15 \% \text { em peso); }\end{array}$ & $\begin{array}{l}\checkmark \\
\text { caso o existência de partículas metálicas, } \\
\text { operado; }\end{array}$ \\
\hline $\begin{array}{l}\checkmark \quad \text { Em caso de bom manuseio, cinzas e } \\
\text { gases serão os produtos finais; }\end{array}$ & $\begin{array}{l}\checkmark \text { Algumas dificuldades para a incineração } \\
\text { de resíduos com alta umidade; f) exigência de } \\
\text { grandes investimentos iniciais; }\end{array}$ \\
\hline $\begin{array}{l}\checkmark \text { A realização das atividades de } \\
\text { incineração ocorre independentemente das } \\
\text { condições meteorológicas; }\end{array}$ & $\begin{array}{l}\checkmark \text { Exigência de grandes investimentos } \\
\text { iniciais; }\end{array}$ \\
\hline \begin{tabular}{lrcc}
\multicolumn{1}{c}{ Eliminação } & de & \multicolumn{2}{c}{ características } \\
repugnantes dos & resíduos & patológicos es e \\
animais; & & & \\
\end{tabular} & $\begin{array}{l}\checkmark \quad \text { A exigência de grandes investimentos } \\
\text { para o controle da seguridade ambiental; }\end{array}$ \\
\hline $\begin{array}{l}\checkmark \quad \text { A dispensa de monitoramento do lençol } \\
\text { freático em longo prazo, considerando o fato } \\
\text { de que os resíduos são destruídos e não } \\
\text { guardados. }\end{array}$ & $\begin{array}{l}\checkmark \text { A variabilidade de composição dos } \\
\text { resíduos que pode acarretar problemas no } \\
\text { manuseio dos resíduos e na operação do } \\
\text { incinerador, além de demandar realização de } \\
\text { manutenções mais frequentemente; }\end{array}$ \\
\hline
\end{tabular}

Fonte: BRIDGWATER, 2015.

A apresentação de elevados teores de enxofre e ácido clorídrico, na reação de combusto. Esses produtos surgiram nos gases de combustão e são expelidos pela chaminé dos incineradores que são inadequadamente projetados ou operados. A incineração se realizada de modo correto, obedecendo às normatizações, configura-se como um método de tratamento adequado para os RSS (BRIDGWATER, 2015). Apesar disso, devem ser considerados o potencial energético dos resíduos e as perdas de gases que ocorrem durante os processos de GCC: no incinerador variam de $8 \%$ a $12 \%$ e na caldeira de $15 \%$ a $25 \%$.

A disposição sobre os procedimentos e critérios para o funcionamento de sistemas tratamento térmico de resíduos está prevista na Resolução ํo 316 do CONAMA, datada de 29 de outubro de 2002 (BRASIL, 2002). Já a ABNT por meio de sua NBR 11.175:1990 (ABNT, 1990) também prevê os parâmetros de desempenho para incineração. Para que os RSS estejam aptos a esse processo, eles devem estar caracterizados para que se conheça a composição tóxica, o poder calorífico, a umidade, os elementos que compõem além de outros listados (ABNT, 1990).
De acordo com a NBR, a incineração é caracterizada como um procedimento de oxidação à alta temperatura que destrói ou reduz o volume ou recupera os materiais ou substancias. Já um incinerador, é qualquer dispositivo, aparato, equipamento ou estrutura utilizada para a execução desse processo.

Em países como Áustria, Alemanha, Reino Unido, França e Itália, o incinerador de resíduos é utilizado comumente (MAVROPOULOS, 2010). Já na cidade de Istambul, um incinerador construído em 1995 tem a capacidade de tratamento de 24 toneladas de RSS por dia, reduzindo a quantidade de resíduos que pode ser depositada em aterros (KARSAK; KARADAYI, 2011). Entretanto, um ponto frequentemente mostrado como possível de desvantagem é a periculosidade referente à emissão de poluentes tóxicos e danosos às pessoas e ao meio ambiente (DURSUN; KARSAK; KARADAYI, 2011). 


\section{CONSIDERAÇÕES FINAIS}

O planejamento constitui-se como o principal instrumento de implantação de todo empreendimento. Nesse sentido, para a instalação de uma empresa especializada em incineração de resíduos sólidos de saúde é necessária a elaboração de um documento chamado plano de negócios. Nesse documento, constarão informações acerca de todos os âmbitos do empreendimento, como aspectos financeiros, logísticos, de marketing, de operações e principalmente de análise sobre viabilidade mercadológica.

A partir da pesquisa aqui desenvolvida, foi possível, por meio da metodologia estabelecida, o alcance dos principais enunciados sobre as temáticas aqui tratadas. Os resíduos sólidos de saúde configuram-se

\section{REFERÊNCIAS}

[1] Abrelpe - Associação Brasileira de Empresas de Limpeza Pública e resíduos Especiais. Panorama dos resíduos Sólidos no Brasil. 2014. São Paulo: ABRELPE, 2015.

[2] Associação Brasileira de Normas Técnicas. NBR 10.004: resíduos sólidos Classificação. Rio de Janeiro: ABNT, 2010.

[3] Bertussi Filho, L.A. Curso de Resíduos de Serviços de Saúde: Gerenciamento, Tratamento e Destinação Final - ABES, Curitiba, 1994.

[4] Bogdan, Robert C. \& BIKLEN, Sari Knopp. Investigação qualitativa em educação: uma introdução à teoria e aos métodos. Porto: Porto Editora. 1994.

[5] Bracht, M. J. Disposição Final de Resíduos de Serviços de Saúde em Valas Sépticas. In: Seminário Internacional sobre Resíduos Sólidos Hospitalares, Cascavel, 1993.

[6] Brasil. Congresso. Câmara dos Deputados. Departamento Médico. Plano de gerenciamento de resíduos de serviços de saúde. Brasília: Demed, 2004. 94 p.

[7] Brasil. Lei no 12.305, de 2 de agosto de 2010: institui a Política Nacional de Resíduos Sólidos, altera a Lei no 9.605, de 12 de fevereiro de 1998 e dá outras providências. Diário Oficial da República Federativa do Brasil, Brasília, Seção 1, 3 ago. 2010, p. 2.

[8] Brasil. Ministério da Saúde. Agência Nacional de Vigilância Sanitária. Resolução Anvisa RDC no 306, de 7 de dezembro de 2004: dispõe sobre o regulamento técnico para o gerenciamento de resíduos de serviço de saúde. Diário Oficial da República Federativa do Brasil, Brasília, Seção 1, 10 dez. 2004, p. 49.

[9] Brasil. Ministério do Meio Ambiente. Conselho Nacional do Meio Ambiente. Resolução Conama no 358, de 29 de abril de 2005: dispõe sobre o tratamento e disposição dos resíduos dos serviços de saúde e dá outras providências. Diário como os principais resíduos produzidos a partir de ações de atendimento médicohospitalar, configurando-se como o resultado dessas intervenções.

Para o gerenciamento desses resíduos, é necessário o uso de técnicas desenvolvidas com competência e menor agressividade ao meio ambiente, sentido pelo qual a incineração aparece, entre as outras metodologias para o gerenciamento desses resíduos, como o principal e menos agressivo à natureza. Por fim, a implantação de um empreendimento que gerencie esses resíduos deve ser pautada pelo planejamento, tendo como principal instrumento, o plano de negócio.

Oficial da República Federativa do Brasil, Brasília, n. 84, Seção 1, 4 maio 2005, p. 63-65.

[10] Bridgwater, A. V.; Meier, D.; Radlein, D. An overview of fast pyrolysis of biomass. Organic Geochemistry, v. 30, n. 12, p. 1479-1493, 1999. ISSN 0146-6380.

[11] Centro Panamericano DE Engenharia Sanitária E Ciencias do Ambiente. Guia para o manejo interno de resíduos sólidos em estabelecimentos de saúde. Brasília, DF. Ed. Opas, 1997.

[12] CETESB. Parecer Técnico №001/91/CAI/CAS. São Paulo, 1991

[13] Conselho Nacional do Meio Ambiente Conama. Resolução № 358, 2005.

[14] Ferreira, J.A. (2005) Lixo domiciliar e hospitalar: semelhanças e diferenças. In: Congresso Brasileiro de Engenharia Sanitária e Ambiental, 20, Anais... Rio de Janeiro: ABES. p. 1903-10

[15] Gil, A. C. Como elaborar projetos de pesquisa. 4. ed. São Paulo: Atlas, 2007.

[16] IPT/Cempre. Lixo Municipal: Manual de Gerenciamento Integrado. São Paulo, 1995.

[17] Kreith, F. Handbook of Solid Waste Management, 2a Ed. New York: McGraw-Hill Professional, 2002.

[18] Li.C.S. \& Jenq.F.T., 1993. Physical and Chemical Composition of Hospital Waste. Infection Control and Hospital Epidemiology, 14: 145-150.

[19] Mattioli, C.E.; Silva, C.L.; Avaliação de Parâmetros na Implantação de Processos para o tratamento de Resíduos Sólidos de Serviço de Saúde. Vitória, ES. Anais. Setem, 2012.

[20] Mavropoulos, ANTONIS. Estudo para a Gestão de Resíduos de Serviços de Saúde no Brasil - Relatório Final. EPEM S.A. Environmental Planning Engineering and Management. Disponível em: . Acesso em: 25 de abril de 2017.

[21] Mora, Soraya Mameluque. et. al. Impacto dos Resíduos de Serviços de Saúde sobre o homem e o meio ambiente. Arquivos em 
odontologia, Belo Horizonte, v.40, n.2, p 111-206, abr./jun.1996.

[22] Poleto, C. (Org.) Ambiente e sedimentos. Porto Alegre: Associação Brasileira de Recursos Hídricos, 2008. 404 p

[23] REGO, R. C. E. Planos de Gerenciamento e Formas de Tratamento de Resíduos de Serviços de Saúde, Mímeo, 2004.

[24] Rosa, R. Introdução ao sensoriamento remoto. Uberlândia: Ed. UFU, 2007. 248 p.
[25] Scheneider, V.E.; A caracterização de resíduos de serviço de saúde como ferramenta para o monitoramento de sistemas de gestão desses resíduos em estabelecimentos hospitalares. Porto Alegre, 2012.

[26] Tchobanoglous, G., THEISEN, H, S., Integrated Solid Waste Management: 


\section{Bapítulo 22}

\section{PERCEPÇÃO DE SUSTENTABILIDADE DO CONSUMIDOR PAULISTA DE COSMÉTICOS}

\section{Keli Cristiane Vido}

\section{Beatriz Goncalves Vicente}

Marcela Amorim Fernandes

Luciano Gemignani Montessanti

\section{Lia Mara Dib}

Resumo: Este artigo apresenta uma pesquisa qualitativa a respeito da percepção do consumidor sobre a compra de produtos sustentáveis, valendo-se não apenas da análise do contexto microeconômico do setor de cosméticos mas também de uma pesquisa semiestruturada realizadas com consumidores do estado de São Paulo. 


\section{INTRODUÇÃO}

O Brasil apresenta um crescimento líquido no consumo de produtos cosméticos de $10 \%$ nos ultimos 18 anos principalmente devido a aumento das classes médias e também ao maior acesso da população a estes produtos. Isso tem atraído muitas empresas multinacionais do setor que viram no país a oportunidade de um mercado promissor e que hoje jé é o terceiro maior do mundo.

Em contrapartida, o consumidor brasileiro tem assistido a uma serie de dados preocupantes sobre os danos ambientais causados pelo consumo desmedido de produtos. Isso fez com que o perfil do consumidor mudasse e este passou a valorizar um estilo de vida mais saudável e sustentável.

No âmbito mundial, grandes encontros tem sido realizados com a finalizade de se discutir a economia sustentável nos paises. Como resultados destes encontros, são feitos grandes acordos em que estes paises se comprometem em ampliar suas políticas sustentaveis.

O objetivo deste trabalho é analisar o nível de engajamento sustentável do consumidor de produtos de cosméticos e observar se este nível varia de acordo com dados demográficos da amostra. Para obtenção das informações necessária, foi feita uma pesquisa semi estruturada com uma amostra heterogenea de pessoas. Posteriormente, os dados foram utilizados para criar categoias e subcategorias de perfis com o objetivo de criar grupos homogeneos de pessoas que podessem ser descritos de forma qualitativa.

\section{REVISÃO BIBLIOGRÁFICA}

Conforme o Bruntland (1991, p.47), publicado em 1987 e intitulado como: "Nosso Futuro Comum", desenvolvimento sustentável compreende:

[... um processo de mudança no qual a exploração e o investimento de recursos, a direção do desenvolvimento tecnológico e as mudanças institucionais estejam em harmonia e estimulem, tanto a geração presente como a futura de suprir suas necessidades e aspirações.

O termo sustentabilidade começou a ganhar a adesão a partir de 1900, nos Estados Unidos. Inicialmente na figura de Carl Schurz, Secretário de Interior que defendia que a destruição das florestas estava levando o país a desperdiçar a sua maior herança. Mais tarde sob a presidência de Theodore Roosevelt, naturalista devoto, o termo "uso inteligente/ racional" começou a se configurar. Em 1930, com a crise econômica, social e ecológica que atingiu os Estados Unidos os termos relacionados a sustentabilidade e uso racional foram repensados por Aldo Leopold convergindo os conceitos anteriores para a chamada ética da terra:

[...] cada questão em termos do que é certo ética e esteticamente vantajoso. Uma coisa é certa quando tende para preservar a integridade, a estabilidade e a beleza da comunidade biótica. É errado quando tende no sentido oposto. (LEOPOLD, 1948, p. 206)

O reconhecimento da vulnerabilidade da sociedade moderna que se sustenta na exploração desmedida de recursos ambientais, fez surgir após a segura guerra mundial, diversas conferências que tiveram o objetivo de discutir as questões relacionadas a ética da terra como por exemplo: "[...] pressão sobre os recursos naturais, interdependência de recursos, carência de alimentos e combustíveis, desenvolvimento de novas tecnologias, técnicas educacionais para países subdesenvolvidos e desenvolvimento integrado das bacias hidrográficas". (AFONSO, 2006, p.18).

Para Guimarães (2006, p.40): "[...] fica cada vez mais evidente que carece de sentido confrontar meio ambiente e desenvolvimento, atualmente os problemas ambientais não são tratados internamente, são debatidos e resolvidos em âmbito mundial."

Contudo, somente após a criação da ONU em 1945, ou seja, no ano de 1972, ocorreu a primeira conferência mundial sobre Homem e o Meio Ambiente, o evento discutiu a poluição atmosférica e o uso de recursos naturais foram debatidos pela primeira vez em âmbito global. Vale ressaltar que na contemporaneidade este conceito de sustentabilidade envolve um sentido mais amplo como: formas limpas de produção; conscientização dos atores sociais; consumo susntetável e economia verde.

A ideia de economia verde é recente, e ganhou notoriedade com a Rio+20. De acordo com a ONU a "[...] economia verde pode ser definida como aquela que resulta em melhoria do bem-estar das pessoas 
devido a uma maior preocupação com a equidade social, com os riscos ambientais e com a escassez dos recursos naturais". Para a ONU, pode é característico de uma economia verde baixa emissão de carbono, usa os recursos com eficiência e tem ação socialmente inclusiva. (ONU, 2006).

\section{MERCADO DE COSMÉTICOS}

A indústria de cosméticos é uma segmentação da indústria química. Este setor tem como função a manipulação de fórmulas destinadas a elaboração de produtos para aplicação no corpo humano, para limpeza, embelezamento ou alteração de sua aparência sem afetar sua estrutura e funções. Desta forma, o conceito de cosmético - liga-se diretamente a produtos destinados essencialmente à melhoria da aparência do consumidor. (GARCIA et al., 2000).

A indústria de produtos para higiene pessoal, perfumaria e cosméticos (HPPC) compreende um setor em constante expansão no Brasil. Marcado nos últimos 18 anos pelo crescimento médio de aproximadamente $10 \%$, seu faturamento líquido passou de $\mathrm{R} \$ 4,9$ bilhões (US\$2,2 bilhões) em 1996 para R\$ 38 bilhões (US\$ 17 bilhões) em 2013. Evolução decorrente do: aumento do poder aquisitivo das classes médias ${ }^{5}$; aprimomaramento da tecnologia de fabricação que, promoveu a redução dos custos de produção e, portanto os preços dos produtos; constantes inovação e lançamentos de novos produtos; aumento da expectativa de vida e a busca pela preservação da aparência jovial. (ABIHPEC $\left.{ }^{6}, 2014\right)$.

No contexto aludido acima, as empresas estrangeiras, tem apostado cada vez mais no Brasil. No ranking mundial o Brasil ocupa o terceiro lugar no mercado cosmético. Perdendo apenas para EUA e China. Com faturamento de R\$ 42,6 bilhões em 2014. (ABIHPEC, 2014)

Parelelo a expansão do setor de cosméticos a consciência ecológica do consumidor brasileiro, também se ampliou bem como, a forma como este avalia todas as atitudes em

5 Segundo publicação feita pela Secretaria de Assuntos Estratégicos do Governo Federal em 2012, as classes média alta, média e média baixa contemplam pessoas com renda média familiar de $\mathrm{R} \$ 1764,00$ a $\mathrm{R} \$ 4076,00$.

${ }^{6}$ ABIHPEC: Associação Brasileira das Indústrias de Higiene Pessoal, Perfumaria e Cosméticos. favor da sustentabilidade. Neste aspecto quanto a preocupação na fabricação de cosméticos, conforme uma pesquisa da GFK (2014), mais da metade dos brasileiros considera o impacto ambiental dos cosméticos em suas cestas de compras.

Outro dado relevante foi o estudo do Instituto Akatu (2014) que evidenciou como os cinco principais aspectos que os consumidores brasileiros privilegiam para escolher cosméticos sãao: "[...] não testado em animais (52\%), socialmente responsável (46\%), comprometido com a preservação do meio ambiente $(46 \%)$, fabricado com baixo consumo de energia" (44\%) e certificado para condições dignas de trabalho (43\%).

Gradualmente o consumidor tem adquirido hábitos sustentáveis na escolha de seus produtos, incluindo cosméticos, porém ainda a passos graduais. Um exemplo, da nova tendência de mercado é a empresa Natura que, se especializou em produtos de higiene pessoal e maquiagem e não realiza testes em animais para testar a eficácia e a segurança para posterior envio ao mercado e consumo dos humanos. Além disso, a organização prima em sua produção pelo diminuição de resíduos, uso responsável dos recursos naturais, relação com steakhoulders, uso de logística reversa e conscientização ambiental do consumidor. Em 2015, a Natura foi eleita a 44를 empresa mais sustentável do mundo, isso em um ranking global de 100 empresas (EXAME, 2015).

\subsection{PERCURSO METODOLÓGICO}

Foram utilizadas duas metodologias de pesquisa para compreender os fatores que influeciam a decisao de compra de cosméticos verdes pelo consumidor. $\mathrm{Na}$ primeira etapa foi a bibliográfica. Na segunda etapa foi realizada uma pesquisa com o método qualitativo exploratório, utilizando como instrumento entrevistas semiestruturas, qual o roteiro foi balizado pelos crivos centrais: decisão de compra, sustentabilidade e cosmético verde.

Participaram da pesquisa 20 sujeitos, com idades entre 19 à 60 ano. As informacoes coletadas foram tratadas pela análise de conteúdo balizada por Flores (1994). Foram utilizadas questões semiestruturadas, para que respostas impostas não interferissem a exatidão da compreensão do entrevistado sobre o assunto. 
De acordo com Minayo (2000, p.21): "[...] a pesquisa qualitativa trabalha com um espaço mais profundo das relações, dos processos e dos fenômenos que não podem ser reduzidos à operacionalização de variáveis".

Desse modo o estudo pressupoe que a realidade pode ser mais bem descrita por meio de um entendimento mais sistêmico das relações existente entre as variáveis, proporcionando assim uma maior validade a pesquisa.

\subsection{MÉTODOS E PROCEDIMENTO}

O método de procedimento busca responder detalhadamente como será realizada a pesquisa e quem são os sujeitos da mesma. Para tanto, aqui serão descritos os processos de escolha e desenvolvimento das técnicas de coleta de dados, o tratamento e análise dos dados coletados e quem são os sujeitos da pesquisa. Sendo que a escolha dos instrumentos e técnicas de coleta de dados deve ser influenciada pelo tipo de estudo e seus objetivos, buscou-se escolher aquelas que melhor se adaptam ao estudo de caso.

Para a realização do desenvolvimento de pesquisa, utilizamos consumidores como amostra. Aplicamos então questionários, com perguntas relacionadas ao nível de consciência sustentável do consumidor ao comprar um produto.

\subsection{PESQUISAS QUALITATIVAS}

O método de pesquisa qualitativo surgiu com a necessidade de analisar um objeto que resistia aos métodos estatísticos tradicionais empregados pela pesquisa quantitativa, o homem, a fim de desvendar um objeto subjetivo do pensamento humano. Segundo o artigo de Bacellar (2000), a pesquisa qualitativa foi sendo gradativamente adotada também pela Sociologia, Psicologia, Educação e outras áreas dos estudos sociais, fazendo eclodir diversas técnicas para o método qualitativo. De acordo com Malhotra
(2001, p. 155) a pesquisa qualitativa é definida como uma técnica de "pesquisa não estruturada, exploratória, baseada em pequenas amostras, que proporciona insights e compreensão do contexto do problema" que está sendo estudado. Segundo Freitas e Janissek (2000, p. 25) a análise qualitativa se baseia "na presença ou ausência de uma dada característica, enquanto a análise quantitativa busca identificar a frequência dos temas, palavras, expressões ou símbolos considerados".

Porém um problema muito encontrado, quando se executa a pesquisa, além de ser ressaltado por alguns autores (DAY, 1997; GABRIEL, 1990), como muito perigoso para o êxito da organização, deve ser abordado. Assim, os resultados obtidos na pesquisa qualitativa são usados incorretamente, quando considerados conclusivos e utilizados para fazer generalizações em relação à população alvo, assim, o ideal é a utilização de pesquisas quantitativas como complemento (FREITAS; CUNHA; MOSCAROLA, 1996; MARCHETTI, 1995), buscando-se generalizações dos resultados, ao invés de usá-las mutuamente como concorrentes. (HUNT, 1991). Todavia a pesquisa qualitativa possui variações em sua formação, conhecidas como técnicas.

\subsection{AMOSTRA}

O enfoque principal da pesquisa foi a aplicação do questionário qualitativo com os consumidores. A pesquisa constitui-se de respostas de 20 pessoas diferentes com algumas opiniões diferentes ou iguais.

\subsection{COLETA DE DADOS}

Para a obtenção dos dados para a pesquisa foi utilizado um questionário qualitativo. Com a pesquisa é possível analisar a influência e comportamento dos consumidores em relação aos cosméticos sustentáveis conforme o quadro 1. 
Quadro 1: Participantes

\begin{tabular}{|c|c|c|c|c|}
\hline & Sexo & Idade & $\begin{array}{c}\text { Nível de } \\
\text { Escolaridade }\end{array}$ & Renda Familiar \\
\hline Entrevistado 1 & Feminino & $\begin{array}{c}\text { Acima de } 43 \\
\text { anos }\end{array}$ & Superior Completo & $\mathrm{R} \$ 5501$ ou mais \\
\hline Entrevistado 2 & Feminino & De 19 a 24 anos & $\begin{array}{l}\text { Ensino Superior } \\
\text { Incompleto }\end{array}$ & $R \$ 5501$ ou mais \\
\hline Entrevistado 3 & Feminino & De 19 a 24 anos & $\begin{array}{l}\text { Ensino Superior } \\
\text { Incompleto }\end{array}$ & $\begin{array}{c}\text { De } R \$ 2.001,00 \text { a } R \$ \\
2.500,00\end{array}$ \\
\hline Entrevistado 4 & Feminino & De 25 a 30 anos & Superior Completo & $\begin{array}{c}\text { De } R \$ 3.501,00 \text { a } R \$ \\
4.000,00\end{array}$ \\
\hline Entrevistado 5 & Feminino & De 25 a 30 anos & Superior Completo & $\begin{array}{c}\text { De } R \$ 2.501,00 \text { a } R \$ \\
3.000,00\end{array}$ \\
\hline Entrevistado 6 & Feminino & $\begin{array}{c}\text { Acima de } 43 \\
\text { anos }\end{array}$ & $\begin{array}{l}\text { Ensino Superior } \\
\text { completo }\end{array}$ & De 725,00 a $1.500,00$ \\
\hline Entrevistado 7 & Feminino & De 25 a 30 anos & Superior Completo & $\mathrm{R} \$ 5501$ ou mais \\
\hline Entrevistado 8 & Feminino & $\begin{array}{c}\text { Acima de } 43 \\
\text { anos }\end{array}$ & $\begin{array}{l}\text { Ensino Médio } \\
\text { completo }\end{array}$ & De 725,00 a $1.500,00$ \\
\hline Entrevistado 9 & Feminino & Até 18 anos & $\begin{array}{l}\text { Ensino Médio } \\
\text { completo }\end{array}$ & De 725,00 a $1.500,00$ \\
\hline Entrevistado 10 & Feminino & De 19 a 24 anos & $\begin{array}{l}\text { Ensino Superior } \\
\text { completo }\end{array}$ & $\mathrm{R} \$ 5501$ ou mais \\
\hline Entrevistado 11 & Feminino & De 19 a 24 anos & $\begin{array}{l}\text { Ensino Superior } \\
\text { incompleto }\end{array}$ & $\mathrm{R} \$ 5501$ ou mais \\
\hline Entrevistado 12 & Masculino & Até 18 anos & $\begin{array}{l}\text { Ensino Médio } \\
\text { completo }\end{array}$ & De 725,00 a $1.500,00$ \\
\hline Entrevistado 13 & Feminino & De 25 a 30 anos & $\begin{array}{l}\text { Ensino Superior } \\
\text { incompleto }\end{array}$ & $\begin{array}{c}\text { De } R \$ 3.501,00 \text { a } R \$ \\
4.000,00\end{array}$ \\
\hline Entrevistado 14 & Feminino & De 25 a 30 anos & Superior Completo & $\mathrm{R} \$ 5501$ ou mais \\
\hline Entrevistado 15 & Feminino & De 19 a 24 anos & $\begin{array}{l}\text { Ensino Médio } \\
\text { completo }\end{array}$ & De 725,00 a $1.500,00$ \\
\hline Entrevistado 16 & Masculino & De 25 a 30 anos & $\begin{array}{l}\text { Ensino Superior } \\
\text { incompleto }\end{array}$ & $\mathrm{R} \$ 5501$ ou mais \\
\hline Entrevistado 17 & Masculino & $\begin{array}{c}\text { Acima de } 43 \\
\text { anos }\end{array}$ & $\begin{array}{l}\text { Ensino Médio } \\
\text { completo }\end{array}$ & De 725,00 a $1.500,00$ \\
\hline Entrevistado 18 & Feminino & De 25 a 30 anos & Superior Completo & $\begin{array}{c}\operatorname{De} R \$ 2.501,00 \text { a } R \$ \\
3.000,00\end{array}$ \\
\hline Entrevistado 19 & Feminino & De 25 a 30 anos & Superior Completo & $\begin{array}{c}\text { De } R \$ 3.501,00 \text { a } R \$ \\
4.000,00\end{array}$ \\
\hline Entrevistado 20 & Feminino & De 19 a 24 anos & $\begin{array}{l}\text { Ensino Superior } \\
\text { incompleto }\end{array}$ & $\begin{array}{c}\operatorname{De} R \$ 2.501,00 \text { a } R \$ \\
3.000,00\end{array}$ \\
\hline
\end{tabular}

Fonte: Autores (2015) 
Após a definição dos participantes, por meio de entrevistas feitas de maneira voluntária, efetuamos o registro escrito do que foi dito pelos participantes sem nenhum tipo de alteração ou intervenção dos entrevistadores.

Quadro 2: Roteiro de entrevistas

\section{ROTEIRO DE ENTREVISTAS}

Objetivo da pesquisa: Analisar o comportamento dos consumidores em relação aos produtos cosméticos verdes

1. Pesquisa Socio econômica

2. Consciencia sustentável

3. Atitudes sustentáveis no dia a dia

4. Comportamento em relação aos produtos cosméticos

5. Atitudes em relação ao processo de decisão de compra

6. Consciencia em relação a origem dos produtos que consome

7. Comportamento em relação aos produtos verdes

8. Finalização: se quer acrescentar algo

Fonte: Autores (2015)

A primeira análise feita na pesquisa foi à demográfica, que classificou os entrevistados de acordo com a sua renda, nível de escolaridade, sexo e idade. Estes dados serviram para dimensionar o tipo de amostra da pesquisa em relação a população alvo total de referência desta pesquisa.

Ainda na ficha de coleta de dados, para se saber o que o consumidor entende por um consumo sustentável, a quinta questão (semiestruturada) possuía esta função. Já para aprofundarmos um pouco mais no assunto, perguntamos na sexta questão, quais atividades sustentáveis o consumidor entrevistado praticava no seu dia-a-dia. A sétima questão procura saber quais fatores influenciavam na decisão de escolha de compra por uma marca com exceção do fator preço. Na questão seguinte (oitava), pedimos para que os entrevistados citassem três características que os fariam mudar os cosméticos que utilizam atualmente. O objetivo da nona questão era saber se os entrevistados saberiam responder quais eram as vantagens de utilizar um cosmético sustentável, seguindo com a questão de numero 10 "Você sabe a origem dos produtos que utiliza?". Na décima primeira questão foi questionada o que o consumidor faz com a embalagem após utilizar o produto. Na ultima questão do questionário perguntamos quais tipos de lâmpadas que tem em casa.

Vale ressaltar que em uma pesquisa qualitativa, os dados são meramente descritivos e o pesquisador é o principal instrumento. Portanto o foco que as pessoas entrevistadas dão as coisas e seu comportamento no momento das respostas são também foco de atenção do pesquisador. (LUDKE, 1986) 
Quadro 3: Descrição das categorias

\section{DESCRIÇÃO DAS CATEGORIAS}

CEN Inclui alusões a duas ou mais atitudes que contribuem para a preservação do meio ambiente.

CNE Inclui alusões a uma atitude que contribui para a preservação do meio ambiente, mesmo que indiretamente.

CSE Inclui alusões sobre atitudes que não contribuem para a preservação do meio ambiente ou a falta de compromisso com o tema.

CPP Inclui alusões sobre a intervenção do homem no meio ambiente.

DEM Inclui alusões sobre o desconhecimento total ou parcial sobre o tema sustentabilidade.

NCO Inclui alusões sobre a origem do produto bem como seu modo de produção.

NCP Inclui alusões sobre a origem do produto e seu modo de produção de forma parcial.

NCC Inclui alusões sobre o total desconhecimento da origem dos produtos e meios de produção.

ALP Inclui alusões a atributos de satisfação individual como motivação para compra de cosméticos verdes.

ALS Inclui alusões a sentimentos de consciência limpa e de "fazer a diferença" como motivação para compra de cosméticos verdes.

NAL Inclui alusões sobre o desconhecimento em relação as vantagens de se comprar um cosmético verde.

PEN Inclui alusões a marca e imagem da empresa ao optar por um produto cosmético

PSE Inclui alusões ao preço ao optar por um produto cosmético

PNM Inclui alusões ao público alvo ao qual o produto é destinado ao optar por um cosmético.

PHA Inclui alusões ao hábito ao optar por um produto cosmético.

Fonte: Autores (2015)

Por meio da codificação e da categorização dos dados foi possível analisar o conteúdo das entrevistas e dividir as respostas em subcategorias a partir de palavras chave presentes nos discursos dos entrevistados. A análise das meta-categorias como um todo é possivel a partir da relação que é estabelecida entre si. Esta relação fica mais clara através do mapa mental a seguir. 
Quadro 4: Sistema de categorias

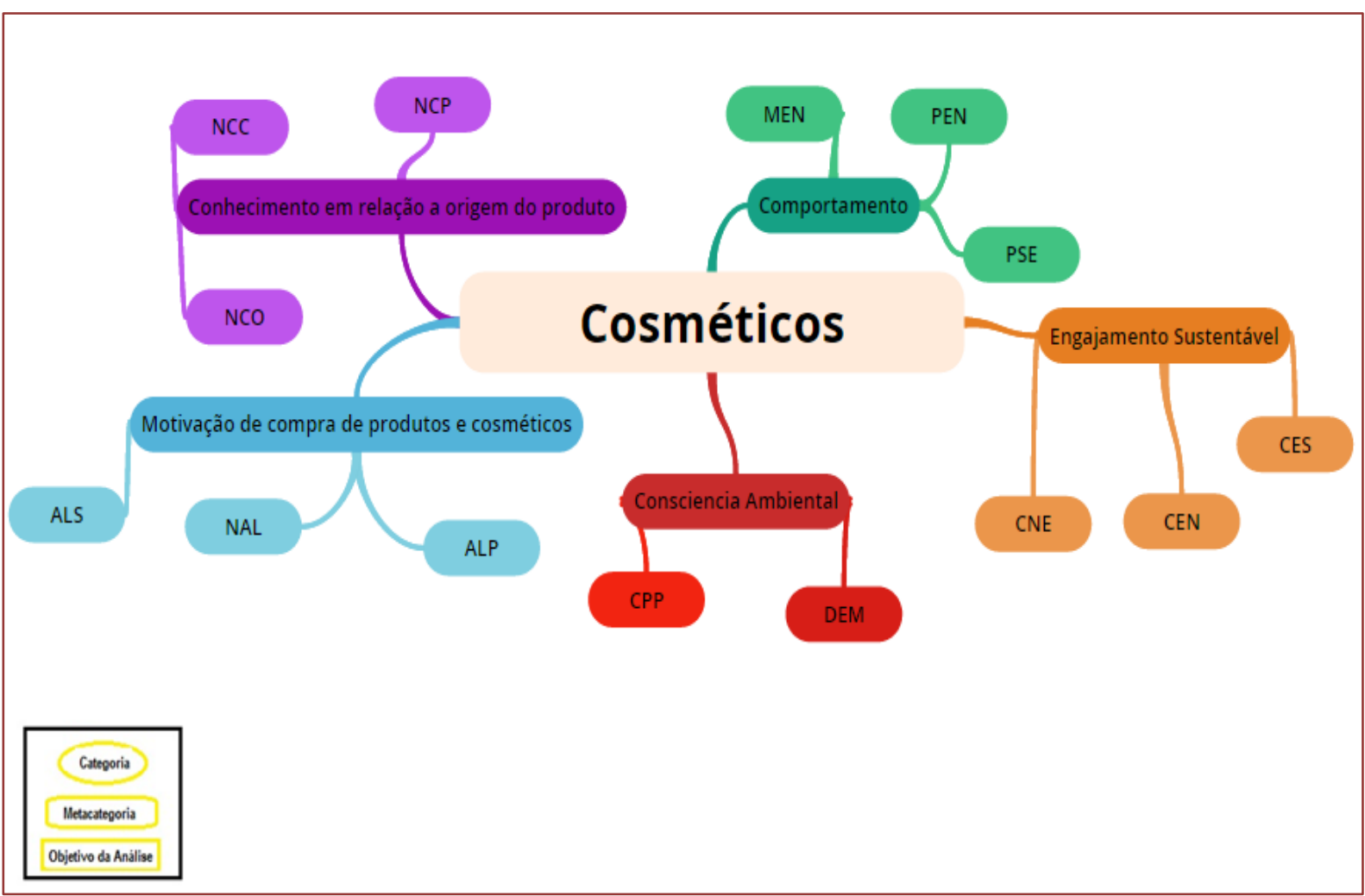

Fonte: Autores (2015)

\section{APRESENTAÇÃO E ANÁLISE DOS RESULTADOS}

Através do conteúdo das entrevistas é possível observar que não foram evidenciadas diferenças na percepção entre homens e mulheres, tampouco entre as diferentes idades. Portanto, é necessário que se leve em consideração que a grande maioria do público entrevistado foi representado por mulheres, uma vez que o envolvimento delas é maior em relação a produtos cosméticos. Portanto o público masculino foi representado em menor número nesta pesquisa.

A análise das meta-categorias foram feitas a partir da transcrição das entrevistas e da identificação de palavras chave que demonstravam um determinado tipo de percepção do entrevistado em relação ao tema.

Quadro 5: Meta-categoria "Engajamento Sustentável"

\begin{tabular}{|l|l|l|l|}
\hline \multicolumn{1}{|c|}{ Código } & \multicolumn{1}{|c|}{$\begin{array}{l}\text { Definição da Categoria } \\
\text { CEN }\end{array}$} & $\begin{array}{l}\text { Inclui alusões a duas ou mais atitudes que contribuem para a } \\
\text { preservação do meio ambiente. }\end{array}$ & R6 e R13 \\
\hline CNE & $\begin{array}{l}\text { Inclui alusões a um atitude que contribui para a preservação do meio } \\
\text { ambiente, mesmo que indiretamente. }\end{array}$ & R6 e R13 \\
\hline CSE & $\begin{array}{l}\text { Inclui alusões sobre atitudes que não contribuem para a } \\
\text { preservação do meio ambiente ou a falta de compromisso com o } \\
\text { tema. }\end{array}$ & R6 e R13 \\
\hline
\end{tabular}

Fonte: Autores (2015) 
A primeira meta-categoria são discutidos os aspectos considerados pelas pessoas para que apontem as suas atitudes do dia a dia como sustentáveis. Segundo Solér (1996) a atitude constitui um processo complexo de decisão de ação que leva em conta a predisposição de componentes cognitivos, de conduta e emotivos. A resposta às perguntas portanto dependeriam primeiramente do que cada entrevistado entendia por consumo sustentável e depois do aspeto emocional no momento da resposta, não se configurando necessariamente um hábito para ele.
André e Salinas (2002) indicam que os indivíduos que possuem um afeto ambiental maior teriam uma atitude ecológica mais positiva. Ou seja, aqueles indivíduos que tem mais acesso a informação tendem a ter uma atitude mais sustentável no dia a dia.

Corrobora com estas definições a próxima meta-categoria que analisa o que o entrevistado entende por consumo sustentável

Quadro 6: Meta-categoria "Consciência Sustentável"

\begin{tabular}{|l|l|l|}
\multicolumn{2}{|c|}{ Código } & \multicolumn{1}{|c|}{ Definição da Categoria } \\
\hline CPP & $\begin{array}{l}\text { Inclui alusões sobre ao prejuízo que o consumo traz ao meio } \\
\text { ambiente. }\end{array}$ & R5 e R12 \\
\hline DEM & $\begin{array}{l}\text { Inclui alusões sobre o desconhecimento total ou parcial sobre o } \\
\text { tema sustentabilidade. }\end{array}$ & R5 e R12 \\
\hline
\end{tabular}

Fonte: Autores (2015)

Nesta categoria foram evidenciados que as pessoas conhecem o significado do termo consumo sustentável - porém em diferentes níveis de maturidade. De modo geral é claro para eles que o consumo afeta de alguma forma o meio ambiente, porém as diferentes formas como isso ocorre e a sua própria responsabilidade por isso foram evidenciadas apenas nas pessoas mais envolvidas com o tema sustentabilidade.

Vale ressaltar que os hábitos de consumo tal qual conhecemos hoje é fruto de uma pressão social imposta pela economia de mercado através da publicidade que impõe estilos de vida para as pessoas. Neste caso, o conhecimento dos impactos ambientais causados pelo consumo não remete a uma decisão de compra mais vantajosa do ponto de vista ambiental.

Ainda neste sentido, Penna (1999, p. 216) ressalta:

Os efeitos da degradação ambiental não podem ser tratados sem que se combatam as suas causas. O capitalismo moderno deu à luz o consumismo, o qual criou raízes profundas entre as pessoas. O consumismo tornou-se a principal válvula de escape, o último reduto de auto-estima em uma sociedade que está perdendo rapidamente a noção de familia, de convivência social, e em cujo seio a violência, o isolamento e o desespero dão sinais alarmantes de crescimento.

Segundo o Programa das Nações Unidas para o Desenvolvimento - PNUD (1998, p. 65),

O consumo sustentável significa o fornecimento de serviços e de produtos correlatos, que preencham as necessidades básicas e dêem uma melhor qualidade de vida, ao mesmo tempo em que se diminui o uso de recursos naturais e de substâncias tóxicas, assim como as emissões de resíduos e de poluentes durante o ciclo de vida do serviço ou do produto, com a idéia de não se ameaçar as necessidades das gerações futuras.

O consumo sustentável portanto deve ser definido como um ato de cidadania, pois cada pessoa assim, é responsável por escolher produtos que não causem prejuízos as gerações futuras, e por fiscalizar as empresas com as quais estabelece alguma relação de consumo. 
Quadro 7: Meta-categoria "Conhecimento em Relação ao Ciclo de Vida do Produto"

\begin{tabular}{|l|l|lr|}
\multicolumn{2}{|c|}{ Código } & \multicolumn{1}{|c|}{ Definição da Categoria } \\
\hline NCO & $\begin{array}{l}\text { Inclui alusões sobre a origem do produto bem como seu modo } \\
\text { de produção e descarte de forma sustentável. }\end{array}$ & $\begin{array}{ll}R 10 \\
R 11\end{array}$ \\
\hline NCP & $\begin{array}{l}\text { Inclui alusões sobre a origem do produto e seu modo de } \\
\text { produção de forma parcial. }\end{array}$ & $\begin{array}{ll}R 10 \\
R 12\end{array}$ \\
\hline NCC & $\begin{array}{l}\text { Inclui alusões sobre o total desconhecimento da origem dos } \\
\text { produtos e meios de produção. }\end{array}$ & $\begin{array}{ll}R \\
R 10\end{array}$ \\
\hline
\end{tabular}

Fonte: Autores (2015)

Esta categoria aponta que os entrevistados não tem conhecimento em relação a origem dos produtos bem como seus meios de produção. Em relação ao descarte de matérias, a grande maioria informa que o descarte no lixo é uma forma de não prejudicar o meio ambiente.

Conforme a Revista de Administração de Empresas - RAE (1995), a maior parte dos resíduos sólidos encontram-se nos grandes centros urbanos, o que na teoria facilitaria a separação e coleta do lixo reciclável por parte dos habitantes. Isso já é observado por exemplo em países desenvolvidos, em que o apoio crescente da comunidades a programas de coleta e reciclagem de resíduos sólidos minimizam o problema do lixo nas grandes cidades.

O problema não está apenas no lixo mas também nos meios utilizados para produção que segundo Brum (1988) são atrativos do ponto de vista econômico pois geram:

\section{[..] a elevação da produtividade do trabalho visando o aumento do lucro; b-) redução dos custos unitários de produção para vencer a concorrência; c- ) necessidade de superar os conflitos entre capital e o latifúndio, visto que a modernização levantou a questão da renda da terra; $d$-) possibilitar a implantação do complexo agroindustrial no país.}

Para Eriksson (1992) a sociedade moderna industrial é caracterizada por um sentido único dos meios de produção. Para ele, não se pode ter sustentabilidade sem um modelo de produção baseado em fluxos que sejam fechados dentro da sociedade, sendo este o grande desafio das relações entre o homem e o meio ambiente.

Quadro 8: Meta-categoria "Motivação para Compra de Cosméticos Sustentáveis"

\begin{tabular}{|l|l|l|}
\multicolumn{2}{|c|}{ Código } & \multicolumn{1}{|c|}{ Definição da Categoria } \\
\hline ALP & $\begin{array}{l}\text { Inclui alusões a atributos de satisfação individual como } \\
\text { motivação para compra de cosméticos verdes. }\end{array}$ & R9 e R13 \\
\hline ALS & $\begin{array}{l}\text { Inclui alusões a sentimentos de consciência limpa e de "fazer a } \\
\text { diferença" como motivação para compra de cosméticos verdes. }\end{array}$ & R9 e R13 \\
\hline
\end{tabular}

Fonte: Autores (2015)

Esta categoria aponta que no momento da decisão da compra, os entrevistados pensam muito mais em benefícios individuais do que coletivos. Para optar por um determinado produto verde ao invés 
de seu consumo habitual, analisam se o custo benefício corresponde a sua expectativa, apesar de apontarem como uma das vantagem de optarem pelo primeiro, o sentimento de 'consciência limpa'.

O processo de decisão de compra tem sido muito estudo pelos empresários uma vez que o conhecimento das variáveis que influenciam o comportamento de compra das pessoas faz com que as empresas tornem se mais competitivas. (ENGEL; BLACKWELL; MINIARD, 2000)

Para Engel (2000), a decisão de compra passa por fatores culturais, sociais, pessoais e psicológicos. Os produtos sustentáveis, por si só, não exercem portanto influencia significativa nos consumidores uma vez que, para que o consumidor haja a favor da sustentabilidade é necessário, não apenas o reconhecimento de um problema ambiental, mas também o reconhecimento de que este problema seja verdadeiramente importante. (ENGEL; BLACKWELL; MINIARD, 2000).

Quadro 9 : Meta-categoria "Motivação para Compra de Produtos Cosméticos"

\begin{tabular}{|l|l|l|}
\multicolumn{1}{|c|}{ Código } & \multicolumn{1}{|c|}{ Definição da Categoria } & \multicolumn{1}{c|}{ Unidade } \\
\hline PEN & $\begin{array}{l}\text { Inclui alusões a marca e imagem da empresa ao optar por } \\
\text { um produto cosmético. }\end{array}$ & $\begin{array}{l}\mathrm{R} 7, \mathrm{R} 8, \mathrm{R} 9, \mathrm{R} 13, \\
\mathrm{R} 14, \mathrm{R} 15\end{array}$ \\
\hline PNM & $\begin{array}{l}\text { Inclui alusões ao publico alvo ao qual o produto é } \\
\text { destinado ao optar por um cosmético. }\end{array}$ & $\begin{array}{l}\mathrm{R} \text { R, R8, R9, R13, } \\
\mathrm{R} 14, \mathrm{R} 15\end{array}$ \\
\hline PHA & $\begin{array}{l}\text { Inclui alusões ao hábito ao optar por um produto } \\
\text { cosmético. }\end{array}$ & $\begin{array}{l}\mathrm{R} \text { R, R8, R9, R13, } \\
\mathrm{R} 14, \mathrm{R} 15\end{array}$ \\
\hline
\end{tabular}

Fonte: Autores (2015)

A meta-categoria motivação dos consumidores ao optar por um produto cosmético, indica que os entrevistados fazem suas escolhas baseadas em seus julgamentos de valor. Ou seja, a avaliação de alternativas depende como o consumidor recebe estímulos como preço, desempenho, confiabilidade, segurança, garantia e satisfação emocional. (ENGEL, BLACKWELL \& MINIARD, 1995). A percepção de valor para os entrevistados ficou clara quando este fez alusão por exemplo a marca do produto como critério de decisão de compra. Por indução, a confiabilidade, segurança e garantia são percebidos por estes consumidores como atributos de alto valor no seu processo de decisão de compra.

Vale ressaltar que nesta parte da pesquisa, o entrevistado foi conduzido a citar outros aspectos que ele leva e consideração para a escolha de um cosmético, além do preço, já que em todas as entrevistas este, de modo geral, foi o primeiro a ser citado.

Engel (1995) complementa que a satisfação do consumidor em relação ao produto é atingida quando o seu desempenho condiz ou excede a sua expectativa. Neste caso, a probabilidade de este produto voltar a ser consumido é muito grande. Por outro lado, se o consumidor fica insatisfeito, o seu consumo não voltará a acontecer da mesma forma, ficando este sujeito a promoção negativa através da advertência de terceiros. (SCHIFFMAN \& KANUK, 2000).

Corroboram com esta teorização os entrevistados que apontaram como o habito de consumo como o fator com mais valor no momento da decisão de compra. Estes entrevistados percebem a segurança como atributo de alto valor no momento da compra.

\section{CONSIDERAÇÕES FINAIS}

O estudo demosntrou que as pessoas estão induzidas a responder sobre as questões ambientais a partir de padrões impostos pela sociedade do século XXI. Esta pesquisa, portanto, sofreu influências externas relativas à imagem, ecologicamente correta, que as pessoas demostraram em seus discursos. De modo geral, os entrevistados apresentam uma ideia bastante madura do conceito de sustentabilidade salvo exceções que não 
souberam ou não se interessaram em definir o termo.

A pesquisa evidencio que, os entrevistado não entendem a questão ambiental como tendo real relevtância nas suas decisões de compra. Outro aspecto, que deve ser levado em consideração é o baixo envolvimento do consumidor em relação a compra de cosméticos por ser algo convencional e frequente. Isso contribui para o baixo nível de conhecimento dos entrevistados em relação aos meios de produção e matérias-primas dos produtos que utilizam.

Em relação ao consumo de produtos sustentáveis, os entrevistados de modo geral

\section{REFERÊNCIAS}

[1] ABIHPEC, Panorama do setor - Higiene pessoal, Perfumaria e Cosméticos. Disponível em: $<$ http://www.abihpec.org.br>. Acesso em: 04 abril de 2015

[2] ALMEIDA, Fernando. Os Desafios da Sustentabilidade: uma ruptura urgente.Rui de Janeiro: Elsevier, 2007

[3] ANVISA, Guia de Avaliação de Segurança de Produtos Cosméticos. Disponível em: http://www.anvisa.gov.br/cosmeticos/material/comp ra_cosmetico.pdf>. Acesso em: 04 abril de 2015.

[4] ARAGONÉS, J. I. \& Amérigo, M. Psicología Ambiental. Ediciones Pirâmide. Madri: 1998 Castello, L. A Percepção em Análises Ambientais. In: Rio, V. \& Oliveira, L. (orgs). Percepção Ambiental: a experiência brasileira. São Carlos, EDUFSCar, 1996.

[5] BARBIERI, José Carlos. Desenvolvimento e Meio ambiente; as estratégias de mudanças da Agenda 21. Rio de Janeiro; Vozes 1997

[6] BARBOSA, Lívia. Sociedade de Consumo. Rio de Janeiro: Zahar, 2004.

[7] BATISTA, Eliezer; CAVALCANTI. Roberto B; FUJIHARA, Marco Antonio, Caminhos da Sustentabilidade no Brasil. São Paulo; Terra das Artes, 2005

[8] BURSZTYN, Marcel. Ciência, Ética e Sustentabilidade: Desafios ao Novo

[9] Século. São Paulo : Cortez ; Brasília, DF : UNESCO, 2001.

[10] BLUM, M. L.; NAYLOR, J. C. Psicología Industrial - SUS ferramentas teóricos y sociales. BRUM, Argemiro J. Modernização da Agricultura Trigo e Soja, Petrópolis: Vozes, 1988.

[11] SCHIFFMAN, Leon G.; KANUK, Leslie Lazar. Comportamento do consumidor. Rio de Janeiro: LTC, 2000.Trilhas: México, 1976 não citaram em nenhum momento que sua decisão demonstra uma atitude sustentável. Porém, informaram que caso o produto verde possua preço e qualidade comparáveis com os produtos comuns mudariam o seu consumo atual por um produto verde.

Neste contexto, os produtos sustentáveis não conseguem ganhar espaço no mercado de cosméticos, os consumidores conhecem de forma clara os problemas ambientais globais e suas consequências para o futuro do planeta, porém estímulos como a satisfação de suas necessidades pessoais são, ainda, mais presentes no seu processo de decisão de compra do que a solução dos problemas do meio ambiente.

[12] SAE, Secretaria de Assuntos Estratégicos de Governo Federal. Disponível em: $<$ http://www.sae.gov.br/imprensa/sae-na-

midia/veja-diferencas-entre-conceitos-que-definemclasses-sociais-no-brasil>. Acesso em 08 outubro de 2016

[13] DEMAJOROVIC, Jacques. Da Política Tradicional de Tratamento do Lixo à Política de Gestão de Resíduos Sólidos. Revista de Administração e Economia (RAE Ambiental), São Paulo, v.35, n.3, p.88-93, Mar./Jun. 1995.

[14] ENGEL, James F.; BLACKWELL, Roger D.; MINIARD, Paul W. Consumer behavior. Orlando: The Dryden Press, 1995.

[15] FERRARA, L. D'A. As Cidades llegíveis: Percepção Ambiental e Cidadania. In: Percepção Ambiental - A Experiência Brasileira. Del Rio, V; Oliveira, L. Studio Nobel, São Paulo, 1999.

[16] GUIMARÃES, Roberto P. O novo padrão de desenvolvimento para o Brasil: inter-relação do desenvolvimento industrial e agrícola com o meio ambiente. In: VELLOSO, João Paulo dos Reis et al. (Orgs.). A ecologia e o novo padrão de desenvolvimento no Brasil. São Paulo: Nobel, 1992.

[17] KOTLER, Philip; KELLER, Kevin Lane. Administração de marketing. São Paulo: Pearson Prentice Hall, 2012.

[18] KOTLER, Philip. Administração de marketing: análise, planejamento, implementação e controle. São Paulo: Atlas, 1994.

[19] Leff, E. Saber Ambiental. Petrópolis, Editora Vozes, 2001. Hawthorne, M. \& Alabaster, T. Citizen 2000: development of a model of environmental citizenship. In: Global Environmental Change, vol.9, n.1, p. 25-43, April /1999.

[20] MARX, Karl e ENGELS, Friedrich. Manifesto do Partido Comunista. São Paulo e Bauru- SP : Edipro, 2015. 
[21] MEDEIROS, João Bosco. Redação Científica: a prática de fichamentos, resumos, resenhas. São Paulo: Atlas, 2009.

[22] MINISTÉRIO DO MEIO AMBIENTE. O que o brasileiro pensa da ecologia. 16 p. Disponível em <http://www.mma.gov.br/port/SE/pesquisa> Acesso em maio de 2015

[23] PACTO GLOBAL, Os 10 Princípios do Pacto Global. Disponível em: 2015.
[24] PENNA, Carlos Gabaglia. O estado do planeta: sociedade de consumo e degradação ambiental. Rio de Janeiro: Record, 1999.

[25] SOLÉR, C. Ecologically friendly buying Theoretical implications of a phenomenological perspective. Scandinavian Journal of Marketing Research, v. 28, p. 232-239, May 1991 
Alutary 


\section{ALEXANDRA SIQUEIRA}

Representante legal da Sociedade Civil do Município de Salvador, eleita como membro do Grupo Operativo, através do termo de posse no 00/2013, junto a Ouvidoria Cidadã da Defensoria Pública do Estado da Bahia, para o exercício do biênio 2013-2015; Membro do Grupo de Pesquisa Trabalho, Desenvolvimento e Tecnologia de Gestão - IFBA, desde 2015; Mestra em Educação pelo Programa de Pós-Graduação em Educação pela Universidade Federal da Bahia; Especialista em Auditoria Fiscal pela Universidade do Estado da Bahia; Bacharel em Ciências Econômicas pela Faculdade Católica de Ciências Econômicas da Bahia; Economista com registro no Conselho Regional de Economia no 5356. ProfessoraPesquisadora nas áreas de: Filosofia da Educação e Economia. Supervisora Técnica nível superior da Secretaria do Trabalho, Emprego e Renda - SETRE.

\section{ALEXANDRE DE CARVALHO PARANAIBA}

Possui graduação em Ciências Contábeis pela Pontifícia Universidade Católica de Goiás (2006). Especialização em Gestão Financeira pela Pontifícia Universidade Católica de Goiás (2009). Coordenador e Professor do curso de Ciências Contábeis da Pontifícia Universidade Católica de Goiás.

\section{ALEXANDRE DE FREITAS CARNEIRO}

Doutorando pelo Programa Doctorado en Administración pela Universidad Nacional de Misiones (UNaM), Argentina. Mestrado em Administração e Especialização em Contabilidade e Controladoria pela Universidade Federal de Rondônia. Bacharel em Ciências Contábeis pela Universidade Vale do Rio Doce (MG). Professor do Departamento de Ciências Contábeis e de Administração da Universidade Federal de Rondônia. Avaliador do Congresso Internacional de Administração e Revisor de periódicos. Possui diversos trabalhos publicados em congressos e revistas nacionais e internacionais, com trabalho premiado na Espanha (Grupo de Investigación en Gobierno, Administración y Políticas Públicas - GIGAPP, 2016).

\section{ALEXANDRE DE VASCONCELLOS FARIA}

Advogado - Graduado pela Faculdade Itaboraí. Atuação profissional como Advogado nas áreas trabalhista, Administrativa e Ambiental.

\section{ALOIR PEDRUZZI JUNIOR}

Mestre em Administração pela Universidade Federal de Rondônia (UNIR), especialização em Auditoria e Perícia Contábil pela Faculdade Educacional da Lapa (FAEL) e graduado em Ciências Contábeis pela Universidade Federal de Rondônia (UNIR). Atualmente é Professor do Ensino Básico, Técnico e Tecnológico do Instituto Federal de Educação Ciência e Tecnologia de Rondônia (IFRO). Experiência na área de Liderança, Auditoria, Controladoria nas Organizações e Ciências Contábeis. Como pesquisador é participante do Grupo de Estudo e Pesquisa em Organizações (GepOrg) e Grupo de Estudo e Pesquisa em Inovação e Sustentabilidade da Amazônia (GEPISA), tendo com foco sistemas de controle no setor público, Controladoria nas Organizações e Liderança. 
Doutoranda em Information Sciences pela UFP (Porto). Mestra em Administração- State Labor and Society. Especialista em Gestão de Pessoas pela Universidade Cândido Mendes (RJ)- em andamento. Graduada em Administração - UFPB. Atuação e experiência em Ensino, Pesquisa e Extensão. Pesquisadora/colaboradora de projetos do CNPq -Pesquisa e Extensão. Capacitação em Projetos - PMDome (PMI) São Paulo (Brasil). Pesquisadora bolsista premiada: Jovem Pesquisadora. Financiamento CNPq. Ministrante de Cursos de Capacitação para servidores e colaboradores em empresas públicas e privadas. Experiência em EAD -IFPBGraduação e Especialização- Administração Pública. Ex- professora da Universidade Federal da Paraíba- UFPB - Campus João Pessoa-PB (Substituta). Assessorou na Expansão e Relações Internacionais de Programas de MBA's e Mestrados. Atuação por 05 anos em empresas do varejo e Assessora e Consultora Administrativa/ Gestão em empresas/ Pessoas. Docente em Pós-Graduações - (MBA`s).

\section{ANDRESSA SAMARA MASIERO ZAMBERLAN}

Possui graduação em Ciências Econômicas com Enfase em Comércio Exterior (Unesc/ RO), sob o registro no CORECON n. 699, pós-graduação (latu senso) em Metodologia e Didática do Ensino Superior (Farol/RO), Mestrado em Administração pela Universidade Federal de Rondônia. Possui proficiência em lingua Inglesa e proficiência em Espanhol. Ocupou ainda cargos públicos como: Coordenadora Administrativa e Financeira da Secretária de Estado de Justiça e o cargo de Superintendente de Compras e Licitação da Assembléia Legislativa do Estado de Rondônia. Atuou como professora na Uniron/ RO do ano 2009 à 2013, ministrando disciplinas como: Introdução a Economia, Economia e Mercado, Macroeconomia, Microeconomia, Comércio Exterior/Internacional, Contabilidade Geral, Empreendedorismo, Adm. do Agronegócio. Já atuou frente a Empresa Junior e como coordenadora adjunta do núcleo de ciências gerenciais da faculdade Uniron. Atualmente é professora nas instituições FACIMED na cidade de Cacoal - RO Coordenadora do curso Superior de Tecnologia de Gestão Pública - EaD - FACIMED.

\section{ANGEL RAMON SANCHEZ DELGADO}

Doutor em Engenharia de Sistemas e Computação pela COPPE/UFRRJ, Mestrado em Ciência da Computação - Universidad Simón Bolivar - Venezuela e Graduação em Licenciatura e Bacharelado em Matemática - Universidad Central de Venezuela. Atualmente é Prof. Titular do Dep. de Matemática da UFRRJ e prof. permanente do Doutorado Binacional (Brasil/Argentina) em Ciência Tecnologia e Inovação Agropecuária (PPGCTIA) da UFRRJ. Tem experiência na área de Matemática Aplicada, com ênfase em Programação Matemática (Modelagem e Simulação), Estatística, Equações Diferenciais e Inteligência Computacional e atua nos temas: Sistemas de Produção Agrícola, Sistemas Integrados Lavoura-Pecuária-Floresta, Otimização do Uso e Reuso de Recursos Hídricos e Métodos de Pontos Interiores.

\section{ANTONIO CALIL NETO}

Possui graduação em Matemática pela Universidade do Estado do Rio de Janeiro, e em Direito pela Universidade Federal Fluminense, bem como possui mestrado e doutorado em Tecnologia de Processos Químicos e Bioquímicos pela Escola de Química da Universidade Federal do Rio de Janeiro. 


\section{AUGUSTO PAULO SALELO JOSÉ}

Licenciado em Economina pelo Instituto Superior Politécnico de Tecnologia e Ciências. Colaborador da empresa PricewaterhouseCoopers Angola, Lda. (PwC Angola), Departamento de Auditoria, Função Auditor.

\section{AVENILSON GOMES DA TRINDADE}

Graduado em Ciências Econômicas pela Universidade Federal de Rondônia. Especialista em Gestão Financeira (ULBRA), MBA em Gestão Pública (FSL). Economista da Agência de Defesa Agropecuária de Rondônia e atualmente Diretor Executivo da Secretaria de Estado da Agricultura (SEAGRI-RO).

\section{BEATRIZ GONCALVES VICENTE}

Bacharel em Administração de empresas pelo Centro Universitário SENAC, certificada na CA 300, e CA 600 pela Fundação Getúlio Vargas, especialista no comércio de produtos de crédito imobiliário. Atua a oito anos como consultora de crédito imobiliário de um banco de grande porte privado.

\section{CARLA OLIVEIRA DE SOUZA}

Mestre em Administração Pública pela Fundação Getúlio Vargas (2016). Possui especialização em Gestão em Administração Pública (2015) e Direito da Administração Pública (2012), ambos pela Universidade Federal Fluminense. Graduada em Administração com ênfase em Ciências da Logística, por meio do curso de Oficiais Intendentes da Academia da Força Aérea (2006). Atua profissionalmente como oficial intendente - Força Aérea Brasileira, exercendo a função de Agente de Controle Interno. Tem experiência na área de Administração, com ênfase em Administração Pública, atuando principalmente nos seguintes temas: Licitação, Contratos e Compras Públicas, Contabilidade e Finanças Públicas e Direito da Administração Pública.

\section{CESAR M KULAK}

Mestre em Administração Profissional pela Universidade Estadual do Centro-Oeste (2017). Especialista em Contabilidade e Finanças UFPR (2006). Graduação em Ciências Contábeis pela Universidade Estadual do Centro-Oeste (2003). Experiência na área de Ciências Contábeis como Analista Contábil e Analista de Custos na Cooperativa Agrária Agroindustrial e Hospital Santa Tereza. Consultor em Controladoria Cooperativa de laticínios. Professor Ciências Contábeis na Unicentro desde o ano de 2012.

\section{CLÁUDIO MELLO}

Prof. Cláudio Palma de Mello, em sua carreira executiva, atualmente é Coord. Executivo no Gabinete do Governador, já atuou como Chefe de Gabinete da Secretaria de Cultura, Coord. Executivo de Pesquisa, Inovação e Extensão Tecnológica na Secretaria da Agricultura e Diretor de Programas e Projetos da Secretaria de Meio Ambiente, além de Coord. Executivo do Parque Tecnológico da Bahia, na Secretaria de Ciência, Tecnologia e Inovação. Na trajetória acadêmica é professor de disciplinas de Economia desde 2001 e no IFBA, desde 2008. É formado em Economia pela UFBA, tem Especialização em Comércio Exterior pela UFPE e Mestrado em Análise Regional pela UNIFACS. 


\section{DÉBORA BATISTA DE FARIAS}

Graduada em Gestão Ambiental pela Universidade Metodista de São Paulo (2014). Especialista em Gestão Ambiental, Gestão, licenciamento e Auditoria Ambiental, Docência na Educação Superior e MBA em Gestão Empresarial: Cooperativas de Saúde pela Fundação Getúlio Vargas (2017). Atualmente é servidora da Prefeitura Municipal de Vilhena. Tem experiência na área de Ciências Ambientais, com ênfase em Gestão Ambiental.

\section{EDUARDO LOPES MARQUES}

Professor Visitante no Departamento de Economia da Universidade Federal de Viçosa. Pósdoutorado em Administração pela Pontifícia Universidade Católica do Paraná, onde desenvolveu um trabalho com foco em Universidades Sustentáveis. É Doutor em Engenharia Ambiental pela Universidade Federal de Santa Catarina (2008), com ênfase em Processos Participativos para a Gestão Ambiental Pública e Privada e Mestre pela mesma instituição. Graduado em Ciências Econômicas pela Universidade Federal de Juiz de Fora. É Auditor Ambiental com credenciamento Internacional. Possui mais de 15 anos de experiência docente no Ensino Superior tanto em instituições privadas como públicas.

\section{ELIZABETH VIEIRA PORTO PEREIRA}

Possui graduação em Ciências Contábeis pela Universidade Salgado de Oliveira (2002). Especialização em Ciências Contábeis pela Pontifícia Universidade Católica de Goiás (2008). Mestrado em Desenvolvimento Regional pelo Centro Universitário Alves Faria (2018). Coordenadora do curso de Ciências Contábeis da Faculdade Unida de Campinas. Professora da Pontifícia Universidade Católica de Goiás. Possui experiência na área de Administração, Contabilidade com especificidade na área rural.

\section{ELMO RODRIGUES DA SILVA}

Possui graduação em Engenharia Sanitária e Ambiental pela Universidade do Estado do Rio de Janeiro (1979), mestrado em Genie de L'environment - Ecole Polytechnique Fédérale de Lausanne (1983) e doutorado em Saúde Pública pela Fundação Oswaldo Cruz (1998). Atualmente é Professor Associado da Universidade do Estado do Rio de Janeiro (UERJ). Tem experiência na área de Engenharia Sanitária, com ênfase em Gestão Ambiental, atuando principalmente nos seguintes temas: gestão de resíduos, gestão ambiental e gestão de recursos hídricos.

\section{ESTEVÃO FREIRE}

Doutor em Engenharia pelo Programa de Engenharia de Minas, Metalúrgica e de Materiais da Universidade Federal do Rio Grande do Sul (2007), Mestre em Ciência e Tecnologia de Polímeros pelo Instituto de Macromoléculas Professora Eloisa Mano/UFRJ (1992) e graduado em Engenharia Química pela Escola de Química da UFRJ (1987). É Professor Adjunto na Universidade Federal do Rio de Janeiro, lotado no Departamento de Processos Orgânicos da Escola de Química. Atua no ensino de graduação e pós graduação, no Mestrado Profissional em Engenharia Ambiental. É docente do corpo permanente do PROFNIT (Programa de Pósgraduação em Propriedade Intelectual e Transferência de Tecnologia para a Inovação), sendo vice-coordenador do Ponto Focal UFRJ. Seus principais interesses em pesquisa são prospecção tecnológica, gestão e inovação tecnológica na indústria química, estudo de cadeias produtivas com foco em tecnologias verdes e identificação de oportunidades de agregação de valor de subprodutos industriais. 


\section{FELIPE BARBOSA CORDEIRO}

Possui graduação em Engenharia Química pela Universidade Federal do Rio de Janeiro (2011), pós-graduação em Engenharia de Segurança do Trabalho pela Universidade Federal do Rio de Janeiro (2013) e mestrado em Engenharia de Processos Químicos e Bioquímicos pela Universidade Federal do Rio de Janeiro (2018). Atualmente é Engenheiro Químico da Prefeitura da Cidade do Rio de Janeiro, alocado na Secretaria de Conservação e Meio Ambiente.

\section{FERNANDO FERRAZ}

Doutorado em Engenharia de Produção pela UFRJ (1999), Mestrado em Engenharia de Produção pelo Instituto Alberto Luiz Coimbra de Pós Graduação e Pesquisa de Engenharia (1991) e Graduação em Engenharia de Produção pela Escola de Engenharia (1988), Professor do Departamento de Engenharia de Produção da UFF, atuando no Programa de Pós-Graduação em Engenharia de Produção e no Mestrado em Sistemas de Gestão. Experiência em Engenharia de Produção, com ênfase em Ergonomia, Qualidade, Inovação e Desenvolvimento Local.

\section{FILIPE BORGES}

Doutorando em Ciências da Educação, Mestre em Educação, Administração e Comunicação pela Universidade São Marcos- SP.Possui graduação em Direito pela Universidade Veiga de Almeida (2006) ( onde é professor pesquisador nas áreas de Responsabilidade Social e Responsabilidade Socioambiental), é especialista em Consultoria Jurídica na Administração Pública pela Universidade da Cidade do Rio de Janeiro. Servidor Público da Secretaria de Assistência Social do Município de Cabo Frio, atualmente é professor do Programa de Mestrado em Ciências da Educação pela Universidade Tecnológica Intercontinental- Teresina PI e Assunción PY. Professor T I da Universidade Veiga de Almeida. Leciona também na Faculdade União Araruama de Ensino - FAC UNILAGOS e Faculdade Professor Miguel Ângelo da Silva Santos - FeMASS.

\section{FILIPE DE CASTRO QUELHAS}

Doutorando em sistemas de gestão sustentáveis pelo laboratório de tecnologia, gestão de negócios e meio ambiente (Latec) da escola de engenharia da Universidade Federal Fluminense (UFF), Mestre em administração pelo programa de pós-graduação stricto sensu de Mestrado em Administração do IBMEC-RJ, participou como avaliador de artigos para o XX SEMEAD da FEA-USP em 2017. Autor em diversos artigos científicos publicados em periódicos e congressos. Possui MBA em gestão pela qualidade total concluído pelo Latec/UFF, MBA em desenvolvimento gerencial avançado com ênfase em gestão de pessoas também pelo Latec / UFF, todos os créditos concluídos do mestrado em engenharia de transportes da COPPE / UFRJ, pós-graduação em administração de empresas completa em parceria da escola de pós - graduação em administração pública e de empresas com a escola de pós-graduação em economia da Fundação Getúlio Vargas (FGV). É pós-graduado MBA em administração da produção e logística, pós-graduado em gestão de recursos humanos, pós-graduado em gestão empresarial, pós-graduado em docência do ensino superior, pós-graduado em administração escolar e planejamento, pós-graduado em gestão competitiva no varejo, pós-graduado em direito do trabalho e pós-graduado em direito administrativo, todos pela Universidade Cândido Mendes (UCAM). Possui curso de graduação sequencial em Empreendedorismo e Inovação concluído pelo departamento de Empreendedorismo da Universidade Federal Fluminense (UFF), pós-graduação em políticas e gestão em segurança pública pela Facibra e graduado em administração. Possui vários 
artigos científicos publicados em periódicos Qualis/Capes, em periódicos avaliados Qualis / capes, e diversos artigos científicos completos apresentados e publicados em congresso na área de administração, engenharia e gestão. Teve grande experiência na educação à distância, tendo sido tutor à distância no curso de graduação à distância em administração da UFRRJ, com diversos cursos concluídos na área de educação à distância. Foi tutor presencial no curso de graduação à distância de administração pública da UFF e monitor em diversas disciplinas. Foi tutor presencial em metodologia da pesquisa no curso de graduação à distância em Engenharia de Produção, em parceria com a UFF. Formado no curso à distância em gestão escolar da universidade federal fluminense (UFF), oferecido a diretores de escolas públicas do RJ. Teve participações em bancas examinadoras de defesa de trabalho de conclusão de curso (tcc) no curso de graduação de administração. Concluiu com êxito o programa latino-americano de seminários em governabilidade, gerência política e gestão pública., em parceria com a FGV, CAF e George Washington University. Possui o GRI certified training module transition to GRI standards pela global reporting initiative, Amsterdam, Holanda.

\section{HELTON LUIZ SANTANA OLIVEIRA}

Doutorando em Engenharia de produção pela UFF. Mestre em Sistemas de Gestão de Segurança, Meio Ambiente e Saúde no Trabalho pela UFF; Especializado em Acústica Aplicada ao Controle de Ruído pela UFSC; Especializado em Análise e Gerenciamento de Riscos Industriais pela UFRJ; Pós Graduado Lato Sensu em Engenharia de Segurança pela Unifenas; Graduado em Engenharia Mecânica pela UnB; Experiência profissional com destacada atuação em: Indústria aeronáutica (manutenção de aeronaves); Indústria de bebidas (cerveja \& refrigerantes); Indústria alimentícia (abate e processamento de frangos \& laticínios ); Indústria cimenteira e de mineração (nióbio); Indústria de energia elétrica (geração \& transmissão); Indústria de petróleo \& gás;

\section{IGOR LAGUNA VIEIRA}

Graduado em Física pela UFMG (2008) e em Engenharia de Produção Civil pelo CEFET-MG (2013). Mestre (2017) e doutorando em Engenharia Ambiental pela UERJ. Possui experiência como professor de Física e Engenheiro, atuando na área de Gestão Ambiental. Atualmente é Analista em Ciência \& Tecnologia da Comissão Nacional de Energia Nuclear (CNEN).

\section{JEDIEL TEIXEIRA MENDES}

Possui graduação em Ciências Contábeis pela Pontifícia Universidade Católica de Goiás (2008), Pós-Graduação em Auditoria Contábil pela Uni-Anhanguera (2011). Tem experiência em Contabilidade de Serviços, Contabilidade Comercial e Pericia Contábil Judicial e Extra Judicial, Professor Universitário na Pontifícia Universidade Católica de Goiás para os Cursos de Ciências Contábeis e Administração.

\section{JONIMAR DA SILVA SOUZA}

Professor do Instituto Federal de Rondônia (IFRO). Já atuou como Coordenador do Curso Superior de Tecnologia em Gestão Pública e Coordenador de Pós-Graduação. É membro da Rede Brasileira de Monitoramento e Avaliação (RBMA). Coordenador do Grupo de Estudos e Pesquisa em Inovação e Sustentabilidade da Amazônia - GEPISA. 


\section{JOSAURA LEITE}

Graduada em Engenharia de Produção pela Universidade Veiga de Almeida - UVA.

\section{JOSE AIRTON CAVALCANTE JUNIOR}

Professor adjunto do Departamento de Tecnologias e Linguagens do Instituto Multidisciplinar da Universidade Federal Rural do Rio de Janeiro. Doutor em Ciência, Tecnologia e Inovação (PPGCTIA/UFRRJ), Mestre em Engenharia Nuclear (COPPE/UFRJ) e Engenheiro Eletrônico (CEFET-RJ). No biênio 2017-2018, atua como vice-coordenador do Curso de Matemática Aplicada e Computacional e do Curso de Licenciatura em Matemática, além de chefia do DLI na Pró-Reitoria de Extensão, a qual é responsável pelo desenvolvimento e assessoria de sistemas computacionais. Em EaD, foi coordenador do curso de extensão a distância de Formação de Conselheiros Municipais de Educação (2014/2015). Tem experiência em Ciência da Computação, com ênfase em redes de computadores, ambientes virtuais de aprendizagem e aprecia o trabalho em áreas multidisciplinares onde podem-se desenvolver temas aplicados a engenharia.

\section{JOSE ANTONIO CARLOS CANEDO}

Doutor em Engenharia Nuclear pela COPPE/UFRRJ, Mestrado em Engenharia Nuclear pela Universidade Federal do Rio de Janeiro e graduação em Engenharia Elétrica pela Universidade do Estado do Rio de Janeiro (1977). Tem experiência na área de Ciência da Computação, com ênfase em Inteligência Artificial, atuando principalmente nos seguintes temas: Sistemas Especialistas, Sistemas Fuzzy, Redes Neurais Artificiais, Sistemas de Supervisão e Controle e Sistemas de Diagnóstico.

\section{JOSE ARILSON DE SOUZA}

Doutorado em Desenvolvimento Regional e Meio Ambiente pela Universidade Federal de Rondônia, Mestre em Administração pela Universidade Federal de Rondônia - UNIR, Mestre em Administração com Ênfase em Liderança -UNISA- SP, MBA em Gestão e Liderança UNISA - SP, Especialista em Consultoria Empresarial e Gestão de Empresas, Especialista em Planejamento Estratégico. Atualmente atua como Professor da Universidade Federal de Rondônia no departamento de Ciências Contábeis, campus de Vilhena -RO. Possui 20 anos de experiência com atuação empresarial nas áreas de: Gestão de Pessoas, Gestão Administrativa e Financeira, Gestão Contábil/ Controladoria e Fiscal, Gestão de Vendas e Distribuição, Gestão Industrial. Linhas de pesquisas em Arranjo produtivo (Apicultura), Liderança e Controladoria, Contabilidade Empresarial, Gestão Empresarial, Gestão de Custo, Responsabilidade Social e Liderança e Agronegócio.

\section{JOSIAS DA SILVA NOGUEIRA}

Bacharel em Ciências Contábeis pela Universidade Federal de Rondônia (RO). Contador.

\section{JOWANER ARAÚJO}

Graduado em Ciência da Computação pela UFBA, Especialista em Administração Empresarial pelo CETEAD/UFBA, Especialista em Sistemas Distribuídos pela UFBA, Mestre em Sistema e Computação pela UNIFACS. Prof. do IFBA desde 1993, além de ter atuado por mais de 20 anos na área de informática no setor bancário. 


\section{JUACYARA CARBONELLI CAMPOS}

Possui graduação em Engenharia Química pela Universidade Federal do Rio de Janeiro (1994), em Licenciatura em Química pela Universidade do Estado do Rio de Janeiro (1998) e doutorado em Engenharia Química pela Coordenação dos Programas de Pós Graduação em Engenharias (2000). Atualmente é Professor Associado II da Universidade Federal do Rio de Janeiro e participa como docente permanente do Programa de Pós-Graduação em Tecnologia de Processos Químicos e Bioquímicos (EQ/UFRJ) e no Programa de Engenharia Ambiental (Mestrado Profissional/UFRJ). Participa do Núcleo Integrado de Reúso de Águas e Efluentes Industriais (NIRAE/RJ). Tem experiência na área de Engenharia Química e Engenharia Ambiental, com ênfase em Controle da Poluição, atuando principalmente nos seguintes temas: lixiviados de aterros de resíduos, resíduos sólidos, tratamento de efluentes, wetlands, água de produção de petróleo, efluentes de refinaria, toxicidade, tratamento de águas e reúso de águas e efluentes.

\section{KELI CRISTIANE VIDO}

Doutoranda em Administração pela Universidade Presbiteriana Mackenzie - linha de pesquisa diversidade nas organizações - Etarismo. Especialista em recursos humanos, marketing, metodologia e didática do ensino superior, Psicopedagoga e possui MBA em gestão educacional do ensino superior. Consultora em recursos humanos e empreendedorismo / carreiras / novos negócios nacionais e internacionais. Professora dos cursos de pósgraduação e graduação do Centro Universitário SENAC e Centro Paula Souza - FATEC. Proprietária da Vido Associados Consultoria em Recursos Humanos e Empresarial e sócio da Pay Party.

\section{KELY BETÂNIA ABRÃO BORGES E BORGES}

Graduada em Direito pela Universidade do Grande Rio. Especialista em Direto e Processo do Trabalho e Complementação Pedagógica pela Universidade Cândido Mendes; Mestrado em Processo Constitucional pela Universidade Nacional Lomas de Zamora. Presidente da comissão do direito consumidor - ORDEM DOS ADVOGADOS DO BRASIL - OAB/RJ 35은 subseção de Rio Bonito/RJ. Advogada na Peixoto \& Rodrigues Advogados associados. Professora da Faculdade Itaboraí em Direitos Civil, Trabalhista, Consumidor e Mediação, Conciliação e Arbitragem.

\section{LAÍS ROCHA PIRES}

Graduada em Administração pelo Instituto Federal de Educação, Ciência e Tecnologia da Bahia com participação nos projetos de extensão: Estruturação do Escritório Técnico de Acolhimento a Demandas e Projetos Sociais e no projeto de pesquisa Trabalho, Desenvolvimento e Tecnologias de Gestão . Tecnóloga em Logística pelo Centro Universitário Jorge Amado. Curso Técnico em Logística pelo Centro Integrado de Manufatura e Tecnologia. Atuação profissional em setor Administrativo, compras e almoxarifado, secretaria entre outras atividades. Curso de Inglês pela Universidade Estadual da Bahia.

\section{LEONARDO BRUM}

Mestre em Ciências da Educação e Filosofia. Especialista em Docência e Gestão na Educação a Distância. Graduado em Engenharia de Produção e Tecnologia em Gestão para a Indústria de Petróleo e Gás. Ainda, Técnico de Segurança do Trabalho. Atualmente, coordenador do curso de Graduação Bacharelado em Engenharia de Produção da Faculdade União Araruama de Ensino - Unilagos. Docente de nível superior, atuando nas seguintes 
instituições de ensino: Faculdade União Araruama de Ensino - Unilagos; Fundação Educacional da Região dos Lagos - FERLAGOS; Faculdade Professor Miguel Ângelo da Silva Santos - FeMASS.

\section{LIA MARA DIB}

Mestre em Ciências Sociais pela Pontifícia Universidade Católica de São Paulo - linha de pesquisa filosofia politica e educacional. Bacharel em Ciências Sociais pela mesma instituição. Docente dos cursos de graduação do Centro universitário SENAC e Uniitalo.

\section{LIDIA YOKOYAMA}

Possui graduação em Engenharia Química pela Universidade Federal do Pará (1981), mestrado em Engenharia Metalúrgica pela Pontifícia Universidade Católica do Rio de Janeiro (1986) e doutorado em Química pela Pontifícia Universidade Católica do Rio de Janeiro (1999). Atualmente é Professor Associado IV do Departamento de Processos Inorgânicos da Escola de Química da Universidade Federal do Rio de Janeiro. Tem experiência na área de Tratamento de Águas e Efluentes com ênfase ao Reúso. Na área de águas, desenvolve pesquisas de monitoramento e manutenção da qualidade da água de corpos hídricos e o tratamento de água propriamente dito, visando a melhoria da qualidade tanto para consumo humano como industrial. Nestes, envolvem processos terciários convencionais e avançados visando a remoção de micropoluentes. No que se refere a área de efluentes, vem desenvolvendo pesquisas para a remoção de sólidos e substâncias dissolvidas por processos convencionais e avançados (Processo Oxidativo Avançado) de efluentes urbanos, sanitários e industriais. Os tratamentos dos efluentes sempre que possível, é dado ênfase a possibilidade de reúso. É membro do Núcleo Integrado de Reúso de Águas e Efluentes do Estado do Rio de Janeiro (NIRAE - RJ), núcleo este voltado para as práticas de reúso de água de qualquer natureza.

\section{LILHAN FERRO DE SOUZA}

Universidade Agostinho Neto, UAN -Angola GESTÃO Doutoranda //Logistica inversa. Universidade de Leon-Espanha Gestão e Auditoria Ambiental Mestre/2011. Universidade de Brasília-UNB-Brasil Matemática Aplicada a Gestão e Economia Especialista em matemática aplicada à economia e gestão/2005. Universidade Católica de Brasília-UCB- Brasil ECONOMIA Licenciada/2003.

\section{LORENA NOGUEIRA DE SOUZA}

Possui graduação em Ciências Contábeis pela Pontifícia Universidade Católica de Goiás (2015). Graduanda em Pedagogia pela Faculdade Araguaia. Atualmente é Analista Contábil na empresa Real Assessoria Contábil. Tem experiência na área Administrativa e Contábil em geral.

\section{LOUISE ANGELOFF}

Advogada - Graduada pela Faculdade Itaboraí. Especialista em Direito Administrativo. Atuação profissional na área de Direito Ambiental e Administrativo 


\section{LUANA FARIAS}

Possui graduação em Administração pela Universidade Estadual de Santa Cruz, UESC, mestrado em Planejamento Ambiental pela Universidade Estadual de Santa Cruz, e doutorado em Administração pela Universidade Federal da Bahia, UFBA. Salvador, Bahia.

\section{LUCIANA TEIXEIRA DA SILVA ABREU}

Administradora - Graduada pela Faculdade Itaboraí Empreendedora Social

\section{LUCIANO GEMIGNANI MONTESSANTI}

Bacharel em Administração pelo Centro Universitário SENAC. Sólida experiência no segmento de logística, atualmente atua na diretoria do departamento de contas a pagar de uma transportadora de médio porte a mais de 40 anos no mercado brasileiro.

\section{LUCIENE LARANJEIRA DINIZ}

Mestra em Engenharia de Produção pela UFPB. Bacharel em Administração com linha de formação em Cooperativismo pela UFPB/CCHSA. Professora do Magistério Superior da Universidade Federal da Paraíba- UFPB, lotada no CCHSA - Departamento de Ciências Sociais Aplicadas, em regime de Dedicação exclusiva. Atualmente Membro do Comitê de Extensão do CCHSA/UFPB.

\section{LUIZ CARLOS UFEI HASSEGAWA}

Graduado em Medicina pela Universidade Severino Sombra. É professor visitante da Faculdade de medicina São Lucas (RO). Médico com titulo de especialista em Cardiologia (AMB/SBC)-Clínica Médica(AMB/SBCM)-Medicina Intensiva(AMB/AMIB). Médico estatutário do Governo do Estado de Rondônia. Coordenador geral da UTI Adulta e Cardiológica do Hospital de Base Dr. Ary Pinheiro. Coordenador da residência em Medicina Intensiva do Hospital de Base Dr. Ary Pinheiro.

\section{MARCELA AMORIM FERNANDES}

Pós-graduanda pela Fundação Getúlio Vargas em Master in Business AdministrationBusiness Process. Bacharel em Administração pelo Centro Universitário SENAC. Formada em telecomunicações pelo Liceu de Artes e Ofícios de São Paulo. Sólida experiência na área de outsourcing de processos financeiros e atualmente coordena esta área na empresa de tecnologia financeira, subsidiária do Grupo Mitsubish.

\section{MARCOS CASTRO}

Possui graduação em Administração e Especialização em Administração de Recursos Humanos pela Unicentro. Mestrado e Doutorado em Administração pela Universidade Federal do Paraná. Atualmente é professor Adjunto no departamento de Administração Unicentro. Líder do Grupo de Pesquisa e Estudos em Estratégia e Organizações. Docente e vicecoordenador do PPGADM/Unicentro (Programa de Mestrado Profissional em Administração da Unicentro) Atua como pesquisador em temas relacionados à cooperação interorganizacional, redes, aglomerações produtivas e temas correlatos. 


\section{MARIA CLAUDIA RODRIGUEZ}

Dra. en Ciencias Biologicas pela UNC - Argentina, Médica Veterinaria pela Universidad Nacional de Rio Cuarto. Atualmente Professora Pesquisadora em La Asignatura Ecologia y Manejo de Residuos Ganaderos da Faculdade de Agronomia y Veterinaria da UNRC. Possui expertise em Gestão de Recursos Hídricos Superficiais, Risco, Manejo de Resíduos Bovinos provenientes de Sistemas de Altos Insumos e Gestão, além de Legislação Ambiental.

\section{MARIA JOSÉ DE OLIVEIRA CAVALCANTI GUIMARÃES}

Possui graduação em Química pela Universidade Federal do Rio de Janeiro, mestrado e doutorado em Ciência e Tecnologia de Polímeros pelo Instituto de Macromoléculas Profa. Eloisa Mano da Universidade Federal do Rio de Janeiro. Atualmente é professor Associado do Departamento de Processos Orgânicos da Escola de Química da Universidade Federal do Rio de Janeiro. Tem experiência na área de Engenharia Química, com ênfase em petróleo e petroquímica, atuando nos seguintes temas: macromoléculas, inibidores e meio-ambiente.

\section{MARILUCE PAES DE SOUSA}

Pós-Doutora em Administração pela Universidade Federal do Rio Grande do Sul - UFRGS (2012), Doutora em Ciências Socioambientais pela Universidade Federal do Pará UFPA/Núcleo de Altos Estudos Amazônicos - NAEA (2004). Mestre em Engenharia de Produção pela Universidade Federal de Santa Catarina (1999). Especialista em Gestão de Recursos Humanos pela Universidade Federal de Santa Catarina (1989). Graduada em Administração pela Universidade Federal de Rondônia (1984). Atualmente é Coordenadora do Centro de Estudos Interdisciplinar em Desenvolvimento Sustentável da Amazônia - CEDSA, Professora associada da Universidade Federal de Rondônia, atua no Departamento Acadêmico de Administração na graduação e no Programa de Pós-Graduação Mestrado em Administração. Coordena a Linha de Pesquisa Governança, Sustentabilidade e Amazônia. Atua nos campos temáticos Sustentabilidade e Competitividade, Governança, Arranjos e Redes Organizacionais e Organizações e Ações Coletivas. Pesquisadora em sistemas agroambientais, produtos florestais não madeiráveis, relacionamentos interorganizacionais, desenvolvimento sustentável da Amazônia, privilegia as abordagens empreendedorismo e inovação social, macromarketing, aprendizagem, cadeias produtivas, arranjos produtivos locais, redes de cooperação e arranjos organizacionais, interorganizacionais complexos e processos econômicos com ênfase em desenvolvimento local e regional. Coordena Projeto Casadinho CNPq/CAPES em parceria com pesquisadores da EA/UFRGS.

\section{MARLETE B MAÇANEIRO}

Possui graduação em Secretariado Executivo UNIOESTE (1995), Mestrado em Administração UFPR (2008), doutorado em Administração UFPR (2012) e pós-doutorado na Universidade Positivo (2015), pelo Programa Nacional de Pós-Doutorado PNPD da CAPES. É professora na UNICENTRO - Guarapuava-PR, do Programa de Pós-Graduação em Administração - Mestrado Profissional da UNICENTRO e do Programa de Pós-Graduação em Propriedade Intelectual e Transferência de Tecnologia para Inovação - PROFNIT. Tem experiência em docência e pesquisa nas áreas de Administração e Secretariado Executivo, atuando principalmente nos temas: gestão da tecnologia e inovação; gestão da ecoinovação; secretariado executivo; e pesquisa em Ciências Sociais Aplicadas. 


\section{MATHEUS SILVA BASTOS}

Possui graduação em Ciências Contábeis pela Pontifícia Universidade Católica de Goiás (2015). Especialização em Docência Universitária pela Pontifícia Universidade Católica de Goiás (2018). Atualmente é Agente Administrativo da Pontifícia Universidade Católica de Goiás. Tem experiência na área de Ciências Contábeis e Administração. Atuando em pesquisas nas áreas de contabilidade, educação, agricultura familiar, agronegócio, sustentabilidade e viabilidade econômico financeiro.

\section{NATALIA CRISTINA CORREA CASTELO BRANCO}

Graduada em Ciências Sociais pela Universidade Federal Fluminense (UFF), Mestrado em Estudos Populacionais e Pesquisas Sociais pela Escola Nacional de Ciências Estatísticas (ENCE) do Instituto Brasileiro de Geografia e Estatística (IBGE). Doutoranda do Programa de Pós Graduação em Sociologia e Direito (PPGSD) da Universidade Federal Fluminense (UFF). Professora Titular da Faculdade Itaboraí - Experiência profissional na área de Sociologia e Ciência Política atuando nas seguintes temáticas: Capital social, organizações civis e movimentos sociais, metodologia e desenvolvimento de pesquisas sociais, eleitorais e de mercado.

\section{NUBIANA DE LIMA IRMÃO PEDRUZZI}

MBA em Gestão de Projeto pela Fundação Getúlio Vargas (FGV) e graduada em Administração pela Universidade Federal de Rondônia (UNIR). Atualmente é Gerente de Governança de TI no Tribunal de Contas do Estado de Rondônia (TCE-RO). Experiência na área de Liderança, Gerenciamento de Projetos, Compras de TI no setor Público. Como pesquisadora tem com foco sistemas Liderança, Gestão de TI e Gestão de Processos.

\section{PANDO ANGELOFF PANDEFF}

Administrador de Empresas. Doutor em Geografia pela Universidade Federal Fluminense UFF/POSGEO. Mestre em Ciência Ambiental pela Universidade Federal Fluminense UFF/PGCA. Mestre em Ensino de Ciências da Saúde e do Ambiente pela UNIPLI. Especializações em Gestão Educacional, Gestão de Negócios Sustentáveis e Gestão de Empresas de Petróleo e Gás. Docente do ensino Superior e Coordenador do curso de Administração da FACULDADE ITABORAÍ e FACULDADE CNEC ITABORAí. Atividade profissional e de pesquisa aplicada nas áreas de: Políticas Públicas, Saneamento e Recursos Hídricos e, Ordenamento Territorial. Livre docente em cursos de Pós Graduação em Meio Ambiente e Sustentabilidade. Analista Ambiental e Coordenador de projetos socioambientais. Atuação complementar como Perito Judicial na área Ambiental. Instrutor em cursos para a formação de Socorristas de Emergência. Instrutor na ESPM - Escola Superior de Polícia Militar do Estado do Rio de Janeiro nos Cursos de Aperfeiçoamento de Oficiais - CAO.

\section{PEDRO VIEIRA DE SOUZA JUNIOR}

Possui graduação pelo Centro Federal de Educação Tecnológica Celso Suckow da Fonseca (2009). Tem experiência na área de Engenharia Mecânica, com ênfase em Estruturas, Vibração e Acústica. Atua no mercado de desenvolvimento automotivo, aeroespacial, militar e instituições de ensino nas linhas de pesquisas com aplicações estruturais. Atualmente no mercado de Engenharia de Aplicações ajudando a fornecer soluções em dinâmica estrutural e oferecendo palestras e treinamentos com ênfases em análise dinâmica estrutural e análise de vibrações. 
RAFAEL DE ABREU PEREIRA

Administrador. Graduado pela Faculdade Itaboraí Empreendedor no segmento de cosméticos

\section{RAMON SCHNAYDER DE FRANÇA FILGUEIRAS D’AMORIM}

Mestrando do Programa de Pós-Graduação em Engenharia de Produção - PPGEP / UFPB. Possui Pós-Graduação em Gestão de Pessoas, pela Faculdade São Francisco da Paraíba FASP (João Pessoa/PB ) e Graduação em Sistemas de Telecomunicações, pelo Instituto Federal de Educação, Ciência e Tecnologia da Paraíba - IFPB (João Pessoa/PB ). Atualmente é Assistente em Administração da Universidade Federal da Paraíba - UFPB. Possui experiência na área de Administração, Comunicação, Informática, Telecomunicações e Música.

\section{RAQUEL EMERICK PEREIRA MENCARINI}

Possui graduação em Química Industrial pela Universidade Federal do Rio de Janeiro (2004) e mestrado em Tecnologia de Processos Químicos e Bioquímicos pela Universidade Federal do Rio de Janeiro (2006). Atualmente é doutoranda em Engenharia de Processos Químicos e Bioquímicos (UFRJ) e trabalha como Analista na Gerência de Informações Hidrometeorológicas e de Qualidade das Águas do Instituto Estadual do Ambiente do Rio de Janeiro (INEA), possuindo experiência no monitoramento e avaliação da qualidade de amostras ambientais e efluentes industriais.

\section{SÉRGIO CANDIDO DE GOUVEIA NETO}

Licenciado em Matemática - Universidade Federal de Rondônia (2002), Mestre em Ciências (Energia Nuclear na Agricultura) - Universidade de São Paulo (2006) e Doutor em Educação Matemática - Universidade Estadual Paulista (UNESP-Rio Claro). Professor Adjunto na Fundação Universidade Federal de Rondônia - Campus de Vilhena.

\section{SIMONE CASTRO}

Doutoranda em Engenharia de Produção da UFF (Universidade Federal Fluminense) e Diretora Regional do Rio de Janeiro da SOBRATT (Sociedade Brasileira de Teletrabalho e Teleatividades). Possui graduação em Engenharia de Telecomunicações pela UFF (1986), pós-graduação em Análise de Sistemas pela PUC-RJ (1988), MBA em Marketing pela COPPEAD (2001) e Mestrado em Engenharia de Produção pela UFF (2012). Larga experiência em vendas e marketing de grandes empresas. Linhas de pesquisa: Teletrabalho, Gestão do Trabalho, Inovação e Sustentabilidade.

\section{STHEFANI NOGUEIRA SARAIVA}

Mestre em Psicologia pela Universidade Federal do Rio de Janeiro. Graduada em Psicóloga e Licenciada em Psicologia pela Universidade Federal do Rio de Janeiro. Professora Titular da Faculdade Itaboraí e Faculdade CNEC Itaboraí, além de Ouvidora e Psicóloga do Núcleo de Apoio Psicológico. Professora de Psicologia da FAETEC e Psicóloga Educacional do NAPEM Prefeitura Municipal de Itaboraí. 


\section{TATIANA CASTRO}

Mestre em Engenharia de Produção na Universidade Federal Fluminense - UFF, linha de pesquisa de Conhecimento e Inovação. Graduação em Engenharia de Produção pela Universidade Federal do Rio de Janeiro - UFRJ (2013). Experiência na área de Engenharia de Produção, com ênfase em Gestão Organizacional.

\section{TULIO GONZAGA BRANDÃO DE MENDONÇA}

Graduado em Engenharia Civil pela Universidade Federal da Paraíba- UFPB ( João Pessoa/PB). Especialista em Gestão de Projetos (IPOG). Capacitação em Projetos - PMDome (PMI) São Paulo (Brasil). Especialista em Gestão de Pessoas pela Universidade Cândido Mendes (RJ)- em andamento. Atuação na área de Engenharia Civil com experiência em Construção, Projetos, Planejamento e Administração.

\section{WLANDER BELÉM MARTINS}

Graduado em Engenharia Mecânica pela Universidade Santa Úrsula, pós-graduado em Engenharia de Segurança do Trabalho pelo CEFET-RJ e Especialização em Acústica Aplicada ao Controle de Ruído pela Universidade Federal de Santa Catarina. Atualmente aposentado pela Petrobras e docente concursado da Fundação de Apoios às Escolas Técnicas do Estado do Rio de Janeiro - FAETEC. 


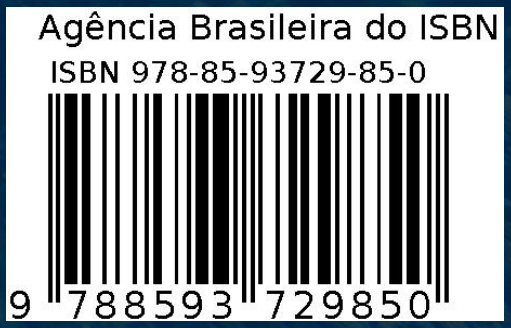

